\title{
5. SITE 516: RIO GRANDE RISE ${ }^{1}$
}

\author{
Shipboard Scientific Party ${ }^{2}$
}

\section{HOLES 516 TO 516F}

Date occupied: 10 March 1980

Date departed: 29 March 1980

Time on site: 19 days, $1.7 \mathrm{hr}$.

Number of holes: 7 (The table below includes data only on the holes with core recovery; see Operations section for discussion of Holes $516 \mathrm{C}, 516 \mathrm{D}$, and 516E.)

Position: $30^{\circ} 16.59^{\prime} \mathrm{S}, 35^{\circ} 17.10^{\prime} \mathrm{W}$

Water depth (sea level; corrected m, echo-sounding): 1313.0

Water depth (rig floor; corrected m, echo-sounding): 1323.0

Bottom felt (m, drill pipe): 1327.9

$\begin{array}{lclcc} & \mathbf{5 1 6} & \mathbf{5 1 6 A} & \mathbf{5 1 6 B} & \mathbf{5 1 6 F} \\ \text { Penetration (m): } & 183.3 & 69.5 & 23.2 & 1270.6 \\ \text { Number of cores: } & 44 & 16 & 1 & 128 \\ \begin{array}{l}\text { Total length of cored } \\ \quad \text { section }(\mathrm{m}):\end{array} & 183.3 & 69.5 & 7.6 & 1101.5 \\ \text { Total core recovered }(\mathrm{m}): & 148.7 & 61.10 & 4.52 & 691.72 \\ \text { Core recovery }(\%): & 81 & 88 & 59 & 63\end{array}$

Oldest sediment cored:

Depth sub-bottom (m): 1250

Nature: Calcarenite

Age: Coniacian

Measured velocity $(\mathrm{km} / \mathrm{s}): 3.5$ to 4.5

Basement:

Depth sub-bottom (m): 1252.6

Nature: Basalt

Velocity range $(\mathrm{km} / \mathrm{s}): 3.8$ to 5.3

Principal results: Hydraulic piston core (HPC) objectives were successfully completed at Site 516 on the upper flanks of the Rio Grande Rise. HPC Holes 516 and 516A penetrated to $183 \mathrm{~m}$ sub-bottom, with $85 \%$ core recovery and duplication of the uppermost $70 \mathrm{~m}$ of the section. Holes 516B, 516C, 516D, and 516E were drilled for instrument development tests and heat flow measurements, and would have continued as rotary holes except for weather and bit loss problems. Rotary drilling at Hole $516 \mathrm{~F}$ continued to $1270.6 \mathrm{~m}$ sub-bottom and recovered a virtually complete sedimentary se-

\footnotetext{
${ }^{1}$ Barker, P. F., Carlson, R. L., Johnson, D. A., et al., Init, Repts. DSDP, 72: Washington (U.S. Govt. Printing Office).

2 Peter F. Barker (Co-Chief Scientist), Department of Geological Sciences, University of Birmingham, Birmingham, United Kingdom; Richard L. Carlson (Co-Chief Scientist), Department of Geophysics, Texas A\&M University, College Station, Texas; David A. Johnson (Co-Chief Scientist), Department of Geology and Geophysics, Woods Hole Oceanographic Institution, Woods Hole, Massachusetts; Pavel Čepek, Bundesanstalt für Geowissenschaften und Rohstoffe, Hannover, Federal Republic of Germany; William T. Coulbourn, Deep Sea Drilling Project, Scripps Institution of Oceanography, La Jolla, California; Luiz A. Gamboa, Lamont-Doherty Geological Observatory, Palisades, New York, (present address: Center for Marine Crustal Studies, Gulf Science and Technology, Peart River, New York); Norman Hamilton, Department of Geology, University of Southampton, Southampton, United Kingdom; Ubirajara de Melo, PETROBRAS, Centro de Pesquisas e Desenvolvimento, Cidade Universitária, Rio de Janiero, Brazil; Claude Pujol, Départment de Géologie et Océanographie, Université de Bordeaux, 33405 Talence, France; Alexander N. Shor, LamontDoherty Geological Observatory, Palisades, New York; Alexey E. Suzyumov, P. P. Shirshov Institute of Oceanology, U.S.S.R. Academy of Sciences, Moscow, U.S.S.R.; R. C. Tjalsma, Exploration and Production Research Laboratory, Cities Service Company, Tulsa, Oklahoma; William H. Walton, Department of Civil Engineering, Cornell University, Ithaca, New York (present address: Charles T. Main, Inc., Boston, Massachusetts).
}

quence down to basal sediments of Coniacian age (approximately $82 \mathrm{Ma})$.

The stratigraphic succession is almost entirely calcareous, and virtually complete from the Recent to the basal sequence of Coniacian age. The lithologic section is continuous across the Cretaceous/Tertiary, Paleocene/Eocene, and Eocene/Oligocene boundaries. The Paleocene sequence is remarkably complete. Shipboard paleomagnetic measurements on more than 500 samples indicate sharp polarity transitions down to Anomaly 33/34. The excellent paleomagnetic and biostratigraphic continuity qualify Site 516 as an appropriate stratigraphic reference section for the South Atlantic, comparable in quality to the Gubbio section, but spanning a longer time interval. Measurements of sediment physical properties, including P-wave velocities, were made on more than 400 samples. These allow a detailed comparison between the extensive multichannel seismic coverage around the site and the lithostratigraphic succession. The $3.5 \mathrm{kHz}$ precision depth recorder (PDR) provides 70-m sub-bottom penetration, which is of value in interpreting the shallow HPC section. The "midsection dome" reflectors coincide with a zone of middle to late Eocene limestones interbedded with volcanogenic turbidites and ash layers absent elsewhere in the section. The base of Hole $516 \mathrm{~F}$ includes calcareous volcanogenic sediments, ferruginous chert, and two or more relatively fresh basalt flow units.

\section{BACKGROUND AND OBJECTIVES}

Site 516 on the Rio Grande Rise lies in $1313 \mathrm{~m}$ of water near $30^{\circ} 16^{\prime} \mathrm{S}, 35^{\circ} 17^{\prime} \mathrm{W}$ (Fig. 1). Sediment thickness on this part of the Rise varies between about 1100 and $1500 \mathrm{~m}(1.0$ and $1.3 \mathrm{~s})$.

The site is the shoalest of those drilled during Leg 72 and was designed to sample sediments deposited in the upper levels of the southwestern Atlantic water column through the Tertiary and late Cretaceous, whereas other sites $(357$ at $2109 \mathrm{~m}, 517$ at $2963 \mathrm{~m}, 518$ at $3944 \mathrm{~m}$, and 515 at $4265 \mathrm{~m}$ ) sampled sediments deposited in deeper water. The HPC samples are the basis for detailed studies of the short-period orbitally induced "Milankovich" effects on sedimentation during the Quaternary and probably into the Miocene (Perch-Nielsen, K. et al., 1977). Among other targets in what was expected to be a fairly continuous carbonate sequence were the Eocene/ Oligocene and Cretaceous/Tertiary boundaries. An important objective was an improved understanding of the origin and subsequent subsidence history of the Rio Grande Rise, both as a contribution to the general problem of aseismic ridge development and to provide midwater paleoecologic datum levels in the southwestern Atlantic. This objective was achieved by penetration to crystalline basement.

Placement of a re-entry cone is so time-consuming that other Leg 72 objectives would have been compromised had one been used at Site 516. Therefore, an attempt was made before drilling to find a location where basement was reasonably shallow and to avoid hiatuses recognized in reflection profiles for the shal- 


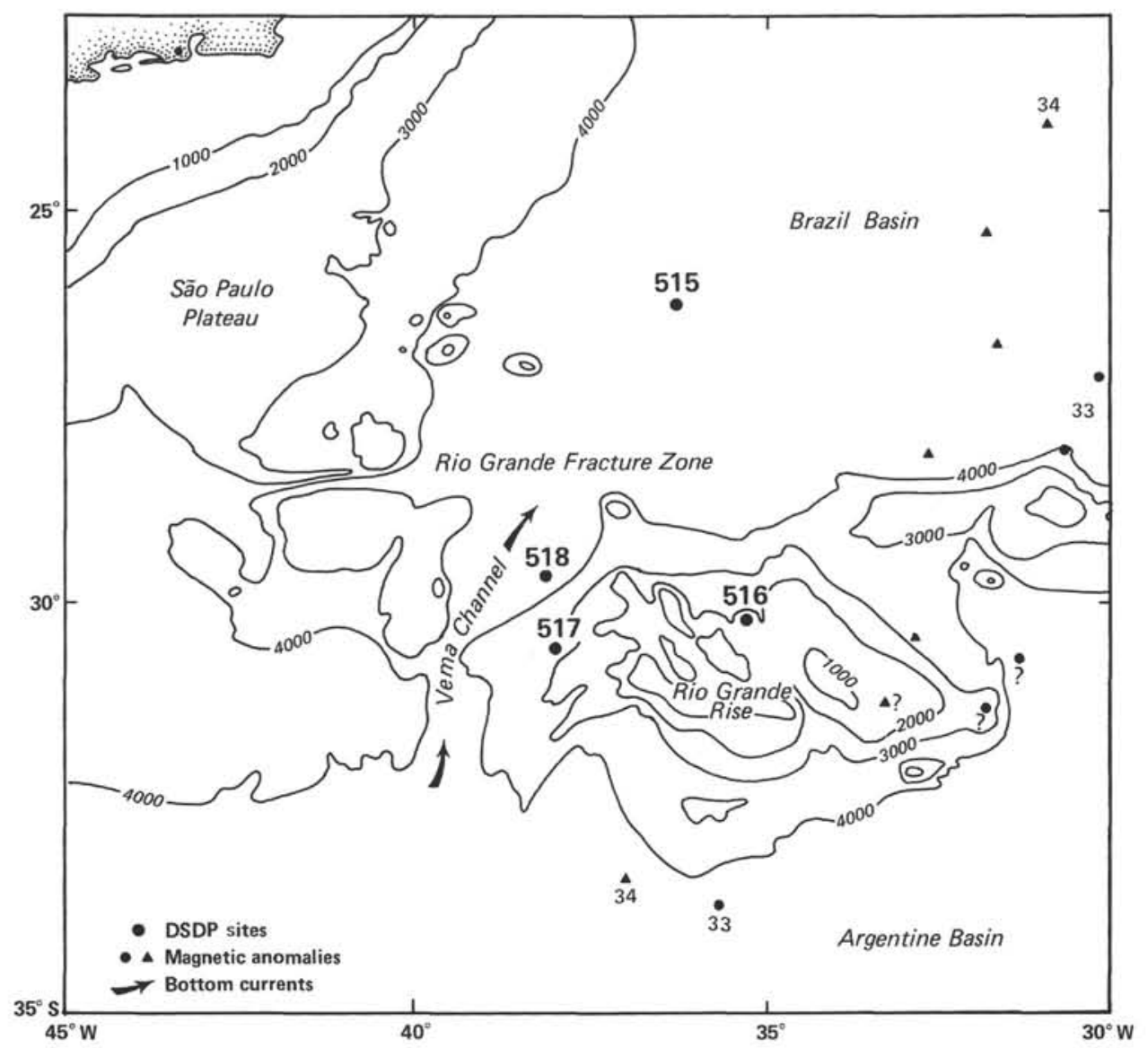

Figure 1. Location map showing positions of Leg 72 sites, marine magnetic anomalies, and generalized bathymetry.

low, HPC part of the section. The mandatory objective of our site survey was, however, to avoid the "midsection dome" reflectors first revealed in University of Texas Marine Science Institute (UTMSI) processed multichannel profiles. Earlier single-channel profiles fostered the belief that these reflectors represented crystalline basement, but at the time of Leg 72 drilling, basement was thought to lie $400-600 \mathrm{~m}$ deeper. The nature of these domes was uncertain before Hole $516 \mathrm{~F}$ was drilled. Interpretations included such possibilities as: reefs fringing a Late Cretaceous Rio Grande island group, volcaniclastic debris flows from the same source, and even late-stage intrusive bodies. The nature of the well-bedded sediments beneath the domes was also uncertain; the Santonian limestones found beneath $700 \mathrm{~m}$ at Site 357 were the obvious candidate, because volcanic basement could not be much older even if it formed at the ridge crest. Volcaniclastic debris flows and ash layers were other possibilities. Site 357 lies about $800 \mathrm{~m}$ deeper than Site 516 , so that processes related to sea level, such as reef formation, should have occurred later at Site 516.

\section{OPERATIONS}

We approached the vicinity of Site 516 on the Rio Grande Rise on the morning of 10 March. At $1112 \mathrm{Z}$ we passed near DSDP Site 22, reduced speed and changed course to $175^{\circ}$, beginning the required presite survey.

We first steamed south along a line some distance to the east of UTMSI multichannel line WSA13 for 30 miles, then crossed it and headed northward $\left(354^{\circ}\right)$ for 16 miles before selecting a site location on a small basement high. We then altered course to $160^{\circ}$ and dropped the beacon at $1848 \mathrm{Z}$. By $2035 \mathrm{Z}$ we were on site at $30^{\circ} 16.59^{\prime} \mathrm{S}, 35^{\circ} 17.11^{\prime} \mathrm{W}$, in $1313 \mathrm{~m}$ of water (Fig. 2).

Our strategy for Site 516 was to use the HPC to the limit of its capability in the first hole, then pull to the mudline and repeat the upper part of the section in anticipation of heavy demand for samples. Hole 516 was cored to a depth of $183.3 \mathrm{~m}$ below the mudline, where HPC coring was terminated at the top of a stiff chalk zone at $1500 \mathrm{Z}$ on $12 \mathrm{March}$. Forty-four HPC cores were taken in Hole 516 , and $148.7 \mathrm{~m}(81 \%)$ of sediment were recovered (Table 1). Hole 516A was spudded at $1716 \mathrm{Z}$ on 12 March and cored using the HPC to a depth of $69.5 \mathrm{~m}$, of which $61.10 \mathrm{~m}(88 \%)$ were recovered. HPC operations were terminated at $0530 \mathrm{Z}$ on 13 March.

The hydraulic piston corer worked very well, but the upper $50 \mathrm{~cm}$ or so of each core were badly disturbed, probably because the bit was washed down to the top of the cored interval. Physical properties measurements in- 


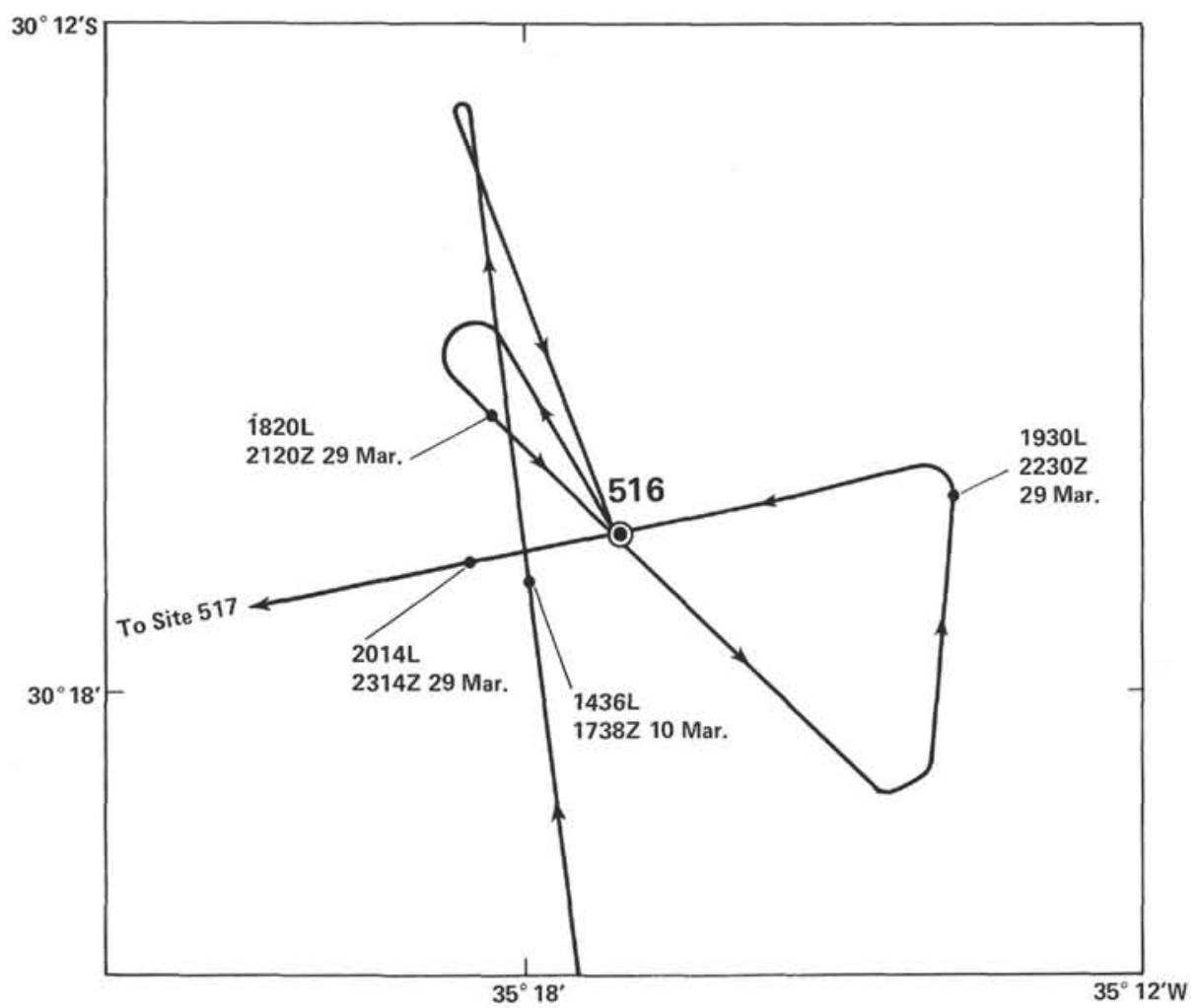

Figure 2. Approach and departure, Site 516.

dicate slight to moderate disturbance throughout. The dominant lithology in the upper part of the section at Site 516 is an unconsolidated foraminifer sand, and its coarse grain-size aggravates the degree of disturbance.

Upon completion of Holes 516 and 516A, the drill string was pulled to the rig floor and we prepared to test the pressurized core barrel. Hole 516B was used to conduct a bit motion experiment. The hole was spudded at $1813 \mathrm{Z}$ on $13 \mathrm{March}$ and terminated at $1830 \mathrm{Z}$. The hole was washed to a depth of $15.6 \mathrm{~m}$, and one $7.6-\mathrm{m}$ core was cut during the test; $4.52 \mathrm{~m}$ of core were recovered.

Hole 516C, spudded at $1947 \mathrm{Z}$ on 13 March, was used to test the pressurized core barrel (PCB). The hole was washed to $14.1 \mathrm{~m}$ and a $6.5-\mathrm{m}$ core was cut. The PCB came up empty and had not held pressure. The bit was pulled clear of the mudline at $2042 \mathrm{Z}$ and pulled to the rig floor at $0030 \mathrm{Z}, 14 \mathrm{March}$. This complete round trip for the purpose of testing the PCB was necessary because it was proved at Site 515 that the PCB was not compatible with the hydraulic bit release.

By $0030 \mathrm{Z}$ on 14 March, the weather had deteriorated, and operations were suspended until $1012 Z$ on 14 March because of high winds. Because our plan was to reach basement at an estimated depth of about $1100 \mathrm{~m}$ without benefit of re-entry, an F93CK bit was selected for rotary coring. A hydraulic bit release was included in the bottom-hole assembly in anticipation of logging the hole.

Hole 516D was spudded at $1532 \mathrm{Z}$ and washed to a depth of $90.1 \mathrm{~m}$ sub-bottom. We were unable to retrieve the wash core, and a second core barrel was dropped. Upon recovery, at $1900 \mathrm{Z}$, the second core barrel con- tained about $1 \mathrm{~m}$ of sediment, which indicated that we had accidentally dropped the bit. The bit release probably shifted partially when it was greased, and it subsequently failed. The drill string was pulled to the surface by $2242 \mathrm{Z}$ on $14 \mathrm{March}$, thereby terminating Hole 516D.

Having lost our only 93 bit, we rigged an F94CK bit for Hole 516E. The 94 bit is designed for hard formations and has substantially shorter teeth than does the 93. Hole 516E was spudded at $0418 \mathrm{Z}$ on 15 March and drilled to $90.1 \mathrm{~m}$ sub-bottom. Between 0508Z and 0704Z on 15 March, we made a temperature measurement at $93.1 \mathrm{~m}$ sub-bottom, and then drilled to a depth of $128.1 \mathrm{~m}$ and made a second temperature measurement between $0757 \mathrm{Z}$ and $0924 \mathrm{Z}$. The temperature probe worked fairly well on each run, but proved to be slightly out of time (slow) in each case and apparently skipped several registers on the second run. No data were lost.

After the second temperature measurement, the combination of wind and swell was such that we could not stay on site and operate safely. The bit was therefore pulled clear of the mudline at $1307 \mathrm{Z}$ on 15 March, and the remainder of the drill string was pulled by $2300 \mathrm{Z}$, ending Hole 516E. The wind and sea did not moderate sufficiently for safe operations until $2306 \mathrm{Z}$ on 16 March, at which time we were again on site and running in the hole.

Hole $516 \mathrm{~F}$ was spudded at $0314 \mathrm{Z}$ on $17 \mathrm{March}$ and washed to $169.1 \mathrm{~m}$ sub-bottom, where another temperature measurement was made. After this measurement was completed at $0714 \mathrm{Z}$, we began continuous coring operations. At $2108 \mathrm{Z}$ on $28 \mathrm{March}$, the hole was ter- 
Table 1. Coring summary, Site 516.

\begin{tabular}{|c|c|c|c|c|c|c|c|}
\hline Core & $\begin{array}{c}\text { Date } \\
\text { (March } \\
1980)\end{array}$ & Time & $\begin{array}{l}\text { Depth from } \\
\text { drill floor } \\
\text { (m) }\end{array}$ & $\begin{array}{l}\text { Depth below } \\
\text { seafloor } \\
\text { (m) }\end{array}$ & $\begin{array}{l}\text { Length } \\
\text { cored } \\
(\mathrm{m})\end{array}$ & $\begin{array}{l}\text { Length } \\
\text { recovered } \\
\text { (m) }\end{array}$ & $\begin{array}{c}\text { Core } \\
\text { recoverec } \\
(\%)\end{array}$ \\
\hline \multicolumn{8}{|l|}{ Hole 516} \\
\hline 1 & 10 & 2314 & $1327.9-1330.4$ & $0.0-2.5$ & 2.5 & 2.34 & 94 \\
\hline 2 & 11 & 0031 & $1330.4-1334.8$ & $2.5-6.9$ & 4.4 & 3.53 & 80 \\
\hline 3 & 11 & 0140 & $1334.8-1339.2$ & $6.9-11.3$ & 4.4 & 4.64 & $100+$ \\
\hline 4 & 11 & 0223 & $1339.2-1343.6$ & $11.3-15.7$ & 4.4 & 4.41 & $100+$ \\
\hline 5 & 11 & 0335 & $1343.6-1348.0$ & $15.7-20.1$ & 4.4 & 4.60 & $100+$ \\
\hline 6 & 11 & 0435 & $1348.0-1352.4$ & $20.1-24.5$ & 4.4 & 4.62 & $100+$ \\
\hline 7 & 11 & 0530 & $1352.4-1356.8$ & $24.5-28.9$ & 4.4 & 4.49 & $100+$ \\
\hline 8 & 11 & 0610 & $1356.8-1361.2$ & $28.9-33.3$ & 4.4 & 4.60 & $100+$ \\
\hline 9 & 11 & 0655 & $1361.2-1365.6$ & $33.3-37.7$ & 4.4 & 4.45 & $100+$ \\
\hline 10 & 11 & 0740 & $1365.6-1370.0$ & $37.7-42.1$ & 4.4 & 4.11 & 93 \\
\hline 11 & 11 & 0834 & $1370.0-1374.4$ & $42.1-46.5$ & 4.4 & 4.13 & 94 \\
\hline 12 & 11 & 0918 & $1374.4-1378.8$ & $46.5-50.9$ & 4.4 & 4.57 & $100+$ \\
\hline 13 & 11 & 1006 & $1378.8-1383.2$ & $50.9-55.3$ & 4.4 & 3.93 & 89 \\
\hline 14 & 11 & 1045 & $1383.2-1387.6$ & $55.3-59.7$ & 4.4 & 4.44 & $100+$ \\
\hline 15 & 11 & 1125 & $1387.6-1392.0$ & $59.7-64.1$ & 4.4 & 2.81 & 64 \\
\hline 16 & 11 & 1300 & $1392.0-1396.4$ & $64.1-68.5$ & 4.4 & 2.91 & 66 \\
\hline 17 & 11 & 1335 & $1396.4-1400.8$ & $68.5-72.9$ & 4.4 & 4.65 & $100+$ \\
\hline 18 & 11 & 1424 & $1400.8-1405.2$ & $72.9-77.3$ & 4.4 & 2.59 & 59 \\
\hline 19 & i1 & 1507 & $1405.2-1409.6$ & $77.3-81.7$ & 4.4 & 0.00 & 0 \\
\hline 20 & 11 & 1554 & $1409.6-1414.0$ & $81.7-86.1$ & 4.4 & 4.30 & 98 \\
\hline 21 & 11 & 1632 & $1414.0-1418.4$ & $86.1-90.5$ & 4.4 & 4.06 & 92 \\
\hline 22 & 11 & 1714 & $1418.4-1422.8$ & $90.5-94.9$ & 4.4 & 3.34 & 76 \\
\hline 23 & 11 & 1800 & $1422.8-1427.2$ & $94.9-99.3$ & 4.4 & 0.00 & 0 \\
\hline 24 & 11 & 2146 & $1427.2-1431.6$ & 99.3-103.7 & 4.4 & 4.67 & $100+$ \\
\hline 25 & 11 & 2232 & $1431.6-1436.0$ & $103.7-108.1$ & 4.4 & 2.78 & 63 \\
\hline 26 & 11 & 2315 & $1436.0-1440.4$ & $108.1-112.5$ & 4.4 & 4.18 & 95 \\
\hline 27 & 11 & 2403 & $1440.4-1444.8$ & $112.5-116.9$ & 4.4 & 4.42 & $100+$ \\
\hline 28 & 11 & 2438 & $1444.8-1449.2$ & $116.9-121.3$ & 4.4 & 4.54 & $100+$ \\
\hline 29 & 11 & 2522 & $1449.2-1453.6$ & $121.3-125.7$ & 4.4 & 4.47 & $100+$ \\
\hline 30 & 12 & 0202 & $1453.6-1458.0$ & $125.7-130.1$ & 4.4 & 3.84 & 87 \\
\hline 31 & 12 & 0303 & $1458.0-1462.4$ & $130.1-134.5$ & 4.4 & 0.00 & 0 \\
\hline 32 & 12 & 0358 & $1462.4-1466.8$ & $134.5-138.9$ & 4.4 & 4.39 & 100 \\
\hline 33 & 12 & 0450 & $1466.8-1471.2$ & $138.9-143.3$ & 4.4 & 3.37 & 77 \\
\hline 34 & 12 & 0530 & $1471.2-1475.6$ & $143.3-147.7$ & 4.4 & 4.07 & 93 \\
\hline 35 & 12 & 0703 & $1475.6-1480.0$ & $147.7-152.1$ & 4.4 & 4.32 & 98 \\
\hline 36 & 12 & 0830 & $1480.0-1484.4$ & $152.1-156.5$ & 4.4 & 2.37 & 54 \\
\hline 37 & 12 & 0920 & $1484.4-1488.8$ & $156.5-160.9$ & 4.4 & 2.69 & 61 \\
\hline 38 & 12 & 1010 & $1488.8-1493.2$ & $160.9-165.3$ & 4.4 & 2.89 & 66 \\
\hline 39 & 12 & 1053 & $1493.2-1497.2$ & $165.3-169.3$ & 4.0 & 3.66 & 92 \\
\hline 40 & 12 & 1150 & $1497.2-1501.2$ & $169.3-173.3$ & 4.0 & 4.05 & $100+$ \\
\hline 41 & 12 & 1233 & $1501.2-1505.2$ & $173.3-177.3$ & 4.0 & 0.00 & 0 \\
\hline 42 & 12 & 1324 & $1505.2-1508.7$ & $177.3-180.8$ & 3.5 & 3.17 & 91 \\
\hline 43 & 12 & 1410 & $1508.7-1510.2$ & $180.8-182.3$ & 1.5 & 0.62 & 41 \\
\hline 44 & 12 & 1458 & $1510.2-1511.2$ & $182.3-183.3$ & 1.0 & 0.05 & 5 \\
\hline & & & & & 183.3 & 148.07 & 81 \\
\hline Hole 516A & & & & & & & \\
\hline 1 & 12 & 1727 & $1327.9-1331.4$ & $0.0-3.5$ & 3.5 & 3.80 & $100+$ \\
\hline 2 & 12 & 1807 & $1331.4-1335.8$ & $3.5-7.9$ & 4.4 & 4.22 & 96 \\
\hline 3 & 12 & 1852 & $1335.8-1340.2$ & $7.9-12.3$ & 4.4 & 3.62 & 82 \\
\hline 4 & 12 & 2012 & $1340.2-1344.6$ & $12.3-16.7$ & 4.4 & 4.25 & 97 \\
\hline 5 & 12 & 2109 & $1344.6-1349.0$ & $16.7-21.1$ & 4.4 & 4.30 & 98 \\
\hline 6 & 12 & 2150 & $1349.0-1353.4$ & $21.1-25.5$ & 4.4 & 4.51 & $100+$ \\
\hline 7 & 12 & 2235 & $1353.4-1357.8$ & $25.5-29.9$ & 4.4 & 4.26 & 97 \\
\hline 8 & 12 & 2315 & $1357.8-1362.2$ & $29.9-34.3$ & 4.4 & 4.35 & 99 \\
\hline 9 & 13 & 0000 & $1362.2-1366.6$ & $34.3-38.7$ & 4.4 & 4.60 & $100+$ \\
\hline 10 & 13 & 0044 & $1366.6-1371.0$ & $38.7-43.1$ & 4.4 & 4.56 & $100+$ \\
\hline II & 13 & 0124 & $1371.0-1375.4$ & $43.1-47.5$ & 4.4 & 3.93 & 89 \\
\hline 12 & 13 & 0211 & $1375.4-1379.8$ & $47.5-51.9$ & 4.4 & 4.66 & $100+$ \\
\hline 13 & 13 & 0250 & $1379.8-1384.2$ & $51.9-56.3$ & 4.4 & 3.96 & 90 \\
\hline 14 & 13 & 0335 & $1384.2-1388.6$ & $56.3-60.7$ & 4.4 & 4.54 & $100+$ \\
\hline 15 & 13 & 0417 & $1388.6-1393.0$ & $60.7-65.1$ & 4.4 & 0.00 & 0 \\
\hline 16 & 13 & 0509 & $1393.0-1397.4$ & $65.1-69.5$ & 4.4 & 1.54 & 35 \\
\hline & & & & & 69.5 & 61.10 & 88 \\
\hline Hole 516B & & & & & & & \\
\hline Washed & 13 & & $1327.9-1343.5$ & $0.0-15.6$ & & & \\
\hline 1 & 13 & 1919 & $1343.5-1351.1$ & $15.6-23.2$ & 7.6 & 4.52 & 59 \\
\hline & & & & & 7.6 & 4.52 & 59 \\
\hline Hole 516C & & & & & & & \\
\hline Washed & 13 & & $1327.9-1342.0$ & $0.0-14.1$ & & & \\
\hline 1 & 13 & 2126 & $1342.0-1348.5$ & $14.1-20.6$ & 6.5 & 0.00 & 0 \\
\hline & & & & & 6.5 & 0.00 & 0 \\
\hline Hole 516D & & & & & & & \\
\hline Washed & 14 & & $1327.9-1418.0$ & $0.0-90.1$ & & & \\
\hline Hole $516 \mathrm{E}$ & & & & & & & \\
\hline Washed & 15 & & $1327.9-1418.0$ & $0.0-90.1$ & & & \\
\hline Hole 516F & & & & & & & \\
\hline Washed & 17 & & $1327.9-1497.0$ & $0.0-169.1$ & & & \\
\hline 1 & 17 & 0805 & $1497.0-1506.5$ & $169.1-178.6$ & 9.5 & 3.02 & 32 \\
\hline 2 & 17 & 0910 & $1506.5-1516.0$ & $178.6-188.1$ & 9.5 & 9.65 & $100+$ \\
\hline 3 & 17 & 1015 & $1516.0-1525.5$ & $188.1-197.6$ & 9.5 & 9.78 & $100+$ \\
\hline 4 & 17 & 1135 & $1525.5-1535.0$ & $197.6-207.1$ & 9.5 & 9.49 & 100 \\
\hline 5 & 17 & 1245 & $1535.0-1544.5$ & $207.1-216.6$ & 9.5 & 9.84 & $100+$ \\
\hline 6 & 17 & 1336 & $1544.5-1554.0$ & $216.6-226.1$ & 9.5 & 2.24 & 24 \\
\hline 7 & 17 & 1419 & $1554.0-1563.5$ & $226.1-235.6$ & 9.5 & 4.51 & 47 \\
\hline 8 & 17 & 1543 & $1563.5-1573.0$ & $235.6-245.1$ & 9.5 & 9.80 & $100+$ \\
\hline 9 & 17 & 1717 & $1573.0-1582.5$ & $245.1-254.6$ & 9.5 & 6.30 & 66 \\
\hline 10 & 17 & 1854 & $1582.5-1592.0$ & $254.6-264.1$ & 9.5 & 4.79 & 50 \\
\hline
\end{tabular}

Table 1. (Continued).

\begin{tabular}{|c|c|c|c|c|c|c|c|}
\hline Core & $\begin{array}{c}\text { Date } \\
\text { (March } \\
\text { 1980) }\end{array}$ & Time & $\begin{array}{l}\text { Depth from } \\
\text { drill floor } \\
\text { (m) }\end{array}$ & $\begin{array}{l}\text { Depth below } \\
\text { seafloor } \\
\text { (m) }\end{array}$ & $\begin{array}{l}\text { Length } \\
\text { cored } \\
\text { (m) }\end{array}$ & $\begin{array}{l}\text { Length } \\
\text { recovered } \\
\text { (m) }\end{array}$ & $\begin{array}{c}\text { Core } \\
\text { recovered } \\
(\%)\end{array}$ \\
\hline
\end{tabular}

Hole 516F Cont.

\begin{tabular}{|c|}
\hline 11 \\
\hline 12 \\
\hline 13 \\
\hline 14 \\
\hline 15 \\
\hline 16 \\
\hline 17 \\
\hline 18 \\
\hline 19 \\
\hline 20 \\
\hline 21 \\
\hline 22 \\
\hline 23 \\
\hline 24 \\
\hline 25 \\
\hline 26 \\
\hline 27 \\
\hline 28 \\
\hline 29 \\
\hline 30 \\
\hline 31 \\
\hline 32 \\
\hline 33 \\
\hline 34 \\
\hline 35 \\
\hline 36 \\
\hline 37 \\
\hline 38 \\
\hline 39 \\
\hline 40 \\
\hline 41 \\
\hline 42 \\
\hline 43 \\
\hline 44 \\
\hline 45 \\
\hline 46 \\
\hline 47 \\
\hline 48 \\
\hline 49 \\
\hline 50 \\
\hline 51 \\
\hline 52 \\
\hline 53 \\
\hline 54 \\
\hline 55 \\
\hline 56 \\
\hline 57 \\
\hline 58 \\
\hline 59 \\
\hline 60 \\
\hline 61 \\
\hline 62 \\
\hline 63 \\
\hline 64 \\
\hline 65 \\
\hline 66 \\
\hline 67 \\
\hline 68 \\
\hline 69 \\
\hline 70 \\
\hline 71 \\
\hline 72 \\
\hline 73 \\
\hline 74 \\
\hline 75 \\
\hline 76 \\
\hline 77 \\
\hline 78 \\
\hline 79 \\
\hline 80 \\
\hline 81 \\
\hline 82 \\
\hline 83 \\
\hline 84 \\
\hline 85 \\
\hline 86 \\
\hline 87 \\
\hline 88 \\
\hline 89 \\
\hline 90 \\
\hline 91 \\
\hline 92 \\
\hline 93 \\
\hline 94 \\
\hline 95 \\
\hline 96 \\
\hline 97 \\
\hline 98 \\
\hline 99 \\
\hline 100 \\
\hline 101 \\
\hline 102 \\
\hline 103 \\
\hline 104 \\
\hline 105 \\
\hline 106 \\
\hline 107 \\
\hline 108 \\
\hline
\end{tabular}


Table 1. (Continued).

\begin{tabular}{|c|c|c|c|c|c|c|c|}
\hline Core & $\begin{array}{c}\text { Date } \\
\text { (March } \\
\text { 1980) }\end{array}$ & Time & $\begin{array}{l}\text { Depth from } \\
\text { drill floor } \\
\text { (m) }\end{array}$ & $\begin{array}{l}\text { Depth below } \\
\text { seafloor } \\
\text { (m) }\end{array}$ & $\begin{array}{l}\text { Length } \\
\text { cored } \\
\text { (m) }\end{array}$ & $\begin{array}{l}\text { Length } \\
\text { recovered } \\
\text { (m) }\end{array}$ & $\begin{array}{l}\text { Core } \\
\text { recovered } \\
(\%)\end{array}$ \\
\hline \multicolumn{8}{|c|}{ Hole $516 \mathrm{~F}$ Cont. } \\
\hline 109 & 25 & 2244 & $2437.0-2446.0$ & $1109.1-1118.1$ & 9.0 & 7.06 & 78 \\
\hline 110 & 26 & 0122 & $2446.0-2455.0$ & $1118.1-1127.1$ & 9.0 & 9.10 & $100+$ \\
\hline III & 26 & 0422 & $2455.0-2464.0$ & $1127.1-1136.1$ & 9.0 & 0.00 & 0 \\
\hline 112 & 26 & 0812 & $2464.0-2473.0$ & $1136.1-1145.1$ & 9.0 & 8.66 & 96 \\
\hline 113 & 26 & 1140 & $2473.0-2481.0$ & $1145,1-1154,1$ & 9.0 & 9.53 & $100+$ \\
\hline 114 & 26 & 1507 & $2481.0-2490.0$ & $1154,1-1163.1$ & 9.0 & 8.82 & 98 \\
\hline 115 & 26 & 1518 & $2491.0-2500.0$ & $1163.1-1172.1$ & 9.0 & 5.90 & 66 \\
\hline 116 & 26 & 2017 & $2500.0-2509.0$ & $1172.1-1181.1$ & 9.0 & 8.16 & 91 \\
\hline 117 & 27 & 0215 & $2509.0-2518.0$ & $1181.1-1190.1$ & 9.0 & 8.98 & 99 \\
\hline 118 & 27 & 0834 & $2518.0-2522.5$ & $1190.1-1194.6$ & 4.5 & 4.01 & 89 \\
\hline 119 & 27 & 1409 & $2522.5-2531.5$ & $1194.6-1203.6$ & 9.0 & 6.57 & 73 \\
\hline 120 & 27 & 1618 & $2531.5-2540.5$ & $1203.6-1212.6$ & 9.0 & 2.10 & 23 \\
\hline 121 & 27 & 1814 & $2540.5-2549.5$ & $1212.6-1221.6$ & 9.0 & 0.68 & 8 \\
\hline 122 & 27 & 2007 & $2549.5-2558.5$ & $1221.6-1230.6$ & 9.0 & 2.97 & 33 \\
\hline 123 & 27 & 2205 & $2558.5-2567.5$ & $1230.6-1239.6$ & 9.0 & 0.94 & 10 \\
\hline 124 & 28 & 0125 & $2567.5-2576.5$ & $1239.6-1248.6$ & 9.0 & 1.39 & is \\
\hline 125 & 28 & 0421 & $2576.5-2580.5$ & $1248.6-1252.6$ & 4.0 & 1.60 & 40 \\
\hline 126 & 28 & 0733 & $2580.5-2585.5$ & $1252.6-1257.6$ & 5.0 & 4.76 & 95 \\
\hline 127 & 28 & 1316 & $2585.5-2594.5$ & $1257.6-1266.6$ & 9.0 & 5.75 & 64 \\
\hline \multirow[t]{2}{*}{128} & 28 & 1808 & $2594.5-2598.5$ & $1266.6-1270.6$ & 4.0 & 3.00 & 75 \\
\hline & & & & & 1101.5 & 691.72 & 63 \\
\hline
\end{tabular}

minated, after continuous coring to a depth of $1270.6 \mathrm{~m}$ sub-bottom. Basaltic basement was encountered at a depth of $1256.2 \mathrm{~m}$ and penetrated another $18.0 \mathrm{~m}$, at which time the bit had been rotated for an incredible $157.8 \mathrm{hr}$. Of the $1270.6-\mathrm{m}$ interval cored, we recovered $691.72 \mathrm{~m}(63 \%)$ in 128 cores (Table 1).

We attempted to log the hole on the morning of 29 March, but found it bridged at about $184 \mathrm{~m}$ sub-bottom. A wiper run was unsuccessful, and we were forced to abandon the hole.

We left Site 516 at $2050 \mathrm{Z}$ on $29 \mathrm{March}$, heading $330^{\circ}$ for approximately two nautical miles before altering course back to the site on heading $135^{\circ}$, crossing the beacon at $2132 \mathrm{Z}$. After maintaining that course for about three miles beyond Site 516, we followed a northerly course $\left(006^{\circ}\right)$ for another three miles in order to obtain a profile linking the site with multichannel line WSA13. At $2230 \mathrm{Z}$ on $29 \mathrm{March}$, we altered course to $260^{\circ}$ enroute to Site 517 and crossed the beacon at Site 516 for the last time at $2302 \mathrm{Z}$.

\section{SEDIMENT LITHOLOGY}

The drilled section at Site 516 is composed of eight different units distinguishable by the microfossil content, carbonate percentage, minor constituents, degree of induration or diagenesis, and sedimentary structures and colors (Fig. 3). (Depths in parentheses are sub-bottom depths.)

\section{Unit 1: Calcareous Ooze (0-193 m)}

Unit 1 is $193 \mathrm{~m}$ thick and spans Cores 1 to 44 (Hole 516); Cores 1 to 16 (Hole 516A); and Cores 1 to 4 (Hole $516 \mathrm{~F})$. It is Quaternary to early Miocene in age and consists of poorly consolidated calcareous ooze including: foraminiferal ooze (0-15 m sub-bottom, Cores 1 to 4 at Holes 516, 516A); foraminiferal-nannofossil ooze (15-135 m sub-bottom, Cores 5 to 32 at Hole 516; Cores 5 to 16 at Hole 516A); and nannofossil ooze (135-193 m sub-bottom, Cores 33 to 44 at Hole 516; Cores 1 to 3 at Hole 516F).

Principal constituents of Unit 1 are calcareous nannofossils and planktonic foraminifers. Total carbonate (entirely biogenic) averages $90 \%$ and exceeds $75 \%$ in all but 6 of more than 350 bomb analyses (Fig. 3). Remaining components are terrigenous clay $(5-20 \%)$; feldspar, quartz, mica, and volcanic glass (rarely exceeding 3\% combined); manganese micronodules or pyrite (0-2\%); and minor siliceous biogenic debris $(0-1 \%)$. Benthic foraminifers, pelecypod shells, and pteropods are also present, although in low abundance. The latter two are only occasionally noted.

Colors vary from pale brown in the foraminifer-rich cores, to white in the foraminiferal-nannofossil and nannofossil oozes, and occasionally to shades of light gray. Burrow mottling is ubiquitous, although often faint and barely perceptible. Minor parallel laminations of pale yellow, green, white, and gray occur in Core 21 (Hole 516) and from Core 27 (Hole 516) to the base of the unit. A layer of Mn-oxide sand and granule-sized foraminifers occurs at the same level in both HPC holes (Cores 16, Holes 516 and 516A). Those components are mixed with gastropod and pelecypod fragments and with fish ossicles (similar components occur in Samples 516-14,CC and 516-37,CC, although no textural difference was noted at those two locations). This sandy interval includes a hiatus (see Biostratigraphy section) and corresponds to an acoustic horizon seen in the $3.5-\mathrm{kHz}$ seismic record. This interval may be related to slumping, but the coarse components could also be concentrated in graded zones produced by resettling during coring, and structures may not represent actual bedding.

Unit 1, in summary, is a typical calcareous ooze deposited in a tranquil environment above the calcite compensation depth (CCD) and the lysocline. There is little evidence of dissolution, cementation or reprecipitation.

\section{Unit 2: Nannofossil and Foraminiferal-Nannofossil Chalks (193-332 m)}

Early Miocene to late Oligocene in age, Unit 2 spans Cores 3 to 18 in Hole 516F. It is somewhat darker than Unit 1; the hues of Unit 2 are generally brown and yellow (white, light gray, brownish gray, and yellowish brown). Sponge spicules in a uniform concentration of approximately $10 \%$ characterize Unit 2 and are associated with thin chert laminations and concretions at various stratigraphic levels. Chert layers are greenish gray to white and very thin and hard; they are probably responsible for the poor recovery in some cores. Carbonate content ranges from 75 to $90 \%$, and the main biogenic components are nannofossils $(70-90 \%)$, foraminifers $(10 \%)$, and sponge spicules $(10 \%)$. The only sedimentary structures identified in this unit were burrows and a few intervals of parallel laminations.

\section{Unit 3: Nannofossil and Nannofossil-Foraminiferal Chalks (332-634 m)}

Unit 3 (Cores 19 to 50 of Hole 516F) consists of upper Oligocene to middle Eocene light gray, olive, olive gray, and greenish gray nannofossil and nannofossilforaminifer chalks. The color change at the upper contact is slight, from yellowish brown to light brownish gray at the base of Unit 2 to light gray, white, and olive 

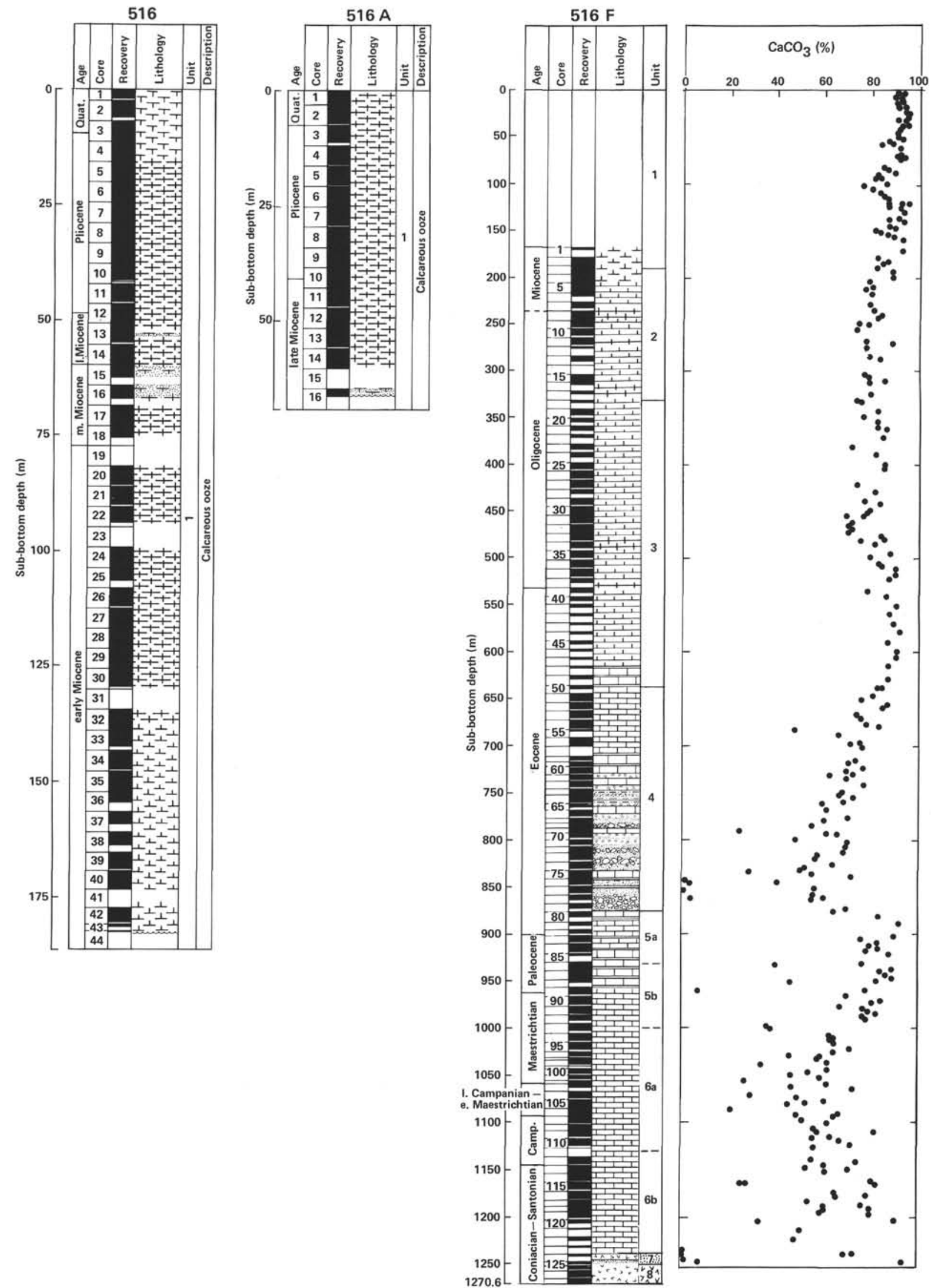

Figure 3. Major lithologic units and percent $\mathrm{CaCO}_{3}$ at Site 516, Rio Grande Rise. Quat. = Quaternary. Note vertical scale change between HPC Holes 516 and 516A and rotary-cored Hole 516F. Symbols according to DSDP convention (Coulbourn, this volume). 
gray at the top of Unit 3. The biogenic silica and chert that characterize Unit 2 are absent. Percentages of foraminifers (less than 10\%) and of nannofossils (60-70\%) decrease slightly in the top third of this unit, but in the remaining two-thirds, both foraminifers (up to 20\%) and nannofossils (70-80\%) increase. Small fluctuations in the relative fossil percentages indicate that Unit 3 is formed by alternations of argillaceous and slightly more consolidated nannofossil chalks, with nannofossil-foraminifer chalks. The carbonate percentage is uniform throughout the unit, ranging from 70 to $90 \%$.

The minor components of this unit are a few bivalve shells, quartz grains, volcanic glass, micronodules (manganese), and unspecified carbonate and clay minerals.

In the upper part, the only sedimentary structures visible are burrows. These are preferentially horizontal to subhorizontal and characteristically occupy the entire core width. In the lower two-thirds of Unit 3, besides bioturbation, parallel laminations are very conspicuous (Sections 516F-33-3 and 516F-36-2, and core catchers of Sections 516F-38-1 and 516F-38-2). Probably the same structures are present in the upper part, but could not be detected because of drilling disturbance and the softness of the sediments.

\section{Unit 4: Nannofossil and Foraminiferal Limestones (634-874 m)}

Unit 4 (Cores $516 \mathrm{~F}-50$ to $516 \mathrm{~F}-79$ ) consists of middle Eocene dark gray, olive gray, yellowish brown, light gray, and reddish brown nannofossil and foraminiferal limestones.

Greenish gray montmorillonitic ash layers are interstratified with calcareous layers and turbidites rich in both glauconite and biotite (Cores 53, 61 to 64, 68, 72, 78,79 of Hole $516 \mathrm{~F}$ ). Unit 4 is lithologically heterogeneous, and its carbonate content is as variable as its lithology. Carbonate content is high in the limestones $(60-70 \%)$ and very low in the clayey sequences $(3-50 \%)$. Limestones are similar to those of Unit 3, although $\mathrm{CaCO}_{3}$ generally decreases down-section towards marly limestone. The relative abundance of nannofossils reaches $80 \%$, and foraminifers $10 \%$. The limestones are laminated, finely crystalline and intensely burrowed. The porosity of these layers is probably derived from the dissolution of foraminifers (moldic porosity). Some volcanic ash is present, but much of what was originally described as volcanic is in fact detrital clay (Bryan and Duncan, this volume). Fining-upward sequences (turbidites), rich in limestone fragments, glauconite, biotite, and montmorillonitic layers, are dispersed throughout the unit. The turbidite layers vary from 3 to $5 \mathrm{~cm}$ in thickness (Figs. 4 and 5). Several of these sequences are repeated, forming intervals tens of centimeters thick. Black to dark gray clayey layers usually underlie these fining-upward sequences. These layers in turn are underlain by $5-10 \mathrm{~cm}$ thick, nonbioturbated limestone. Usually only the " $A$ " interval of the classic Bouma turbidite sequence is present; in Core 61 , however, one nearly complete Bouma sequence was recovered associated with several thinner fining-upward sequences (Fig. 6). The graded components of the fining-upward

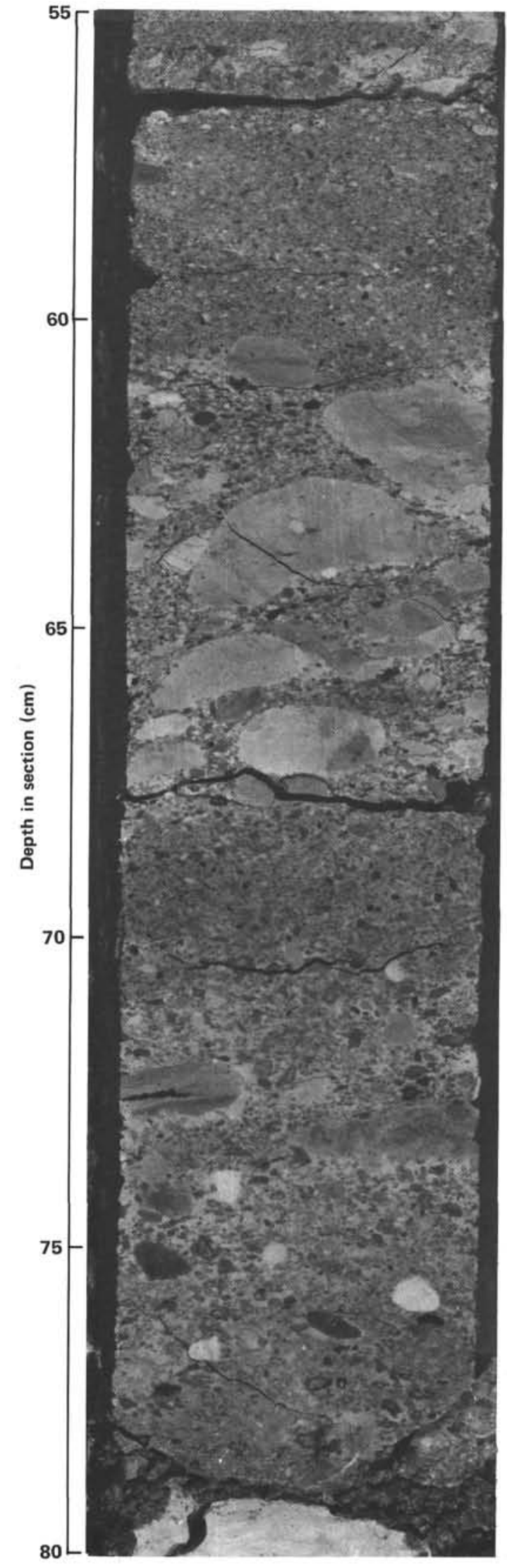

Figure 4. Calcareous sandstones and limestone breccia in 516F-68-3, $55-80 \mathrm{~cm}$. 


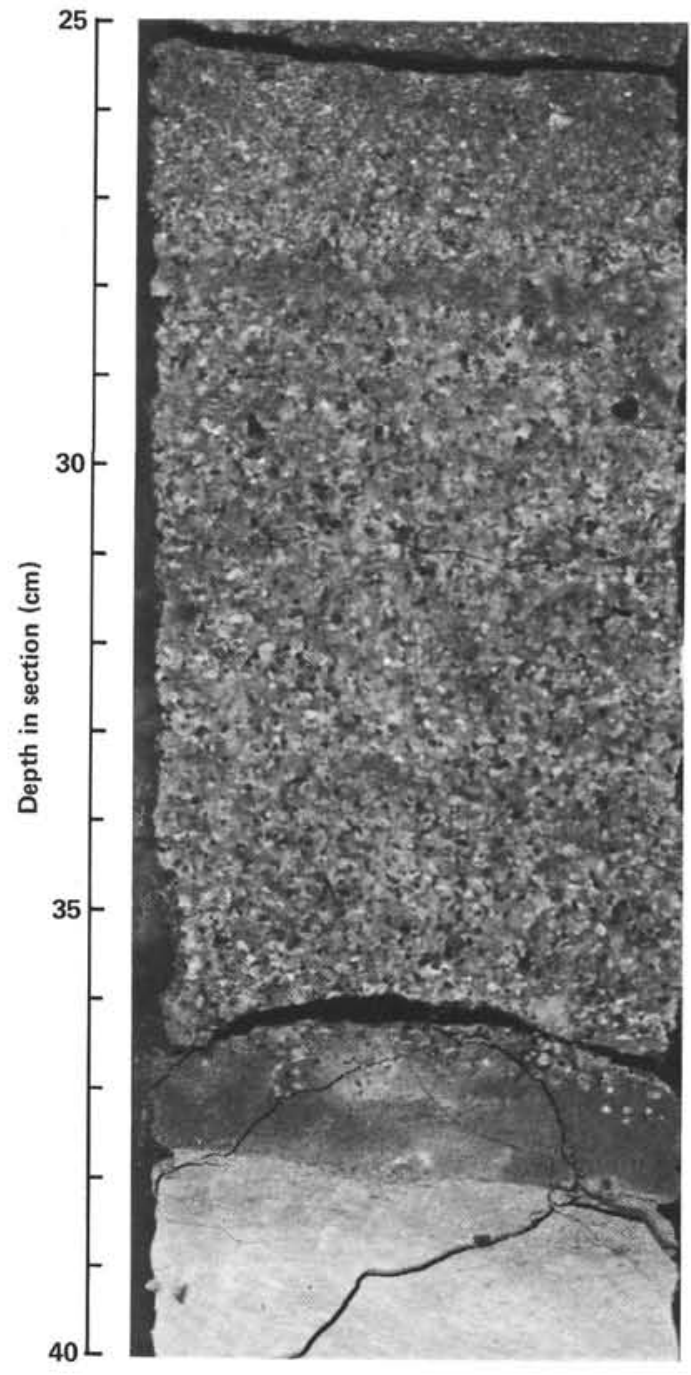

Figure 5. Turbidites in $516 \mathrm{~F}-62-3,25-40 \mathrm{~cm}$.

sequences are montmorillonitic aggregates, biotite, pyrite, and fossil fragments. These components are grit size or coarse sand size at the base and grade upward to very fine clay.

The largest allochthonous contribution to Unit 4 is a 15-m thick deposit occupying much of Cores 78 and 79 (Fig. 7). Specifically, this interval contains two slump blocks of dark brown to dark red-brown limestone of Late Cretaceous age separated by a $30-\mathrm{cm}$ thick layer of graded beds and small cobble-size clasts of volcanic rock and volcanogenic sediment. The Cretaceous limestone is undeformed in places, but its borders show considerable soft sediment deformation, which suggests that it was emplaced as a semiconsolidated ooze or chalk by downslope slumping.

In addition to the sedimentary structures described above, mottling (mainly due to bioturbation) and possible parallel and cross laminations are present in Unit 4. Mottling is conspicuous in the calcareous layers where recrystallization was not extensive. A large vertical burrow (1.5 cm diameter; $100 \mathrm{~cm}$ long) occurs in Section $516 \mathrm{~F}-50-1$ (Fig. 8). This burrow is mostly filled by medium gray calcarenite that is rich in large benthic fora-

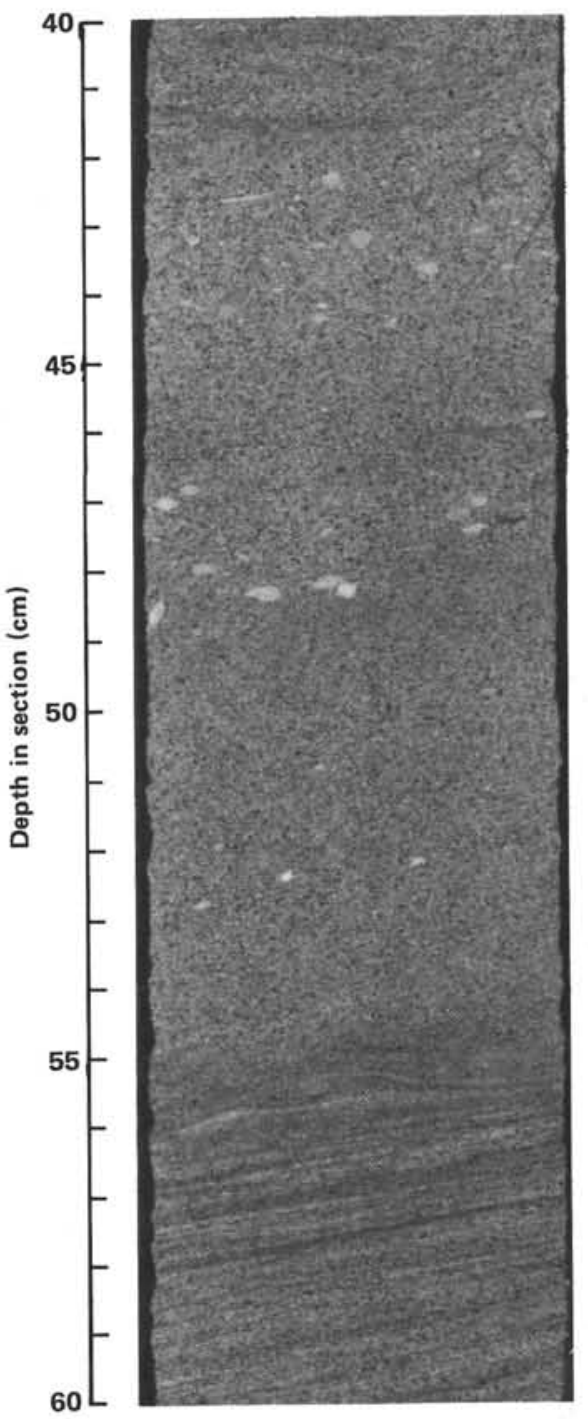

Figure 6. Bouma sequence in $516 \mathrm{~F}-61-5,40-60 \mathrm{~cm}$.

minifers, as is the calcarenite layer that lies at the upper extremity of the burrow. Limestone clasts within a fanglomeratic layer are imbricated (Core 516F-63, Fig. 9). Parallel laminations and possible cross-bedding occur in Unit 4, but most of these structures are partially disturbed by compaction (Figs. 10 and 11).

The lower boundary of Unit 4 is placed at the base of the Cretaceous block (Section 516F-79-4). At that level, colors change from reddish brown and dark red at the base of Unit 4 to gray, light gray, and white at the top of Unit 5; the carbonate percentage increases rapidly from a variable level $(5-50 \%)$ at the base of Unit 4 to uniformly higher levels near $80 \%$ at the top of Unit 5 . The fining-upward, glauconite-rich turbidites and other volcanic-derived sediments common in Unit 4 are absent in Unit 5.

\section{Unit 5: Limestones and Marly Limestones (874-1000 m)}

Unit 5 (Cores 80 to 93 of Hole 516F) consists of 2 subunits: light gray limestones at the top (Subunit 5a) grading to reddish brown limestones and marly lime- 


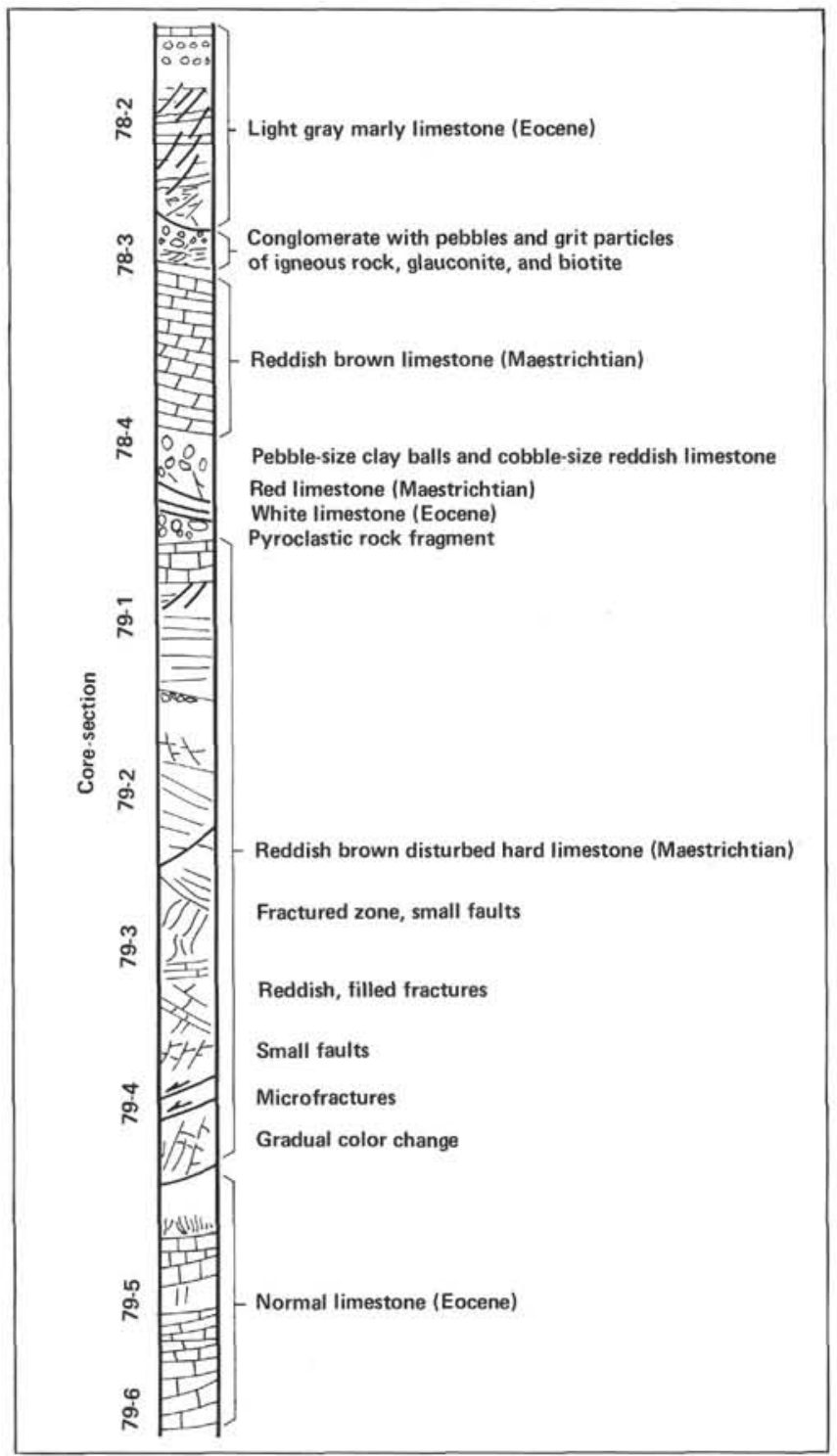

Figure 7. Graphic summary of Cores $516 \mathrm{~F}-78$ and $516 \mathrm{~F}-79$ showing Cretaceous slump block.

stones below $930 \mathrm{~m}$ sub-bottom (Subunit $5 \mathrm{~b}$ ). The subunit boundary is gradational and somewhat arbitrary.

Subunit $5 a(874-930 \mathrm{~m}$, Cores 80 to 86$)$ contains middle Eocene to middle Paleocene, gray to light gray and light green limestones, with small intervals of dark greenish gray sediment slightly rich in organic matter. The limestones of Cores 81,86 , and 87 are partially dolomitized and harder than those in surrounding intervals.

Pressure solution has altered the internal organization of the carbonate components of Subunit 5a, producing a series of false sedimentary structures similar to convolute bedding, lenticular bedding, and parallel laminations. The only sedimentary structures still present in these rocks are burrows, some partially destroyed by dissolution and recrystallization. In some cases, flattened burrows and clay balls interpenetrate. Porosity increases slightly downcore in the Subunit 5a limestones.

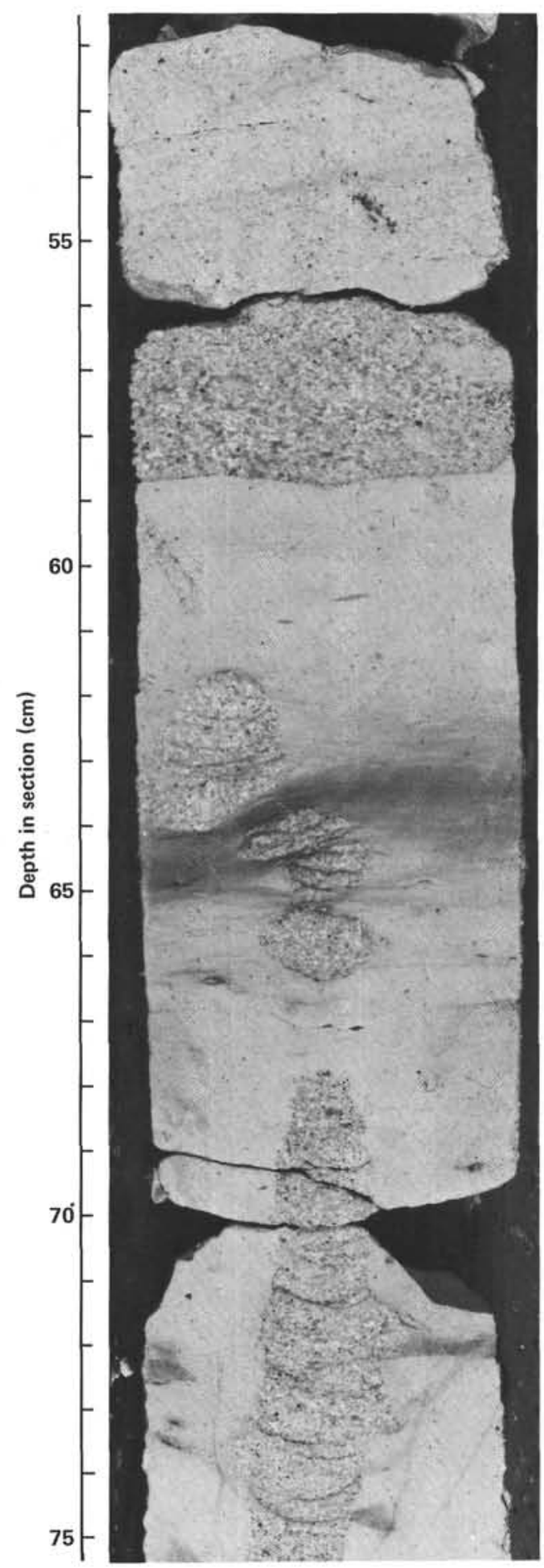

Figure 8. Large vertical burrow in 516F-50-1, 51-75 cm.

The 3 to $5 \mathrm{~cm}$ thick, dark greenish gray layers that are slightly rich in organic matter are marly limestone and are present in almost all cores of Unit 5 .

Carbonate percentages are high, ranging from 75 to $90 \%$, and the microfossil content is as follows: foraminifers 5-10\%; nannofossils variable from 10 to $80 \%$. The fossils are best preserved in the darker layers where recrystallization was less extensive, although initially the 


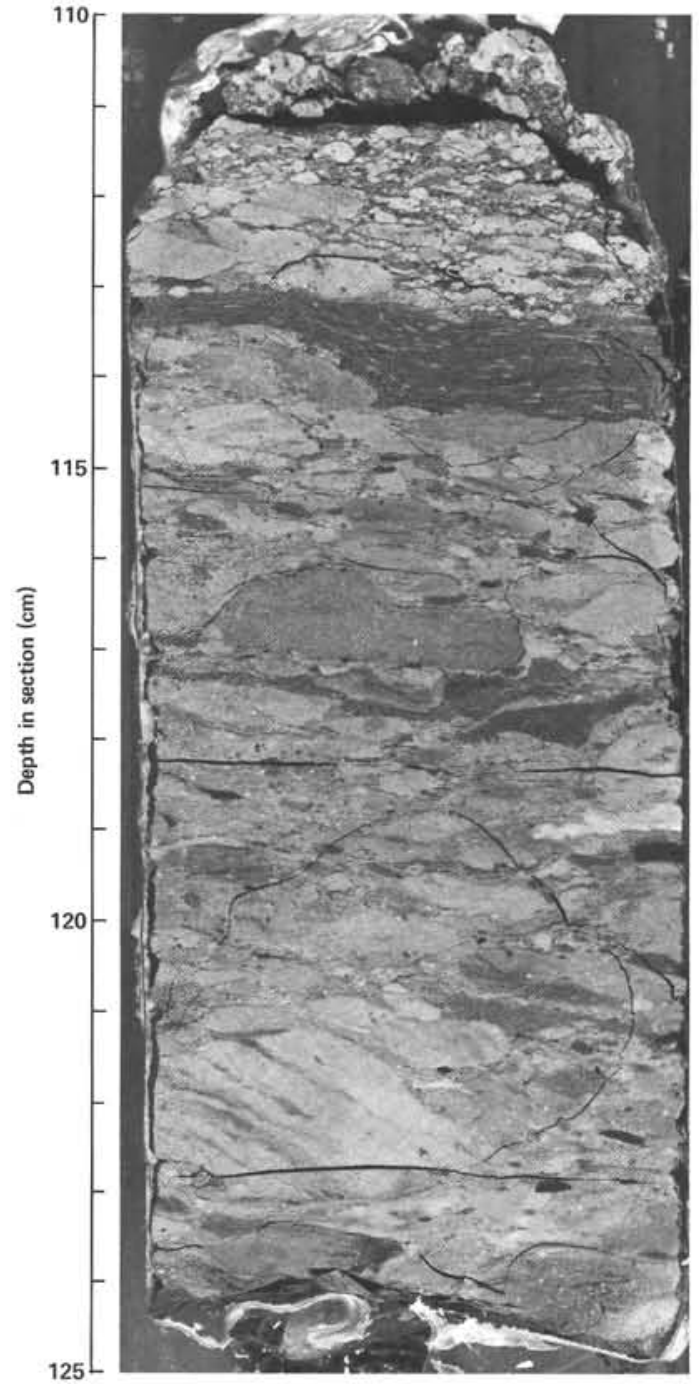

Figure 9. Imbricated limestone clasts in $516 \mathrm{~F}-63-6,110-125 \mathrm{~cm}$.

carbonate content of those intervals was relatively low. Minor components are calcite and dolomite rhombs, detrital clays, volcanic glass, and quartz $(2-3 \%)$. The lower boundary of this subunit is a gradational color change from white in Core 85 to light brownish gray in Core 86.

Subunit 5b (930-1000 m sub-bottom, Cores 86 to 93) consists of Paleocene and Maestrichtian interbedded reddish limestones and reddish brown marly limestones. The sediments of Subunit $5 \mathrm{~b}$ are intensively burrowed, except in light-colored zones where recrystallization reaches a high degree. Kaolinite and illite are present in this subunit, but not above. The Cretaceous/Tertiary boundary occurs in Section 516F-89-5 (see frontispiece and Fig. 12). Its lithology is described in detail by Michel et al. (this volume).

\section{Unit 6: Marly Limestones and Claystones (1000-1240 m)}

Unit 6 (Cores 93 to 124 in Hole 516F) contains Maestrichtian to Coniacian-Santonian light gray to white,

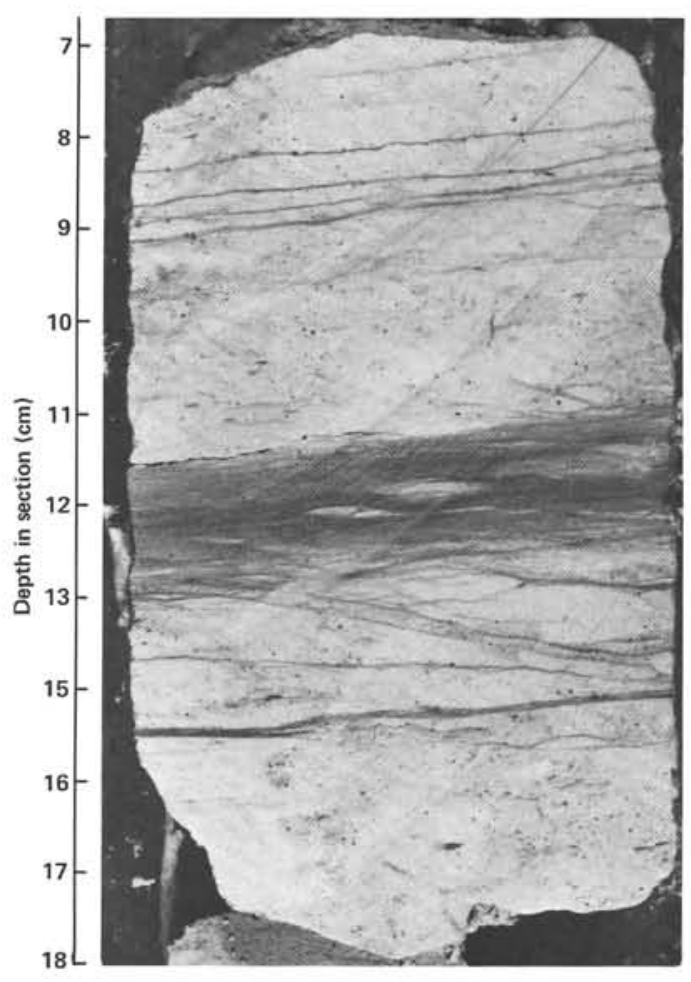

Figure 10. Parallel laminations in 516F-48-2, 7-18 cm.

and gray to dark gray marly limestone and claystone. It consists of two subunits as follows.

Subunit 6a (1000-1130 m sub-bottom, Cores 93 to 111) contains marly limestones interbedded with micritic nannofossil limestones. Variegated colors range from light greenish gray to dark brownish red. The limestone is intensively burrowed throughout.

Subunit $6 \mathrm{a}$ is lithologically distinct from the unit above in that the pressure solution effects abundant in Unit 5 are absent. In addition, marly intervals are more common in Unit 6.

Some greenish gray, gray, and light gray marly limestones and claystones are present in the middle part of this subunit (Cores 98 to 103), and these have the lowest carbonate content of all sediments within Subunit 6a. Carbonate contents range from 70 to $30 \%$. The terrigenous components-clay, detrital quartz (up to 10\%), feldspar (up to $5 \%$ ), biotite, zeolite (up to $5 \%$ ), and volcanic glass-increase in relative abundance toward the base of Subunit 6a. Nannofossils (10-80\%), foraminifers (up to $10 \%$ ), and recrystallized calcite (up to $50 \%$ ) account for the carbonate fraction. Remains of Inoceramus first appear at Core $101(1050 \mathrm{~m}$ sub-bottom). A gradual color change from weak red, reddish brown, and light reddish brown to grays marks the base of Subunit 6a.

Subunit $6 b$ (1130-1240 m sub-bottom, Cores 111 to 124) consists of Campanian and Santonian-Coniacian microcrystalline, light gray to white limestone and gray to dark gray marly limestone and claystone.

Bioturbation is intense in Cores 112 to 117 , producing a mottled pattern apparent in the polished sections 


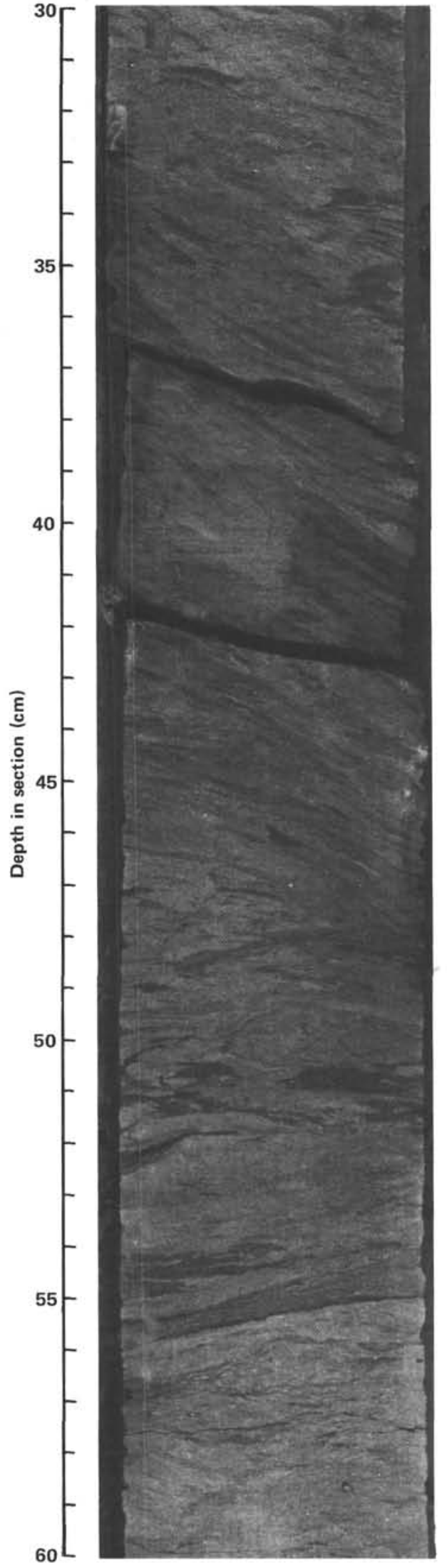

Figure 11. Cross-bedding in $516 \mathrm{~F}-64-4,30-60 \mathrm{~cm}$.

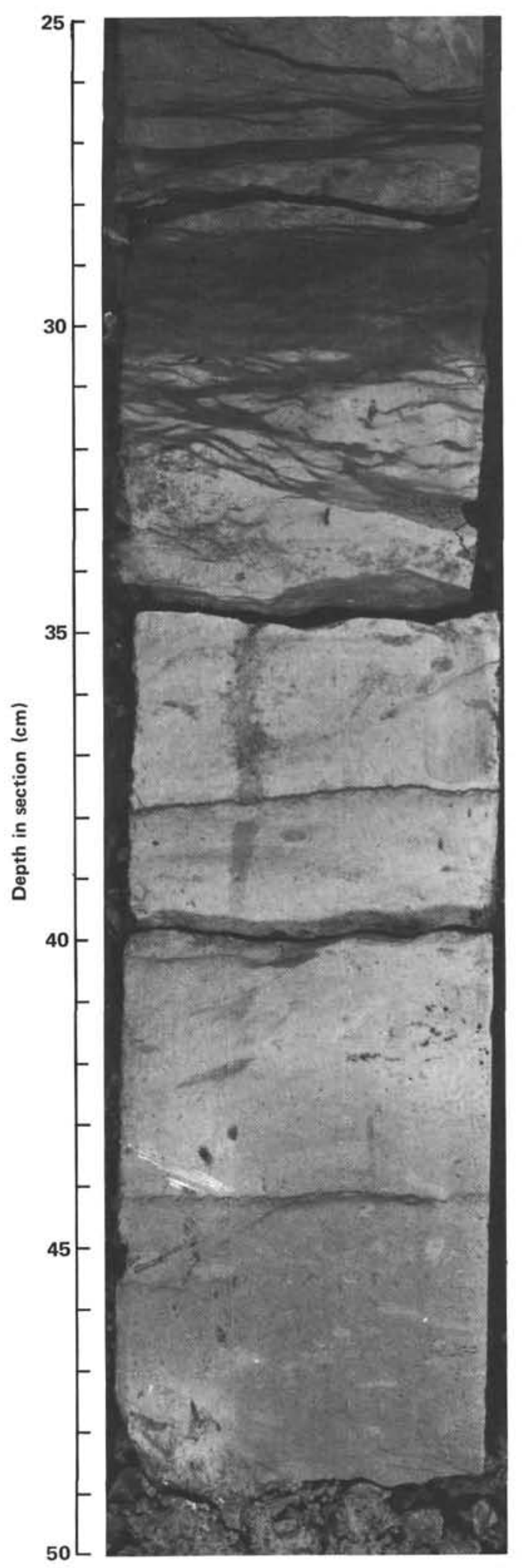

Figure 12. Cretaceous/Tertiary boundary recovered in 516F-89-5, $25-50 \mathrm{~cm}$. 
of these rocks. This section is cemented by dolomite, and is much harder than the otherwise similar rocks in Cores 108 to 110 .

Carbonate content is variable, ranging from 25 to $91 \%$. A few thin dark gray to black layers of claystone or mudstone are present in the intervals of low carbonate content. Some of them are richer in wood fragments and in organic matter than all other sediments recovered at this site. The thickest of these intervals is a $78 \mathrm{~cm}$ sequence of interbedded claystones and shales in Core 122 containing $95 \%$ organic carbon (Fig. 13 and de Quadros et al., this volume). From top to bottom, this sequence consists of $5 \mathrm{~cm}$ of laminated, but slightly burrowed shale; $15 \mathrm{~cm}$ of massive claystone; $30 \mathrm{~cm}$ of laminated shale; $23 \mathrm{~cm}$ of black massive claystone; and finally $3 \mathrm{~cm}$ of parallel-laminated shale at the base. The contacts of these dark gray to black claystones and shales with the limestone and marly limestone are usually very sharp.

Inoceramus fragments and shells are very abundant from Core 114 to the base of the unit, and occur as high as Section $516 \mathrm{~F}-110-6$ in scattered abundance. Foraminifers and nannofossils are present in low percentages at the top of the unit but are rare near the base; most of the carbonate is recrystallized. The terrigenous components are dark gray clays, quartz (2-3\%), feldspars (trace), and mica.

Parallel laminations, faint cross laminations, and burrows are the most important structures and features of Subunit $6 \mathrm{~b}$, but some microfaults occur.

Unit 7: Ferruginous Chert, Limestones, Glauconiterich Sands, Turbidites, and Shallow-Water Microfossils (1240-1252 m)

The calcareous, volcanogenic sediments of Unit 7 (Cores 124 and 125 of Hole 516F) consist of red, Inoceramus-rich baked calcareous mud; dusky red sandy mudstone with dispersed glauconite grains; dark altered volcanic glass, montmorillonite, and breccia; and some fining-upward sequences of coarse-grained to fine-grained sandstones rich in feldspar, glauconite, and biotite (green sandstones). On the top of this sedimentary section there is $10 \mathrm{~cm}$ of dark reddish gray ferruginous chert. The list below shows the composition of the ferruginous chert from Sample 516F-124-1, 1-10 cm (analysis courtesy of M. E. Cosgrove, Department of Geology, University of Southampton, Southampton, SO9 $5 \mathrm{NH}$, United Kingdom).

\begin{tabular}{lc}
\hline $\mathrm{SiO}_{2}$ & $82.16 \%$ \\
$\mathrm{TiO}_{2}$ & 0.204 \\
$\mathrm{Al}_{2} \mathrm{O}_{3}$ & 0.481 \\
$\mathrm{Fe}_{2} \mathrm{O}_{3}$ & 11.99 \\
$\mathrm{MgO}$ & 0.282 \\
$\mathrm{CaO}$ & 0.530 \\
$\mathrm{Na}{ }_{2} \mathrm{O}$ & 0.018 \\
$\mathrm{~K}_{2} \mathrm{O}$ & 0.064 \\
$\mathrm{P}_{2} \mathrm{O}_{5}$ & 0.000 \\
Loss of ignition & 4.67 \\
$\mathrm{X}-$ ray total & $100.40 \%$ \\
$\mathrm{CO}_{2}$ & 0 \\
$\mathrm{H}_{2} \mathrm{O}$ & 0 \\
\hline
\end{tabular}
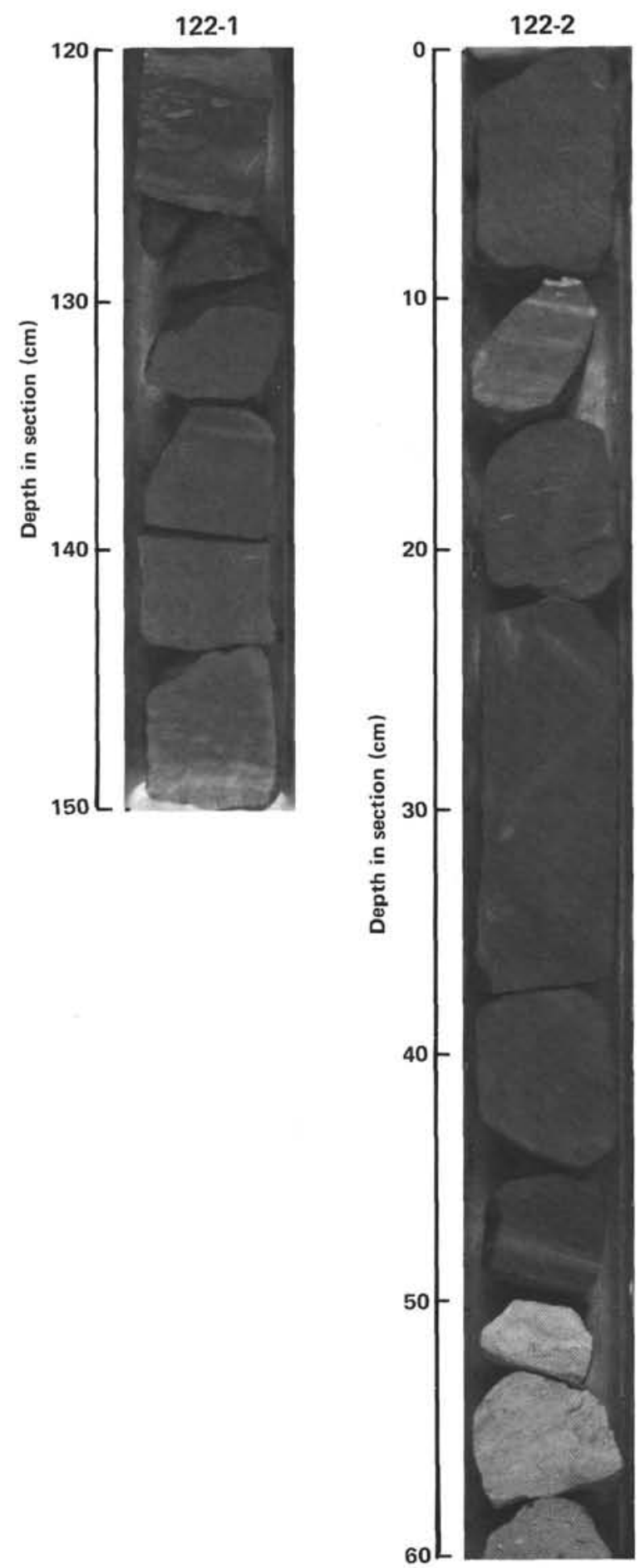

Figure 13. Interbedded claystone and shale, containing $0.95 \%$ organic carbon in Core 122. 
Unit 8: Veined and Partly Altered Vesicular Basalt (1252-1271 m)

In Unit 8 (Cores 125 to 128 of Hole $516 \mathrm{~F}$ ), two flow units are distinguished on the basis of primary mineralogy and the degree of alteration. Both units were originally dark, fine-grained, variably vesicular plagioclasepyroxene-phyric tholeiites. Plagioclase phenocrysts are commonly euhedral or lath shaped, often zoned. Pyroxene phenocrysts, usually only $1 \%$ by volume, are euhedral to subhedral and display zoning (sometimes oscillatory) and simple twinning. The groundmass consists of microlites of plagioclase, granular pyroxene, opaque minerals, and glass. Much of the glass is replaced by calcite or clay minerals and, in the more weathered samples, both plagioclase and pyroxene phenocrysts are partially replaced by calcite.

The upper flow unit (down to Sample 516F-127-4, $48 \mathrm{~cm}$ ) is the more extensively veined and altered of the two, and it has more glass, less pyroxene in the groundmass, and smaller grains of iron oxide. The differences between the two units, however, are minor compared with their similarities, and they may represent a single flow. The scarcity of quench textures and lack of glassy selvages suggests emplacement as a thick flow, and leaves open the question of a submarine or subaerial origin.

Compared to normal (N-type) mid-ocean ridge basalts (MORB), the basalts of Hole 516F have high contents of the incompatible minor and trace elements ( $\mathrm{Ti}$, $\mathrm{P}, \mathrm{Zr}, \mathrm{Nb}, \mathrm{Y}, \mathrm{La}, \mathrm{Ce}$ ) and correspondingly low contents of $\mathrm{Ni}, \mathrm{Cr}$, and the more mobile, compatible trace elements (see Thompson et al., this volume, and Weaver et al., this volume). The degree of alteration casts doubt on the primary nature of the $\mathrm{Mg}, \mathrm{K}, \mathrm{Rb}$, and $\mathrm{Ba}$ concentrations, but the high $\mathrm{Sr}$ content is probably unaffected.

Incompatible trace element ratios suggest an "enriched" parental magma compared with N-type MORB, and the high total iron, along with low levels of $\mathrm{Ni}, \mathrm{Cr}$, and possibly $\mathrm{Mg}$, suggest high level fractionation of a magma with transitional (T-type) MORB characteristics (Wood et al., 1979). The argument for high level fractionation is strengthened by the petrographic evidence (oscillatory zoning of phenocrysts and the presence of augite). The chemistry of the Hole $516 \mathrm{~F}$ basalts is similar to that of Reykjanes Ridge and Icelandic basalts, to tholeiites from the Azores, and to samples from the far eastern Walvis Ridge.

The basalt of Core 126 encloses a large vein filled primarily with quartz and calcite and with inclusions of clays and iron oxides. The calcite occurs as large crystals, sparite, and micrite enclosing Inoceramus, algal, and bryozoan fragments. A thin section of vein filling from Core 126 contains calcareous algae, bryozoans, oolites, and benthic foraminifers, indicating a shallowwater provenance. There is no evidence of downslope reworking or mixing with faunas from a deeper or pelagic environment (see Milliman, this volume).

\section{SEDIMENTARY GEOCHEMISTRY}

\section{Carbonate Analyses}

A total of 586 bomb carbonate analyses were made on Site 516 sediment samples, including 241 from Hole 516,101 from $516 \mathrm{~A}$, and 244 from $516 \mathrm{~F}$. The values are listed in the core description forms accompanying this chapter. Estimated accuracy is approximately $3 \%$ for the values shown in Figure 3. This accuracy is less than normal, apparently because of a volume error with one measuring flask.

\section{X-Ray Diffraction Analysis}

$\mathrm{X}$-ray diffractograms for 255 samples from Site 516 were collected as part of a shipboard study (Coulbourn, this volume), and additional samples were also analyzed as part of a shore-based study (Zimmerman, this volume). Calcite occurs throughout the section; quartz is present in most samples, with the exception of cores from Unit 4. Feldspar occurs as phenocrysts of the glomerophyric basalt of Cores 516F-126 and 516F-127.

The clay minerals montmorillonite, kaolinite, and illite are common in samples from below $625 \mathrm{~m}$ sub-bottom at Site 516. These minerals were recovered in samples from Unit 4, an interval of turbidites, ash, and allochthonous slump blocks of Cretaceous limestone. Montmorillonite may be the product of the alteration of volcanic glass. Illite is the clay that makes up marly intervals within the allochthonous red-brown Cretaceous limestone and marly limestone of Cores $516 \mathrm{~F}-78$ and $516 \mathrm{~F}-79$, and typifies the autochthonous Cretaceous rocks of Unit 6. In diffractograms produced from samples from the base of Subunit 6a, kaolinite and illite peaks are dominant. Kaolinite peaks intensify as illite peaks diminish downsection towards Subunit $6 \mathrm{~b}$. The clays of Subunit $6 \mathrm{~b}$ are kaolinitic. Chert and dolomite generally do not co-occur; chert occurs above the Cretaceous/Tertiary boundary, and dolomite below.

The frequency of occurrence of chert and dolomite also corresponds to increases in velocity. Between 600 and $880 \mathrm{~m}$ sub-bottom, the frequency of occurrence of chert increases within Cores $516 \mathrm{~F}-75$ to $516 \mathrm{~F}-82$, the lower portion of Unit 4, and in Subunit 5a. A velocity inversion near $880 \mathrm{~m}$ sub-bottom probably corresponds to a diagenetic front, the lower boundary of silica cementation. Beneath $880 \mathrm{~m}$ sub-bottom, velocities again increase gradually, as does the frequency of occurrence of dolomite. Again, the increase in $\mathrm{V}_{\mathrm{p}}$ probably corresponds to the extent of diagenesis within the sediment, the diagenetic effect arising this time from dolomitization rather than chertification.

\section{Interstitial Water}

Results of the shipboard analyses of interstitial water indicate fairly constant values for $\mathrm{pH}$, salinity, chlorinity, alkalinity, and calcium ion concentration throughout the section cored at Site 516 (Table 2 and Fig. 14). The magnesium ion concentration decreases with depth, 
Table 2. Interstitial water geochemistry, Holes $516 \mathrm{~A}$ and $516 \mathrm{~F}$.

\begin{tabular}{|c|c|c|c|c|c|c|c|}
\hline $\begin{array}{c}\text { Core-section } \\
\text { (interval in } \mathrm{cm} \text { ) }\end{array}$ & $\begin{array}{l}\text { Sub-bottom } \\
\text { depth } \\
\text { (m) }\end{array}$ & $\mathrm{pH}$ & $\underset{\%}{\text { Salinity }}$ & $\begin{array}{c}\text { Chlorinity } \\
\%\end{array}$ & $\begin{array}{l}\text { Alkalinity } \\
\text { meq } /\end{array}$ & $\begin{array}{l}\text { Calcium } \\
\mathrm{mmol} / 1\end{array}$ & $\begin{array}{c}\text { Magnesium } \\
\mathrm{mmol} / /\end{array}$ \\
\hline \multicolumn{8}{|l|}{ Hole 516A } \\
\hline $1-2,144-150$ & $2.94-3.00$ & 7.324 & 35.2 & 19.14 & 2.687 & 10.94 & 58.36 \\
\hline $12-2,140-150$ & $50.40-50.50$ & 7.217 & 35.2 & 19.34 & 2.925 & 12.02 & 55.35 \\
\hline \multicolumn{8}{|l|}{ Hole $516 \mathrm{~F}$} \\
\hline $2-6,140-150$ & $187.50-187.60$ & 7.142 & 35.2 & 19.48 & 3.838 & 14.71 & 44.16 \\
\hline $7-2,140-150$ & $229.00-229.10$ & 7,074 & 35.2 & 19.51 & 3.813 & 15.23 & 41.84 \\
\hline $13-2,140-150$ & $286.00-286.10$ & 7.071 & 37.7 & 19.51 & 4.289 & 16.04 & 38.29 \\
\hline $19-3,140-150$ & $363.50-363.60$ & 7.289 & 35.2 & 19.64 & 2.702 & 15.75 & 36.54 \\
\hline $25-3,140-150$ & $401.50-401.60$ & 7.356 & 35.2 & 19.88 & 1.377 & 15.35 & 33.34 \\
\hline $30-5,140-150$ & $452.00-452.10$ & 7.688 & 35.2 & 20.15 & 0.578 & 15.87 & 30.27 \\
\hline $35-3,140-150$ & $496.90-496.60$ & 7.422 & 35.2 & 20.01 & 1.685 & 16.04 & 32.21 \\
\hline $51-3,140-150$ & $648.50-648.60$ & 7.356 & 35.2 & 20.15 & - & 17.08 & 25.58 \\
\hline
\end{tabular}

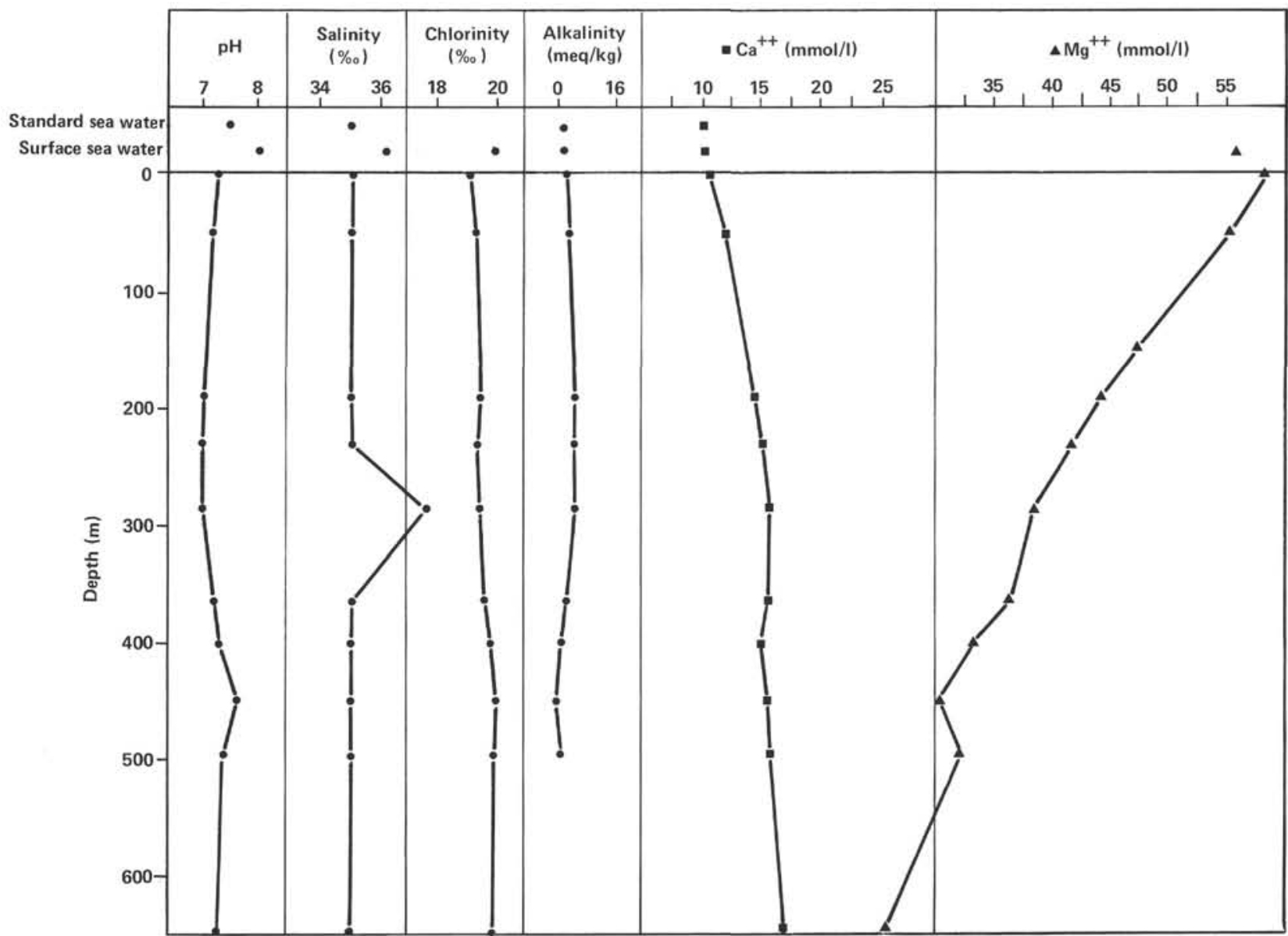

Figure 14. Interstitial water geochemistry, Site 516.

in inverse relation with the amount of dolomite detected in the X-ray diffraction analyses.

\section{BIOSTRATIGRAPHY}

Stratigraphic continuity and high rate of core recovery are the most significant aspects of the drilling results from Site 516. The continuous stratigraphic sequence from the Recent to the Late Cretaceous, approximately $80 \mathrm{Ma}$ (Santonian/Coniacian), includes relatively unaltered basaltic basement. All calcareous microfossil groups are sufficiently abundant and well preserved to yield reliable age determinations. At Hole 516, 44 cores were recovered. The oldest level corresponds to the early Miocene. Hole 516A reached only the upper Miocene. The last hole, $516 \mathrm{~F}$, began at the base of the lower Miocene and extended to the Late Cretaceous limestones and basalt.

Two relatively minor stratigraphic gaps at Site 516 may correspond to hiatuses at nearby Site 357 . Seismic reflection profiles suggest, however, that these are of local rather than regional significance. The intervals are as follows:

1) The uppermost Pliocene (Zone PL6 of Berggren, 1977 a) is relatively condensed, indicating a possible unconformity of short duration. 
2) The upper Miocene is partially missing. Foraminiferal Zone N15 (and perhaps N16) and nannofossil Zone NN10 are missing, and portions of Zones NN9 and NN11 may also be missing. Altogether, there is perhaps a gap of $2 \mathrm{Ma}$ in the upper Miocene.

In spite of these minor gaps, Site 516 successfully recovered a continuous depositional record across the Santonian/Campanian boundary, Campanian/Maestrichtian boundary, the Cretaceous/Tertiary boundary, the Paleocene/Eocene boundary, and the Eocene/Oligocene boundary. The lowermost planktonic foraminiferal zone of the Danian (Globigerina eugubina Zone) is well represented, as well as the uppermost planktonic foraminiferal zone of the Maestrichtian below ( $\mathrm{Aba}$ thomphalus mayaroensis). Apparently, the Paleocene sequence is complete, which is uncommon in previous DSDP sites.

\section{Microfossil Abundance and Preservation}

All calcareous microfossil groups are common and very well preserved from the Recent to the middle Miocene. From that point to the middle Eocene, preservation gradually deteriorates, though all groups remain common in abundance. In the middle and lower Eocene samples, all calcareous components are relatively rare with moderate to poor preservation, with extensive fragmentation of nannofossils, and with common overgrowths of calcite on the planktonic foraminifers. In the Paleocene, the nannofossil assemblages become abundant and diverse, and remain so into the Maestrichtian. Planktonic foraminifers are moderately to poorly preserved in the Paleocene and Upper Cretaceous of Site 516 , with the Globotruncana spp. largely unrecognizable because of clay adhering to the shell surfaces. Benthic foraminifers are well preserved in the lower Paleocene and upper Maestrichtian, but are poorly preserved at the base of the Maestrichtian and barely recognizable (though present) in the lower Campanian/Santonian. In a similar way, the preservation of the nannofossil assemblage begins to deteriorate in the lower Maestrichtian with significant calcite overgrowths and dissolution; this effect increases downward in the Campanian/Santonian section.

\section{Reworking}

As we expected for this location, reworking effects at Site 516 were minimal. Nannofossils and planktonic foraminifers show no evidence of contamination of any of the assemblages by stratigraphically older taxa. Benthic foraminiferal assemblages suggest the presence of minor, penecontemporaneous downslope reworking within portions of three stratigraphic intervals:

1) Shallow-water benthic foraminiferal taxa occur at the top of the middle Miocene, just below the probable unconformity.

2) Pelecypods and shallow-water benthic foraminifers are present intermittently within Cores $516 \mathrm{~F}-5$ through $516 \mathrm{~F}-31$, extending from the lower Miocene (Zone N4) to the upper Oligocene (Zone P20). The fact that planktonic assemblages in this interval show no evidence of reworking suggests penecontemporaneous downslope reworking and not the erosion of sediment from stratigraphically older sections exposed as outcrops nearby.

3) Reefal debris, containing calcareous algae, bryozoans, and larger foraminifers, is present in the middle Eocene (Cores 516F-50 and 516F-63). These Eocene (Zone NN14) limestones surround a lower Maestrichtian slump block.

Absence of downslope reworking throughout the $\mathrm{Pa}$ leocene and Upper Cretaceous intervals contrasts with the presence of considerable reworking of Cretaceous sediments at Site 357 (Supko et al., 1977). This difference suggests that the downslope reworking during the Cretaceous was of local extent.

Within Core 516F-126, allochthonous fragments occur in hydrothermal veins cutting the basalt. The fragments include calcareous algae, Inoceramus prisms, and possibly bryozoans, suggesting that the basaltic vulcanism represented in the lowermost cores of Site 516 took place near sea level (see Milliman, this volume). In contrast, the overlying Santonian foraminiferal assemblages (e.g., the Globotruncana spp. in Core 516F-119) suggest accumulation in upper bathyal depths. Significant erosion and/or subsidence must have occurred during the 5 to $10 \mathrm{Ma}$ immediately after the cessation of volcanism, because the bulk of the depositional sequence at Site 516 corresponds to a pelagic facies accumulating in bathyal (probably upper bathyal) depths.

\section{Nannoplankton}

The calcareous nannofossil-based age determinations and zonal boundaries for the Tertiary are based upon the zonation of Martini (1971). For the stratigraphic age determination of the Cretaceous sediments and for correlation with the biostratigraphy of Site 357 (Leg 39), the zonation of Perch-Nielsen (1977) was used.

Eight biostratigraphic intervals were identified:

1) Quaternary (Cores $516-1$ to $516-3,0-8.7 \mathrm{~m}$, and $516 \mathrm{~A}-1$ to $516 \mathrm{~A}-2,0-7.9 \mathrm{~m}$ )

2) Pliocene (Cores $516-3$ to $516-12,10.2$ to about $40 \mathrm{~m}$, and Cores 516A-3 to 516A-10, 7.9-43.1 m)

3) Miocene (Cores 516-12 to 516-44, about 40 to $183.3 \mathrm{~m}$; Cores 516A-11 to 516A-15, 43.1-65.1 m; and Cores $516 \mathrm{~F}-1$ to $516 \mathrm{~F}-8,169.1-245.1 \mathrm{~m}$ )

4) upper Oligocene to lower Miocene (Sample 516F$9, \mathrm{CC}, 254.6 \mathrm{~m})$

5) Oligocene (Cores 516F-10 to 516F-38, 283.1$530.1 \mathrm{~m})$

6) Eocene (Cores 516F-39 to 516F-82, 539.6-900.6 m)

7) Paleocene (Cores $516 \mathrm{~F}-83$ to $516 \mathrm{~F}-89$, 910.1$961.4 \mathrm{~m})$

8) Cretaceous (Cores 516F-89 to $516 \mathrm{~F}-124,964.0$ $1240.4 \mathrm{~m}$ )

\section{Quaternary}

Well-preserved and abundant Quaternary nannoplankton assemblages occur in the intervals from 516$1-1,0-2 \mathrm{~cm}$ to $516-3-2,30-32 \mathrm{~cm}(0-8.7 \mathrm{~m})$, and from $516 \mathrm{~A}-1, \mathrm{CC}$ to $516 \mathrm{~A}-2, \mathrm{CC}(0-7.9 \mathrm{~m})$. The assemblages in the interval 516-1-1, 0-2 cm to 516-1-1, 5-6 cm belong 
to the Emiliania huxleyi/Gephyrocapsa oceanica Zone (NN21/NN20). The last occurrence of Pseudoemiliania lacunosa marks the base of the interval (NN21 to NN20). The principal floral components include G. oceanica, Ceratolithus cristatus, Rhabdosphaera clavigera, Cyclococcolithus leptoporus, and Helicopontosphaera kamptneri.

The assemblages from Samples 516-1-1, $42 \mathrm{~cm}$ to 516-3-2, $32 \mathrm{~cm}(1.9-8.7 \mathrm{~m})$ contain $P$. lacunosa but lack discoasters, indicating the $P$. lacunosa Zone s.l. (NN19). No hiatus between the Pliocene and Quaternary exists in Holes 516 and 516A.

\section{Pliocene}

Pliocene floras were recovered in Samples 516-3-2, $41-42 \mathrm{~cm}$ to $516-11, \mathrm{CC}(10.2$ to about $40 \mathrm{~m})$. The coccoliths and discoasters of the Pliocene are abundant, with moderate to good preservation in the upper Pliocene and moderate preservation in the lower Pliocene.

The presence of Discoaster brouweri without any other discoasters suggests that the sediments of Samples 516-3-3, 30-32 cm and 516A-3,CC are in Zone NN18. Zone NN17 occurs in Sample 516-3,CC. The nannofossil assemblages in Core 516-4 to Sample 516-5-2, $100 \mathrm{~cm}$ with $D$. surculus but without Reticulofenestra pseudoumbilica indicate Zone NN16.

The interval between Samples 516-5-2, $100 \mathrm{~cm}$ and $516-5-3,100 \mathrm{~cm}$ with $R$. pseudoumbilica but without Amaurolithus tricorniculatus belong to $R$. pseudoumbilica Zone (NN15). Because of uncertainties regarding the first occurrence of $D$. asymmetricus in this section, it is impossible to distinguish the interval of the Ceratolithus rugosus Zone (NN13) from the D. asymmetricus Zone (NN14) in Cores 516-6 to 516-10. The top of this interval is determined by the last occurrence of $A$. tricorniculatus, and the base by the first occurrence of $C$. rugosus. The base of the Pliocene at Site 516 is placed within the $C$. tricorniculatus Zone (NN12) in Core $516-10$, based on the first occurrence of $C$. acutus.

\section{Miocene}

Miocene sediments were recovered in Samples 516$14, \mathrm{CC}$ to $516-44, \mathrm{CC}(59.7-183.3 \mathrm{~m})$ and in Samples $516 \mathrm{~F}-1, \mathrm{CC}$ to $516 \mathrm{~F}-8, \mathrm{CC}(169.1-245.1 \mathrm{~m})$. The Miocene calcareous nannofossils are abundant with generally moderate preservation.

The top of the Miocene is within the C. tricorniculatus Zone (NN12). The D. quinqueramus Zone (NN11) is present in Sections 516-11-2 through 516-14-1, and it is determined by the range of that species. $D$. calcaris (NN10) is missing, and the lower part of the $D$. quinqueramus Zone (NN11) and upper part of the D. hamatus Zone (NN9) are probably also missing, indicating a hiatus at the base of the upper Miocene. Calcareous nannofossil assemblages containing $D$. hamatus in Sections 516-14-1 and 516-14-2 and matching intervals at Hole $516 \mathrm{~A}$ indicate that this part of the section is in Zone NN9. In Sample 516A-16,CC, the assemblage is a mixture of Pliocene-Miocene nannofossils. In Cores 516-15 to 516-17, D. challengeri and Cyclococcolithus neogam- mation are present, whereas $D$. pentaradiatus, $D$. exilis, and $D$. kugleri are absent. The Pliocene/Miocene contact is probably somewhere within the $D$. exilis Zone (NN6) and the D. kugleri Zone (NN7). In the interval from 516-17-2, $110 \mathrm{~cm}$ to 516-20-3, Sphenolithus heteromorphus occurs without Helicopontosphaera ampliaperta and $H$. parallela, suggesting an age corresponding to Zone NN5. In Sections 516-20-3 to 516-25-2, the occurrence of $H$. ampliaperta without $S$. belemnos suggests Zone NN4. The interval from 516-25-2 to 516-32-3 belongs to Zone NN3. The top of this interval is defined by the last occurrence of $S$. belemnos and the bottom by the last occurrence of Triquetrorhabdulus carinatus. The $D$. druggi Zone (NN2) is very thick. The first occurrence of $S$. belemnos marks the top of this interval in Section 516-32-3, and the last occurrence of $T$. carinatus marks the bottom of Section 516F-3,CC. Assemblages lacking $D$. druggi, $S$. ciperoensis, and $H$. recta characterize the oldest Miocene sediments of Zone NN1. These and older sediments are seen only in cores from Hole $516 \mathrm{~F}$.

The nannoplankton assemblage Sample 516F-9,CC consists of $H$. cf. recta without $S$. ciperoensis. The questionable determination of $H$. species is not sufficiently certain to indicate an Oligocene age.

\section{Oligocene}

Oligocene assemblages were found in Section 516F$10, \mathrm{CC}$ and in Cores 516F-12 through 516F-38 (283.1$530.1 \mathrm{~m}$ sub-bottom). The Oligocene section contains all calcareous nannoplankton zones according to Martini's (1971) zonation. The nannofossils are generally abundant but with poor to moderate preservation.

The occurrence of $S$. ciperoensis in Sample 516F$10, \mathrm{CC}$ without $S$. distentus distinguishes Zone NP25. Sample 516F-11,CC lacks index sphenoliths, but the presence of $H$. recta gives this sample an age between Zones NP24 and NP25. In Cores 12 to $18, D$. lidzii is present; its range restricts this assemblage to Zone NP24. The overlap of $S$. distentus and $S$. predistentus without $D$. lidzii in Cores 19 to 25 assigns this interval to Zones NP23 to NP24. Chiasmolithus oamaruensis occurs in Sample 516F-26,CC; its last known occurrence is in Zone NP23, which indicates that this sample and those from Cores 27 to 31 belong to Zone NP23. The co-occurrence of $S$. distentus and $R$. pseudoumbilica characterize the interval from Cores 27 to 35 . This overlap, which is not quoted by Martini (1971), assigns this interval to Zones NP22 to NP23. An assemblage with $R$. pseudoumbilica but without $S$. distentus occurs in Sample 516F-36,CC, assigned to Zone NP22. An assemblage containing Cyclococcolithina formosa, but lacking $D$. saipanensis, represents the base of the Oligocene, Zone NP21 in Sample 516F-38,CC. C. formosa has its last known occurrence in the base of Oligocene-Zone NP21.

No distinct hiatus between the Oligocene and Eocene was noted. Zones NP19 and NP20 represent the top of the Eocene, but determination of the youngest zone (NP20) was not possible due to the absence of S. pseudoradians, a species ranging from NP20 to NP23. De- 
spite the absence of this key species, the evidence for the three oldest zones of the Oligocene (NP21 to NP23) is good.

\section{Eocene}

More than $350 \mathrm{~m}$ of Eocene sediment were recovered in Cores 516F-93 to 516F-82 (539.6-900.6 m). The calcareous nannofossils are few to abundant with poor to moderate preservation.

The upper part of the Eocene (Sample 516F-39,CC) belongs to Zones NP19 to NP20, because the index species for the last zone is missing. The top of interval is marked by the last occurrence of $D$. saipanensis and the bottom (Core 43) by the first occurrence of Isthmolithus recurvus. Cores 44,45 , and 46 belong to Zone NP18. The first occurrence of Chiasmolithus oamaruensis defines the base of this zone. The assemblages in Cores 47 to 51 (and probably to 53) identify Zone NP17, based on the presence of $D$. saipanensis and $H$. compacta, but without $C$. solitus. The last occurrence of $C$. solitus and $H$. seminulum in Core 516F-54 defines the top of Zone NP16, easily recognizable down to Sample 516F-58,CC. The assemblage in this interval lacks Chiphragmalithus alatus and Rhabdosphaera gladius. Sample 516F-59,CC contains $R$. cf. gladius, which last occurs at the top of the Chiphragmalithus alatus Zone (NP15), meaning that this zone should be present beneath this sample. The identification of this species is uncertain, however, and the interval down to Sample $516 \mathrm{~F}-66, \mathrm{CC}$ is assigned to Zones NP15 to NP16. D. nonaradiatus and D. sublodoensis are present in Sample 516F-67,CC; both have their last occurrence in Zone NP15. Their presence and the absence of $D$. lodoensis assign Cores $516 \mathrm{~F}-67$ to $516 \mathrm{~F}-76$ to Zone NP15. The presence of $D$. lodoensis in Sample 516F-77,CC and in the upper part of Core $516 \mathrm{~F}-78$ limits the age of this interval to Zones NP13 to NP14. Section 516F-78-3 is part of a lower Maestrichtian slump block (Arkhangelskiella cymbiformis Zone). The Eocene sediments below this slump in Sample $516 \mathrm{~F}-79, \mathrm{CC}$ belong to the same stratigraphic interval as above the slump. The exact determination of the first three Eocene cores ( 80 to 82 ) is difficult. Index fossils are missing, or fossils are not typical of the assemblages. Tentatively, Core $516 \mathrm{~F}-80$ belongs to Zone NP12, and Cores $516 \mathrm{~F}-81$ and $516 \mathrm{~F}-82$ to Zones NP10 to NP12.

\section{Paleocene}

No distinct hiatus between the Eocene and Paleocene was noted. The top of the Paleocene is represented with the youngest Paleocene zone (NP9).

The Paleocene sequence at Hole $516 \mathrm{~F}$ is about $50 \mathrm{~m}$ thick (Cores $516 \mathrm{~F}-83$ to Sample $516 \mathrm{~F}-89-3,33.5 \mathrm{~cm}$; 910.1-961.4 m). That is relatively thin compared to the Eocene and Cretaceous sections; nevertheless, it contains all nine Paleocene zones without any hiatus. Coccoliths and discoasters are few to abundant and fairly well preserved. Only at the base of the Paleocene are the nannofossils rare with poor preservation. Core $516 \mathrm{~F}-83$ to Sample 516F-84-3, 3-4 cm contains D. multiradiatus, an index species of Zone NP9. The presence of Heliolithus riedeli identifies the interval $516 \mathrm{~F}-84-4,13-14 \mathrm{~cm}$ to $516 \mathrm{~F}-85-1,46-47 \mathrm{~cm}$ as the zone of the same name (NP8). The co-occurrence of D. mohleri and H. kleinpellii assigns Sample $516 \mathrm{~F}-85-2,40-70 \mathrm{~cm}$ to the $D$. mohleri Zone ( $=D$. gemmeus Zone) (NP7). In Samples $516 \mathrm{~F}-85-1,16-17 \mathrm{~cm}$ to $516 \mathrm{~F}-86-5,54-55 \mathrm{~cm}, \mathrm{H}$. kleinpellii is present and $D$. mohleri is missing, criteria necessary for identification of the $H$. kleinpellii Zone (NP6). The presence of Fasciculithus tympaniformis without H. kleinpellii determines the interval from Cores $516 \mathrm{~F}$ $86-6,50-51 \mathrm{~cm}$ to $516 \mathrm{~F}-87-3,55-56 \mathrm{~cm}$ as the $F$. tympaniformis Zone (NP5). Core $516 \mathrm{~F}-87-4,44-45 \mathrm{~cm}$ to $516 \mathrm{~F}-87-5,46-47 \mathrm{~cm}$ include the first occurrence of $\mathrm{El}$ lipsolithus macellus to the first occurrence of $F$. tympaniformis, indicating the E. macellus Zone (NP4). Samples $516 \mathrm{~F}-87-6,17-18 \mathrm{~cm}$ to $516 \mathrm{~F}-89-3,86-87 \mathrm{~cm}$ contain Chiasmolithus danicus but E. macellus is missing, indicating the $C$. danicus Zone (NP3). The occurrence of Cruciplacolithus tenuis without Chiasmolithus danicus places Samples 516F-89-3, 142-143 cm to 516F-89-4, 38-39 cm in the Cruciplacolithus tenuis Zone (NP2). The Markalius inversus Zone (NP1) is the base of the Paleocene in Samples 516F-89-4, 138-139 cm to 516F$89-5,33.5 \mathrm{~cm}$.

\section{Cretaceous}

The Cretaceous/Tertiary boundary was recovered in Core $516 \mathrm{~F}-89$. Calcareous nannoplankton stratigraphy of that core indicates no hiatus between the Cretaceous and Paleocene. The oldest zone of the Paleocene (M. inversus Zone NP1) occurs in Sample 516F-89-5, $33.5 \mathrm{~cm}$. The youngest zone of the Cretaceous (Micula mura Zone) is assigned to Sample $516 \mathrm{~F}-89-5,34.3 \mathrm{~cm}$.

Cores 89 to 124 comprise the $284.5 \mathrm{~m}$ of Cretaceous sediments recovered from Hole 516F. Calcareous nannoplankton are abundant and fairly well preserved in the upper Maestrichtian. Lower Maestrichtian coccoliths vary downward from abundant to rare and the preservation ranges from good to poor. Dissolution and fragmentation increase downward. The ten zones present in the Cretaceous section span the Coniacian/Santonian to Maestrichtian. The M. mura Zone (Cores 89 to 91), with M. mura and Nephrolithus frequens, represents the top of the Cretaceous. In Cores 91 to 93, the assemblage lacks $M$. mura but $N$. frequens is still present, suggesting the $N$. frequens Zone. The top of the middle Maestrichtian (Lithraphidites quadratus Zone) is present in Samples 516F-93,CC through 516F-94-2, 25-26 cm, and the lower to middle Maestrichtian is indicated in Cores 94 to 96 by the Arkhangelskiella cymbiformis Zone. The first occurrence of $L$. quadratus defines the top of this interval, and the last occurrence of Tetralithus trifidus marks the base. The Campanian/Maestrichtian boundary is within the T. trifidus Zone (Cores 96 to 107). The T. gothicus Zone was recovered in Cores 107 and 108. The assemblage of this zone contains $T$. gothicus, but $T$. trifidus is missing. Similarly, the T. aculeus Zone (Cores 108 and 109) contains the index species but lacks $T$. gothicus. The interval from the last occurrence of Marthasterites furcatus and/or Lithastrinus grillii to the first occurrence of $T$. aculeus defines the Broinsonia parca Zone in Cores 110 to 113 . The assemblage with $B$. 
parca and $M$. furcatus assigns Cores 113 to 116 to the Eiffellithus eximius Zone of the late Santonian. The oldest Cretaceous samples recovered at Site 516 are Coniacian to Santonian and belong to the $M$. furcatus Zone (Cores 116 to 124). The assemblages contain $M$. furcatus and $L$. grillii but are lacking $B$. parca.

\section{Planktonic Foraminifers}

Usually one sample per section was examined for foraminifers, but in a few cases more samples were analyzed especially for the Quaternary and Cretaceous/Tertiary boundary intervals. The zonation of Berggren (1973, 1977a, b) is utilized for the Pliocene. Blow's (1969) zonation is retained for the other Neogene sequences, and that of Stainforth and others (1975) for the Paleogene sequence. Weiss (this volume) analyzed the Cretaceous sequence.

The assemblages are relatively well preserved and are summarized in the following categories:

1) Quaternary (between the top of Core 516-1 to Section 516-3-2; from the top of Core 516A-1 to Sample 516A-2,CC).

2) Pliocene (Sections 516-3-3 to 516-11-3; Sections 516A-3-4 to 516A-12-2)

3) Miocene (Sections 516-12-3 and 516A-12-3 to the base of each HPC hole-Samples 516-44, CC and 516A16 , CC; Core $516 \mathrm{~F}-1$ to Section $516 \mathrm{~F}-5-6$ )

39-2)

4) Oligocene (Sample 516F-5, CC to Section 516F-

5) Eocene (Cores $516 \mathrm{~F}-39$ to $516 \mathrm{~F}-80$ )

6) Paleocene (Sections 516F-81-3 to 516F-89-5)

7) Cretaceous/Tertiary boundary (at Sample 516F$85-5,21-26 \mathrm{~cm})$

8) Cretaceous (Section 516F-85-5 through Core 516F122) (Weiss, this volume)

\section{Quaternary}

Well-preserved and abundant Quaternary foraminiferal assemblages occur in the intervals from 516-1-1, $0-2 \mathrm{~cm}$ to $516-3-2,30-32 \mathrm{~cm}$ and from 516A-1-1, 0-2 cm to 516A-2,CC. In these two holes, right-coiling Globorotalia hirsuta determines Zone N23 (mudline to Samples 516-1-1, 30-32 cm and 516A-2-3, 50-52 cm). Below this level, the association of $G$. truncatulinoides with a subtropical to transitional assemblage indicates that the sequence is Pleistocene (Zone N22).

\section{Pliocene}

Pliocene microfauna were recovered in Section 5163-3 to Sample 516-12,CC and in Sections 516A-3-1 to 516A-12-2. This microfauna is abundant with good preservation and may allow a differentiation of the zones proposed previously by Berggren $(1977 \mathrm{a}, \mathrm{b})$ based on the first (FAD) or last appearance datum (LAD) of a few species, such as: G. miocenica (LAD), Sphaeroidinella dehiscens (FAD), Globoquadrina altispira (LAD), Globorotalia multicamerata (LAD), Sphaeroidinellopsis sp. (LAD), Globigerina nepenthes (LAD), Globorotalia margaritae (FAD), and Globoquadrina dehiscens (LAD).

The Miocene/Pliocene boundary is located at the last occurrence of $G$. dehiscens, and occurs in Sample
$516-12, \mathrm{CC}$ and Section 516A-12-2. It is difficult to determine if a hiatus exists between the upper Pliocene Zone PL6 and the Pleistocene, because of some reworking or contamination. Any gap in that interval must be less than that at Hole 357 (Berggren, 1977a).

\section{Miocene}

An extensive Miocene sequence was retrieved from Hole 516 and from the upper part of Hole 516A; the base of the Miocene occurs in the cored portion of Hole 516F. A high latitude indicator group, including Globorotalia miozea conoidea (upper Miocene to lower Pliocene), G. zealandica, and Globigerina woodi (lower Miocene) is abundant and shows dissolution effects, particularly in those from the middle to upper Miocene. An unconformity represented by a mixture of Quaternary, Pliocene, and Miocene fauna may span the uppermost middle to the lowermost upper Miocene in Core 516A-16. Contamination and reworking also occur in the uppermost lower Miocene of Hole 516.

The upper Miocene is characterized by the occurrence of Globoquadrina dehiscens, Globorotalia miozea conoidea group, and Sphaeroidinellopsis seminulina. This association is typical for the $G$. conomiozea and $G$. mediterranea zones of Berggren (1977b), and considered by that author as approximately correlative to Zone N17 (Blow, 1969). In Hole 516, however, the absence of typical $G$. acostaensis and the disappearance of the G. siakensis in Core 516-15 are negative criteria in zonal determinations, suggesting the absence of both Zones N15 and N16.

Orbulina first appears in Core 516-17. The fauna of the sequence between this event and the last occurrence of $G$. siakensis is not diversified. The $G$. fohsi group disappears with the first bed. It is, therefore, difficult to differentiate the zones of the middle Miocene or to confirm that they exist in this sedimentary sequence.

The lower Miocene is a long and complete sequence with a fairly monotonous fauna. The association includes: Globigerinoides altiaperturus, Globorotalia zealandica, Globoquadrina div. sp., Catapsydrax dissimilis, and, in the earliest part, Globigerinoides primordius and Globorotalia kugleri. An abundance of Globigerinoides primordius in Section 516F-5-6 signals the base of the Miocene.

\section{Oligocene}

The upper Oligocene Globigerina angulisuturalis Zone $\mathrm{P} 22$ is indicated between Cores $516 \mathrm{~F}-5$ and $516 \mathrm{~F}-14$ by the presence of the nominate taxon and by the absence of Globorotalia opima opima. In Hole 516F, the Globigerina angulisuturalis-G. opima opima Zone P21 and the Globigerina ampliapertura Zone P20 are recognized in Cores 15 to 24 and in Cores 25 to 31 , respectively. G. angulisuturalis resembles the compact high-latitude forms more than the more open and flaring lower-latitude ones. The boundary between the upper and lower Oligocene is based at the last occurrence of Pseudohastigerina barbadoensis.

Older zones are difficult to differentiate because of the poor representation of tropical taxons. The sedimentary sequence between Cores $516 \mathrm{~F}-32$ to Section 
516F-39-2 is, therefore, assigned to the Cassigerinella chipolensis-P. micra Zones (Stainforth et al., 1975) as the equivalent of the lower Oligocene. The foraminifers are often corroded, and the faunas are not diverse. The dominant species are Globigerina galavasi, G. euapertura, Globigerinita unicava, and, in the upper Oligocene, Globigerina praebulloides s.l.

\section{Eocene}

An extensive Eocene sequence, about $340 \mathrm{~m}$ thick, with common, high-latitude indicator species makes up the interval from Sample 516F-39,CC to Core 516F-78. An upper Eocene sequence begins with the occurrence of Globorotalia cerroazulensis and the disappearance of the keeled-margin and spinose $G$. in Section $516 \mathrm{~F}-49-1$. Below, the lower/middle Eocene contact is set at the first appearance of the genus Hantkenina in Core 516F-71. G. bullbrooki also appears at the base of the middle Eocene (Zone P10), but in Core 516F-77 the species occurs with Globigerina frontosa. Cores 78 and 79 of Hole 516F contain some Globotruncana sp. that are either contaminants or representatives of an lower Maesstrichtian slump block. Foraminifers in samples of Core $516 \mathrm{~F}-80$ are barren or badly dissolved.

\section{Paleocene}

The Paleocene sequence at Hole $516 \mathrm{~F}$ occurs in Cores 81 to 89 . Cores 81 and 82 contain Globorotalia velascoensis and a few $G$. subbotinae and are assigned to Zone P6a. The $G$. pseudomenardii Zone is well represented with the nominate taxon in Section 516F-83-5 to Sample $516 \mathrm{~F}-85, C C$. Below, G. angulata and $G$. pusilla represent the upper part of Zone P3 in Core 516F-86 to Section $516 \mathrm{~F}-88-2$. Section $516 \mathrm{~F}-88-3$ contains the first $G$. uncinata, indicating Zone P2.

The interval between Sections 516F-89-1 and 516F-894 contains $G$. praecursoria and $G$. compressa. This assemblage belongs to the upper part of Zone P1 (P1d). The base of the Paleocene is represented by Zones P1b-c in Samples 516F-89-4, $96 \mathrm{~cm}$ to $516 \mathrm{~F}-89-5,0-21 \mathrm{~cm}$.

The Cretaceous/Tertiary boundary was recovered in Section 516F-89-5. The oldest sediments without typical Cretaceous foraminifers are in Sample 516F-89-5, 21-26 $\mathrm{cm}$. They contain only a few small foraminifers (Eoglobigerina div. sp.), preservation is moderate, and the coarse fraction (greater than $160 \mu$ ) is barren.

\section{Cretaceous}

Upper Cretaceous planktonic foraminifers were recovered in Cores $516 \mathrm{~F}-89$ to $516 \mathrm{~F}-122$. Frequency and preservation are moderate in the upper Maestrichtian and deteriorate from there to the base. Except for the upper Maestrichtian, therefore, the interval cannot be clearly delimited with the generally accepted foraminiferal zonation. Some of the important zonal markers, moreover, were missing, possibly for paleobiogeographic reasons.

The top of the Uppermost Cretaceous Abathomphalus mayaroensis Zone is assigned to Sample $516 \mathrm{~F}-89-5$, $29.3-31.2 \mathrm{~cm}$. The base of the oldest zone of possible
Santonian-Coniacian age ("Globotruncana concavata" Zone) occurs in Section 516F-119-2. The first planktonic foraminifers occur in Section 516F-122-1; they are double keeled and of $G$. renzi type. In all, five planktonic zones and two unzoned intervals are distinguished.

The $A$. mayaroensis Zone is the best identified and ranges from Sections $516 \mathrm{~F}-89-5$ through $516 \mathrm{~F}-95-2$. At Section 516F-95-2, A. mayaroensis first occurs with other globotruncanids, such as Globotruncana lamellosa, G. stuarti, G. conica, G. cf. gansseri, and G. contusa, and with heterohelicids, such as Racemiguembelina fructicosa, Pseudoguembelina excolata, P. palpebra, and Planoglobulina acervulinoides. Other tropical Tethyan species (such as Globotruncana patelliformis, $G$. galeoides, and Planoglobulina multicamerata) indicate the higher part of the A. mayaroensis Zone. The total range of the $A$. mayaroensis Zone is the upper Maestrichtian, according to the general planktonic foraminiferal zonation scheme.

The $G$. falsostuarti Zone spans the interval from the first appearance of $G$. falsostuarti to the first appearance of $A$. mayaroensis, That sequence occurs in Sections 516F-95-3 through 516F-104-4 and identifies these as possible lower to middle Maestrichtian rocks. The early to middle Maestrichtian zonal marker G. gansseri is absent within this interval. The long-range species $(G$. fornicata, G. arca, G. linneiana, and Rugoglobigerina rugosa) are dominant; single-keeled globotruncanids are rare. New species are G. aegyptiaca, G. gagnebini, and some multiserial heterohelicids, such as Guembelina robusta, G. cuvillieri, P. riograndensis, and P. manuelensis.

The Campanian/Maestrichtian boundary is placed between Sections 516F-101-3 and 516F-101-44. Globotruncana calcarata was not found; therefore, the first appearance of $G$. falsostuarti possibly indicates proximity to the Campanian-Maestrichtian transition.

\section{Campanian}

The interval from Sections $516 \mathrm{~F}-101-4$ through $516 \mathrm{~F}$ 104-4 yielded no useful planktonic foraminifers and was not zoned. At the base, G. scutilla and some primitive multiserial planoglobulinids are evident. Globotruncanella havanensis appears in higher parts at Core $516 \mathrm{~F}$ 103-3 and could indicate the Globotruncana calcarata Zone.

The G. ventricosa Zone includes Sections 516F-104-5 through 516F-112-2, and the index species refers the upper part of this section to the early and the lower part to the late Campanian. Together with this characteristic form, G. rosetta, G. stuartiformis, G. stephensoni, and $G$. linneiana have their first appearance. In the upper part, rare specimens of $G$. subspinosa, G. obliqua, $R$. rugosa, and Pseudoguembelina costulata were found.

The first appearance of $G$. arca to the first appearance of $G$. ventricosa defines the $G$. arca Zone and makes up the lower Campanian Sections $516 \mathrm{~F}-112-3$ to $516 \mathrm{~F}$ 114-2. The faunal change within this zone is remarkable; specimens belonging to $G$. renzi, $G$. coronata, and $G$. 
paraconcavata give way to a dominantly $G$. arca assemblage. Specimens of $G$. cf. asymmetrica are rare and poorly preserved.

The Campanian/Santonian boundary is based on the first appearance of $G$. arca at Section 516F-114-4, because neither typical $G$. elevata nor true $G$. asymmetrica could be identified.

\section{Santonian}

The sequence below the possible Campanian/Santonian boundary contains poorly preserved foraminifers of the $G$. renzi, G. coronata, G. paraconcavata type, and some large specimens of $G$. fornicata; forms that could only indicate a Santonian to Santonian-Coniacian age. The occurrence of $G$. cf. concavata between Core $516 \mathrm{~F}-117$ and Section 516F-119-2 allows a subdivision into the " $G$. concavata" Zone and an overlying unzoned interval between the last occurrence of $G$. cf. concavata and the first appearance of $G$. arca.

\section{Benthic Foraminifers}

In general benthic foraminifers occur frequently at Site 516 and are well preserved down to the upper middle Eocene. Below this level all foraminifers become diluted in the clastic sediments, and their preservation deteriorates with increased lithification.

The core-top assemblage (Sample 516-1-1, 1-2 cm) is dominated by Hoeglundina elegans, Epistominella exig$u a$, and Globocassidulina subglobosa. The Pliocene assemblages exhibit a lower species dominance and lack $H$. elegans altogether. These rich assemblages include Stilostomella cf. lepidula, G. subglobosa, Planulina wuellerstorfi, Cibicidoides kullenbergi, Nuttalides umbonifera, E. exigua, Oridorsalis umbonatus, Pullenia bulloides, P. quinqueloba, Bolivina globulosa, Uvigerina auberiana, Eggerella bradyi, Siphotextularia rolshauseni, Karreriella bradyi, Textularia flintii, Rectuvigerina multicostata, Bulimina subacuminata, Ehrenbergina carinata, Osangularia culter, Planulina karsteni, Laticarinina pauperata, and Sphaeroidina bulloides. Upper and middle Miocene assemblages resemble those of the Pliocene. Dominant genera are Stilostomella, Planulina, Cibicidoides, Globocassidulina, and Bolivina, with Uvigerina and Bulimina abundant at certain levels.

Lower Miocene assemblages are distinctly different, partly because of changes in generic dominance, specifically increased frequencies of Cibicidoides, Lenticulina, and Sphaeroidina, and, at greater sub-bottom depths, Osangularia and Siphonina. Planulina renzi replaces $P$. wuellerstorfi, and both Nuttalides umbonifera and Epistominella exigua disappear. New faunal elements include Siphonina tenuicarinata, Osangularia mexicana, Bulimina tuxpamensis, B. impendens, Astrononion pusillum, Anomalinoides cf. alazanensis, and A. spissiformis.

The generic dominance in the upper Oligocene is much like that of the lower Miocene sediments, except for the increased abundance of Cibicidoides and the disappearance of Sphaeroidina. New species include Uvigerina mexicana, Bolivina tectiformis, Cibicidoides sp., $C$. dickersoni, and $C$. ungerianus. The Neogene species
S. bulloides, Textularia milletti, Rectuvigerina vesca, $C$. kullenbergi, $C$. cicatricosus, and $O$. culter do not occur below the upper Oligocene. At many levels, the assemblages are dominated by Bulimina impendens, B. tuxpamensis, $P$. renzi, and $C$. kullenbergi (or $C$. ungerianus).

The dominant genera in the lower Oligocene and upper Eocene are Cibicidoides, Lenticulina and Bulimina. The assemblages of each interval share many characteristic species, such as Gavelinella micra, C. sp., Hanzawaia cushman, U. havanensis, Bolivina byramensis, Anomalina corrugata, Discorbis subvilardeboanus, Siphonina tenuicarinata, and $P$. renzi.

Benthic foraminifers are sparse in the expanded middle Eocene section. This heterogeneous, displaced series of pelagic limestones is interbedded with volcanic ash layers, turbidites, breccias, and strata with reefal debris, and contains low-diversity benthic assemblages even in the pelagic limestones. The assemblages are dominated by Cibicidoides, buliminids, Lenticulina and agglutinants, whereas Globocassidulina, Siphonina, and Planulina are no longer present. The most frequently occurring species are $C$. ungerianus and Oridorsalis umbonatus. H. cushmani, Plectina elongata, and Bulimina impendens; several unidentified species of Pyramidina, Reussella, and Trifarina are more irregular in their distribution. Nuttallides truempyi and Buliminella grata are abundant only at the base of the section.

A displaced block of upper Maestrichtian limestone separates the lower from the middle Eocene. The benthic assemblage of Sample 516F-79-2, 85-87 cm is dominated by Gavelinella beccariiformis and Praebulimina reussi, with lower frequencies of nodosariids, Gyroidinoides spp., $N$. truempyi, and representatives of Gavelinella, Lenticulina, Pullenia, and Bolivinoides.

The poorly preserved early Eocene assemblages (Zone P6b) exhibit low species diversity. The most commonly occurring species include $O$. umbonatus, $N$. truempyi, and $L$. spp. Also present are Vulvulina mexicana, V. spinosa, Abyssamina poagi, Clinapertina inflata, Alabamina dissonata, Aragonia semireticulata, Buliminella grata, B. tuxpamensis, Nonion havanense, and Anomalina capitata.

The Paleocene fauna differs radically from the overlying lower Eocene assemblages in its increased species diversity and by the predominance of Gavelinella. Numerous rapidly occurring extinctions initiated the faunal turnover in the latest Paleocene (Zone P6a). The transition occurs between Samples 516F-83-3, 115-172 cm and $516 \mathrm{~F}-83-4,12-20 \mathrm{~cm}$. The dominant taxa of the Paleocene are $G$. beccariiformis and $N$. truempyi in association with Anomalinoides welleri, Bulimina velascoensis, G. hyphalus, G. velascoensis, Gyroidinoides globosus, L. macrodisca, O. umbonatus, $P$. coryelli, and Tritaxia trilatera. Additional species of limited stratigraphic range are $B$. trinitatensis (early Paleocene) and Cibicidoides pseudoperlucidus (late Paleocene).

Rapid change in the benthic fauna occurs across the Cretaceous/Tertiary boundary. Species diversity shows a moderate increase because about one-third of the latest Maestrichtian species do not survive the end of the Cretaceous. 
The relatively richer benthic fauna recovered from Campanian and Maestrichtian sediments is characterized by Gavelinella stephensoni, Gyroidinoides goudkoffi, G. nitidus, Nuttallinella florealis, and Praebulimina reussi, together with the species listed above (except $B$. velascoensis and $A$. welleri), occurring throughout the Paleocene.

In Hole 516F, below Core 109, recrystallization hampers species identification, and much of this section is too highly indurated to be disaggregated. Faunal composition of Santonian assemblages (Cores 116 to 119) are poorly diversified, and probably only those species resistant to diagenetic processes are present. Taxa present include Globorotalites multiseptus, Gyroidinoides praeglobosus, Lenticulina muensteri, as well as various gavelinellids.

\section{Paleobathymetry}

Only two major assemblages of benthic foraminifers existed below $1 \mathrm{~km}$ water depth during the Paleocene, Eocene, and Oligocene, and the boundary between them did not remain isobathyal. Further differentiation of the early Cenozoic faunas offers a somewhat better resolution for the late Eocene and Oligocene.

Starting with the Oligocene, the assemblage in Hole $516 \mathrm{~F}$ with its relative high abundance and diversity of uvigerinids is limited to bathyal depth, as are Sphaeroidinella bulloides, Cibicidoides laurisae, Bulimina macilenta, and $B$. antegressa. The presence (often in abundance) of Siphonina, B. tuxpamensis, B. anastomosa, C. mexicana, and Planulina renzi suggests a shallower, middle bathyal depth range. For the late Eocene, the occurrences of Uvigerina basichordata, Siphonina, Discorbis sp., Tritaxia californica, Reussella mexicana, and Bulimina tuxpamensis indicate a similar middle bathyal depth range.

The dominance of Gavelinella, Nuttalides, and Cibicidoides in Paleocene benthic assemblages and a generally high frequency of planktonic foraminifers suggest deeper bathyal depths before the onset of the Eocene.

Downward, progressive shallowing occurs in the Cretaceous section. Campanian and Maestrichtian sediments contain a fauna that, although not significantly different at the generic level from that of the Paleocene, includes increased abundances of nodosariids, buliminids, and gyroidinoids, suggesting middle bathyal to shallow lower bathyal depths. Benthic foraminiferal assemblages dominated by Gavelinella, Globotalites, Gyroidinoides, and Lenticulina and reduced abundance of the planktonic foraminifers indicate upper bathyal depths during the Santonian. The overall picture of the Coniacian-Santonian interval below $1200 \mathrm{~m}$ based on thin-section study is one of progressive shallowing downcore, from outer neritic-upper bathyal conditions in the younger part of this sequence to depths probably less than $20 \mathrm{~m}$ at the base of the sedimentary section.

\section{Shallow Water Indications}

Coarse levels containing concentrations of pelecypods, large benthics, or larger foraminifers occur at discrete intervals at Site 516. In HPC Hole 516, coarse lev- els occur characteristically in the upper $10 \mathrm{~cm}$ of every core and in some core catchers. In the first case, they are associated with pipe scale and probably are the result of washing out the hole after each piston core is taken.

In Hole 516, the core catchers of Cores 14 (upper Miocene) and 37 (lower Miocene) and Sections 1 and 2 of Core 16 contain small pelecypods, gastropods, otoliths, bryozoans, and large benthics in association with minor amounts of pipe scale. In Core 14, large agglutinated benthic foraminifers, such as Karreriella bradyi, $K$. novangliae, Vulvulina pennatula, and Gaudryina spp. form a conspicuous part of the assemblage. The calcareous part of the coarse fraction consists of large nodosariids, Vaginulinopsis, lenticulinids, Planulina wuellerstorfi, Sphaeroidinella bulloides, and Gyroidinoides. Core 37 contains smaller agglutinants (Vulvulina, Karreriella bradyi) but more large calcareous species, such as the pustulate Lenticulina papillosa, Nodosaria, Sphaeroidinella bulloides, Globocassidulina subglobosa, Planulina wuellerstorfi, Cibicidoides kullenbergi, and Pyrgo sp. Large agglutinants are abundant and concentrated at discrete levels in Core 516A-2. Thus, most contaminants (planktonics and benthics) throughout Holes 516 and 516A are Quaternary and the result of downhole caving and the HPC coring process.

In Hole $516 \mathrm{~F}$, pelecypods are concentrated at a few levels, mainly Core 5 (basal Miocene, Zone P4) and Cores 30 and 31 (upper Oligocene, base of Zone P20). Scattered pelecypods occur throughout the section. The accompanying association of large benthic foraminifers varies for each level, but includes calcareous genera such as Lenticulina, Saracenaria, Vaginulinopsis, Nodosaria, Dentalina, and agglutinated species such as Dorothia, Martinottiella, and Vulvulina. In particular, the association of calcareous benthic genera indicates a shallower water, approximately an outer shelf-upper slope environment.

Another episode of shallow water influx is found in the middle Eocene of Hole 516F. Reefal debris consisting of calcareous algae and bryozoans in association with larger foraminifers occur at two levels. In Core 50, a thin limestone bed contains Discocyclina, Linderina(?), and Nummulites. In Core 63, specimens of Discocyclina, Asterocyclina, and Nummulites were isolated from a soft nodule of reefal debris. These two levels occur in an interval of turbidites and of displaced Maestrichtian limestone. In the (smaller) benthic assemblage, this sedimentary regime is reflected by the unusually high frequencies of large agglutinant species, of which several have their optimal abundance on the upper slope.

\section{Radiolarians}

Radiolarian slides were prepared from core catcher samples of all cores at Holes 516, 516A, and 516F. In stratigraphic intervals containing radiolarians, additional samples were prepared from more closely spaced intervals.

Radiolarians are absent from Hole 516, Cores 1 to 34 (0-148 m sub-bottom; Quaternary to lower Miocene, Zone N6). In Cores 35 and 36, siliceous fragments appear for the first time and are increasingly abundant and 
more well preserved downward. Core 35 contains only spines of siliceous organisms; Core 36 contains scattered fragments of Cyrtocapsella cornuta, C. tetrapera, and Dorcadospyris ateuchus, which are consistent with an early Miocene age. Cores 37 through 41 contain rare, moderately preserved radiolarians of the early Miocene, probably belonging to the $C$. tetrapera Zone. Some samples within this interval are moderately well preserved, whereas others are poorly preserved and yield only spines or unidentifiable fragments. Cores 42 through 44 contain only spines, and no age can be assigned on the basis of the siliceous microfossils. On the basis of calcareous microfossils, these cores can be assigned to the earliest Miocene (Zone N4).

Radiolarians are totally absent from all samples examined from Hole 516A, Cores 1 to $16(0-69.5 \mathrm{~m}$ subbottom; Quaternary to middle Miocene, Zone N9).

At Hole $516 \mathrm{~F}$, radiolarian samples were prepared from each of the cores. In Cores 1 to 16 (169-321 m subbottom), radiolarian spines and test fragments are present, but they are not sufficiently preserved to allow identification of the taxa. In Cores 18 through 125, no radiolarians were identified in any of the prepared samples. The coarse fraction (carbonate free) consisted almost entirely of clay aggregates and rare detrital mineral grains. A few samples in the interval between Cores 66 and 70 contain aggregates whose morphology bears a faint resemblance to a siliceous skeletal meshwork, suggesting that radiolarians may have been deposited during this interval, and the silica was subsequently remobilized. At Hole $516 \mathrm{~F}$, consequently, the radiolarian fragments remaining are insufficient to provide any form of stratigraphic control.

\section{Diatoms}

Diatoms were identified in a total of 61 samples prepared and examined from Hole $516 \mathrm{~F}$, Cores 1 through 18 . Only rare and sporadic diatoms were observed in Cores 1 through 5. Two diatom zones of Gombos and Ciesielski (in press) occur in Cores 6 through 15. The Rocella gelida Zone, which straddles the Oligocene/Miocene boundary in the reference section (Site 513A, Leg 71), is present in Cores 6 through 10. The late Oligocene Triceratium groningensis Zone is present in Cores 11 through 15 . In Cores 16 through 18, diatoms are not sufficiently well preserved to allow specific zonal designations.

\section{PALEOMAGNETICS}

\section{Sedimentary Sequence}

\section{Introduction}

A study of the downhole variation in sediment magnetism and the development of the magnetostratigraphy constitutes an important objective for the continuously cored sediment sequence recovered from Site 516 .

As a historical background to this summary of results of remanence measurements, two earlier paleomagnetic investigations in the area are relevant. One of the first reliable polarity determinations to be made for sediment cored by Glomar Challenger was reported by Henry and Opdyke (1970) from Site 22 . They determined that the upper Oligocene Braarudosphaera chalk unit had a reliable direction of magnetization, indicating deposition during an interval of normal geomagnetic polarity. Berggren (1977) described a preliminary magnetic investigation of samples from a number of piston cores collected in the vicinity of Site 357. The investigation was intended to provide a paleomagnetically calibrated chronology for the microfloral and microfaunal biozonations established from the Quaternary-upper Neogene sediments of the Rio Grande Rise. Unfortunately, this goal was not directly achieved because the magnetic signature in these shallow piston cores is somewhat confused and considered unreliable as a recorder of any polarity stratigraphy.

Following these studies, we have an excellent opportunity to appraise the magnetic characteristics of the more complete sequence of Cenozoic through upper Mesozoic sediment recovered at Site 516. The absence of major hiatuses makes this site particularly promising for the resolution of a continuous magnetostratigraphy. The uppermost sub-bottom section at the site cored with the HPC, Holes 516 and 516A, revealed a well-preserved carbonate sequence spanning a time interval from early Miocene to the present. Deeper targets were penetrated by conventional rotary coring, Hole $516 \mathrm{~F}$, to a terminal depth of $1270.6 \mathrm{~m}$.

\section{Remanence Measurements-HPC Holes 16 and 516A}

Shipboard natural remanent magnetization (NRM) investigations included a study of 175 samples taken from the cores obtained from Holes 516 and 516A. Because Hole 516A duplicates the upper $60 \mathrm{~m}$ or so of Hole 516, it provides an ideal opportunity for a comparative spatial study of magnetic properties. Kukla and Zijderveld (1977) maintain that such duplication on a parallel section is a critical test for validating any proposed magnetic polarity stratigraphy.

Some constraint on the remanence investigations is imposed by the physical nature of the nannofossil-foraminifer ooze, the major lithologic unit recovered at the site by hydraulic piston coring. Dewatering on recovery and the generally dilatant character of these sediments made sampling difficult. Despite this problem, every effort was made to achieve a reasonable sampling coverage of the cored intervals; the initial goal was one sample every $0.5 \mathrm{~m}$ depth downhole. Low levels of magnetization caused a further difficulty for shipboard remanence measurement. Many samples have intensities close to or only just above instrument noise levels of approximately $0.3 \mathrm{~mA} / \mathrm{m}$. Because of this, relatively few samples were subjected to alternating field (AF) demagnetization as part of the shipboard procedure. Subsequently, we remeasured the majority of samples on shore and then subjected them to magnetic cleaning either using a peak AF of $20 \mathrm{mT}$ or thermal demagnetization to $280^{\circ} \mathrm{C}$. Although these nannofossil oozes and chalks exhibit some differences in their stability behavior, it is possible to determine the polarity from the cleaned remanence inclination value with a tolerable degree of certainty. 
Inclination variations with sub-bottom depth correlate reasonably well between the two HPC holes through the overlap depth interval down to $60 \mathrm{~m}$, confirming the inferred polarity reversal stratigraphy in the upper part of the sequence.

The mean (NRM) inclination values of $35.1 \pm 19.0^{\circ}$ (Hole 516, $\mathrm{n}=144$ ) and $35.4 \pm 17.7^{\circ}$ (Hole 516A, $\mathrm{n}=$ $31)$ are closely comparable. Corresponding values after demagnetization are $45.3 \pm 15.3^{\circ}($ Hole $516, \mathrm{n}=72$ ) and $39.2 \pm 20.0^{\circ}$ (Hole 516A, $\left.n=32\right)$. The large scatter in these inclination values may reflect the character of the remanence carriers in these dominantly biogenous sediments. As observed in earlier paleomagnetic investigations, inclinations shallower than the computed axial geocentric dipole field inclination, $49.4^{\circ}$ for Hole 516, are not uncommon and could be caused by an inclination error or compactive effects (Blow and Hamilton, 1975, 1978; Ellwood and Ledbetter, 1977).

The quality of the downhole inclination data for these HPC holes enables tentative conclusions to be drawn about the magnetostratigraphy (Fig. 15). Provisional assignments can be suggested according to the revised Cenozoic geomagnetic polarity time scales of Hailwood and others (1979), Ness and others (1980), and Lowrie and Alvarez (1981). The first reversal boundary identified at a sub-bottom depth of $4 \mathrm{~m}$ is correlated to the base of the Jaramillo Event, about $0.97 \mathrm{Ma}$. If the base of the Olduvai Event is correctly identified at $9 \mathrm{~m}$ sub-bottom depth (within Core 516-3), then the underlying Gauss Epoch spans the depth range from $11.5 \mathrm{~m}$ to $18.5 \mathrm{~m}$. These assignments imply an average sediment accumulation rate of about $5 \mathrm{~m} / \mathrm{Ma}$ through the late Pliocene and the Pleistocene. Much increased sedimentation rates characterize the lower Pliocene in Hole 516. Between $18.5 \mathrm{~m}$ and $52.5 \mathrm{~m}$ depth (Cores 516-5 through 516-13), an interval of dominantly reversed polarity, split by possibly five thin normal zones, is assigned to the Gilbert Epoch. The paleomagnetic evidence, although not conclusive, indicates that part of Epoch 5 (late Miocene) may be present just above a hiatus (inferred from biostratigraphic evidence) at approximately $55 \mathrm{~m}$ depth.

Core 516-14 and part of Core 516-15 are normally magnetized. An unambiguous assignment here is difficult; biostratigraphic studies (see Berggren et al., this volume) suggest the presence of a condensed sequence. Therefore, only tentative correlation to Magnetic Anomaly $5 \mathrm{~A}$ (Epoch 11$)$ is made.

A considerable degree of coring disturbance renders the interval from 63 to $85 \mathrm{~m}$ unsuitable for paleomagnetic study. Resolution of the polarity stratigraphy is better from 90 to $180 \mathrm{~m}$, almost at the terminal depth of HPC recovery at Hole 516. The sequence spans the upper Miocene so that an interval from Anomaly 5C (Epoch 16, 90-105 $\mathrm{m}$ depth) to the normal polarity event above Anomaly 6B (Epoch 21) is encountered.

\section{Remanence Measurements-Hole 516F}

About 370 of the 400 samples obtained from the cores recovered from the deep penetration hole, $516 \mathrm{~F}$, were used for initial NRM measurements on the ship. The full results of NRM intensity and remanence directions

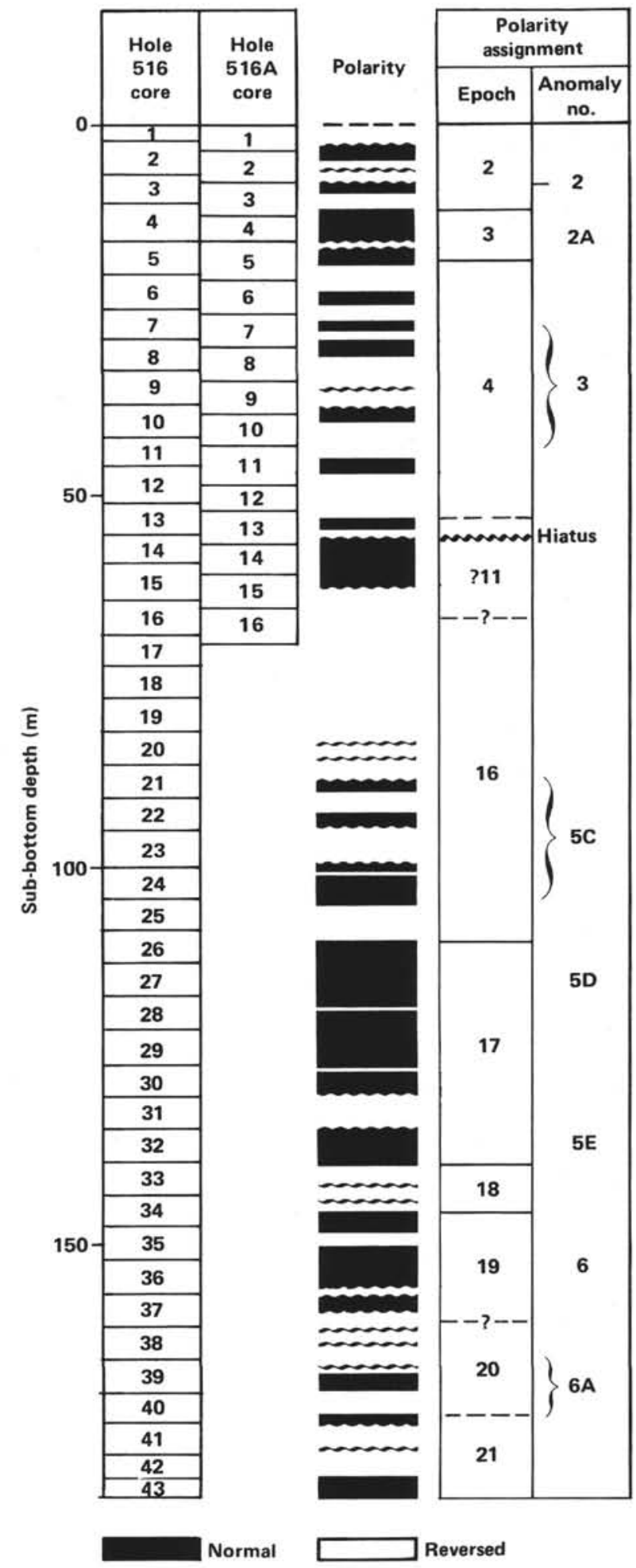

Figure 15. Magnetic polarity of the hydraulic piston corer holes at Site 516.

for all samples are deposited in the DSDP data bank. A number of pilot demagnetizations were undertaken for representative lithologic types from Hole 516F. These samples come mainly from the deeper parts of the sequence. For the most part, the thermal and AF demag- 
netization studies indicate that the pelagic sediments at Hole $516 \mathrm{~F}$ have a fair degree of stability.

As in the upper part of the sequence, the modal value of the NRM inclinations is shallower than the axial geocentric dipole value. Some two-thirds of sample population have negative NRM inclinations, however, which suggests a component of normal polarity overprinting. After magnetic cleaning, approximately equal numbers of the samples had positive and negative inclinations, confirming the effectiveness of the cleaning procedures in removing this normal overprint.

Figure 16 shows the observed downhole NRM inclination values for the entire hole, together with the inferred magnetic polarity. The polarity reversal stratigraphy is well preserved by the pelagic sediments of this hole. Clearly this is better resolved for the lower (Paleogene and late Mesozoic) part of the hole, which has a high sampling frequency. Assignment of the inferred Paleogene magnetostratigraphy is discussed by Hamilton and others (this volume).

Finally, we note an important reversal boundary detected in Section 516F-89-5 (965 m sub-bottom depth). This reversal occurs very close to the Cretaceous/Tertiary boundary. The underlying Maestrichtian through Santonian sediments are lithologically very similar to those studied paleomagnetically from the classic Late Cretaceous/Paleogene section of the Umbrian Appenines at Gubbio in Italy (Alvarez et al., 1977). The detailed magnetostratigraphy established for Gubbio can be used in the assessment of the Late Cretaceous polarity stratigraphy deduced for Site 516 (Hamilton and Suzyumov, this volume). The $289-\mathrm{m}$ thick pelagic limestone sequence of the Rio Grande Rise preserves a welldefined magnetostratigraphy that can be correlated to the Gubbio Magnetozones $\mathrm{A}^{-}$through $\mathrm{H}^{+}$, marine Magnetic Anomalies 34 to 29 .

The oldest sediments (recrystallized limestone), recovered in Core $516 \mathrm{~F}-125$, are normally magnetized and appear to belong to the upper part of the Late Cretaceous long normal interval, Anomaly 34.

\section{Igneous Basement}

Penetration and recovery of igneous basaltic basement from 1252 to $1271 \mathrm{~m}$ depth is achieved in Cores $516 \mathrm{~F}-126$ through $516 \mathrm{~F}-128$. Twelve samples from these basalts were selected for paleomagnetic study. The results of remanence and bulk susceptibility measurements made on these standard core samples are listed in Table 3.

All NRM inclinations are negative (normal polarity), and this is maintained after AF demagnetization up to $80 \mathrm{mT}$ or after thermal demagnetization. The mean NRM inclination of $-68.5 \pm 5.3^{\circ}$ is considerably steeper than the axial geocentric dipole field inclination of $-55^{\circ}$ for the paleolatitude of the Rio Grande Rise in the Late Cretaceous. This mean inclination is not significantly changed from magnetic cleaning (mean inclination = $\left.-65.5 \pm 11.4^{\circ}\right)$. It is difficult to account for the relative steepness of this inclination, except for the possibility that the drill hole was nonvertical at these depths or that there was postextrusion tectonic tilting. Another feature of interest is the apparently small scatter of the NRM in-

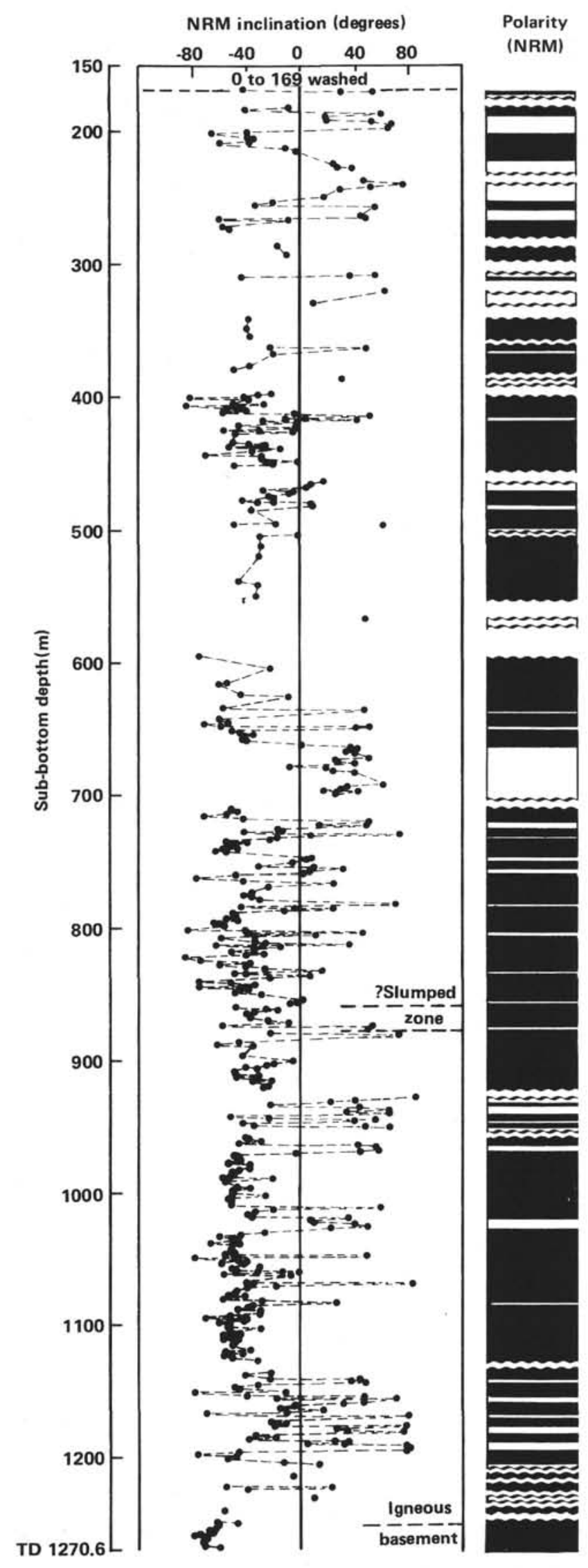

Figure 16. Downhole natural remanent magnetization (NRM) inclination and magnetic polarity for Hole $516 \mathrm{~F}$. TD $=$ Terminal depth. 
Table 3. Summary of magnetic data for Hole $516 \mathrm{~F}$ basalts.

\begin{tabular}{|c|c|c|c|c|c|c|c|}
\hline \multirow{2}{*}{$\begin{array}{l}\text { Core-section } \\
\text { (interval in cm) }\end{array}$} & \multirow{2}{*}{$\begin{array}{l}\text { Sub-bottom } \\
\text { depth } \\
\text { (m) }\end{array}$} & \multirow{2}{*}{$\begin{array}{c}\text { NRM } \\
\text { intensity } \\
(\mathrm{A} / \mathrm{m})\end{array}$} & \multirow{2}{*}{$\begin{array}{c}\text { Volume } \\
\text { susceptibility } \\
\left(\times 10^{-6}\right)\end{array}$} & \multirow[b]{2}{*}{$\mathbf{Q}^{\prime}$} & \multicolumn{2}{|c|}{ Inclination $\left({ }^{\circ}\right)$} & \multirow{2}{*}{$\begin{array}{l}\text { Median } \\
\text { destructive } \\
\text { field } \\
(\mathrm{mT})\end{array}$} \\
\hline & & & & & $I_{(0)}$ & ${ }^{1}(60)$ & \\
\hline $126-1,99-101$ & 1253.60 & 0.014 & 48 & 0.29 & -62.6 & -62.4 & 26 \\
\hline $126-2,32-34$ & 1254.43 & 0.686 & 105 & 6.53 & -67.1 & -71.3 & 26 \\
\hline $126-2,145-147$ & 1255.56 & 1.305 & 376 & 3.47 & -66.2 & -71.6 & 26 \\
\hline $126-3,59-61$ & 1256.20 & 2.277 & 680 & 3.35 & -66.6 & $-66.0^{\circ}$ & - \\
\hline $126-3,127-129$ & 1256.88 & 0.485 & 157 & 3.09 & -64.9 & -58.3 & 2.5 \\
\hline $127-1,64-66$ & 1258.25 & 0.663 & 773 & 0.86 & -74.9 & $-76.0^{*}$ & - \\
\hline $127-2,54-56$ & 1259.65 & 0.992 & 1007 & 0.99 & -79.1 & -72.8 & 23 \\
\hline $127-3,55-57$ & 1261.16 & 0.073 & 98 & 0.75 & -69.5 & -74.4 & 20 \\
\hline $127-4,15-17$ & 1262.26 & 0.175 & 79 & 2.22 & -69.4 & -68.3 & 41 \\
\hline $127-4,138-140$ & 1263.49 & 2.705 & 891 & 3.04 & -72.1 & -33.2 & 18.5 \\
\hline $128-1,35-37$ & 1266.96 & 1.420 & 273 & 5.20 & -70.8 & -67.0 & 49 \\
\hline $128-3,26-28$ & 1269.87 & 2.299 & 850 & 2.71 & -59.3 & -65.4 & 34 \\
\hline
\end{tabular}

Note: $Q^{\prime}$ is a modified Konigsberger ratio (i.e., in a field strength of unity); ${ }^{*}$ indicates cleaned inclination values after thermal demagnetization; dashes indicate no information available. $1(0)$ and $\mathbf{I}_{(60)}$ are inclinations before and after alternating-field demagnetization in a peak field of $60 \mathrm{mT}$.

clination values. Lack of scatter may indicate either a phase of rapid extrusion, which is short compared with the periods of secular variation (about $10^{3} \mathrm{yr}$.), or alternatively point to a single episode of remagnetization during a later phase of reheating.

NRM intensities, susceptibilities, and modified Konigsberger ratios $\left(Q^{\prime}\right)$ given in Table 3 are towards the lower end of the range of values normally found for the drilled oceanic crust.

\section{SEDIMENTATION RATES}

Site 516 provides one of the most complete successions of Tertiary and Late Cretaceous marine sediments in the world. With the exception of a hiatus in the middle to late Miocene, there is no evidence of missing sections in this continuously cored sequence. Important stratigraphic boundaries are intact, including the Cretaceous/Tertiary boundary (Core 516F-89), the Eocene/Oligocene boundary (Core $516 \mathrm{~F}-82$ or $516 \mathrm{~F}-83$ ), and the preglacial to glacial transition of the Pliocene (Holes 516 and 516A, Cores 5 to 6 ).

Computed sedimentation rates are shown in Figure 17. Stratigraphic control comes from calcareous nannofossils, planktonic foraminifers, and magnetic reversals. In the Tertiary, the revised time scales of Berggren, Kent, and Van Couvering (in press) have been used for the Neogene, and Berggren, Kent, and Flynn (in press) have been used for the Paleogene. The only significant discrepancy among age assignments in the Tertiary is within the middle Eocene, and estimates of Tertiary sedimentation rates should be fairly good.

For the Cretaceous, biostratigraphic control is less precise. The stratigraphic scheme of van Hinte (1976) is accepted in a general way, but absolute ages are recalibrated using the measured magnetic reversal stratigraphy and the reversal time scale of Berggren, Kent, and Flynn (in press). Thus, the apparent consistency of nannofossil, foraminiferal, and magnetic reversal ages within the Cretaceous in Figure 17 is partly artificial.

Measured sedimentation rates in Figure 17 are not corrected for compaction. For comparison with modern sedimentation rates, the measured rates may be corrected to a common $60 \%$ (seabed) porosity, using the wetbulk density measurements in Figure 18B, and a (calcite) grain density of $2.71 \mathrm{~g} / \mathrm{cm}^{3}$. "Seabed" rates are obtained by multiplying the measured rate in Figure 17 by $1.48 \varrho_{\mathrm{B}}$ -1.521 , where $\varrho_{B}$ is the wet-bulk density.

Sedimentation at Site 516 is predominantly pelagic, and sedimentation rates are typical for sediments beneath relatively productive surface waters. Rates are reduced abruptly at the Cretaceous/Tertiary boundary (see Hamilton et al., this volume), and Paleocene rates are extremely low. Pelagic sedimentation during the middle Eocene is augmented by partly volcanogenic turbidites derived probably by subaerial erosion from a tilted and uplifted block upslope (see Bryan and Duncan, this volume; Barker et al., this volume). High rates continued into the early Miocene, however, which suggest a real increase in productivity, possibly of local extent, following the middle Eocene uplift. $\mathrm{An}{ }^{40} \mathrm{Ar} /{ }^{39} \mathrm{Ar}$ age (Mussett and Barker, this volume) for the basal lavas in Hole $516 \mathrm{~F}$ is consistent with the age of the basal sediments, but the $\mathrm{K}$-Ar age of $47.4 \pm 0.7 \mathrm{Ma}$ on biotites from an ash bed within Unit 4 (Bryan and Duncan, this volume), is compatible with only the nannoplankton age, in a region where ages are not mutually consistent.

\section{PHYSICAL PROPERTIES}

A large number of physical properties measurements were made at Site 516 in both the HPC holes (516 and $516 \mathrm{~A})$ and in the rotary hole (516F). Properties measured include shear strength, acoustic velocity, density, water content, porosity, and thermal conductivity. The principal purpose of this section is to describe the variation of physical properties down the hole and their relation to lithology. The mechanical properties of sediments in the upper part of the section are discussed by Walton and others (this volume). Tables of physical properties for Hole $516 \mathrm{~F}$ are included in three chapters in this volume (Carlson et al., Schaftenaar et al., and Gebhard and Carlson).

Hole 516 was cored using the HPC to a depth of about $180 \mathrm{~m}$. The physical properties of the sediments recovered appear to reflect the degree of disturbance caused by coring in carbonate oozes, as opposed to in situ properties. The first section of each core was often visibly disturbed. Furthermore, after the core was split, significant disturbance could be produced by tapping lightly on the core liner. Measured velocities also suggest disturbance because they fail to increase with depth. The average of 69 measurements made through the core liner is $1.58 \mathrm{~km} / \mathrm{s}$, with a standard deviation of only $0.02 \mathrm{~km} / \mathrm{s}$. By contrast, the near-surface velocity gradient in calcareous sediments of the equatorial Pacific is $1.83 \mathrm{~s}^{-1}$ and Hamilton (1979) has suggested that the gradient should be 1.5 to $1.8 \mathrm{~s}^{-1}$ in the upper $200 \mathrm{~m}$ of undisturbed carbonate sections.

Perhaps the most striking evidence of disturbance in the HPC cores is in the variation of shear strength (Fig. 19). The apparent shear strength shows a systematic decrease from about $160 \mathrm{~g} / \mathrm{cm}^{2}$ in the uppermost few meters of the section to about $0.85 \mathrm{~g} / \mathrm{cm}^{2}$ at a depth of $75 \mathrm{~m}$. Below $80 \mathrm{~m}$, the shear strength does increase, but so does the variability. Of the 31 cores in which two or more measurements were made, 17 show a net decrease 


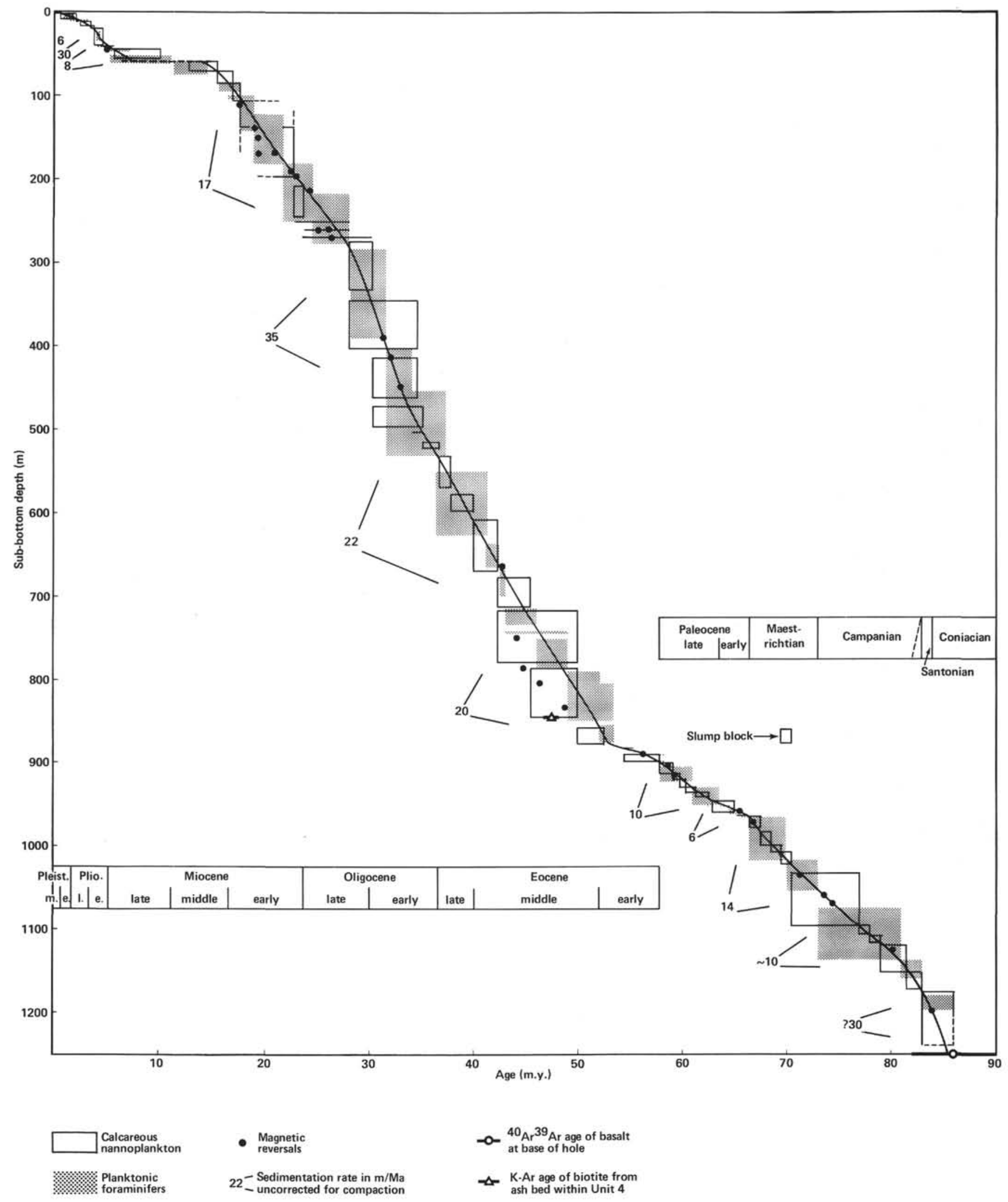

Figure 17. Accumulation rates based on calcareous nannoflora and planktonic foraminifers at Site 516. 


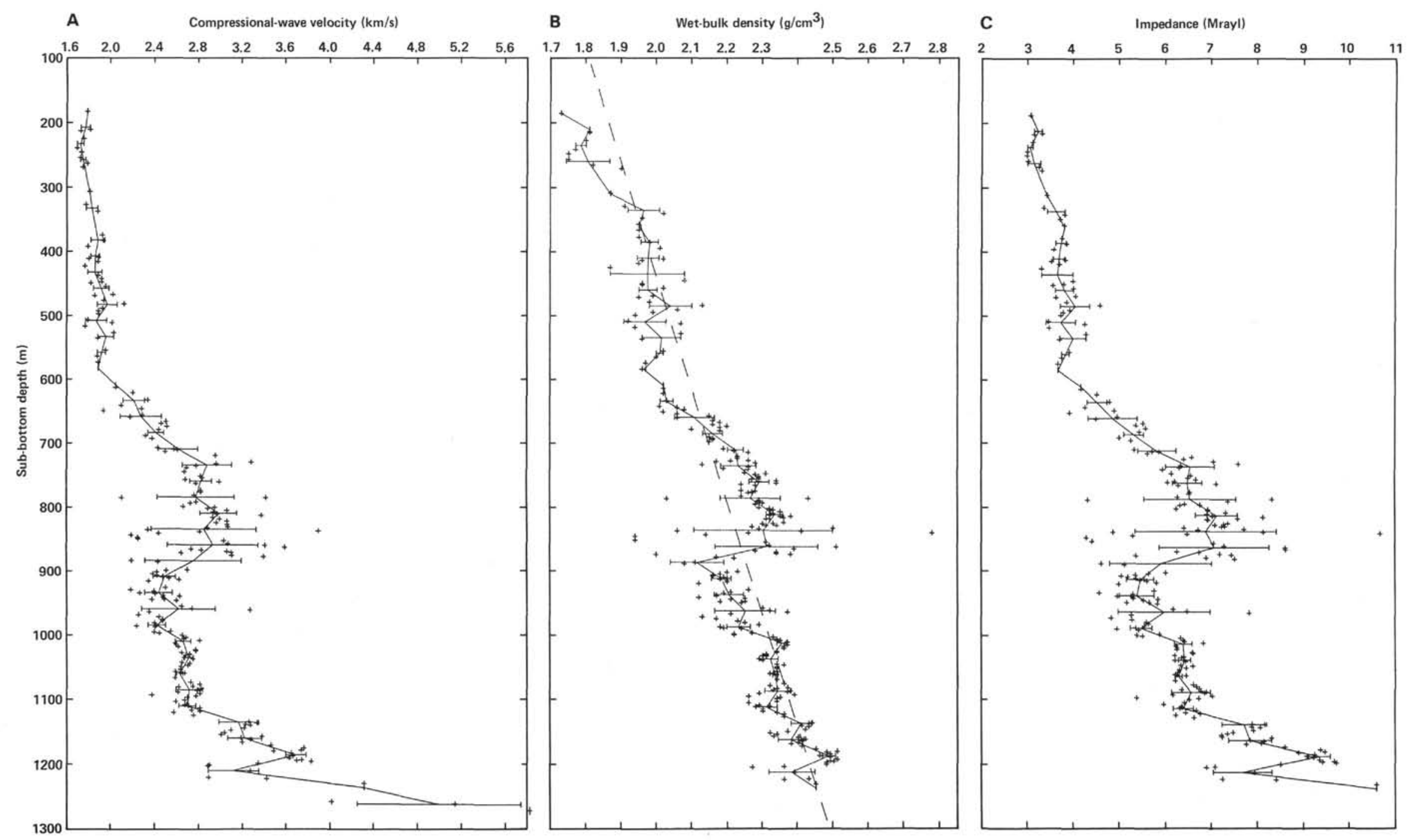

Figure 18. Physical properties measurements for Hole 516F. A. Compressional-wave velocity versus sub-bottom depth. B. Wet-bulk density versus sub-bottom depth. C. Impedance versus sub-bottom depth. 


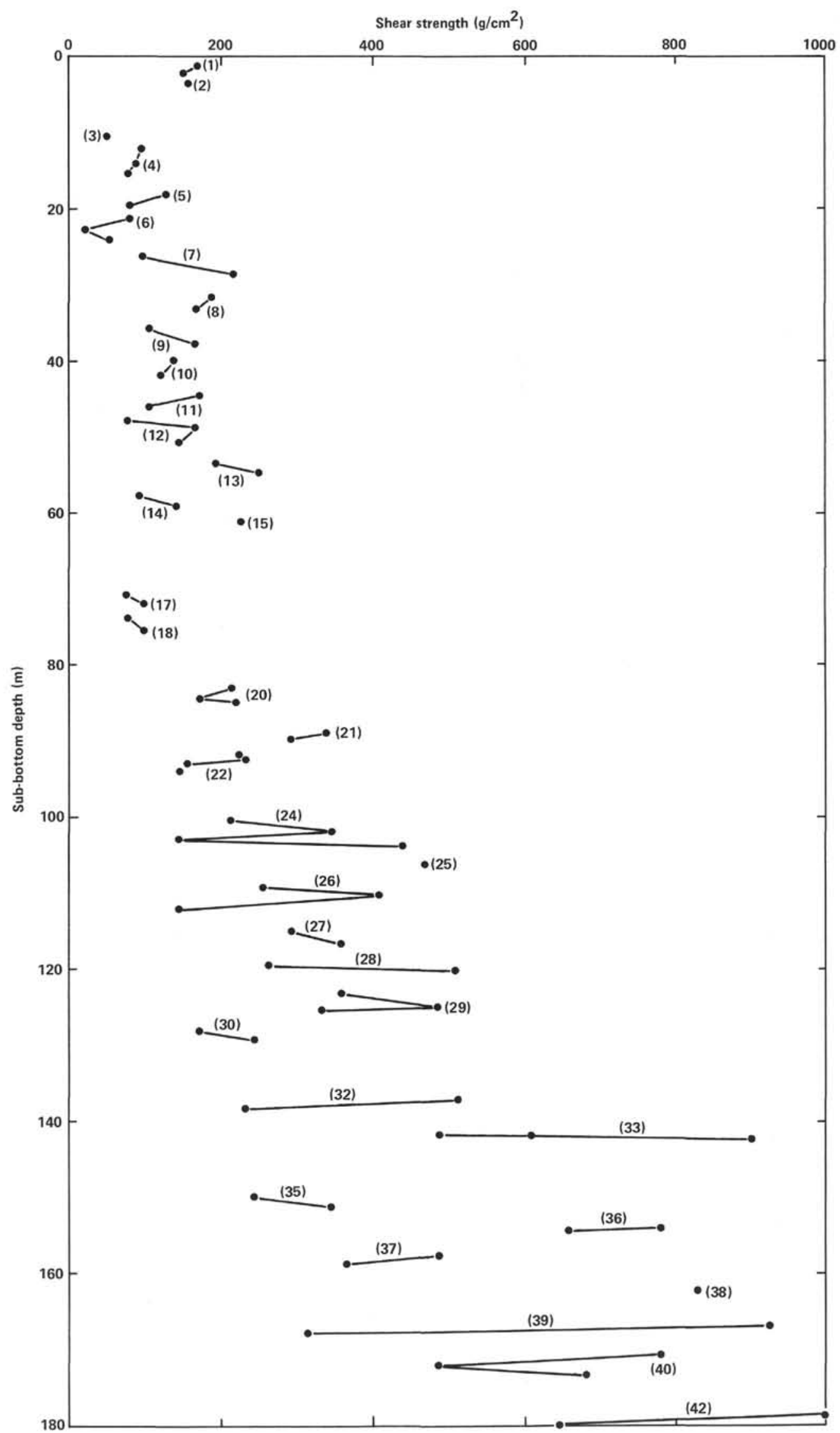

Figure 19. Shear strength versus sub-bottom depth in hydraulic piston corer Hole 516. Core numbers are in parentheses. 
in shear strength down the core. In several cases, the magnitude of the decrease is quite large. The variation in shear strength within cores is often more than $100 \mathrm{~g} /$ $\mathrm{cm}^{2}$, and frequently reaches magnitudes of 300 to $400 \mathrm{~g}$ / $\mathrm{cm}^{2}$ in cores recovered from depths greater than $80 \mathrm{~m}$. Results of a shore laboratory study of the mechanical properties of unconsolidated sediments sampled with the HPC (Walton et al., this volume) strongly support the conclusion that these sediments are significantly disturbed in the coring process, and that the measured properties are not representative of in situ values. Consequently, acoustic velocities, bulk densities, and porosities are not included in this report.

Continuous rotary coring in Hole $516 \mathrm{~F}$ through more than one $\mathrm{km}$ of calcareous sediments, ranging in age from $20 \mathrm{Ma}$ to about $84 \mathrm{Ma}$, provided an excellent opportunity to study the variation of physical properties downsection, and a large number of measurements was made. Figure 18 illustrates variations of compressionalwave velocity, density, and acoustic impedance with depth. Physical properties, including water content and porosity and the acoustic properties of indurated calcareous sediments from this site, are described in Schaftenaar and others and Carlson and others (both this volume). The elastic properties of the basalts are described by Gebhard and Carlson and Schaftenaar and others (both this volume).

Wet-bulk densities were measured by immersion or by the 2-minute GRAPE method, but only the immersion values are shown in Figure 18. Compressional-wave velocities were measured parallel $\left(\mathrm{V}_{\mathrm{h}}\right)$ and perpendicular to bedding $\left(\mathrm{V}_{\mathrm{v}}\right)$. The average sound velocity, $\mathrm{V}_{\mathrm{av}}=\left(\mathrm{V}_{\mathrm{v}}+\right.$ $\left.2 V_{h}\right) / 3$ is shown in the figure. Acoustic impedance is the product of density and velocity, here given in Mega rayls $\left(1 \mathrm{rayl}=1 \mathrm{~kg} \cdot \mathrm{m}^{-2} \cdot \mathrm{s}^{-1}\right)$.

The variation of physical properties corresponds well with variations in lithologic characteristics and with the reflection profile (see next section). Because of coring disturbance, few measurements were made in Unit 2, a nannofossil ooze with chert nodules that has velocities in the range 1.6 to $1.7 \mathrm{~km} / \mathrm{s}$ and bulk densities ranging from near $1.7 \mathrm{~g} / \mathrm{cm}^{3}$ to near $1.9 \mathrm{~g} / \mathrm{cm}^{3}$. Both velocity and density increase slightly at the top of Unit 3, a chalk and limestone sequence in which densities increase from about 1.95 to $2.05 \mathrm{~g} / \mathrm{cm}^{3}$ at a depth of $634 \mathrm{~m}$. Velocities increase from 1.8 to about $1.95 \mathrm{~km} / \mathrm{s}$ at a depth of $600 \mathrm{~m}$, then increase rapidly to $2.1 \mathrm{~km} / \mathrm{s}$ at the base of the unit. The abrupt change in velocity gradient does not correspond to an identifiable lithologic change, and the boundary between Units 3 and 4 is not marked by a significant change in the gradient. Bulk density increases slightly, however, across the contact. Unit 4 , which extends from 634 to $874 \mathrm{~m}$ depth, consists of interbedded pelagic limestones, altered volcanic ash, and turbidites. Densities and velocities are highly variable. Average densities increase from 2.1 to $2.35 \mathrm{~g} / \mathrm{cm}^{3}$; velocities increase from 2.1 to $2.85 \mathrm{~km} / \mathrm{s}$. At a depth of about $740 \mathrm{~m}$, the average velocity is near $2.8 \mathrm{~km} / \mathrm{s}$, and at this point the velocity gradient decreases abruptly. The boundary between Units 4 and 5 is the site of a marked inversion in physical properties; densities decrease abruptly from
2.35 to $2.15 \mathrm{~g} / \mathrm{cm}^{3}$, and velocities decrease from 2.85 to about $2.4 \mathrm{~km} / \mathrm{s}$. Unit 5 is a nannofossil limestone sequence in which both velocity and density exhibit slight depth gradients. Unit $6 \mathrm{a}$ is a sequence of interbedded limestones and marly limestones. Both velocity and density increase slightly at the top of the unit, which is characterized by a relatively low degree of scatter and low gradients; velocities in Subunit $6 \mathrm{a}$ are near $2.7 \mathrm{~km} / \mathrm{s}$ and densities average $2.33 \mathrm{~g} / \mathrm{cm}^{3}$. The boundary between Subunits $6 \mathrm{a}$ and $6 \mathrm{~b}$ is marked by an increase in density to about $2.4 \mathrm{~g} / \mathrm{cm}^{3}$. The acoustic velocity increases to $2.9 \mathrm{~km} / \mathrm{s}$. Subunit $6 \mathrm{~b}$ is a recrystallized, dolomitic limestone in which the vertical velocity gradient is 12 to $14 \mathrm{~s}^{-1}$; the velocity at the bottom of the unit is near $4.4 \mathrm{~km} / \mathrm{s}$. The corresponding increase in density is not so dramatic, and the drastic increase in velocity is probably related to cementation and dolomitization. The underlying basalts are highly altered and range in velocity from $4.3 \mathrm{~km} / \mathrm{s}$ to more than $5.7 \mathrm{~km} / \mathrm{s}$ (Gebhard and Carlson, this volume). Thus, the velocity contrast between the basal limestones and underlying basalts is small.

Abnormally high velocities are associated with Unit 4. If data in the interval between 600 and $884 \mathrm{~m}$ sub-bottom is neglected, the vertical velocity gradient in the upper $1000 \mathrm{~m}$ at Site 516 is 0.75 to $1.25 \mathrm{~s}^{-1}$. Thus, the higher velocities in the middle of this section may be regarded as anomalous. Unit 4 includes a significant proportion of volcaniclastic debris and correlates with the "midsection domes" seen on regional reflection profiles. Velocities in this interval increase with decreasing carbonate content. These conditions suggest that the anomalous properties of rocks in this interval are related to diagenetic processes occurring in a sequence of calcareous and siliceous sediments. The fact that the anomalous velocity gradient at the top of Unit 4 extends into the lower part of Unit 3 appears to support this view.

\section{CORRELATION OF REFLECTION PROFILER DATA WITH DRILLING RESULTS}

The distribution of reflection profiles in the immediate vicinity of Site 516 is shown in Figure 20. Original site selection was based on the Lamont-Doherty Vema 26-06 profile (Fig. 21), in which basement appears to lie about $0.8 \mathrm{~s}$ sub-bottom. The potential Site 516 was then surveyed further during the UTMSI multichannel survey of most of the South Atlantic sites in July 1979. When the processed data became available in December 1979 , it was clear that the $0.8 \mathrm{~s}$ reflector lay some distance above the base of the sediment pile. Figure 22, an extract of line WSA13 of that survey, shows acoustic basement at between 1.1 and $1.25 \mathrm{~s}$; the earlier assumed basement is a strong composite midsection reflector in the form of domes rising to varying heights above a flatter base. Glomar Challenger was required to undertake further survey to ensure that the drill site avoided these domes, which were considered potential hydrocarbon reservoirs.

The Glomar Challenger profile approaching the site (Fig. 23) consists of one long section steamed northward, followed by a turn to the south for the final approach. Arrows on both of these crossings indicate the 


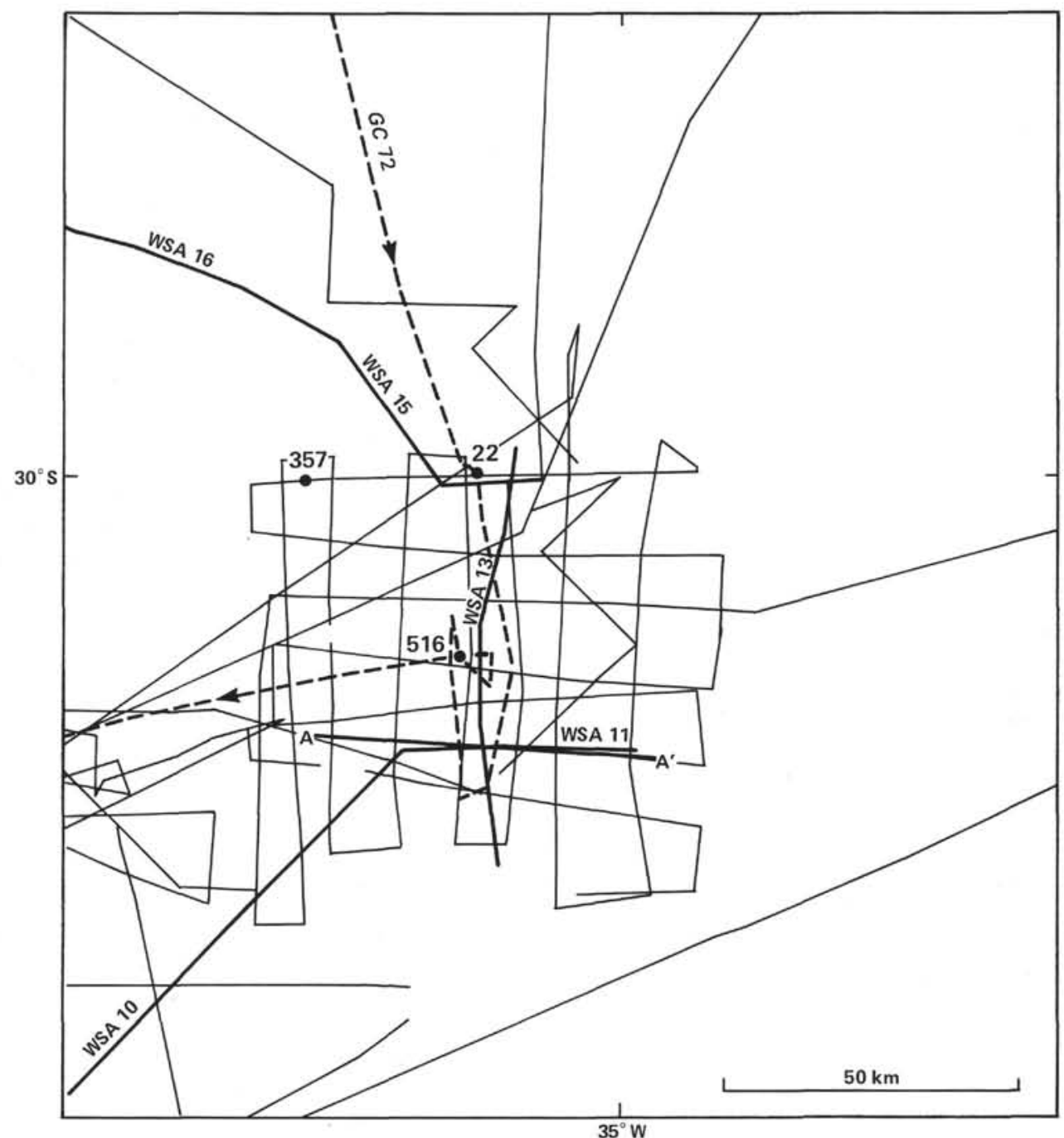

Figure 20. Track line plot of profiles around Site 516. Track segment $\mathrm{AA}^{\prime}$ is shown in Figure 21, dashed line is Glomar Challenger track (Figs. 23 and 24), and thick line is Fred H. Moore track (UTMSI profile, Fig. 22).

site location. The final position was chosen over a basement high (only $1.04 \mathrm{~s}$ sub-bottom) and on the edge of the "domes" province, so that the uppermost part of the dome reflector lies at 0.69 to $0.74 \mathrm{~s}$. The site is about $3 \mathrm{n}$. miles away from the UTMSI line at its closest approach (arrow in Fig. 22), and was linked to this line by surveying after drilling.

Sonic velocity measurements on the samples cored at Site 516 are described in the Physical Properties section. Figure 24 shows a velocity model fitted to the data. Following experience at Site 515, and taking into account the measurements at elevated pressure (reported by Carlson, this volume; open circles in Fig. 24), the model is drawn as a slightly high-biased fit to the horizontal (parallel to bedding) shipboard measurements (solid dots in Fig. 24). It is consistently faster than almost all of the shipboard vertical velocity values. The data coverage is excellent, although only horizontal velocity measurements could be made in the less consolidated sediments above
$185 \mathrm{~m}$. Scatter of the measurements increases considerably below about $720 \mathrm{~m}$, and uncertainty about an appropriate velocity model also increases.

The velocity structure down the hole results from progressive compaction and diagenesis of a uniform carbonate sequence, from ooze to chalk to limestone, interrupted in midsection (between about 600 and $880 \mathrm{~m}$ ) by a much more cemented and recrystallized interval. As the carbonate content diagram clearly shows (Fig. 3), velocity and the proportion of noncalcareous sediment (possible volcanic ash layers, turbidites) are highly correlated. The highest velocities occur within limestones, whereas the turbidites are unconsolidated and possess low velocities. Some migration of fluids (probably mainly of silica) has likely taken place from the noncarbonate components and contributed to the cementation and diagenesis of the carbonates.

In general, wet-bulk density changes and velocity changes coincide so that the discontinuities in the ve- 


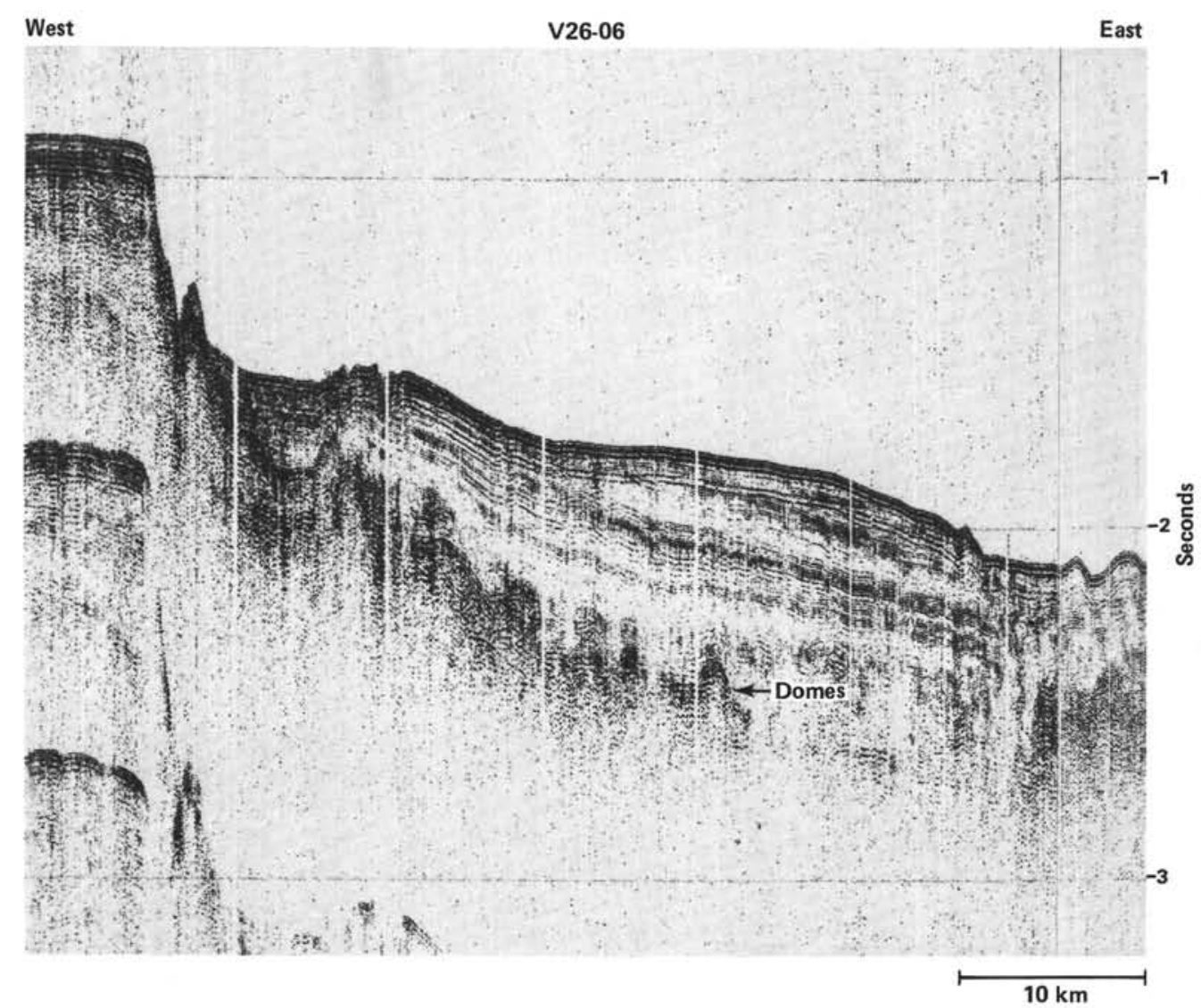

Figure 21. Lamont-Doherty Geological Observatory seismic reflection profile and location of middle Eocene "midsection domes."
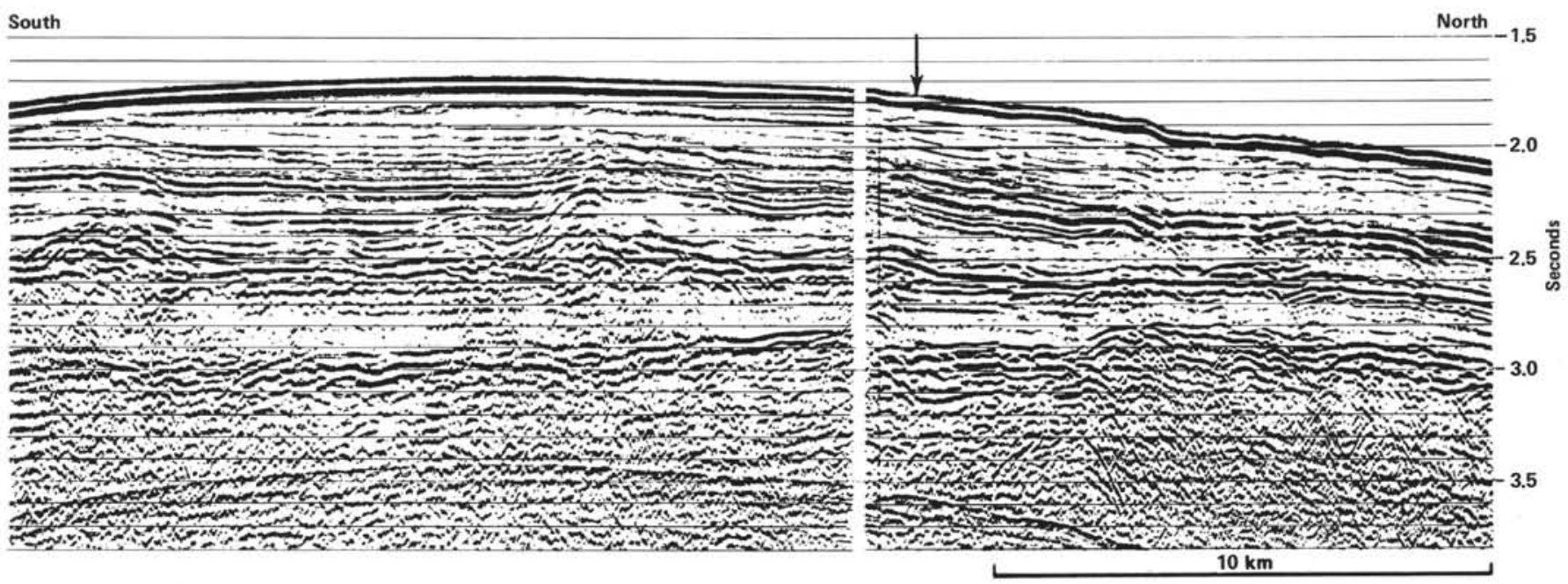

Figure 22. UTMSI processed multichannel line WSA13. Arrow indicates closest approach to Site 516 ( $3 \mathrm{n}$. mile).

locity structure, as picked out by the velocity model, should produce reflectors in the seismic record at approximately the times noted in Figure 24.

The most prominent features of the Glomar Challenger profile approaching the site (Fig. 23) are (1) the "basement"' high at about $1.04 \mathrm{~s}$, (2) the "midsection domes" horizon, the top of which lies with the range 0.69 to $0.74 \mathrm{~s}$ at the site, and (3) a suite of reflectors beneath $0.40 \mathrm{~s}$ that have the draped appearance of pelagic sediments. It seems clear, despite the slight discrepancy (less than $3 \%$ ) between the velocity model's predictions and actual time to the reflectors, that these represent, respectively, (1) the velocity change at $1125 \mathrm{~m}$; (2) the steep velocity gradient beneath $600 \mathrm{~m}$; and (3) the step in the velocity model at $330 \mathrm{~m}$. If this is accepted, it is possible to correlate the entire lithologic section with 


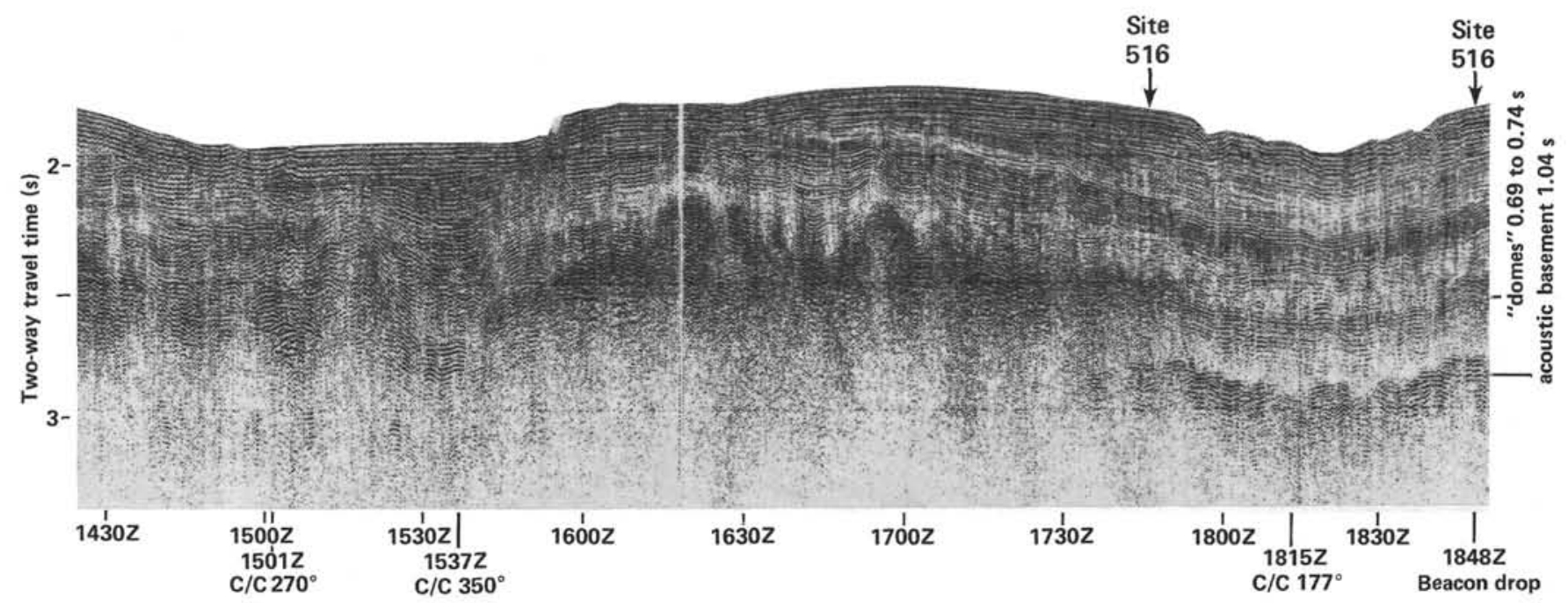

Figure 23. Glomar Challenger single-channel seismic profile showing the approach to Site $516 . \mathrm{C} / \mathrm{C}=$ course change.

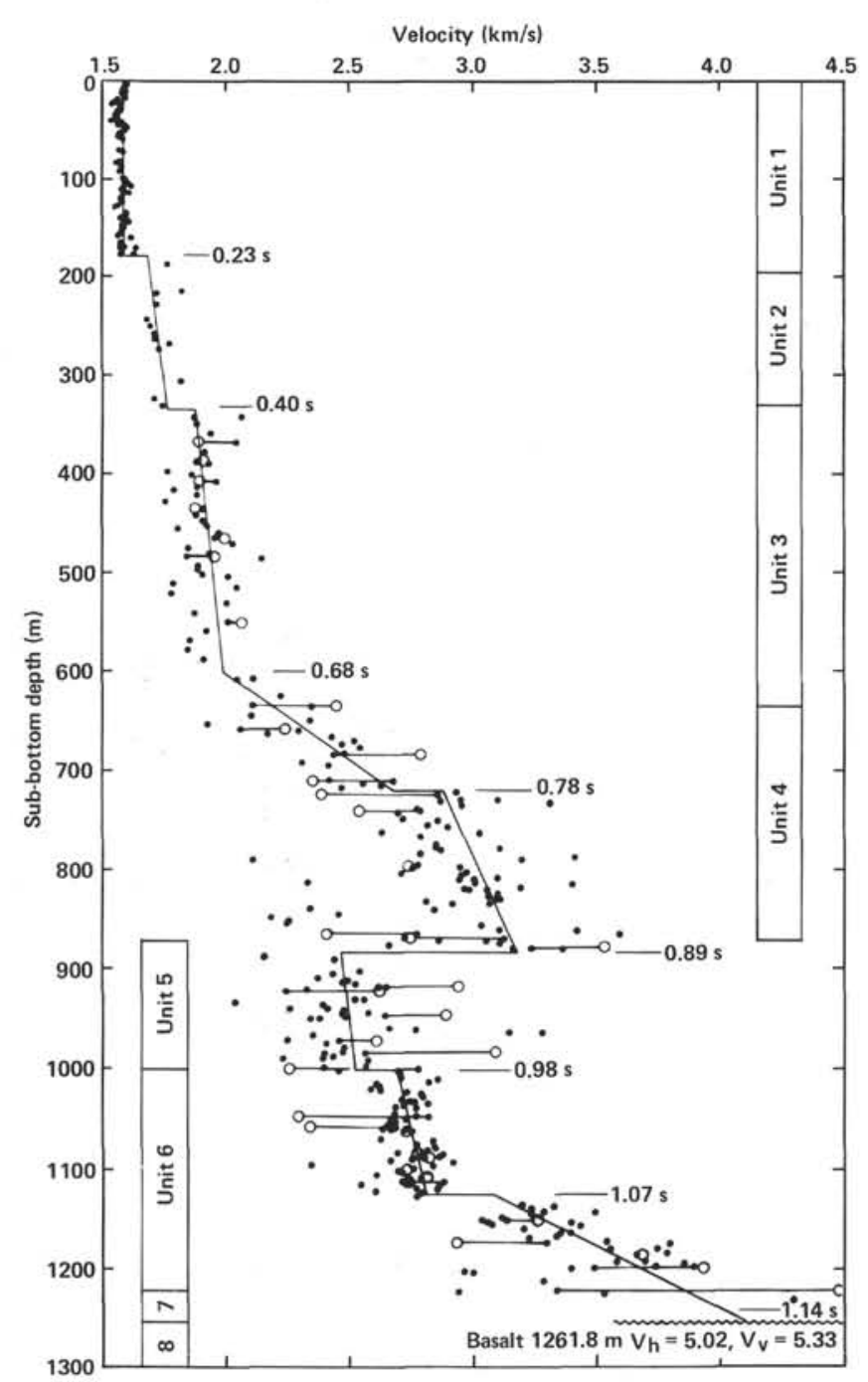

Figure 24. Shipboard measurements of horizontal p-wave velocity $\left(V_{h}\right)$ plotted against depth (solid circles), and compared with lithologic units cored at Site 516. Open circles are vertical P-wave velocities $\left(\mathrm{V}_{\mathrm{v}}\right)$ at $0.1 \mathrm{kbar}$ confining pressure (Carlson et al., this volume). the profile. Figure 25 is an enlargement of part of Figure 23 , showing the identifications made.

Acoustic basement at $1.04 \mathrm{~s}$ is not the basaltic basement of Cores $516 \mathrm{~F}-126$ to $516 \mathrm{~F}-128$, but is the top of the white microcrystalline limestone and gray marly limestone and claystone of the top of Subunit $6 \mathrm{~b}$. Velocities within these sediments range up to $4.4 \mathrm{~km} / \mathrm{s}$, and it is not surprising that the basalt beneath them does not give rise to a distinct reflection at the site. A single-channel, Glomar Challenger seismic profile (Figs. 23 and 25) shows that Site 516 stands on a local basement high, which may be diagenetically controlled. The strong, widespread reflector of the multichannel profiles, which is probably basalt, lies slightly deeper at the intersection of the multichannel and the Glomar Challenger profiles. On the multichannel profiles, other reflectors occur beneath this basalt. Barker and others (this volume) interpret these reflectors as interbedded subaerial lavas and sediments produced by subaerial seafloor spreading, as in Iceland at present.

The other high-velocity, strongly recrystallized part of the drilled section lies between 600 and $800 \mathrm{~m}$ subbottom, the "midsection dome" sequence of the reflection profiles. The dome sequence is clearly thick and irregular in Figures 23 and 25, and, because of its depth range, is confidently identified with the middle to upper Eocene Unit 4 at the site. Its character away from the site is seen better in Figure 22, however, because of the reduced vertical exaggeration. The sequence has an irregular upper surface, a complicated internal structure and a relatively flat base. It does not appear to be influenced by the underlying "basement" topography, but the overlying reflectors are influenced by it, apparently undergoing differential compaction and faulting. It seems very likely that, away from the site also, the dome sequence is diagenetic; its distribution is controlled mainly by the availability of silica and reflects the distribution of volcanogenic sediment deposited as slumps, turbidite flows, or ash falls. Depth of subsequent burial would be an additional, probably secondary, influence. 


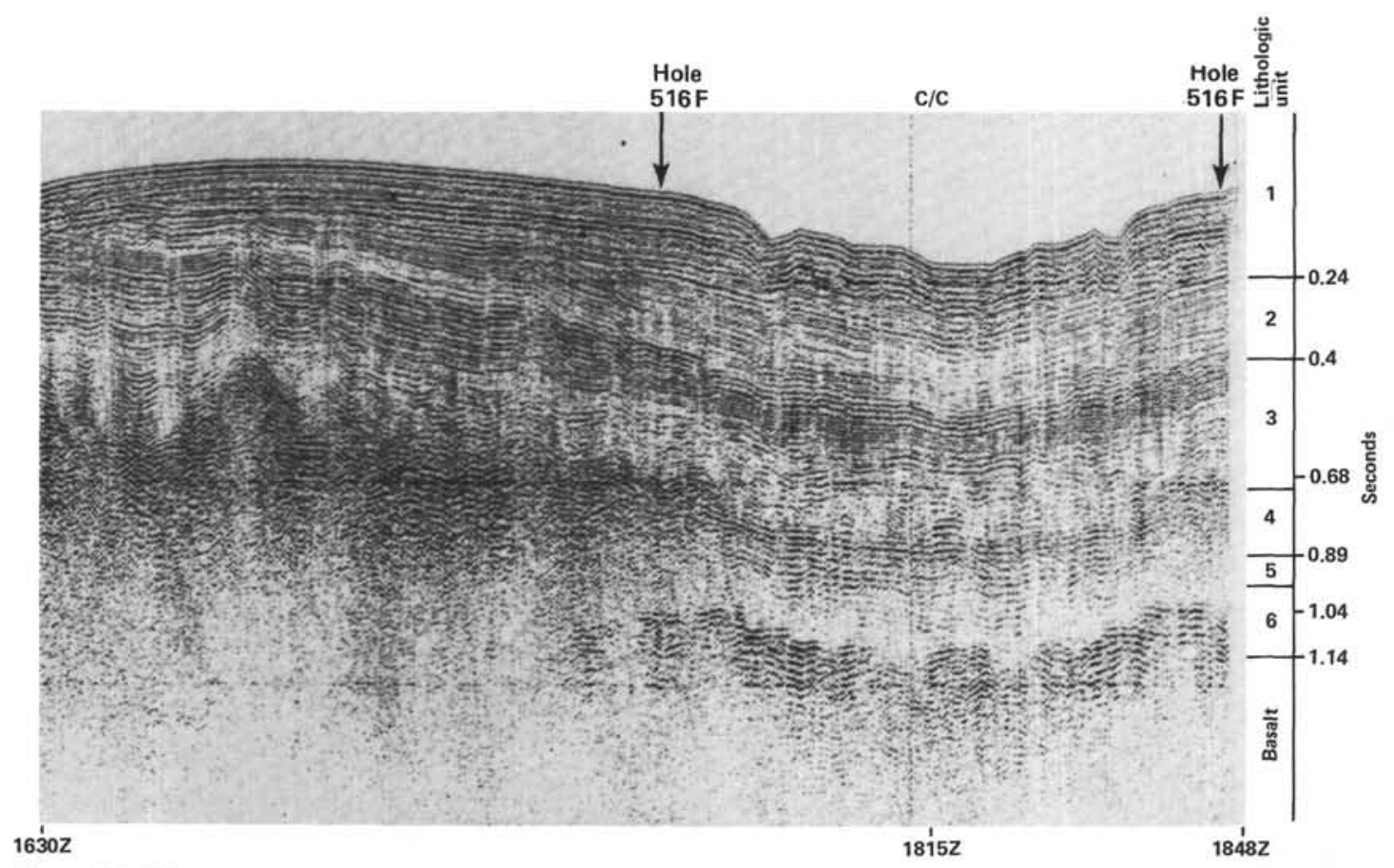

Figure 25. Enlargement of part of Figure 26: Glomar Challenger profile recorded during the vessel's approach to Site 516. $\mathrm{C} / \mathrm{C}=$ course change.

At Site 357, $36 \mathrm{~km}$ downslope from Site 516 and more distant from the topographic highs, the middle Eocene noncarbonate component is more restricted, and the excursions in the physical properties were less pronounced (Supko et al., 1977), in accordance with this interpretation. Also, if the dome reflectors are associated with turbidites and slumps in the way suggested then they should become more extensive upslope, nearer to the source, and should die out downslope, which they appear to do (Fig. 21).

The reflectors above the domes follow the shape of the domes themselves. Sediments younger than middle Eocene (Units 2 to 3 ) are essentially pelagic and could merely have been draped over hummocky slump topography. Signs of high-angle faulting (Fig. 22), however, suggest that some differential compaction may be taking place, effectively propagating upward and preserving the dome topography. One such fault reaches the surface very near to Site 516 (Fig. 26).

The $3.5-\mathrm{kHz}$ echo sounder proved most useful in providing penetration of the uppermost $50-100 \mathrm{~m}$. This depth range lies within the wave train of the seabed reflection in normal air gun profiles, but is of great interest in the context of HPC sampling. Figure 26 shows the $3.5-\mathrm{kHz}$ profile on the approach to Site 516 , with an enlarged on-site record inset. Two prominent reflectors are visible in both records at sub-bottom depths of about 56 and $66 \mathrm{~m}$. The higher, weaker of these lies within Core 14 of Holes 516 and 516A; the lower, stronger reflector lies within Core 16. Recovery in Cores 15 and 16 was severely disrupted in both holes, perhaps by a coarse foraminiferal sand with manganese nodules, which marks a hiatus of several million years' duration during the late and middle Miocene. The $3.5-\mathrm{kHz}$ profile clearly shows that the relationship of these two reflectors is uncomformable and that the hiatus is probably more extensive upslope.

The seismic reflection character of Rio Grande Rise sediments and basement is considered in greater detail by Barker and others (this volume).

\section{SUMMARY AND CONCLUSIONS}

Site 516 , located in $1313 \mathrm{~m}$ of water on the northeast flank of the Rio Grande Rise, occupied 19 days of Leg 72. Of the seven holes drilled, four were abandoned with little or no recovery either because of bad weather or because of equipment malfunction. Of the remainder, Hole 516 is an HPC hole continuously cored to $183.3 \mathrm{~m}$ with $81 \%$ recovery; $516 \mathrm{~A}$ repeated the uppermost $69.5 \mathrm{~m}$ of the section, with $88 \%$ recovery, in anticipation of heavy sample demand; and Hole $516 \mathrm{~F}$ was washed to $169.1 \mathrm{~m}$ and then rotary drilled with continuous coring to $1270.6 \mathrm{~m}$. An attempt to log Hole 516F failed because of caving at $184 \mathrm{~m}$.

One of the most significant results of drilling at Site 516 is that the recovered carbonate sequence appears to be continuous from the Santonian-Coniacian to the Recent, with the exception of a minor unconformity in the upper Miocene. Several important boundaries were recovered intact, including the Cretaceous/Tertiary boundary, the Eocene/Oligocene boundary, and the lower Pliocene glacial to interglacial boundary. Absolute ages according to the time scale of Hardenbol and Berggren (1978) are well defined for the Tertiary, and age assignments based on assemblages of foraminifers and nannofossils are in agreement. For the Cretaceous, the nannofossil succession is not entirely consistent with that suggested by van Hinte (1976), but does agree with results from nearby Site 357. Sedimentation rates exceed $10 \mathrm{~m} / \mathrm{Ma}$ (uncorrected for compaction), except within 


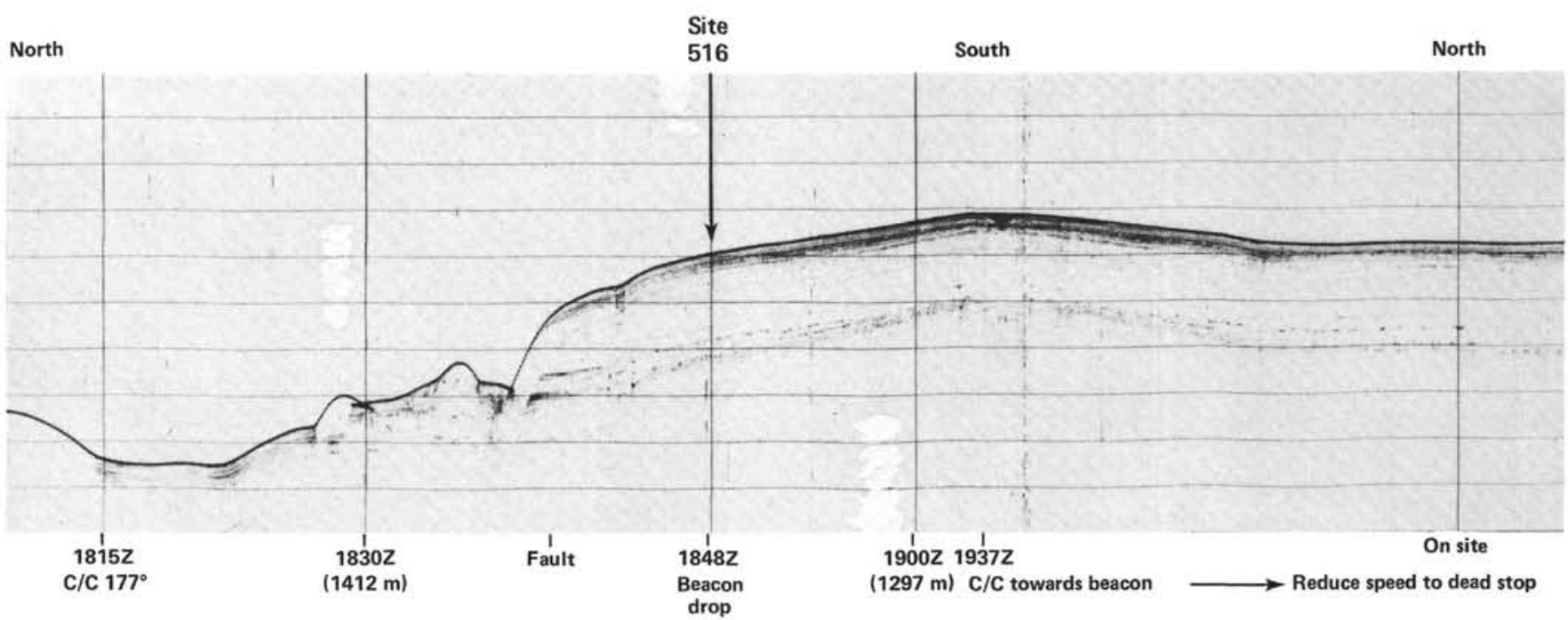

Figure 26. Seismic record ( $3.5 \mathrm{kHz})$ approaching Site 516 (see Figs. 2 and 23). $\mathrm{C} / \mathrm{C}=$ course change.

the Paleocene and parts of the Neogene, and the sediments appear stably (though weakly) magnetized.

Because of its stratigraphic continuity, average sedimentation rate, generally moderate to well preserved microfossil assemblages, and stable magnetization, this dominantly carbonate sequence will probably become a biostratigraphic and magnetostratigraphic type section.

Eight lithologic units were distinguished on the basis of degree of lithification and diagenesis of an essentially continuous pelagic carbonate succession, and its contamination by mainly volcanogenic sediment. These units are tabulated in Table 4.

The eighteen meters of basalt cored below $1252.6 \mathrm{~m}$ sub-bottom is transitional (T-type) MORB, similar to that found on the eastern Walvis Ridge. Its ${ }^{40} \mathrm{Ar} /{ }^{39} \mathrm{Ar}$ radiometric age of $86.0 \pm 4 \mathrm{Ma}$ is essentially coincident with the estimate of $84.5 \pm 0.5 \mathrm{Ma}$ for the age of the mid-ocean ridge crest at the site, based on regional magnetic anomaly data. Two flow units are distinguished on the basis of their primary mineralogy and degree of alteration. The upper $5-10 \mathrm{~m}$ of basalt has a calcitized groundmass, but fresh rock lies beneath. The presence of large vesicles and an abundance of coralline algae, echinoid, bryozoan, and mollusk fragments in cracks in

Table 4. Summary of lithologic units distinguished at Site 516.

\begin{tabular}{|c|c|c|c|}
\hline Unit & $\begin{array}{l}\text { Depth } \\
(\mathrm{m})\end{array}$ & Lithology & Age \\
\hline 1 & $0-193$ & Foraminiferal and nannofossil ooze & $\begin{array}{l}\text { Recent to early } \\
\text { Miocene }\end{array}$ \\
\hline 2 & $193-332$ & $\begin{array}{l}\text { Foraminiferal-nannofossil semiconsolidated } \\
\text { ooze and chalk }\end{array}$ & $\begin{array}{l}\text { early Miocene to } \\
\text { late Oligocene }\end{array}$ \\
\hline 3 & $332-634$ & $\begin{array}{l}\text { Nannofossil and foraminiferal-nannofossil } \\
\text { chalk }\end{array}$ & $\begin{array}{l}\text { late Oligocene to } \\
\text { late Eocene }\end{array}$ \\
\hline 4 & $634-874$ & $\begin{array}{l}\text { Nannofossil and foraminiferal chalks and } \\
\text { limestones with turbidites and ash layers }\end{array}$ & middle Eocene \\
\hline 5 & $874-1000$ & Microcrystalline limestones & $\begin{array}{l}\text { middle Eocene to } \\
\text { early Paleocene }\end{array}$ \\
\hline 6 & $1000-1240$ & $\begin{array}{l}\text { Limestones, marly limestones, and clay- } \\
\text { stones }\end{array}$ & $\begin{array}{l}\text { early Paleocene to } \\
\text { Santonian/ } \\
\text { Coniacian }\end{array}$ \\
\hline 7 & $1240-1252$ & $\begin{array}{l}\text { Calcareous and volcanogenic breccia over } \\
\text { basalt }\end{array}$ & Coniacian(?) \\
\hline 8 & $1252-1270$ & Basalt & \\
\hline
\end{tabular}

the basalt and in the overlying breccia suggest eruption in or near the photic zone.

A sharp transition above Unit 7 to the (upper?) bathyal Coniacian-Santonian limestones at the base of Unit 6 may encompass the magnetic polarity change of Amomaly 34. The normal magnetization of the basalt confirms other evidence that it is not a sill and suggests a period of rapid subsidence shortly after eruption. Sediments directly overlying basement also indicate rapid subsidence from a very shallow initial depth. Table 5 lists these lithologic indicators of paleodepth (after Daley, this volume; Milliman, this volume).

Deposition on the Rio Grande Rise during the middle Eocene (Unit 4) was dominantly calcareous but included volcanogenic turbidites and ash beds and a $15-\mathrm{m}$ thick

Table 5. Lithologic indicators of paleodepth, Hole 516F.

\begin{tabular}{|c|c|c|c|}
\hline Core(s) & Age & Lithology & Paleodepth \\
\hline 125 & Coniacian & $\begin{array}{l}\text { Miliolids, ophthalmidiids, ostra- } \\
\text { codes in well-sorted skeletal } \\
\text { grainstone }\end{array}$ & $\begin{array}{l}<20 \mathrm{~m} \text {; high-energy en- } \\
\text { vironment }\end{array}$ \\
\hline 124 & Coniacian & $\begin{array}{l}\text { Inoceramus shell fragments, cal- } \\
\text { cispheres, coralline algae, ver- } \\
\text { neuilinids, miliolids, hetero- } \\
\text { helicid and globotruncanid } \\
\text { planktonics; iron-stained mud } \\
\text { matrix }\end{array}$ & $\begin{array}{l}20-150 \mathrm{~m} \text {; open marine } \\
\text { shelf conditions }\end{array}$ \\
\hline 123 & Coniacian & $\begin{array}{l}\text { Alternating layers of claystone } \\
\text { and fine-grained skeletal de- } \\
\text { bris in a claystone matrix; } \\
\text { common Inoceramus prisms, } \\
\text { ostracodes, and heterohelicid } \\
\text { and hedbergellid planktonic } \\
\text { foraminifers }\end{array}$ & $\begin{array}{l}200-500 \mathrm{~m} \text {; deeper ne- } \\
\text { ritic or shallow } \\
\text { bathyal depths }\end{array}$ \\
\hline $116-119$ & Santonian & $\begin{array}{l}\text { Abundant deep-water benthics } \\
\text { (including Gavelinella beccari- } \\
\text { iformis); no shallow indica- } \\
\text { tors; high planktonic/benthic } \\
\text { ratio (about } 10: 1 \text { ); modest } \\
\text { density, evidence of selective } \\
\text { dissolution }\end{array}$ & $\begin{array}{l}500 \text { - } 1000 \mathrm{~m} \text {; upper to } \\
\text { middle bathyal } \\
\text { depths }\end{array}$ \\
\hline $89-113$ & $\begin{array}{l}\text { Campanian/ } \\
\text { Maestrichtian }\end{array}$ & $\begin{array}{l}\text { Diverse and well-preserved ben- } \\
\text { thic assemblages; High plank- } \\
\text { tonic/benthic ratio; diverse } \\
\text { gyroidinids and agglutinated } \\
\text { benthics }\end{array}$ & $\begin{array}{l}1000-1500 \mathrm{~m} \text {; middle } \\
\text { bathyal to shallow } \\
\text { lower bathyal depths }\end{array}$ \\
\hline $83-89$ & Paleocene & $\begin{array}{l}\text { Benthics dominated by a deep } \\
\text { water association; wide fluc- } \\
\text { tuations in abundance in } \\
\text { earliest Paleocene; pelagic } \\
\text { character }\end{array}$ & $\begin{array}{l}1500-2000 \mathrm{~m} \text {; lower } \\
\text { bathyal depths }\end{array}$ \\
\hline
\end{tabular}


slide of Maestrichtian limestone. A K-Ar age of $47.4 \pm$ $0.7 \mathrm{Ma}$ based on fresh euhedral biotite from an ash bed confirms that early middle Eocene age of volcanism. The limestones within this sequence, particularly near the base, exhibit higher compressional-wave velocities than occur above, or for some depth beneath, Unit 4 . This unit corresponds to the strong, irregular composite reflector that forms the "midsection domes" of the UTMSI multichannel seismic profiles and that was thought at one time to be crystalline basement. The cause of the high velocities is perhaps silicification of the calcareous material by silica-enriched fluids derived from the volcanogenic sediment (which itself yields abnormally low velocities). Thus the "domes" may be diagenetic "fronts" associated with and confined to the immediate vicinity of turbidites and slumps. Reflection profiles around Site 516 (Barker et al., this volume) show that a guyot located just upslope, which contains an uplifted and tilted oceanic section truncated by subaerial erosion, is the likely source of the slide and turbidites. The steep slope of the guyot is one wall of a graben that strikes west-northeast/east-southeast across the crest of the Rio Grande Rise, between other guyots with a similar summit depth. A short volcanotectonic event, interpreted as a midplate hot spot and probably unique in the history of the Rise, probably affected the entire crestal area.

A model for the tectonic evolution of the Rise has been constructed (Barker, this volume), in which the present Tristan da Cunha mantle inhomogeneity (hot spot) first helped initiate South Atlantic opening; then, with the slight westward drift of the mid-ocean ridge crest, it effected a series of captures of the ridge crest, causing the crest to jump eastward and to return to the hot-spot center. The mechanism proposed is reversal of the balance of ridge-push forces on the young lithosphere by the greater elevations of the hot-spot swell. The massive eastern Walvis and Rio Grande bodies therefore represent off-axis volcanism that succeeded in capturing a ridge crest, and the younger seamount province represents off-axis volcanism that failed.

A detailed subsidence history for the Rio Grande Rise in the vicinity of Site 516 is constructed based on the age and origin of the basal volcanics at Site 516 and the age and nature of the middle Eocene off-axis volcanic activity. The model uses an oceanic, thermal subsidence (age $\mathrm{e}^{1 / 2}$ ), but takes account of the hot-spot environment of the original subaerial spreading center and considers the effects of subaerial isostatic subsidence. It incorporates the middle Eocene event as partly a thermal rejuvenation (thinning) of the lithosphere, which is reversible, and partly a compositional change, which is not. The resulting subsidence curve for Site 516 starts at $180 \mathrm{~m}$ above sea level $84.5 \mathrm{Ma}$, passes through sea level $0.5 \mathrm{Ma}$ later, and falls to $1260 \mathrm{~m}$ in the Paleocene, before rising rapidly to $600 \mathrm{~m}$ in the early middle Eocene and then falling more gently to its present depth of $1313 \mathrm{~m}$. Assuming that, after the middle Eocene, the guyot upslope from Site 516 followed a similar thermal subsidence curve, its submergence below sea level $35 \mathrm{Ma}$ is compatible with early Oligocene shallow water fauna found downslope near Site 357.

A similar subsidence history is applied to Site 357 so that the independent data set of paleoecological depth estimates from both sites may be compared with the tectonic subsidence model. The paleoecologic estimates are generally deeper (see Table 5), and it is difficult to see how the tectonic model may be modified to remove the discrepancy. The difficulty may lie in delays in the precise correction of comparison sites elsewhere in the world for the effects of thermal subsidence and sediment compaction. For this effort, Site 516 itself should provide a new and useful datum, even though some modification of this tectonic model is expected.

\section{REFERENCES}

Alvarez, W., Arthur, M. A., Fischer, A. G., Lowrie, W., Napoleone, G., Premoli Silva, I., and Roggenthen, W. M., 1977. Type section for the Late Cretaceous-Paleocene geomagnetic reversal time scale. Bull. Geol. Soc. Am., 88:367-371.

Berggren, W. A., 1973. The Pliocene time scale: calibration of planktonic foraminiferal and calcareous nannoplankton zones. Nature, 243:391-397.

1977a. Late Neogene planktonic foraminiferal biostratigraphy of Site 357 (Rio Grande Rise). In Supko, P. R., PerchNielsen, K., et al., Init. Repts. DSDP, 39: Washington (U.S. Govt. Printing Office), 591-615.

1977b. Late Neogene planktonic foraminiferal biostratig raphy of the Rio Grande Rise (South Atlantic). Mar. Micropaleontol., 2:265-313.

Berggren, W. A., Kent, D. V., and Flynn, J. J., in press. Paleogene geochronology and chronostratigraphy. In Snelling, N. J. (Ed.), Geochrononology and the the Geologic Record: London (Geol. Soc. London Spec. Publ.).

Berggren, W. A., Kent, D. V., and Van Couvering, J. A., in press. Neogene geochronology and chronostratigraphy. In Snelling, N. J. (Ed.), Geochronology and the Geologic Record: London (Geol. Soc. London Spec. Publ.).

Blow, R. A., and Hamilton, N., 1975. Paleomagnetic evidence from DSDP cores of northward drift of India. Nature, 257:570-572.

, 1978. Effect of compaction on the acquisition of a detrital remanent magnetization in fine-grained sediments. Geophys. J. $R$. Astron. Soc., 52:13-23.

Blow, W. H., 1969. Late middle Eocene to Recent planktonic foraminiferal biostratigraphy. In Brönnimann, P., and Renz, H. H. (Eds.), Proc. First. Int. Conf. Plankt. Microfossils: Leiden (E. J. Brill), 1:199-422.

Ellwood, B. B., and Ledbetter, M. T., 1977. Antarctic bottom water fluctuations in the Vema Channel: effects of velocity changes in the particle alignment and size. Earth Planet. Sci. Lett., 35: 189-198.

Hailwood, E. A., Bock, W., Costa, L., Dupeuble, L., Müller, C., and Schnitker, D., 1979. Chronology and biostratigraphy of northeast Atlantic sediments. In Montadert, L., Roberts, D. G., et al., Init. Repts. DSDP, 48: Washington (U.S. Govt. Printing Office), 1119-1141.

Hamilton, N., 1979. A paleomagnetic study of sediments from Site 397 northeast African continental margin. In von Rad, U., Ryan, W. B. F., et al., Init. Repts. DSDP, 47, Pt. 1: Washington (U.S. Govt. Printing Office), 463-477.

Hardenbol, J., and Berggren, W. A., 1978. A new Paleogene time scale. In Cohee, G. V., Glaessner, M. F., and Hedberg, H. D. (Eds.), Contributions to the Geologic Time Scale: Tulsa (Am. Assoc. Petrol. Geol. Studies in Geology), No. 6:213-234.

Henry, K. W., and Opdyke, N. D., 1970. Paleomagnetism of sediments from Leg 3 of the Deep Sea Drilling Project. In Maxwell, A. E., Von Herzen, R. P., et al., Init. Repts. DSDP, 3: Washington (U.S. Govt. Printing Office), 667-685.

Kukla, G., and Zijderveld, J. D. A., 1977. Magnetostratigraphic pitfalls. Nature, 266:774-776. 
Lowrie, W., and Alvarez, W., 1981. One hundred million years of geomagnetic polarity history. Geology, 9:392-397.

Martini, E., 1971. Standard Tertiary and Quaternary calcareous nannoplankton zonation. In Farinacci, A. (Ed.), Proc. II Plankt. Conf. Roma: Rome (Edizioni Tecnoscienza), 2:739-785.

Ness, G., Levi, S., and Couch, R., 1980. Magnetic anomaly time scales for the Cenozoic and Late Cretaceous: A prècis, critique and synthesis. Rev. Geophys. Space Phys., 18:753-770.

Perch-Nielsen, K., 1977. Albian to Pleistocene calcareous nannofossils from the western South Atlantic, DSDP Leg 39. In Supko, P. R., Perch-Nielsen, K., et al., Init. Repts. DSDP, 39: Washington (U.S. Govt. Printing Office), 699-823.

Perch-Nielsen, K., Supko, P. R., and Shipboard Scientific Party, 1977. Site 357. In Supko, P. R., Perch-Nielsen, K., et al., Init. Repts. DSDP, 39: Washington (U.S. Govt. Printing Office), 231-328.
Stainforth, R. M., Lamb, J. L., Luterbacher, H., Beard, J. H., and Jeffords, R. M., 1975. Cenozoic planktonic foraminiferal zonation and characteristics of index forms. Contrib. Univ. Kans., Article 62.

Supko, P. R., Perch-Nielsen, K., et al., 1977. Init. Repts. DSDP, 39: Washington (U.S. Govt. Printing Office).

van Hinte, J. E., 1976. A Cretaceous time scale. Am. Assoc. Pet. Geol. Bull., 60:498-548.

Wood, D. A., Tarney, J., Varet, J., Saunders, A. D., Bougault, H., Joron, J. L., Treuil, M., and Cann, J. R., 1979. Geochemistry of basalts drilled in the North Atlantic by IPOD Leg 49: implications for mantle heterogeneity. Earth Planet. Sci. Lett., 42:77-97.

Date of Initial Receipt: November 19, 1982 


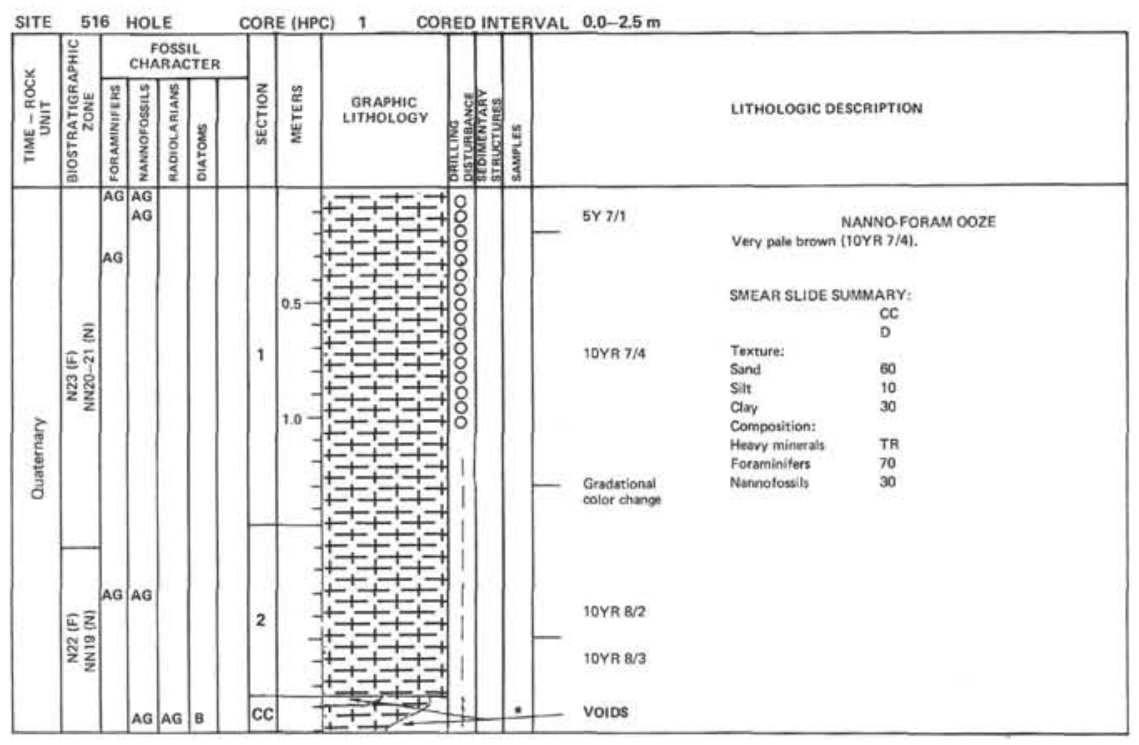

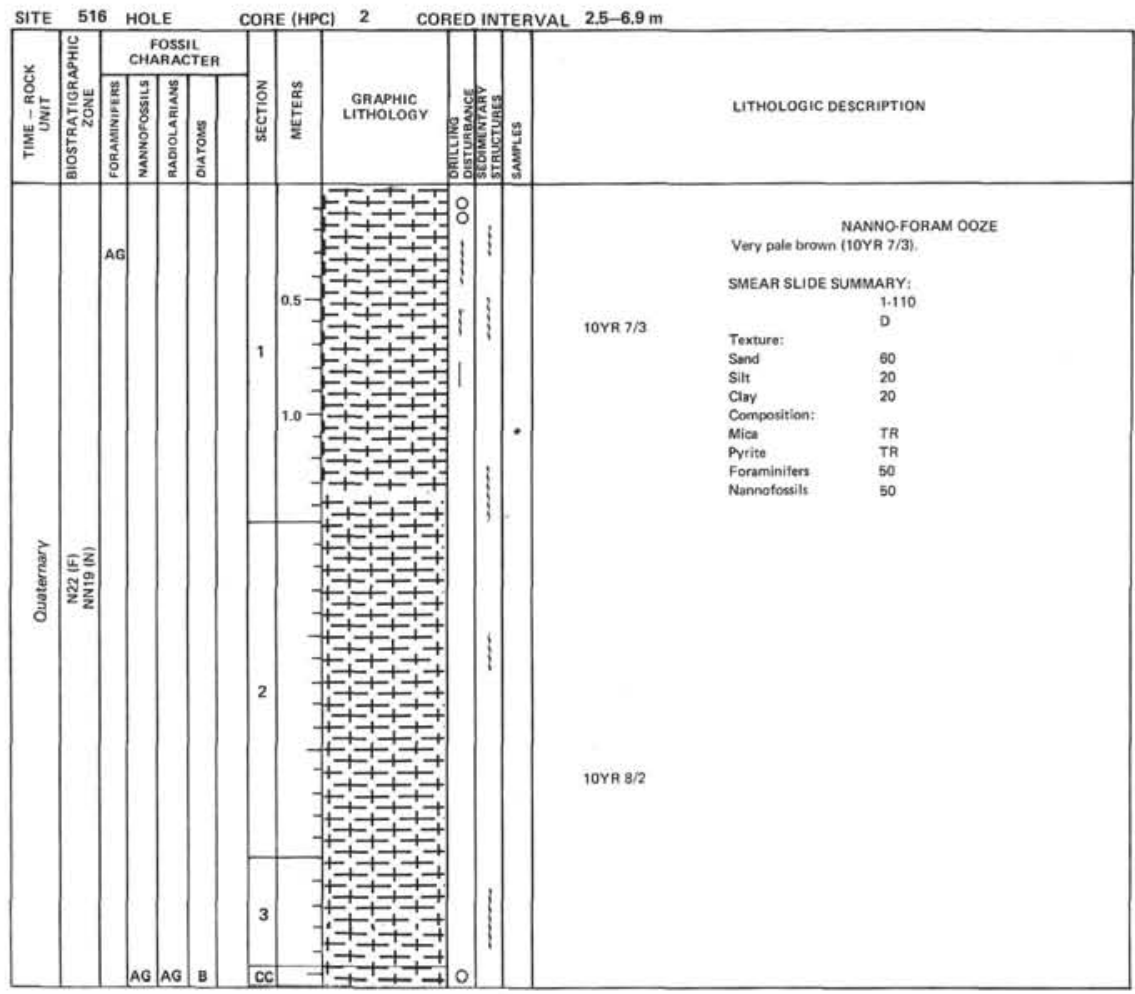



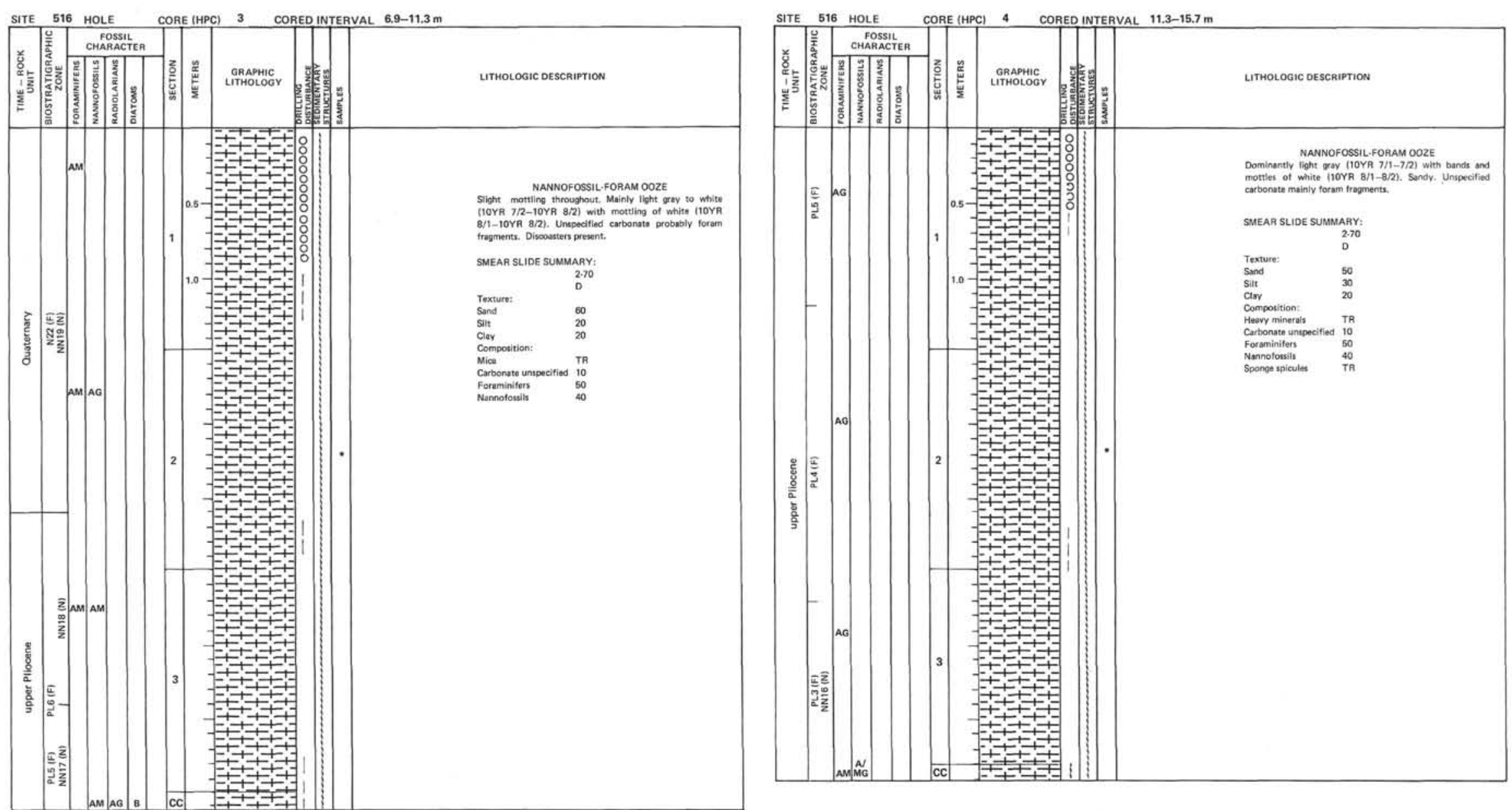

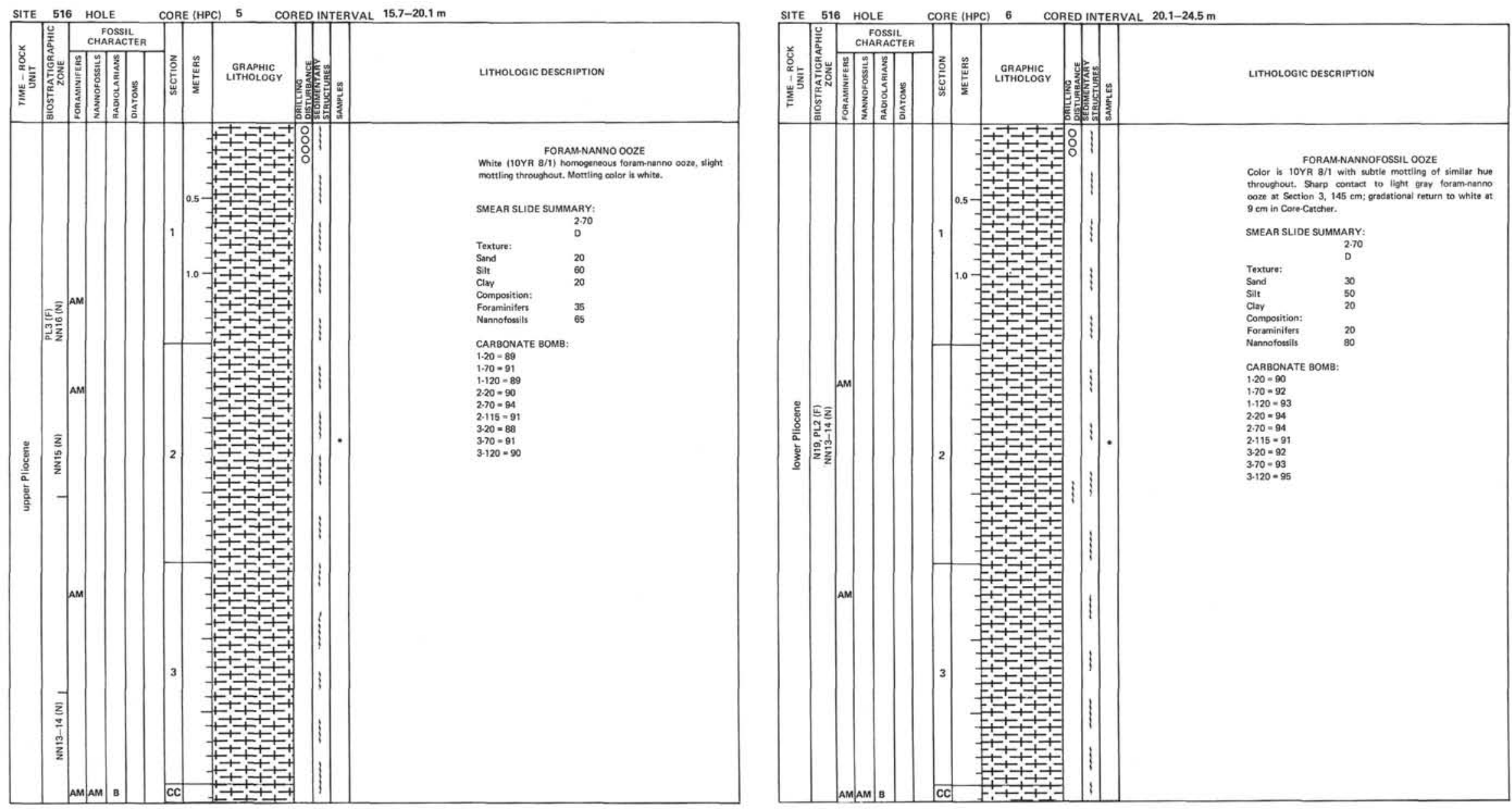

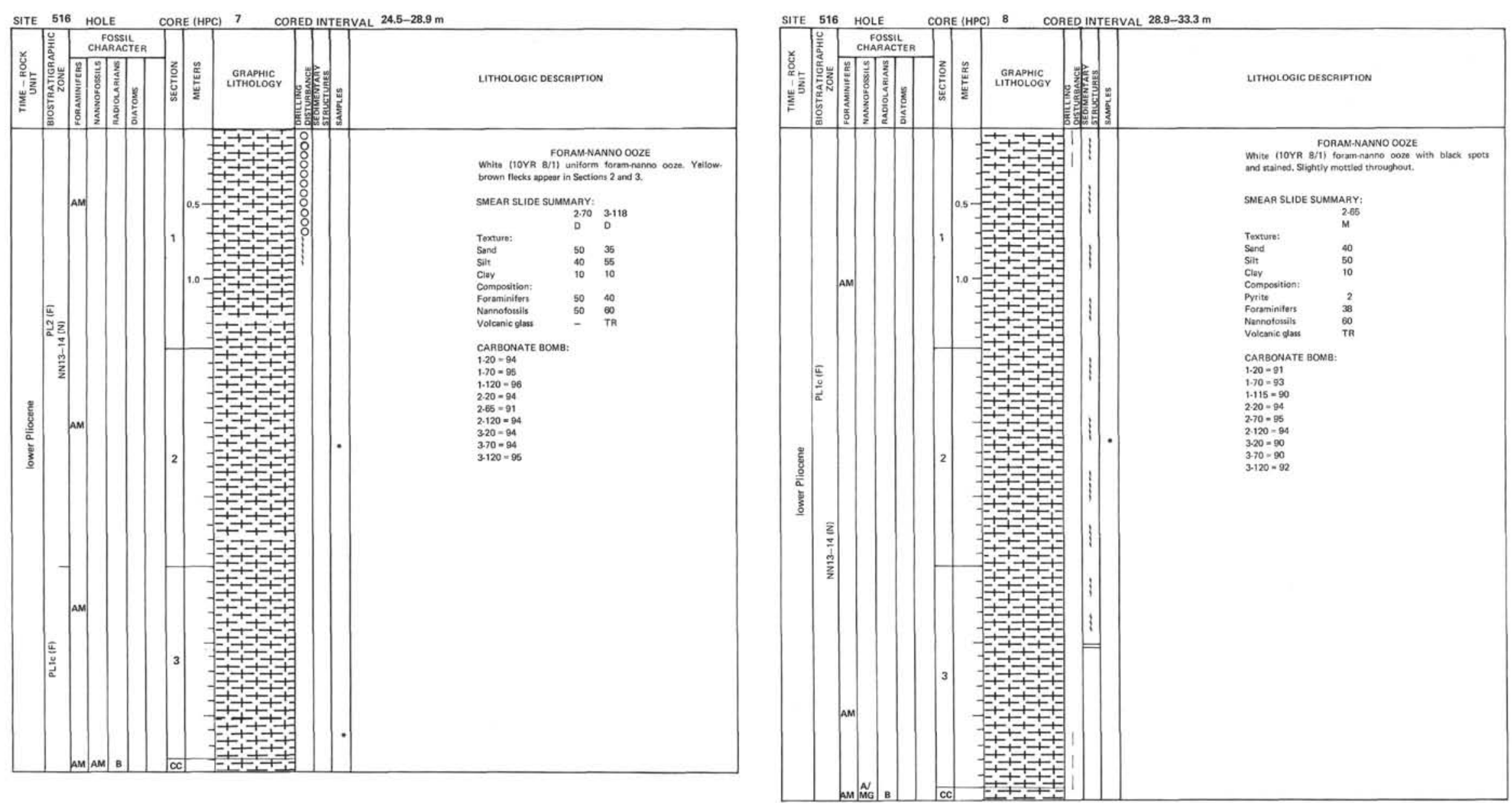

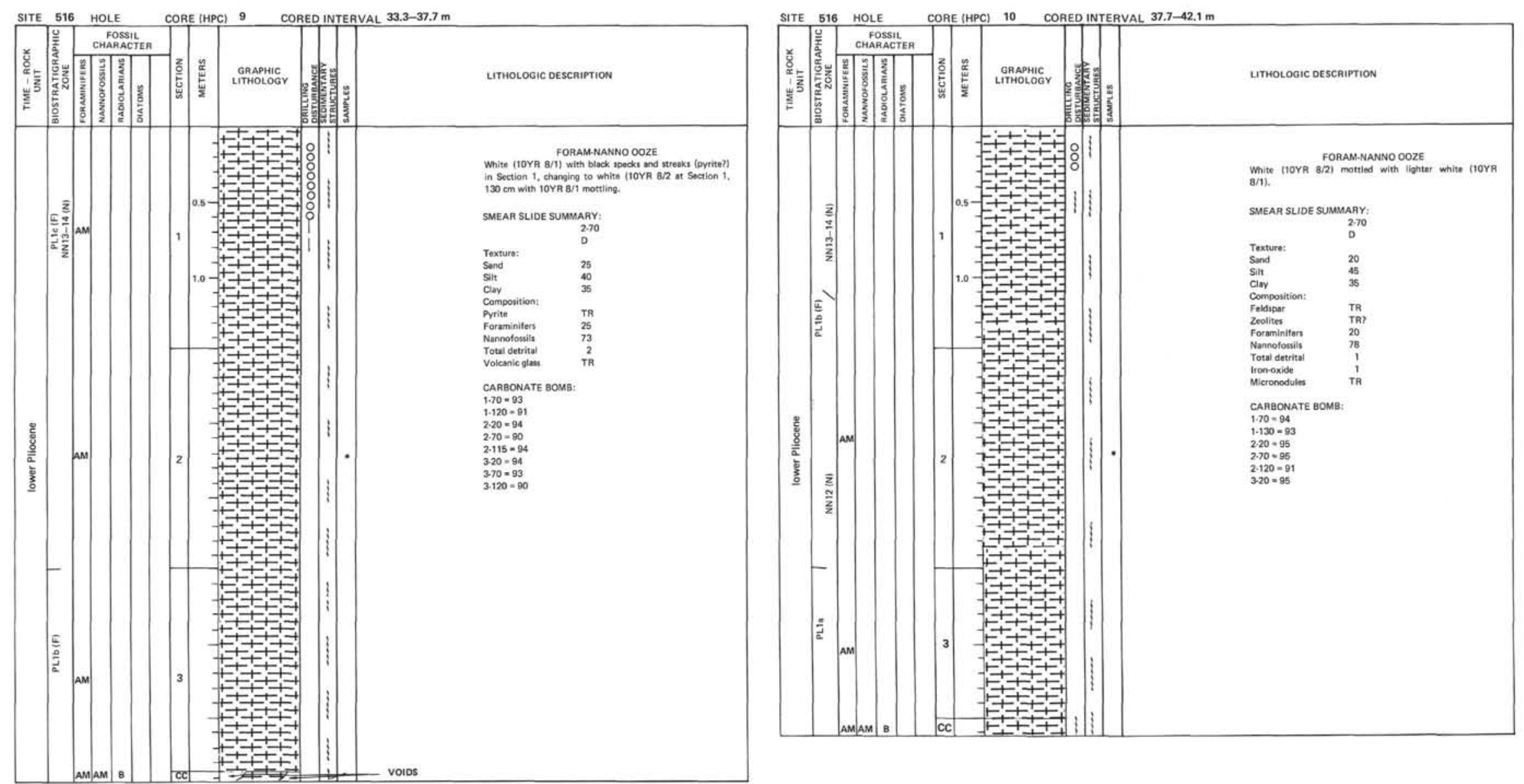

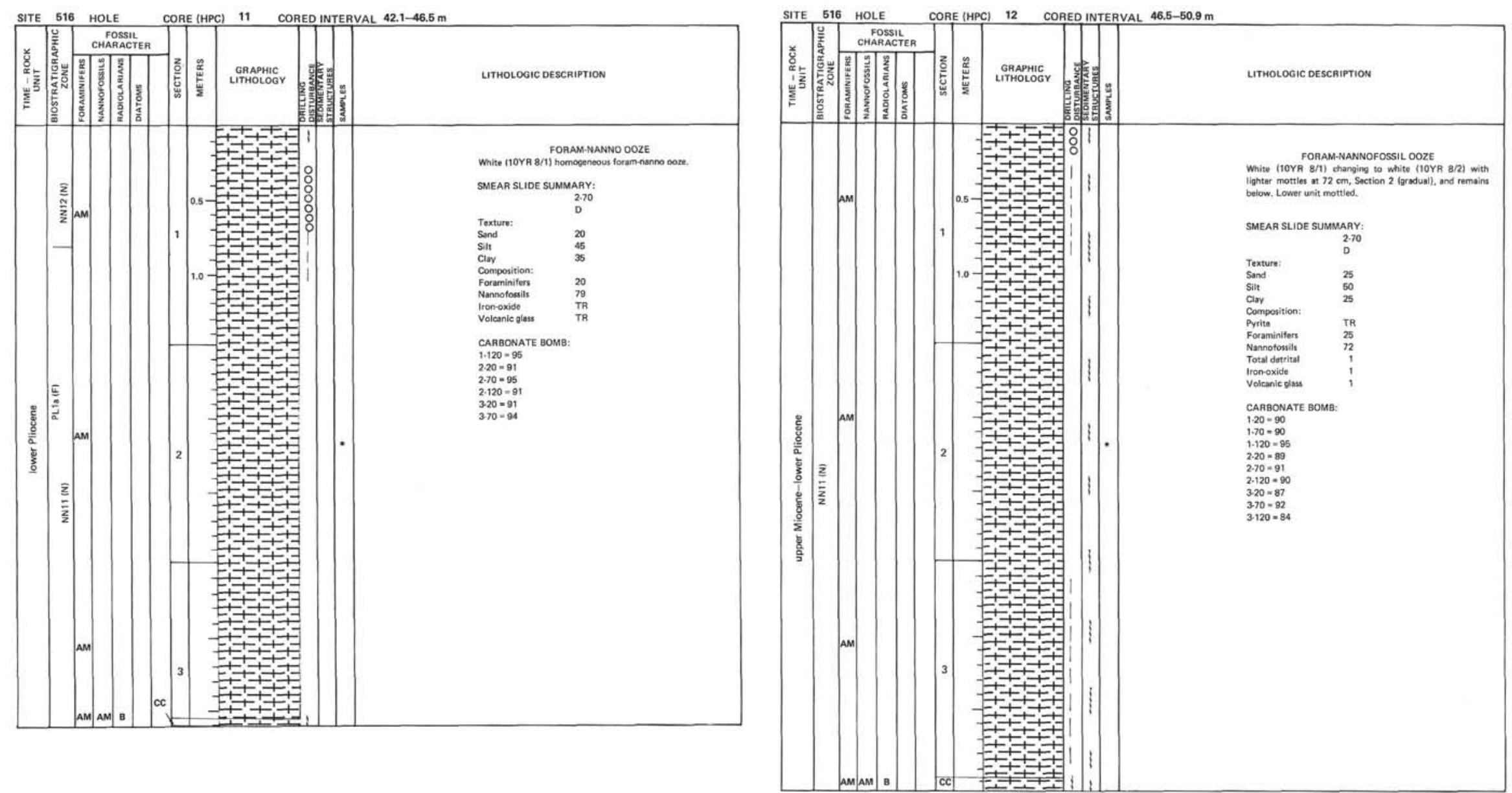

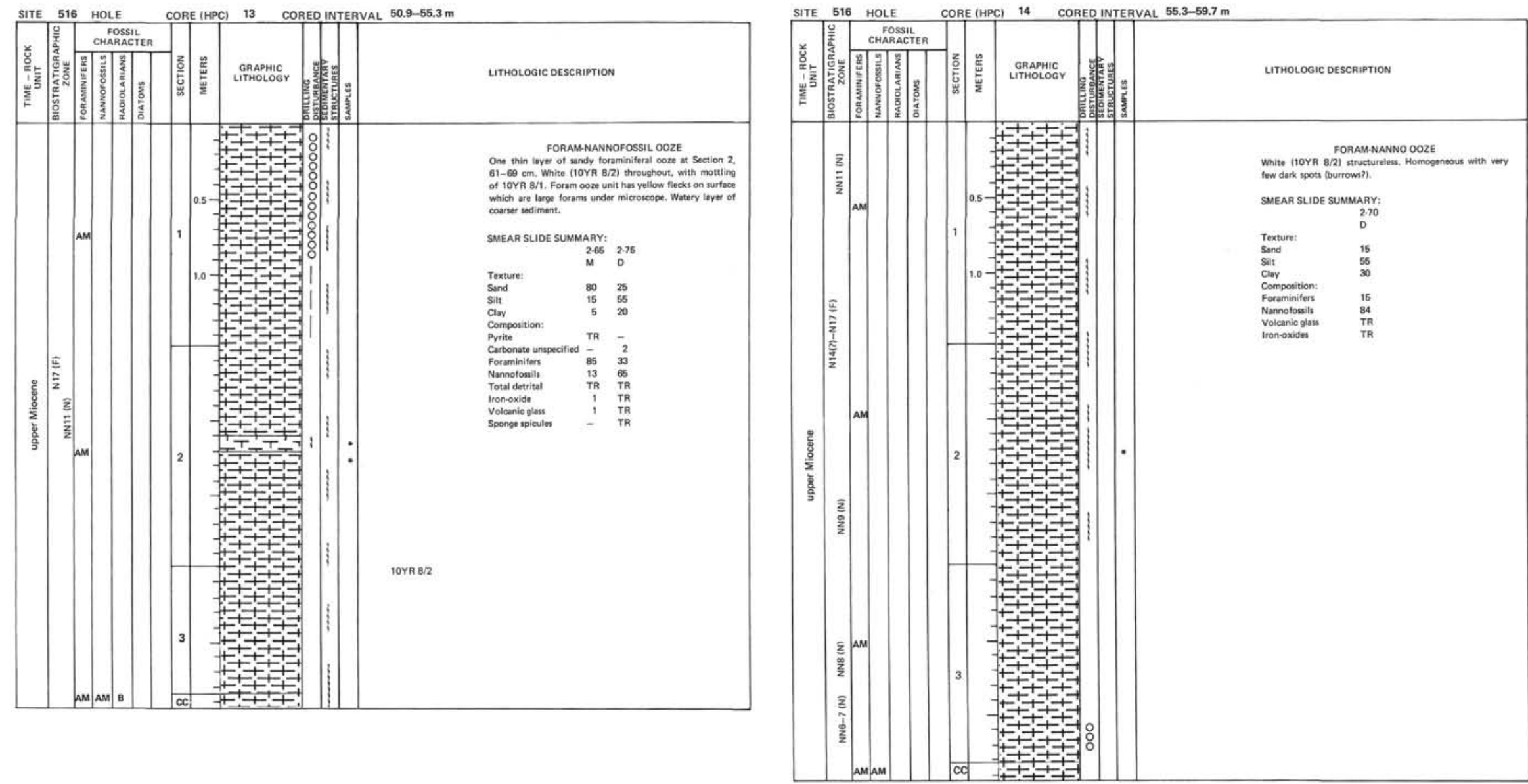

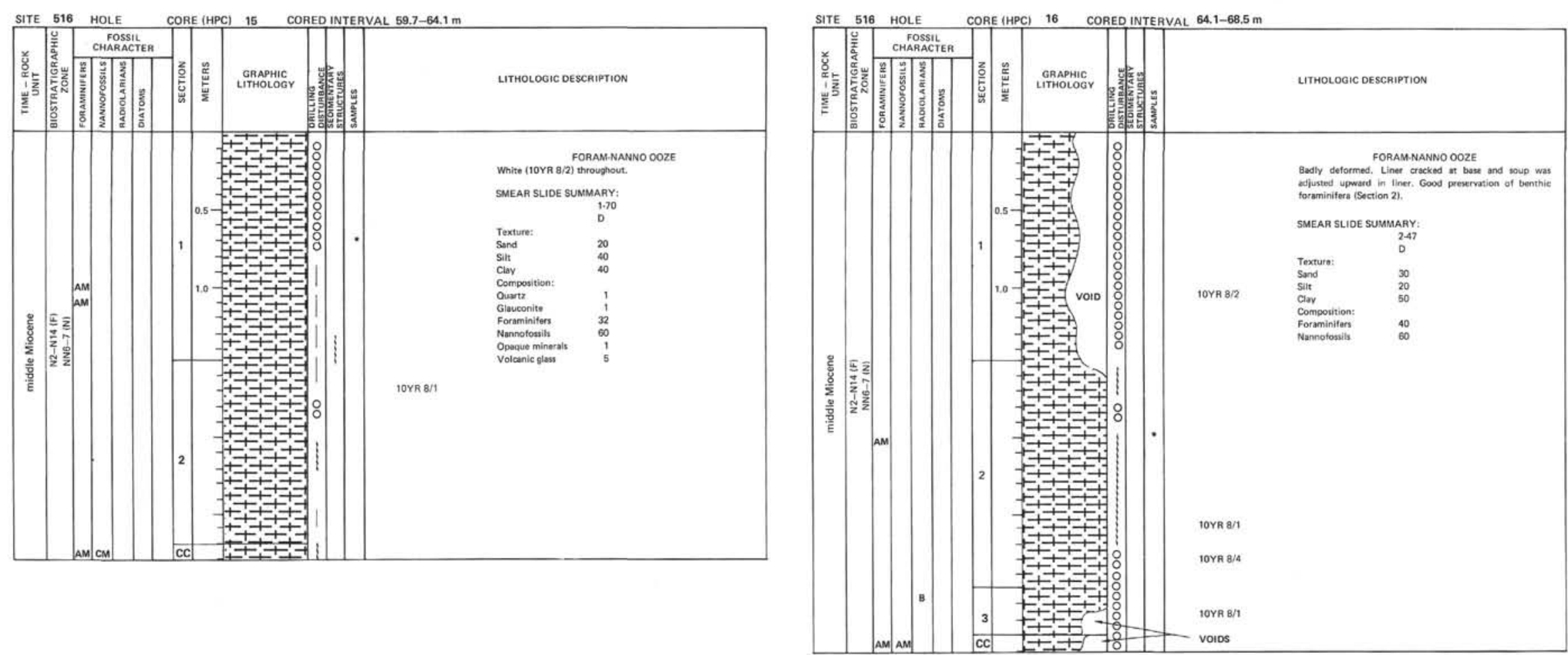


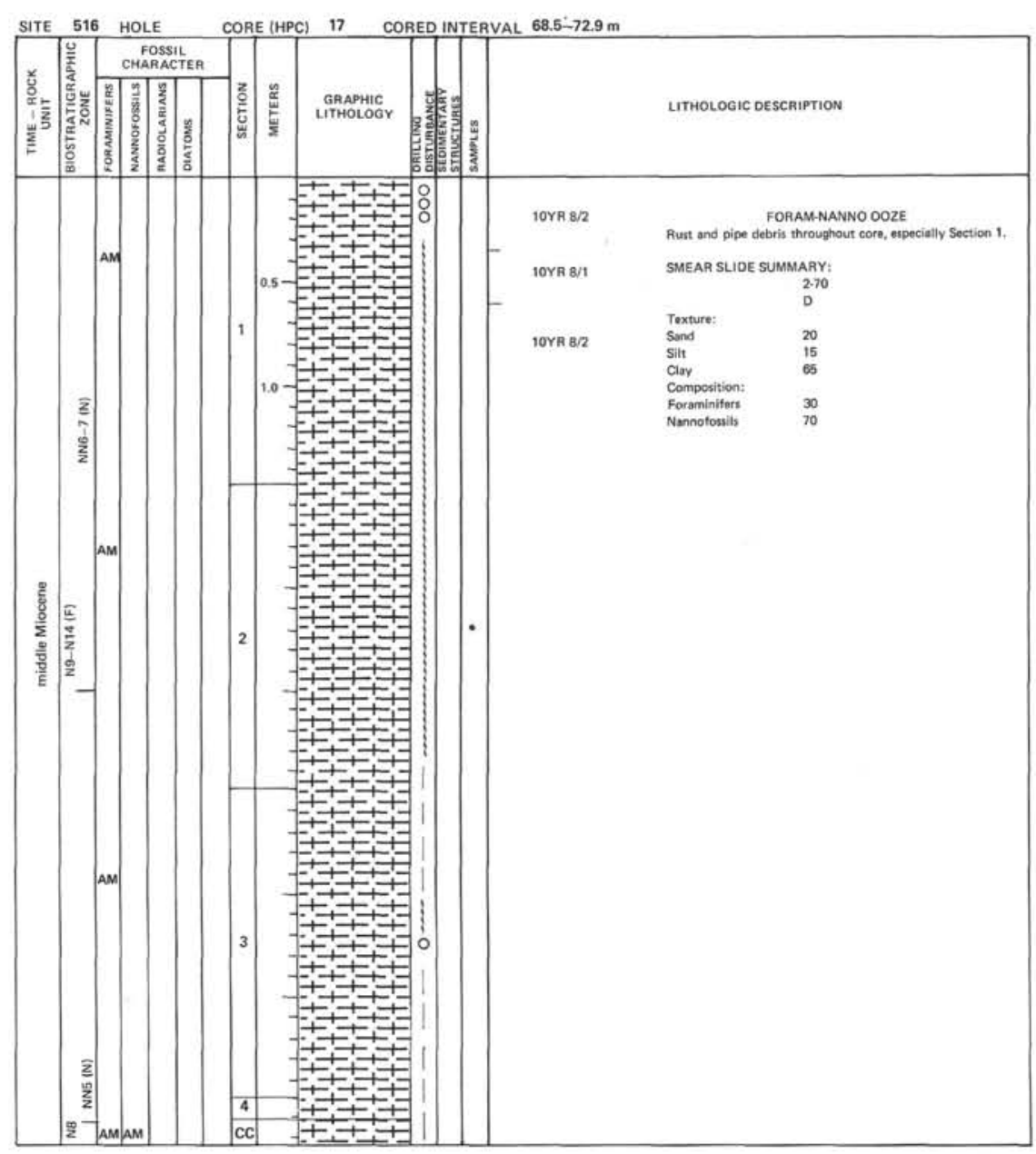

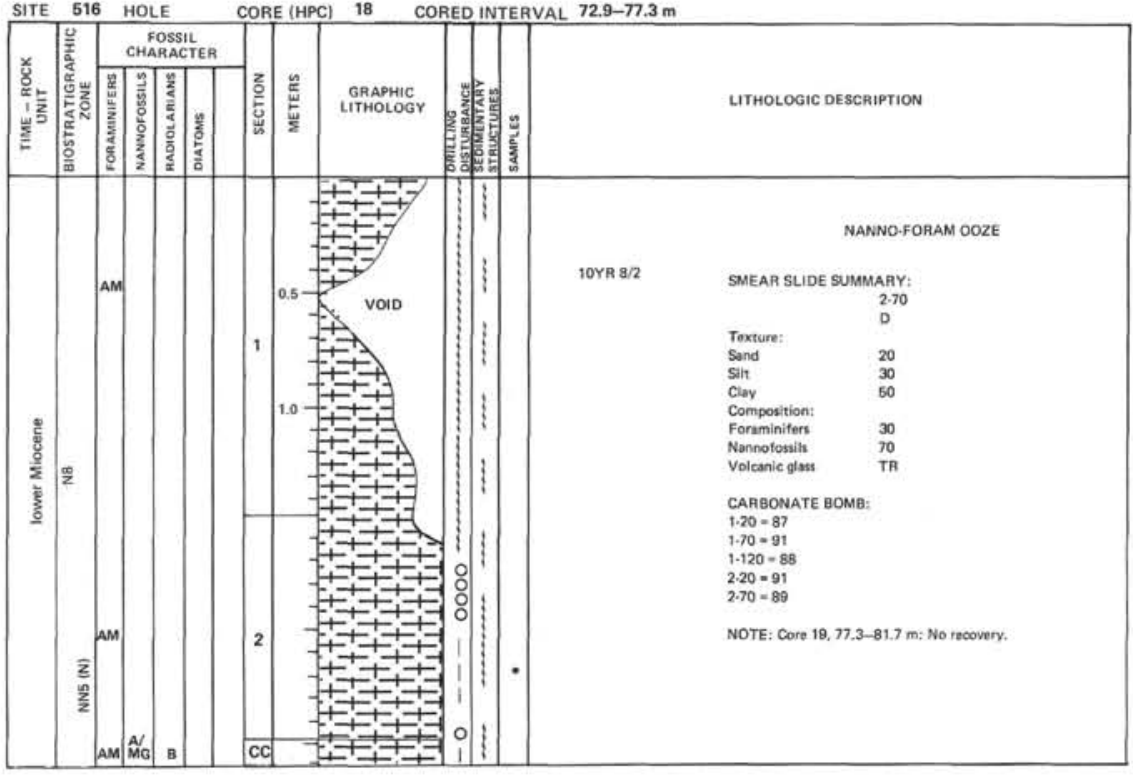



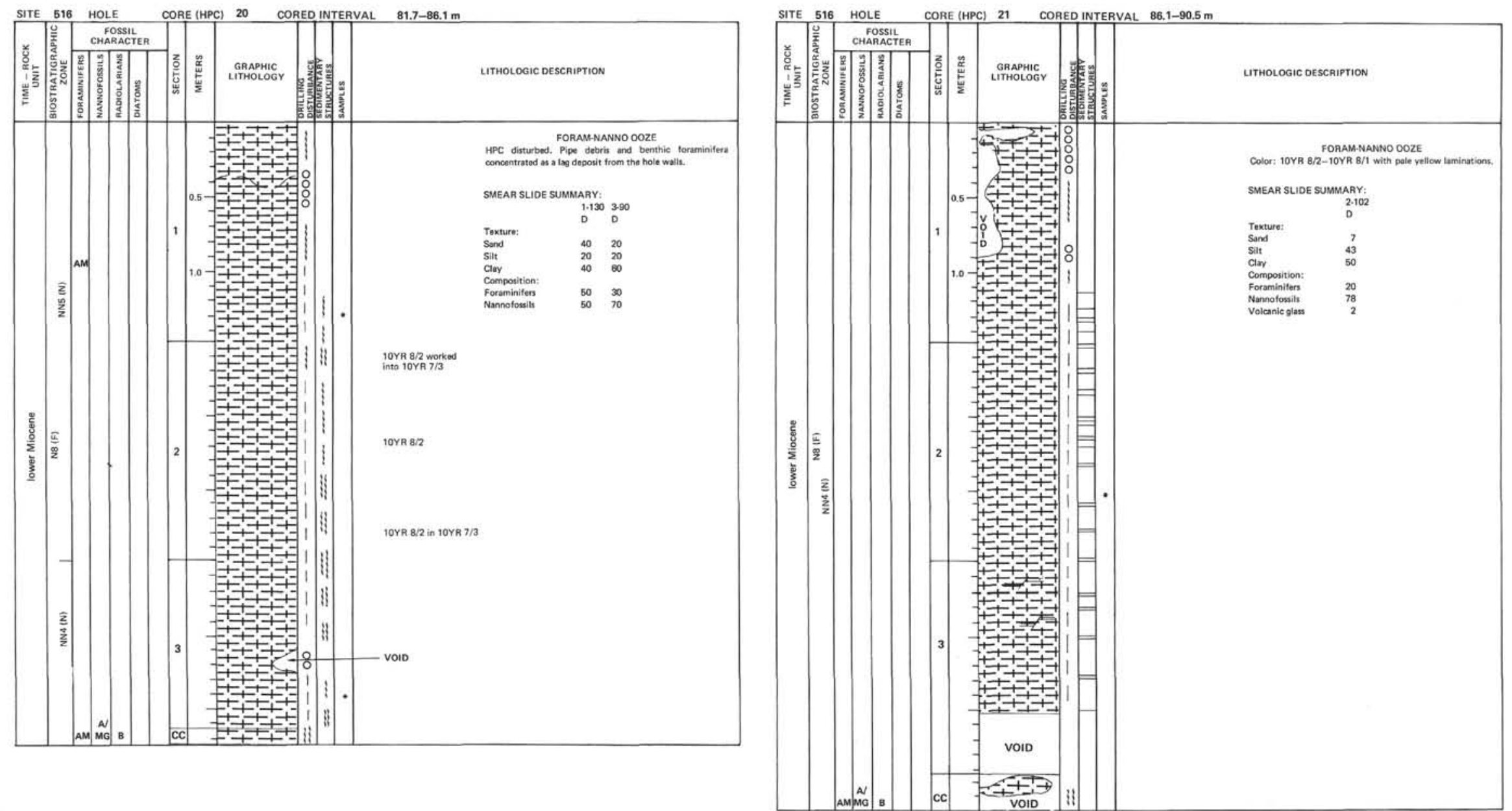


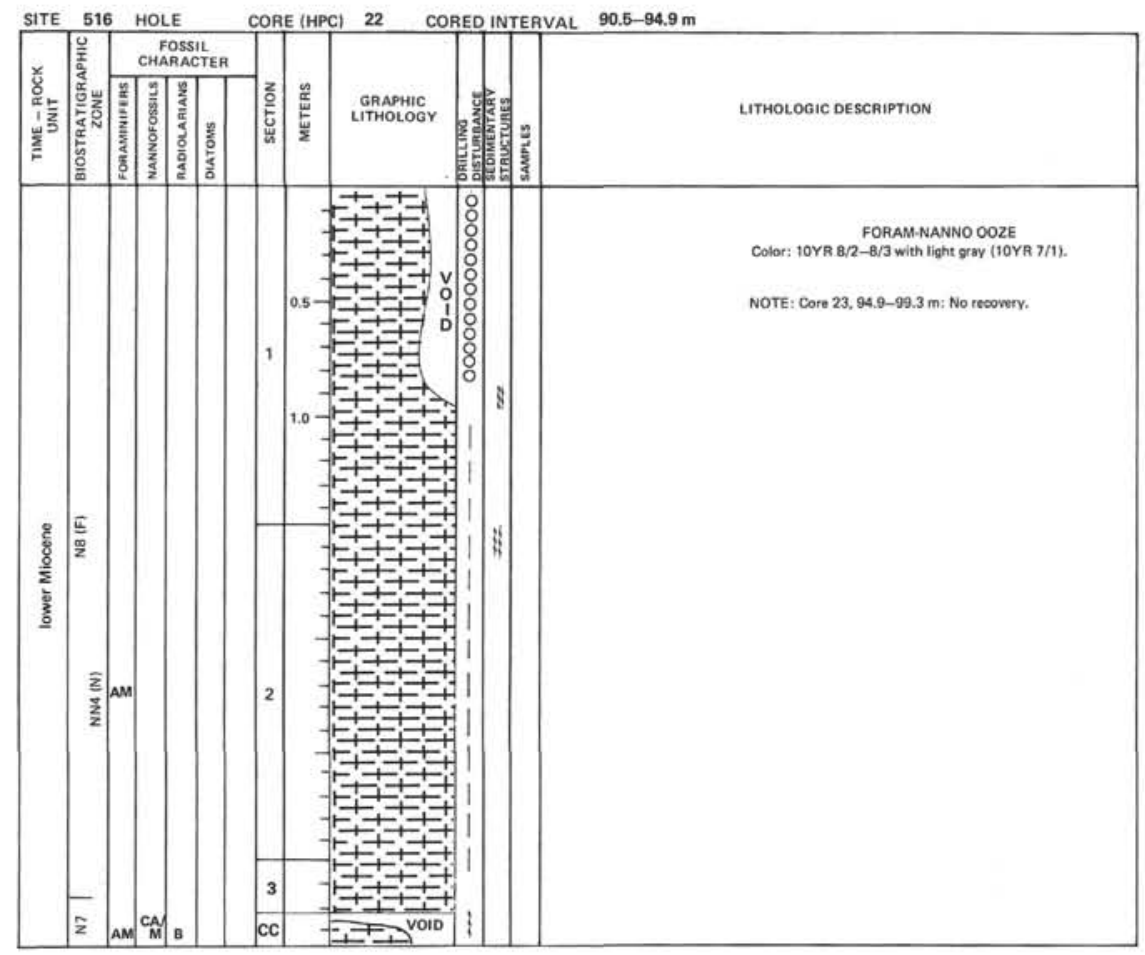

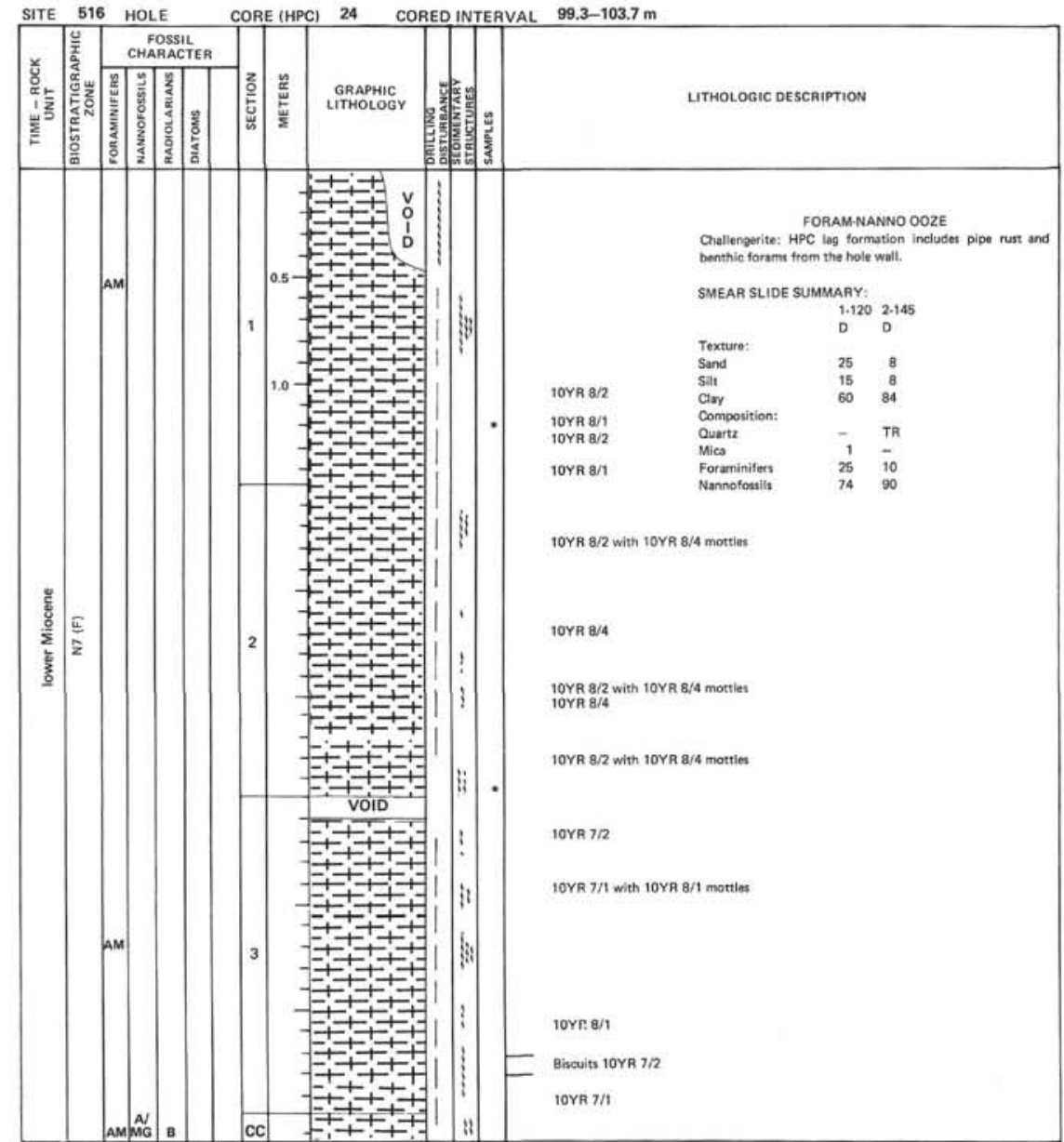



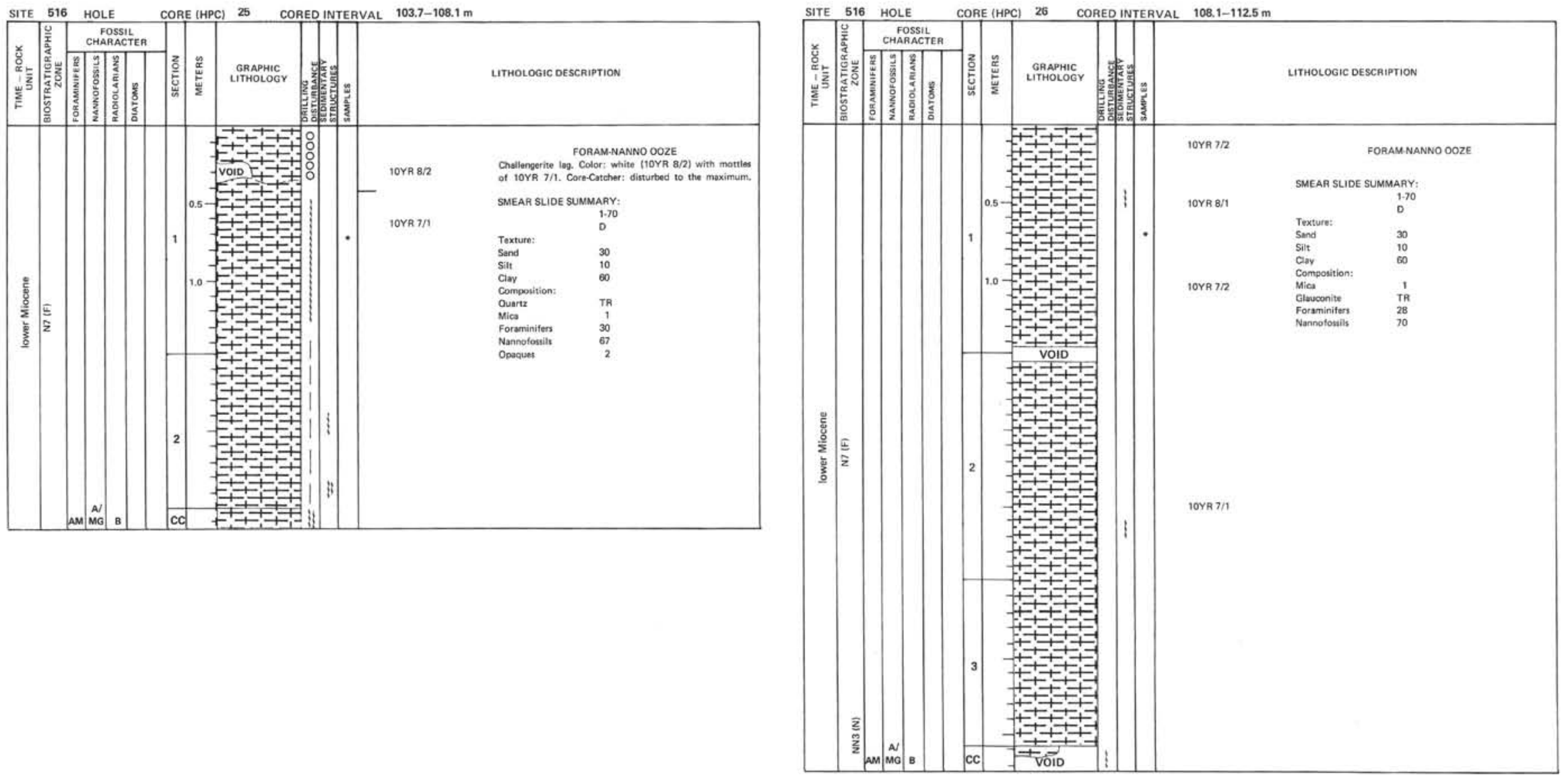

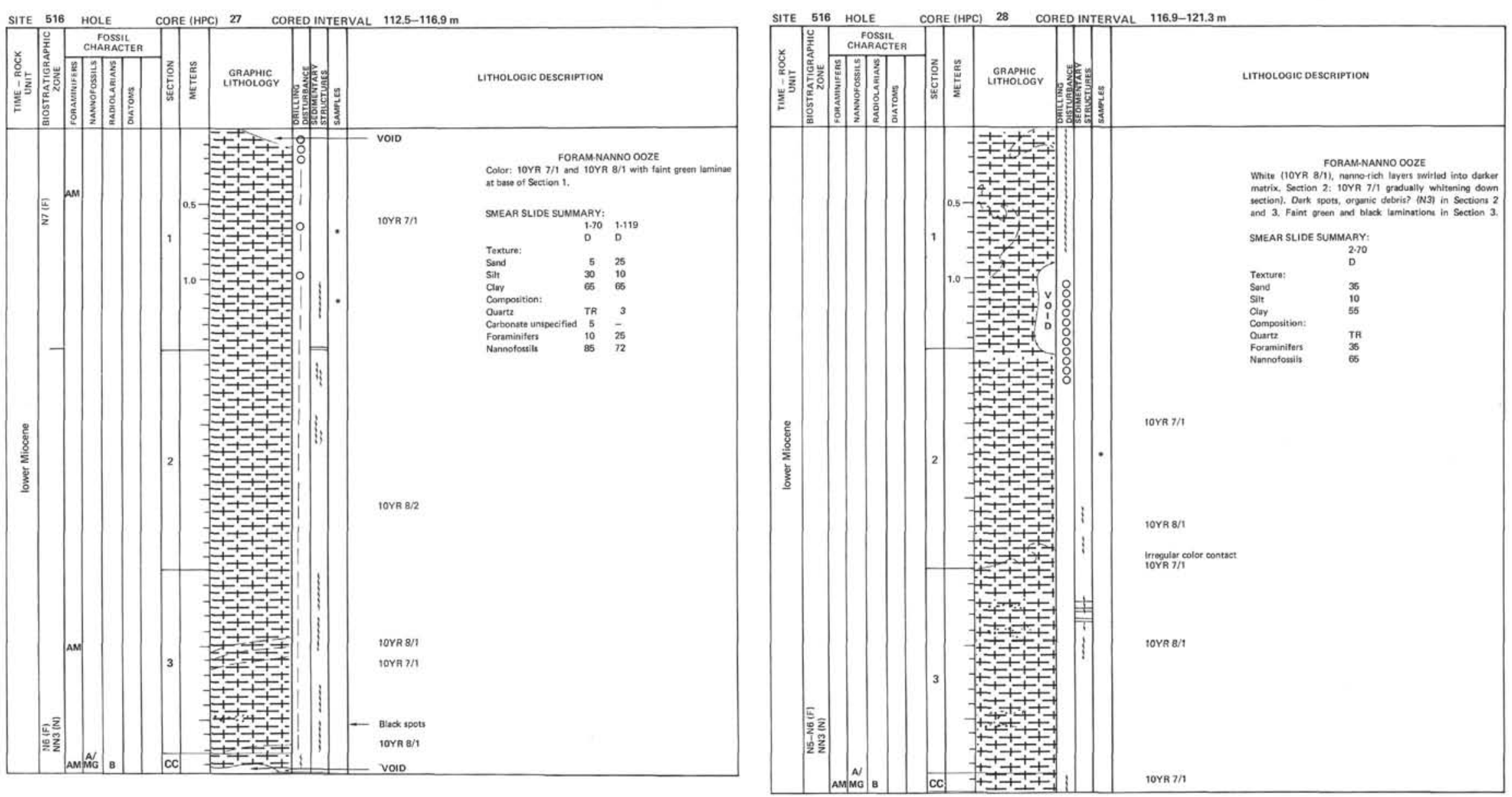

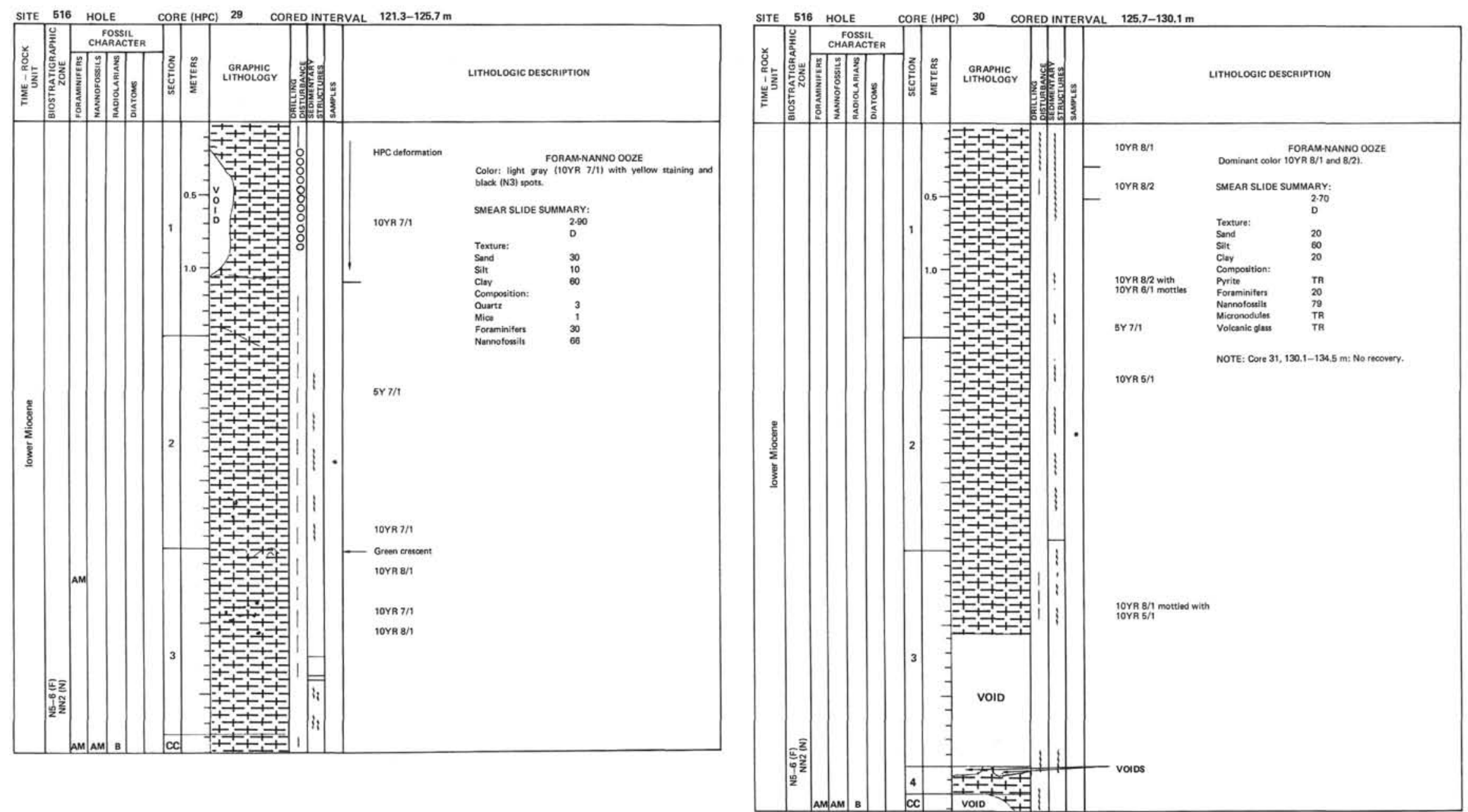


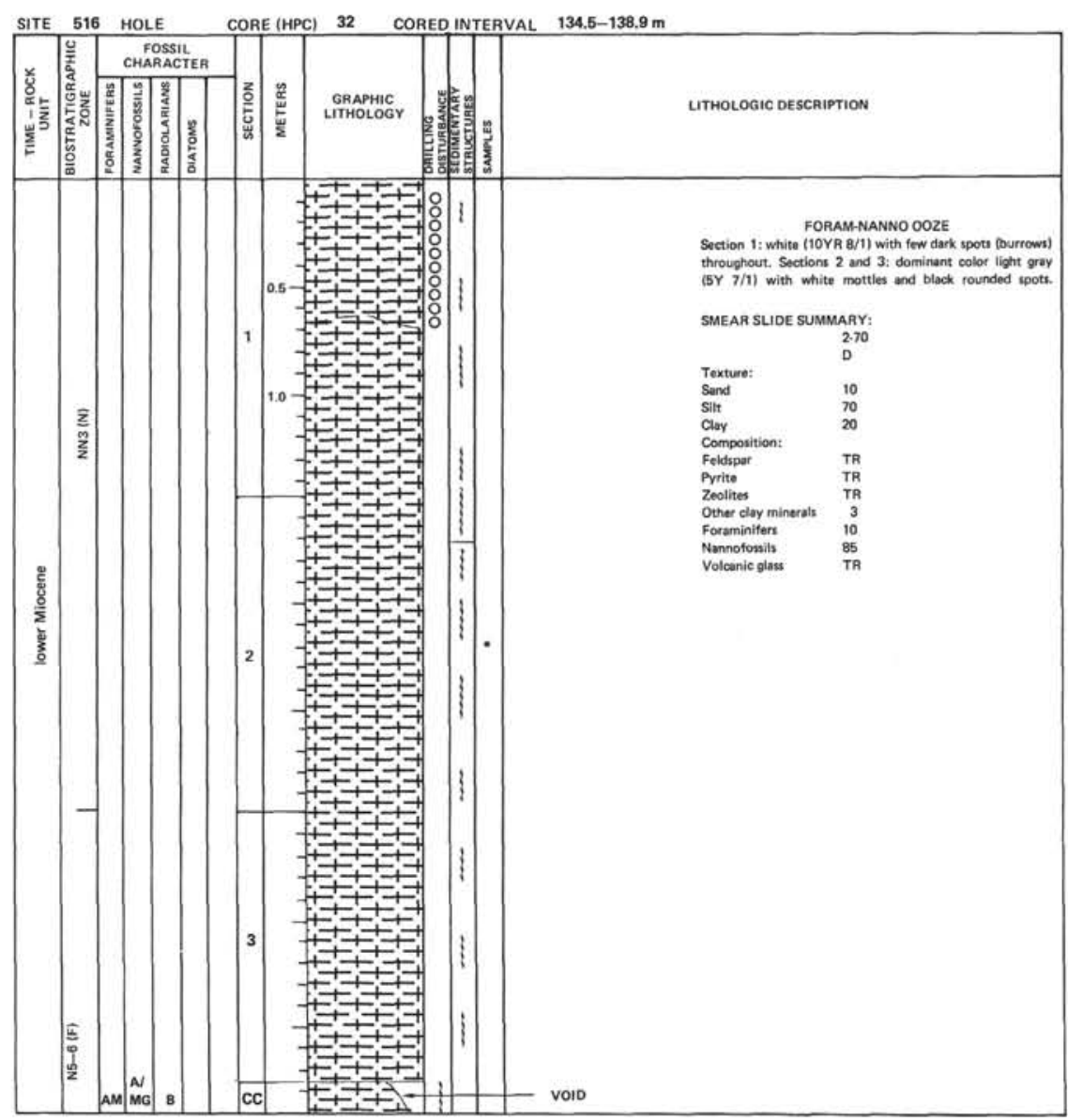

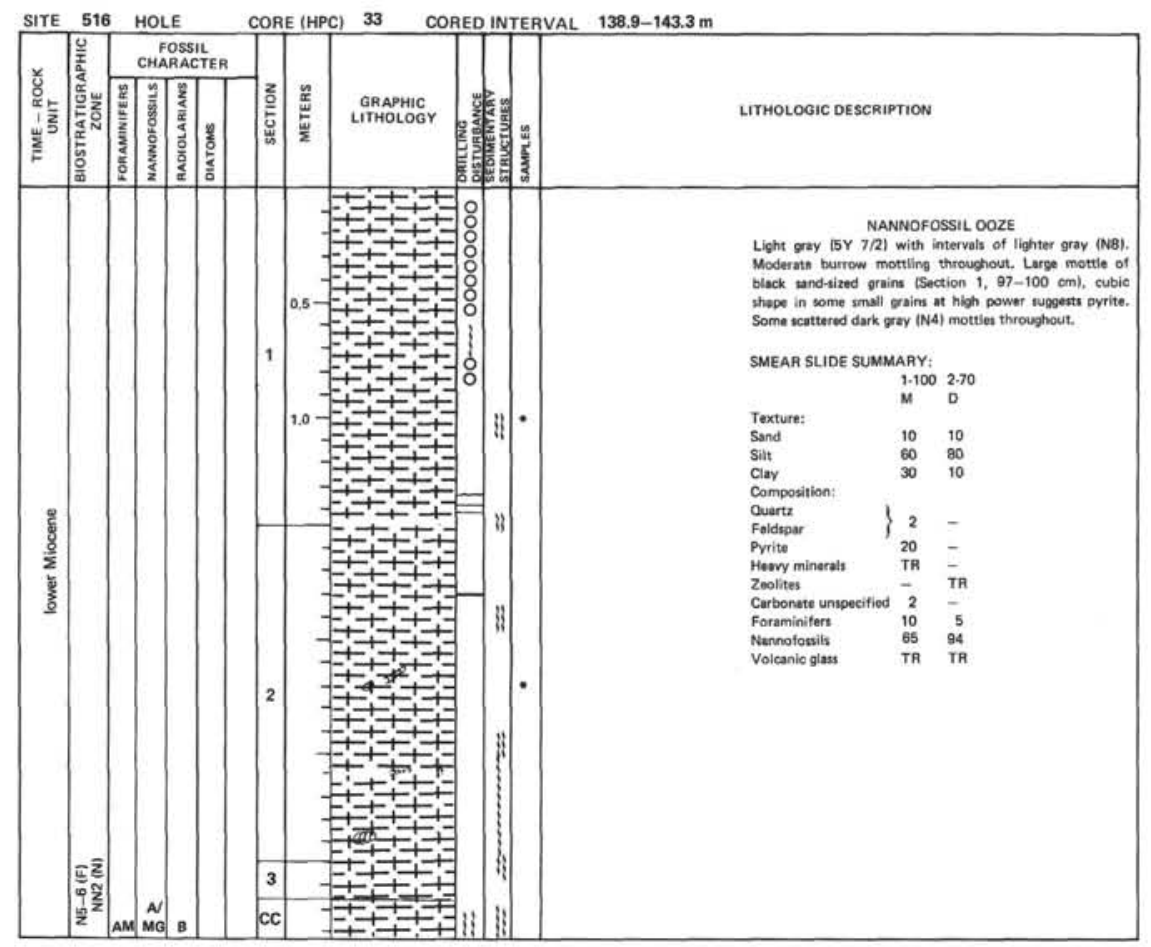



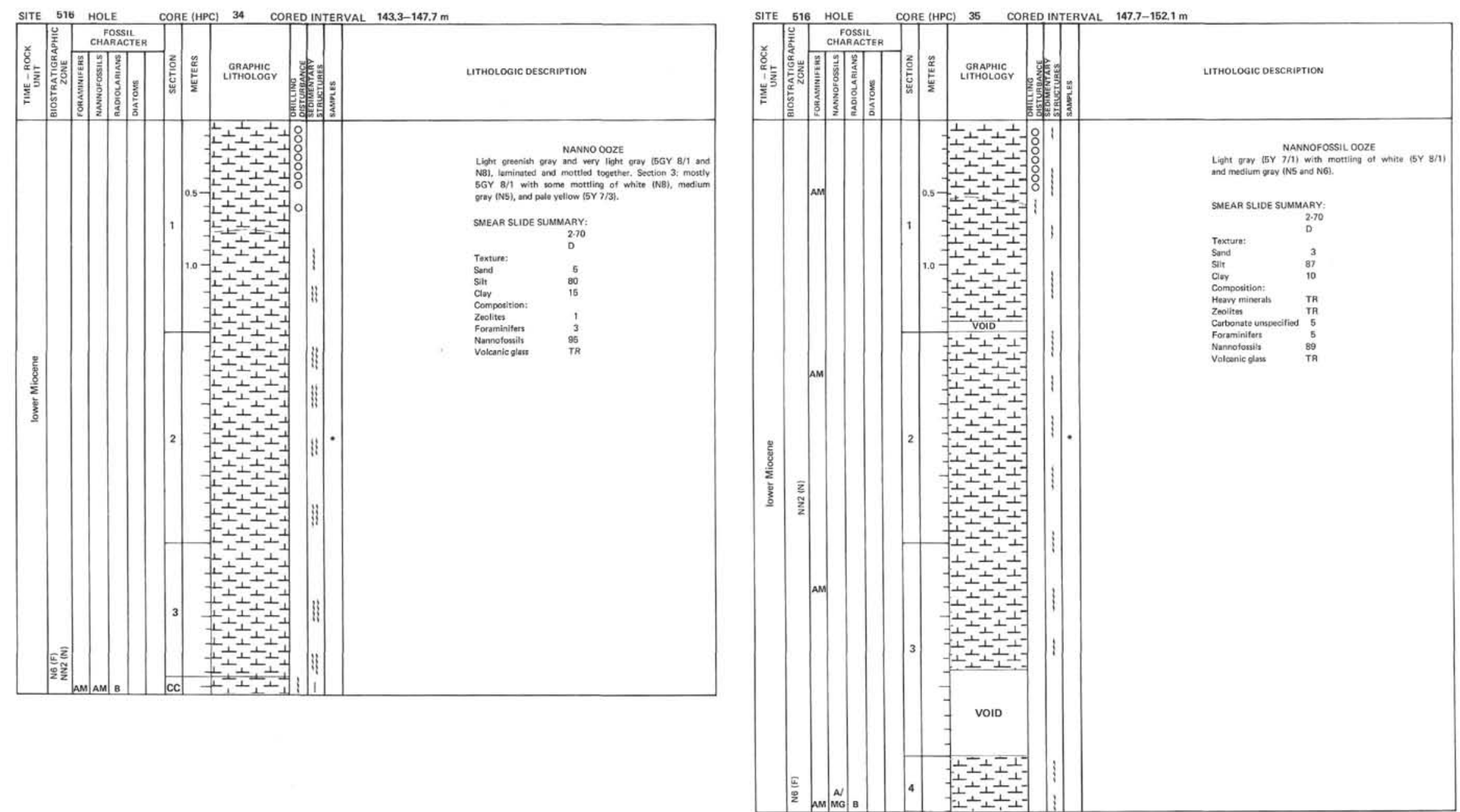

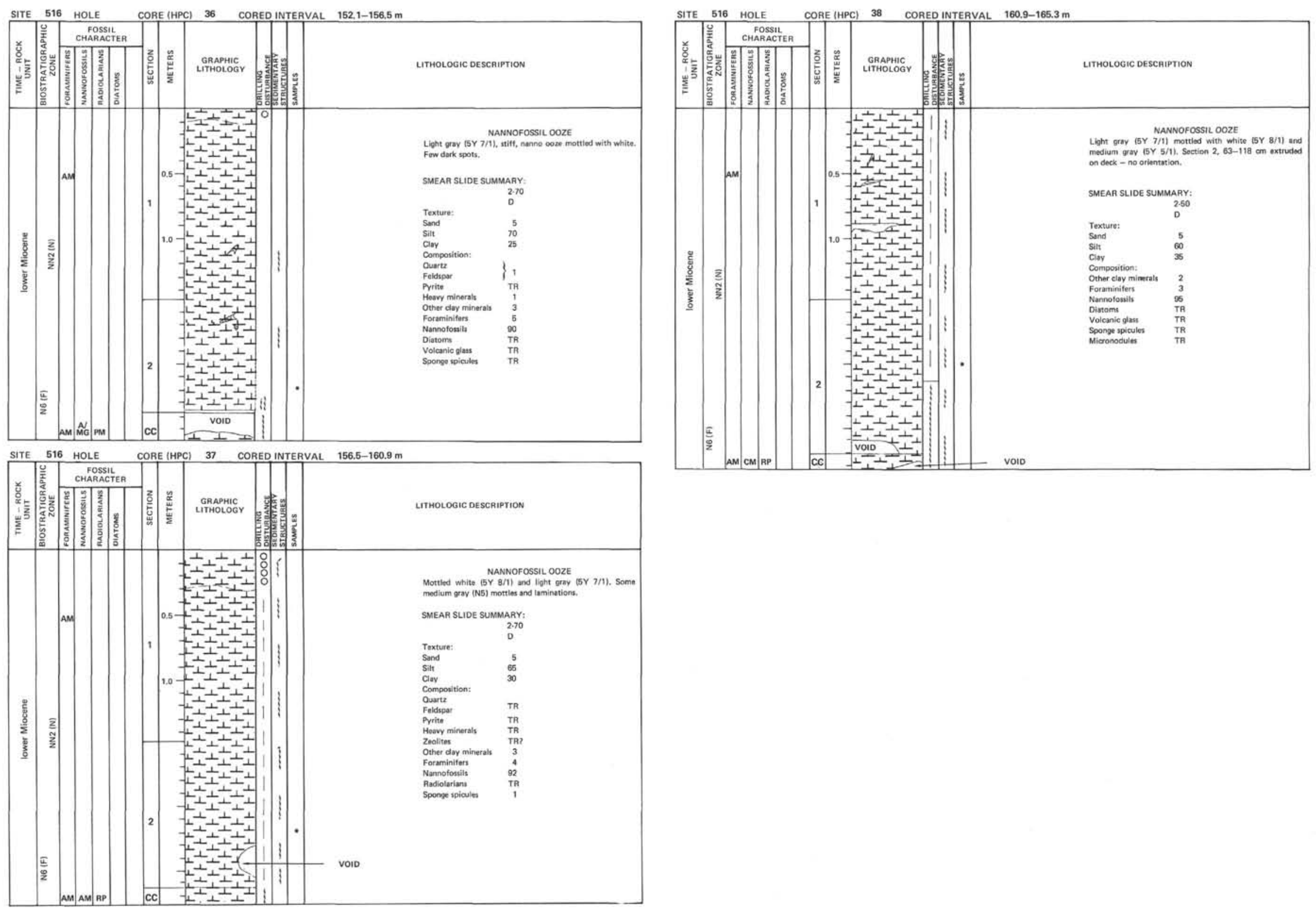

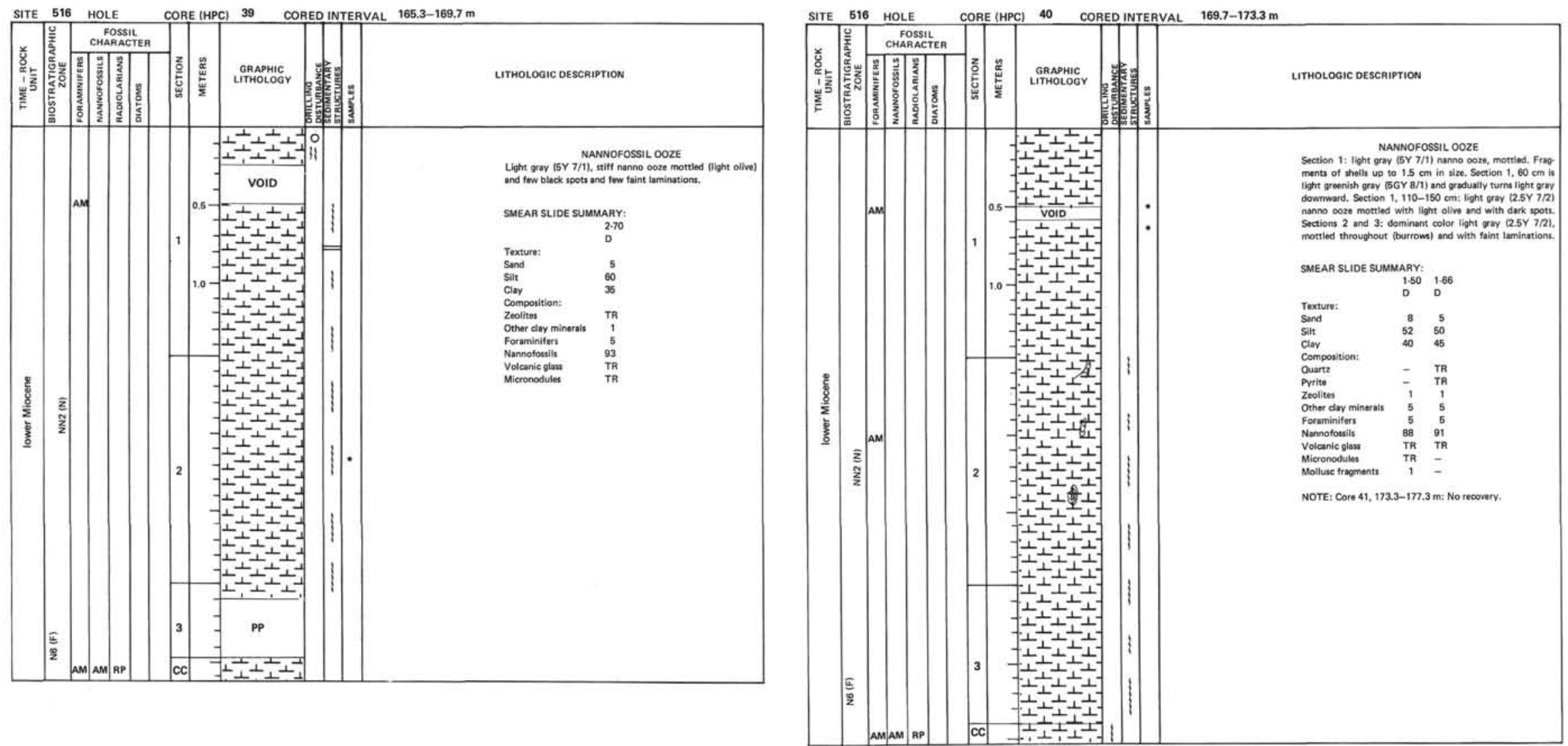


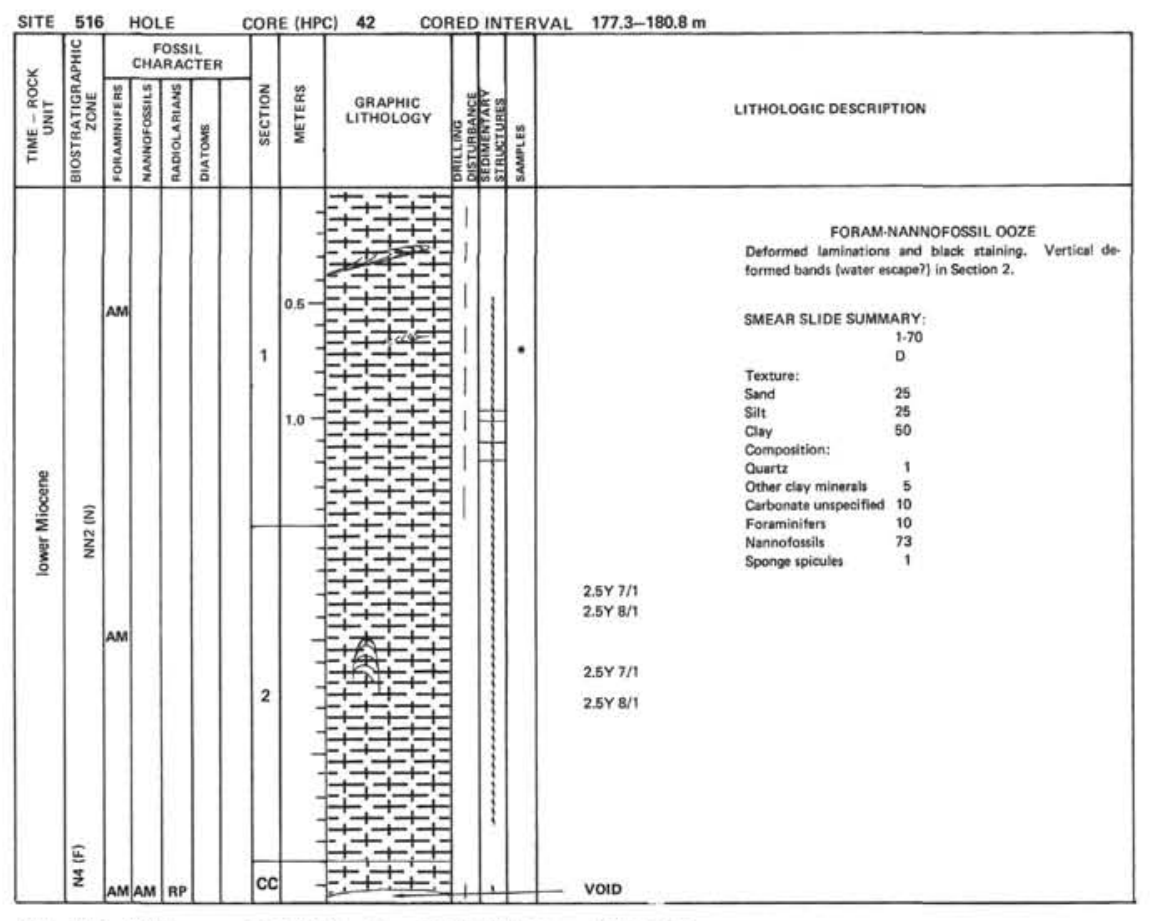

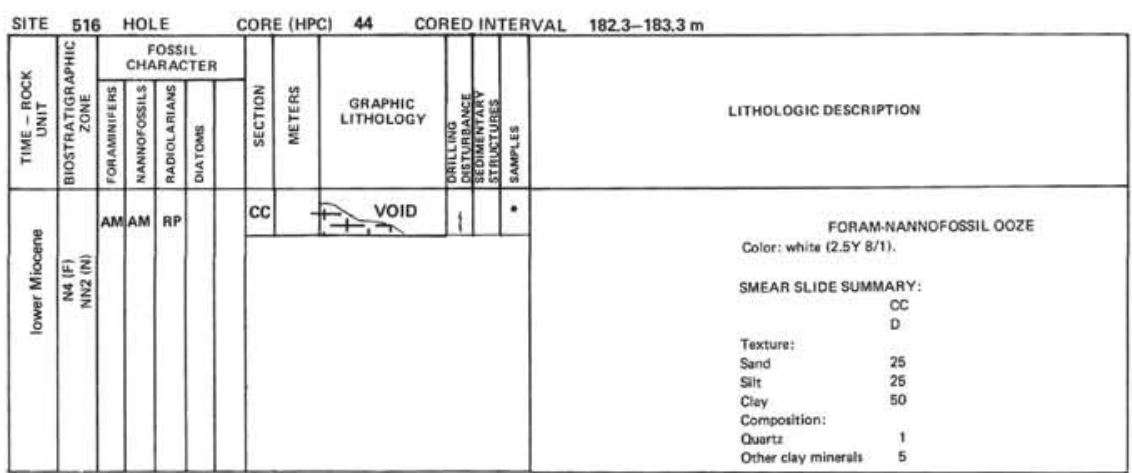

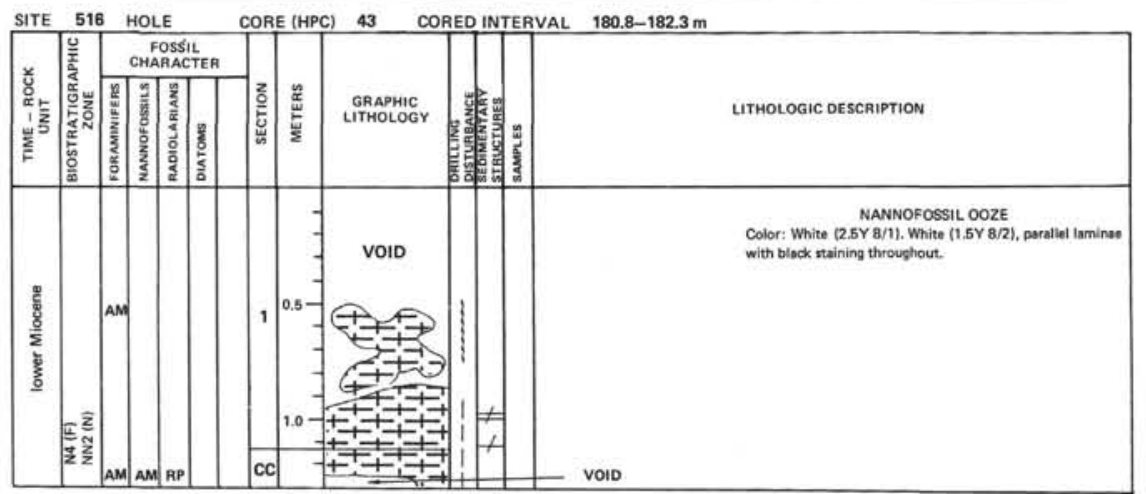



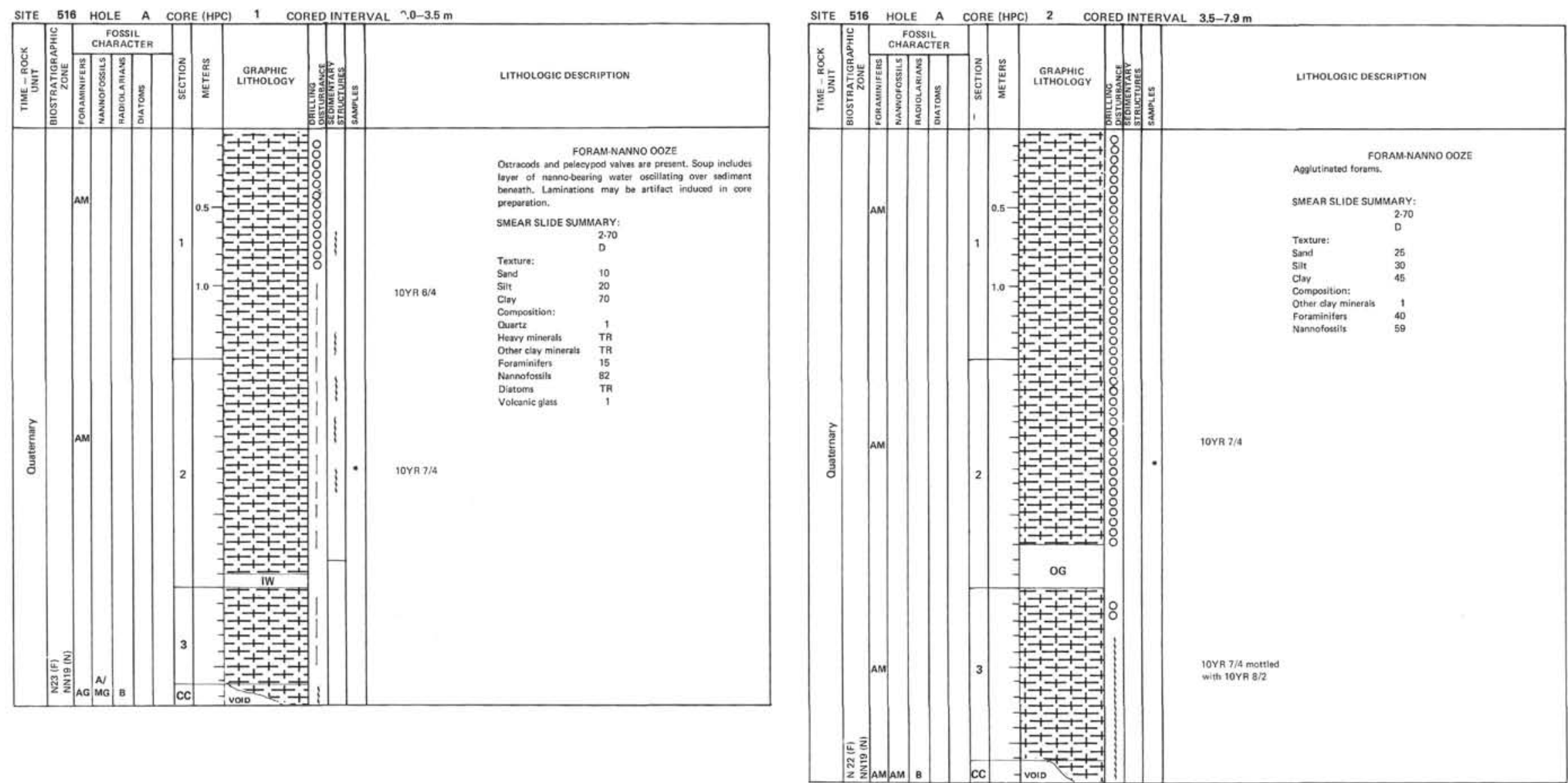

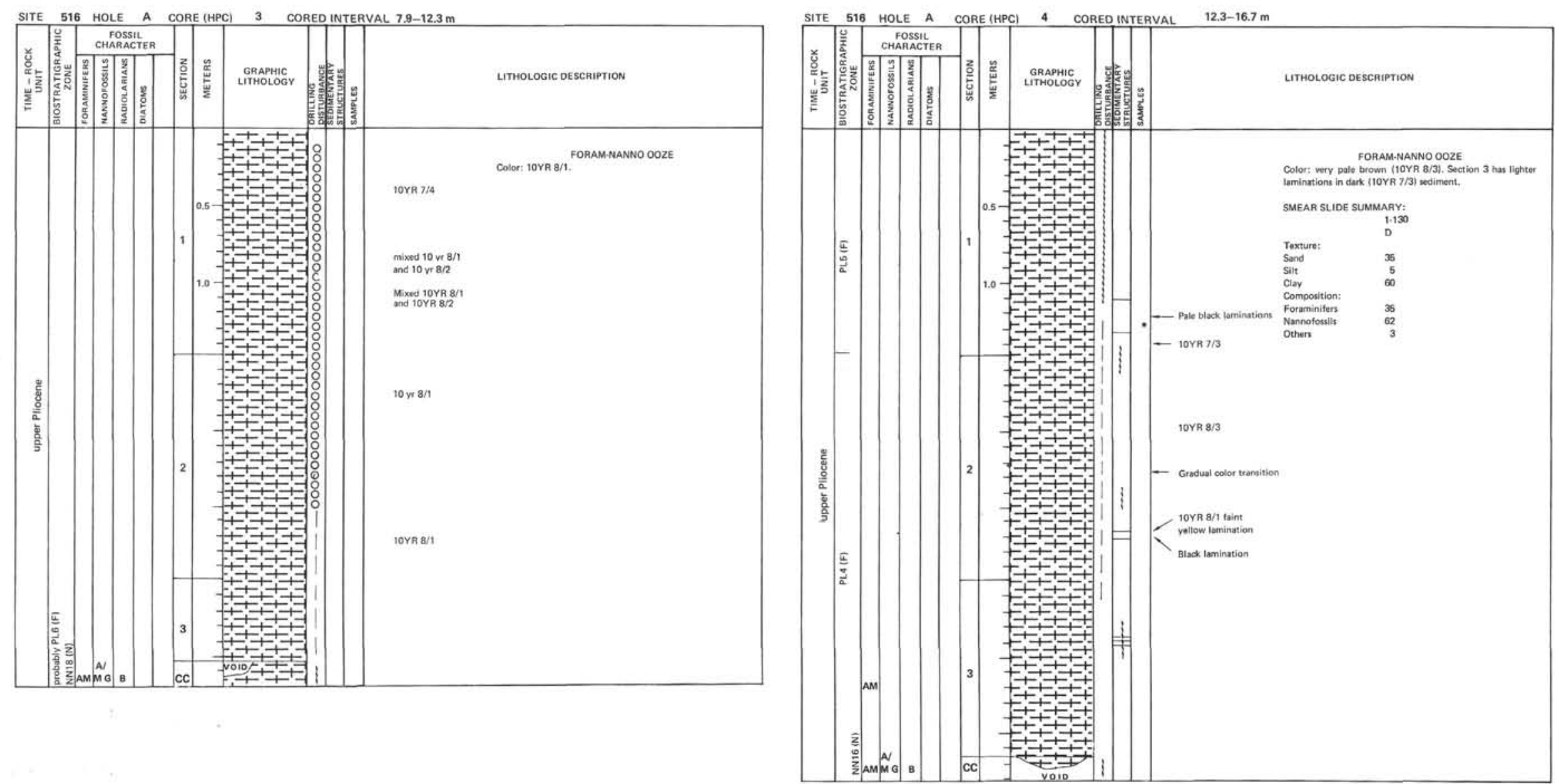

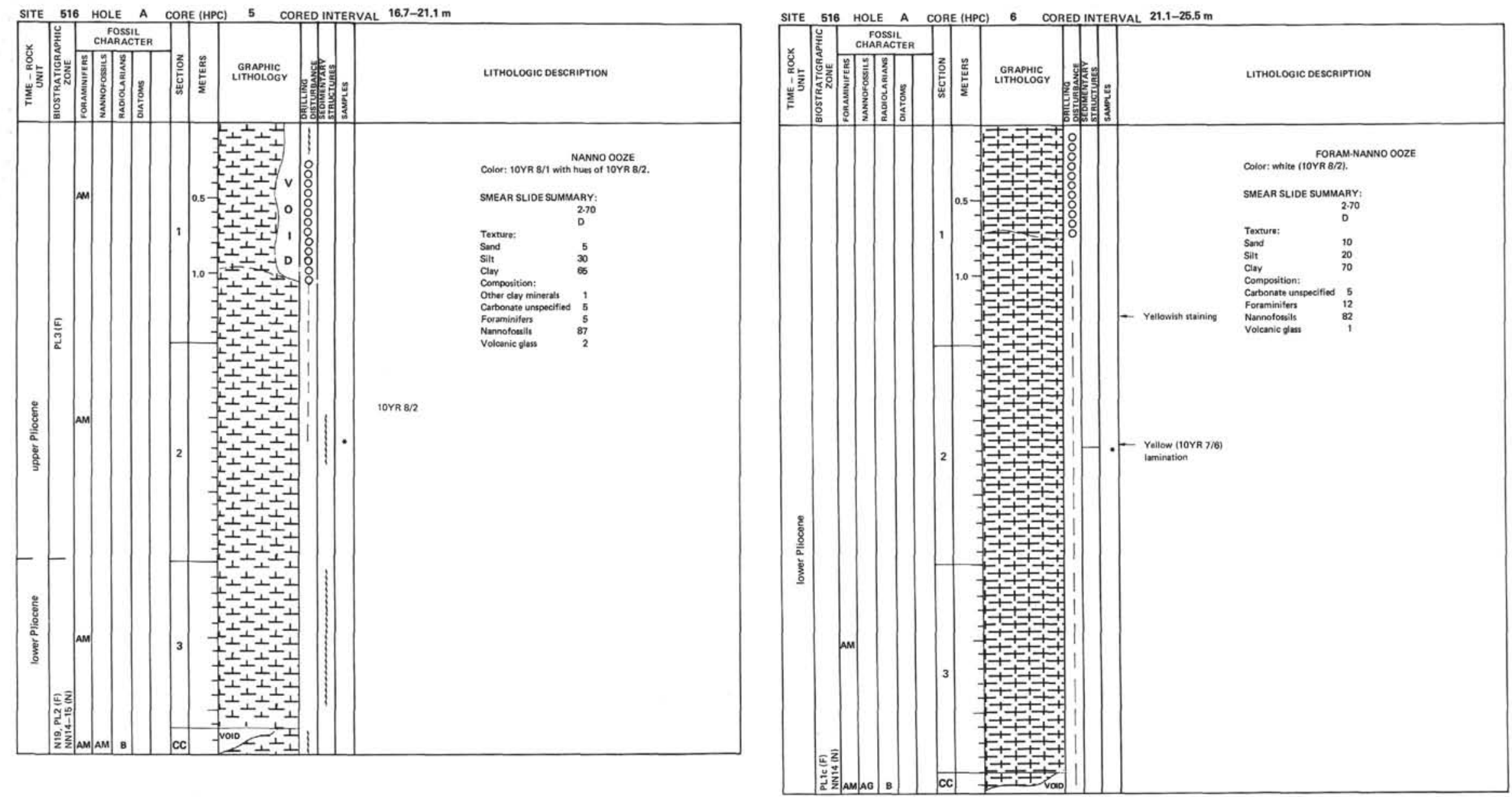

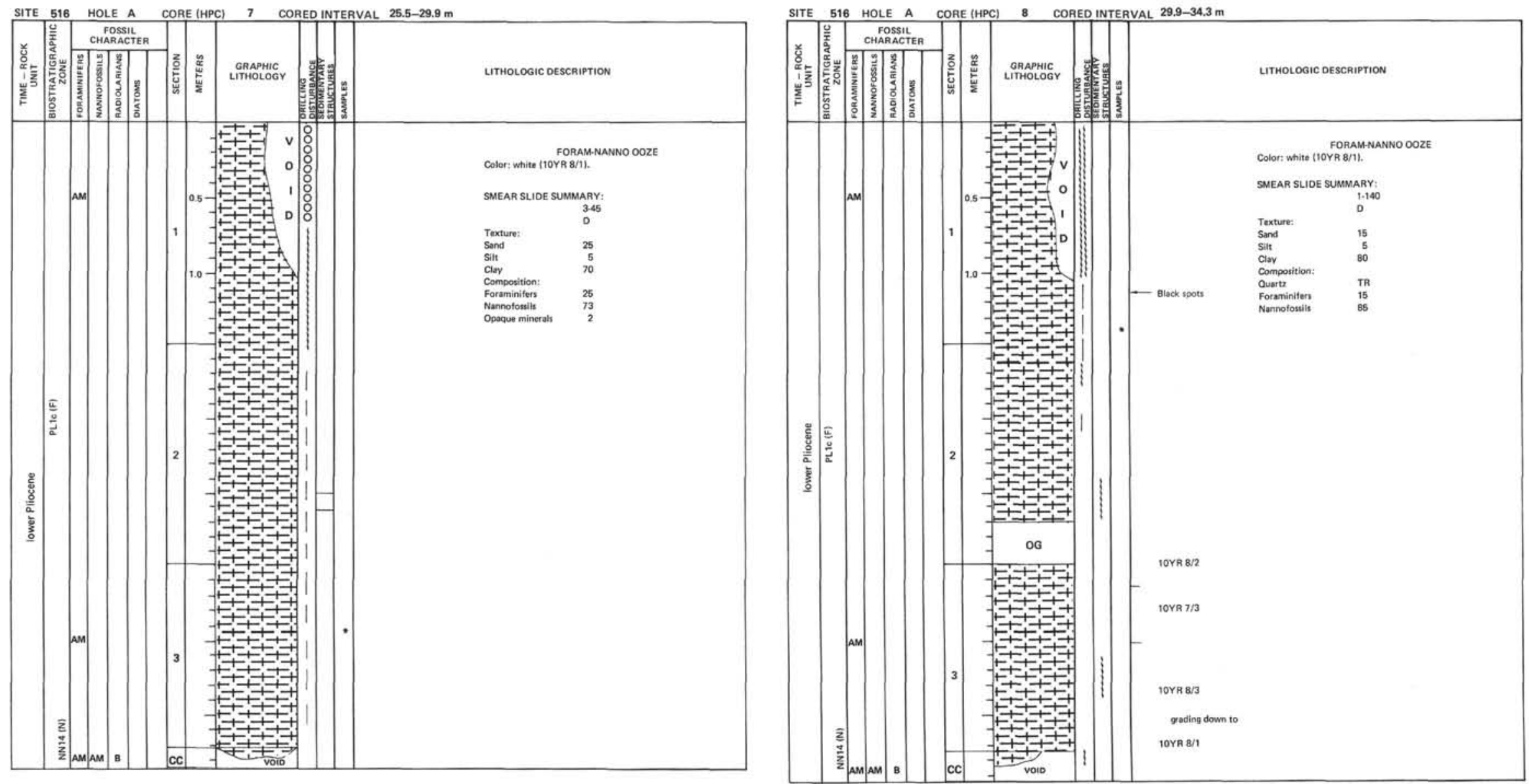

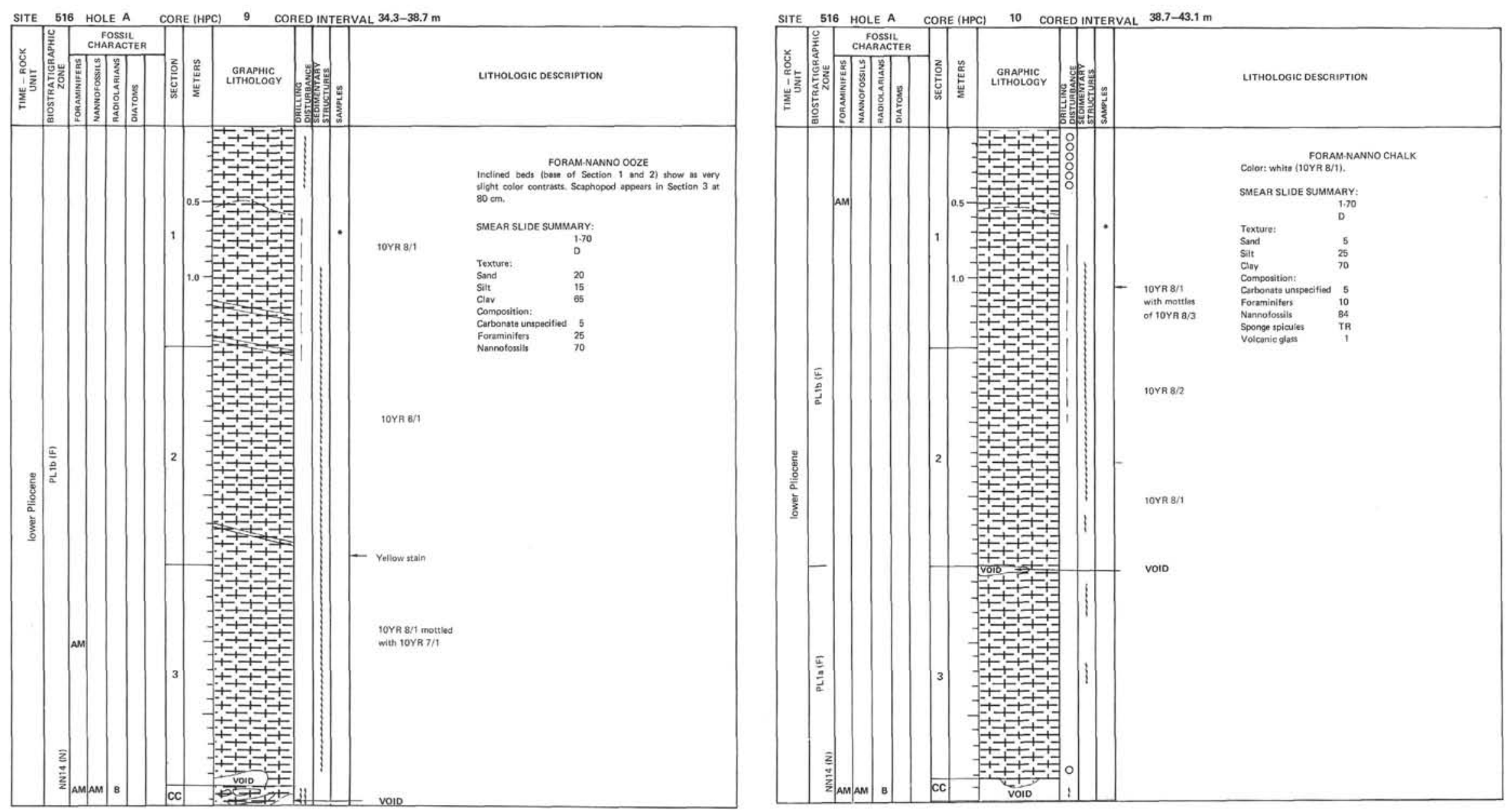


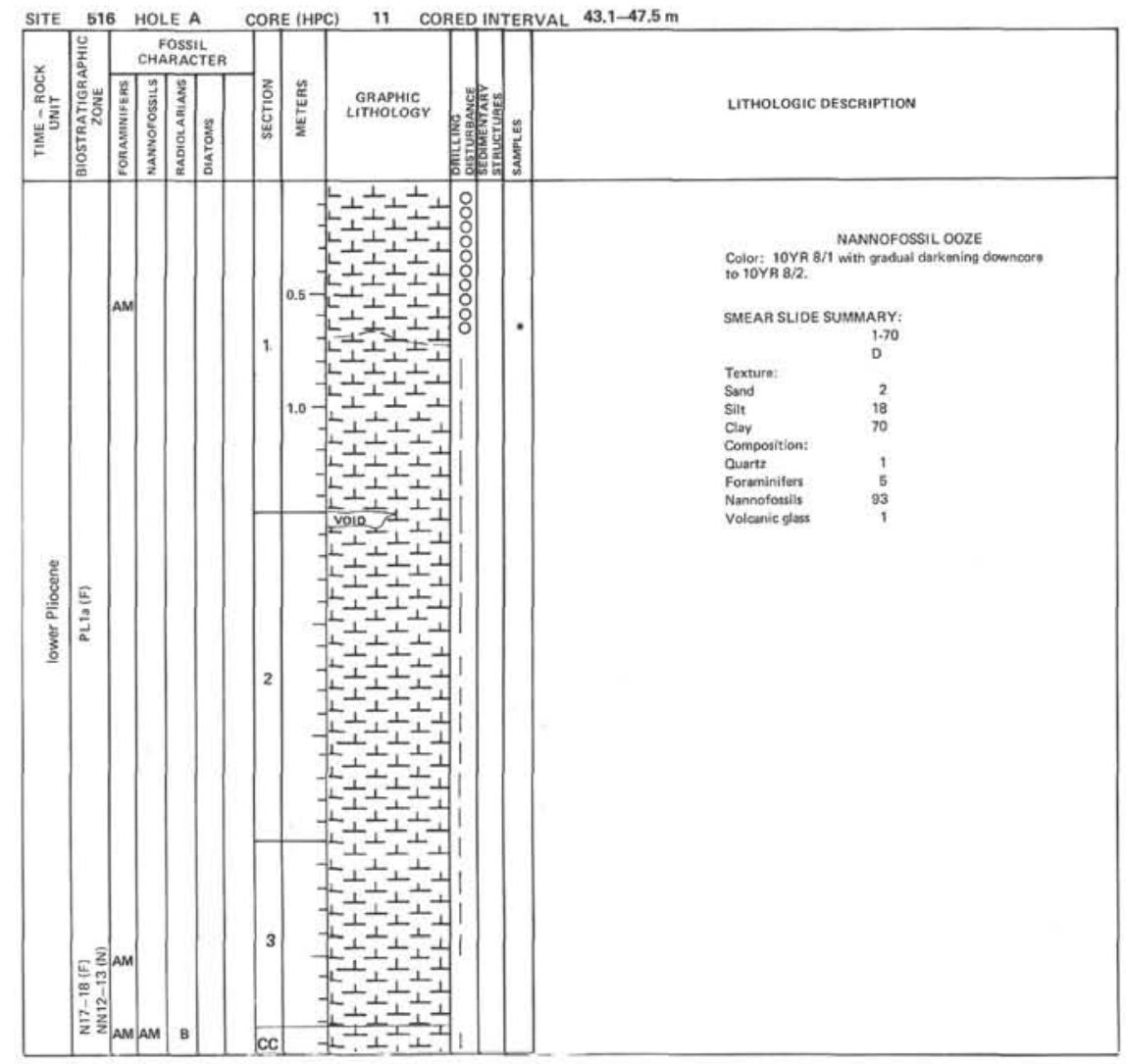

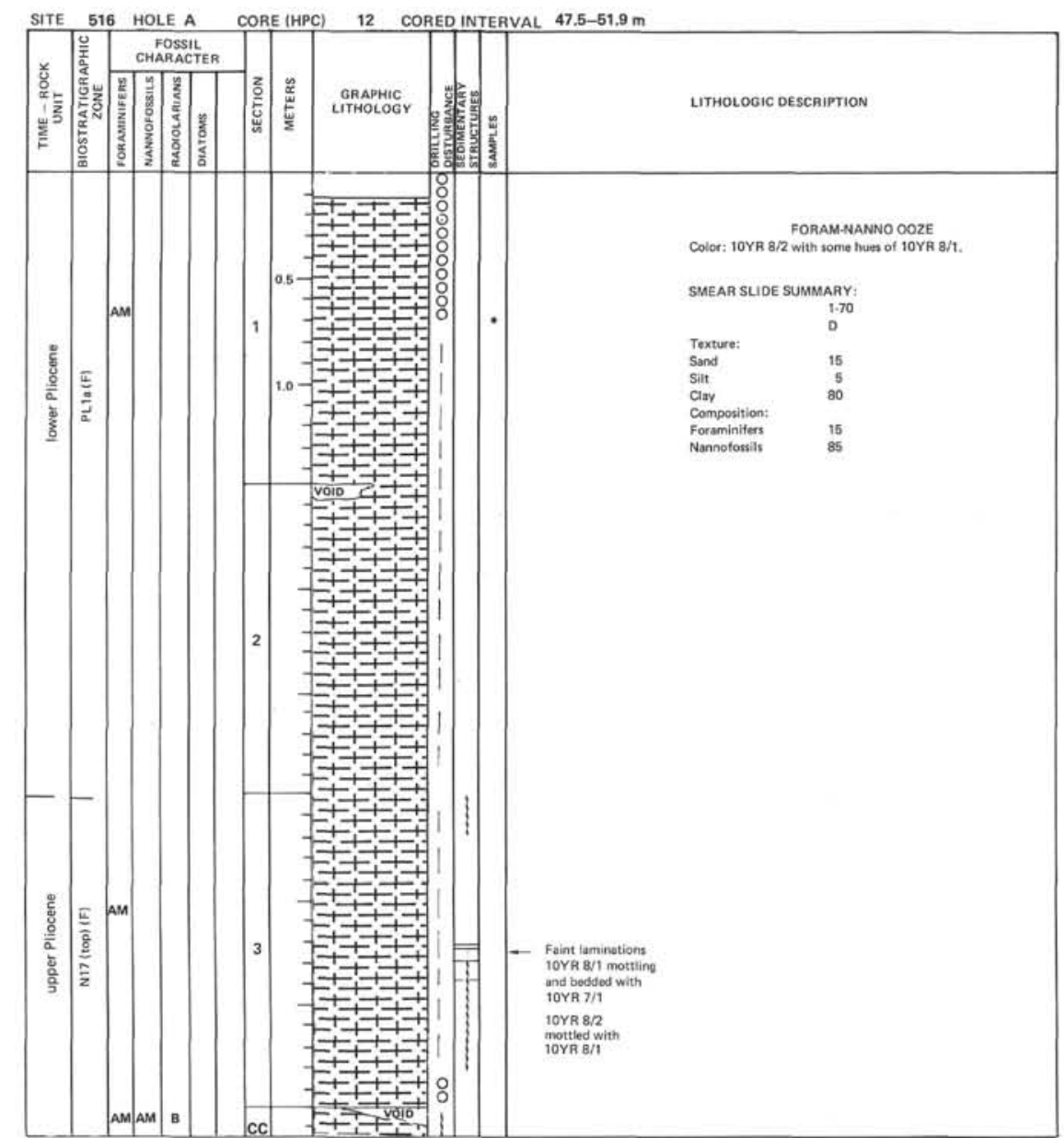

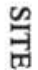



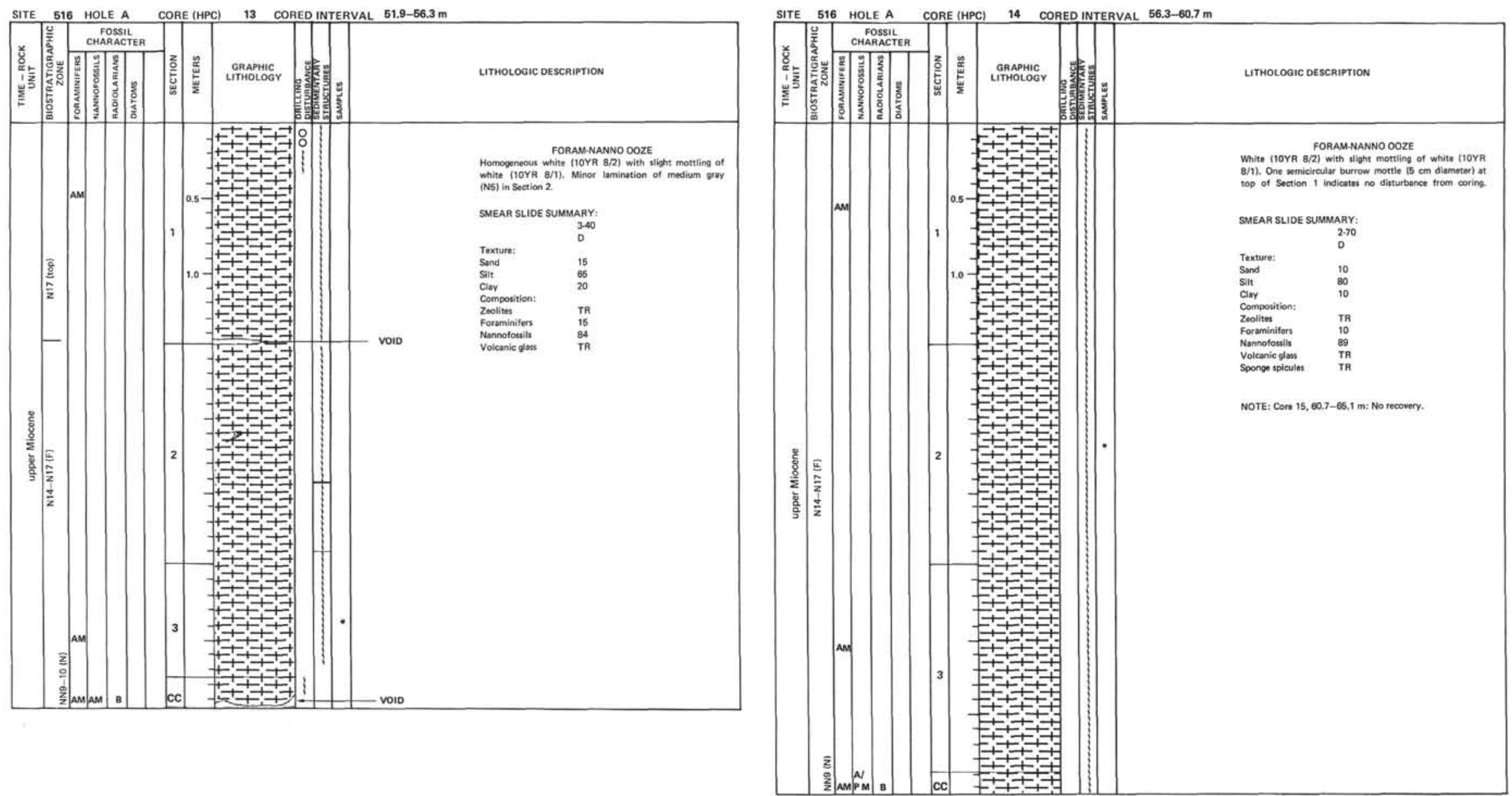


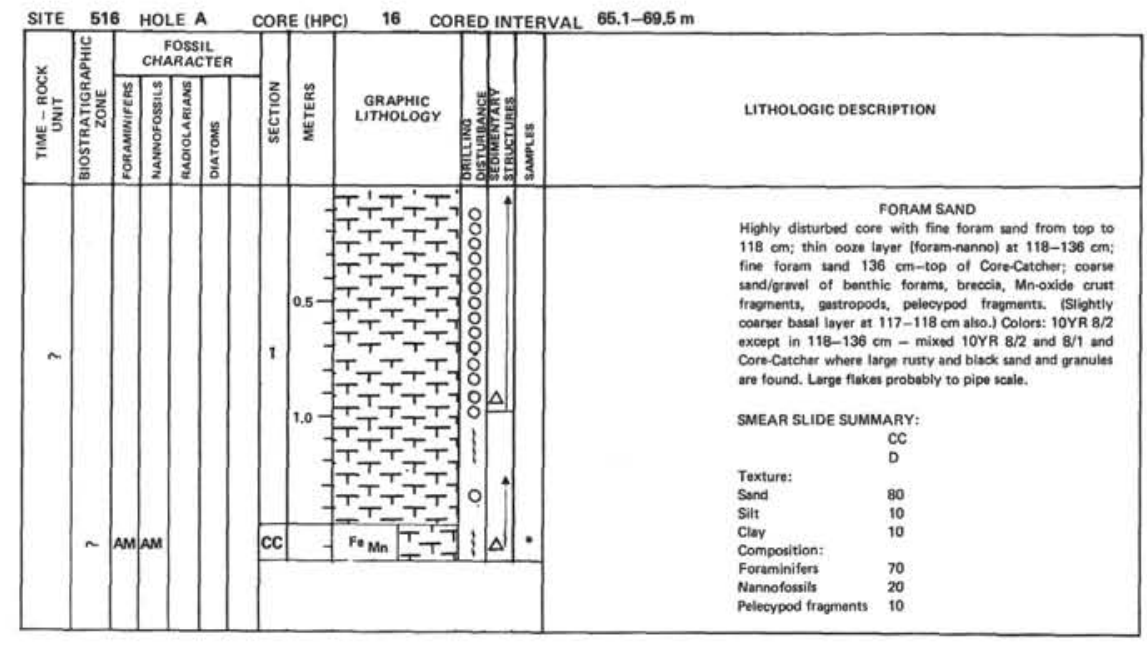

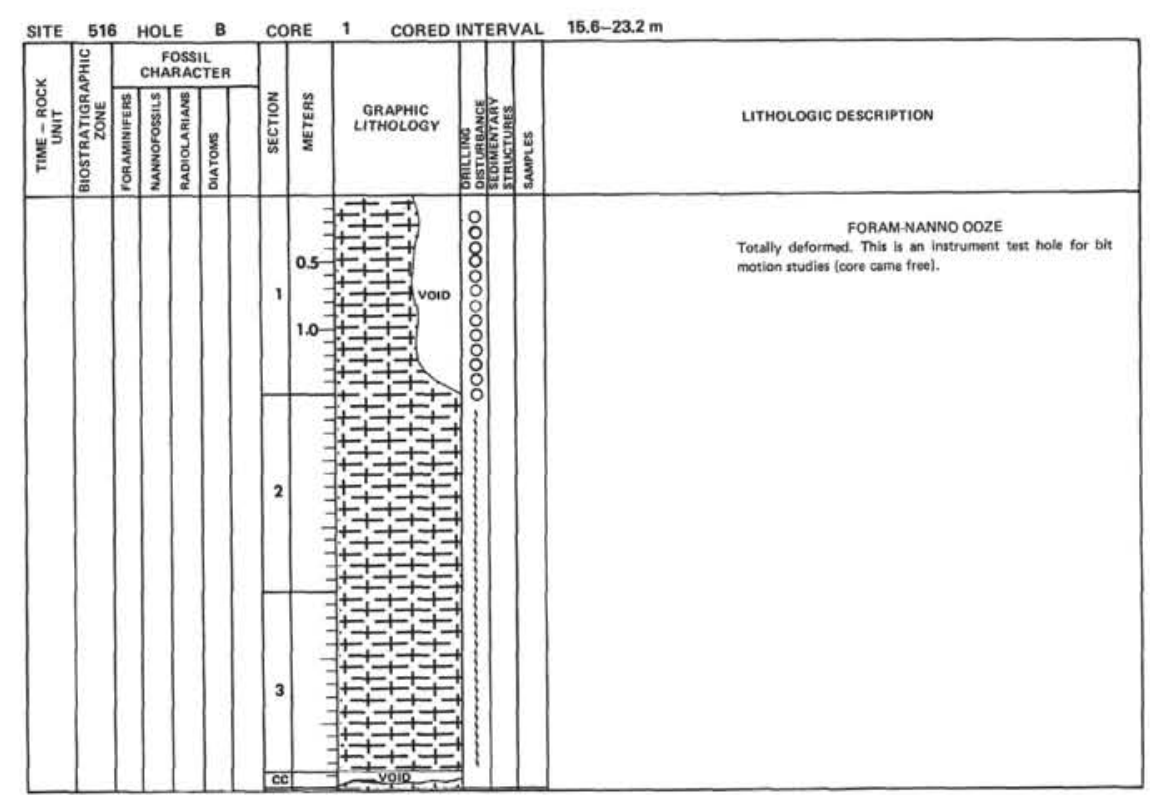



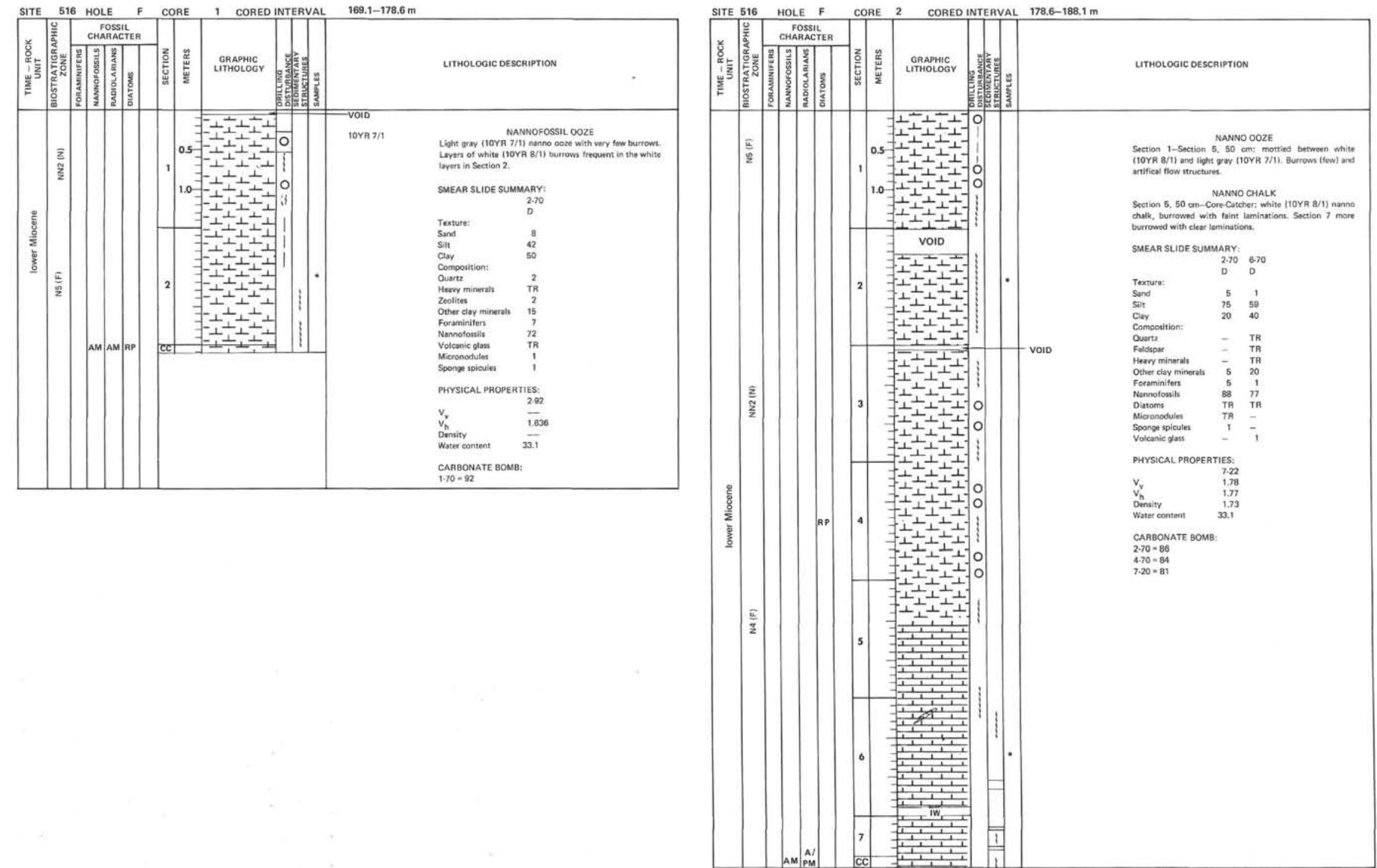


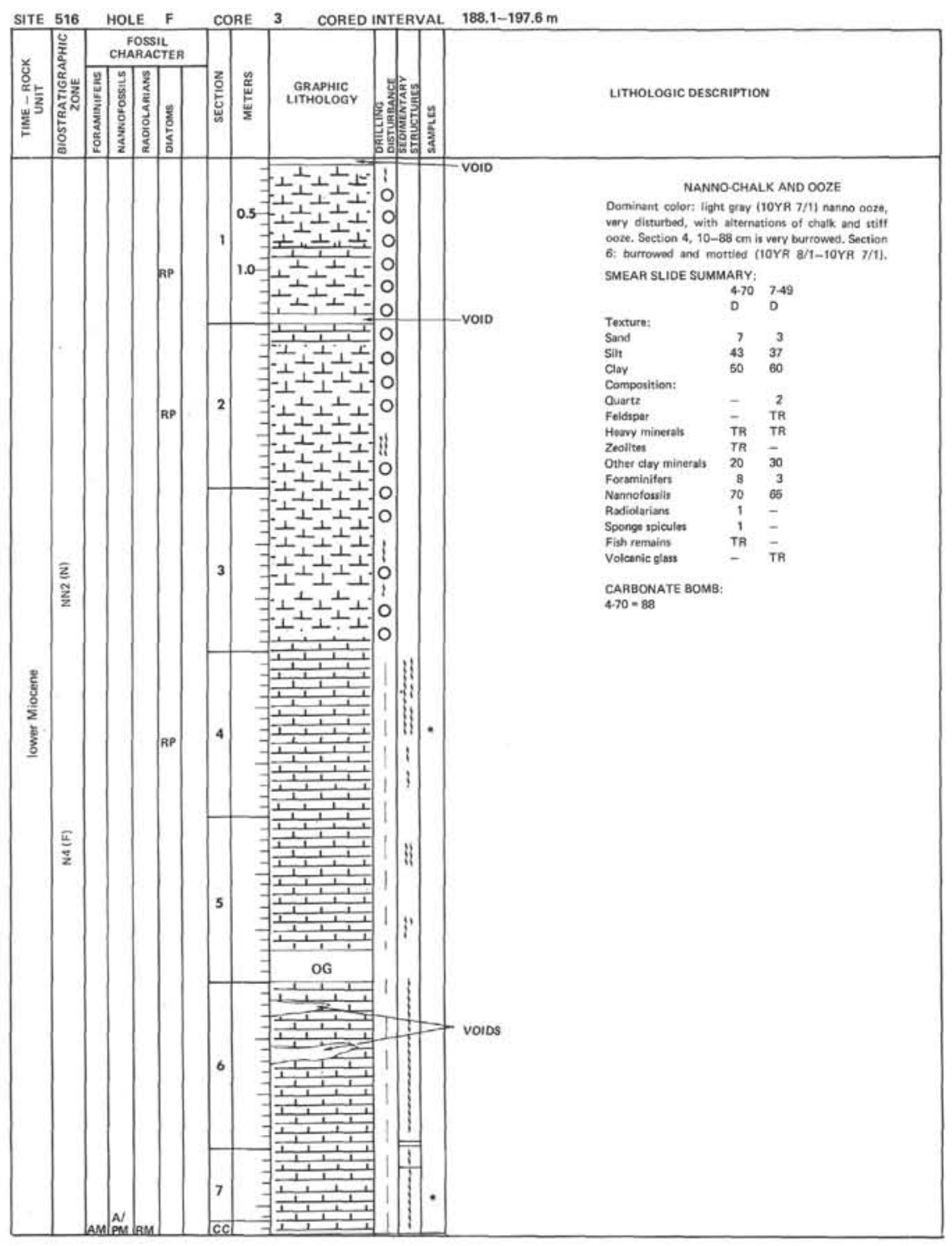

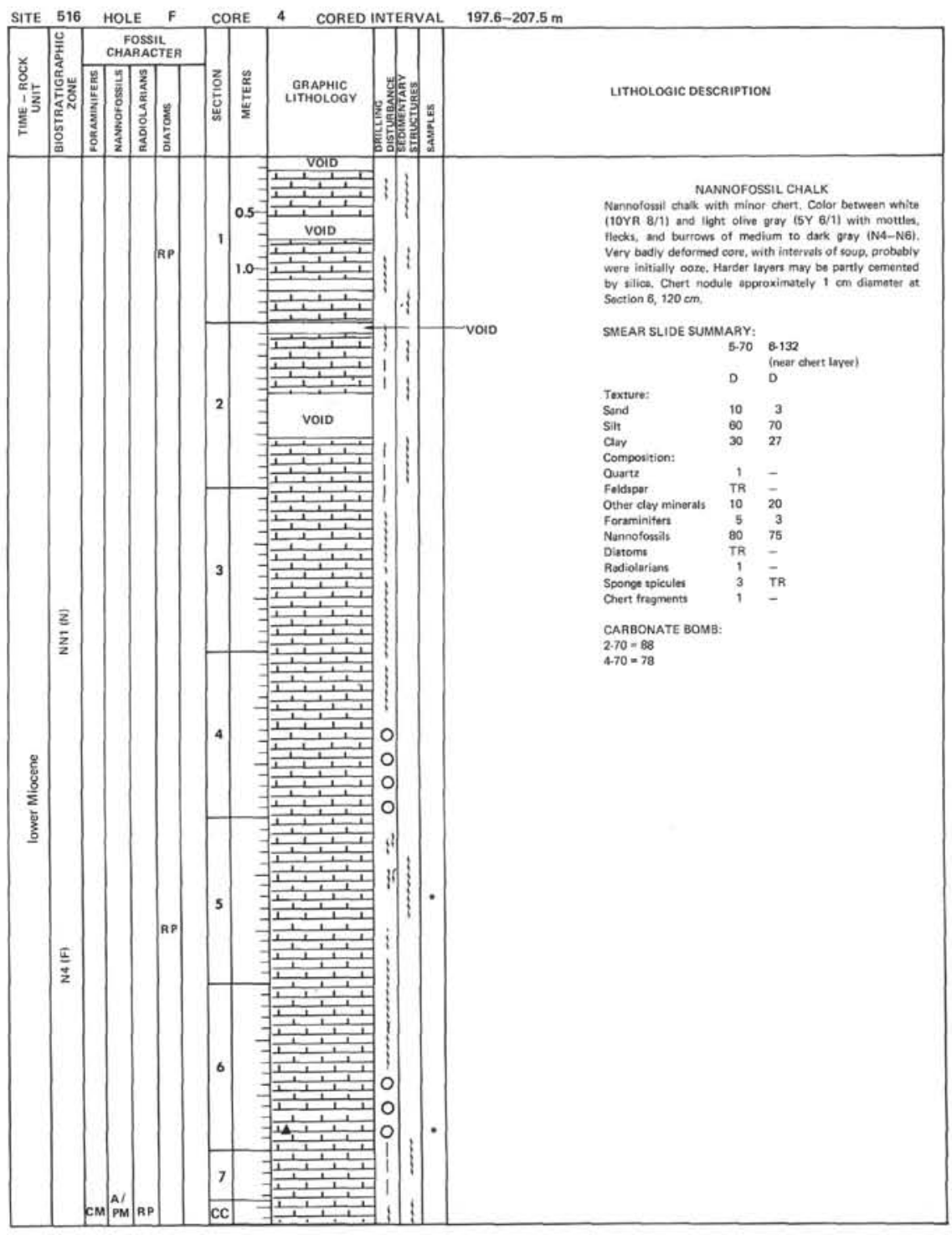



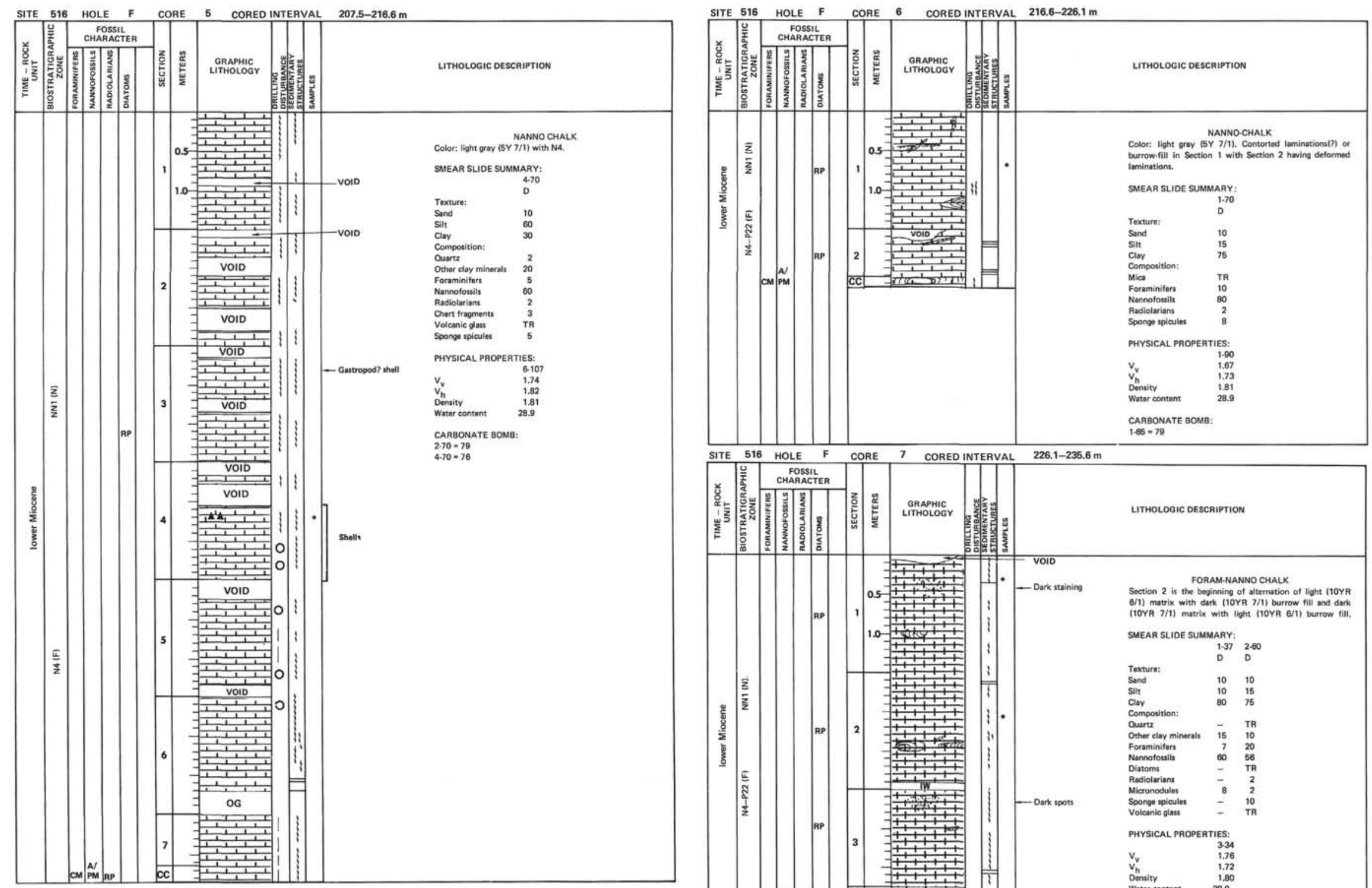

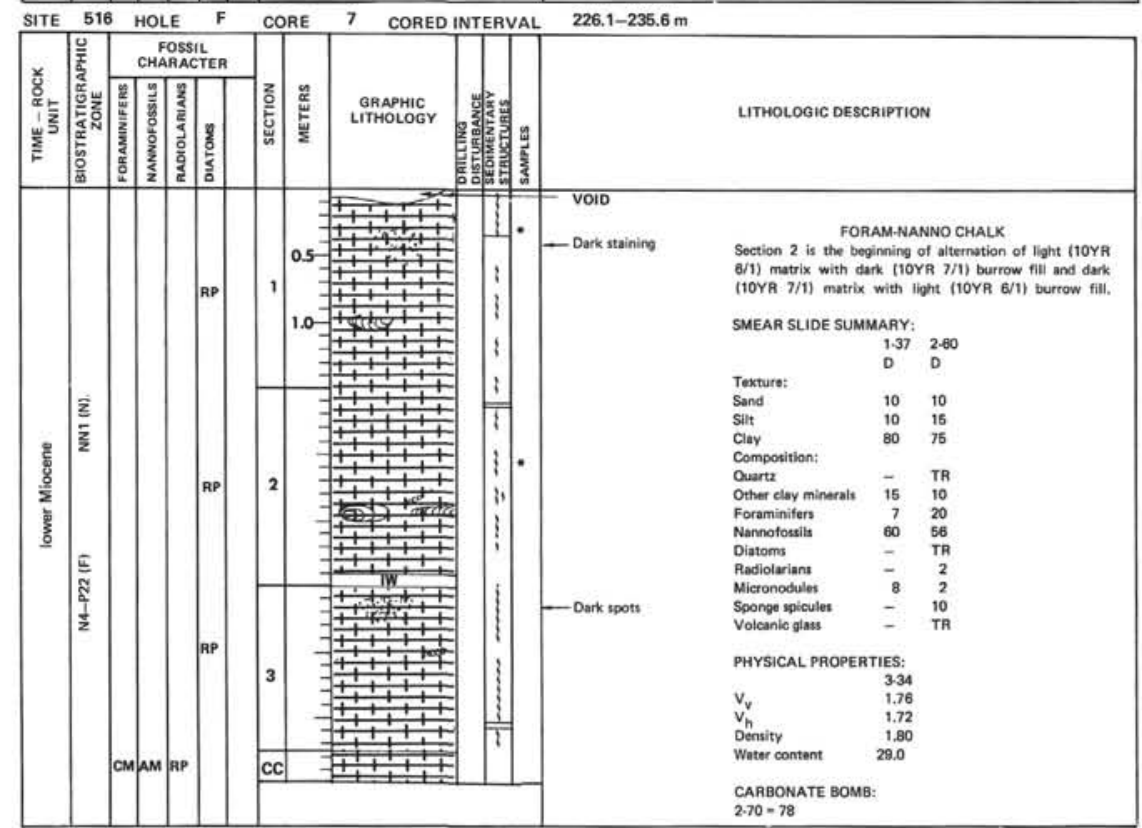



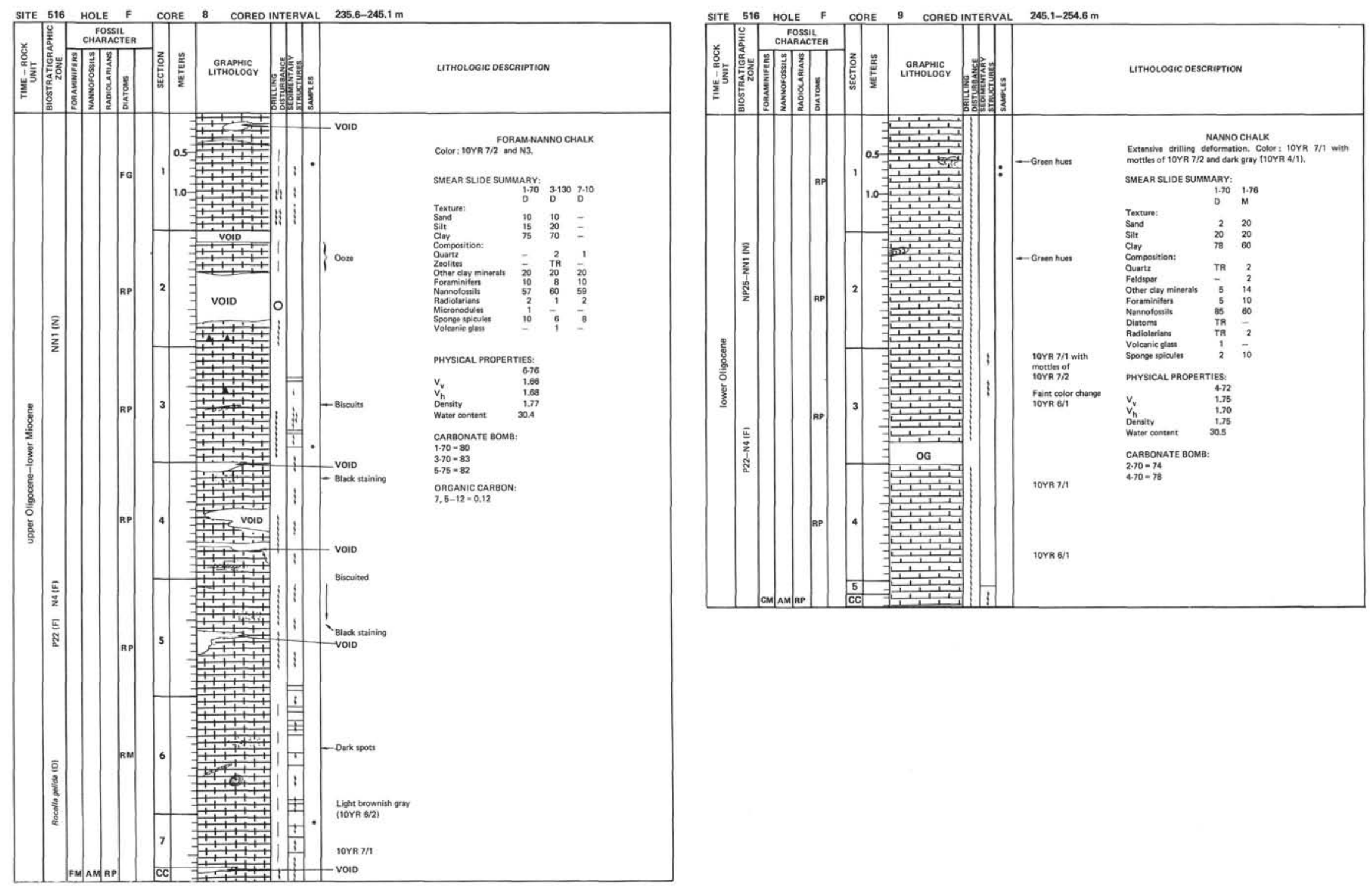

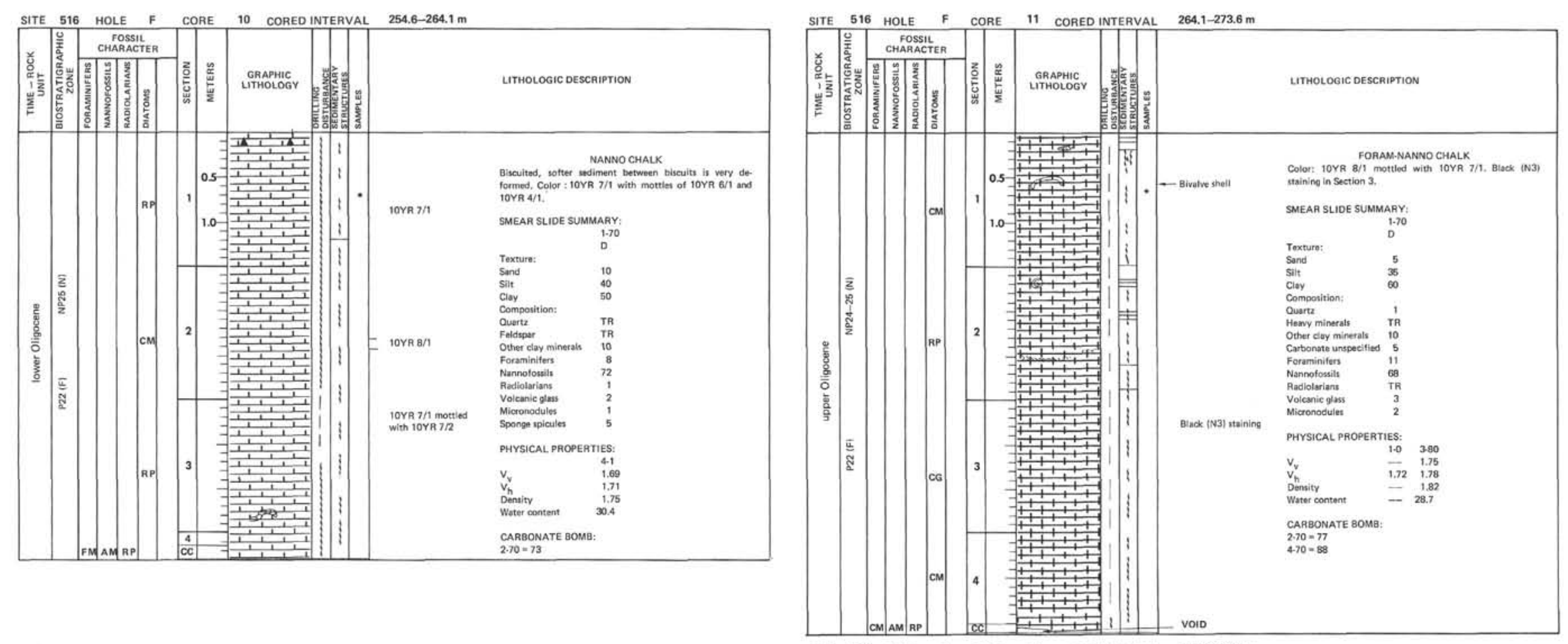

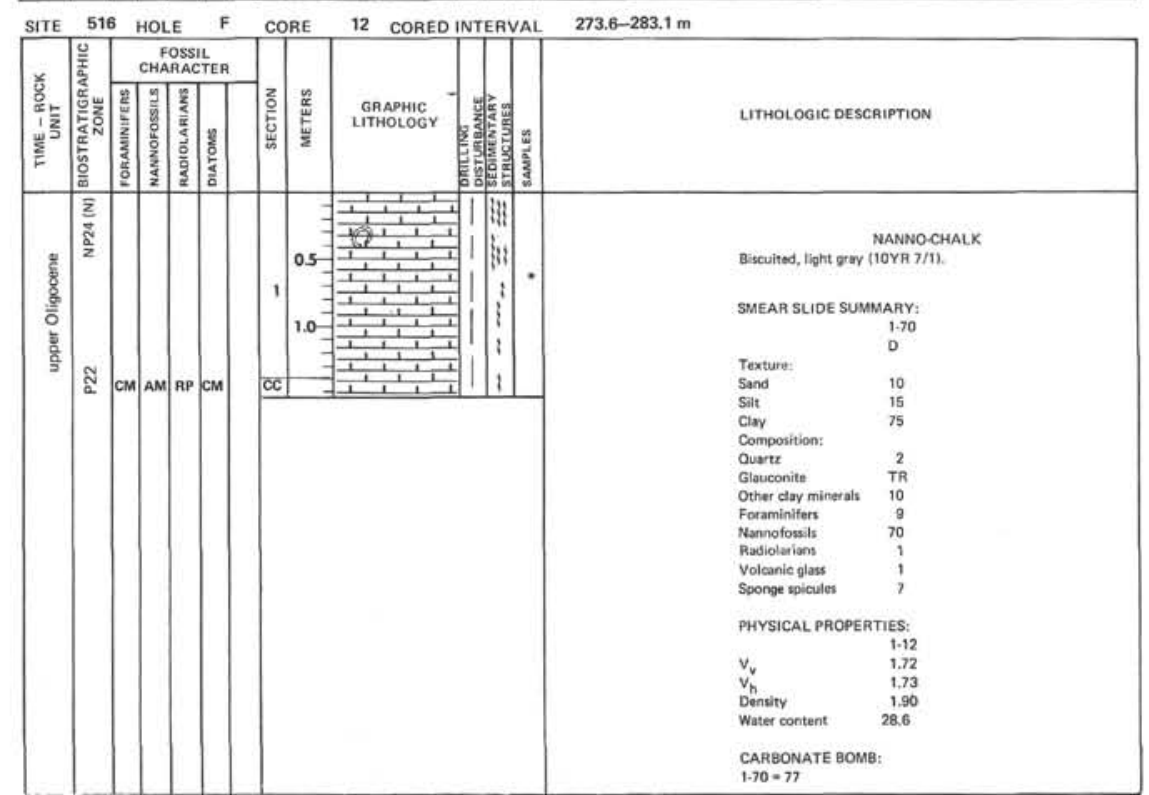



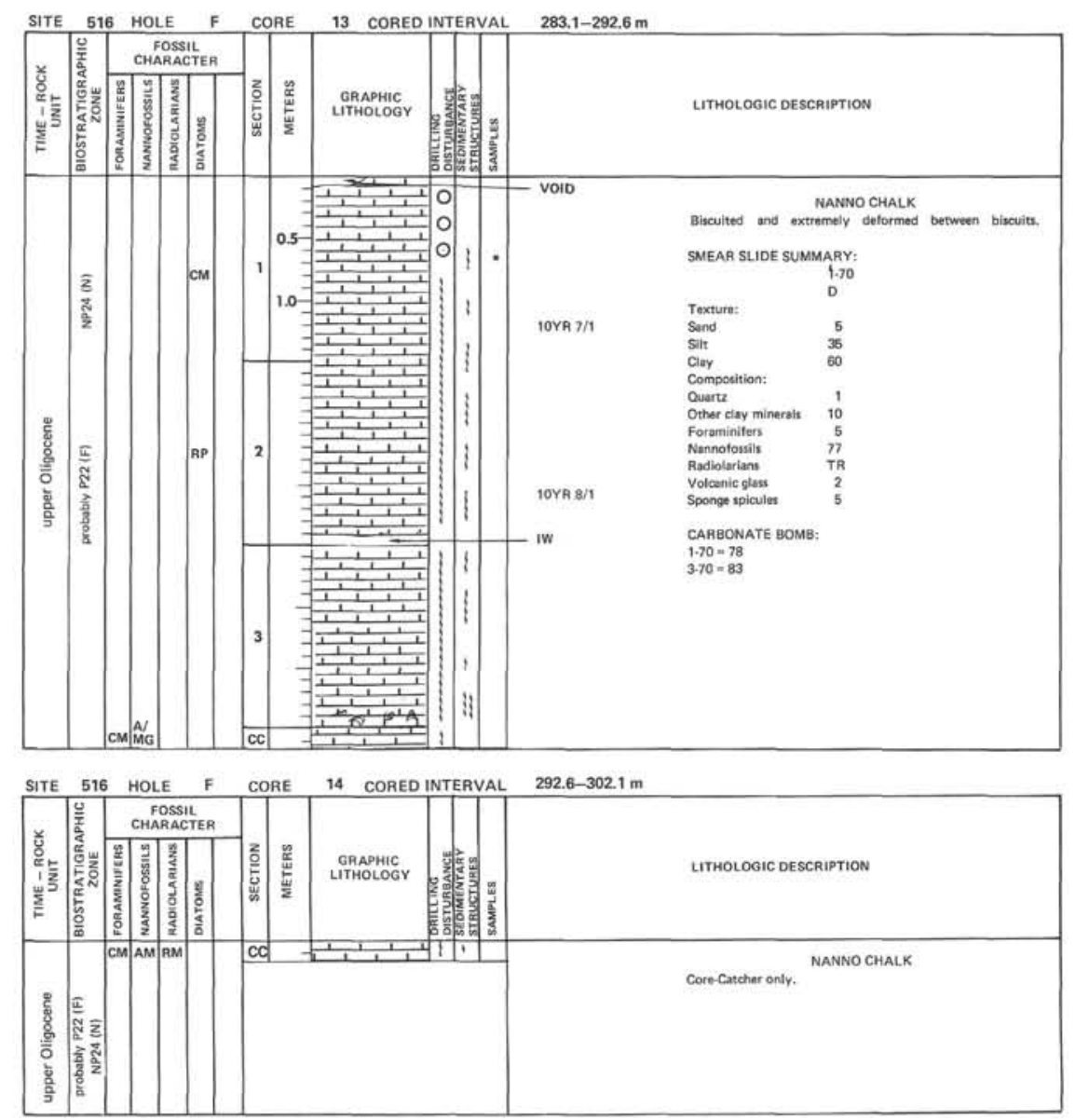

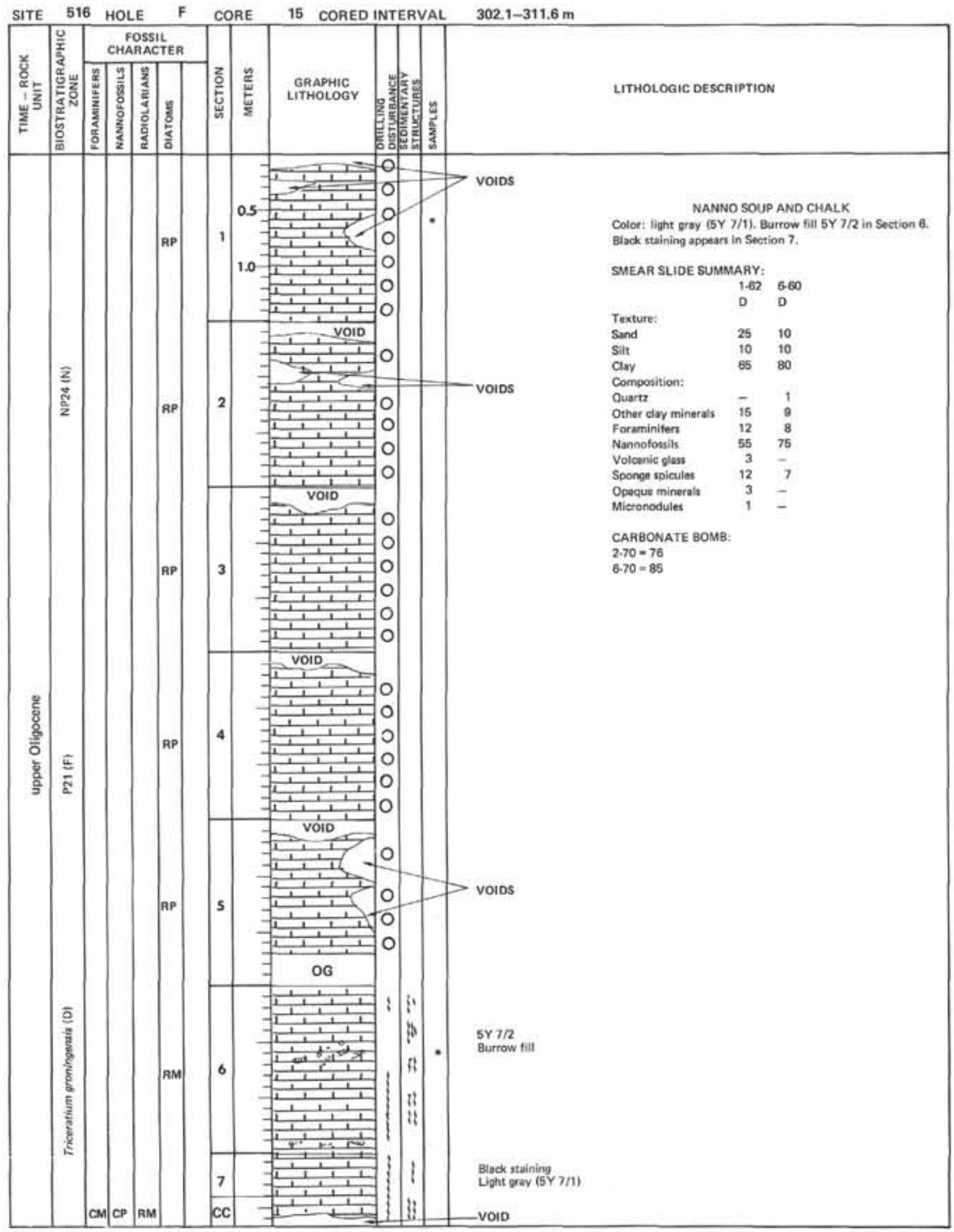



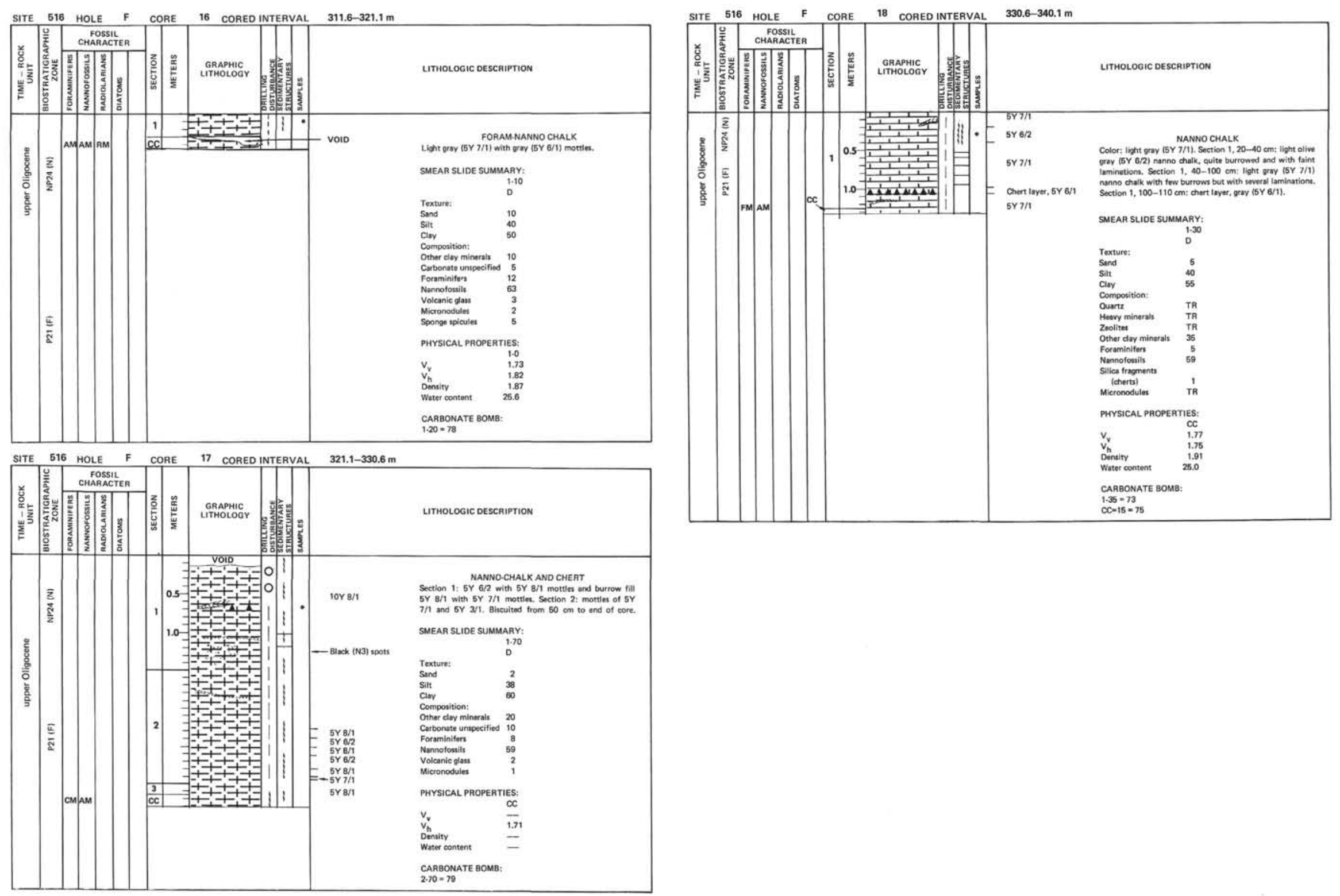


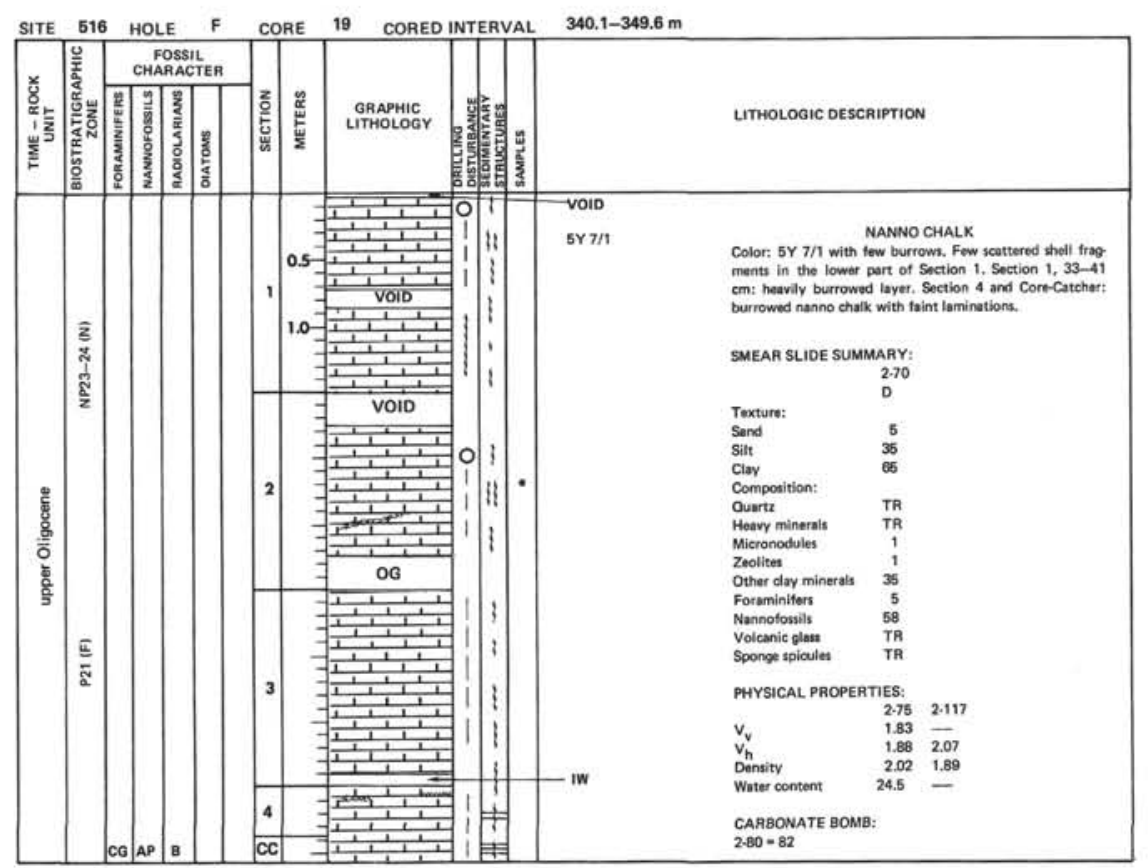

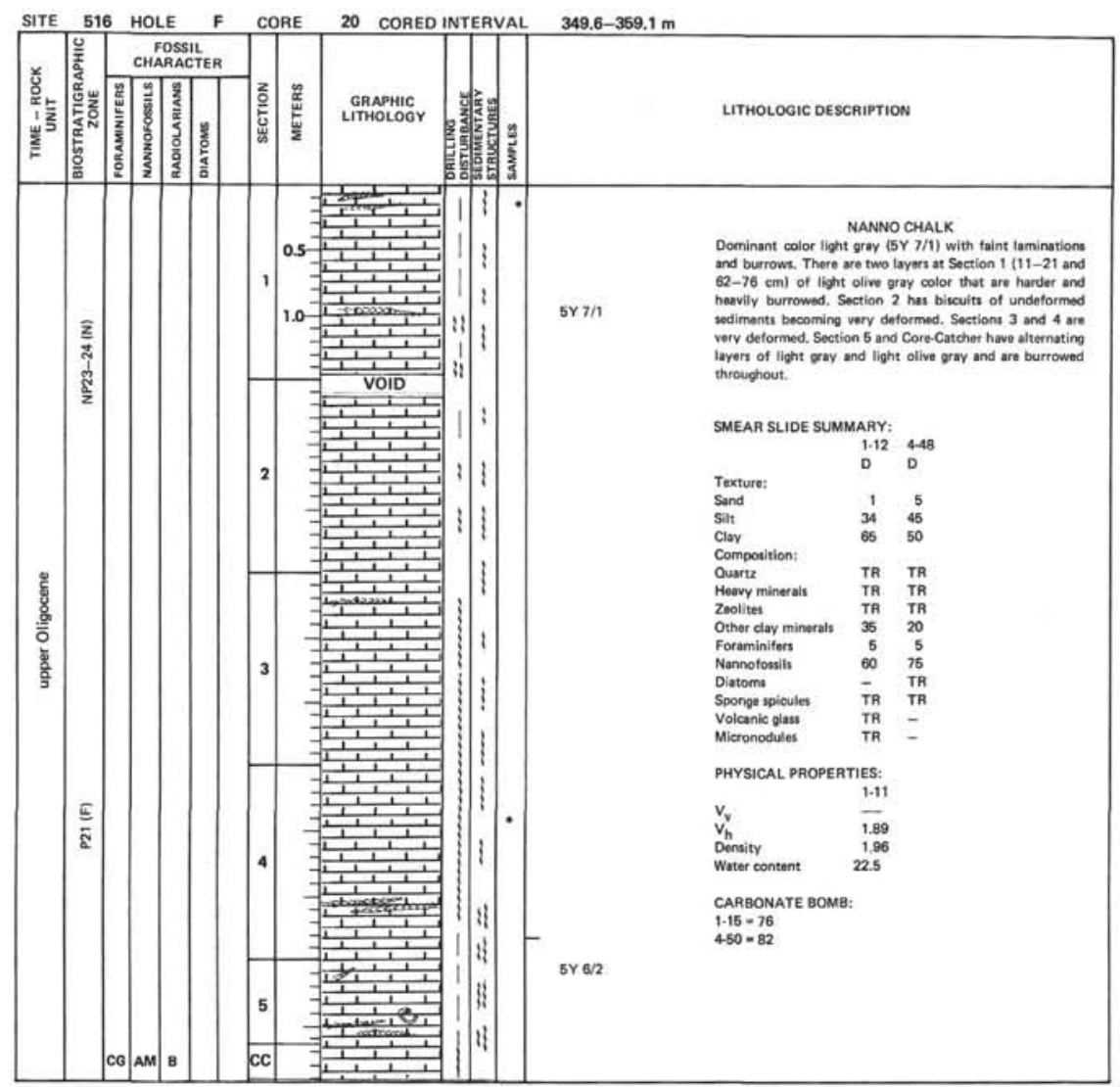




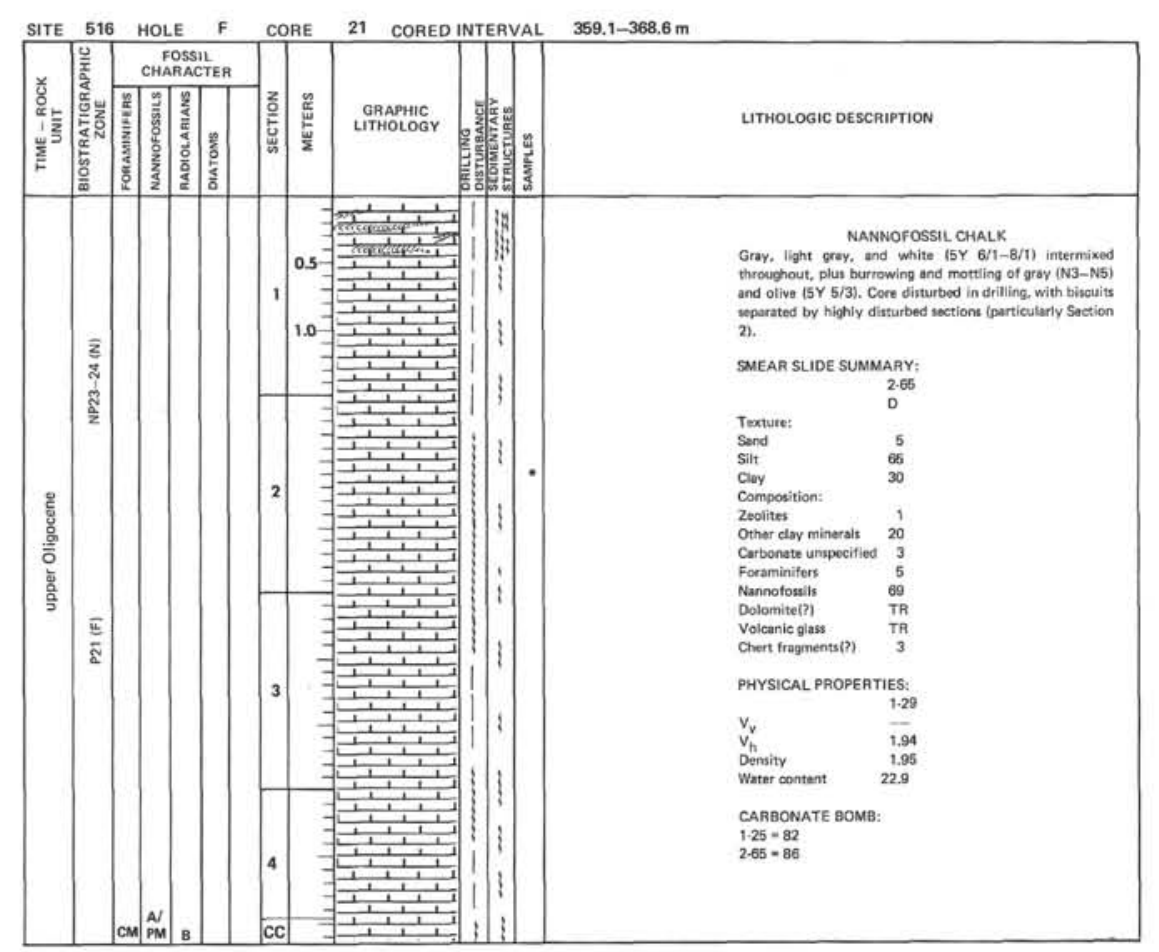

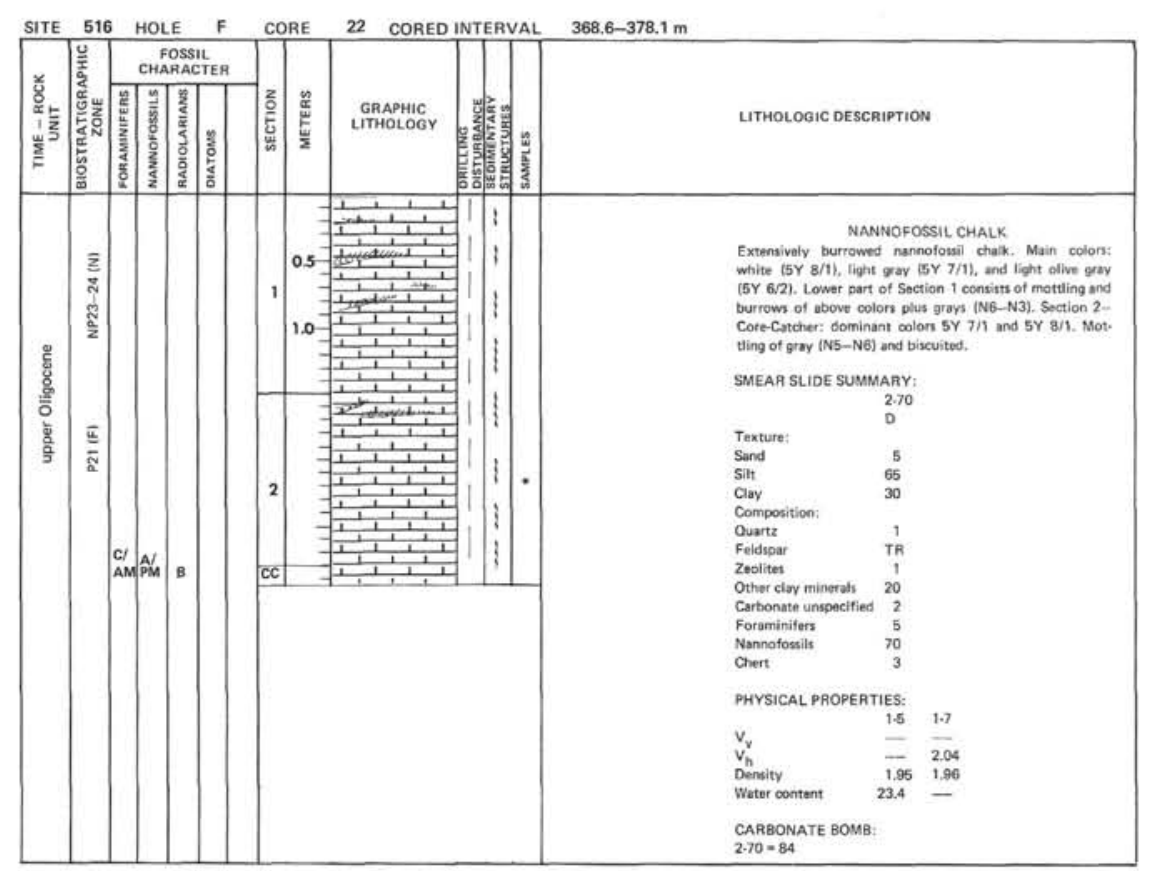




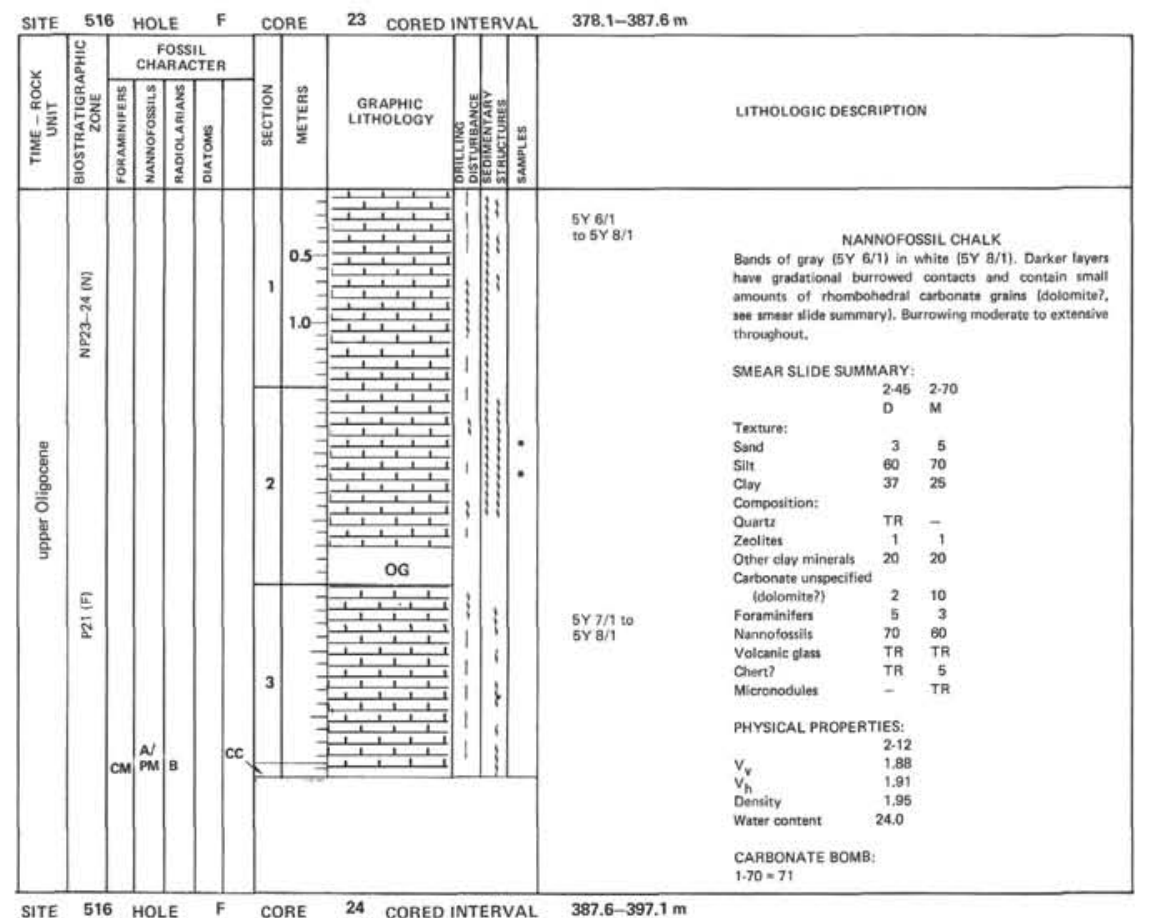

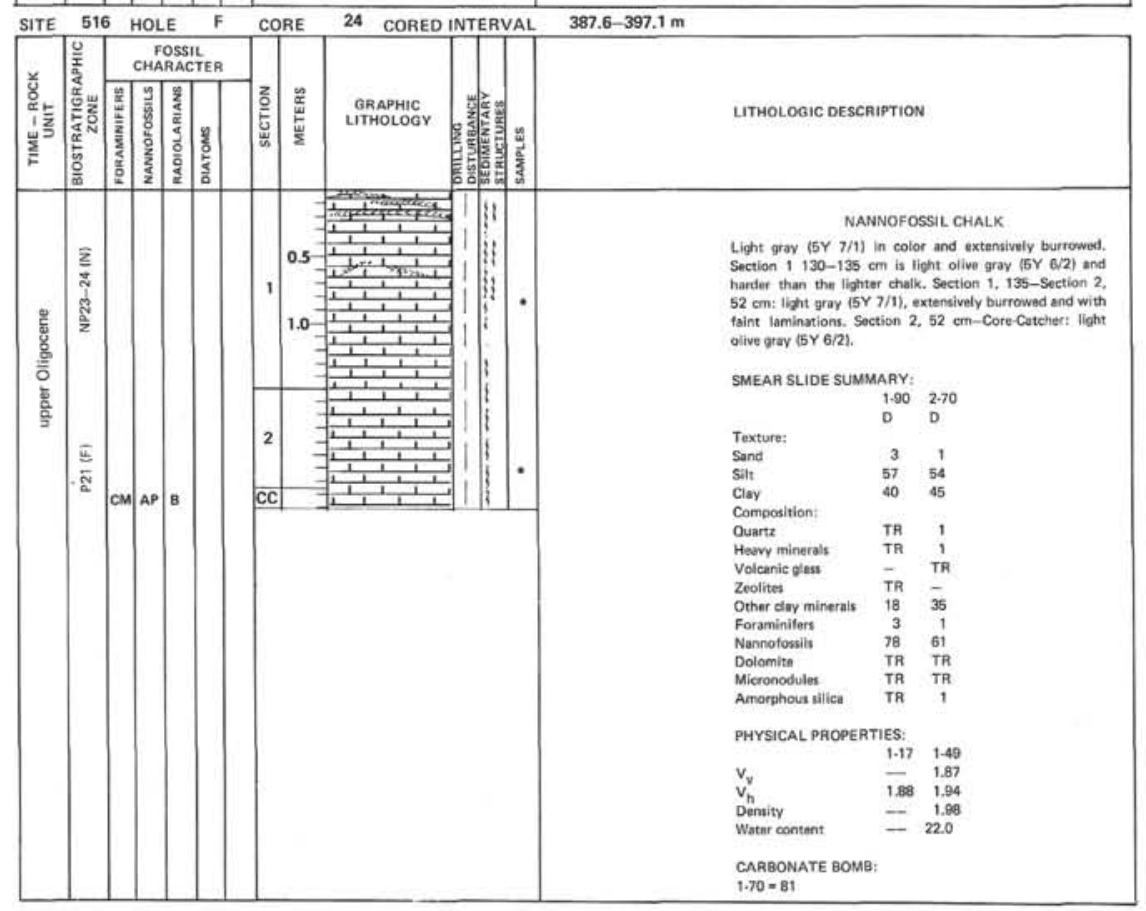

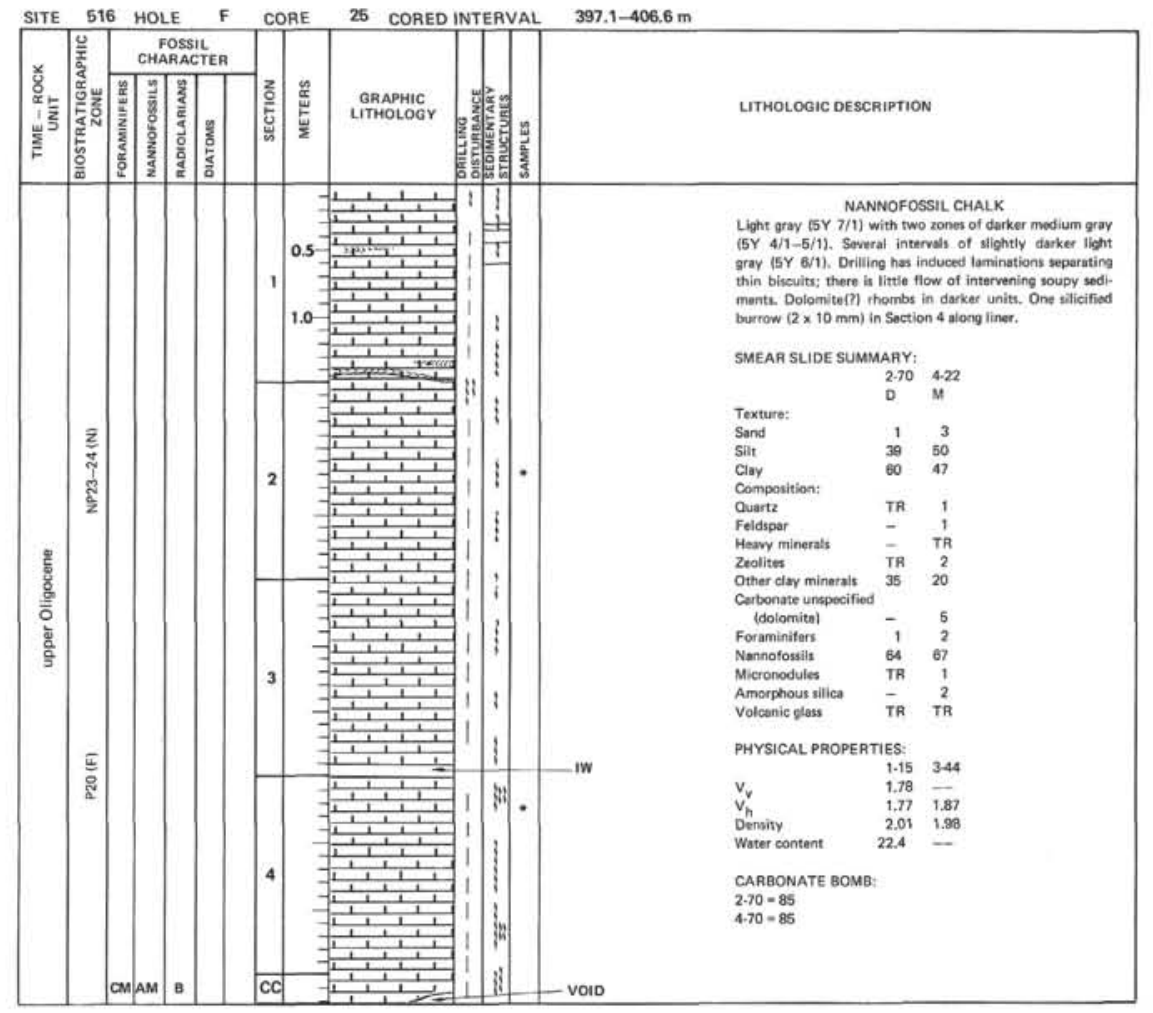




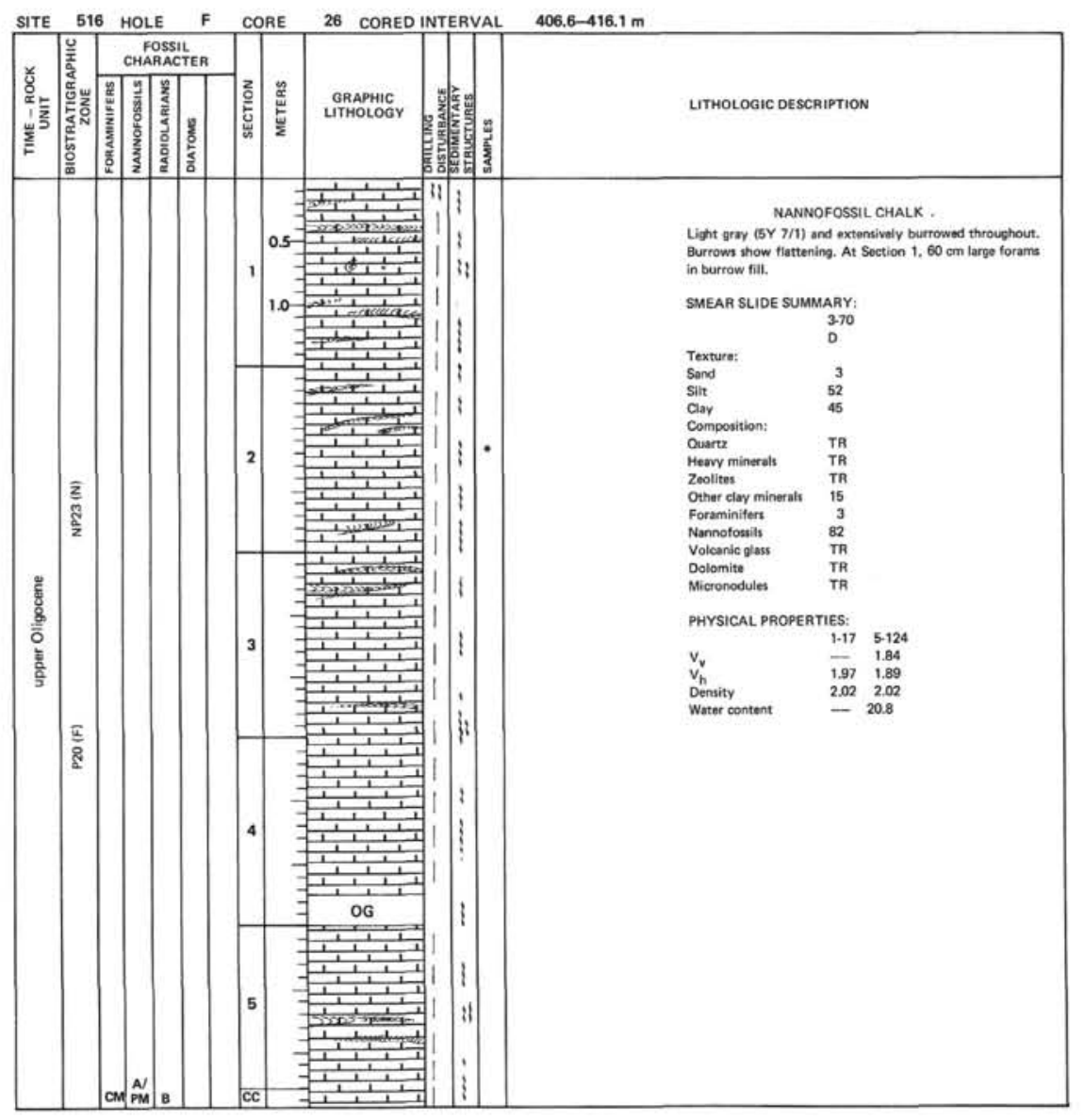

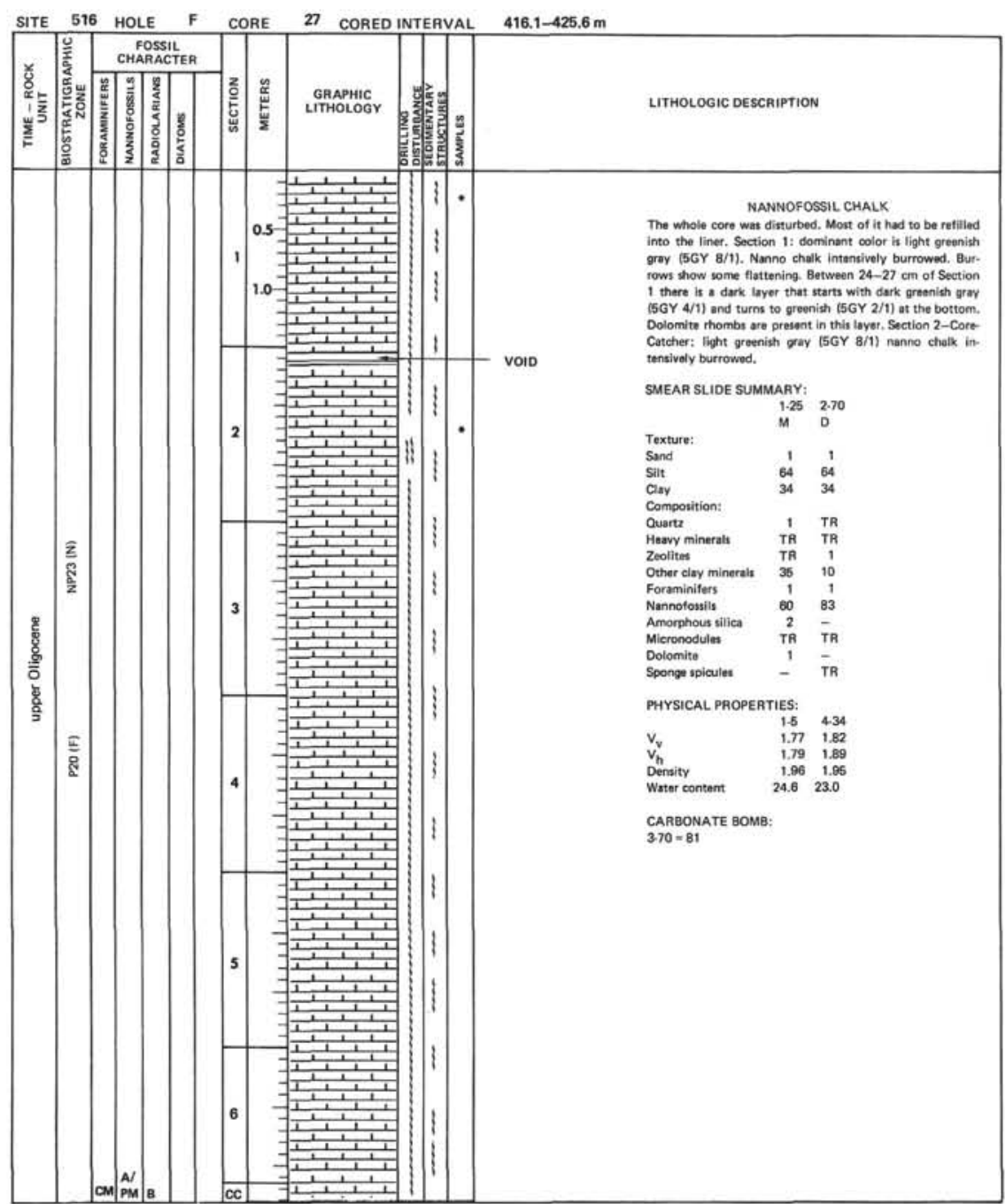



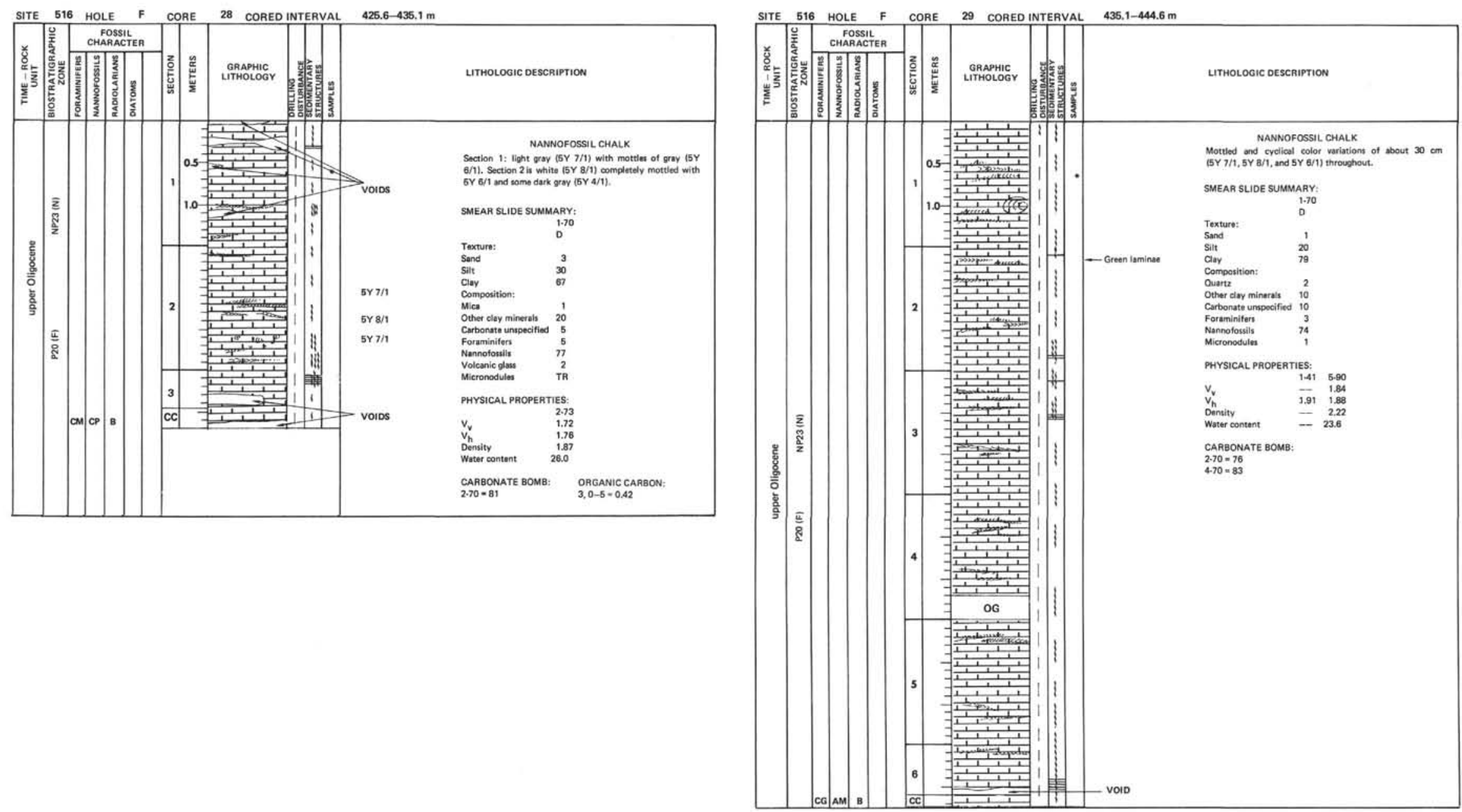

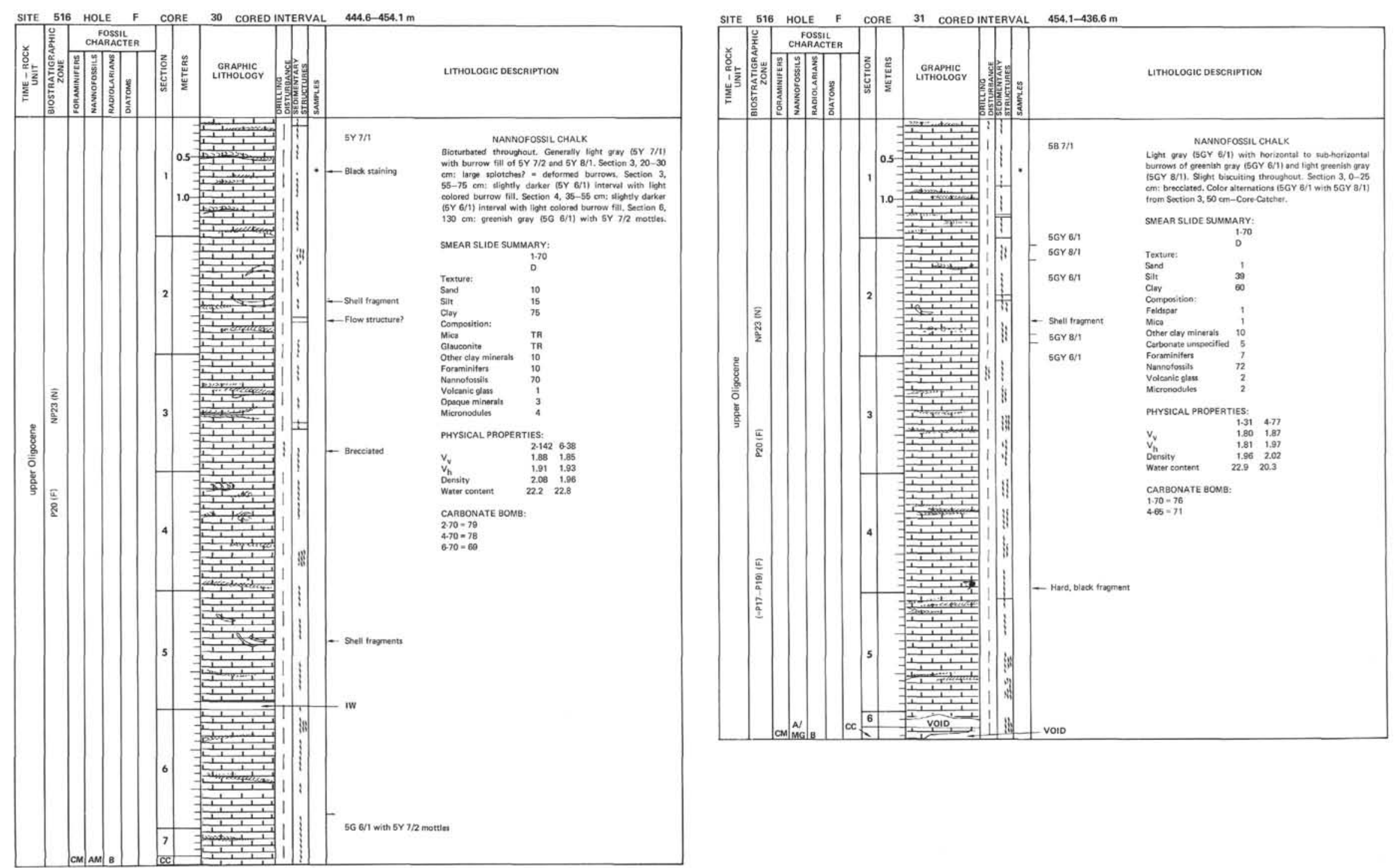

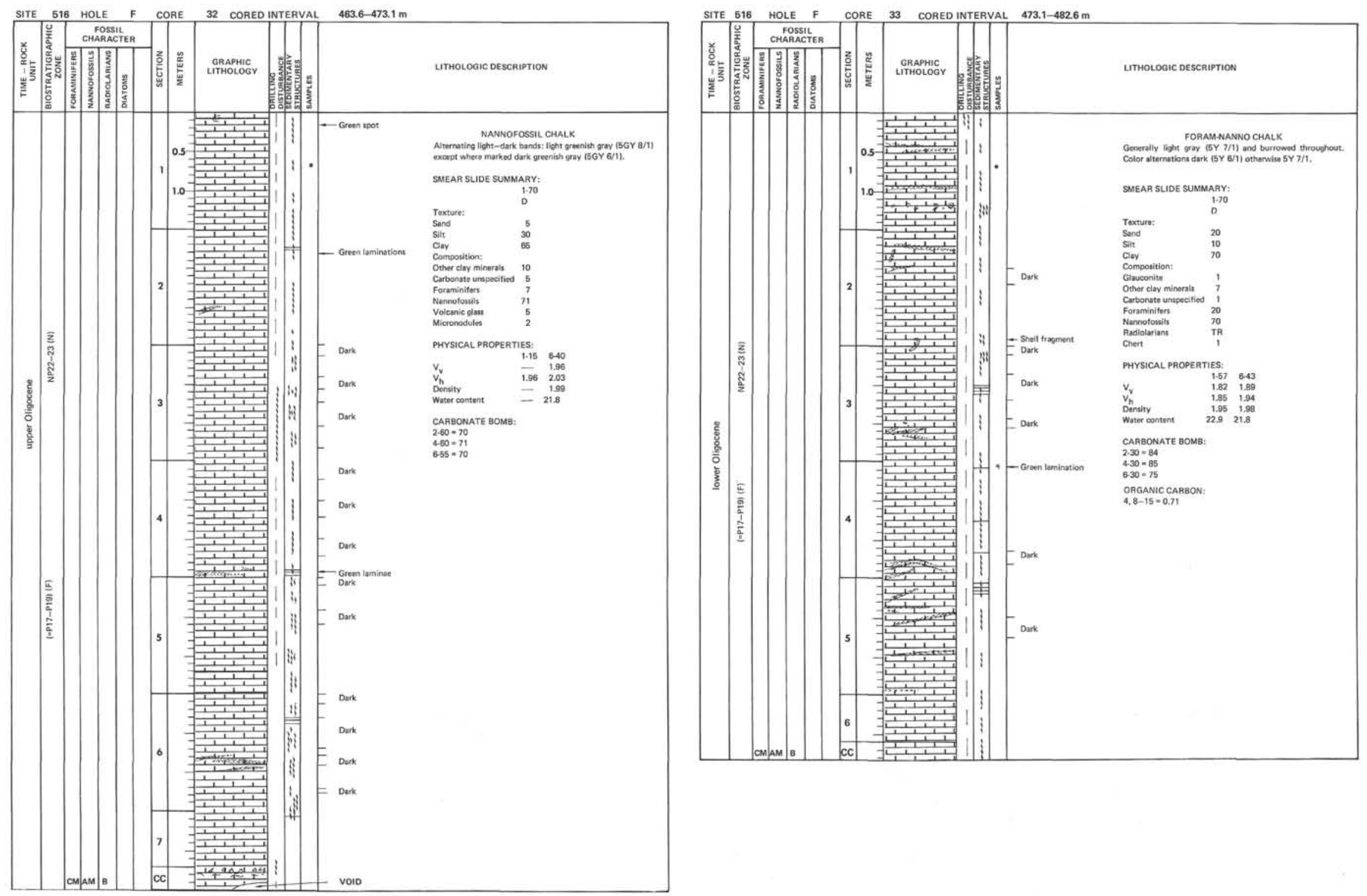

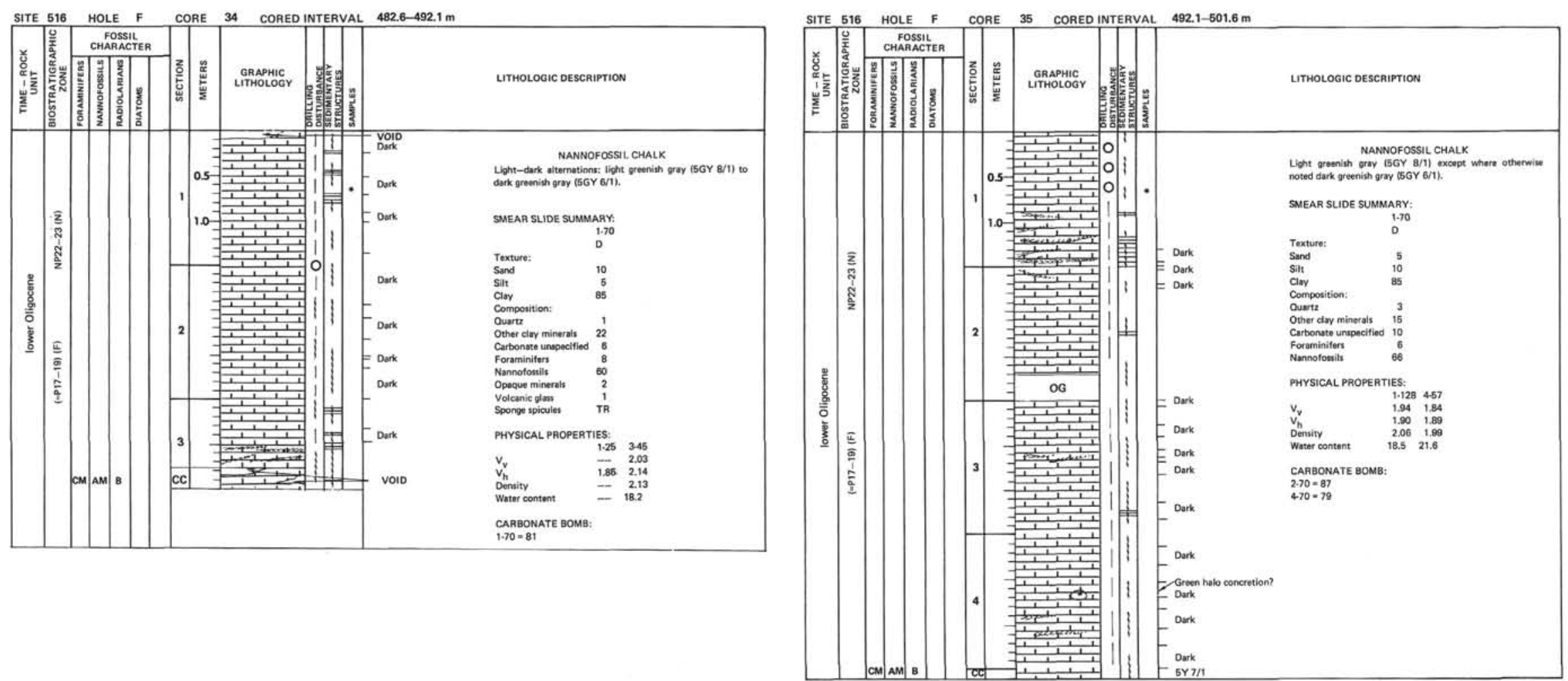

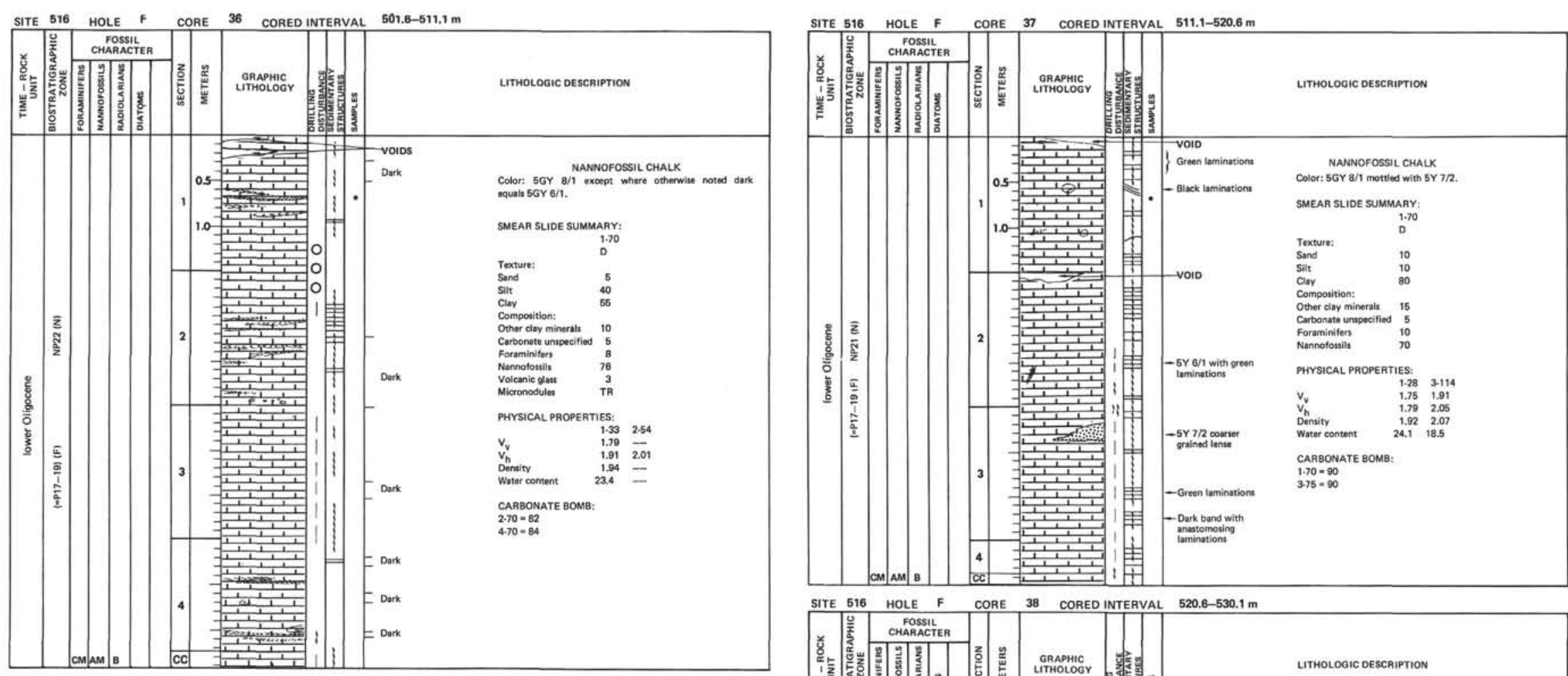

SITE 516 HOLE $F$ CORE 38 CORED INTERVAL $520.6-530.1 \mathrm{~m}$

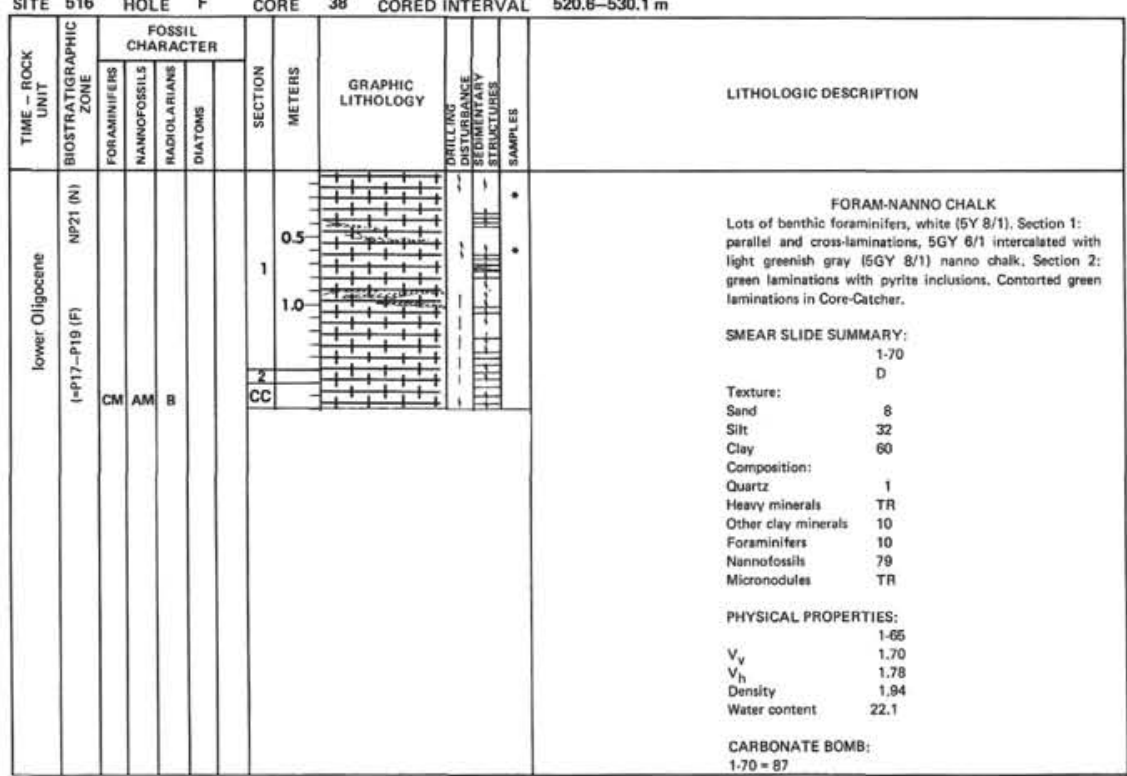



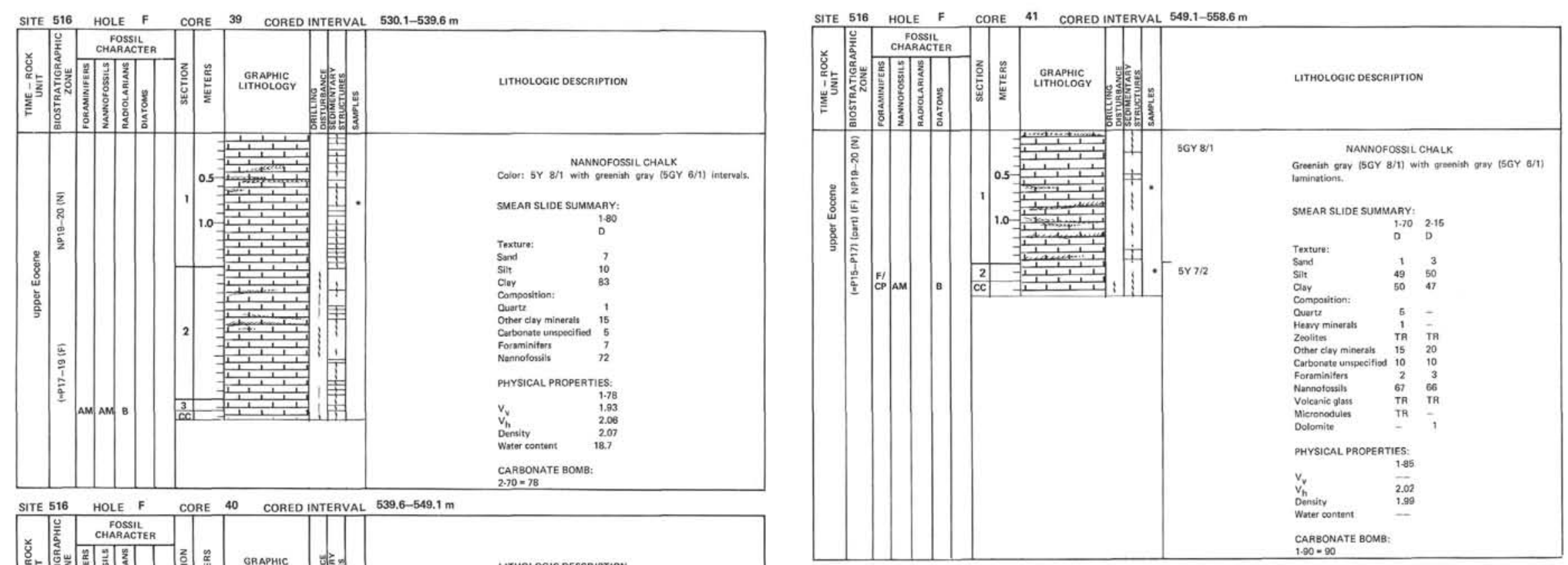

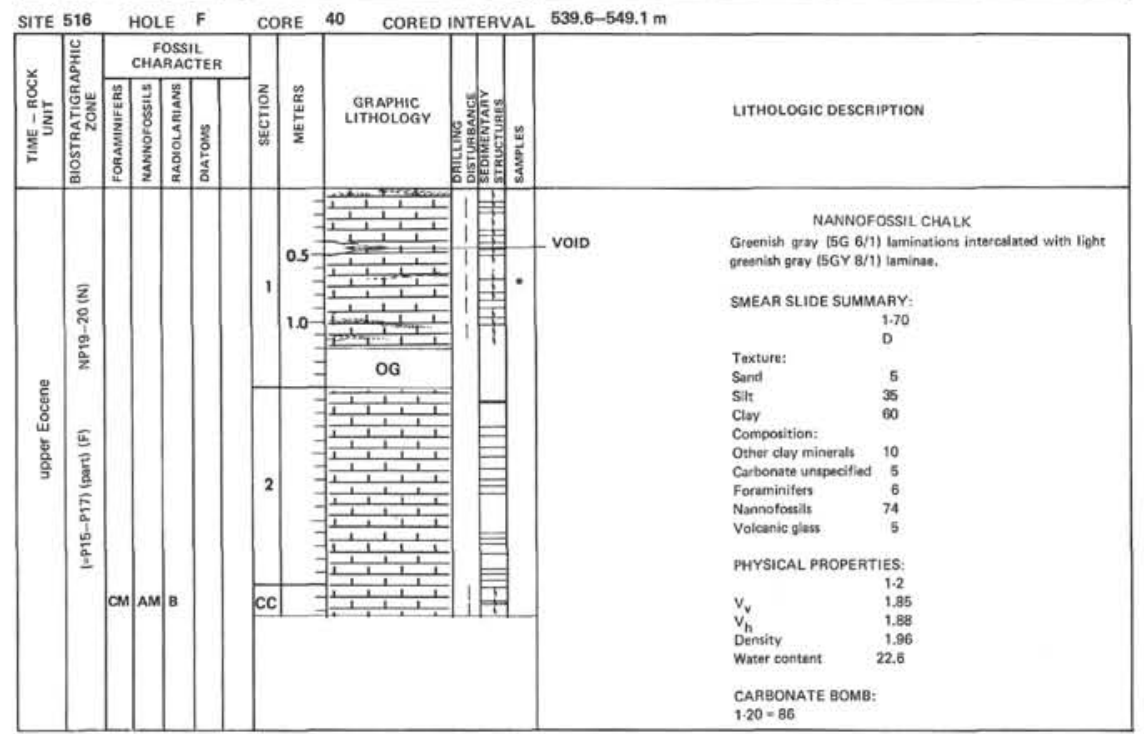

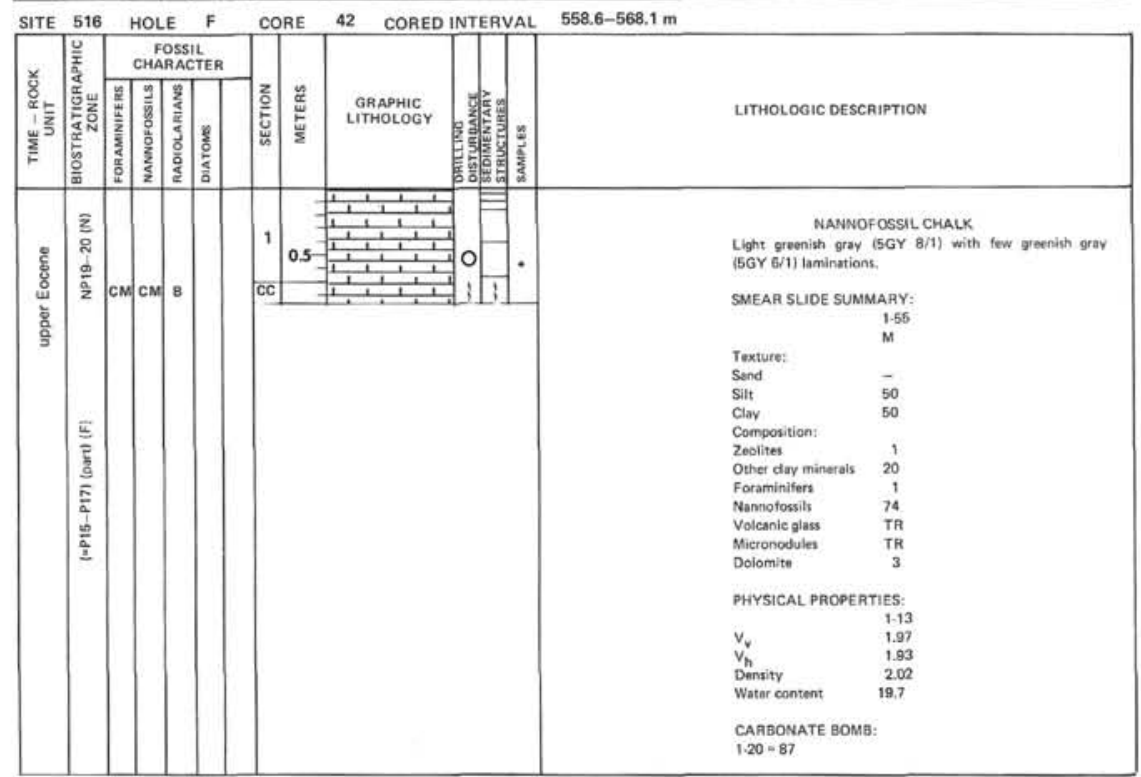




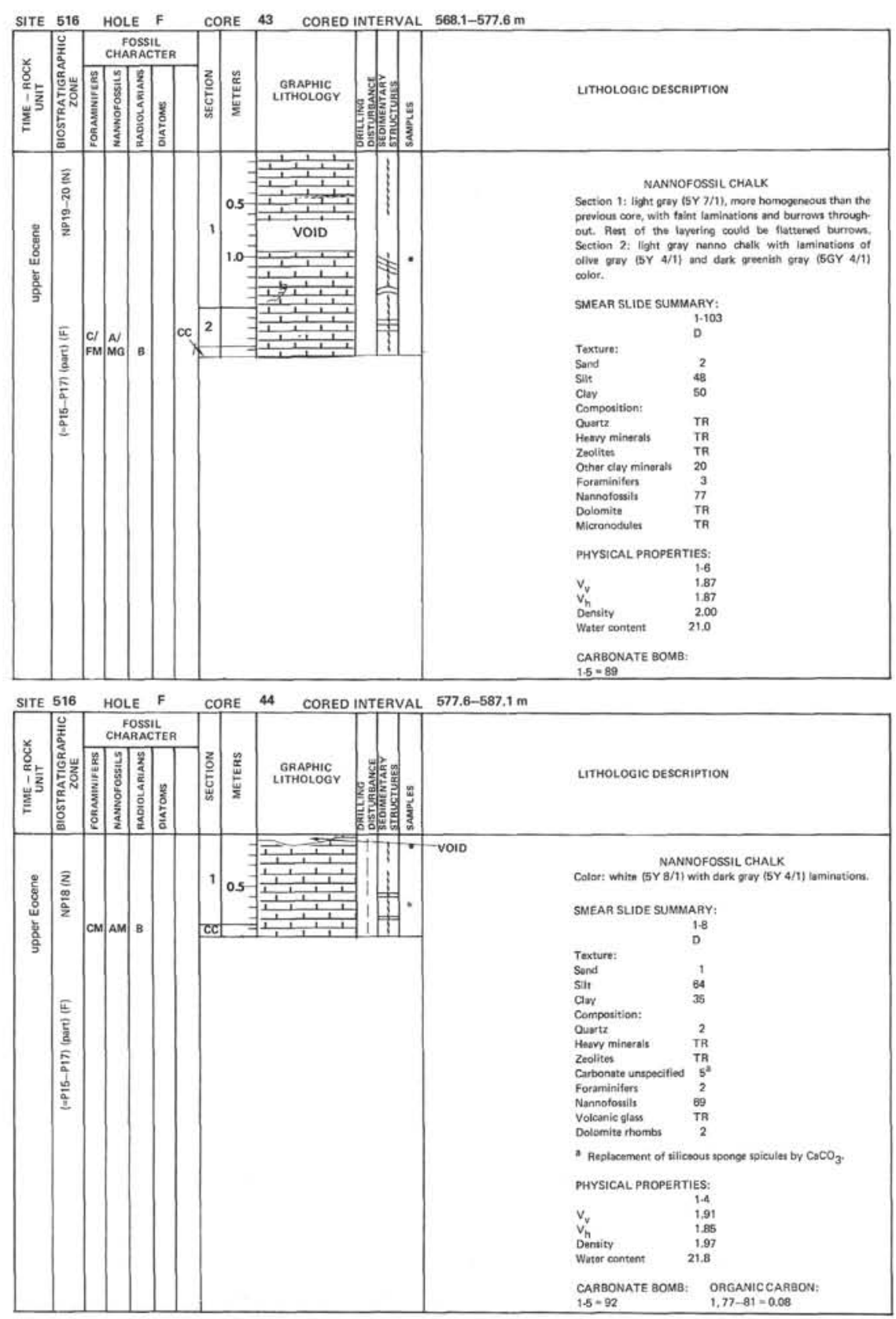

SITE 516 HOLE $F$ CORE 45 CORED INTERVAL $587.1-596.6 \mathrm{~m}$

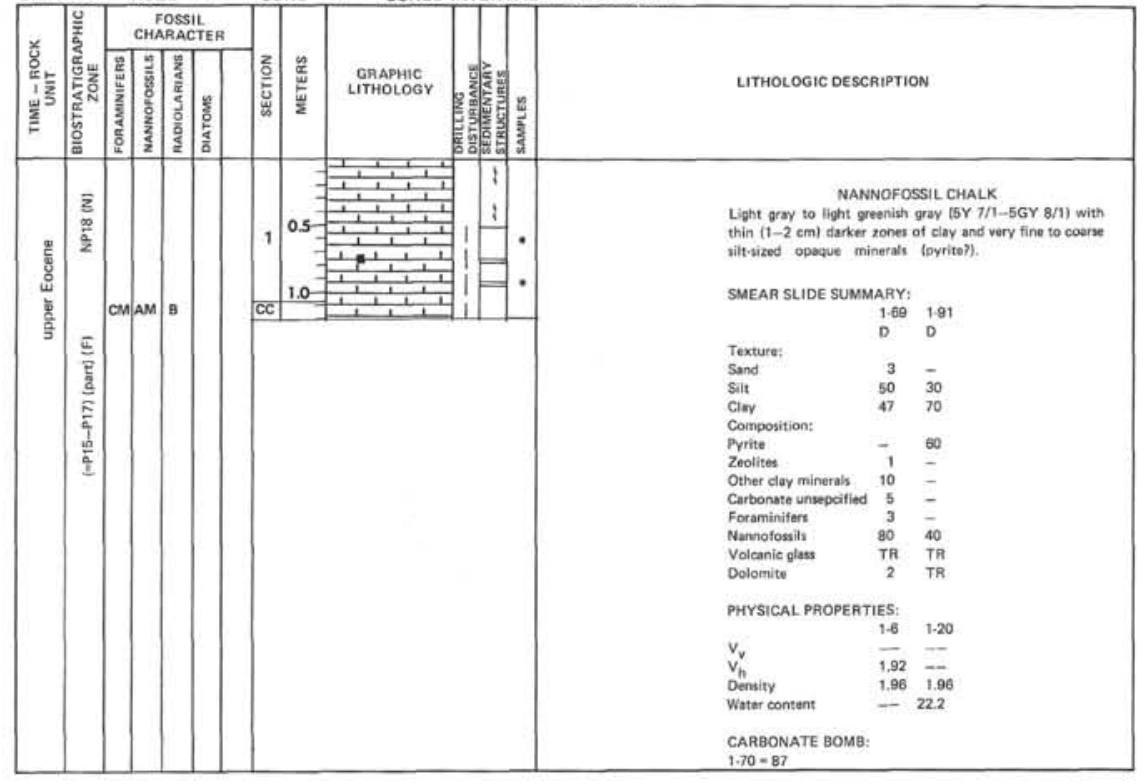

SITE 516 HOLE $F$ CORE 46 CORED INTERVAL $596.6-606.1 \mathrm{~m}$

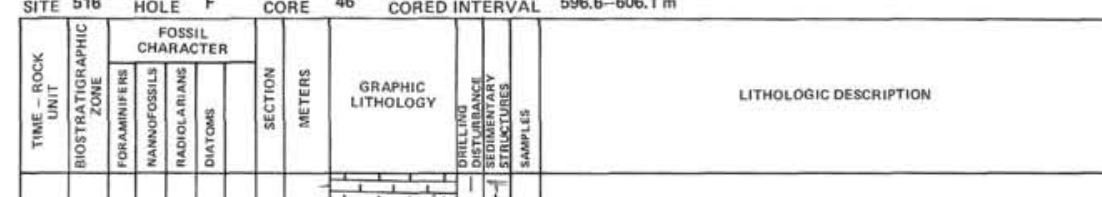

\section{NANNOFossL CHALK}
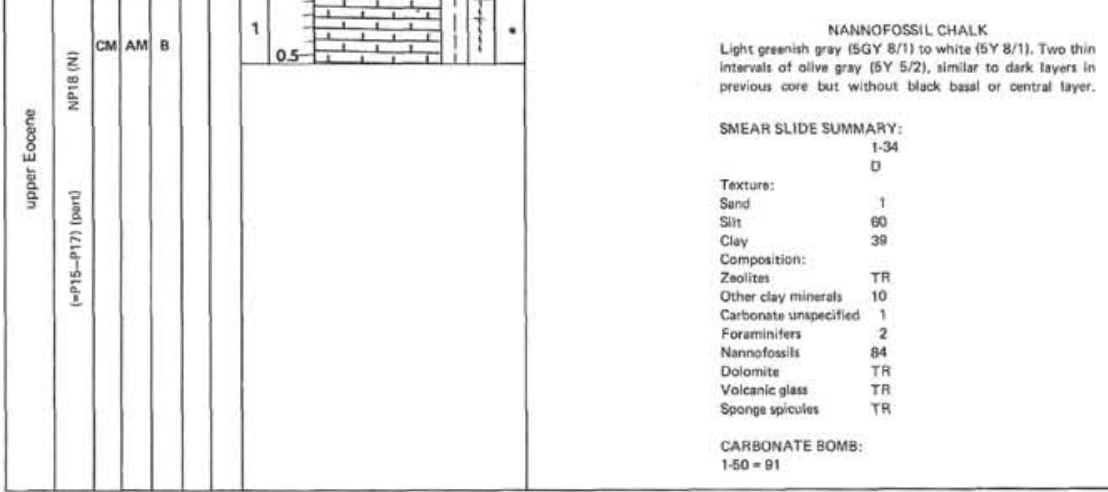

SMEAR SLIDE SUMMARY:

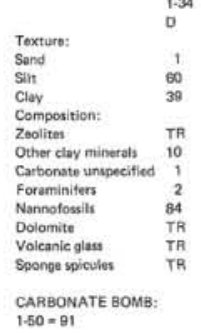



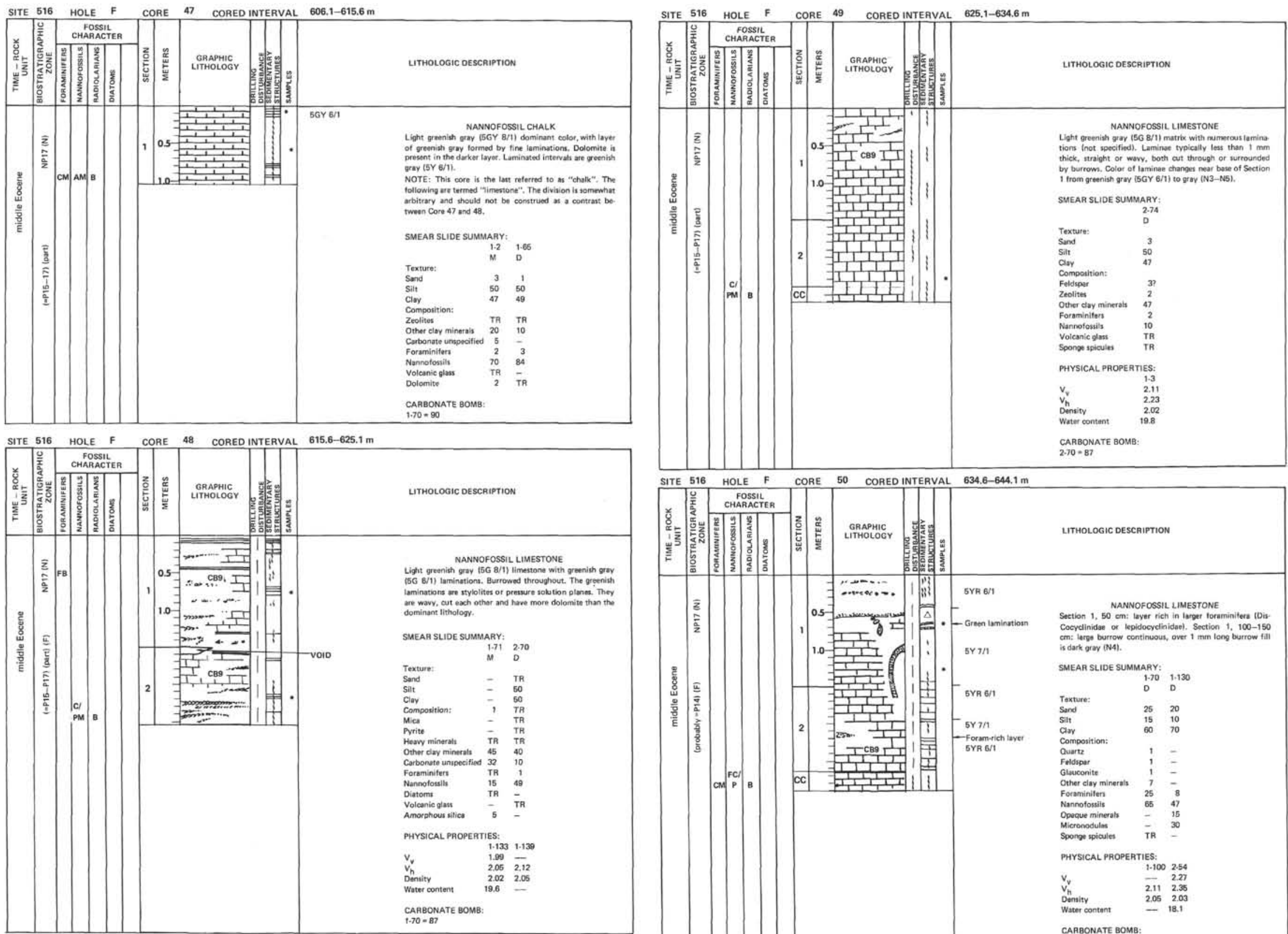

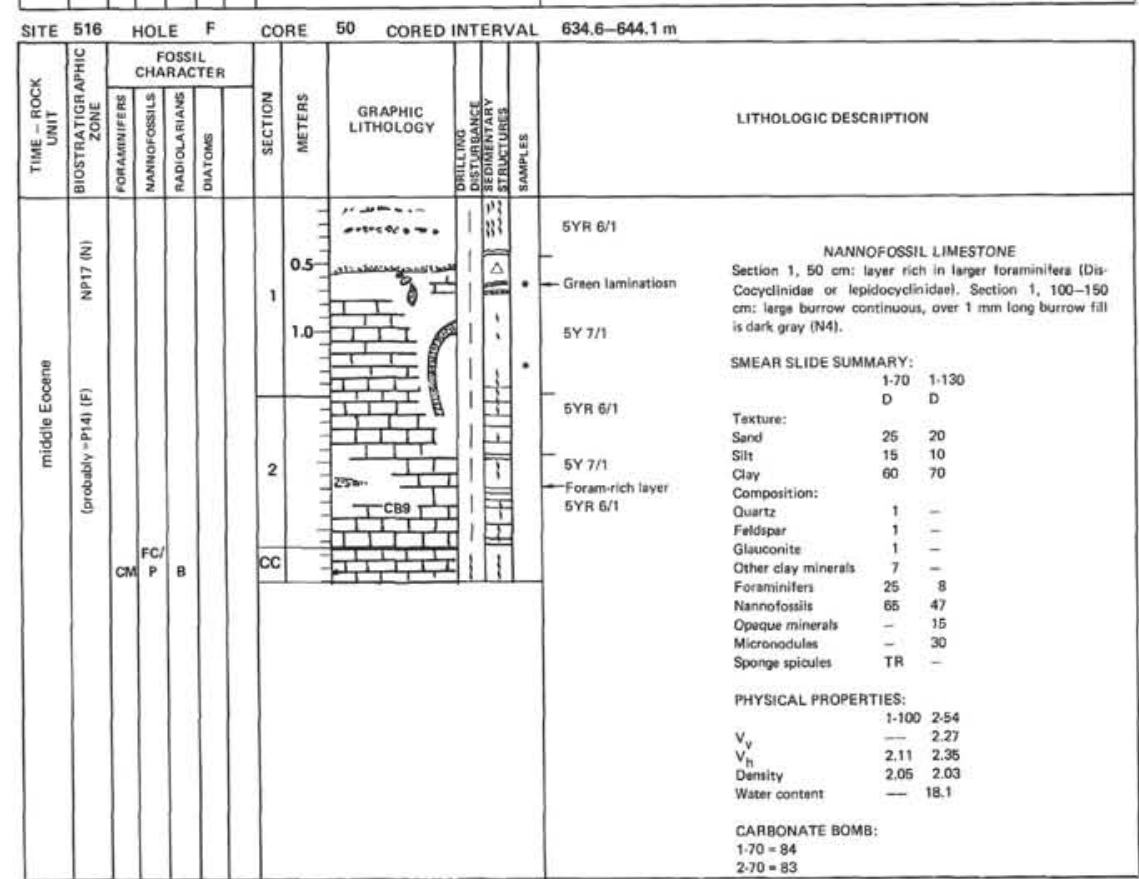




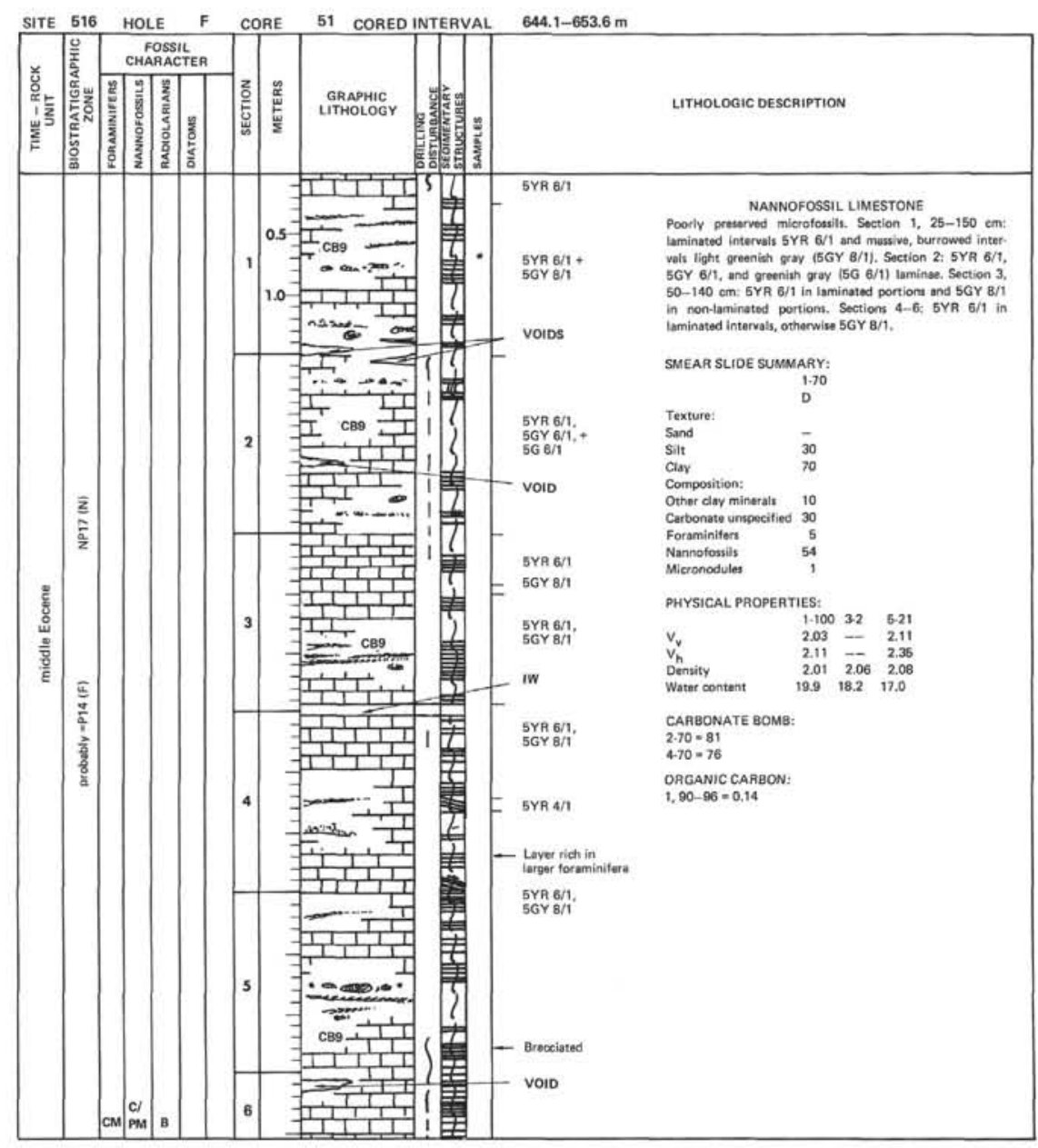

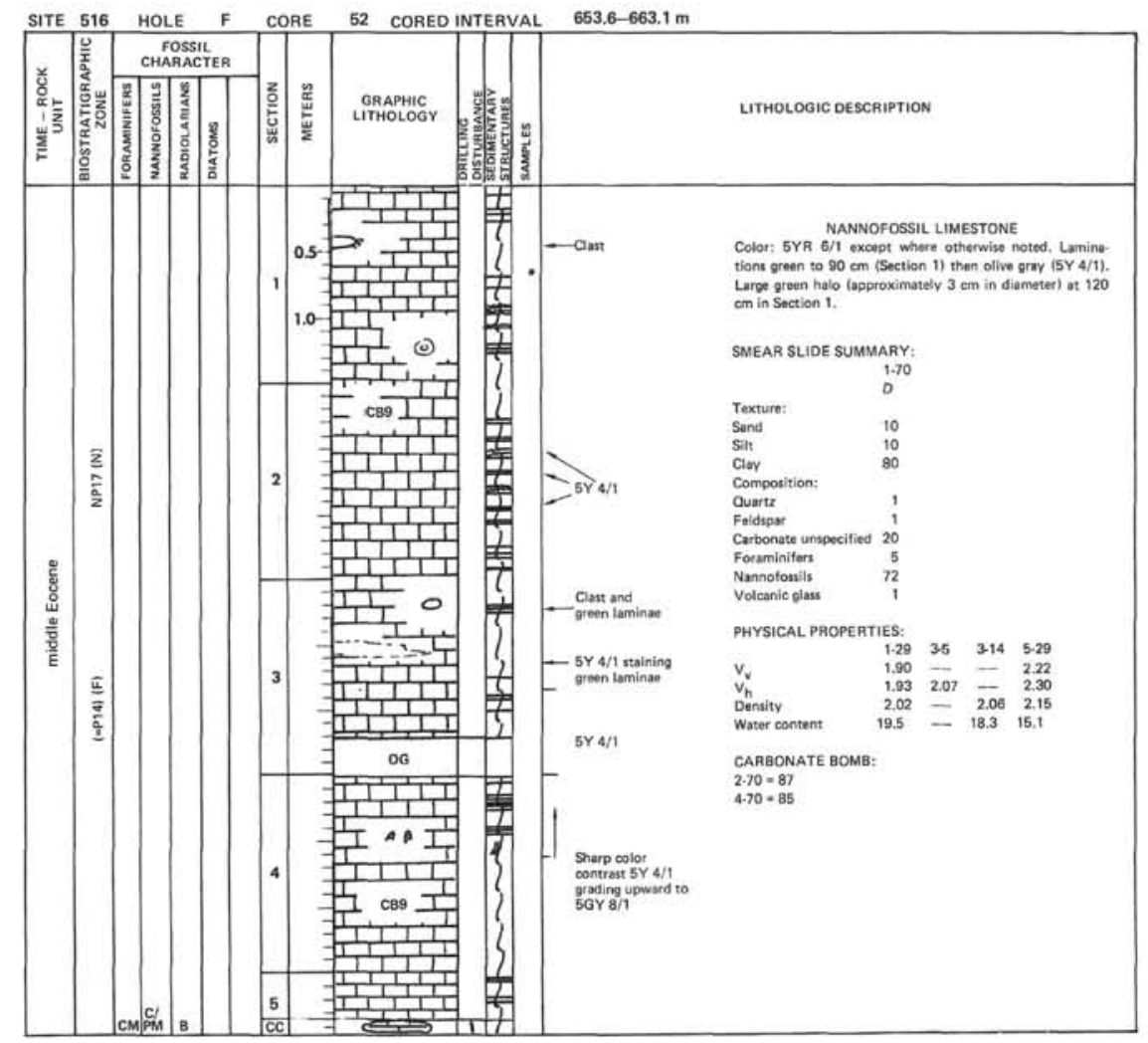




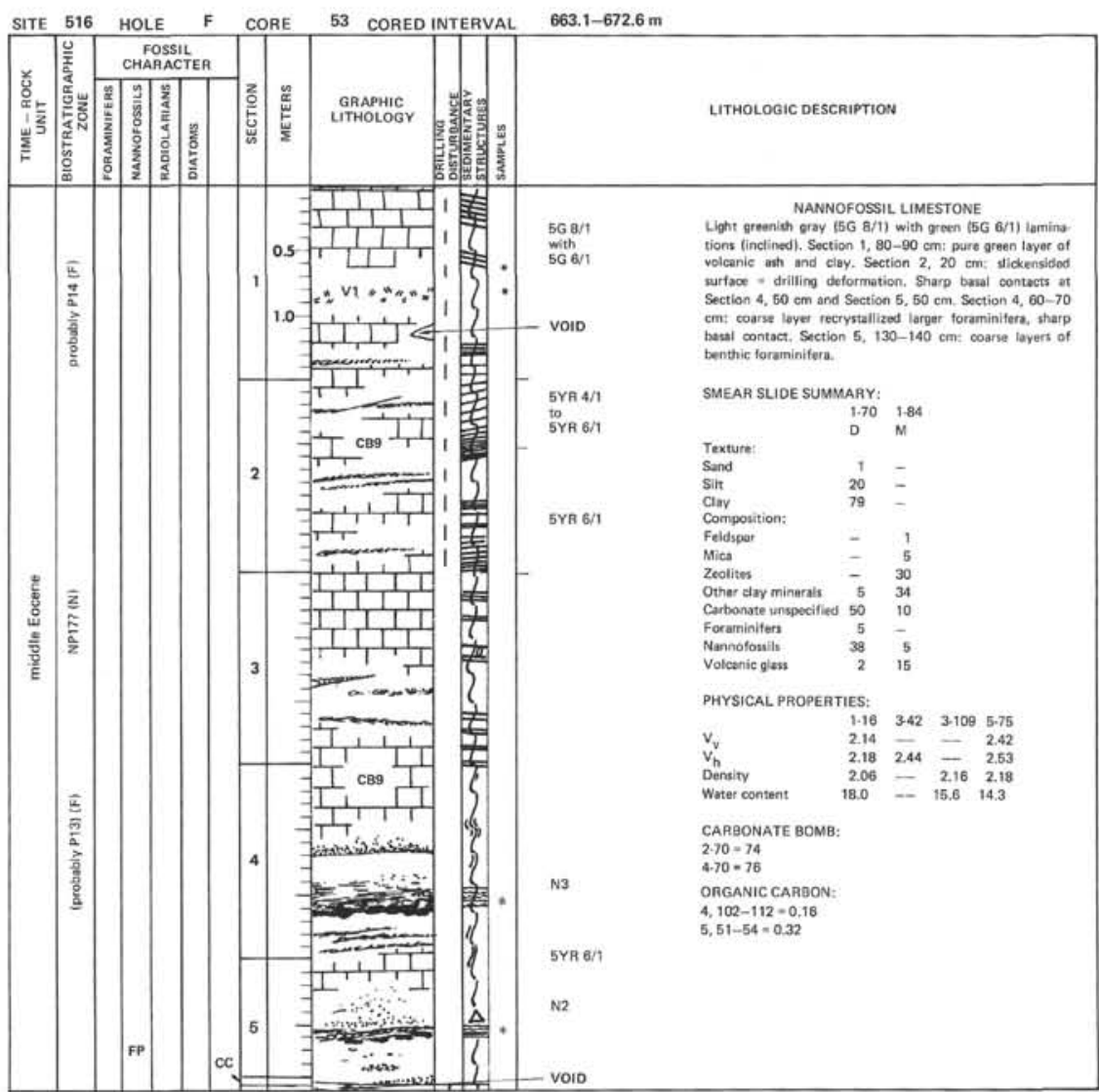

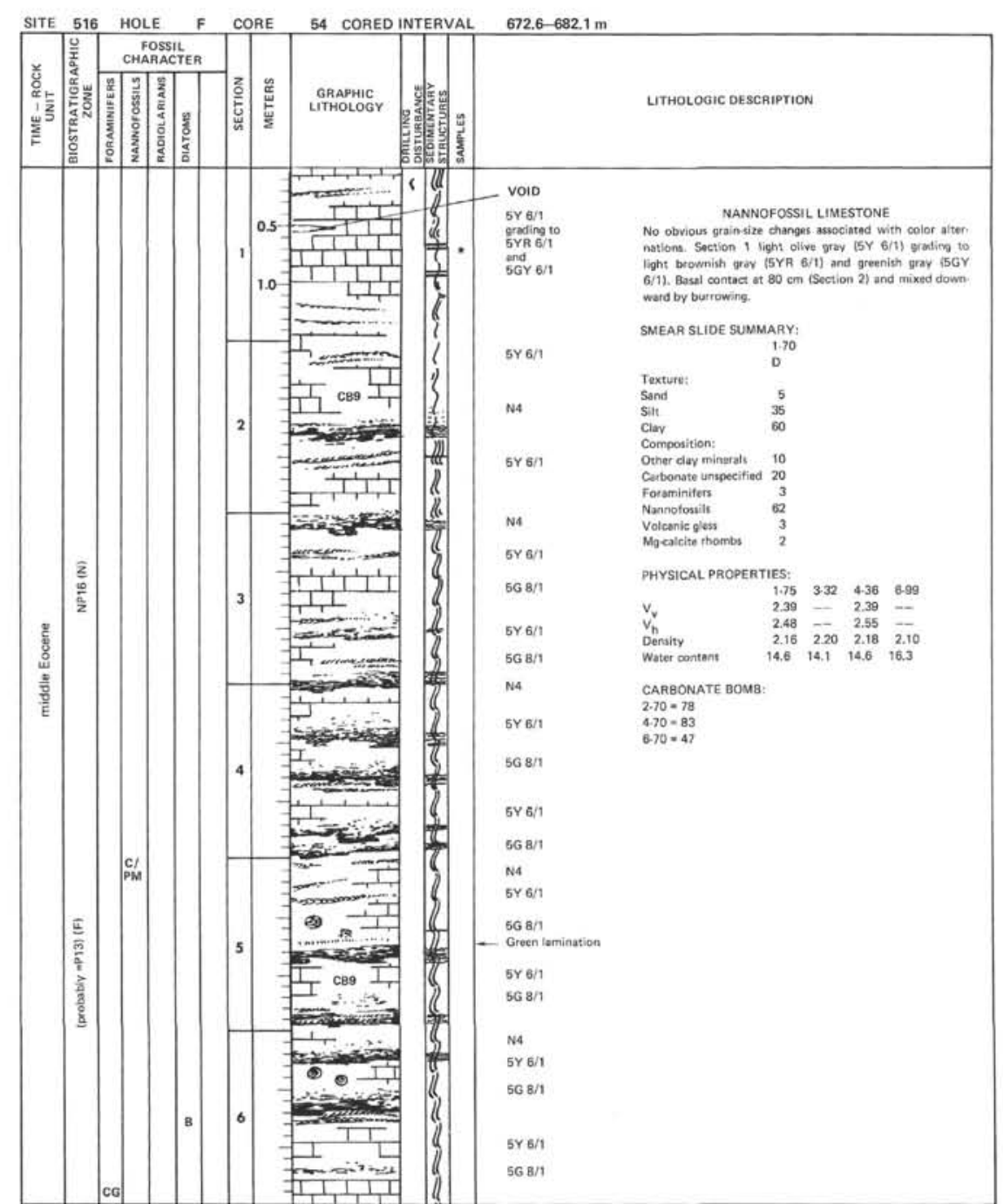




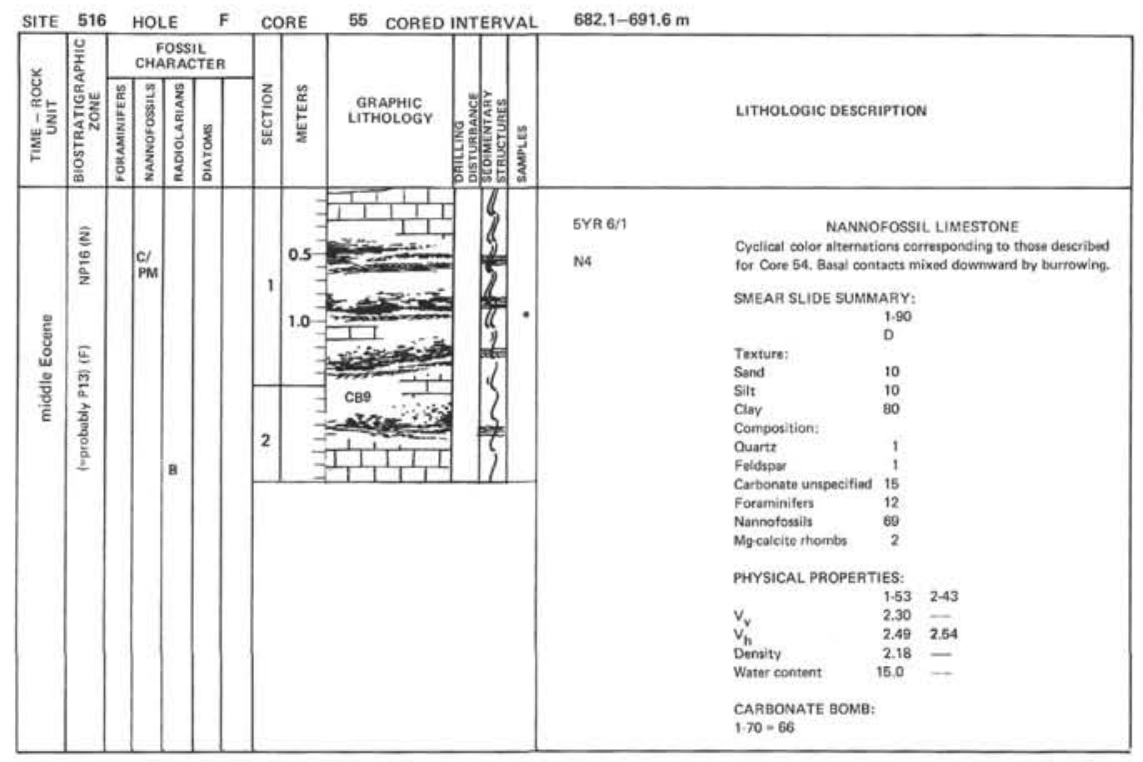

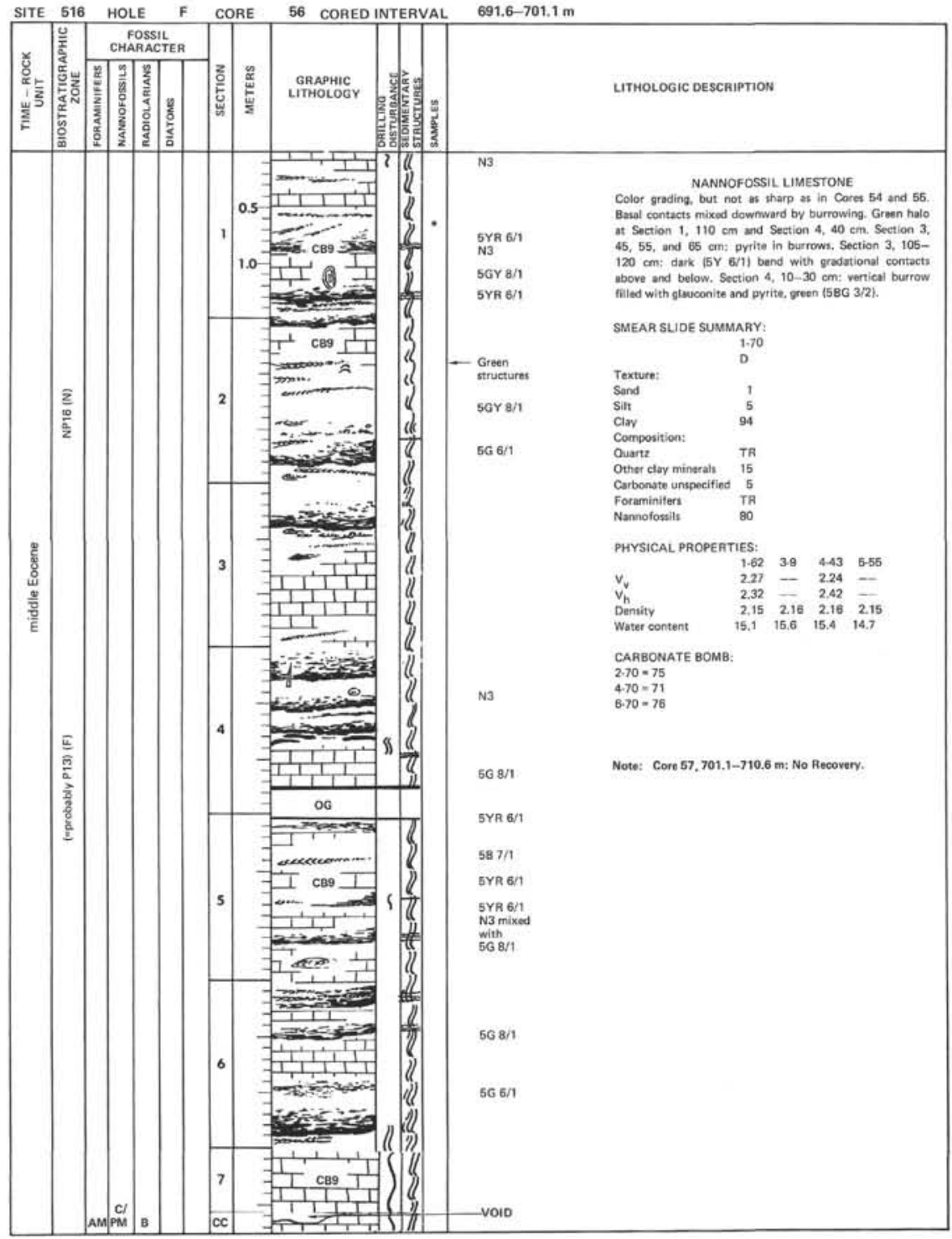




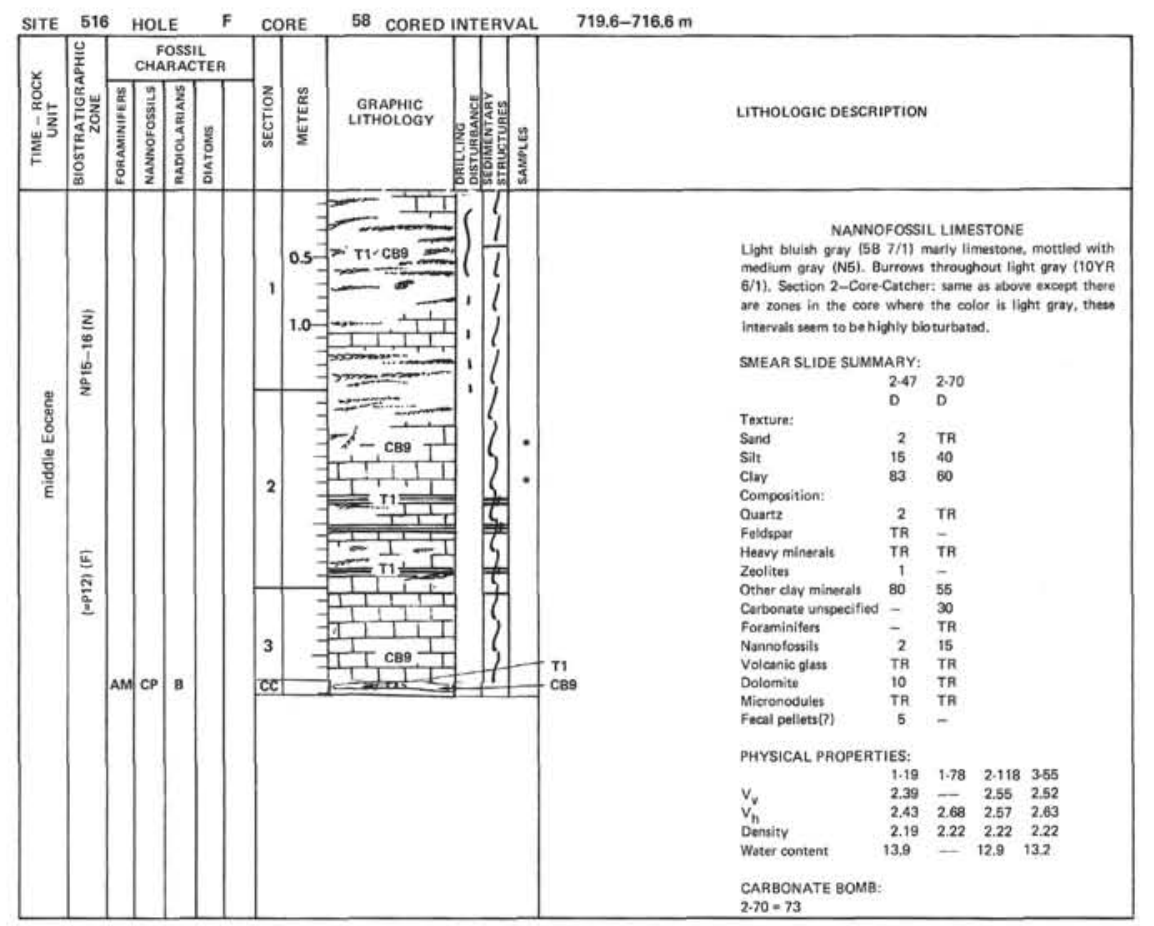

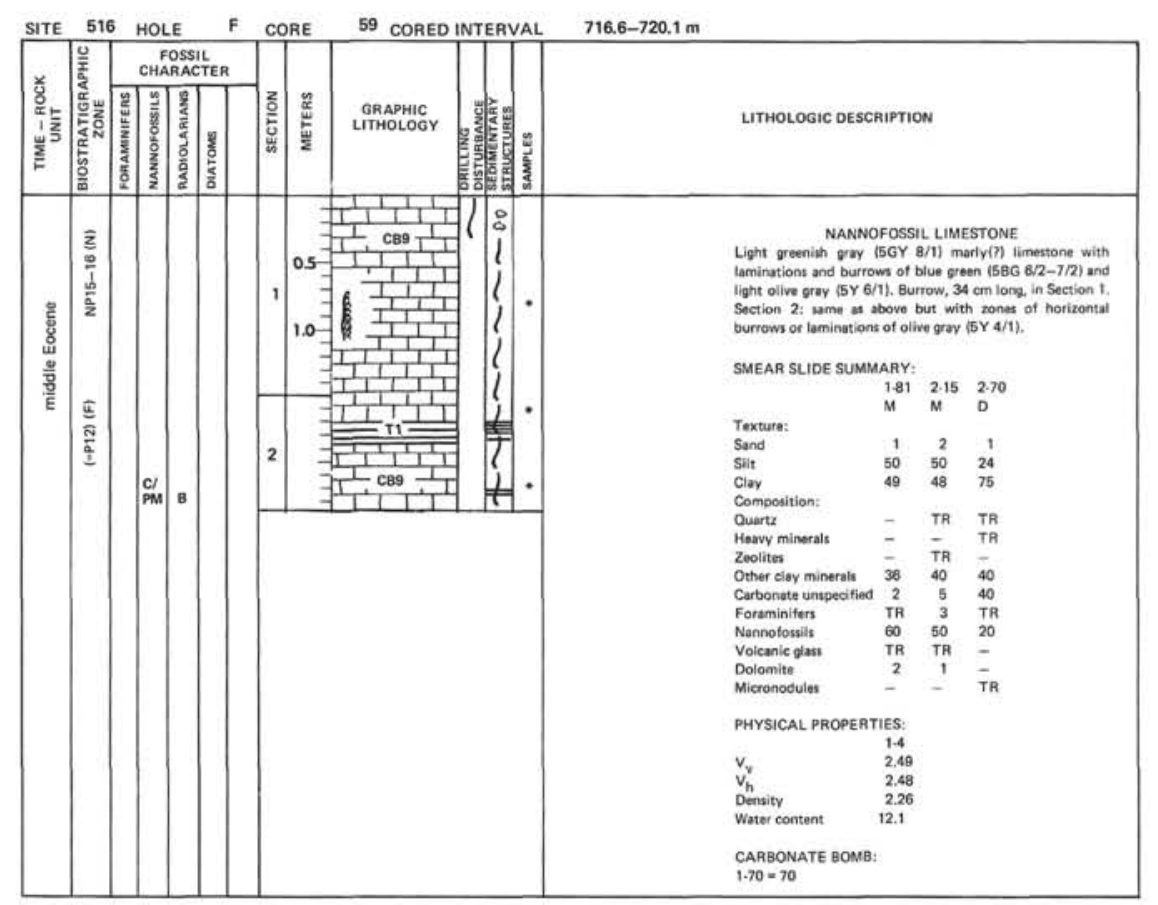




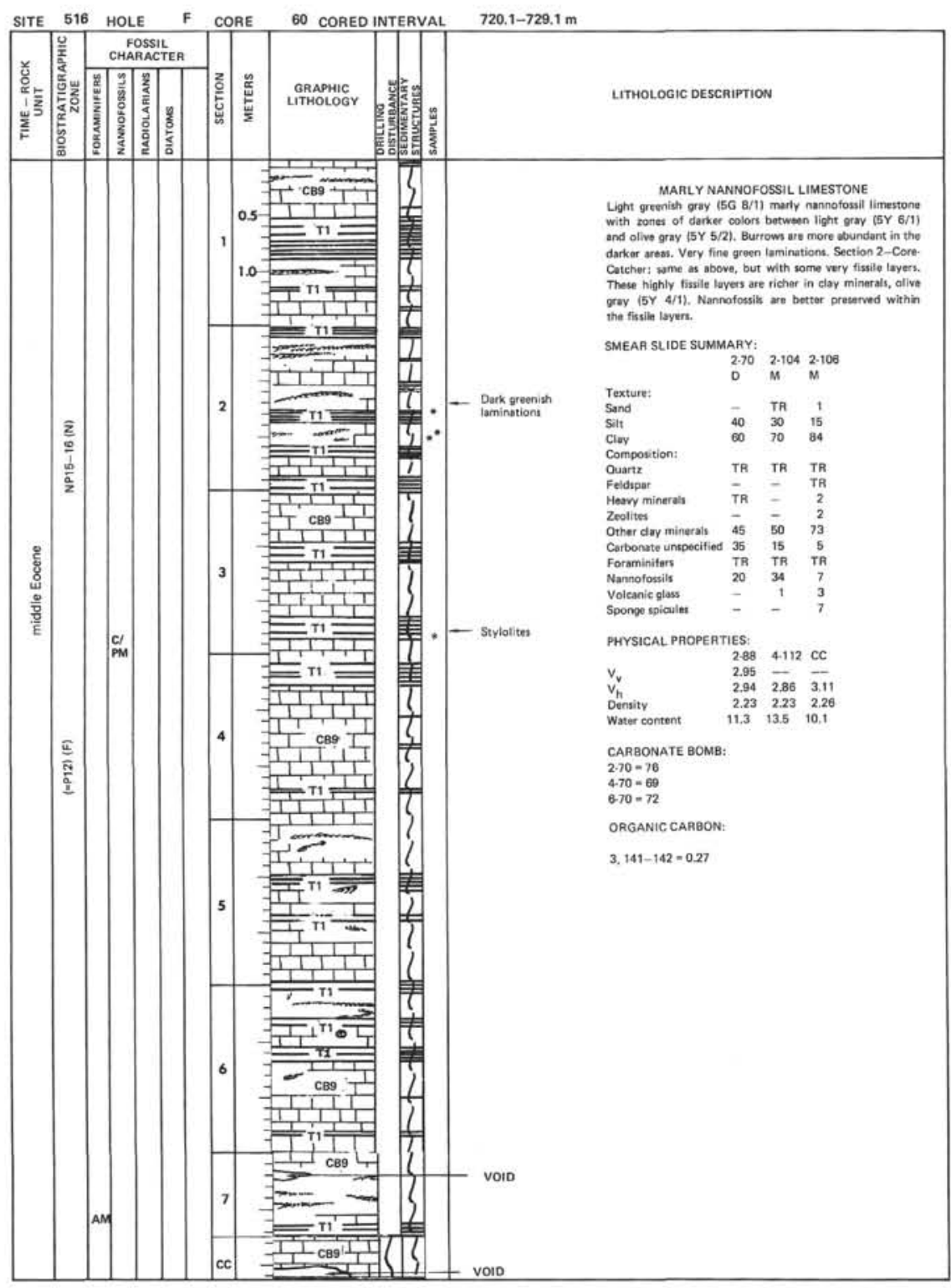

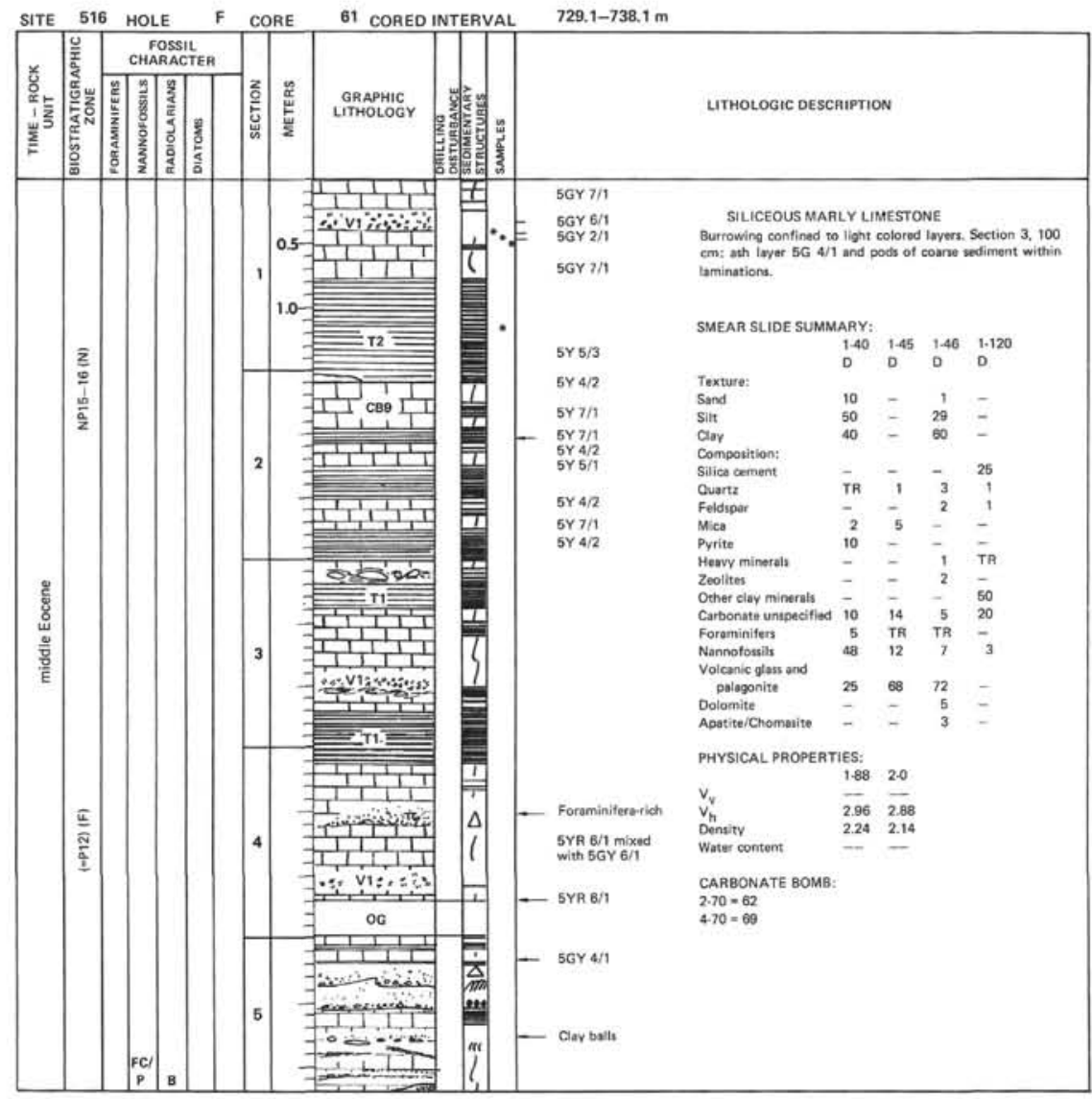




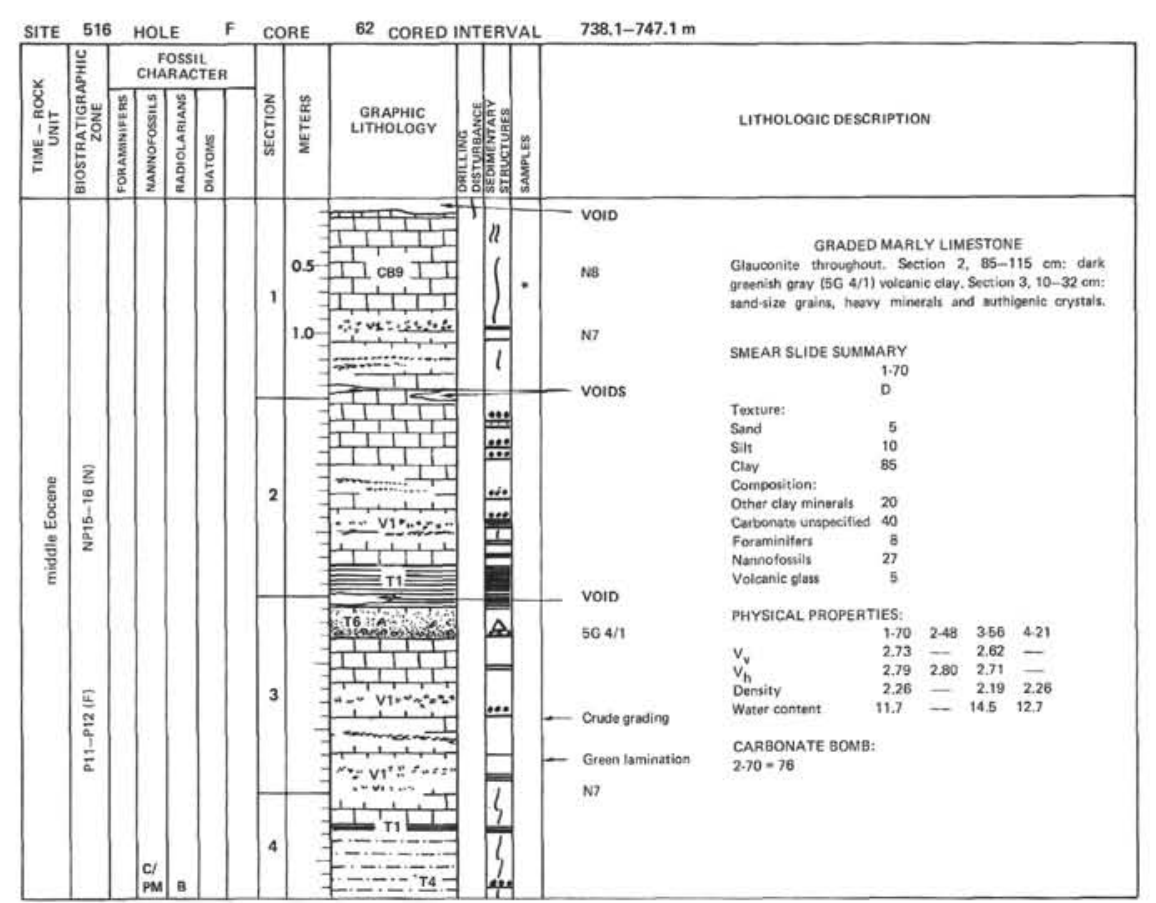

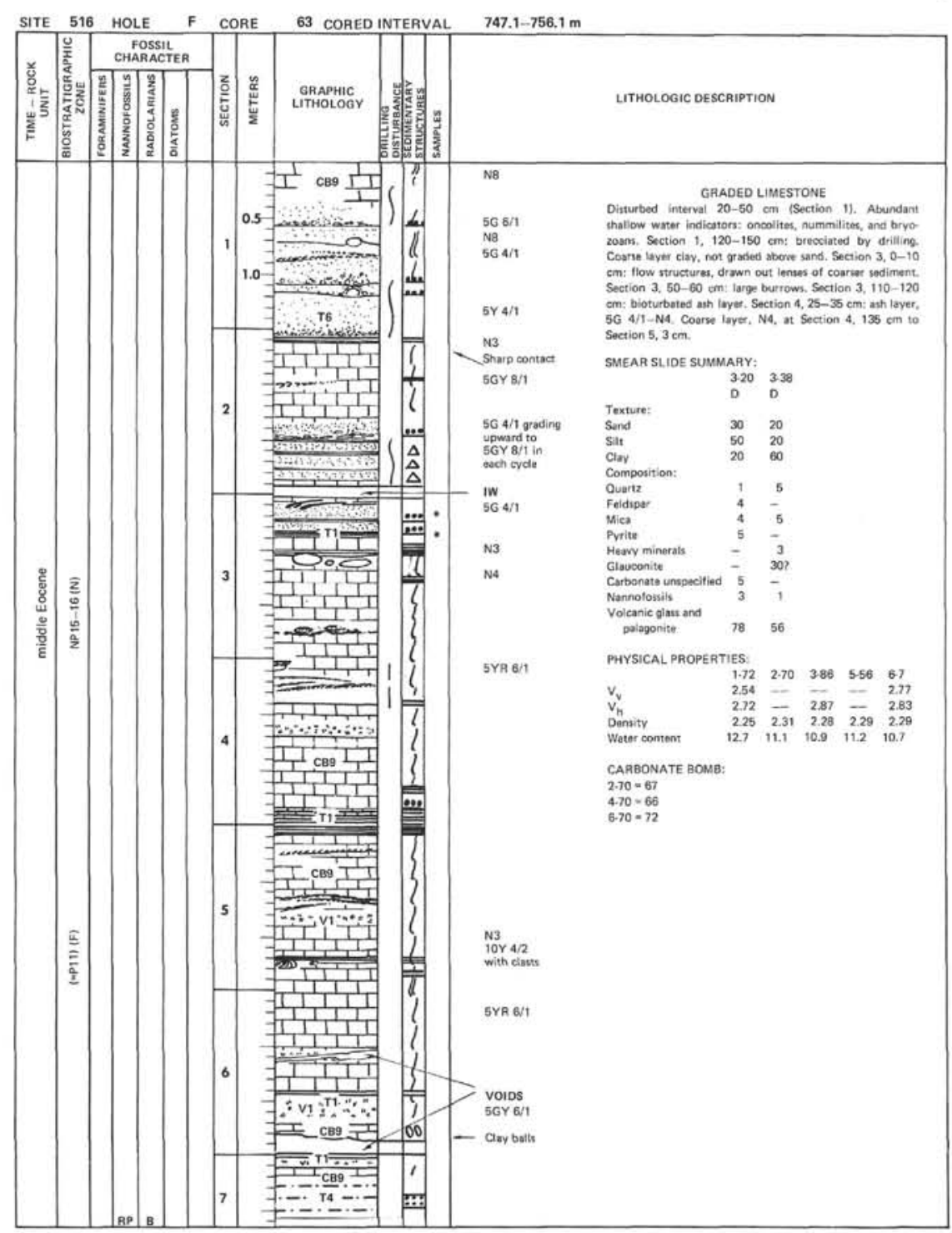




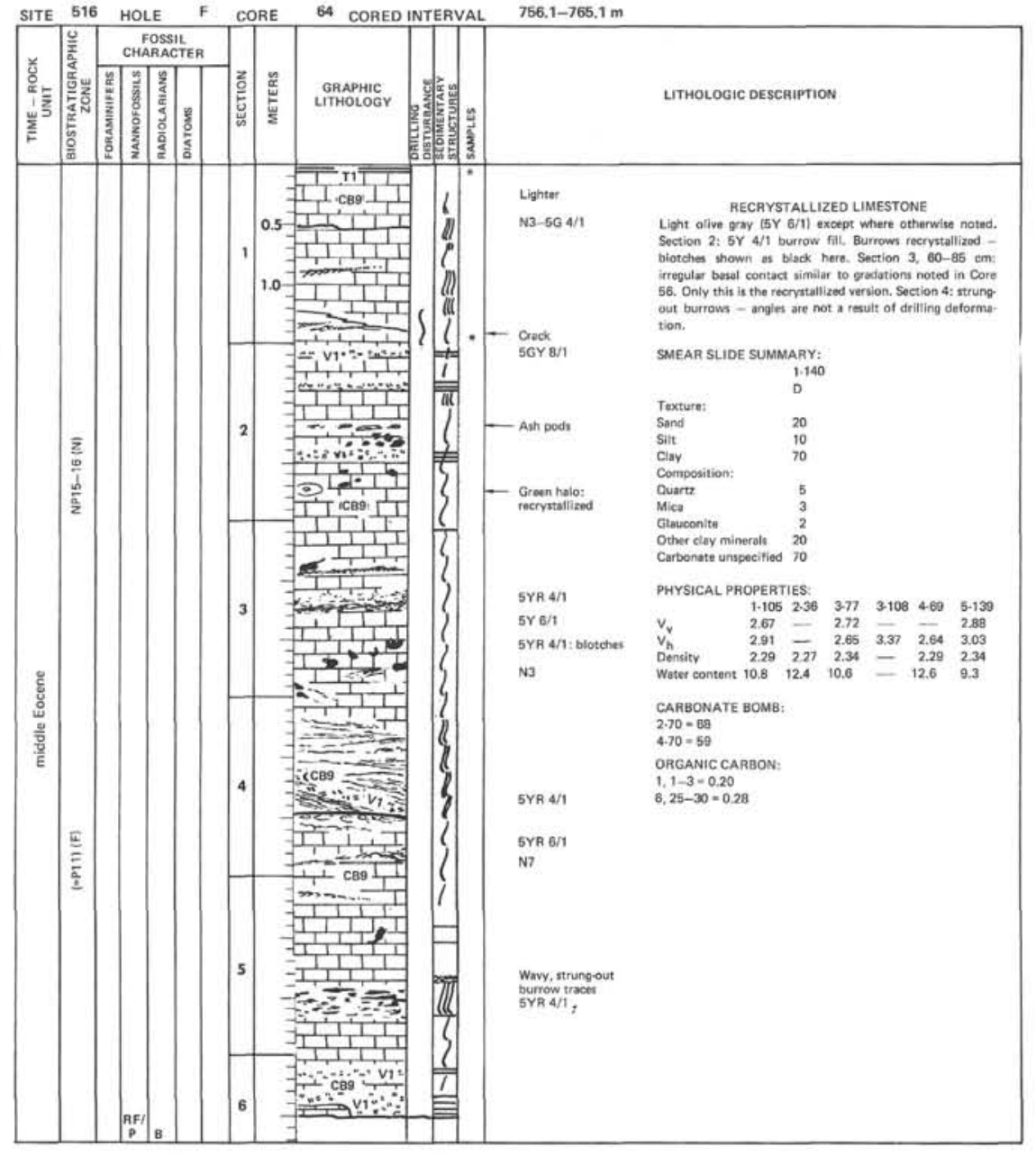

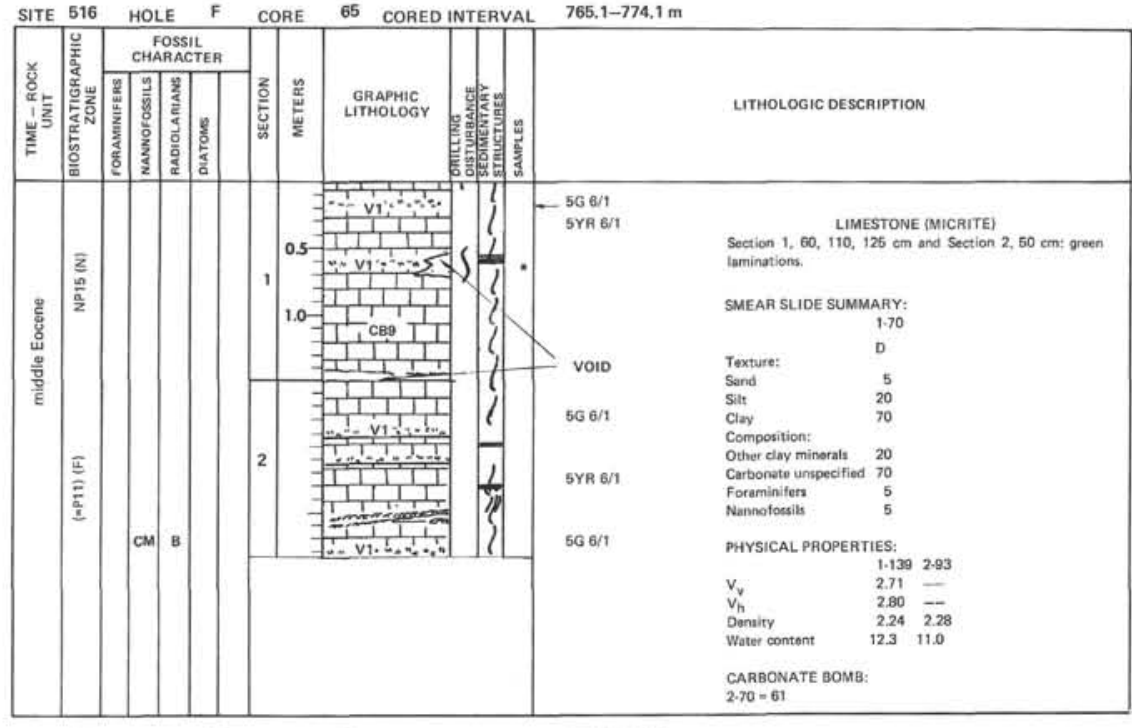

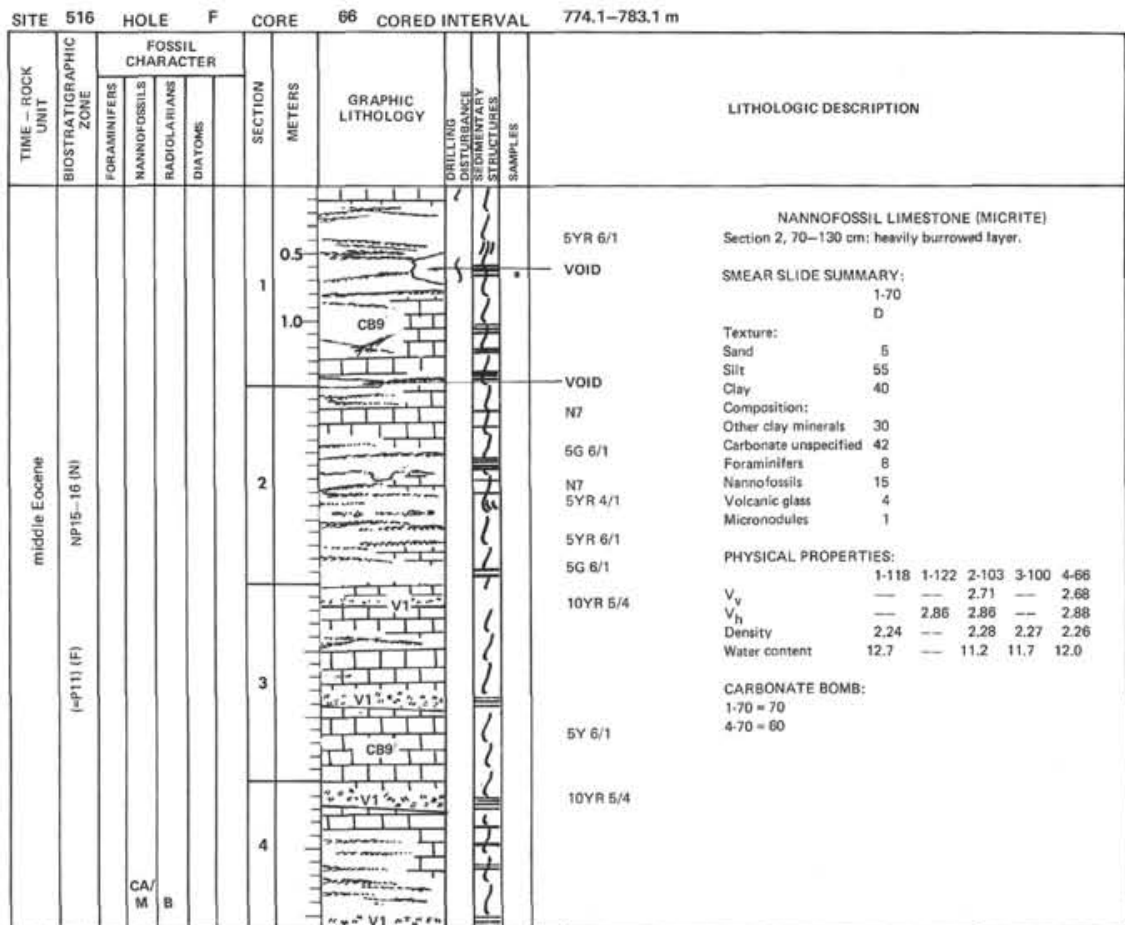




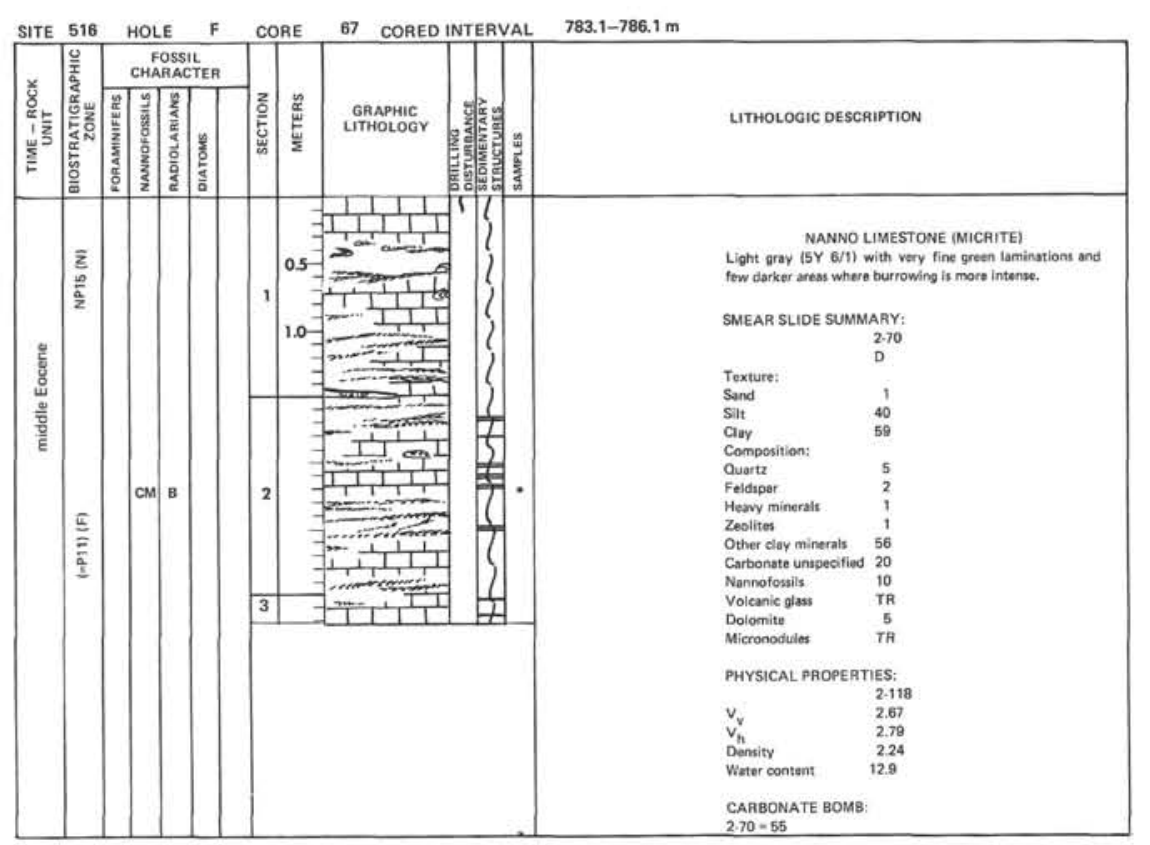

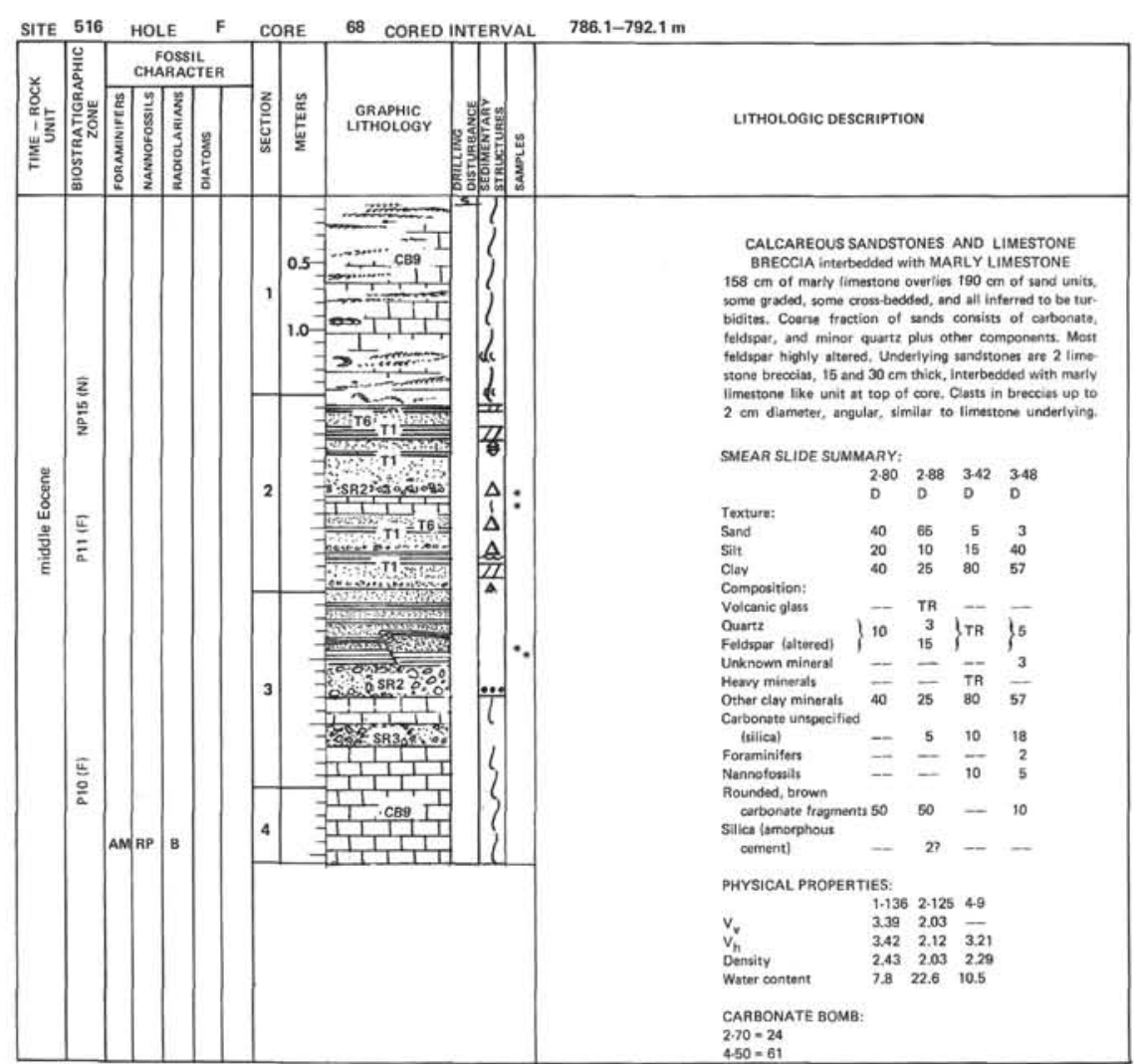



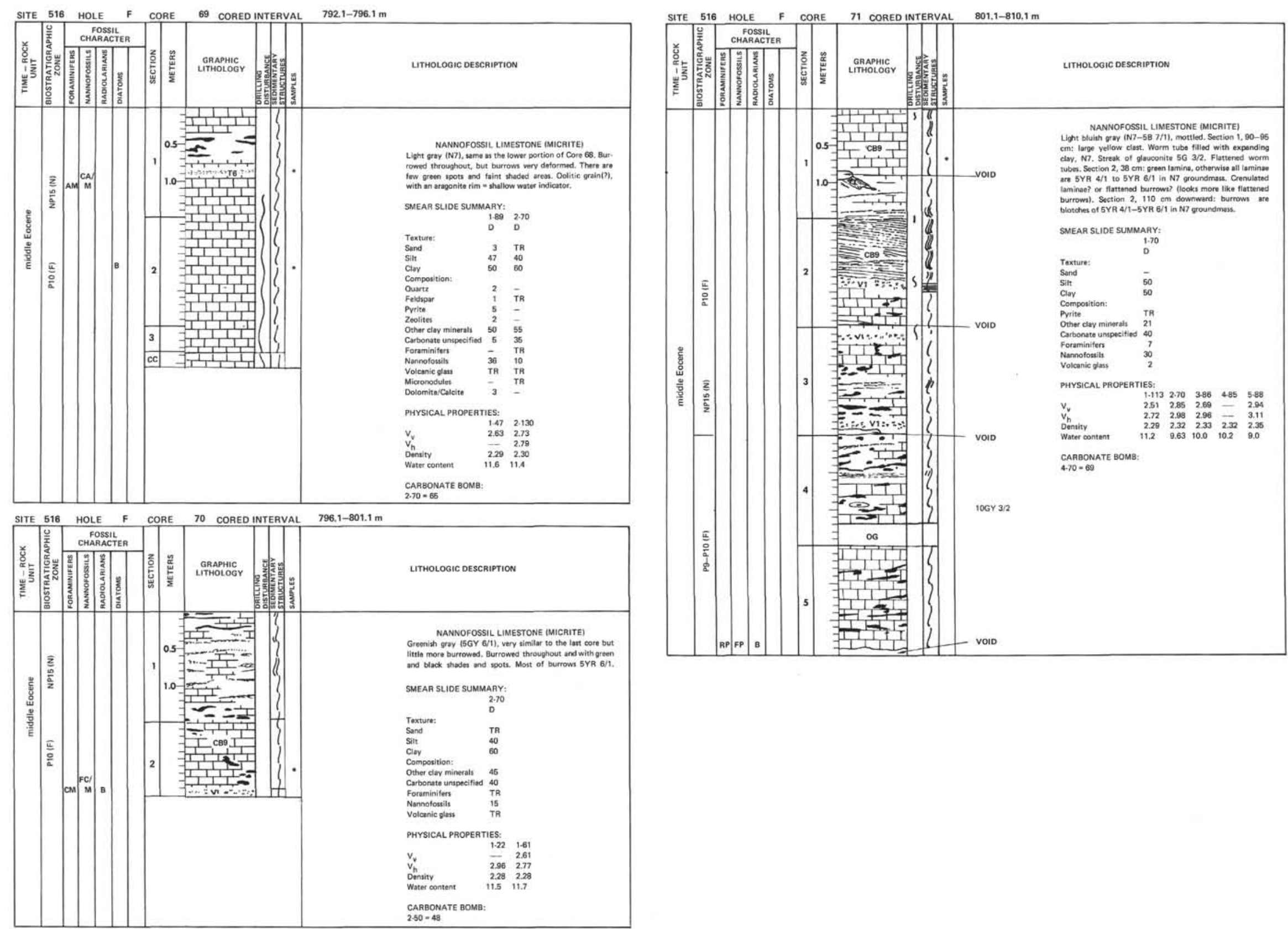

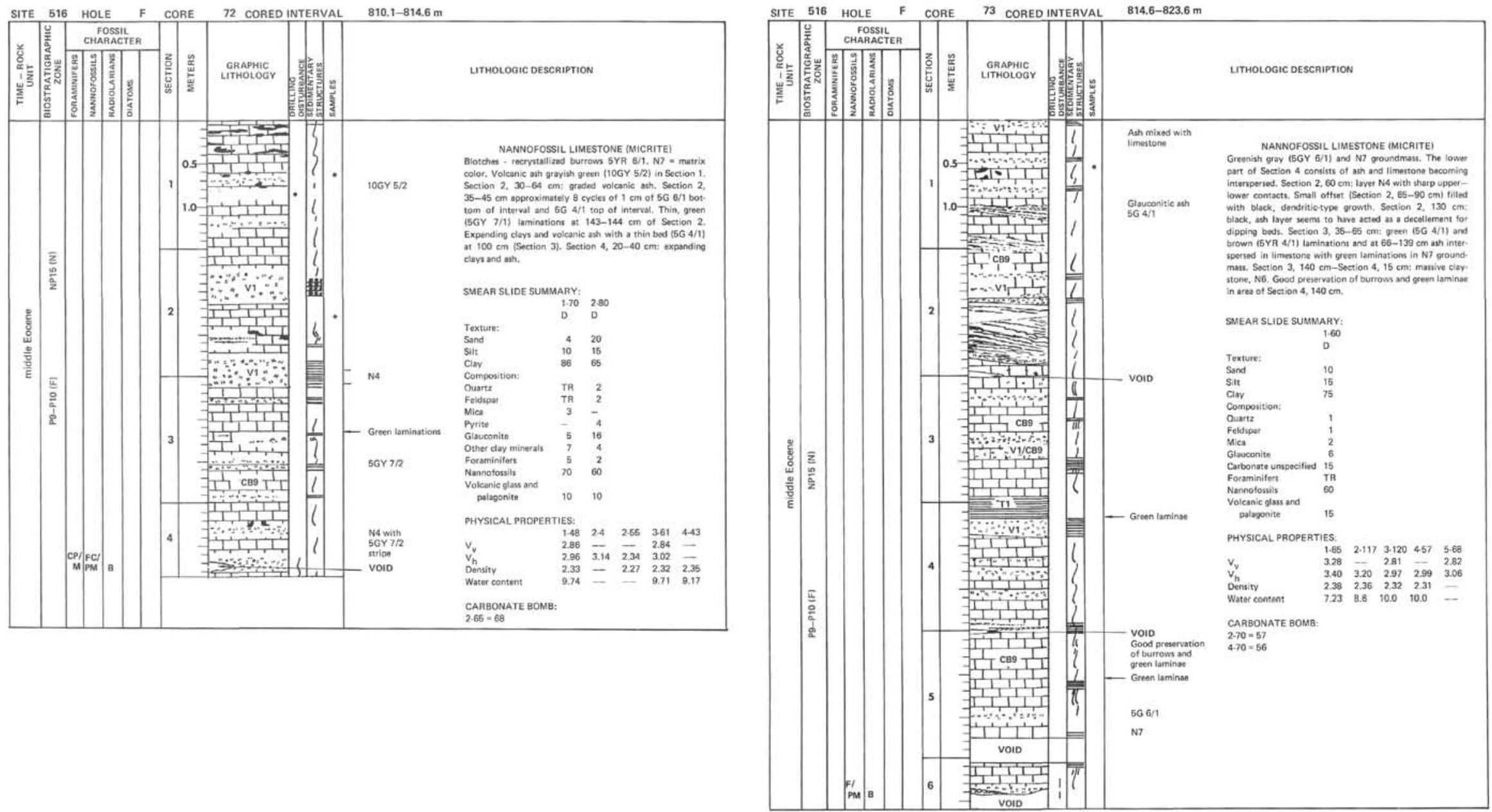


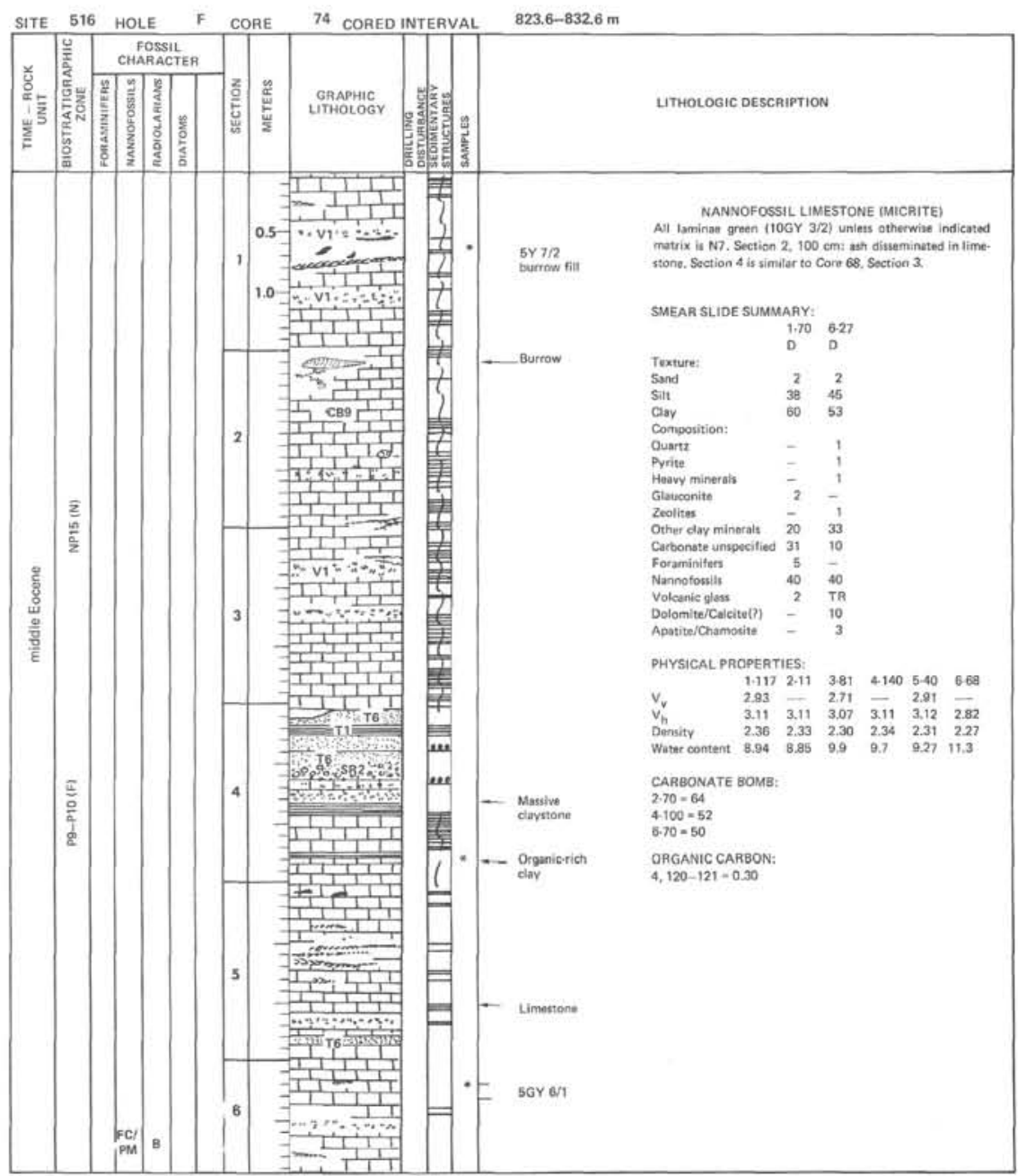

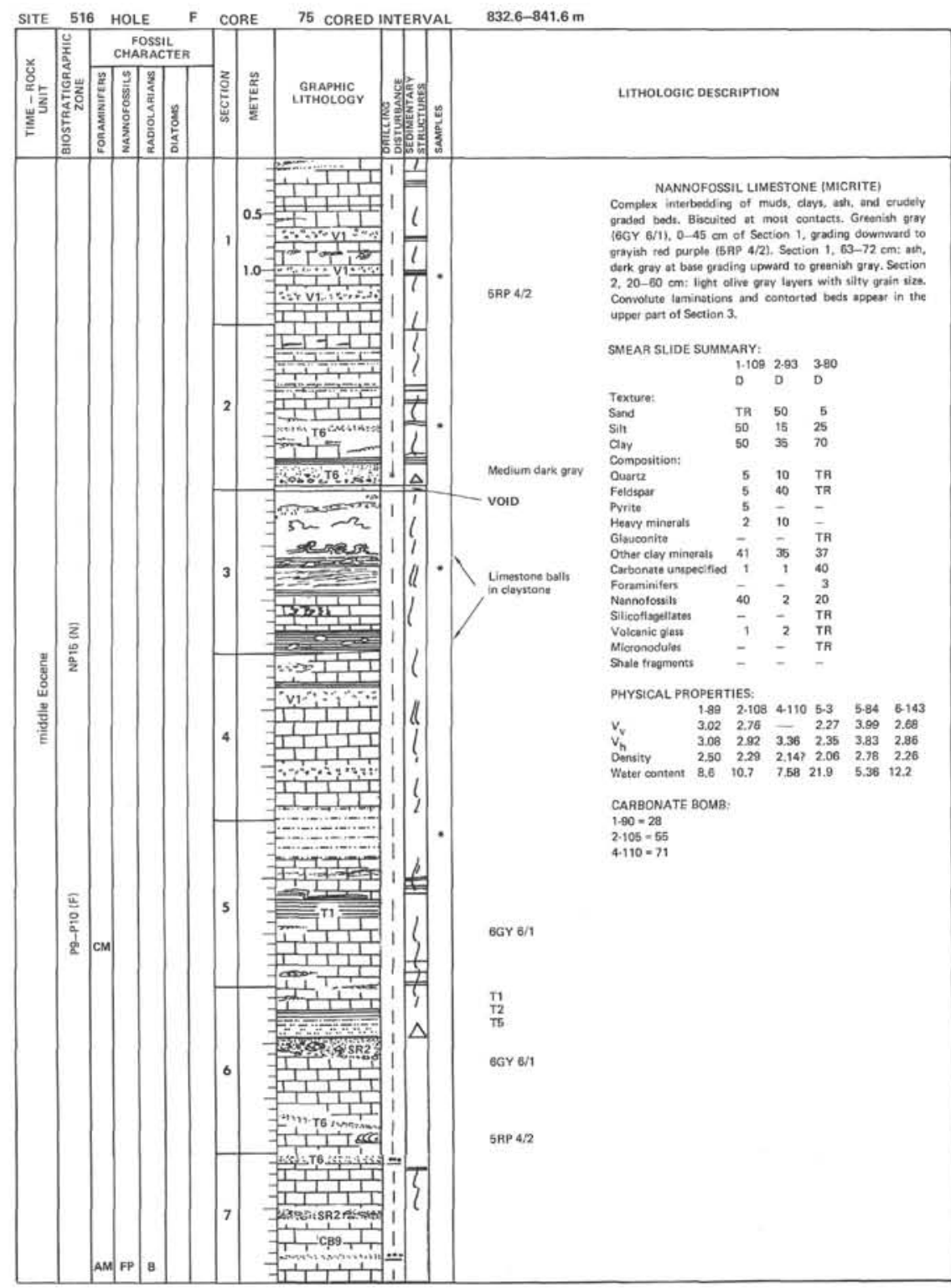



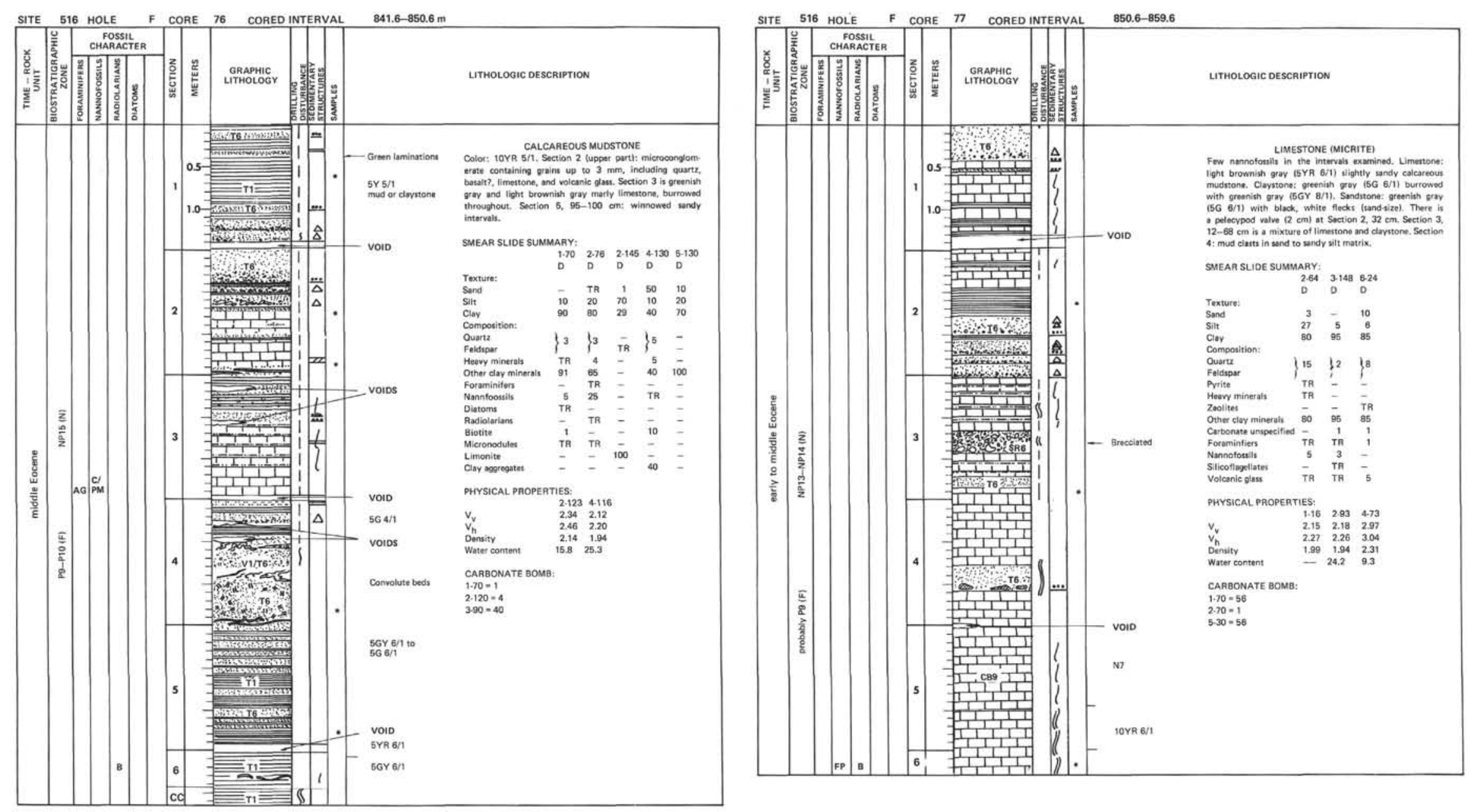


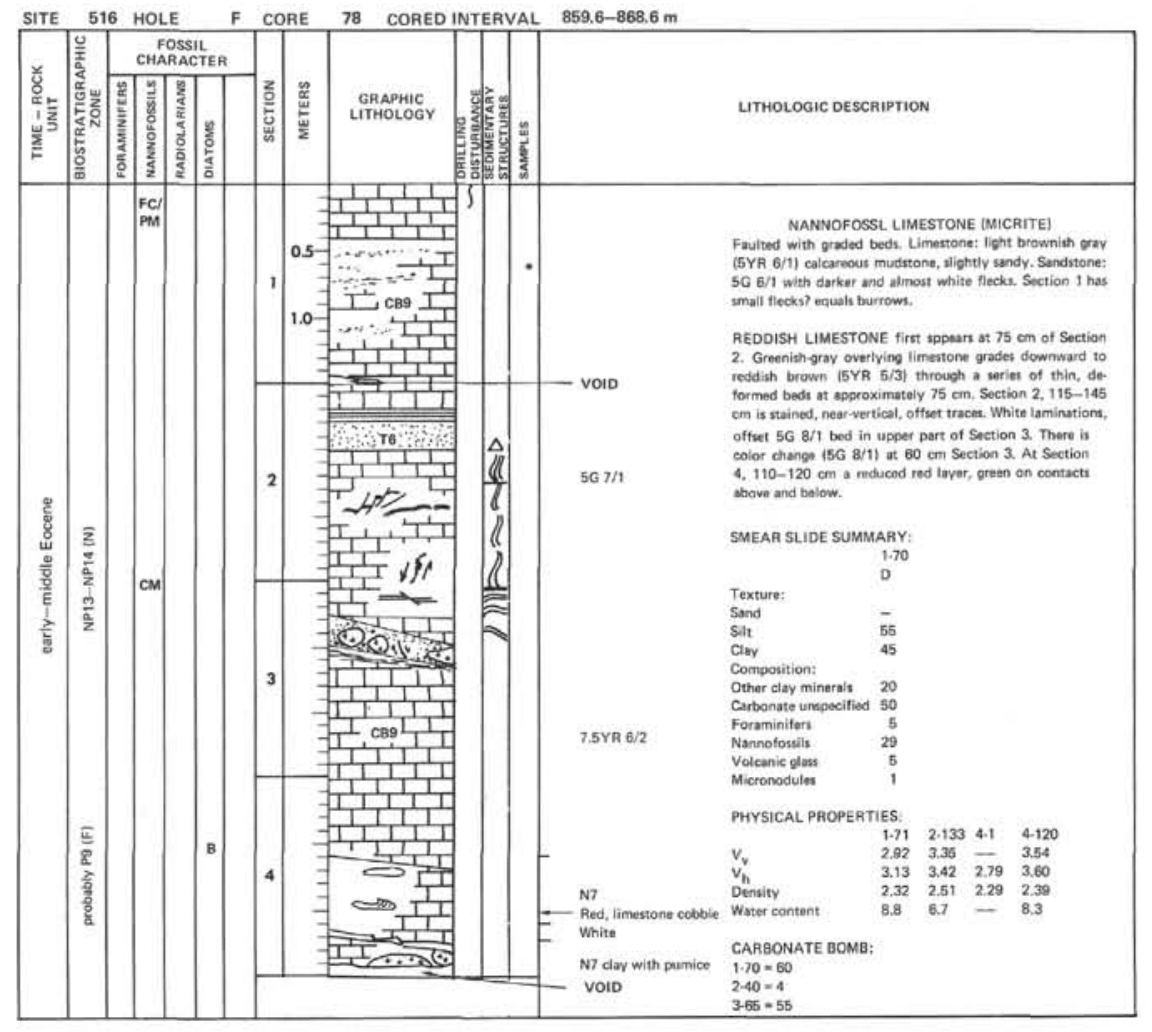

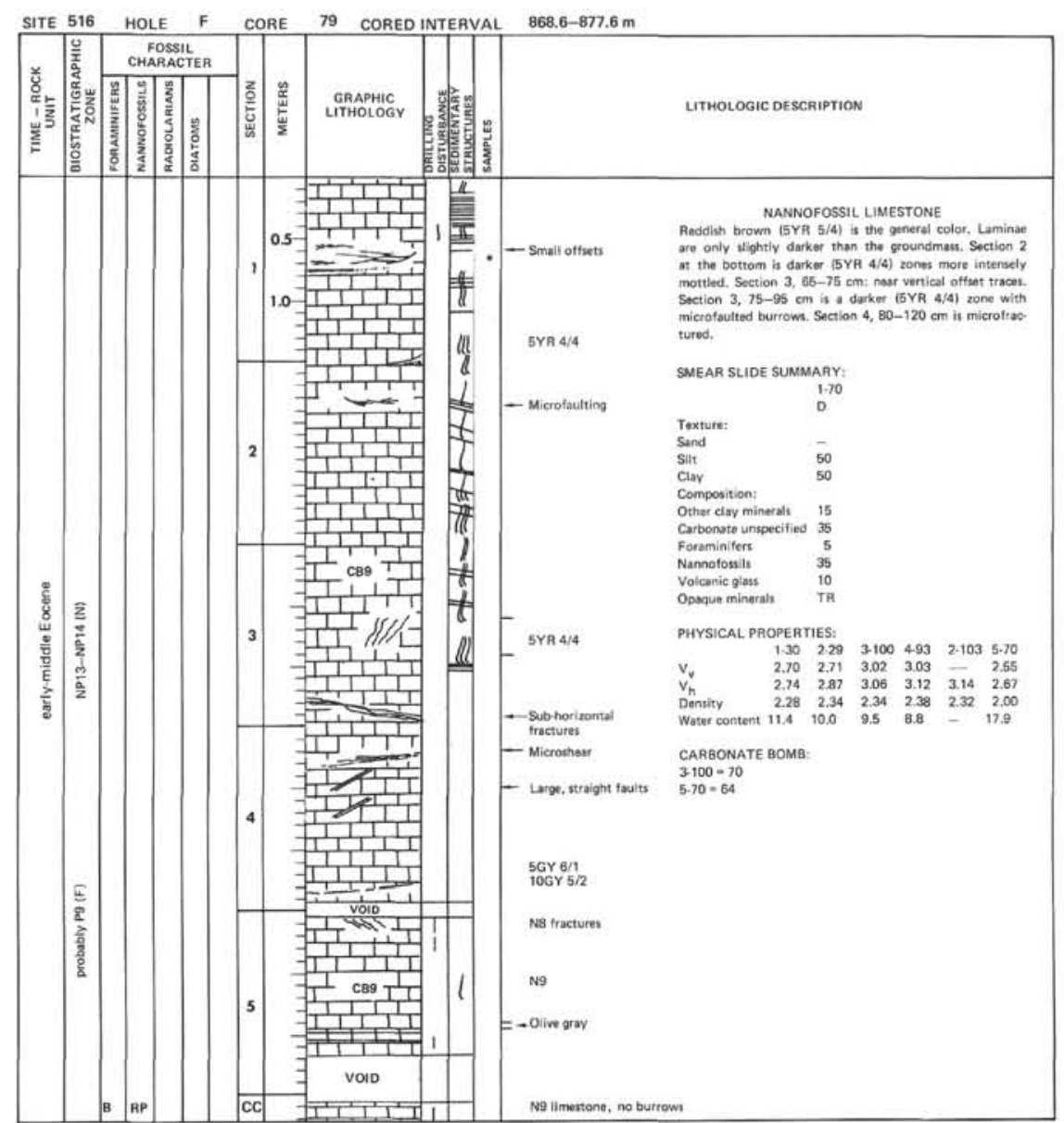



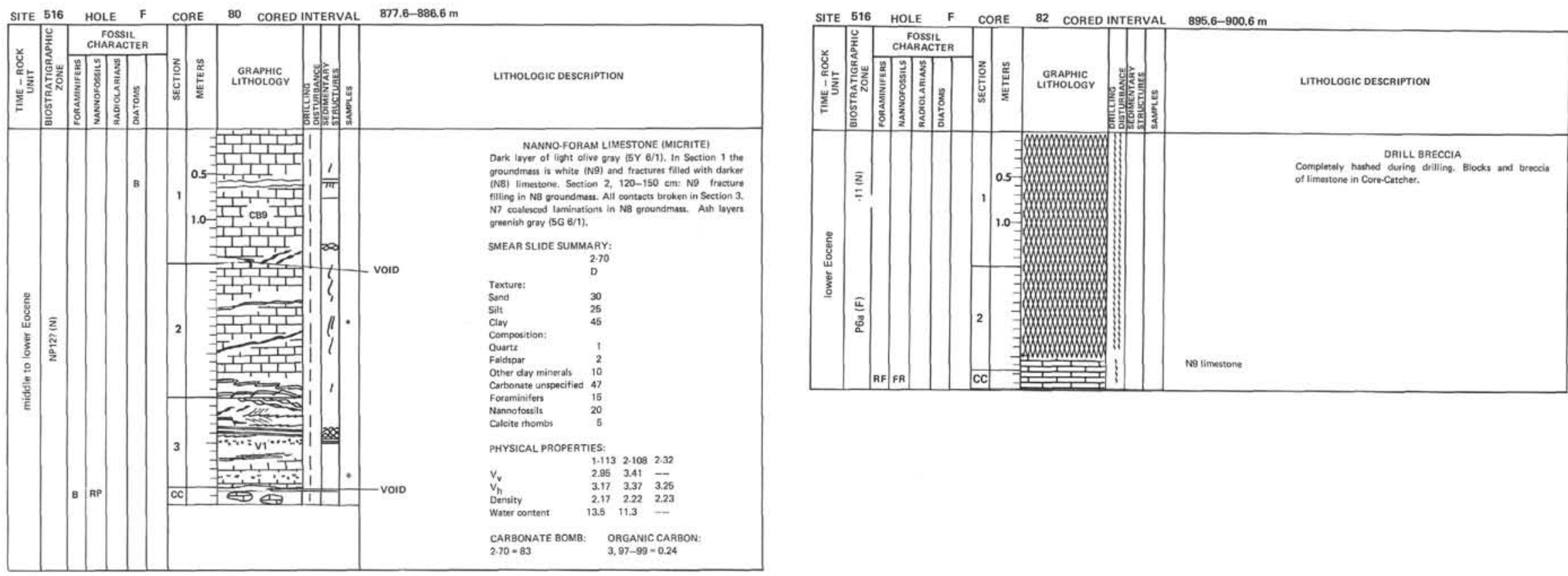

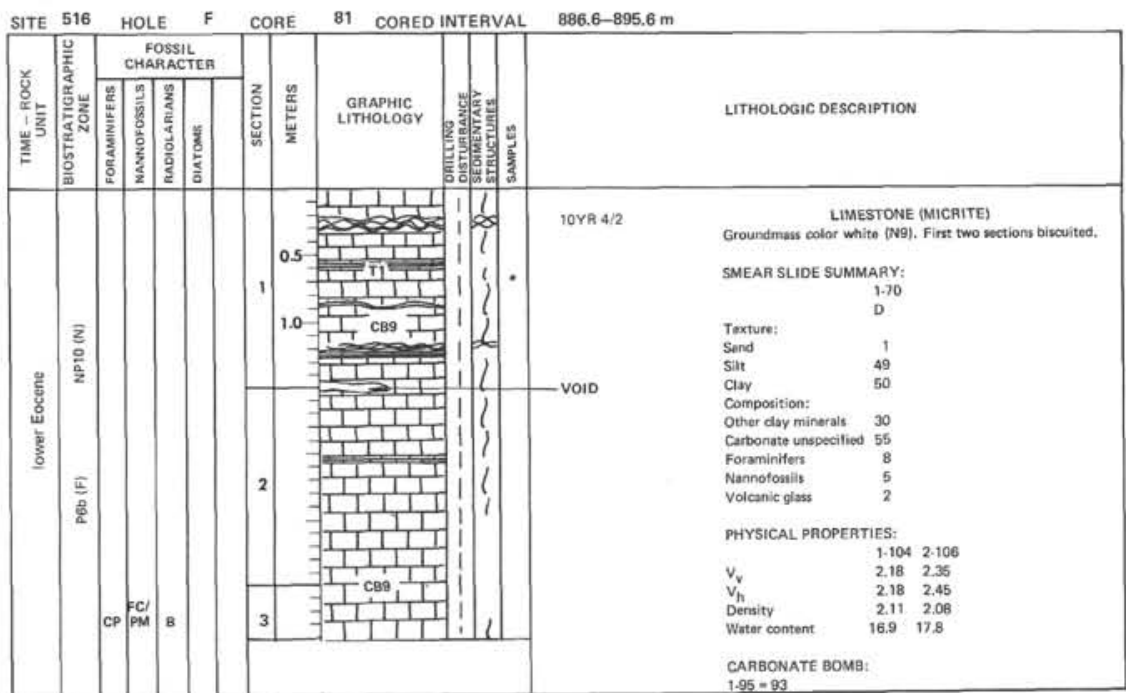



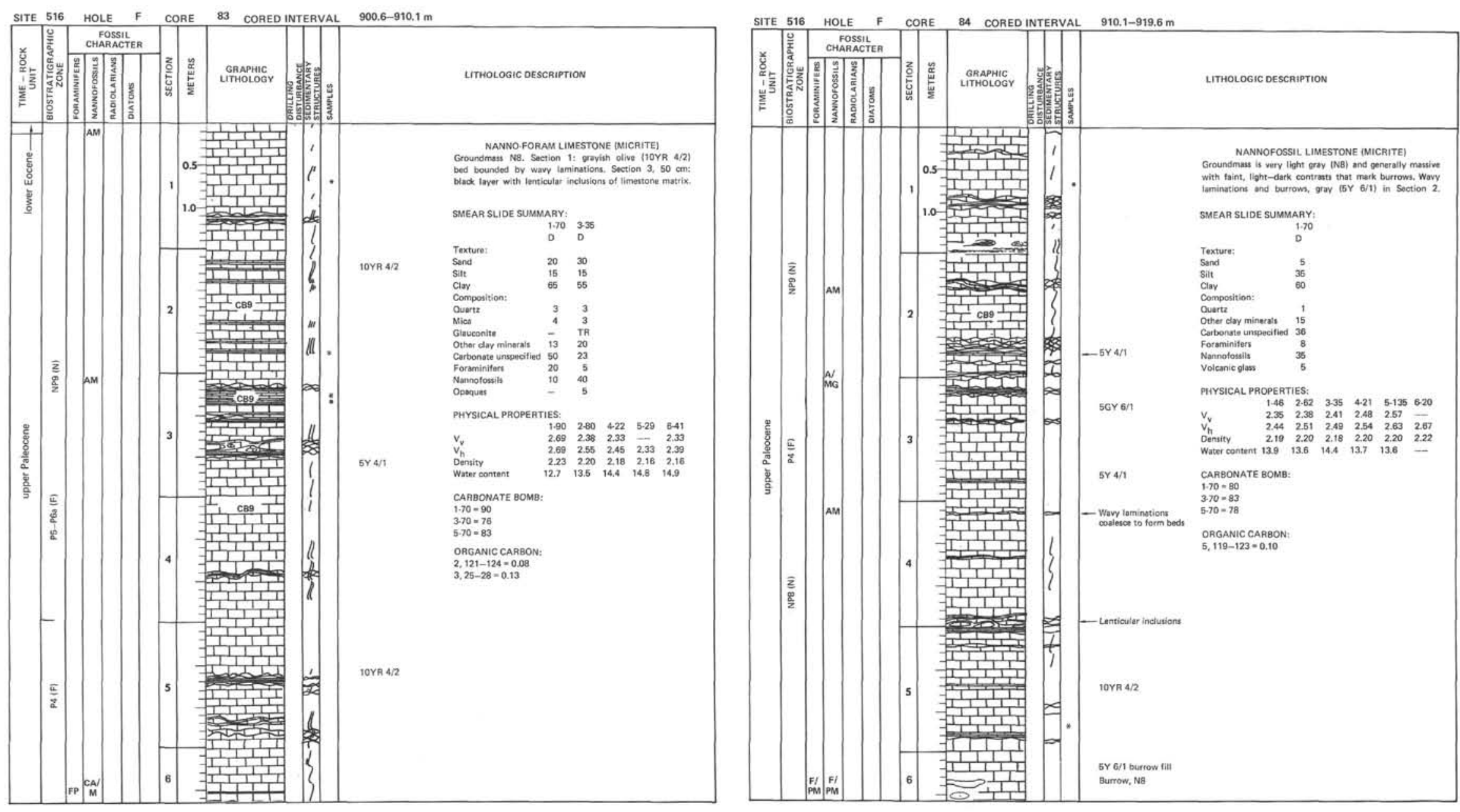

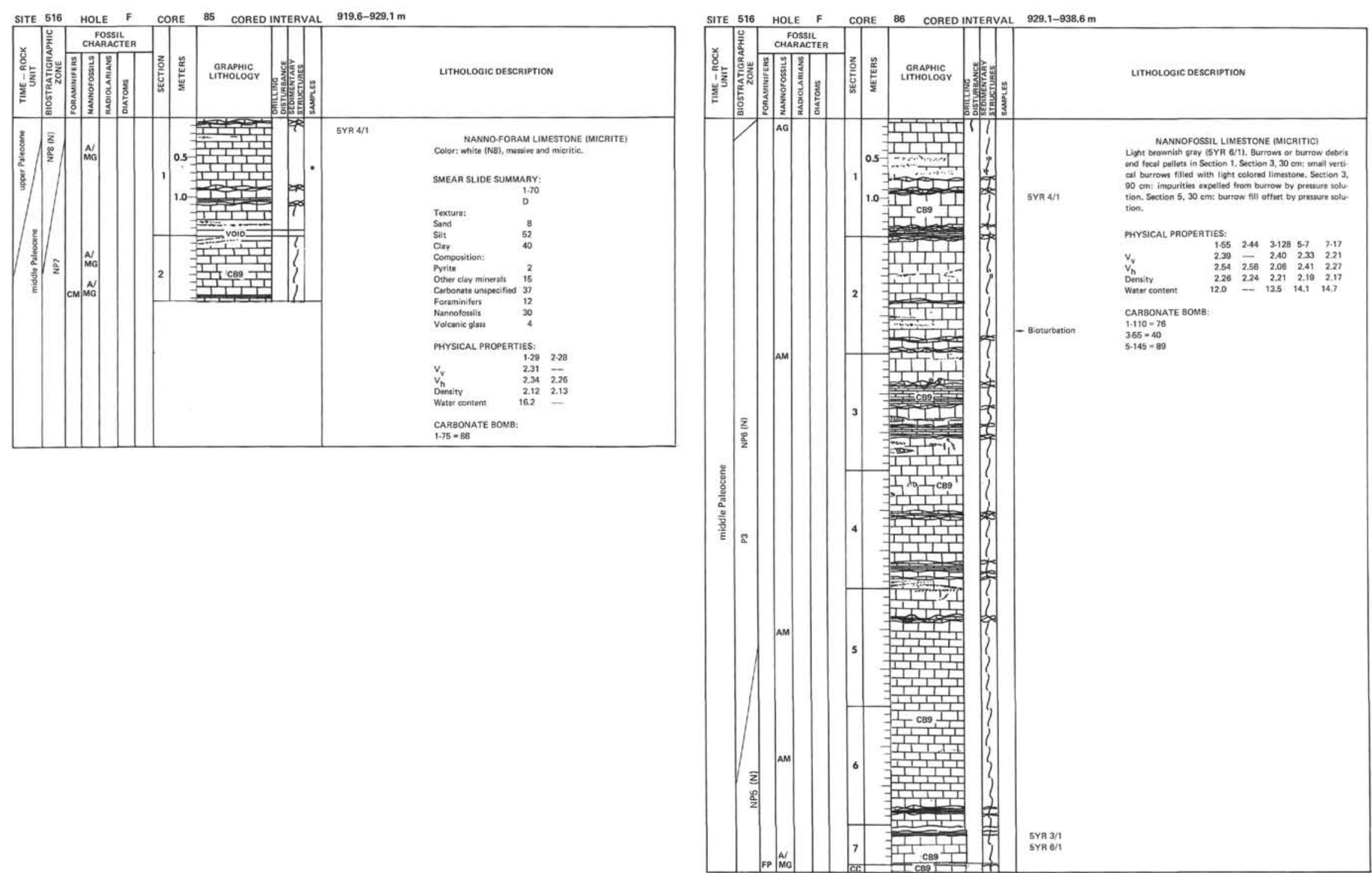


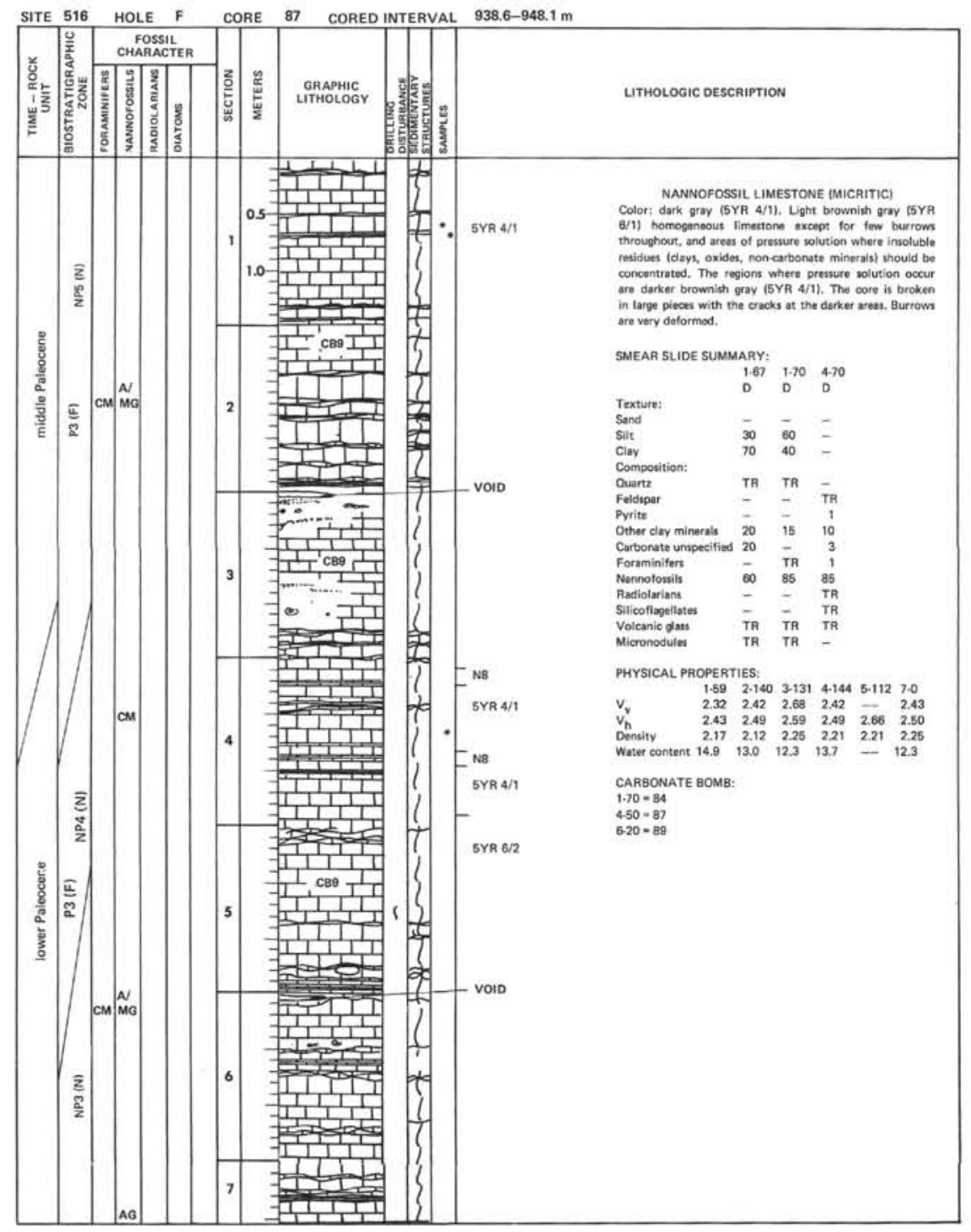

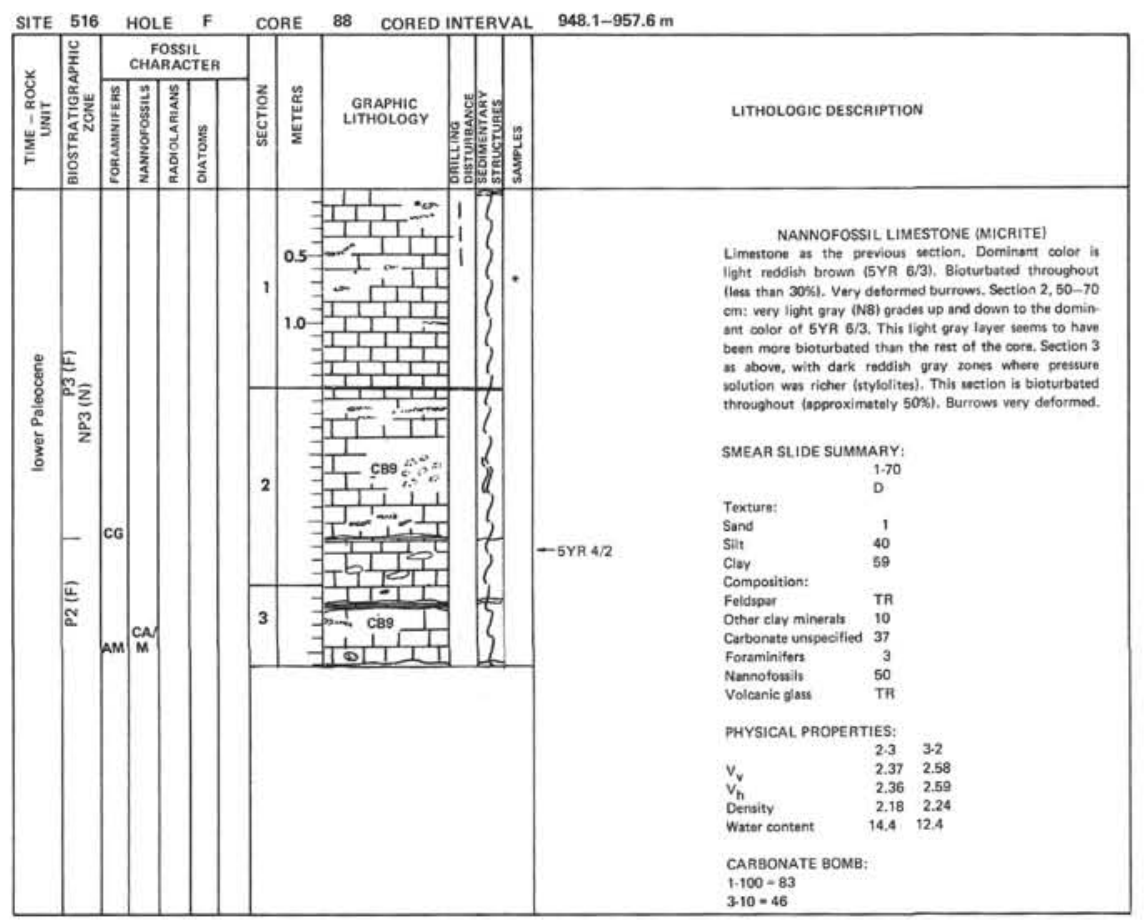



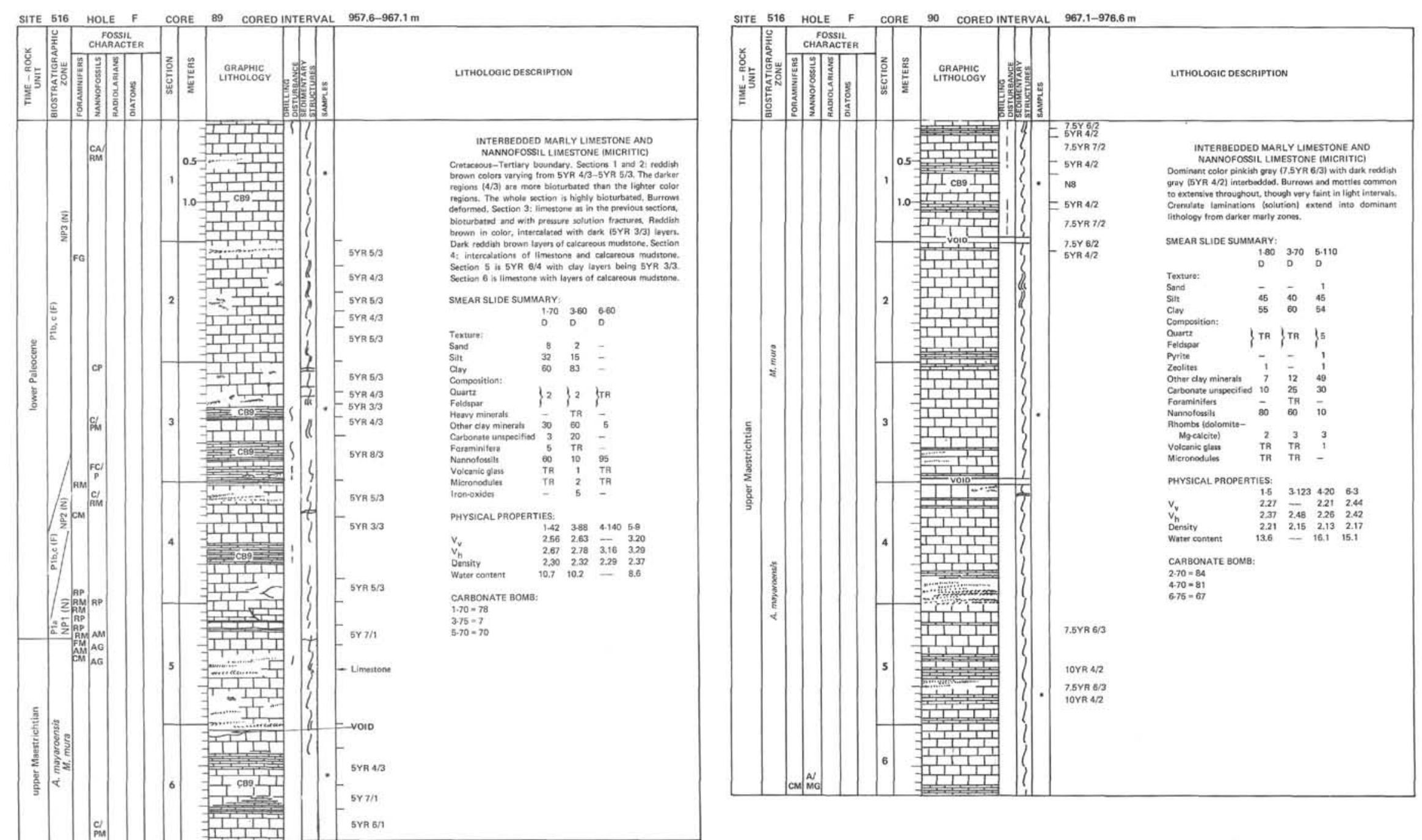


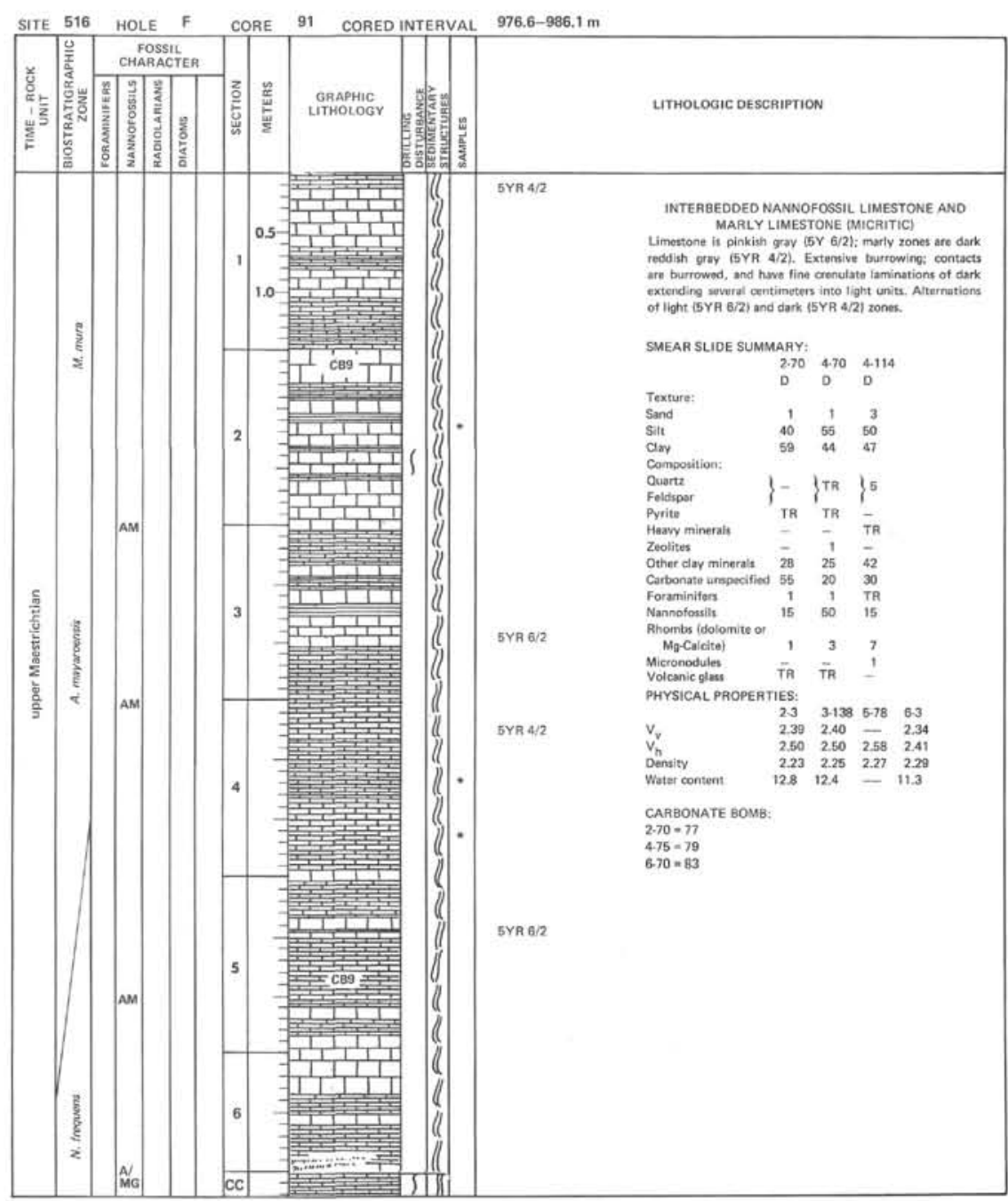

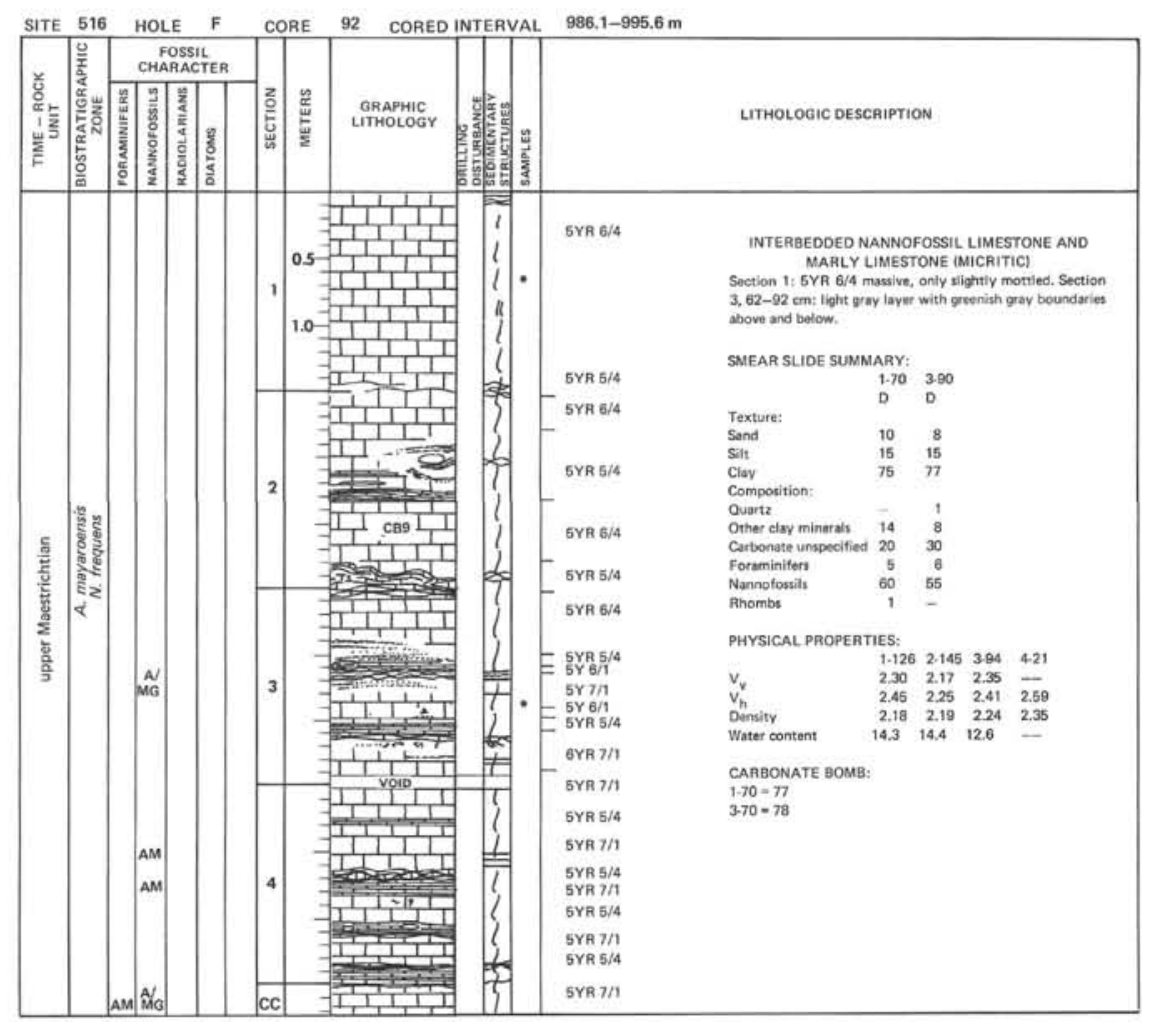




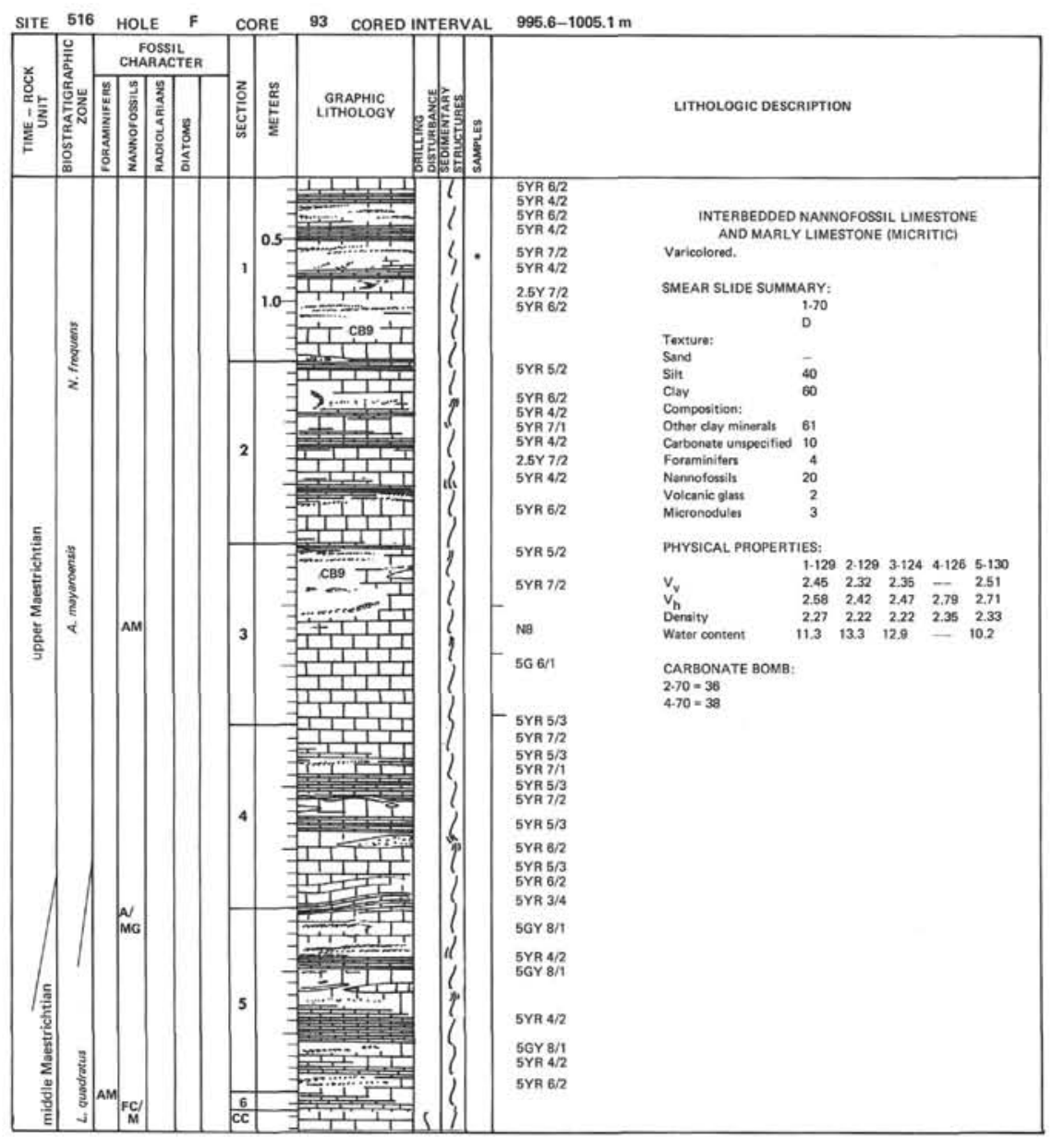

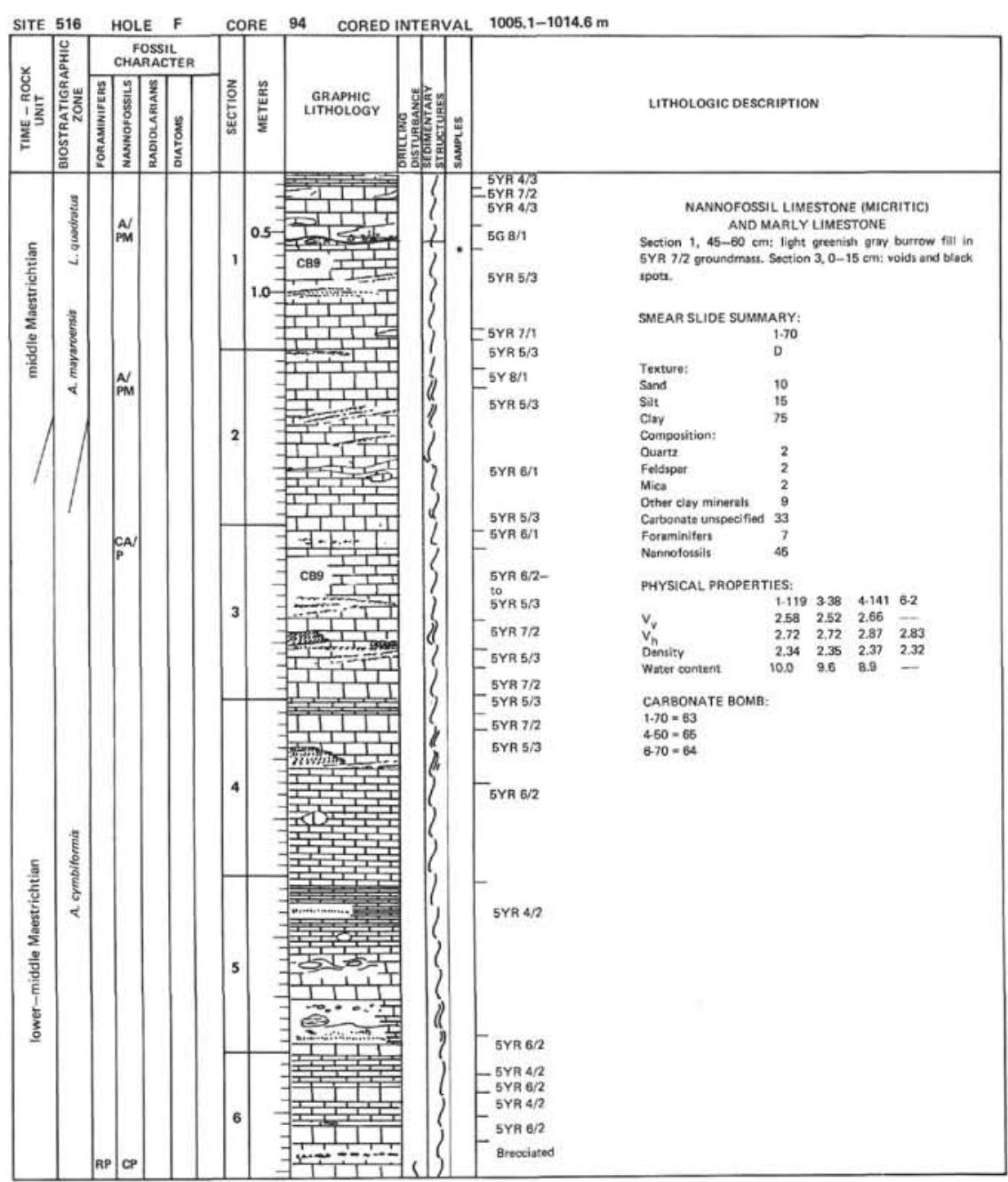




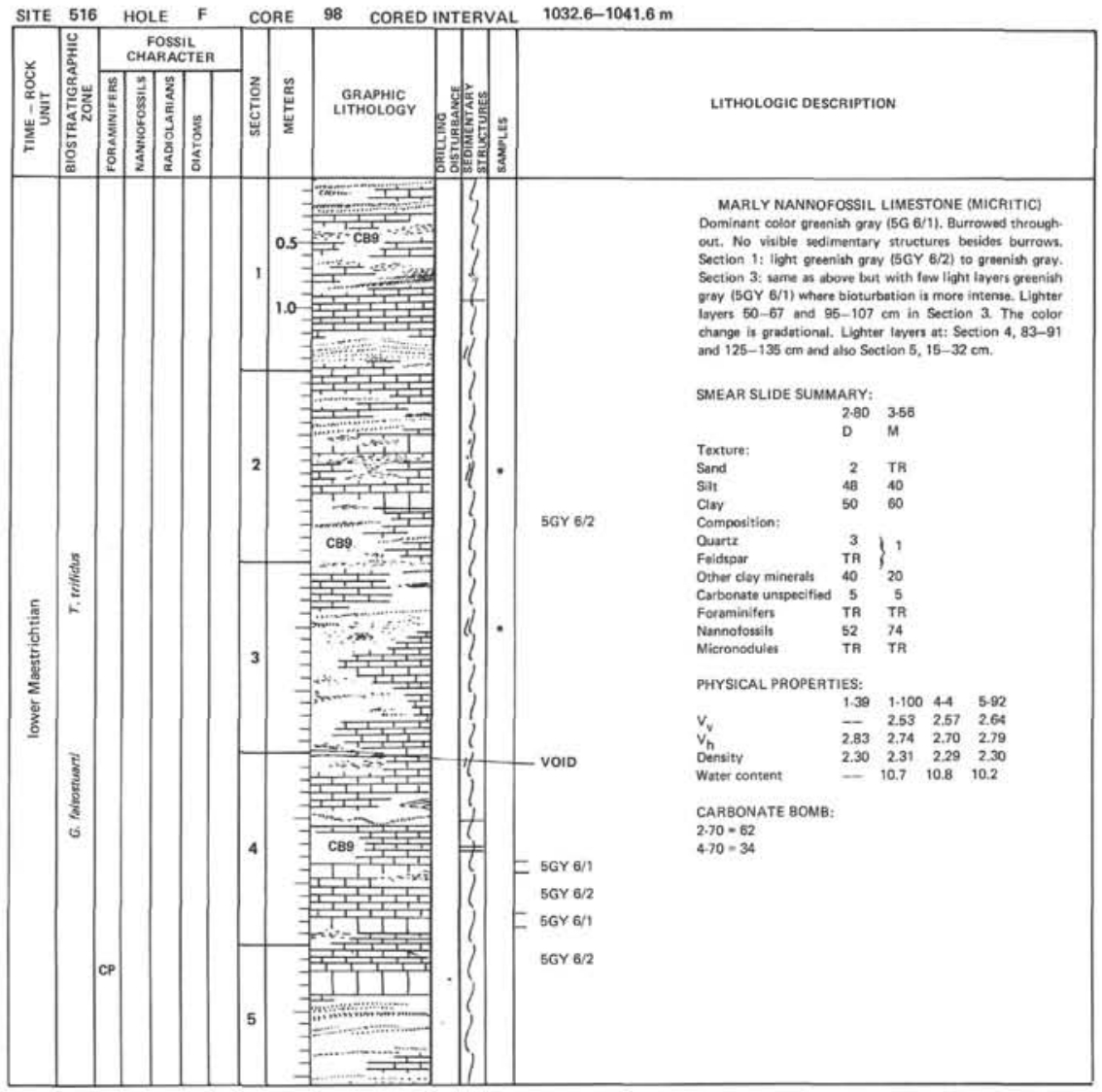

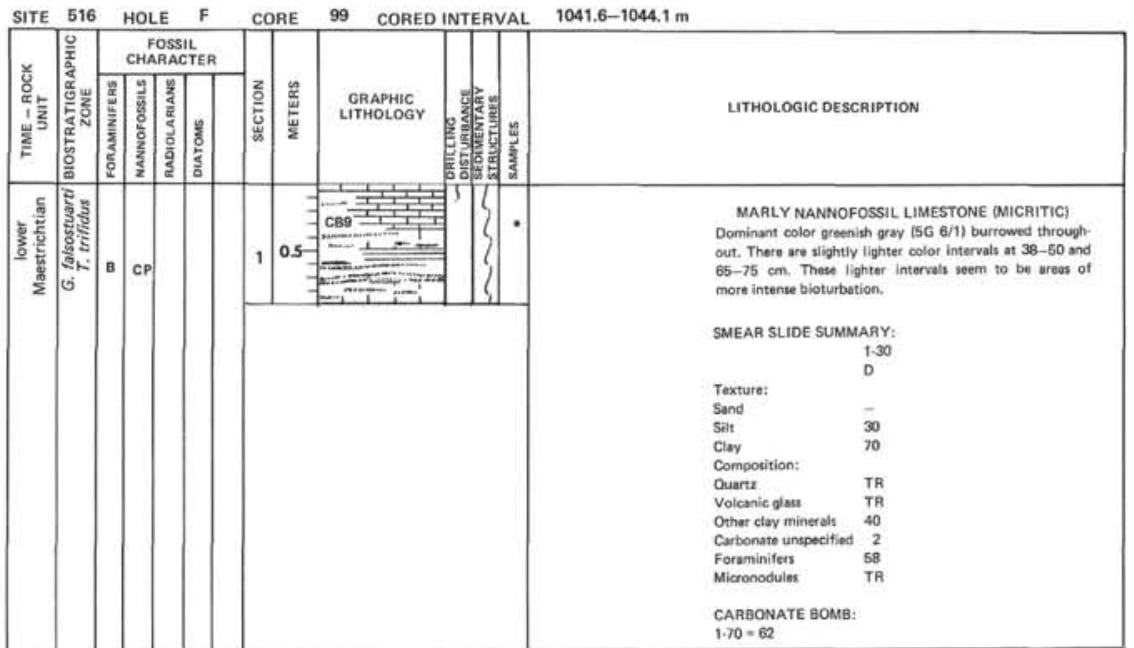

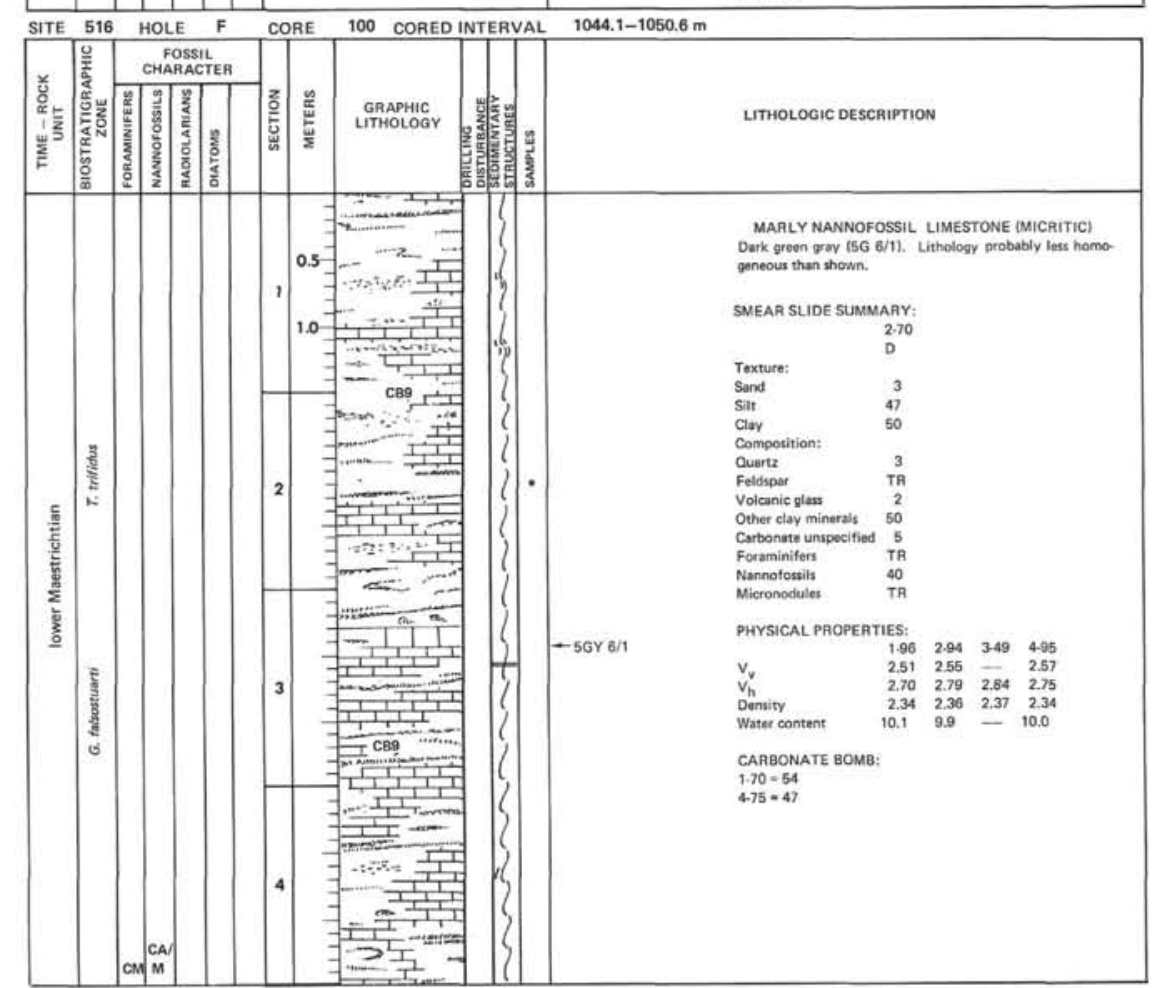




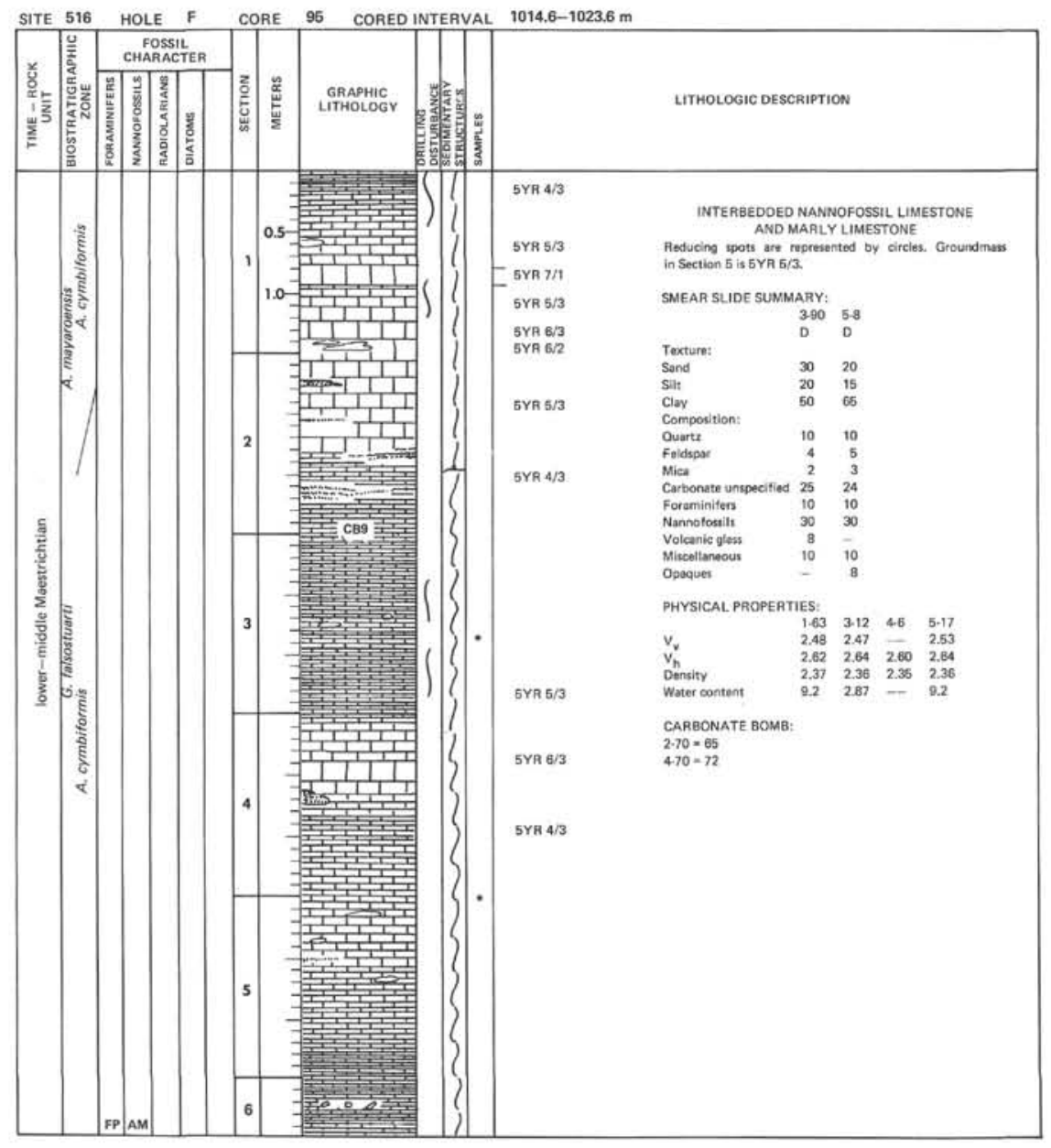

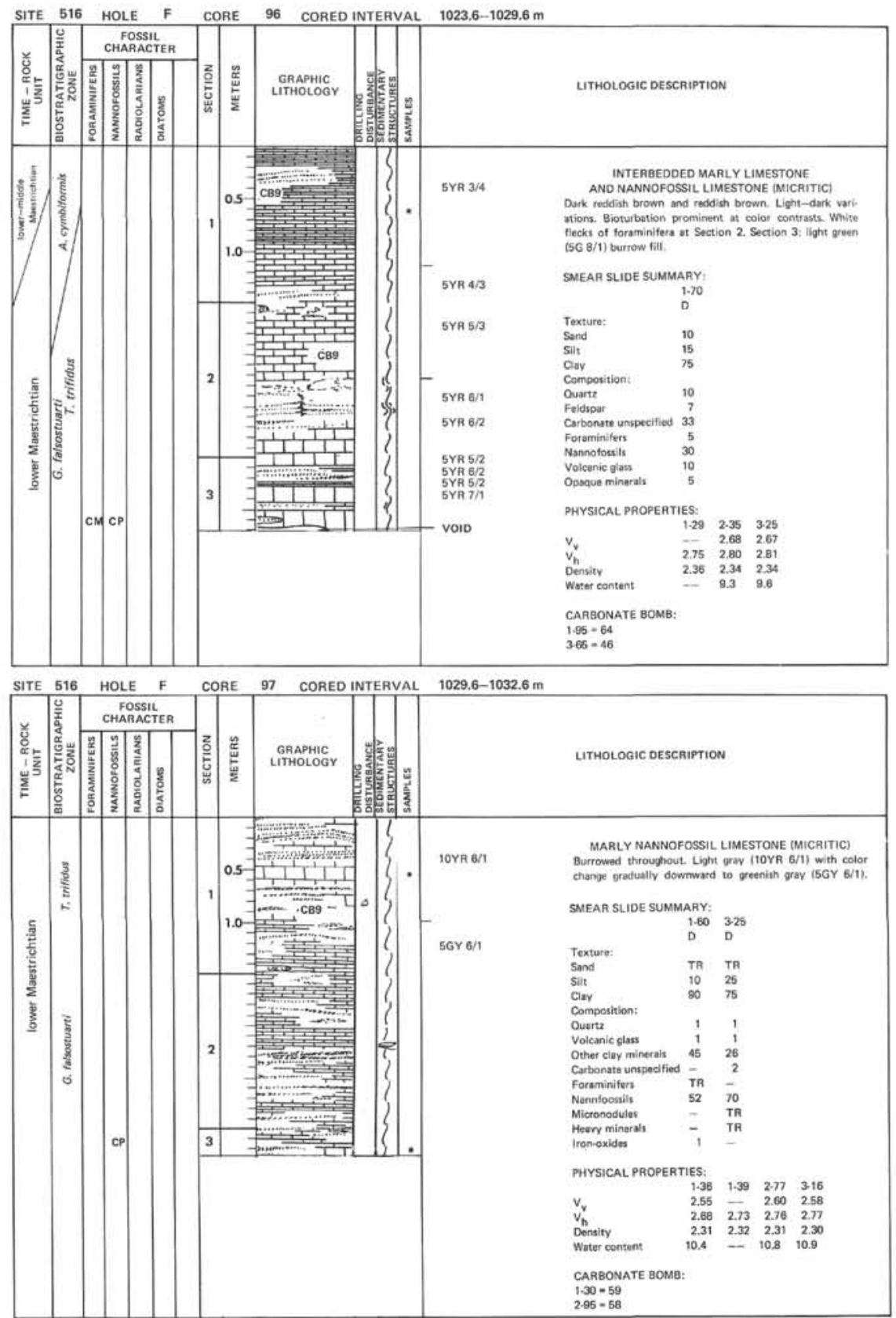




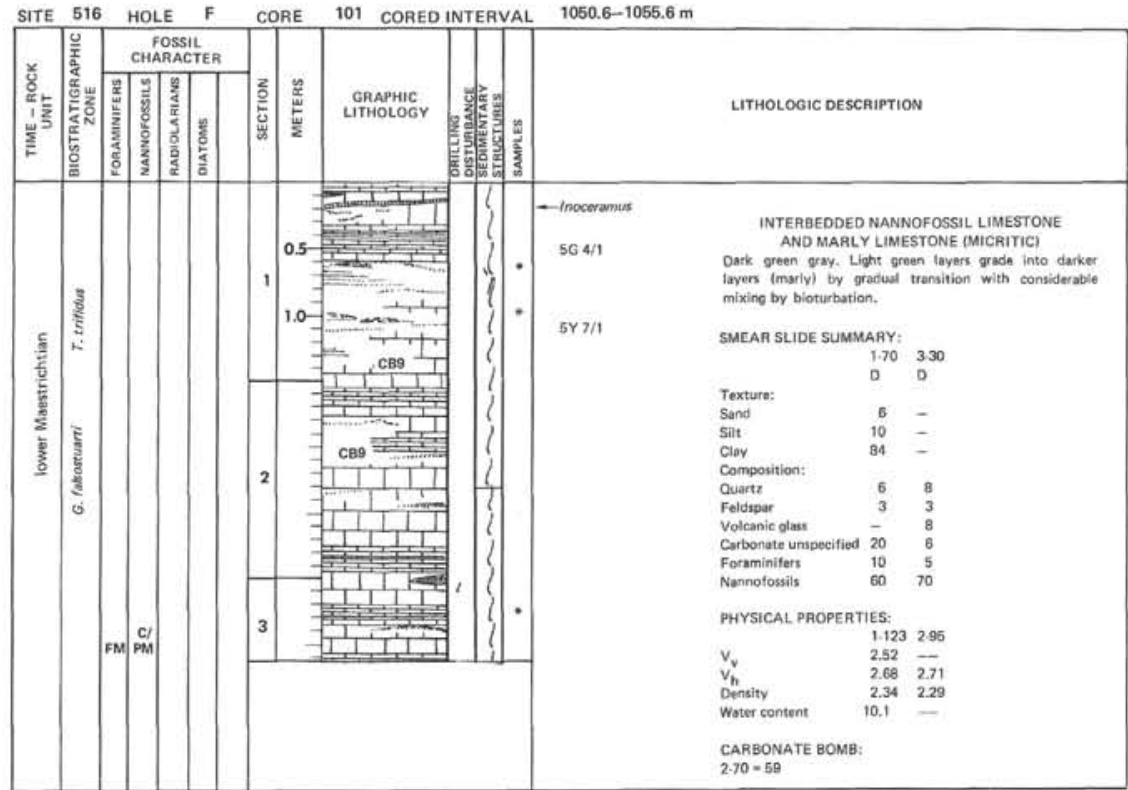

SITE 516 HOLE $F$ CORE 102 CORED INTERVAL $1055.6-1059.6 \mathrm{~m}$

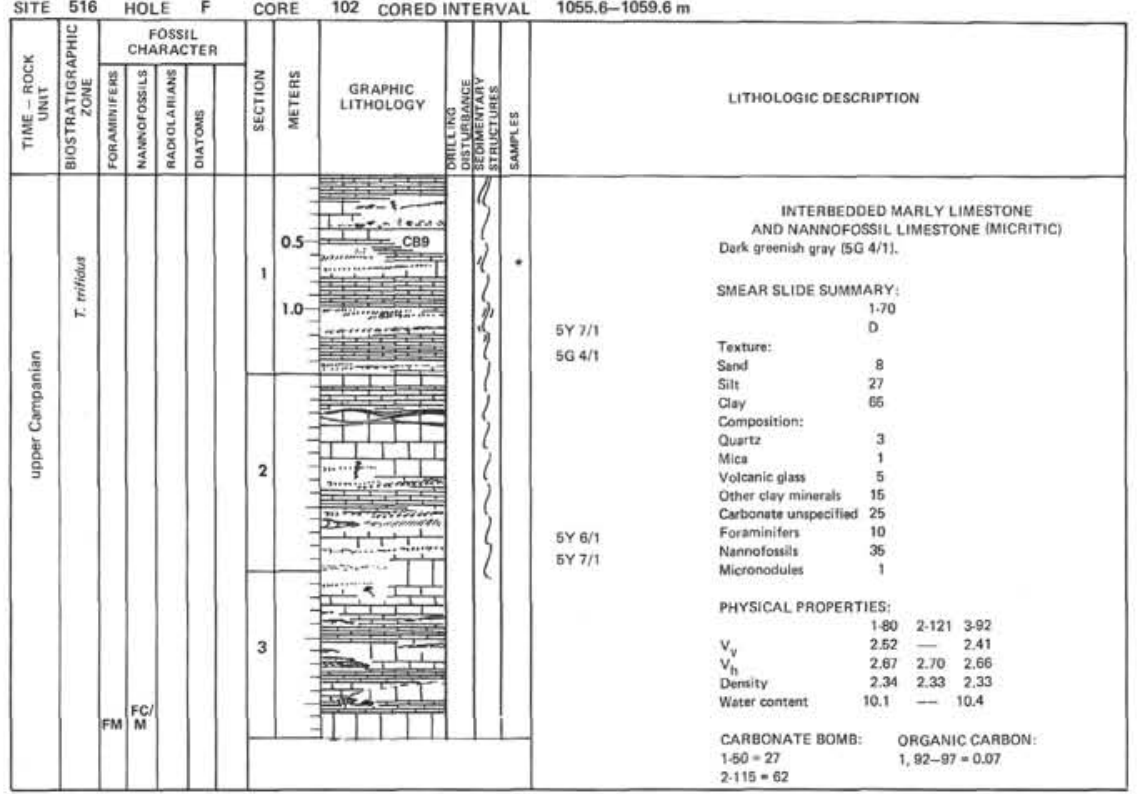

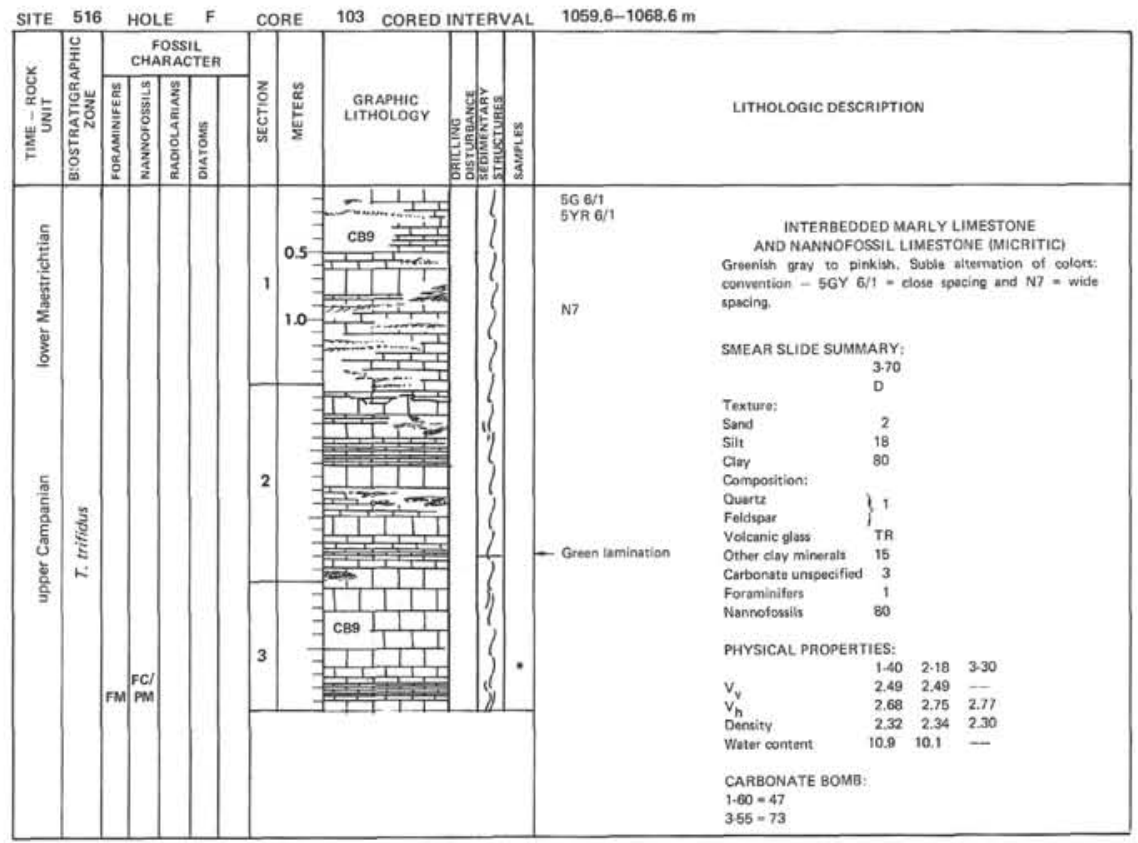




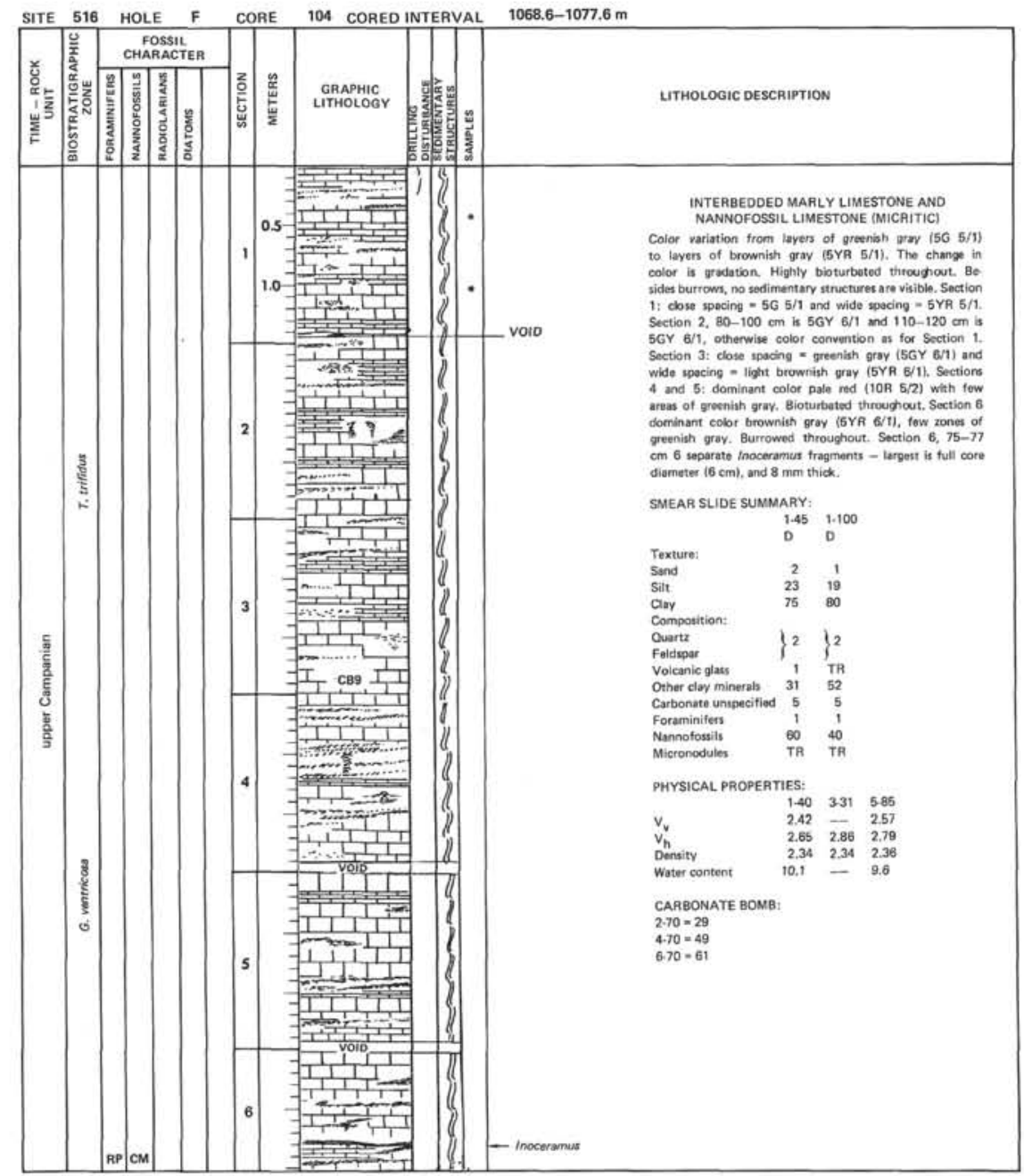

SITE 516 HOLE $F$ CORE 105 CORED INTERVAL 1077.6-1086.6 m

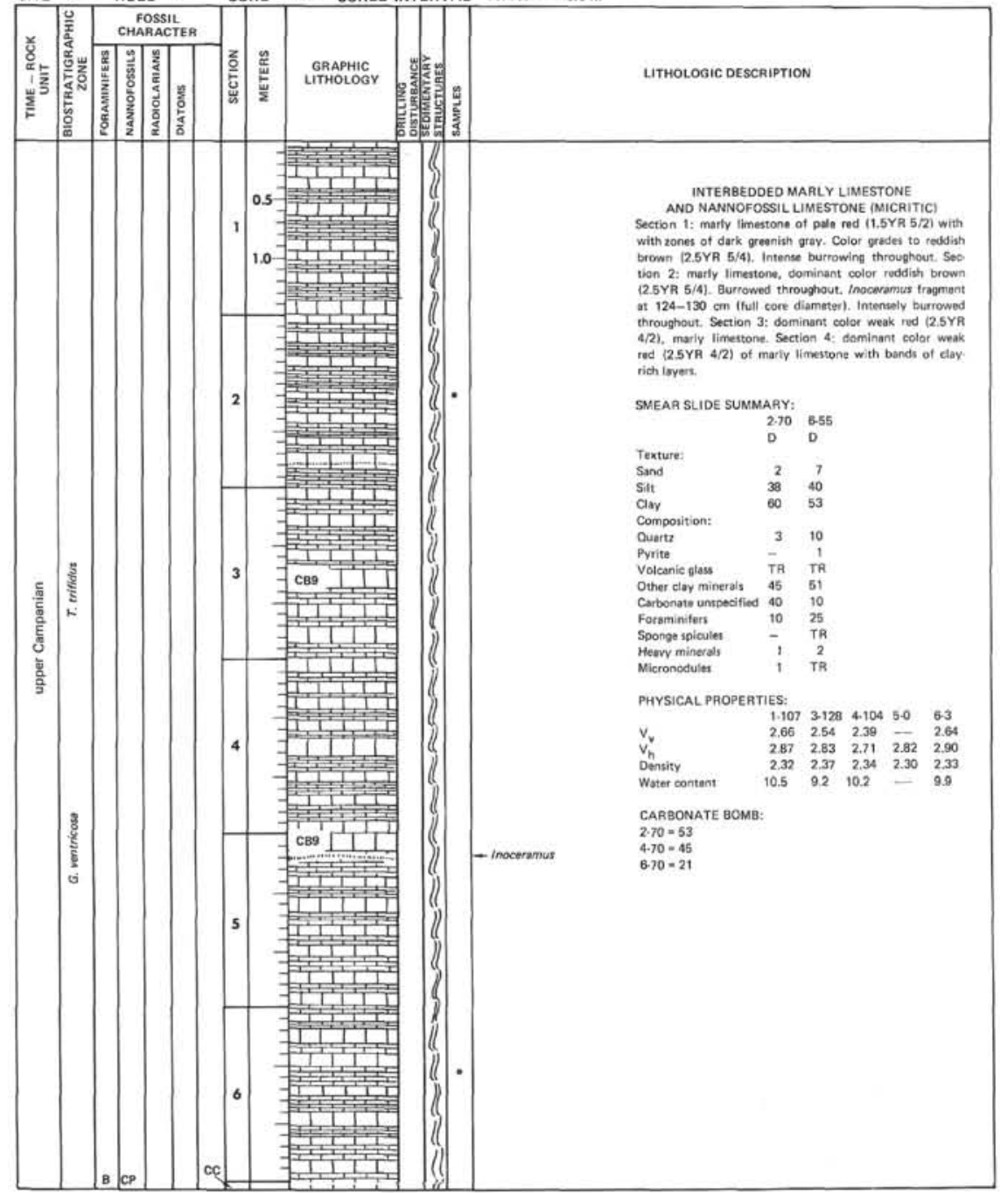




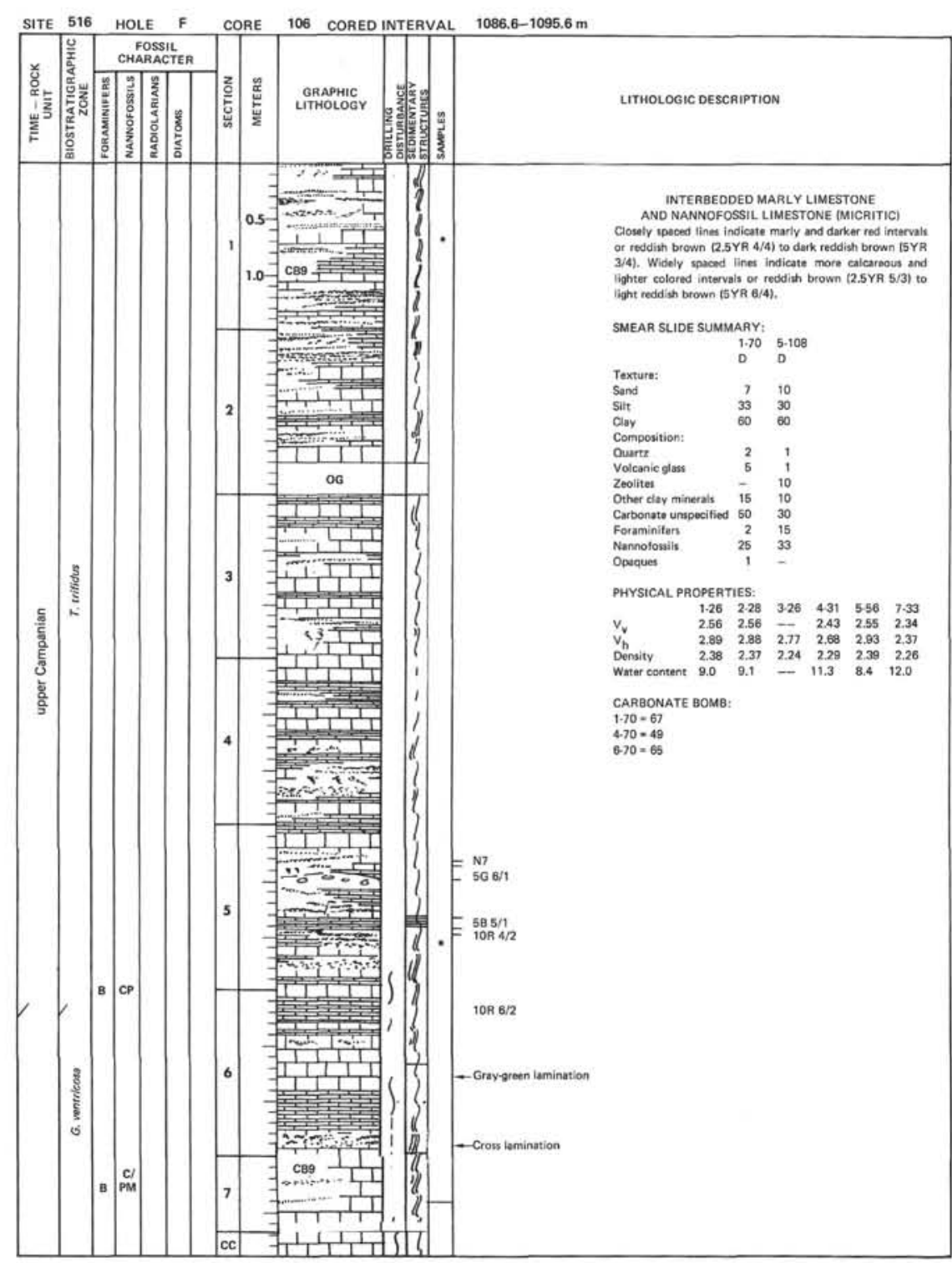

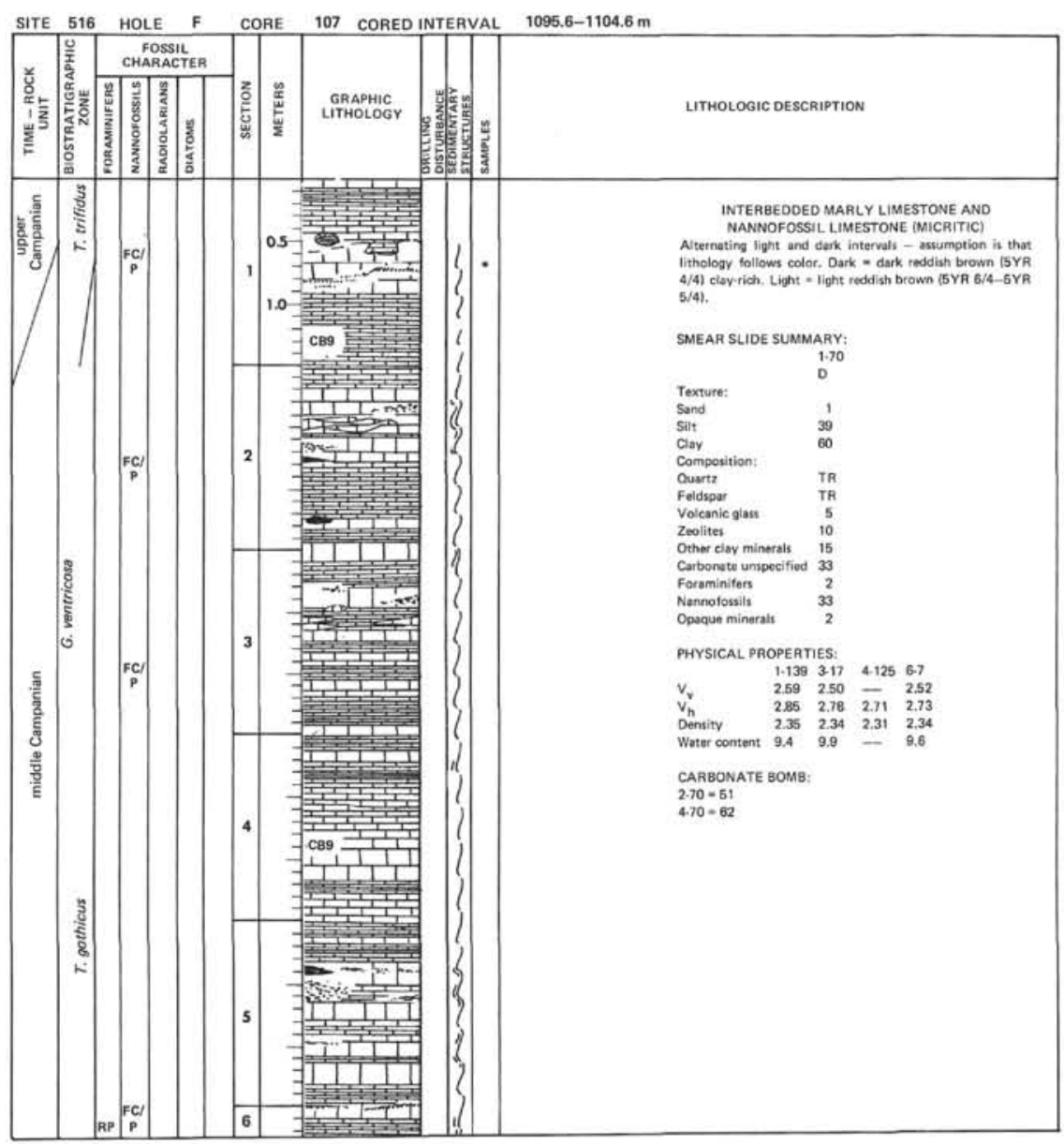




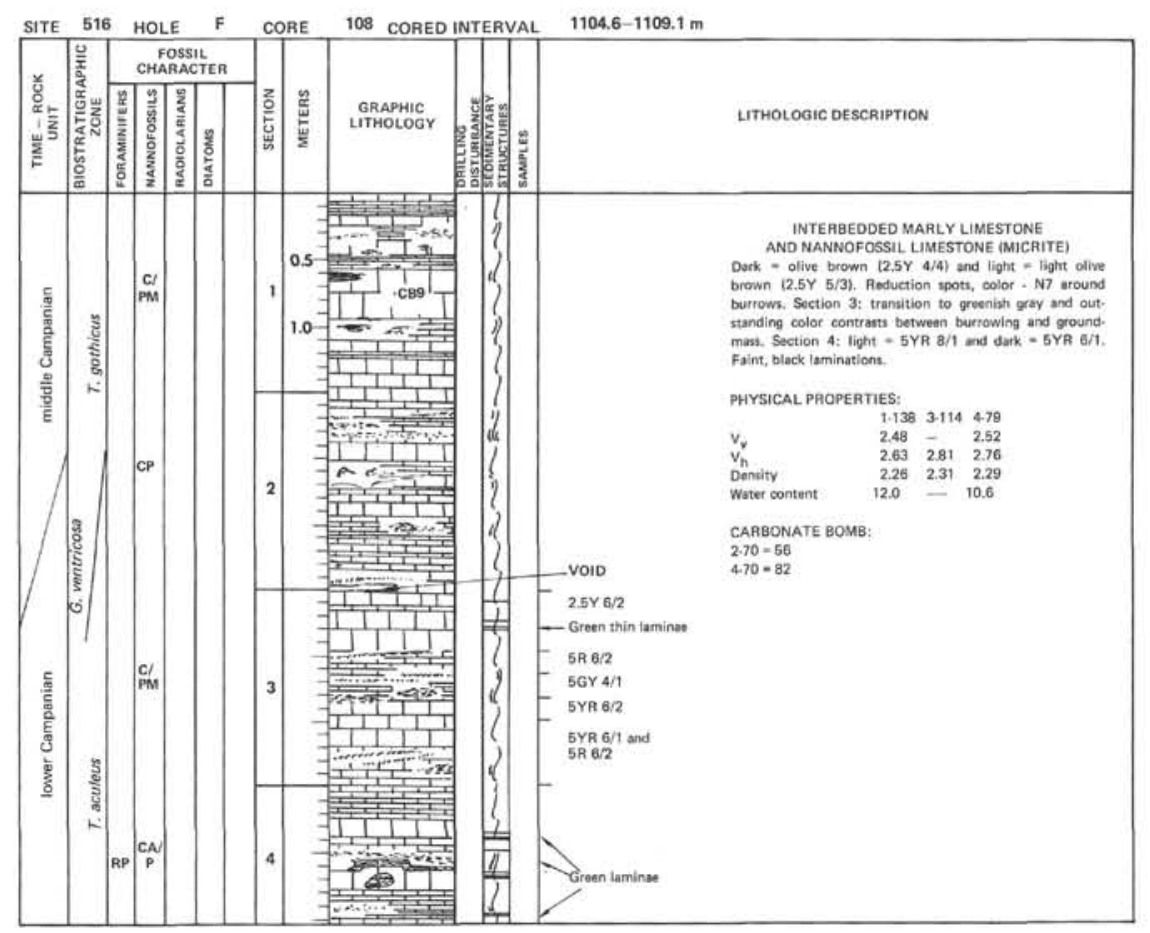

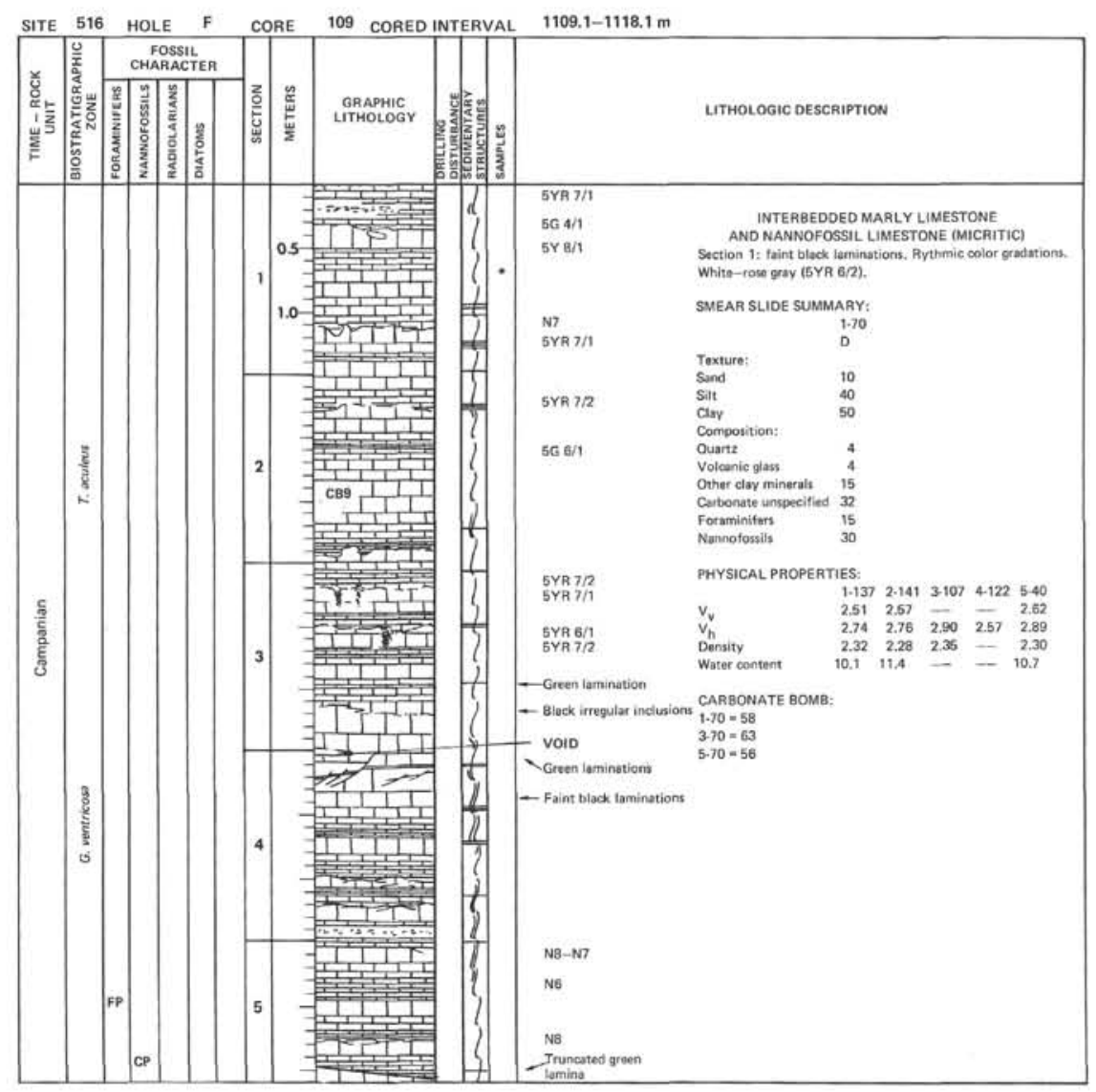




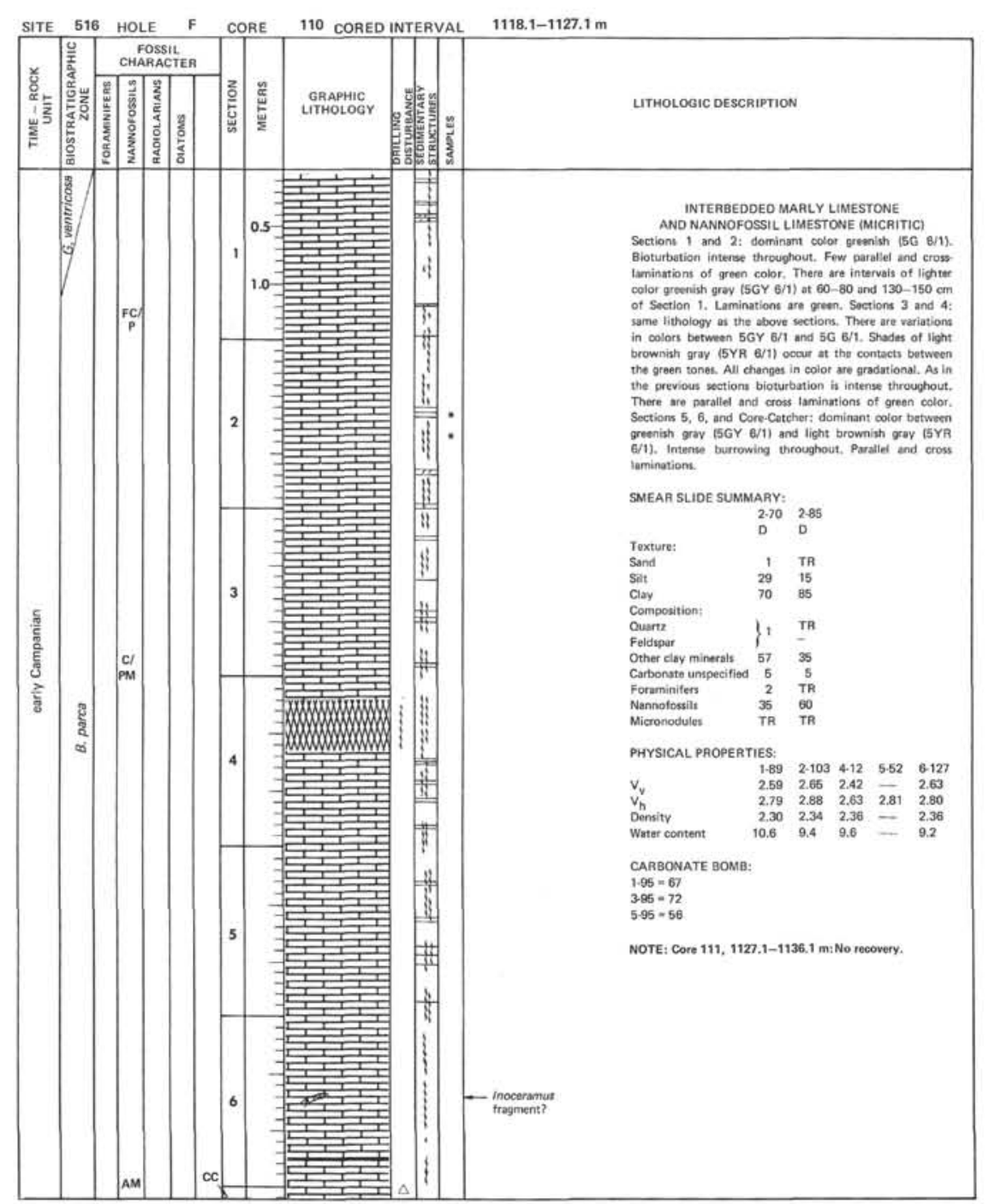

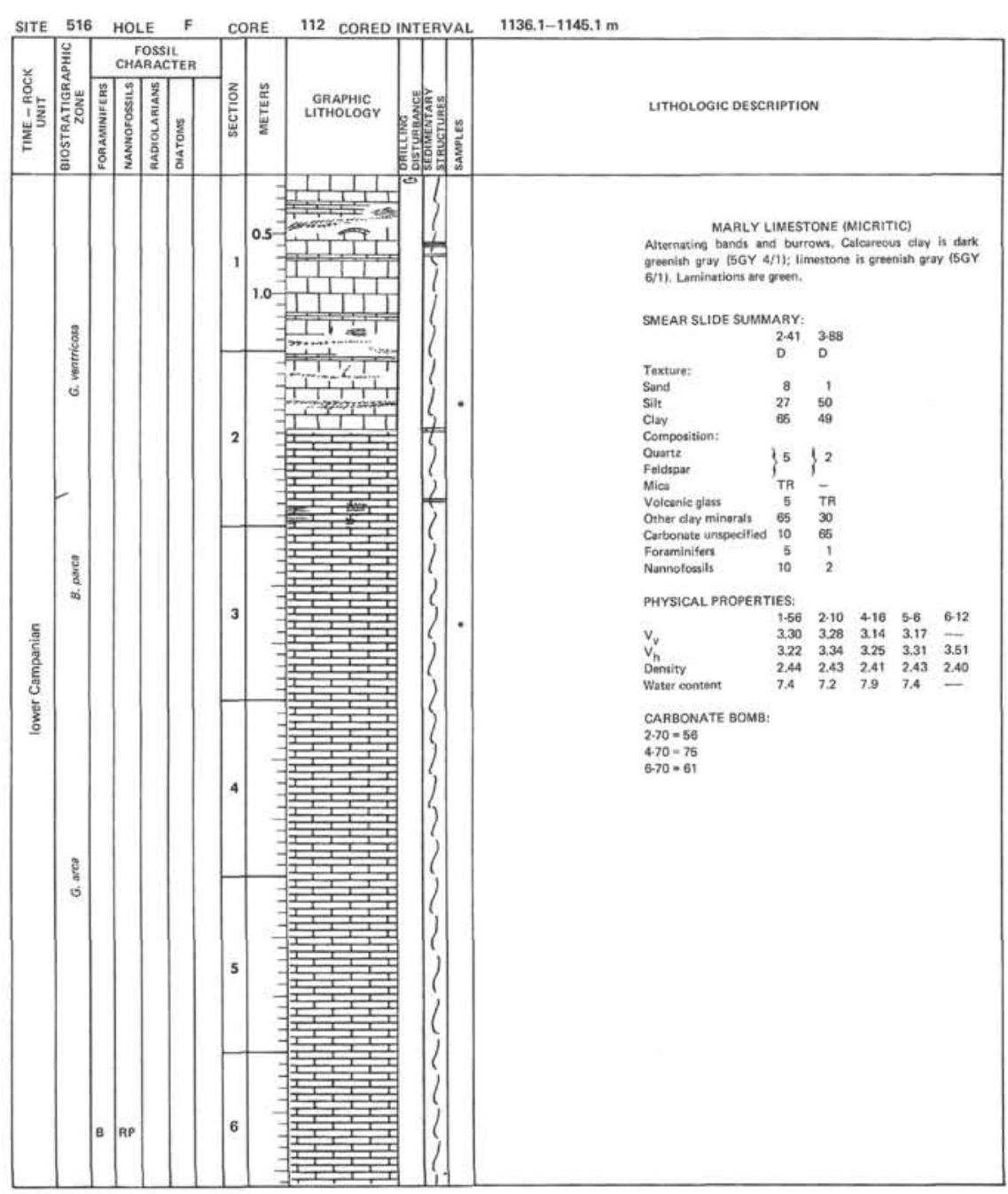



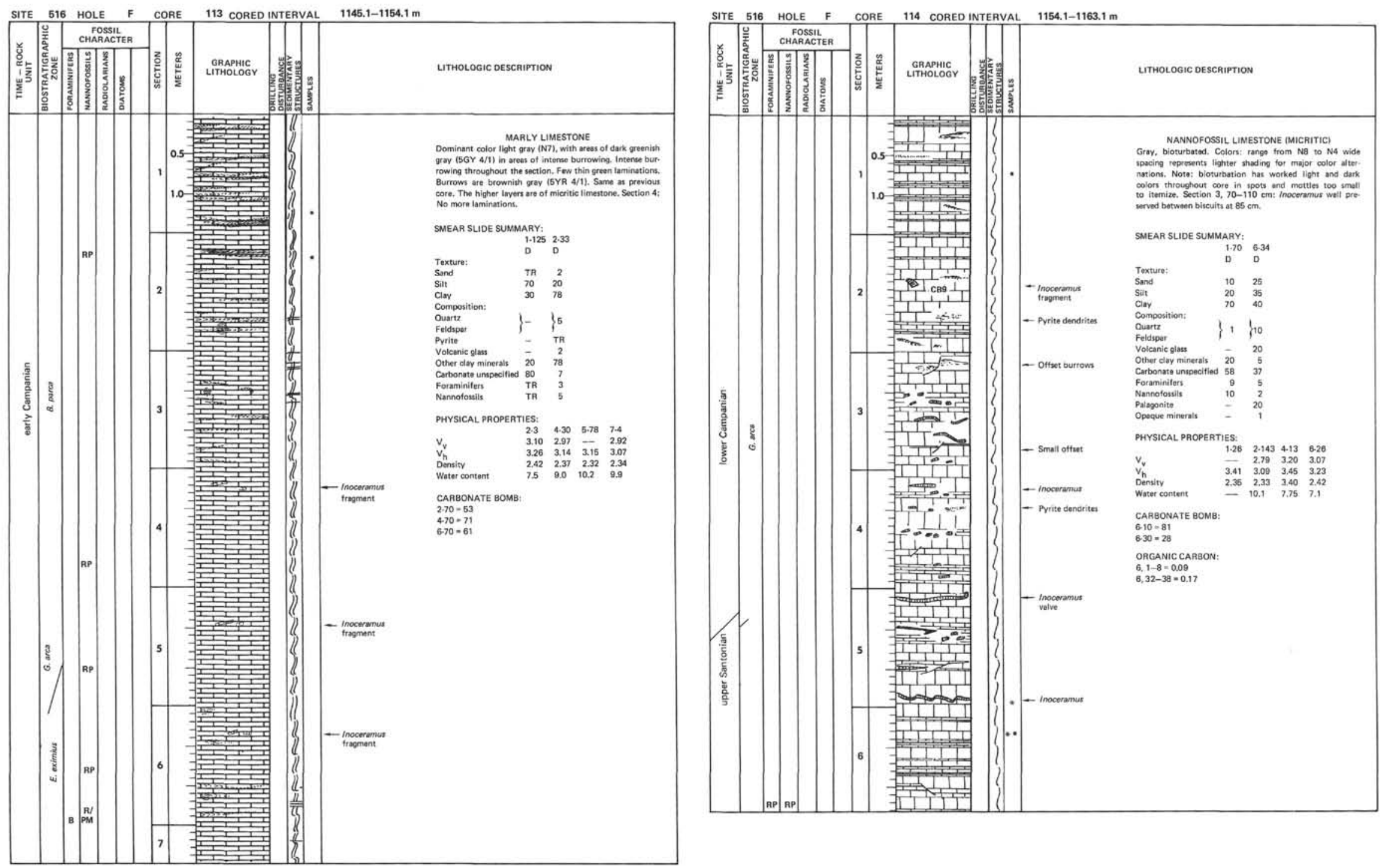


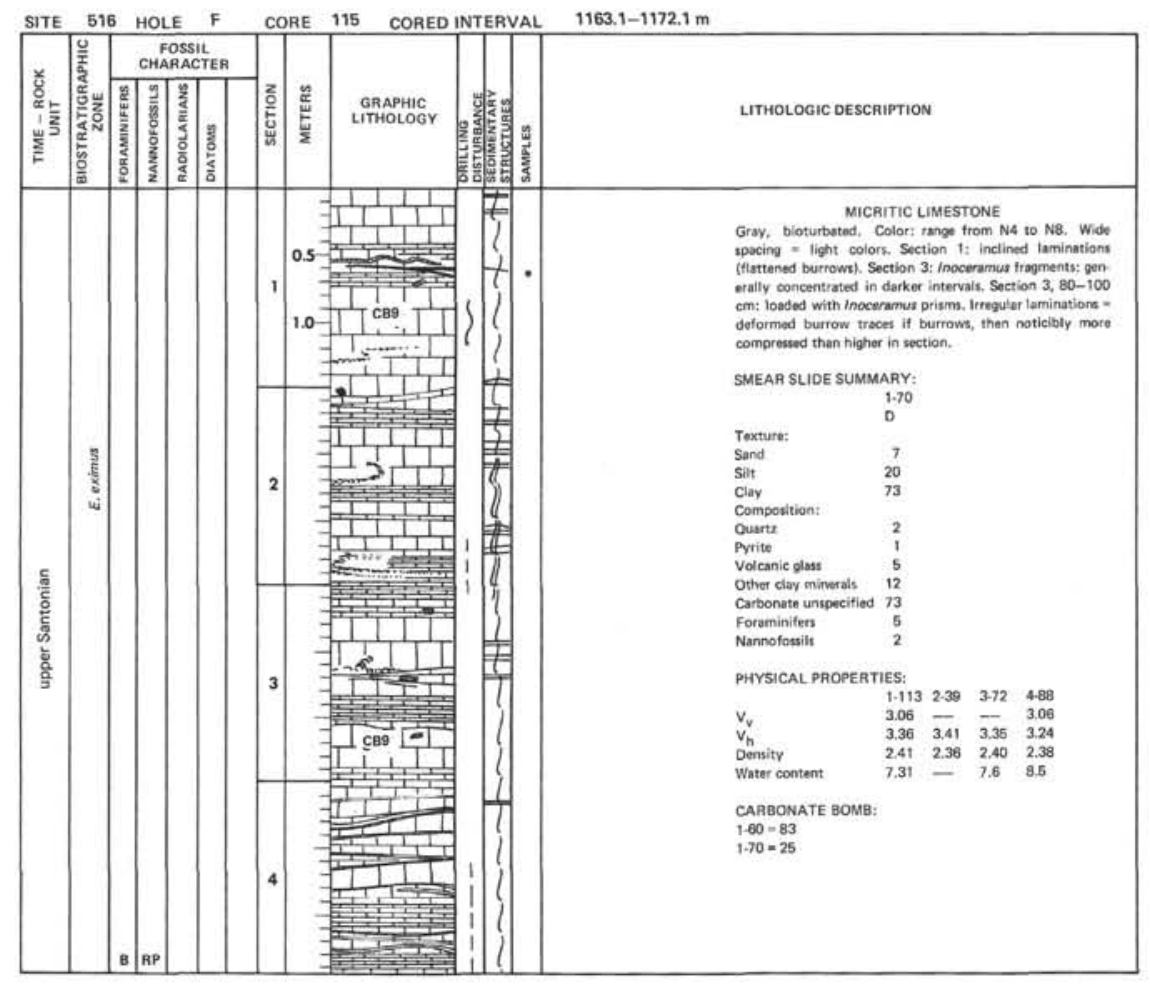

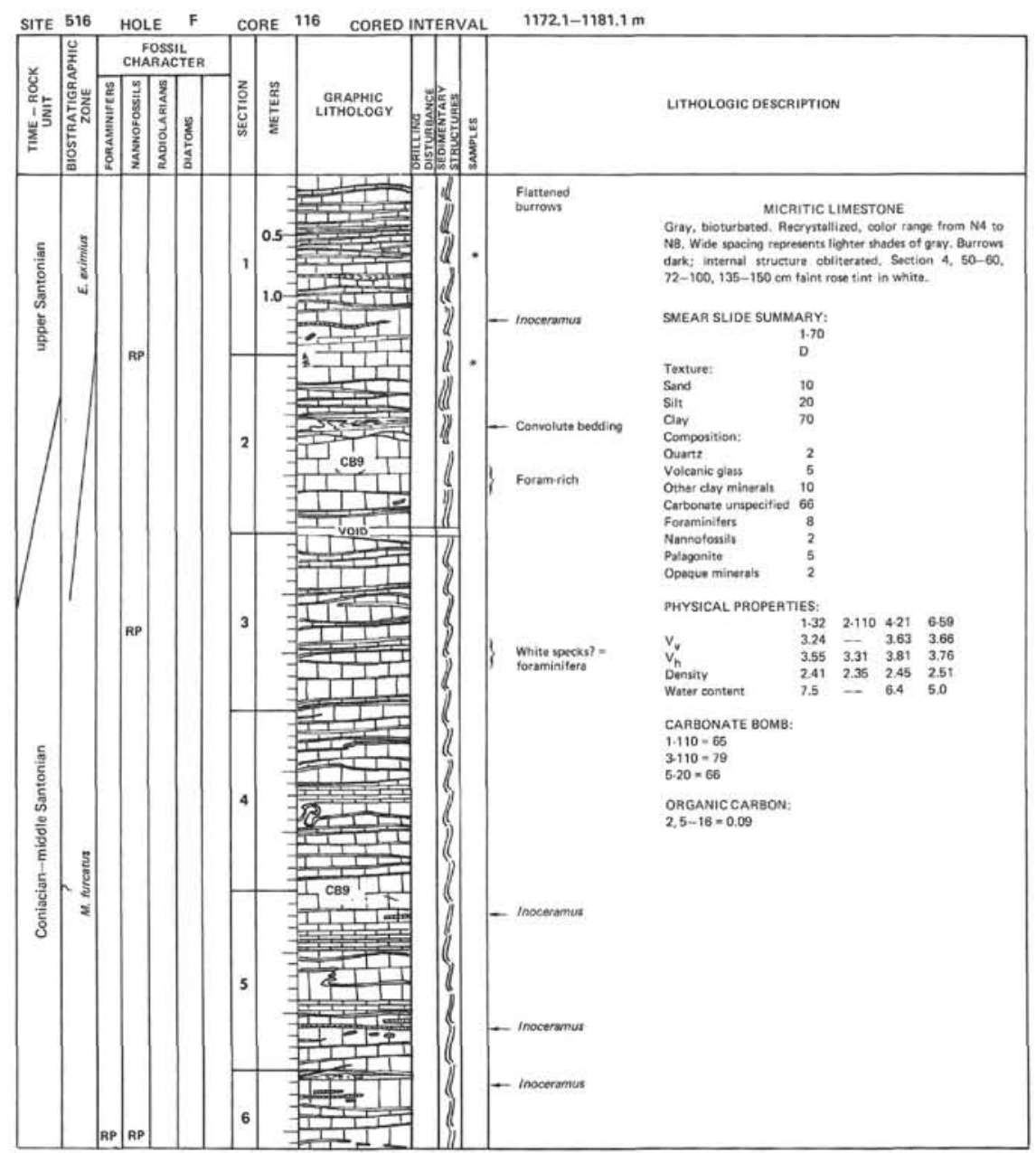




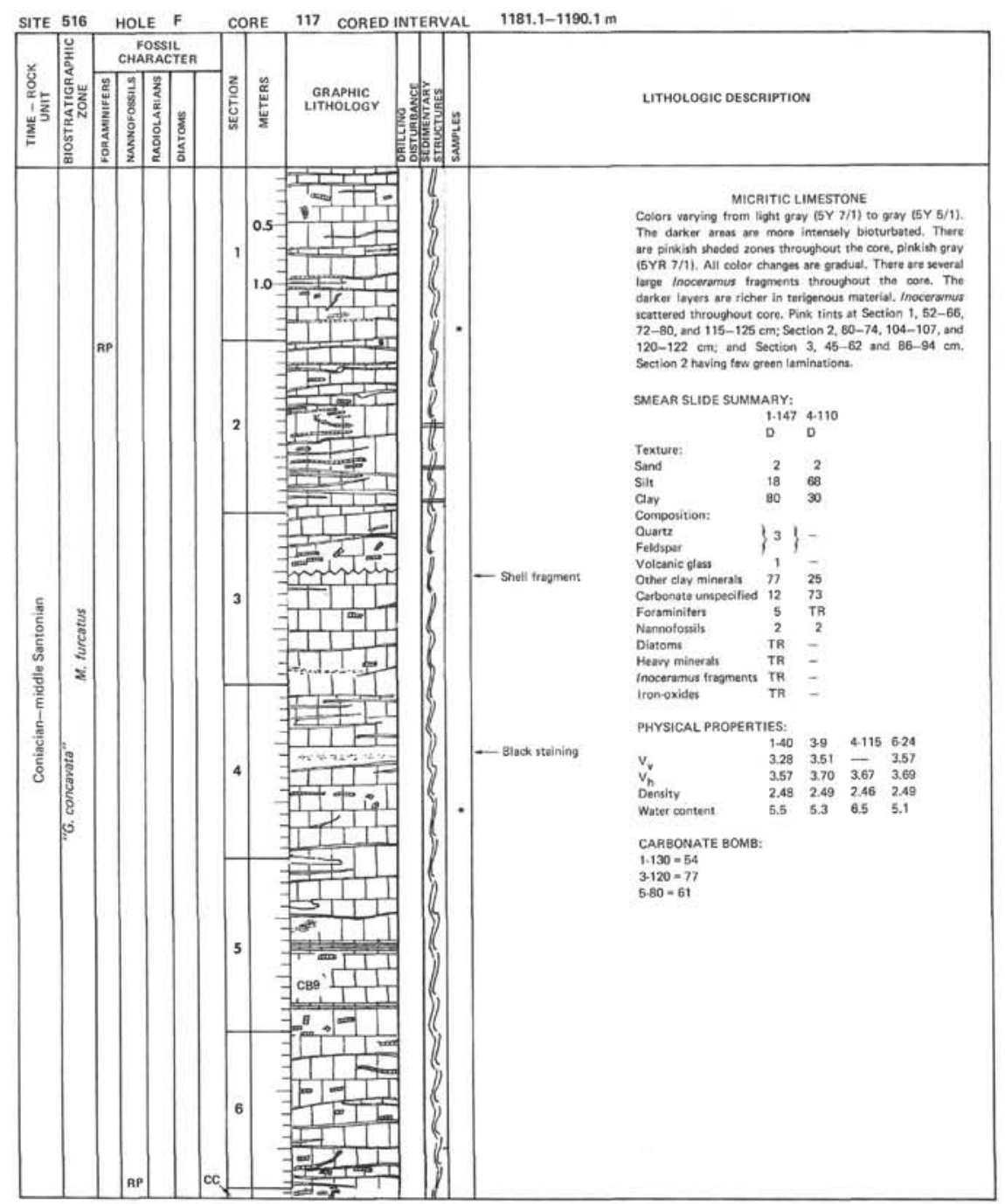

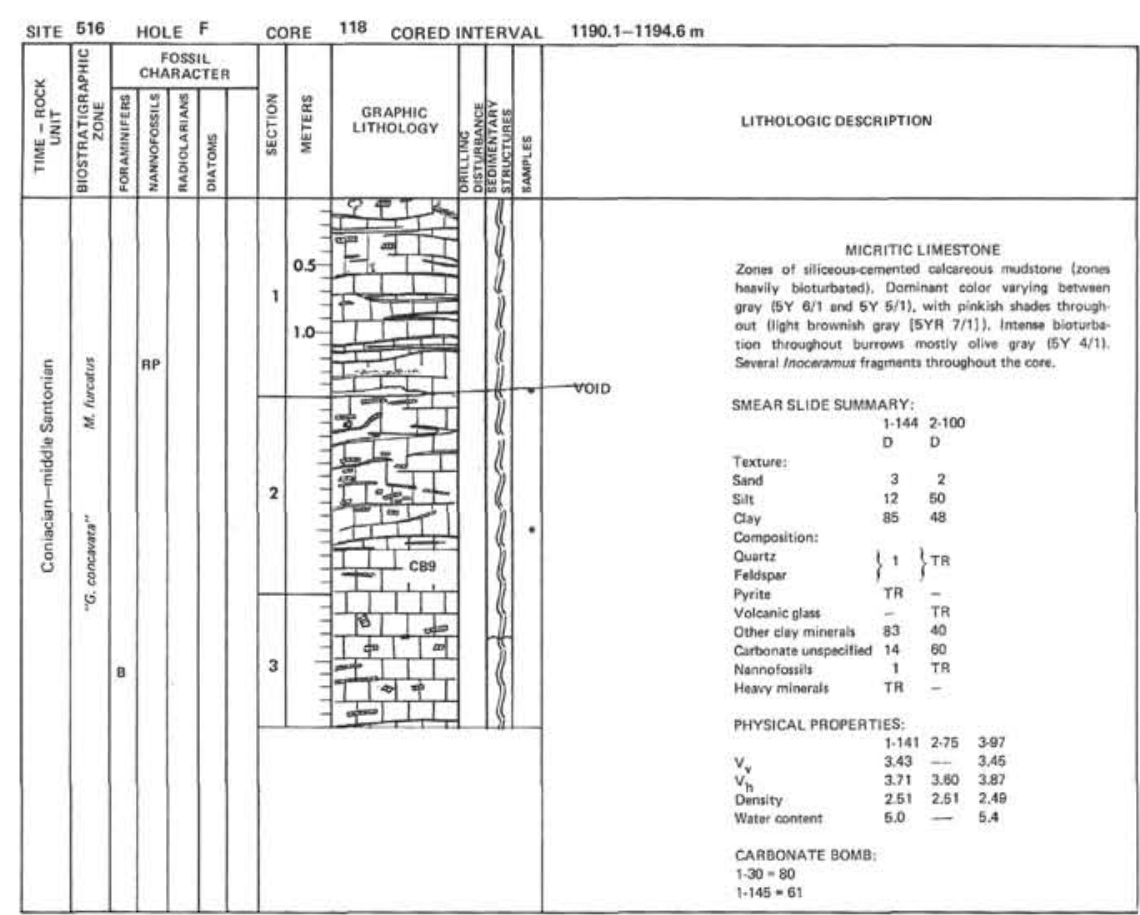



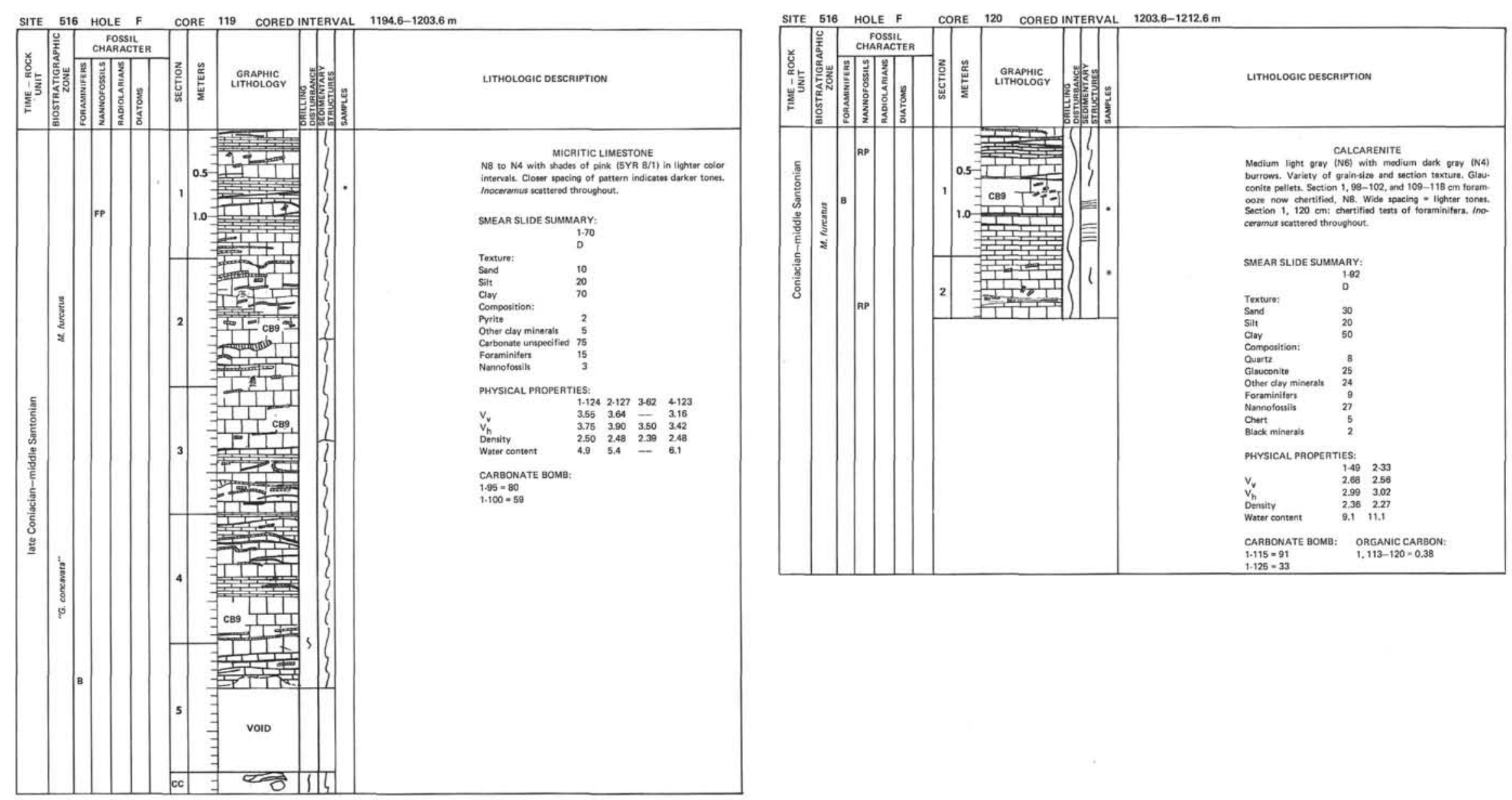

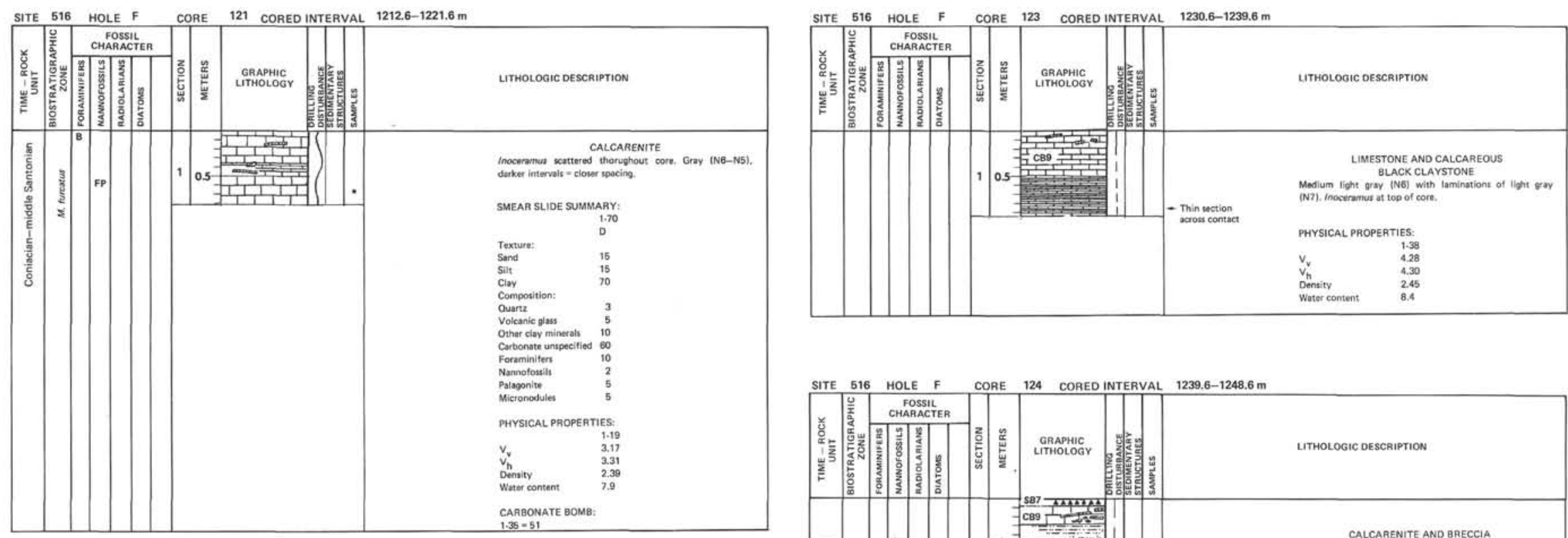

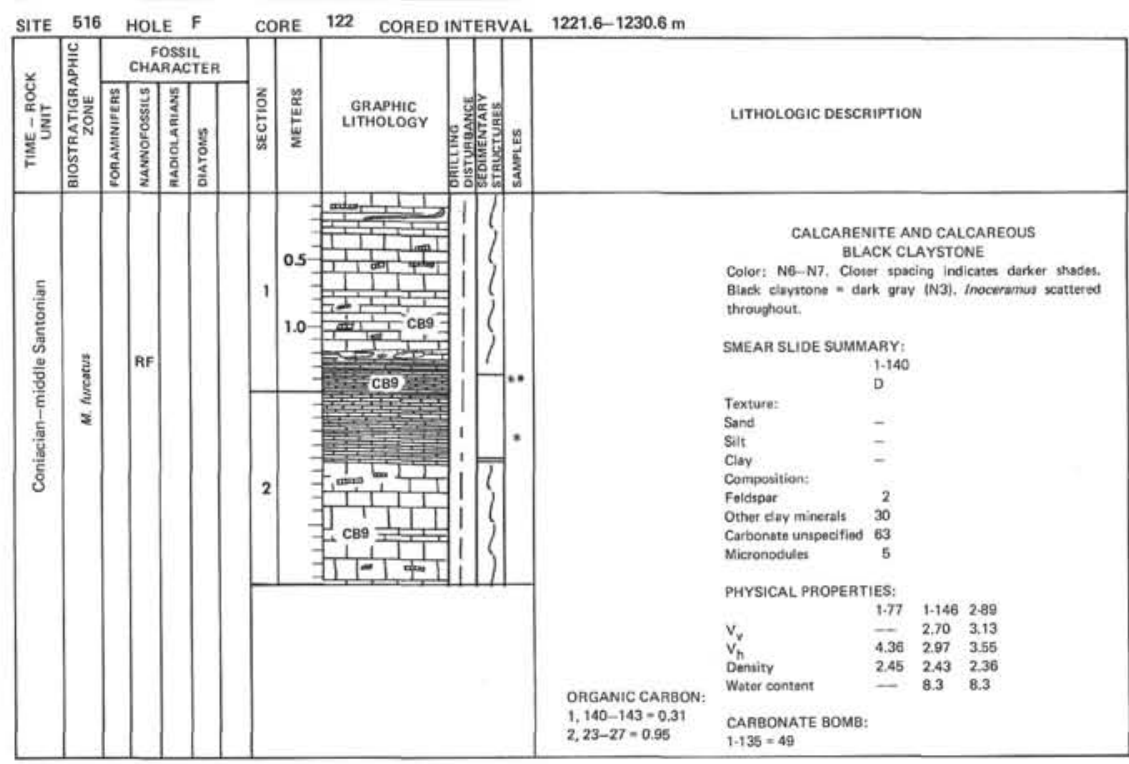

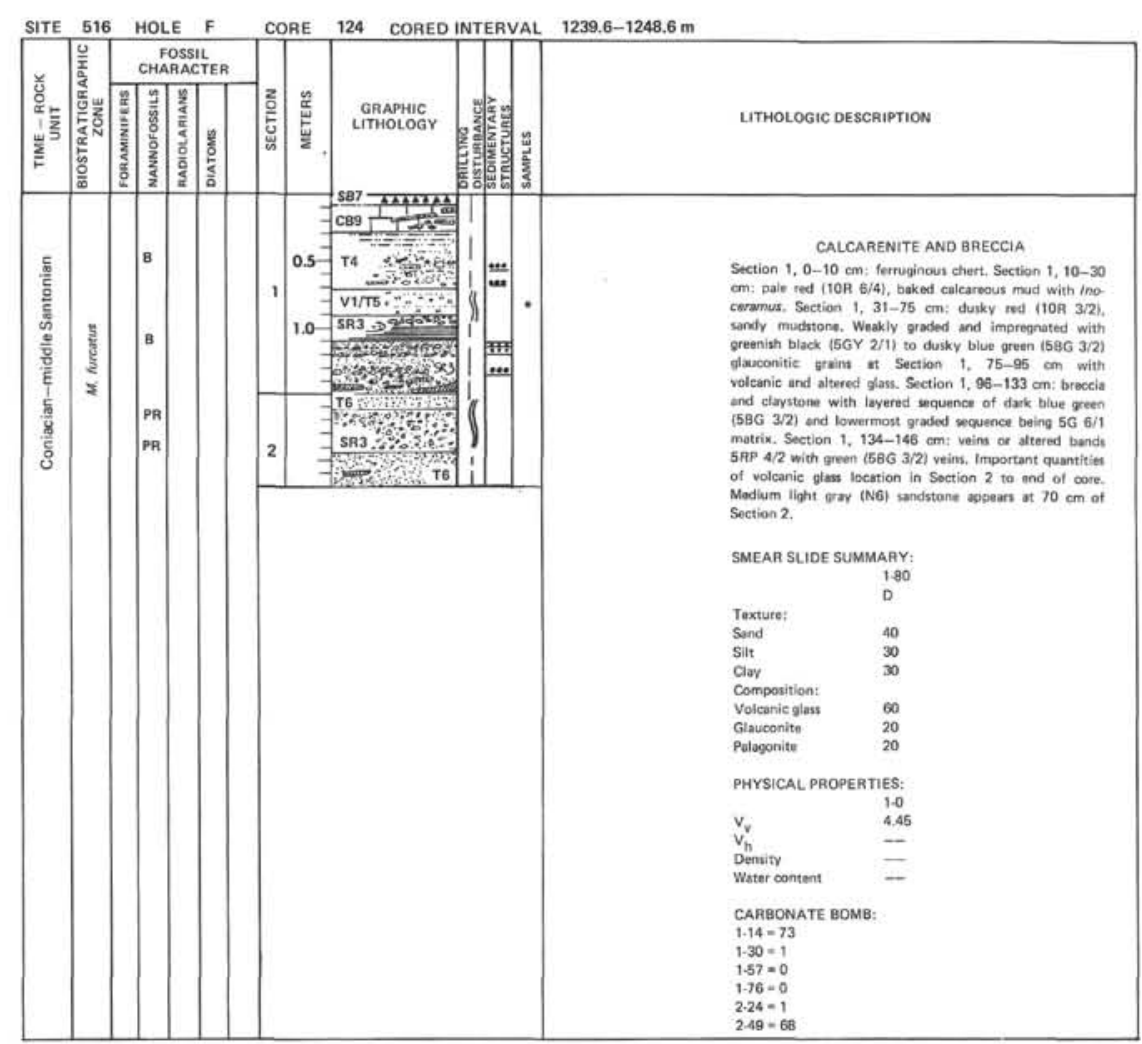




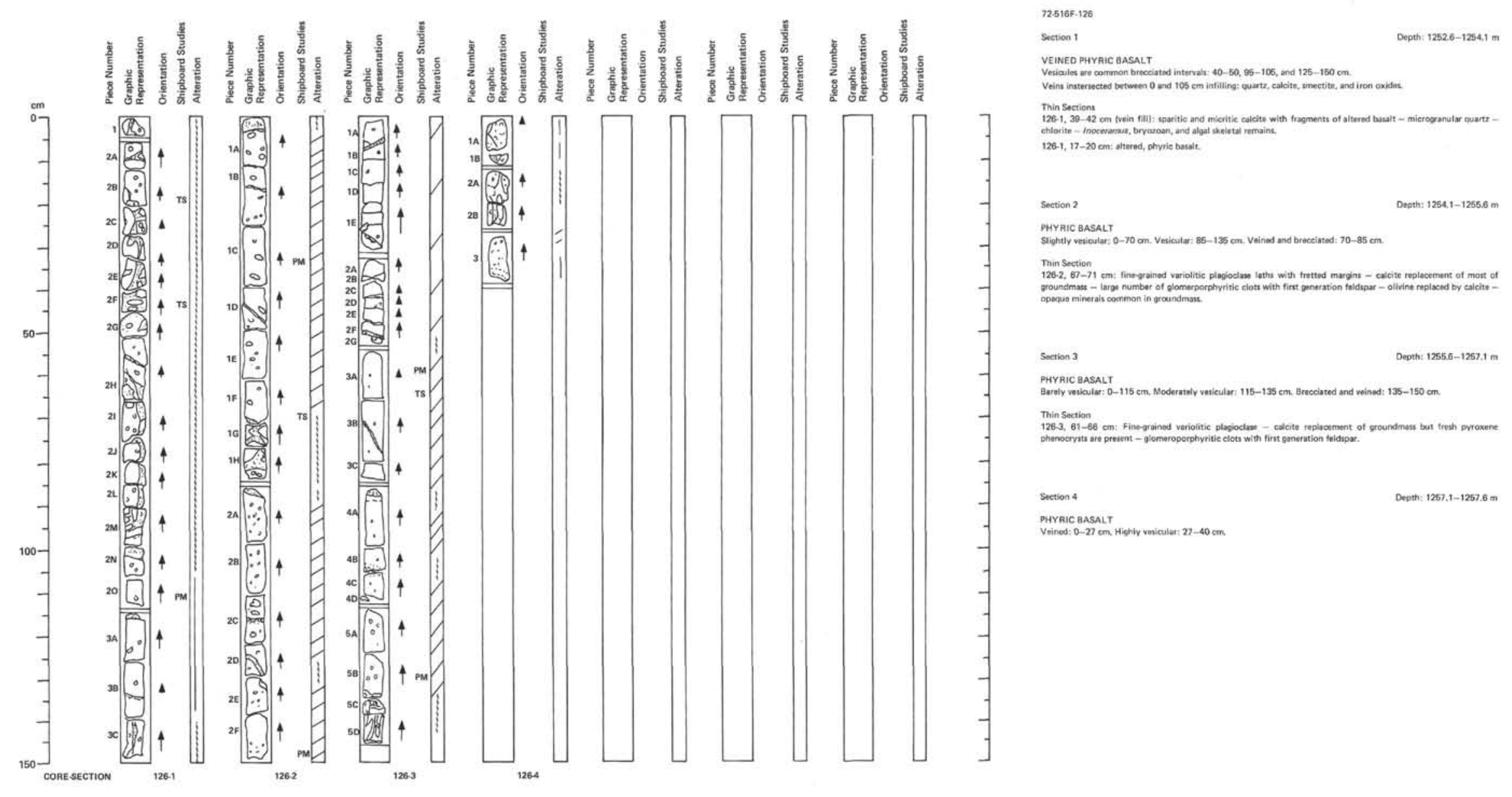




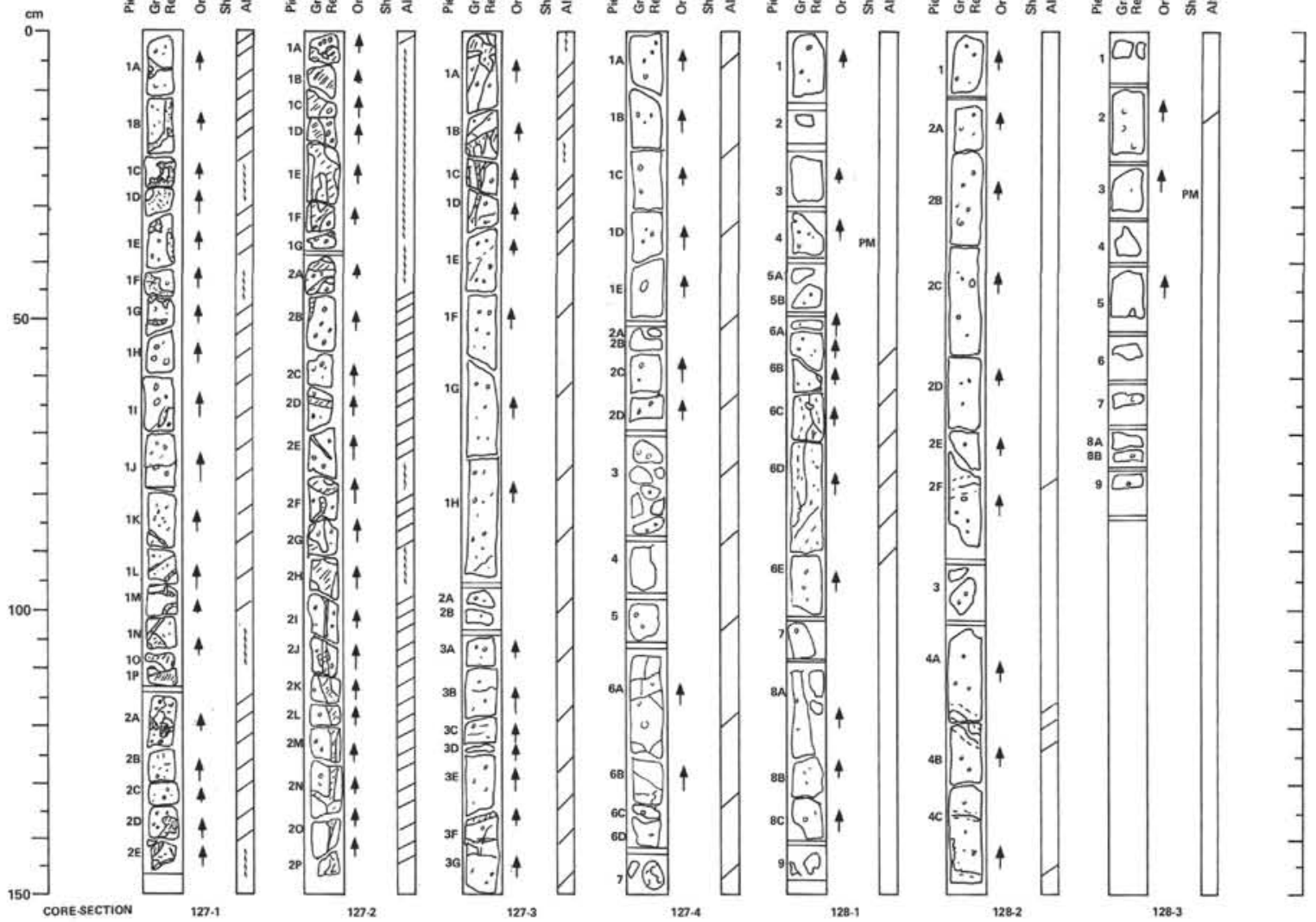

Section 2

Depth: $1259.1-1280.5 \mathrm{~m}$

DHYAIC Basait

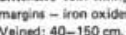

Soction 3

PHYRIC BASALT

Section 4

Deph: $1262.1-1206.6 \mathrm{~m}$

2.5165.120

Section 1

PHYAIC BASALT

Soction 2

Depth: 1268.1-126.96 m

PYYAIC BASALT

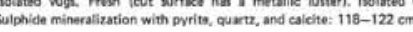

Section 3

Dopth: $1269.6-1270.6 \mathrm{~m}$

PHYRIC BASALT 


\begin{tabular}{|l|l|l|l|l|l|l|l|}
\hline \\
$\mid$
\end{tabular}




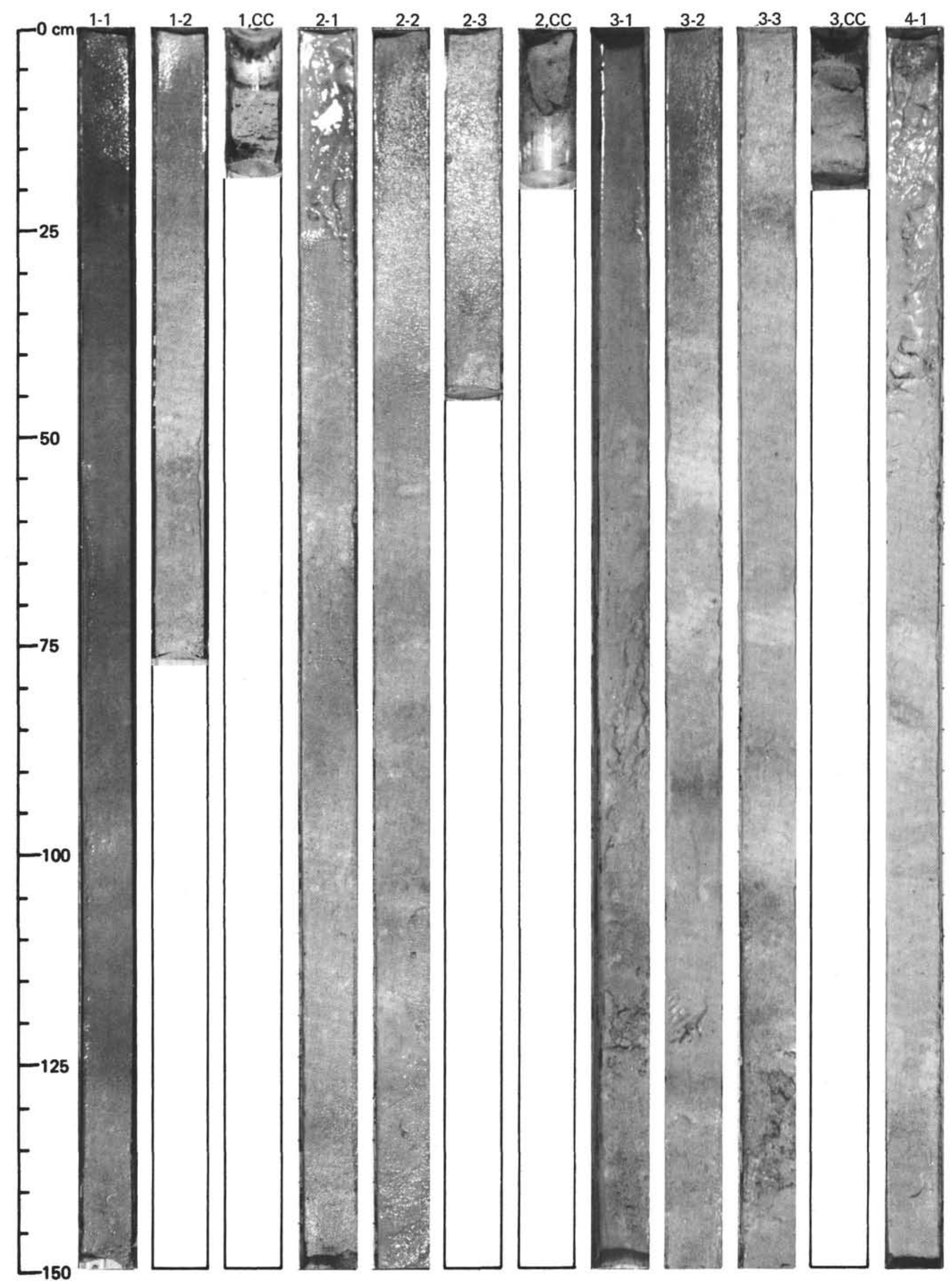


SITE 516 (HOLE 516)






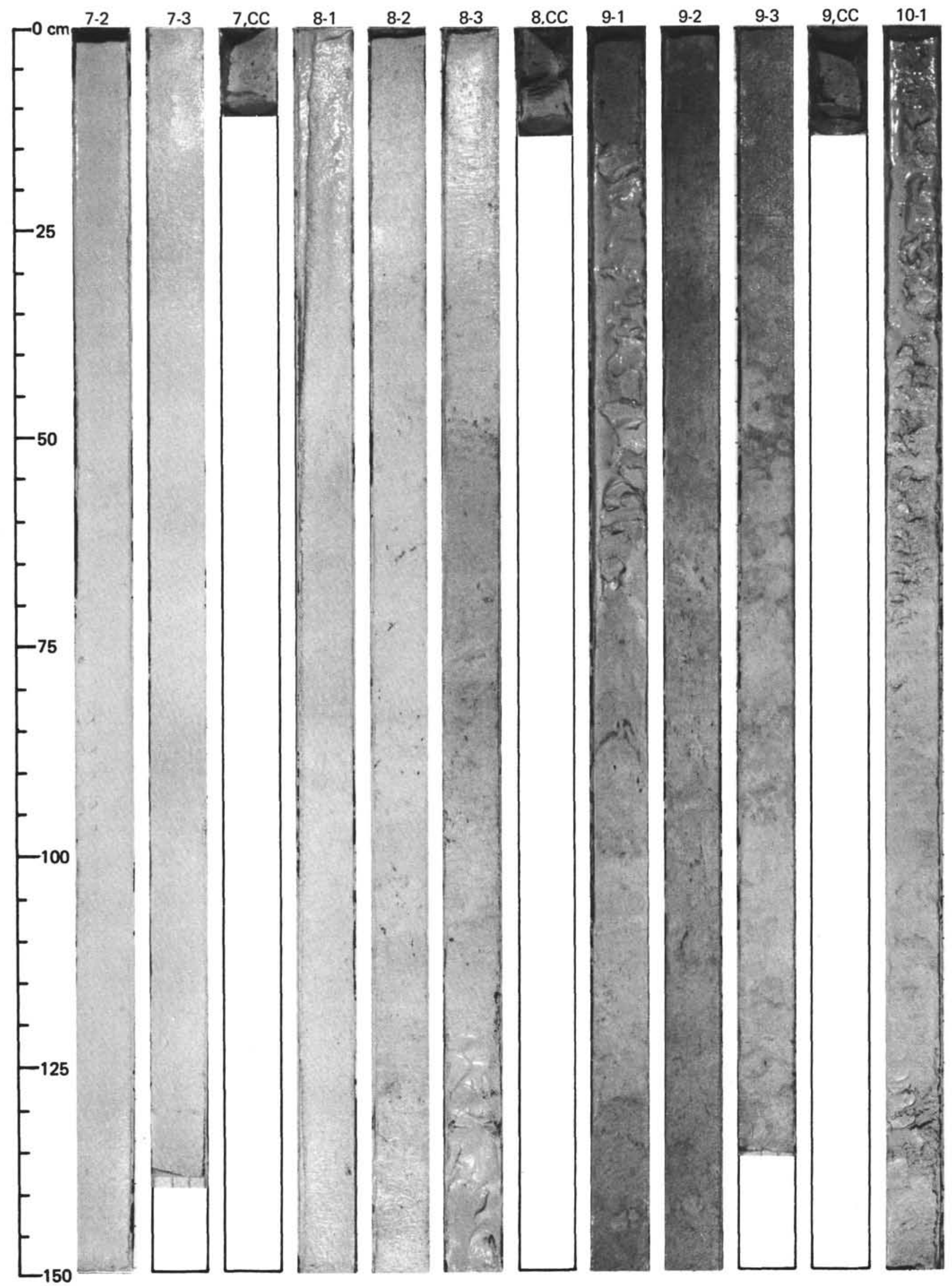


SITE 516 (HOLE 516)

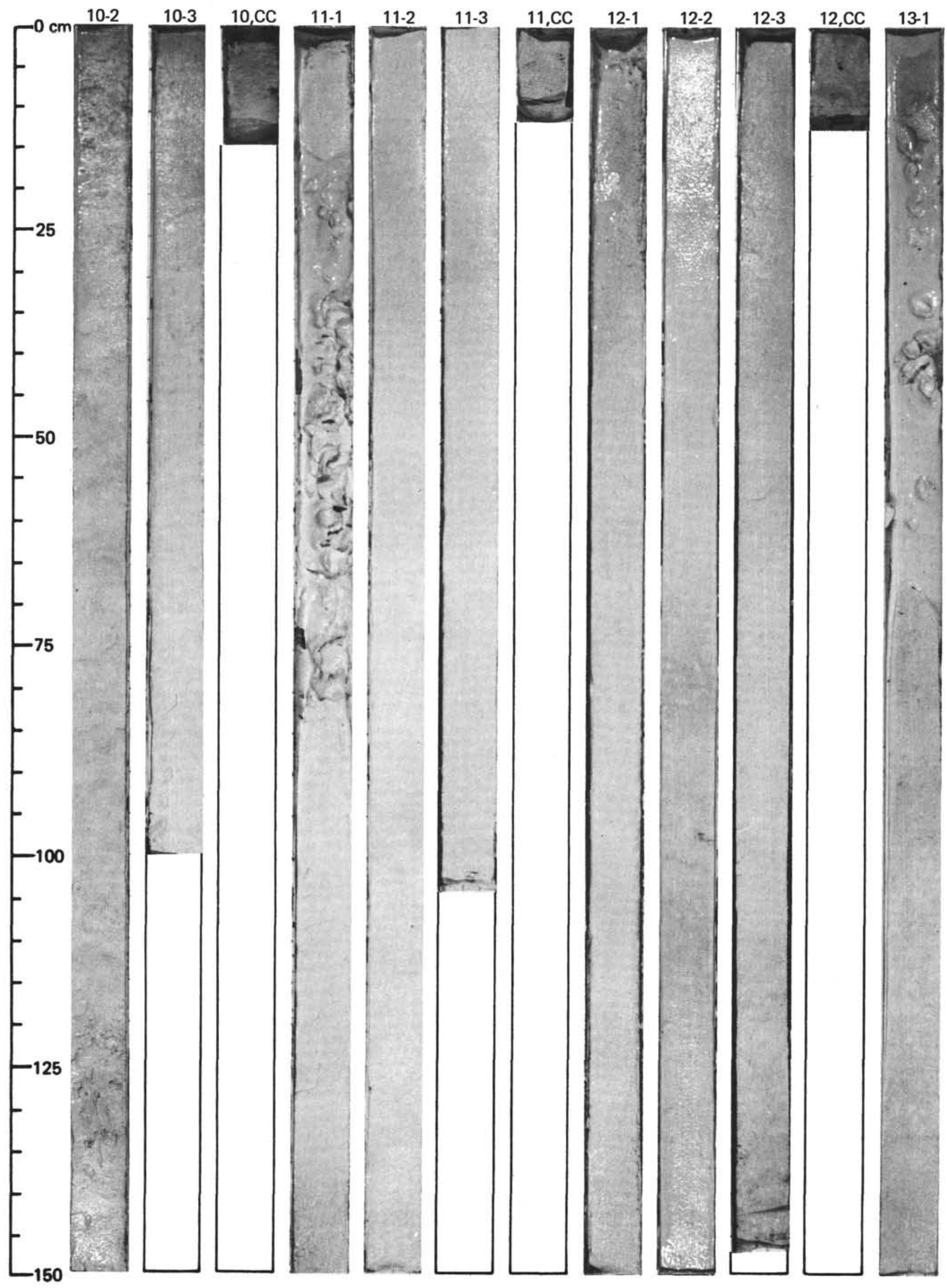




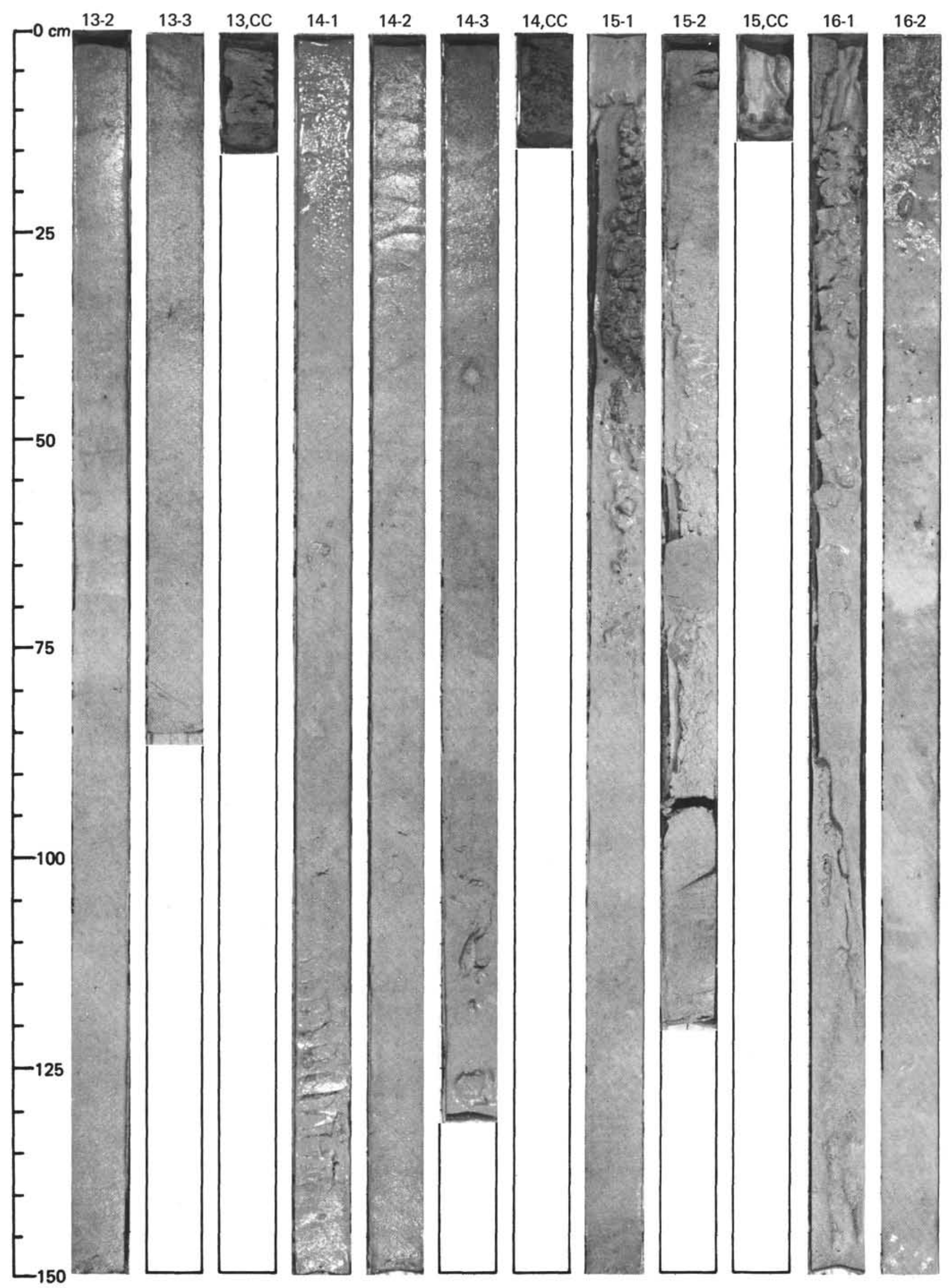


SITE 516 (HOLE 516)

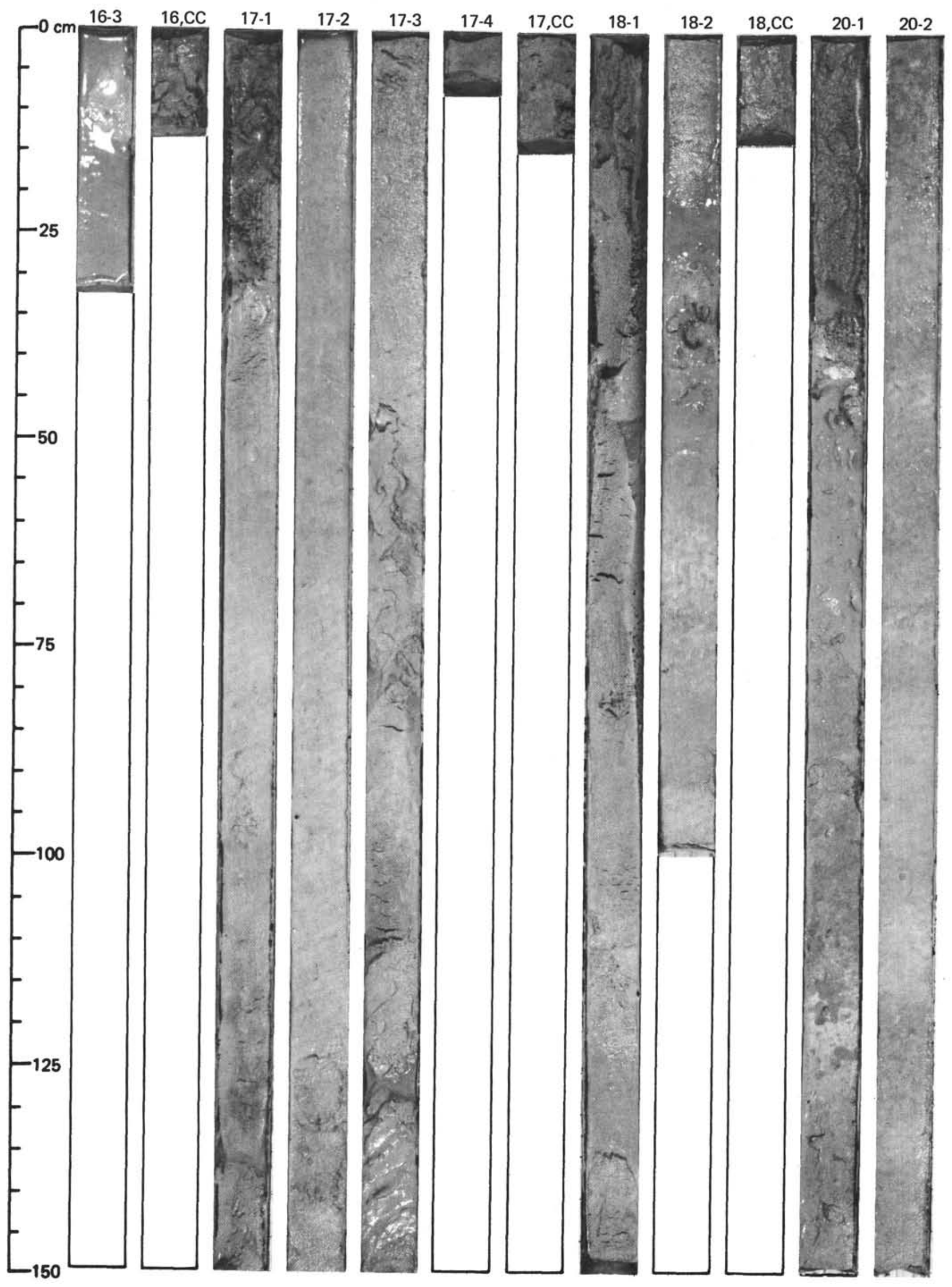




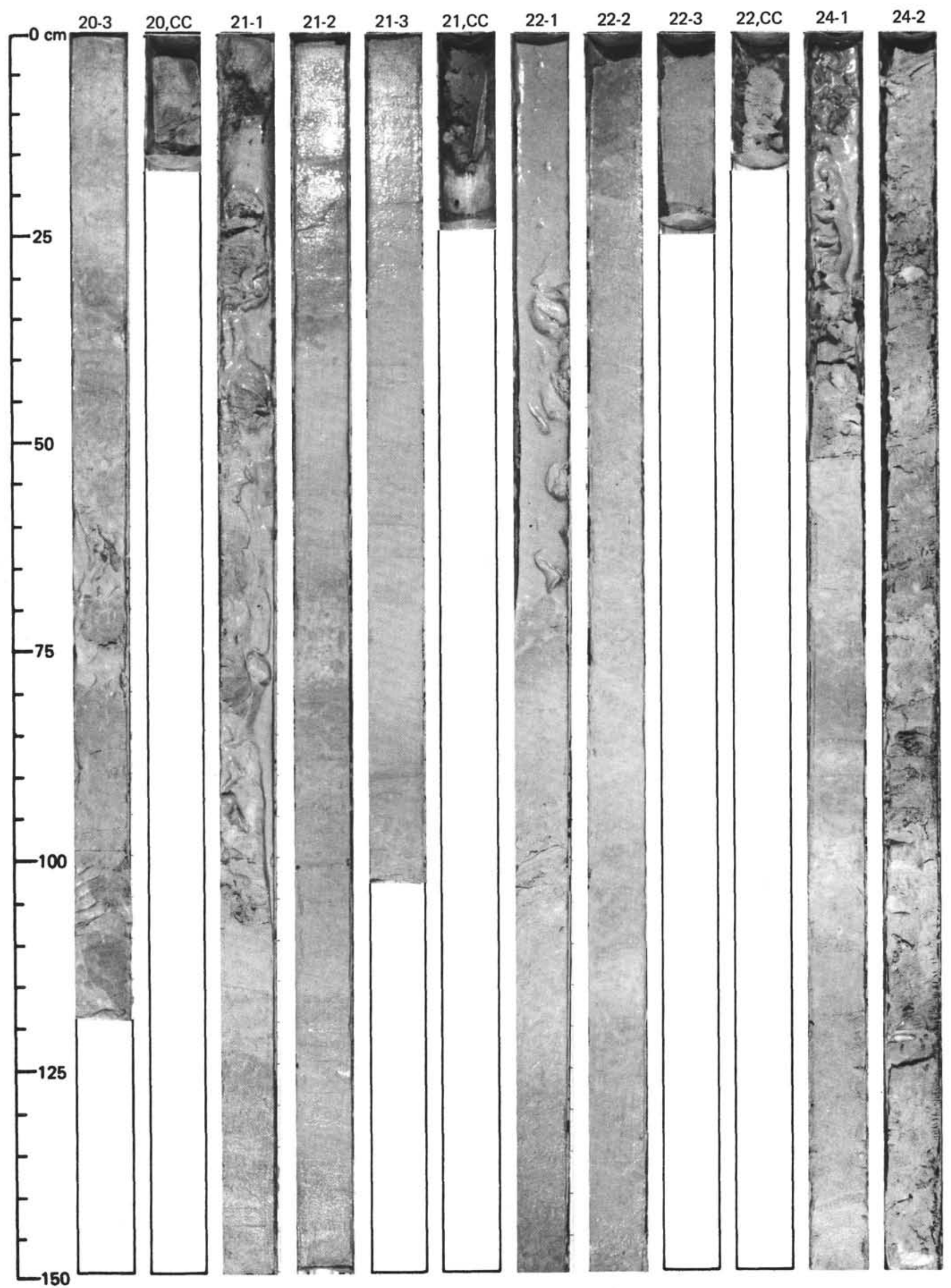




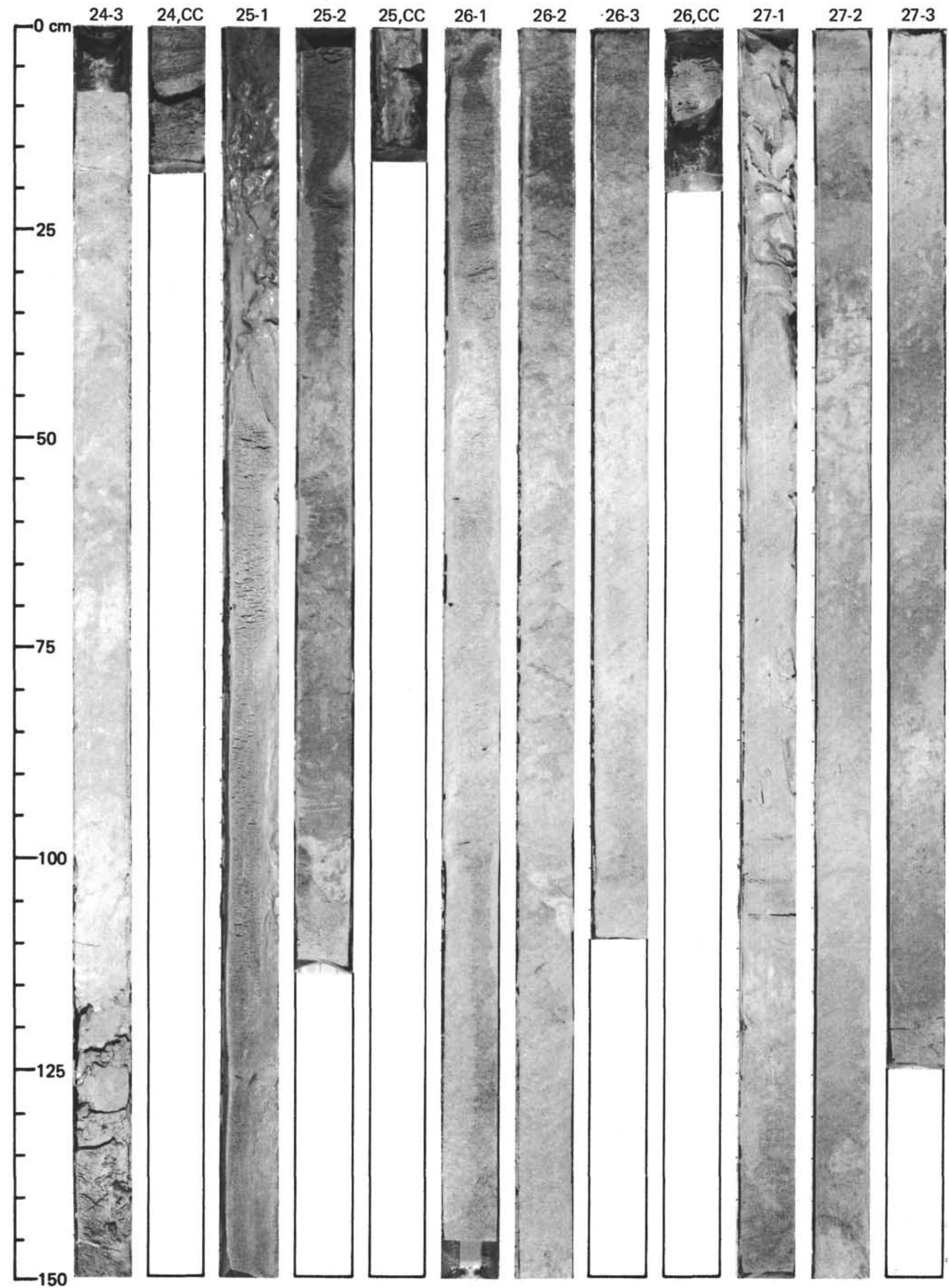




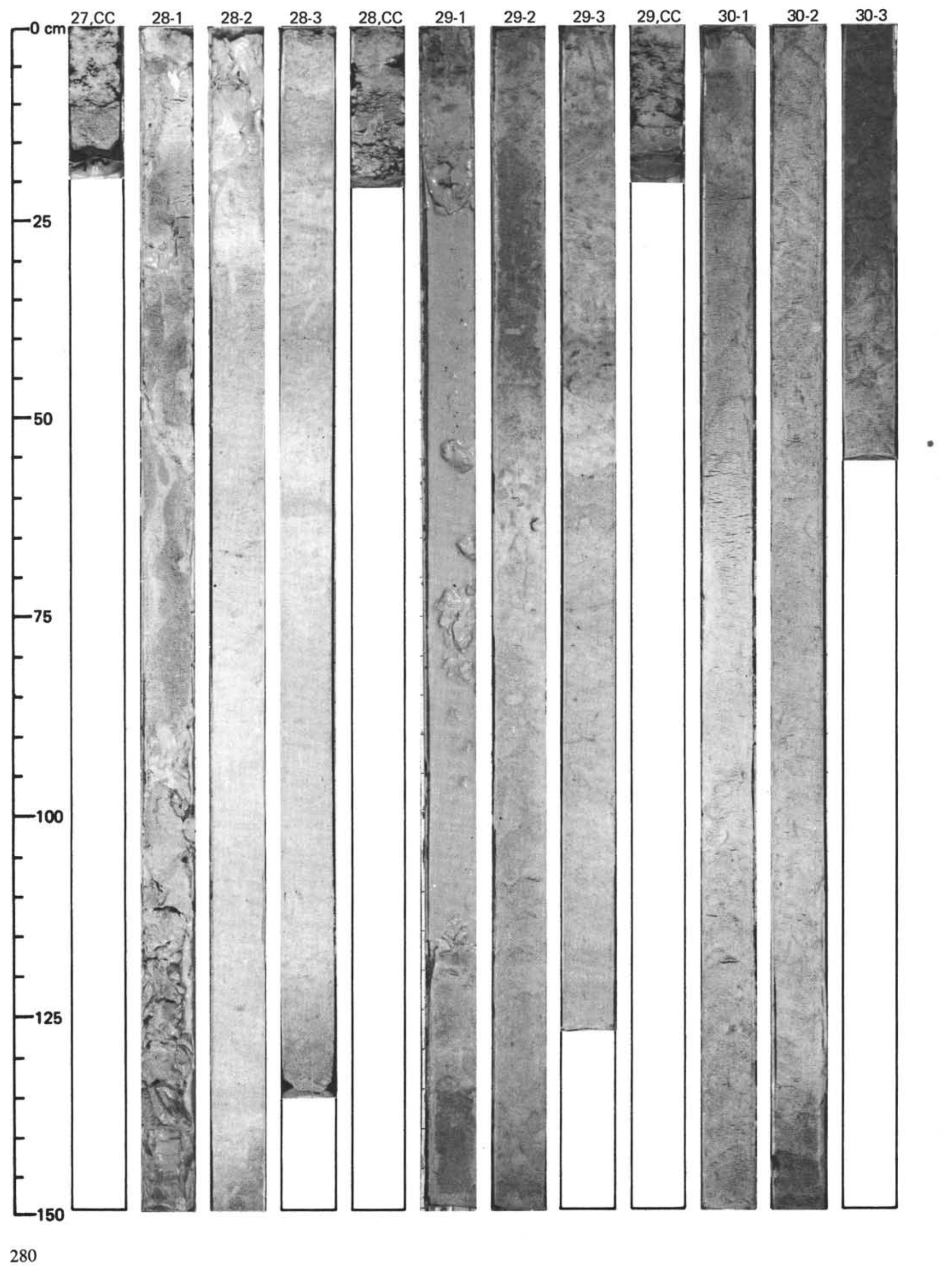


SITE 516 (HOLE 516)

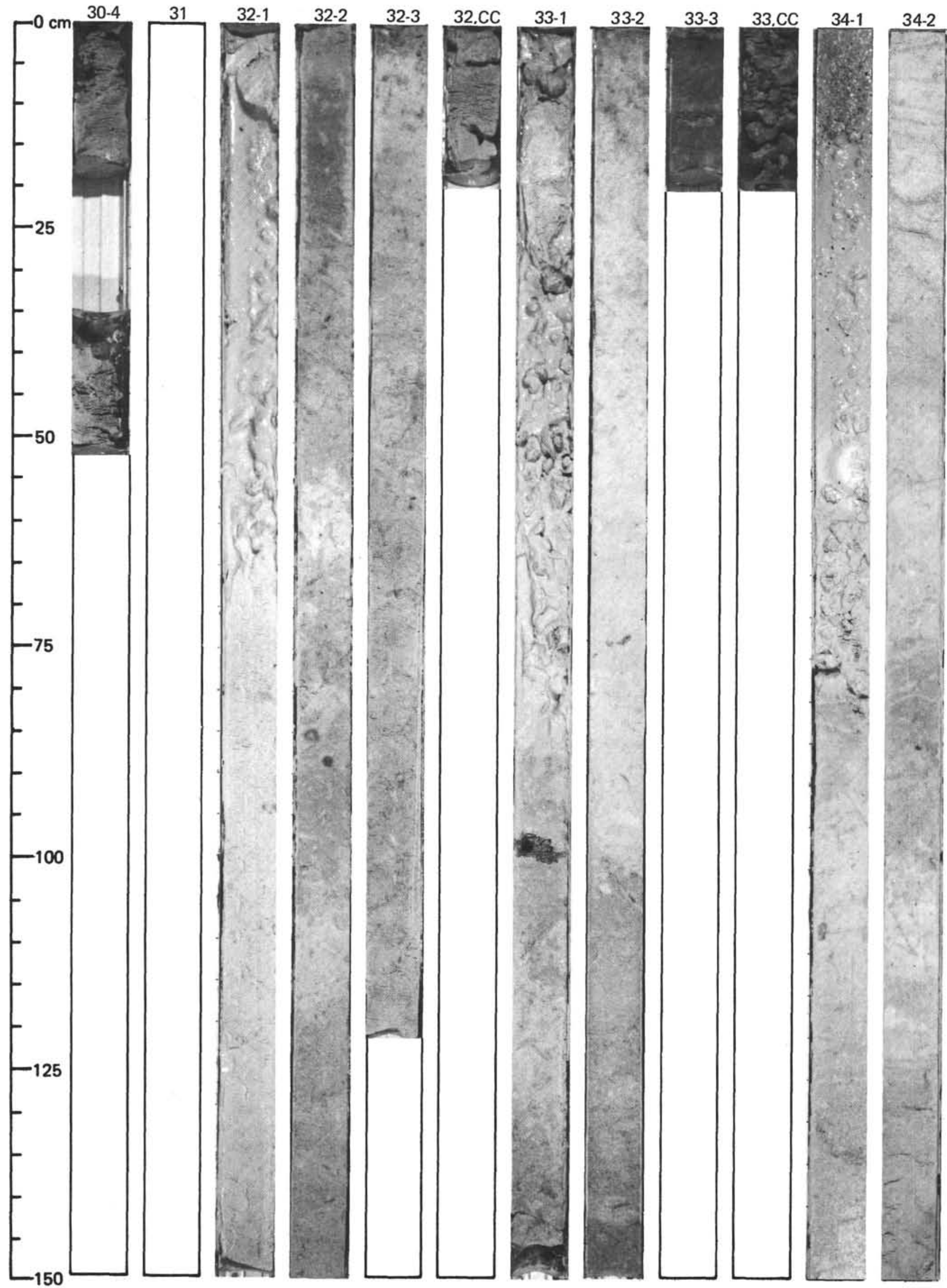


SITE 516 (HOLE 516)

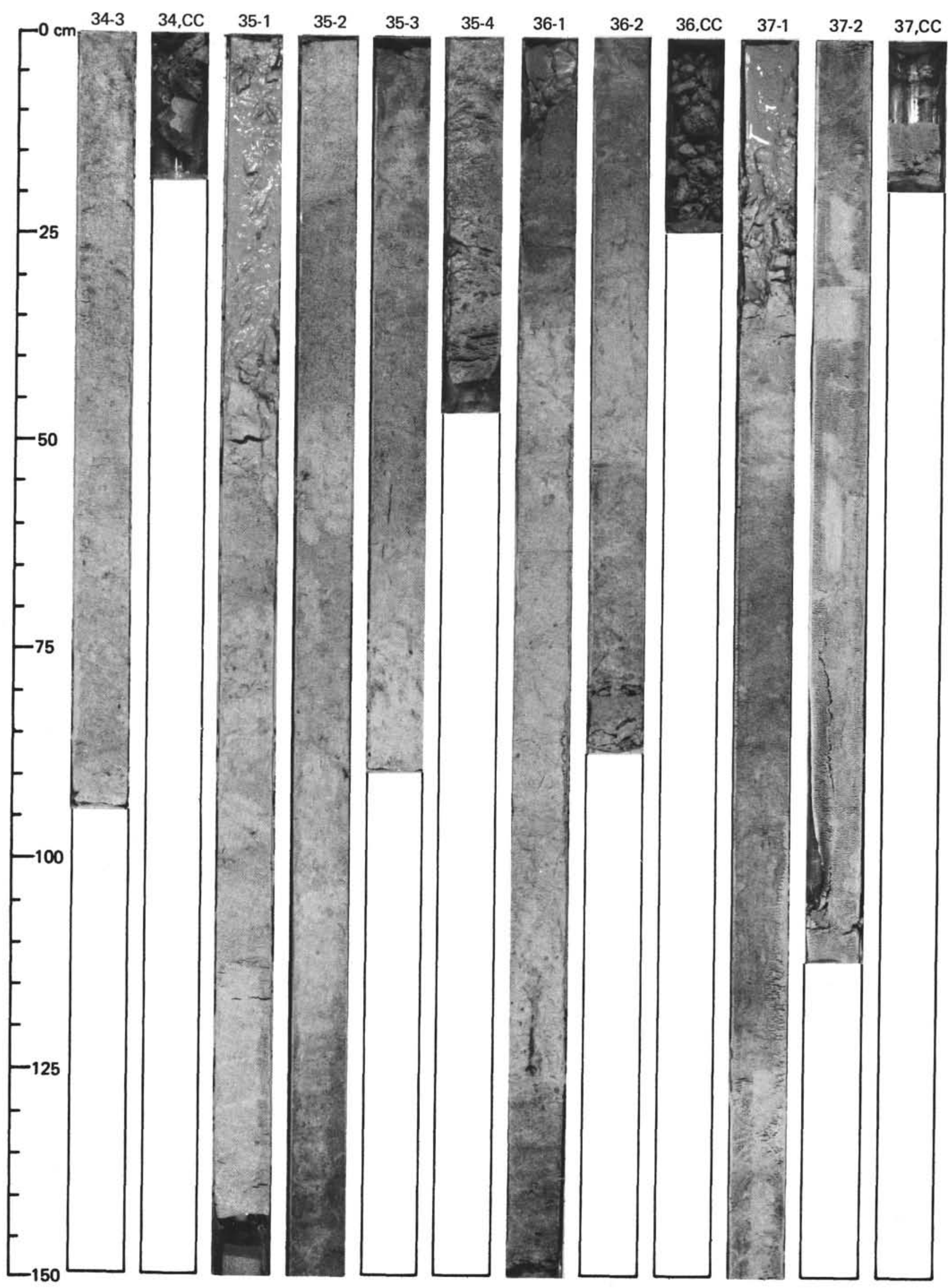


SITE 516 (HOLE 516)

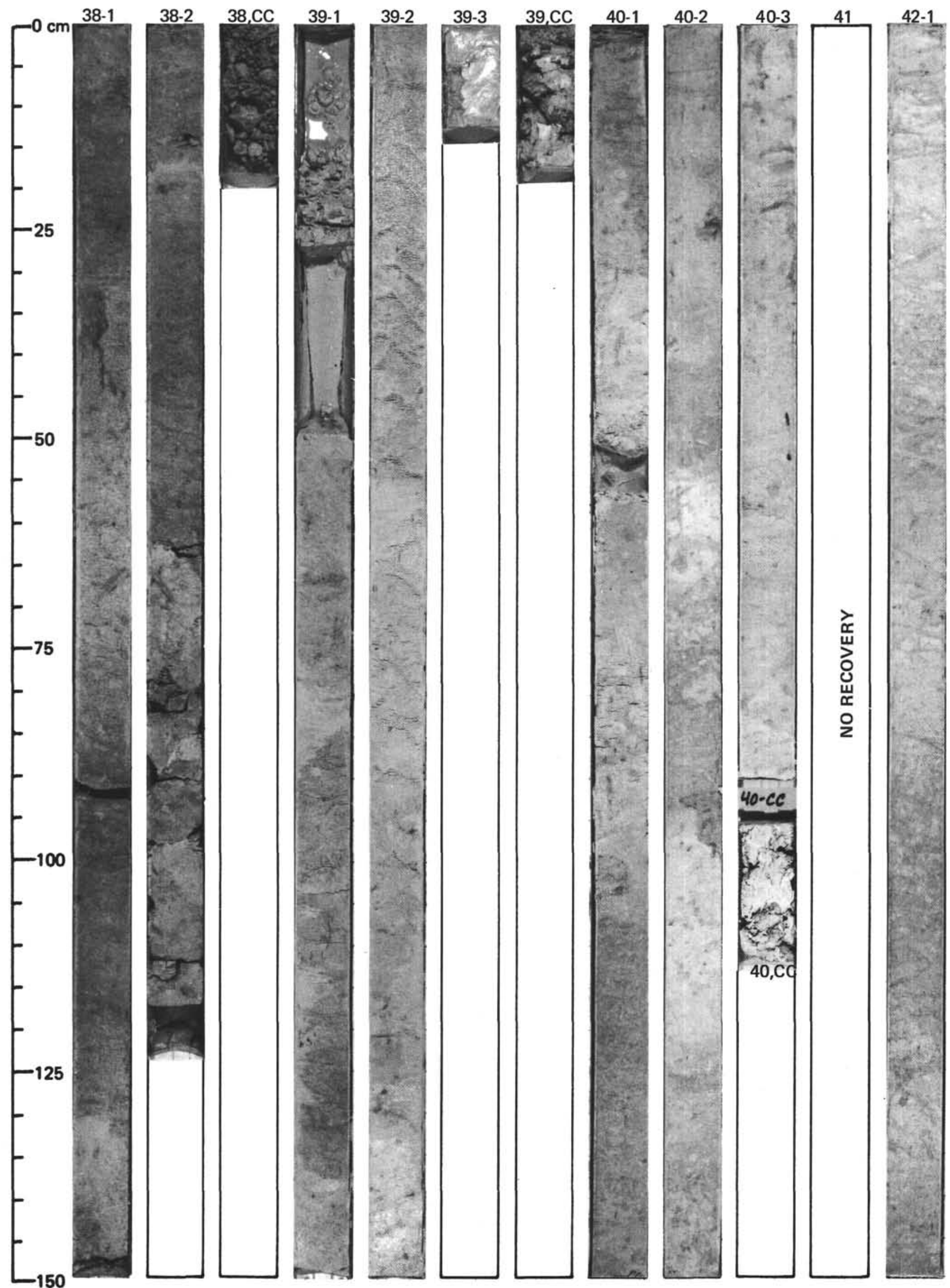


SITE 516 (HOLE 506)

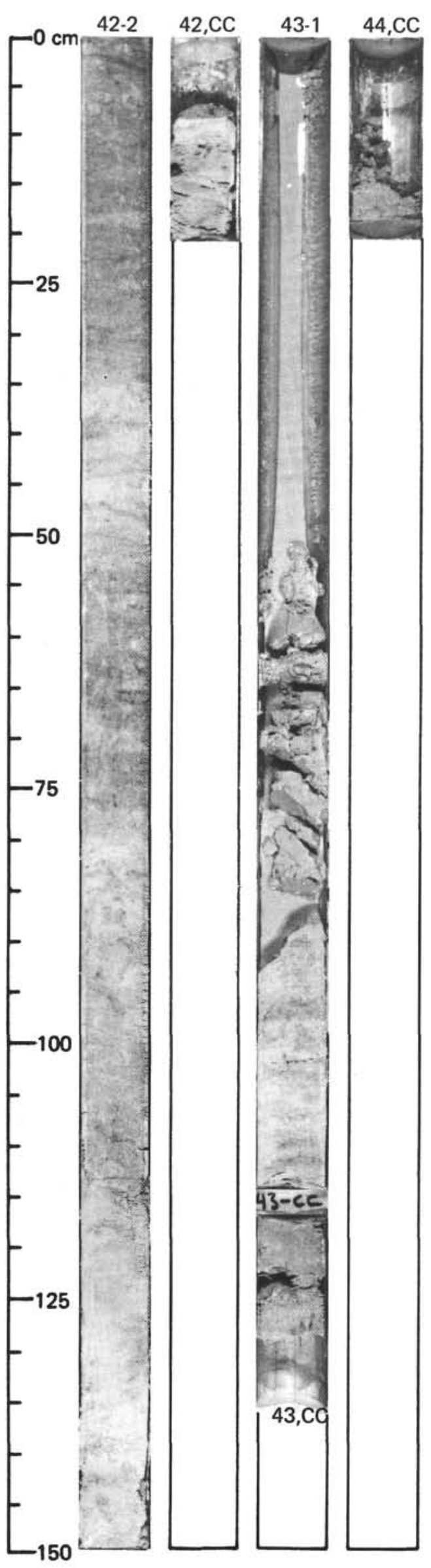


SITE 516 (HOLE 516A)






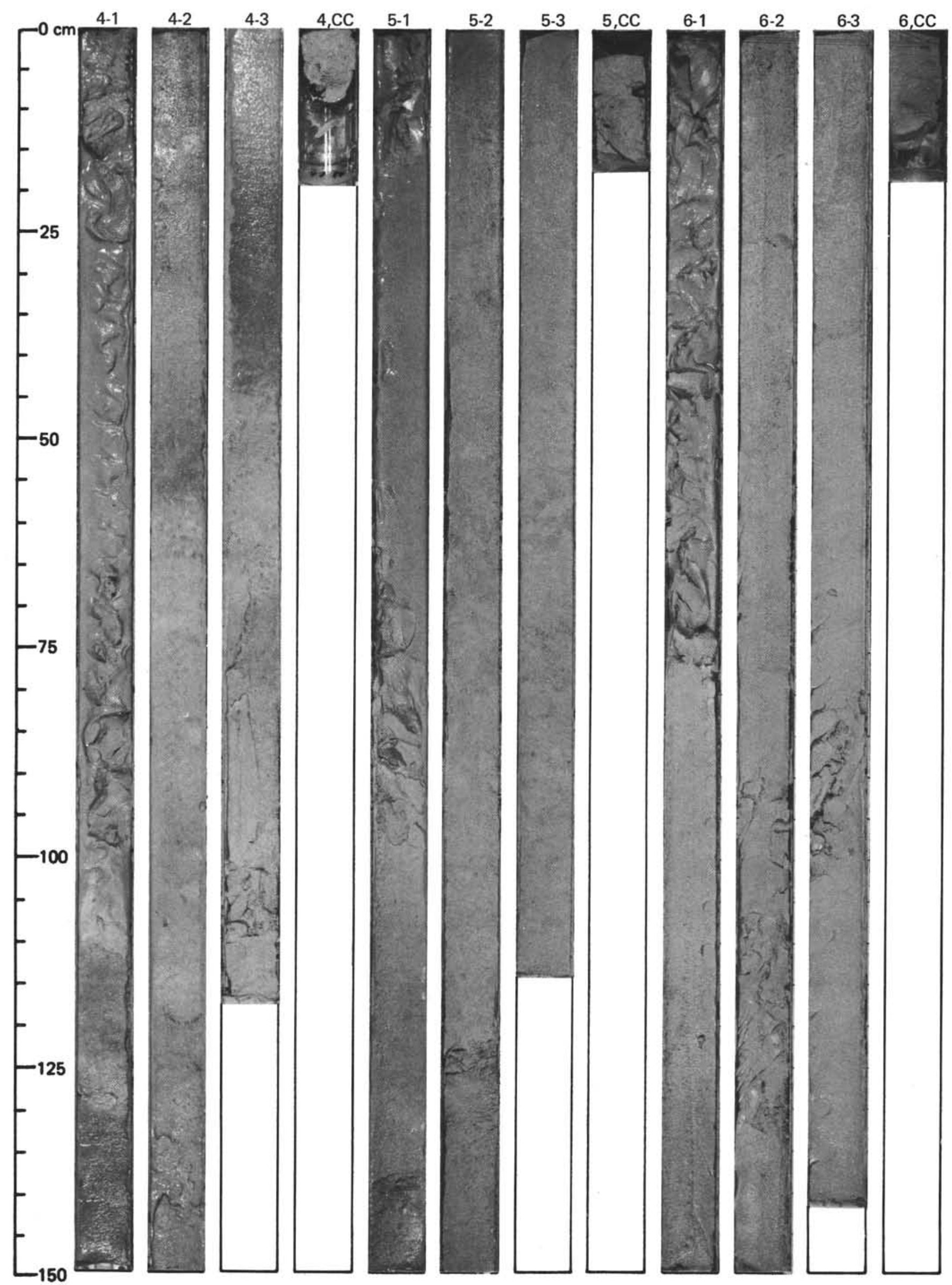




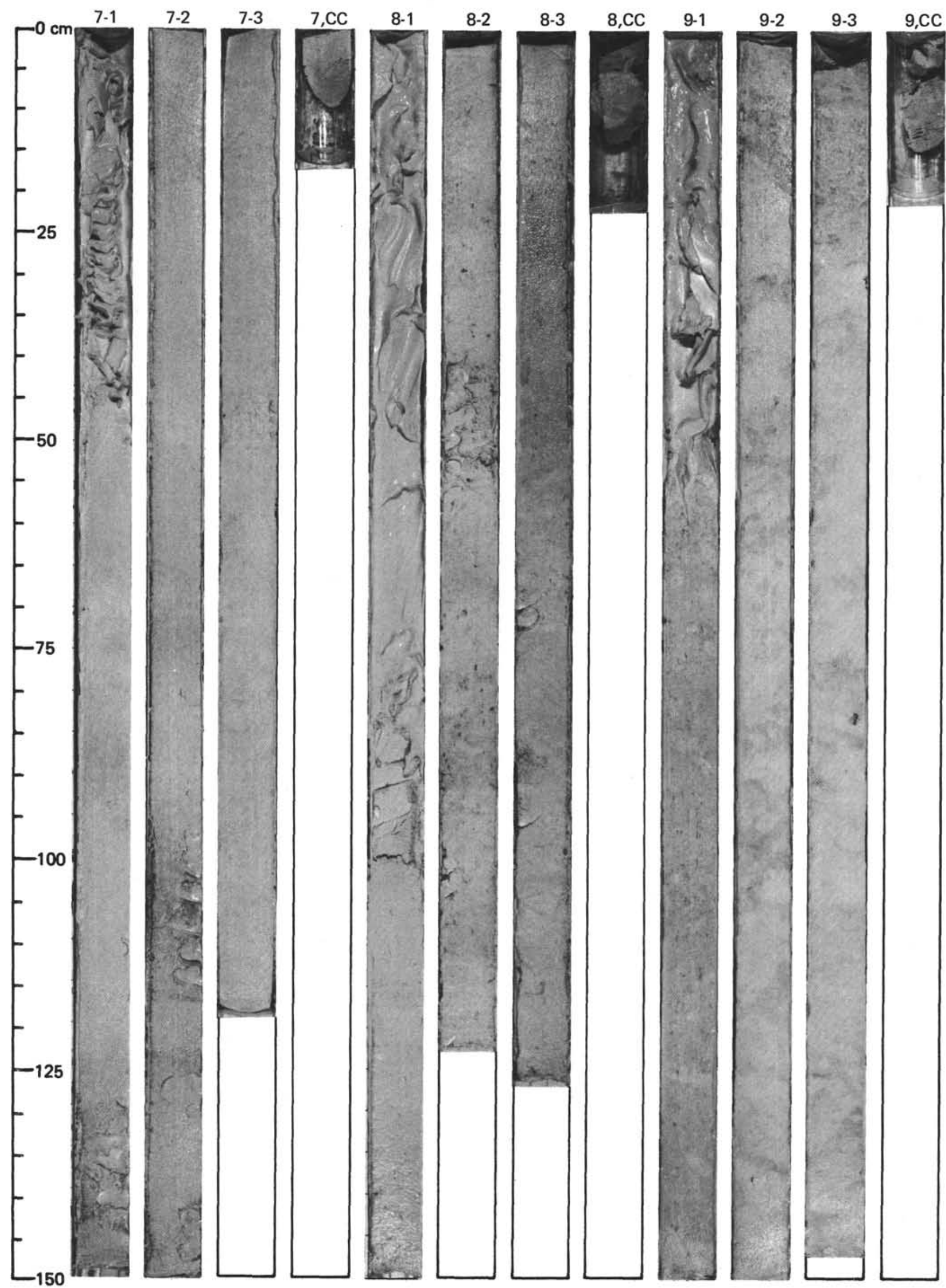




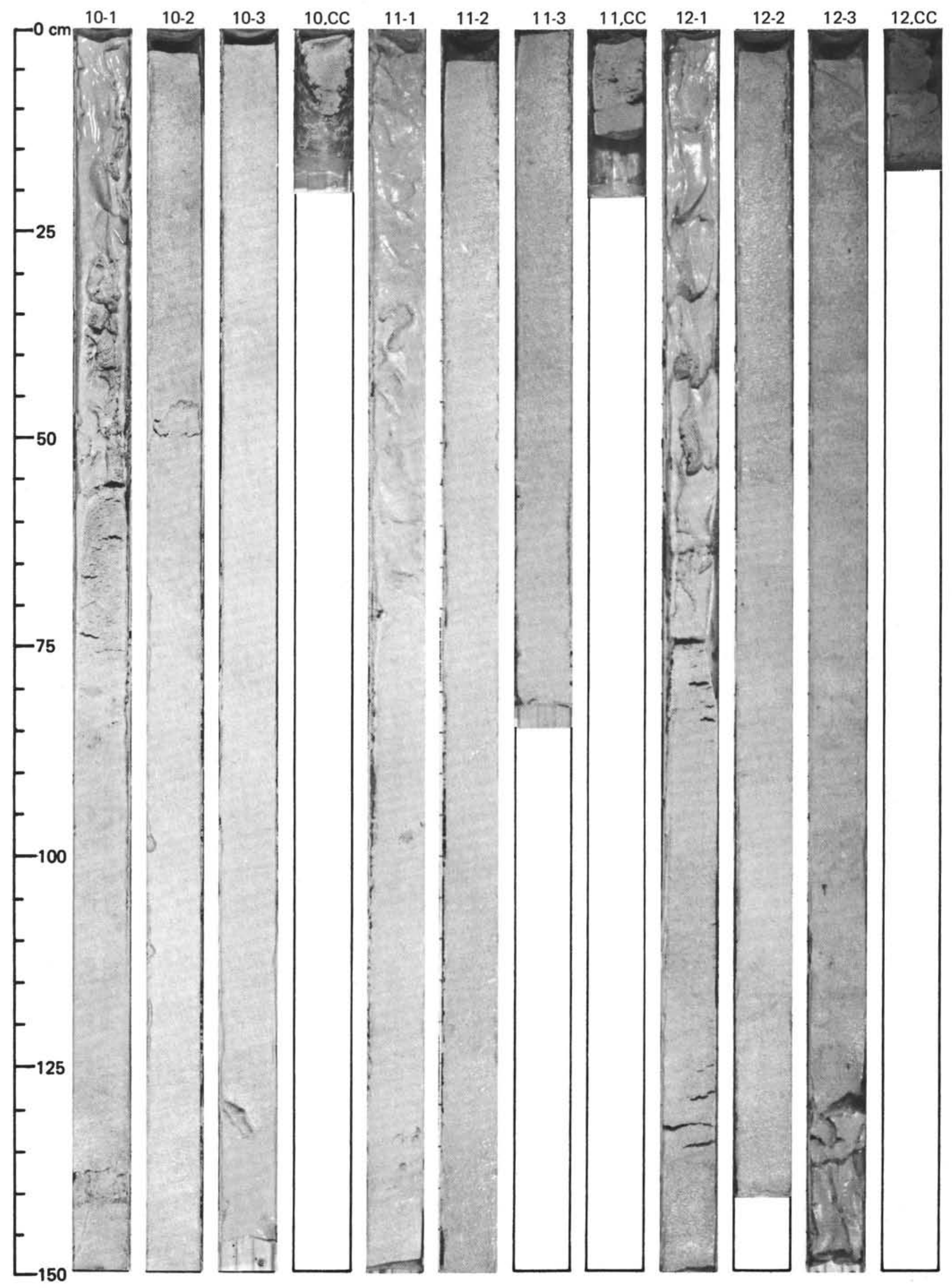


SITE 516 (HOLE 516A)

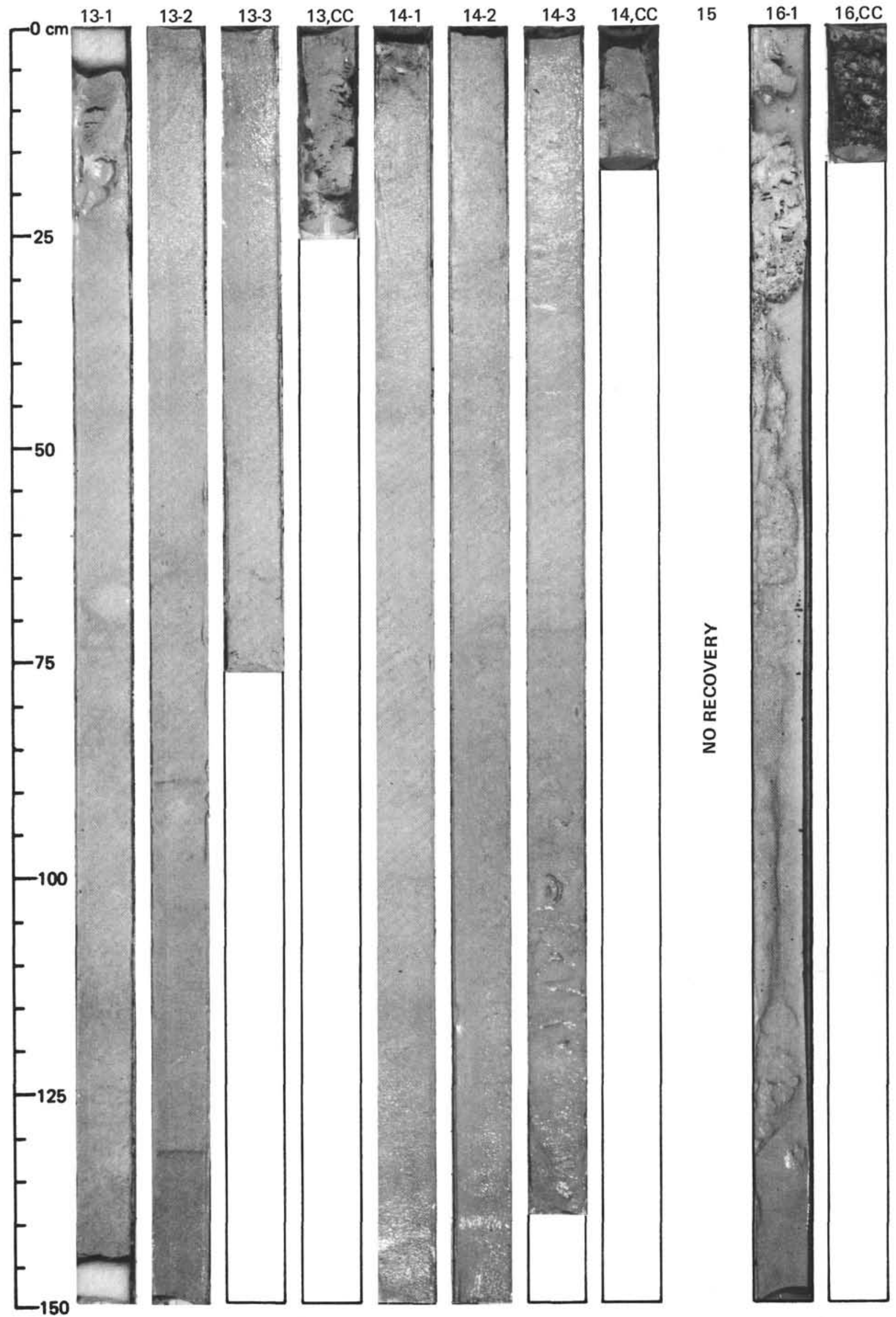


SITE 516 (HOLE 516B)

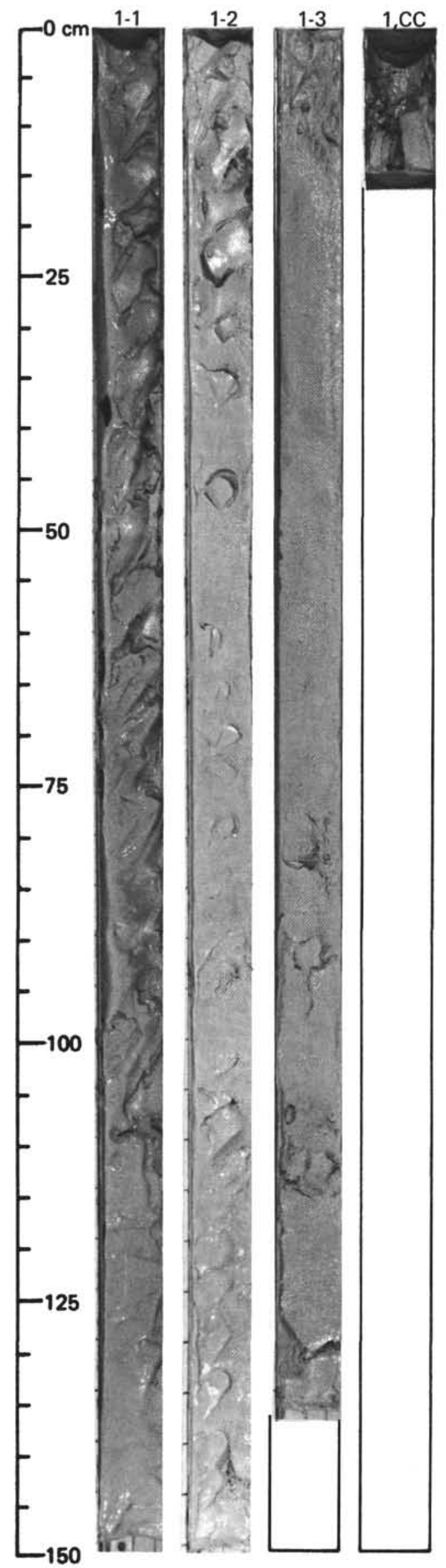


SITE 516 (HOLE 516F)

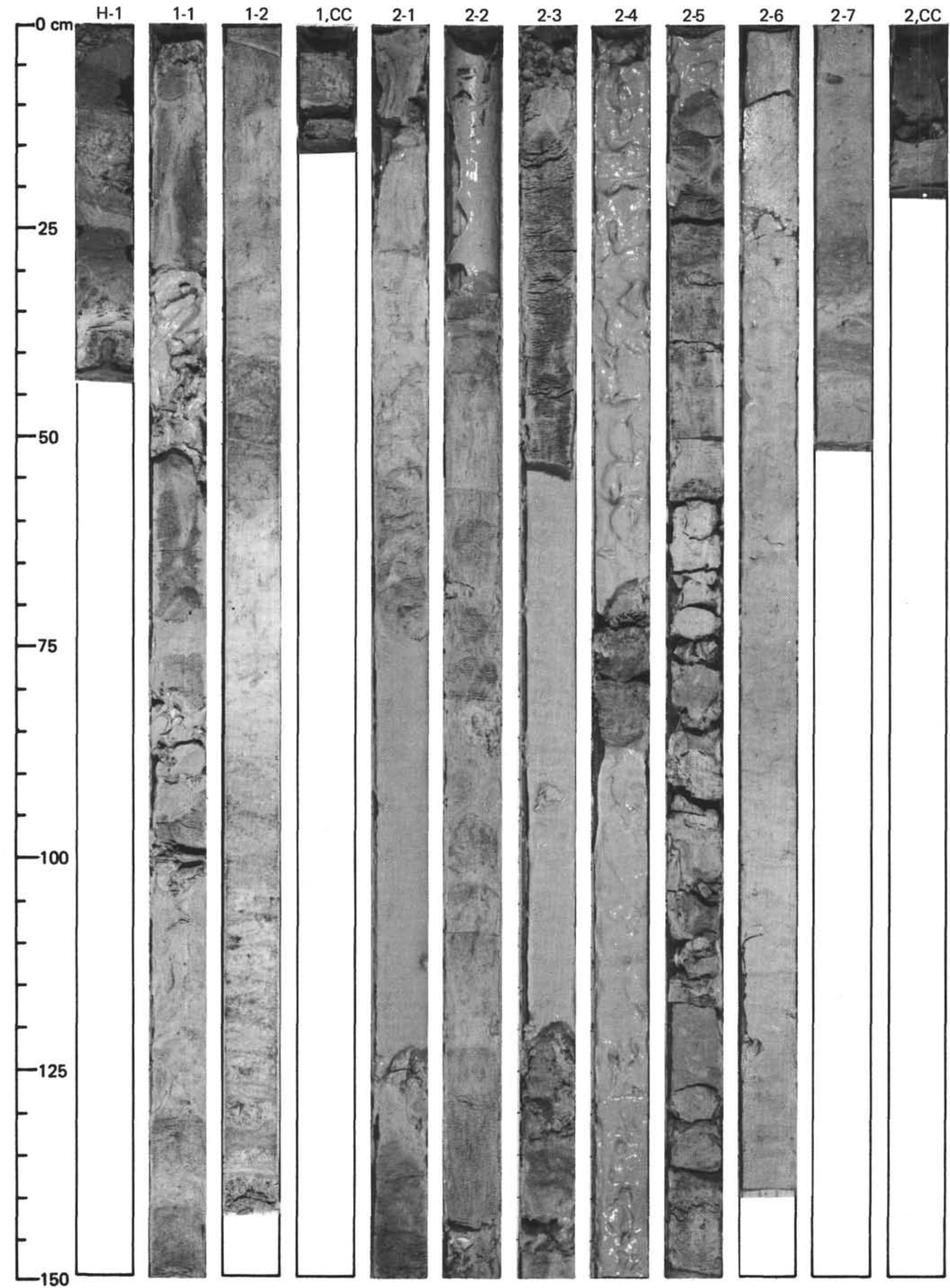




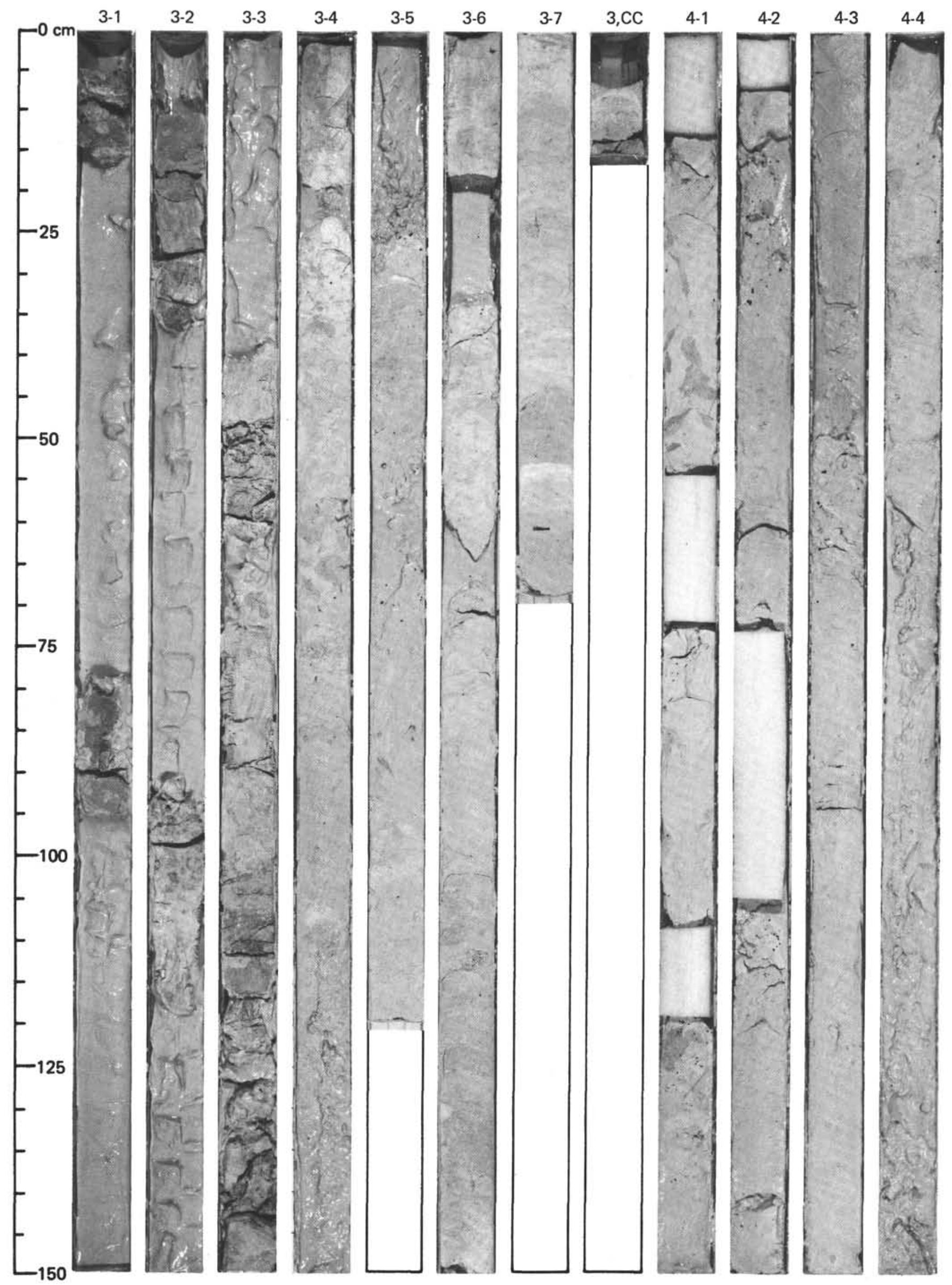


SITE 516 (HOLE 516F)

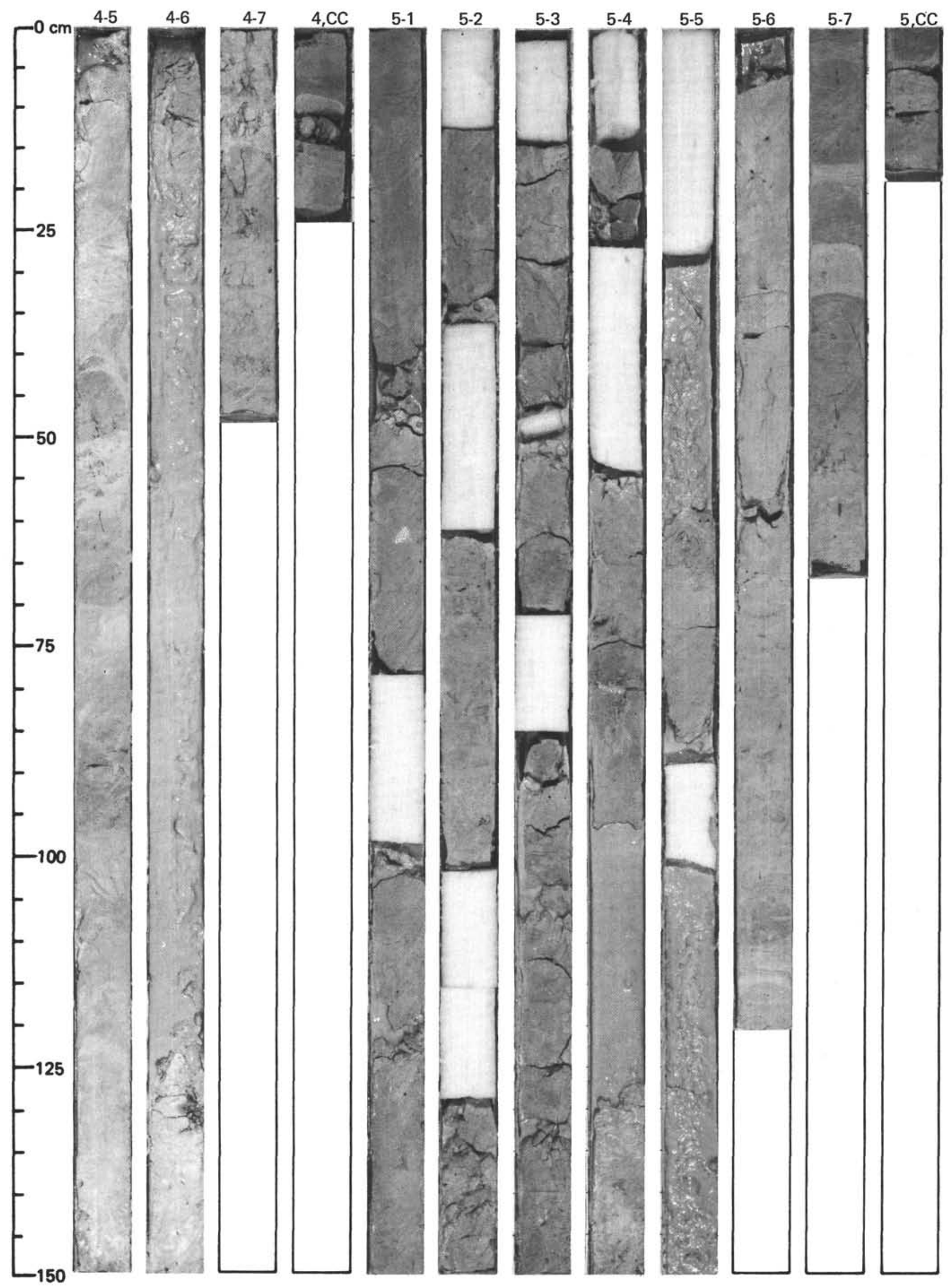




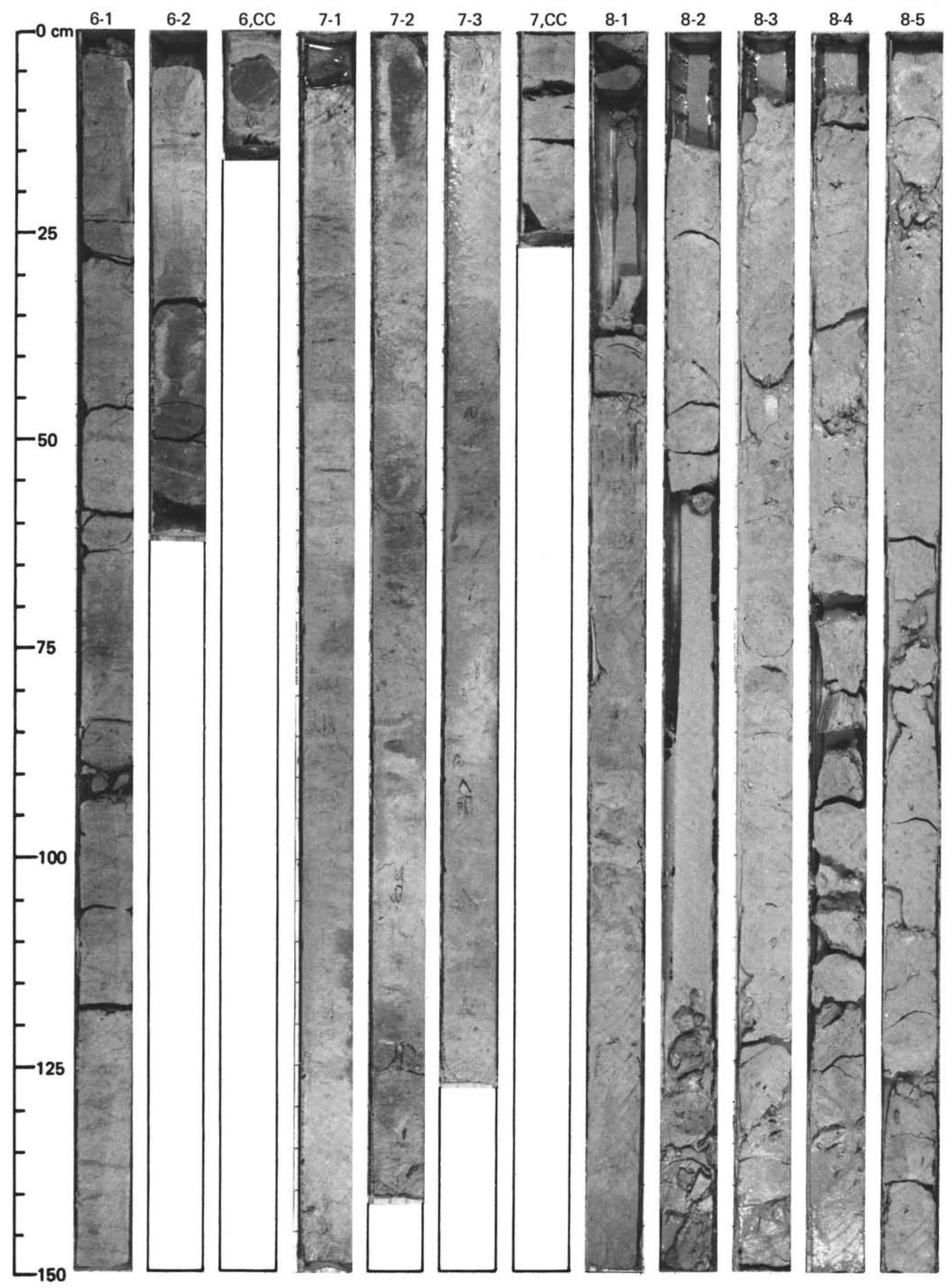




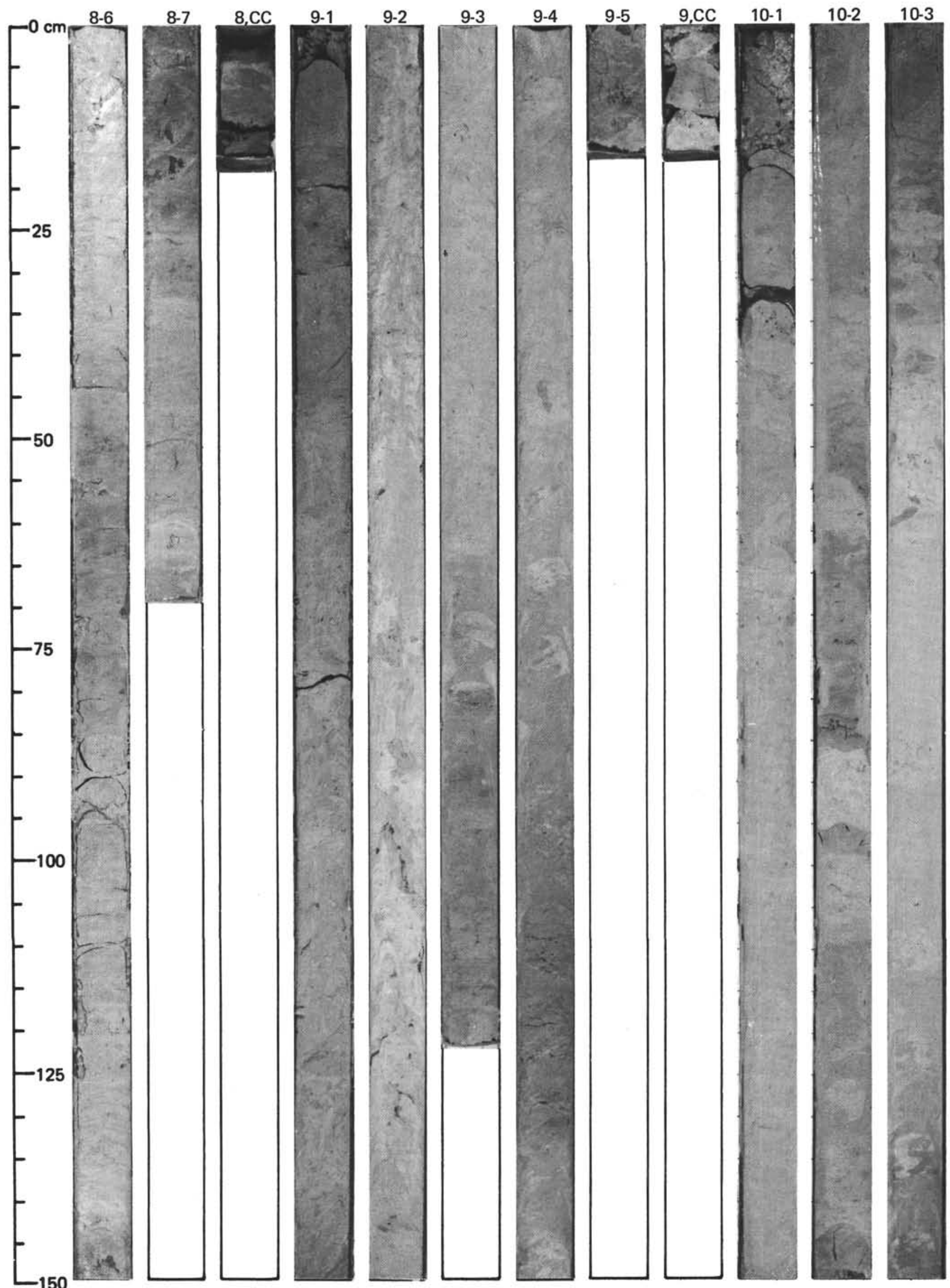


SITE 516 (HOLE 516F)

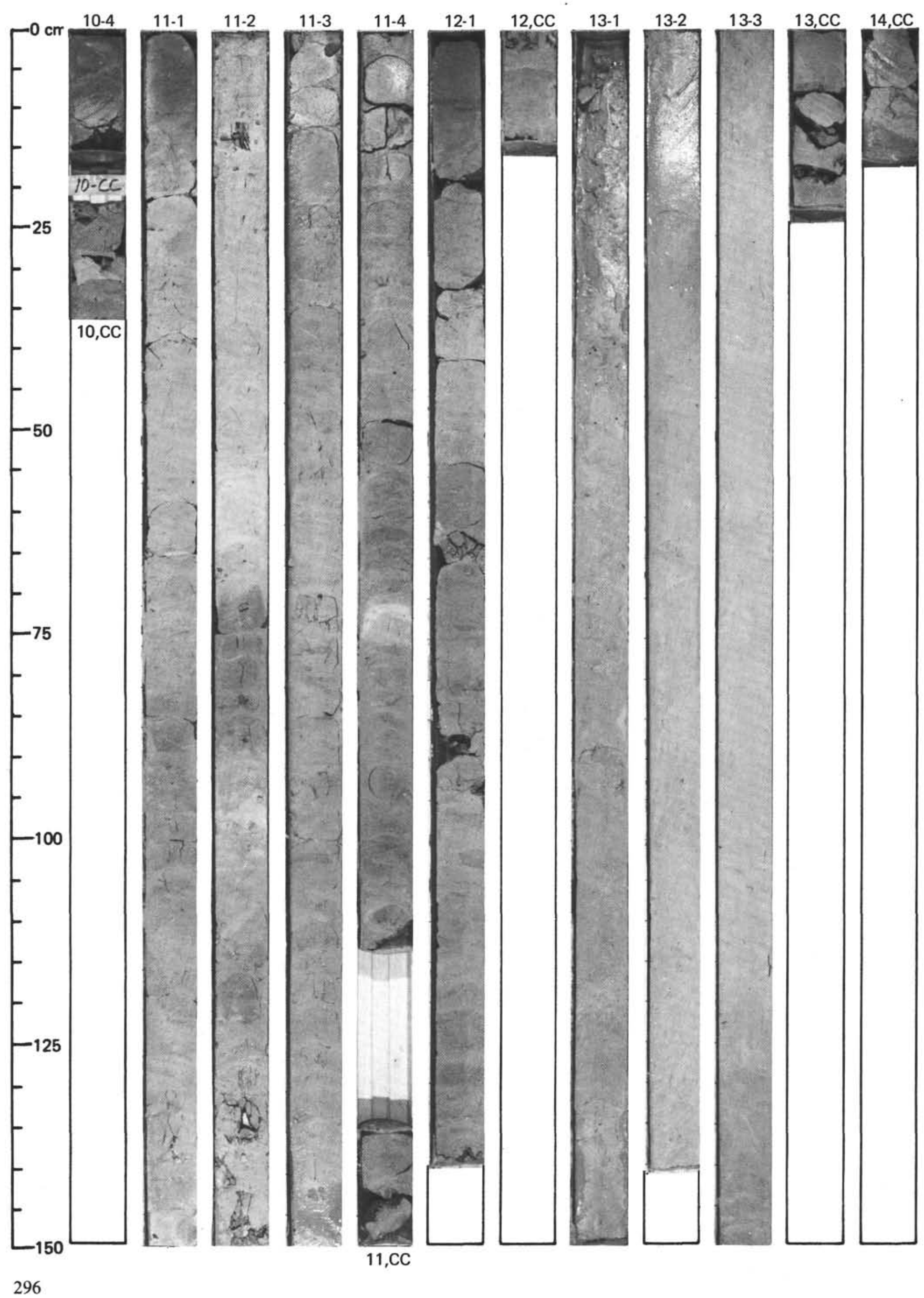


SITE 516 (HOLE 516F)

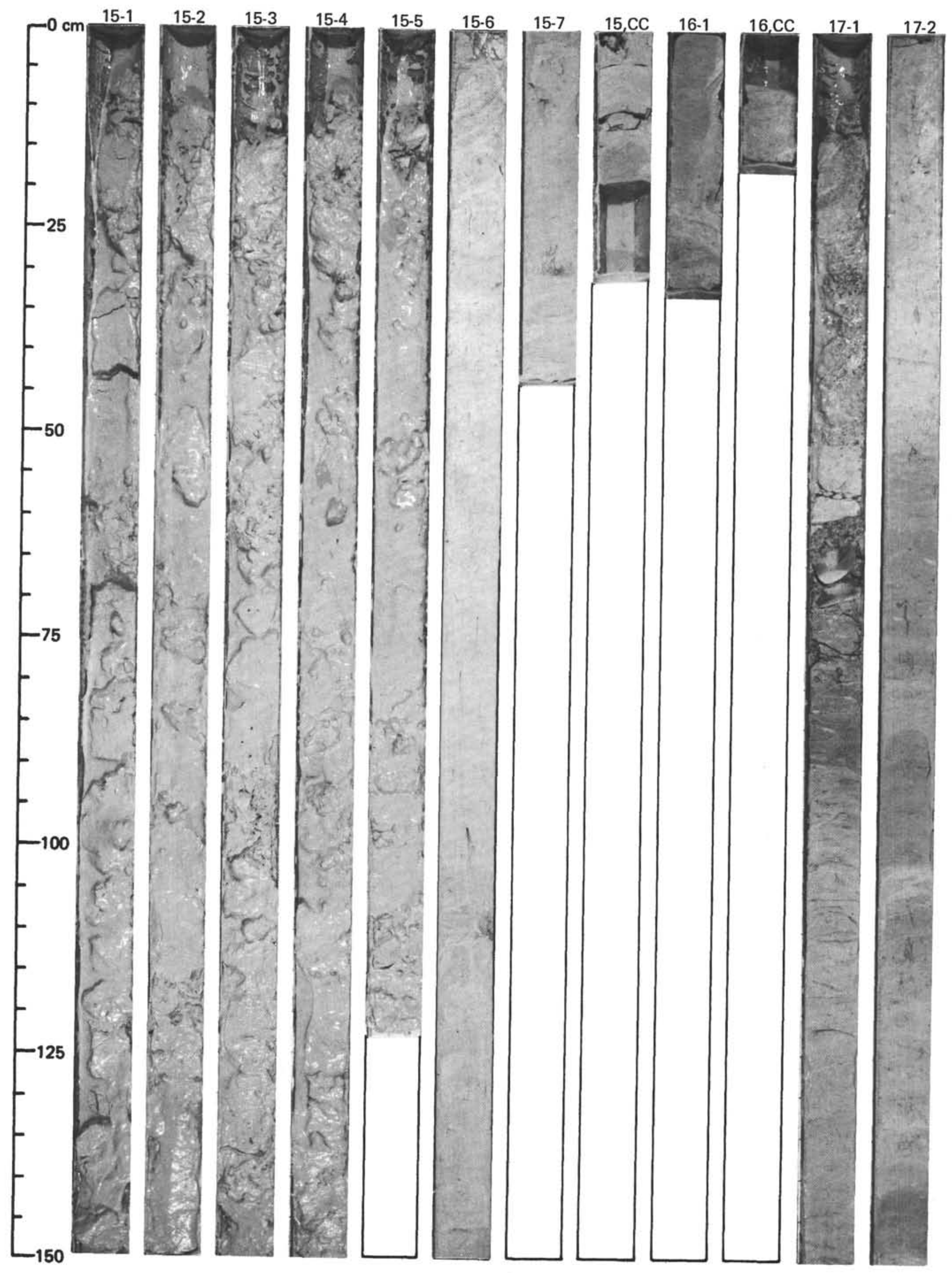


SITE 516 (HOLE 516F)

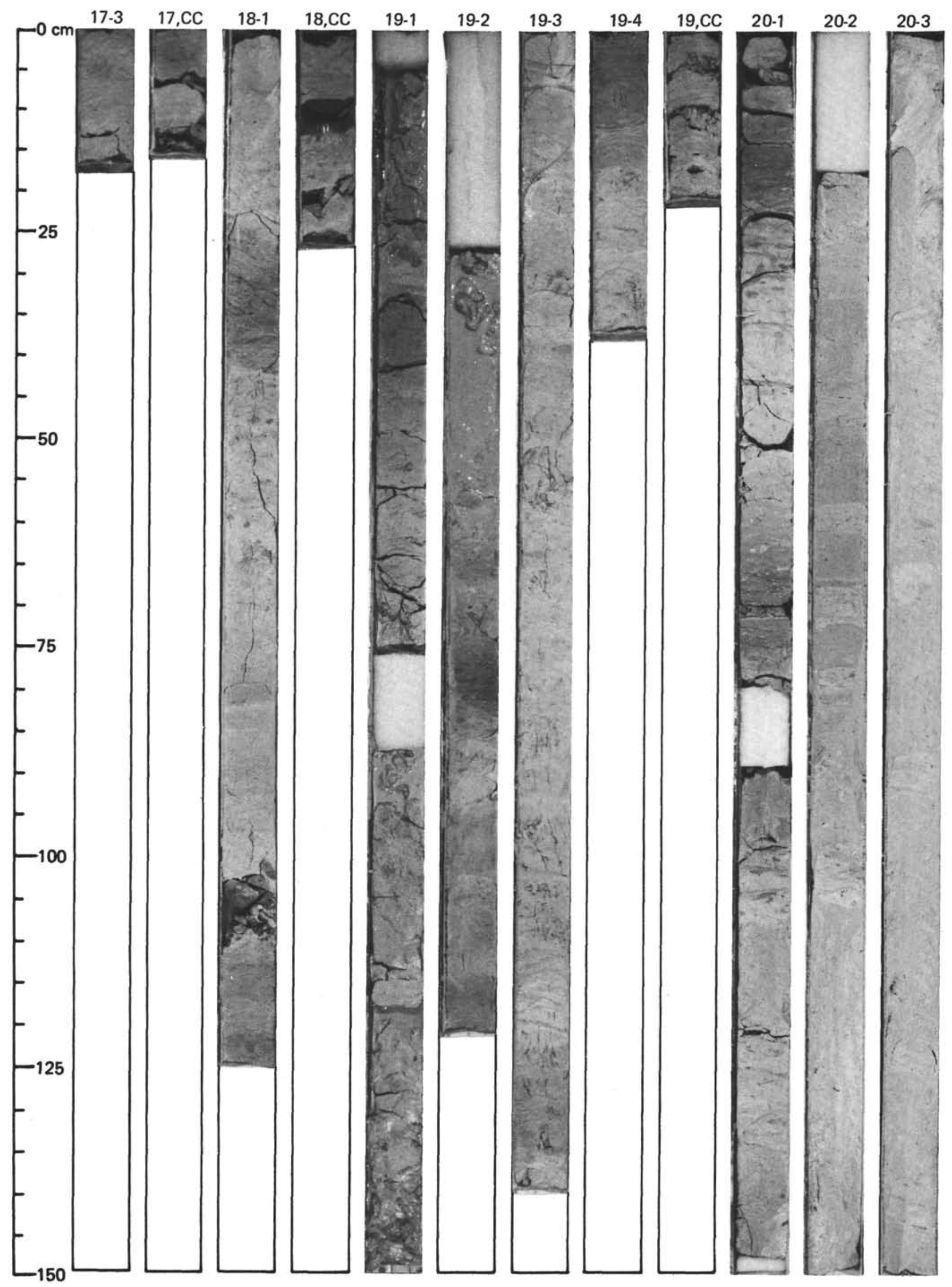


SITE 516 (HOLE 516F)

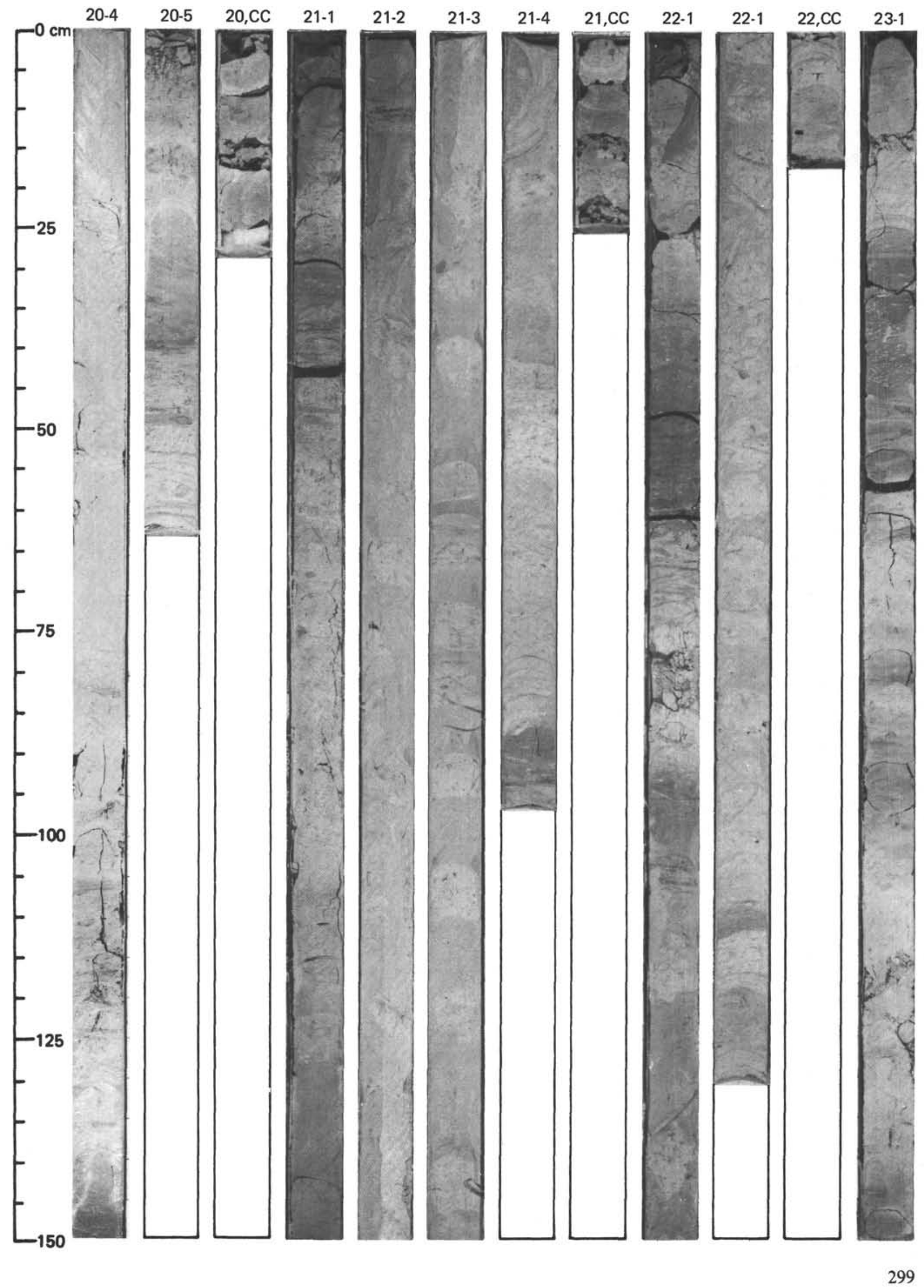




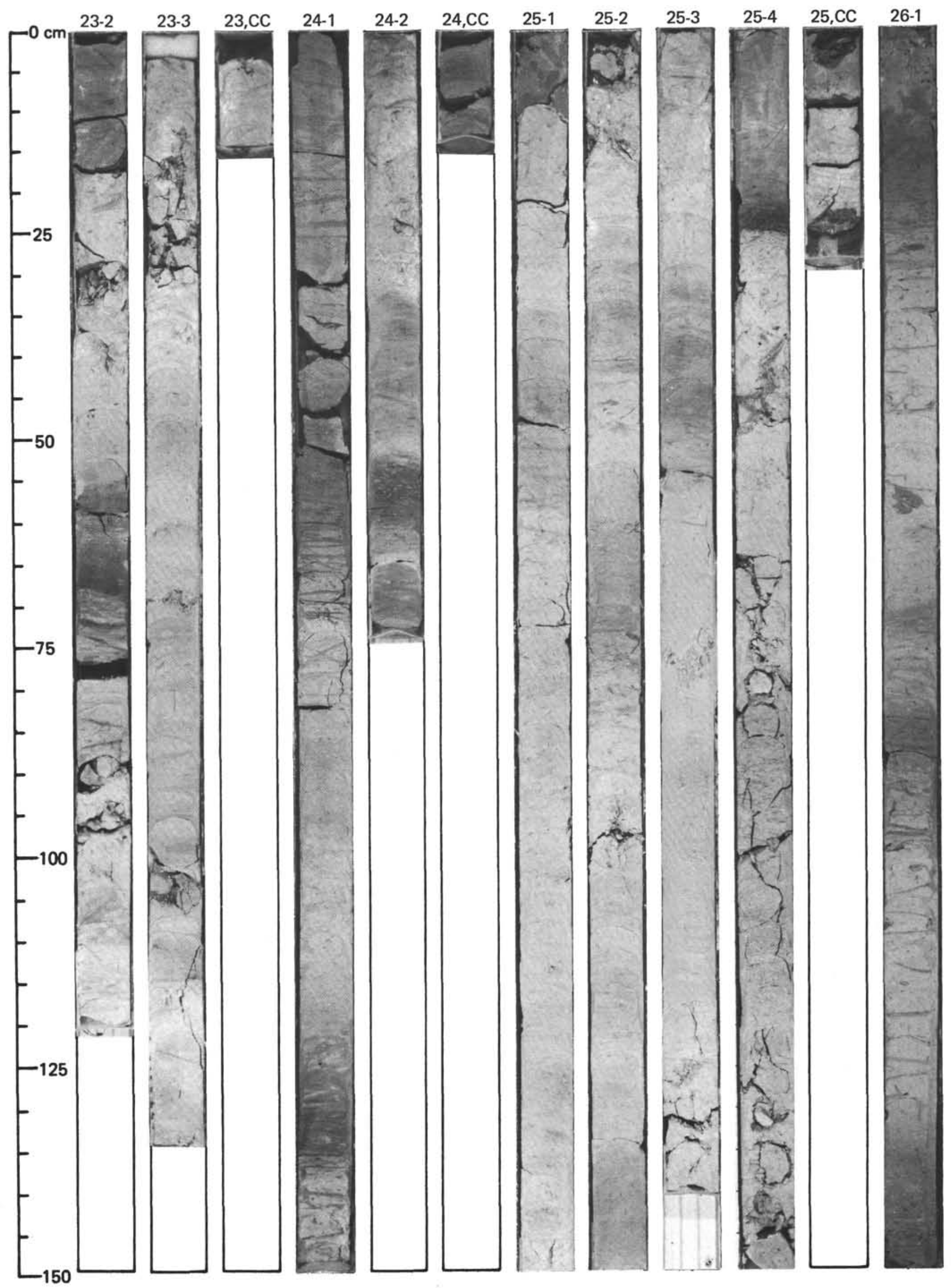




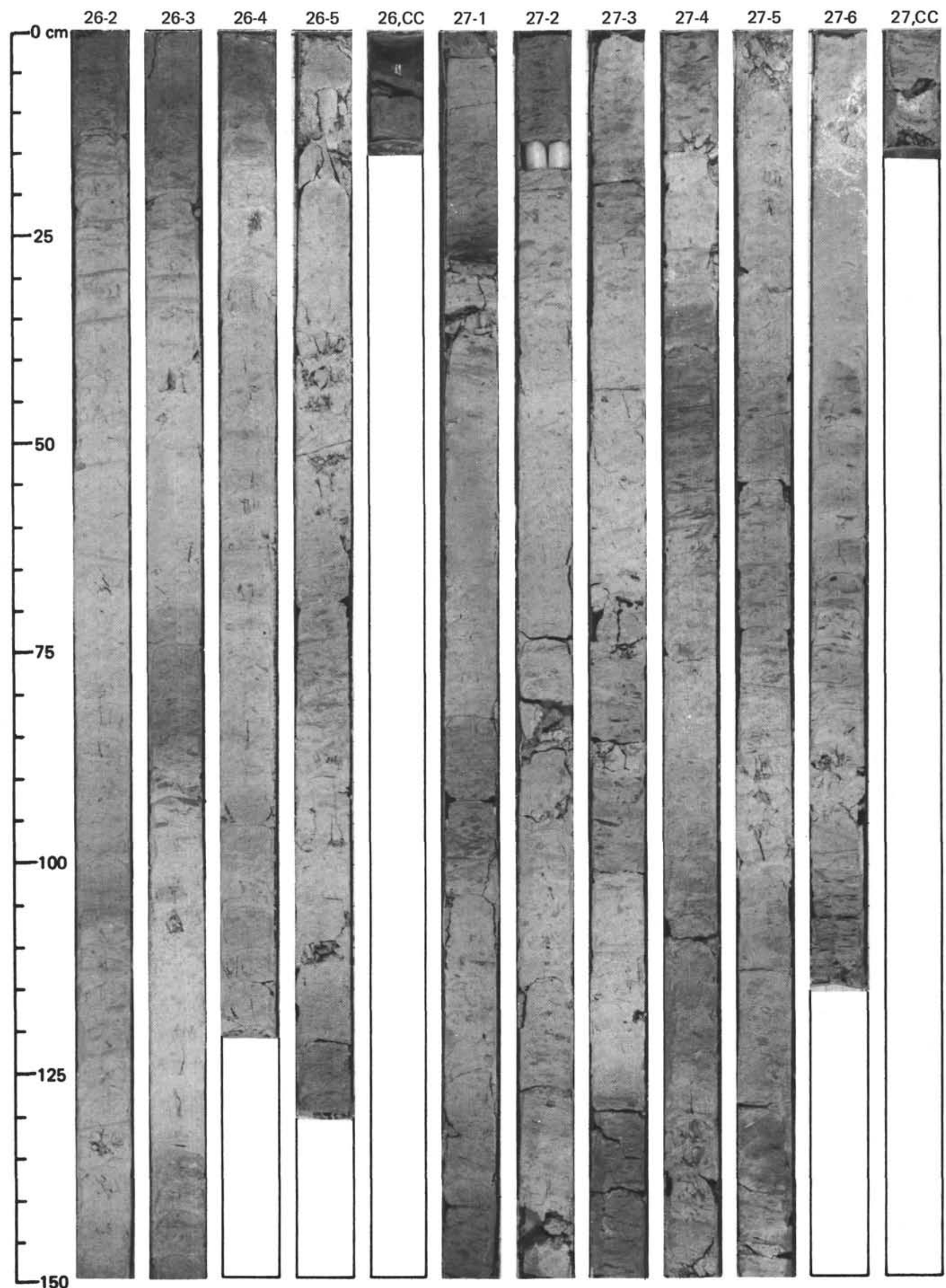




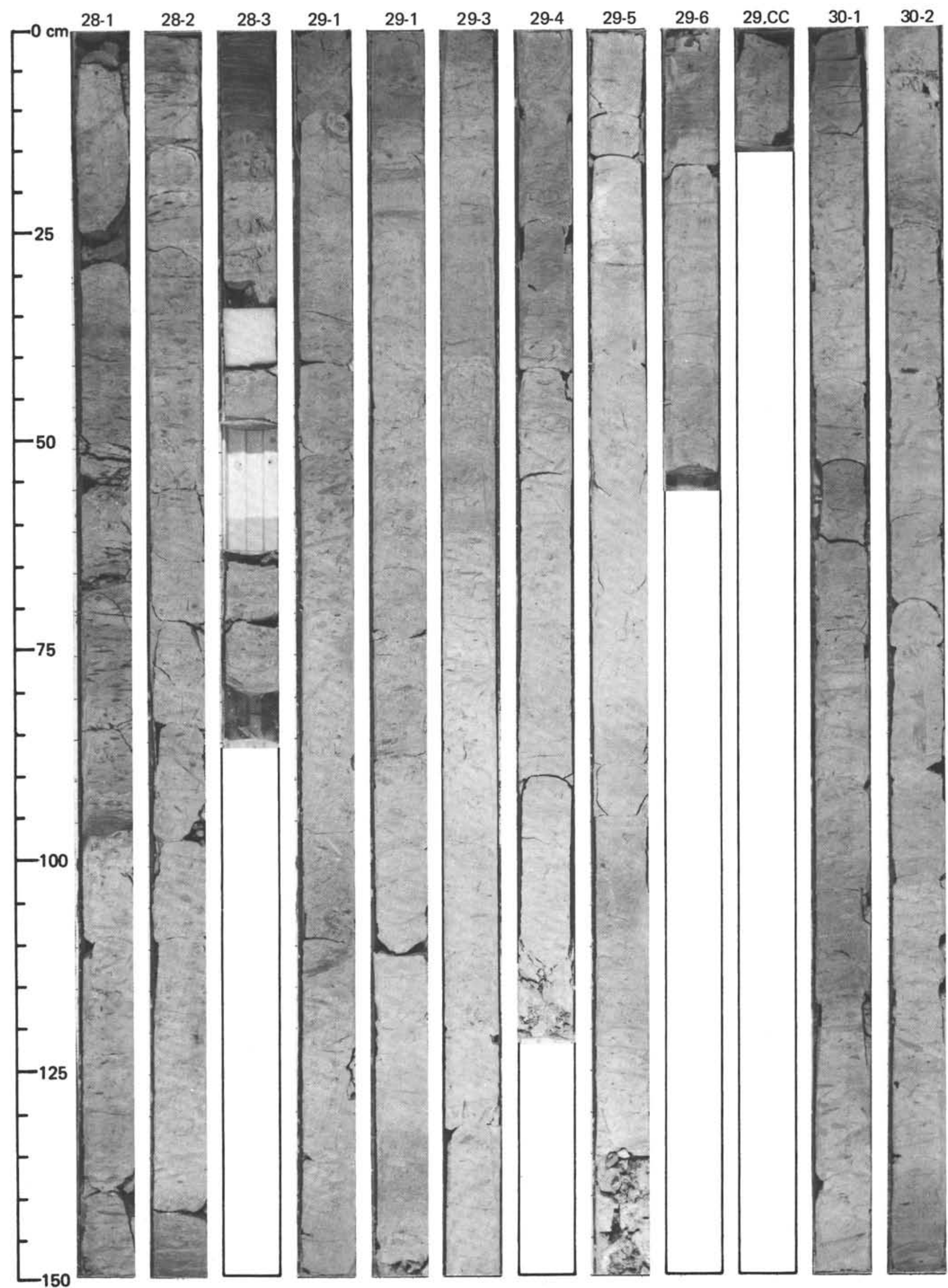


SITE 516 (HOLE 516F)

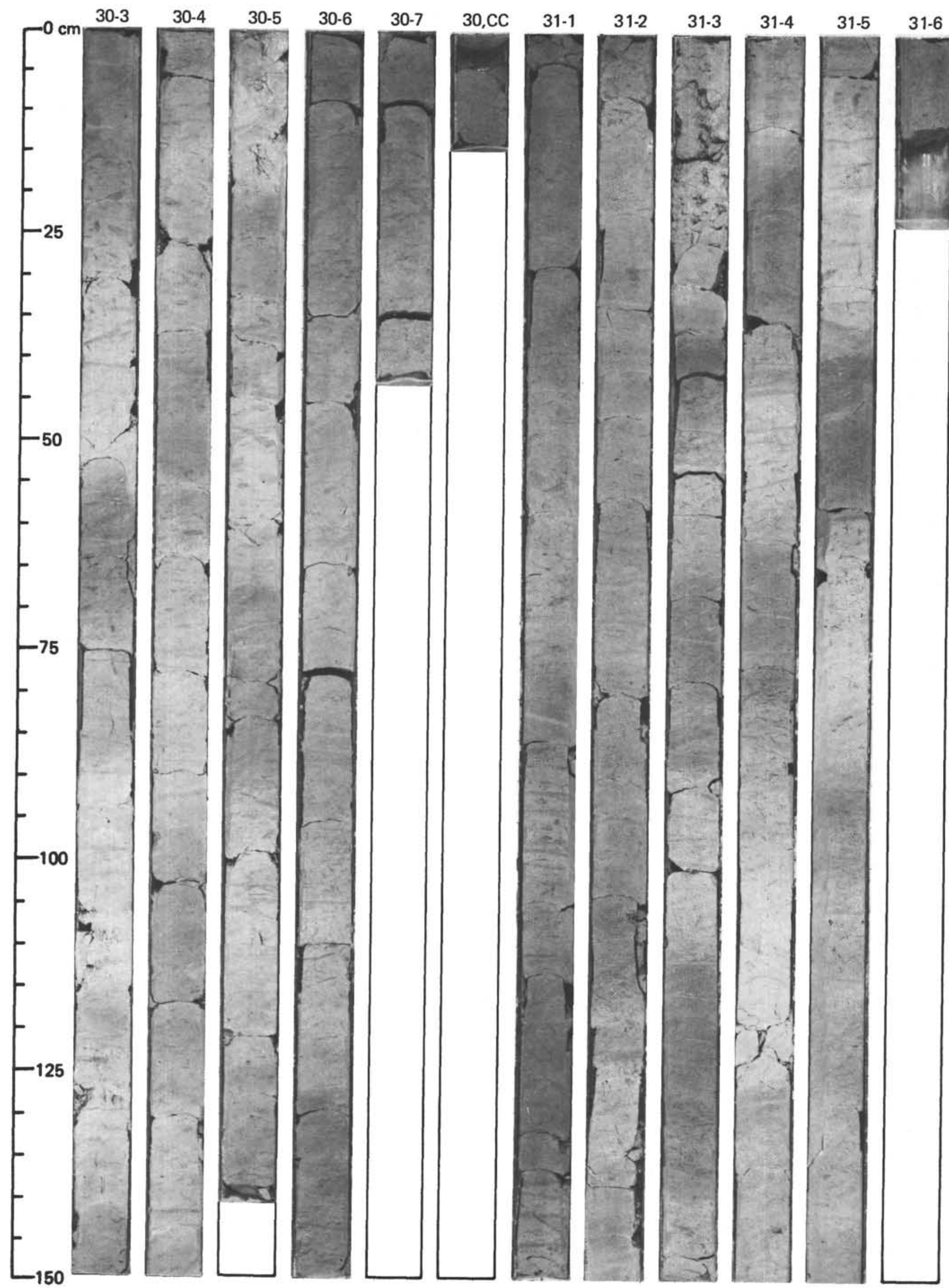




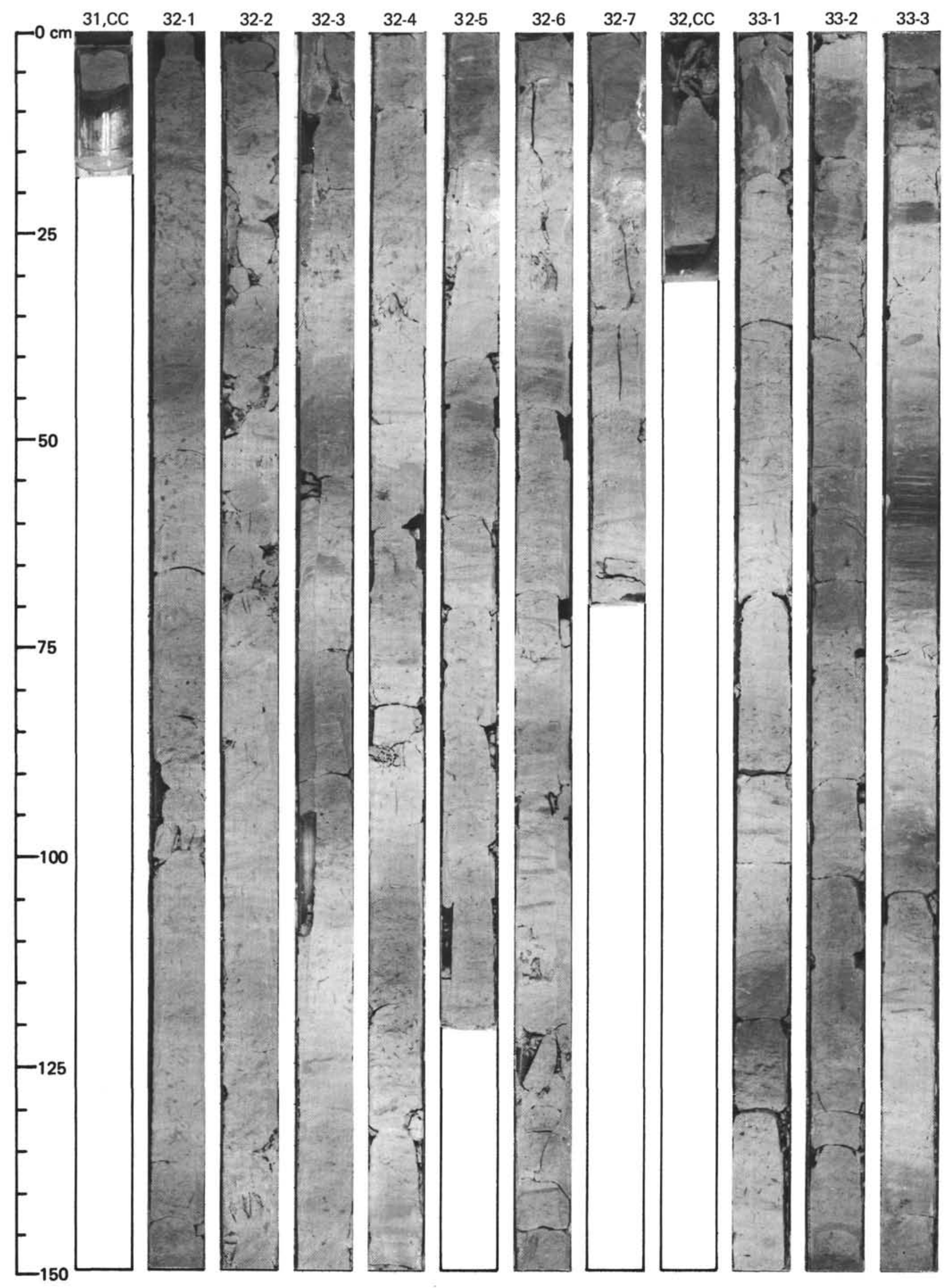


SITE 516 (HOLE 516F)

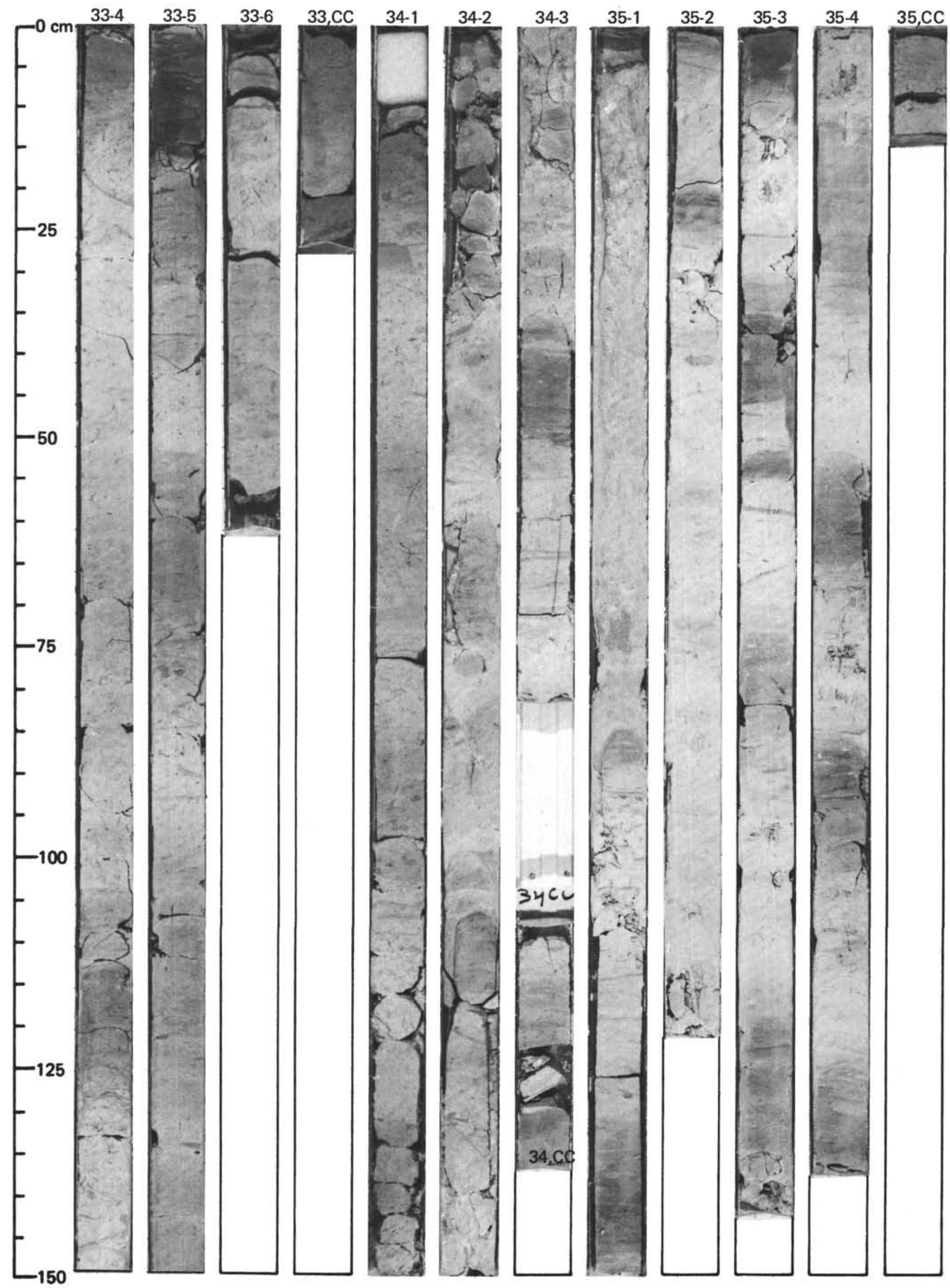




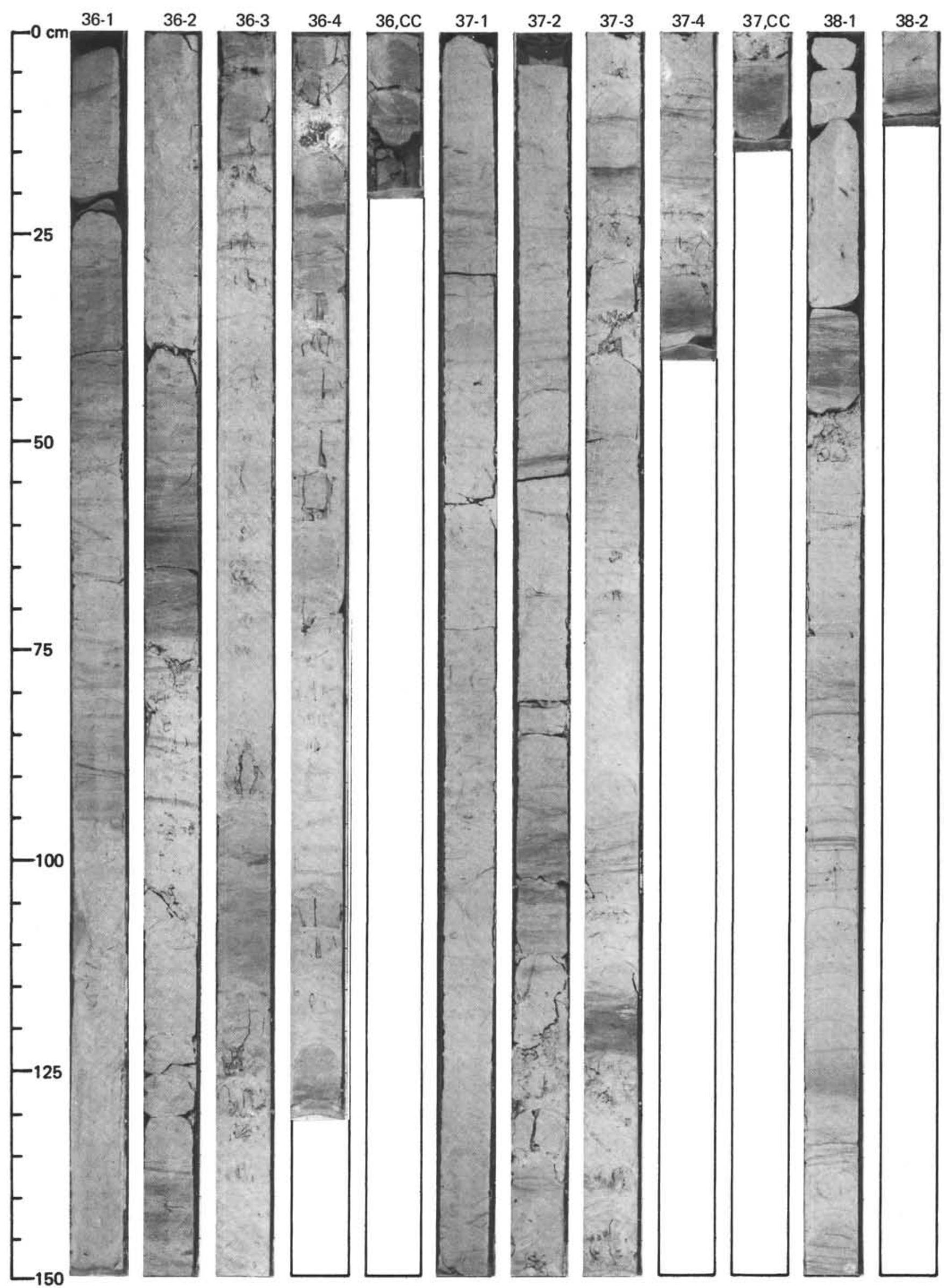


SITE 516 (HOLE 516F)

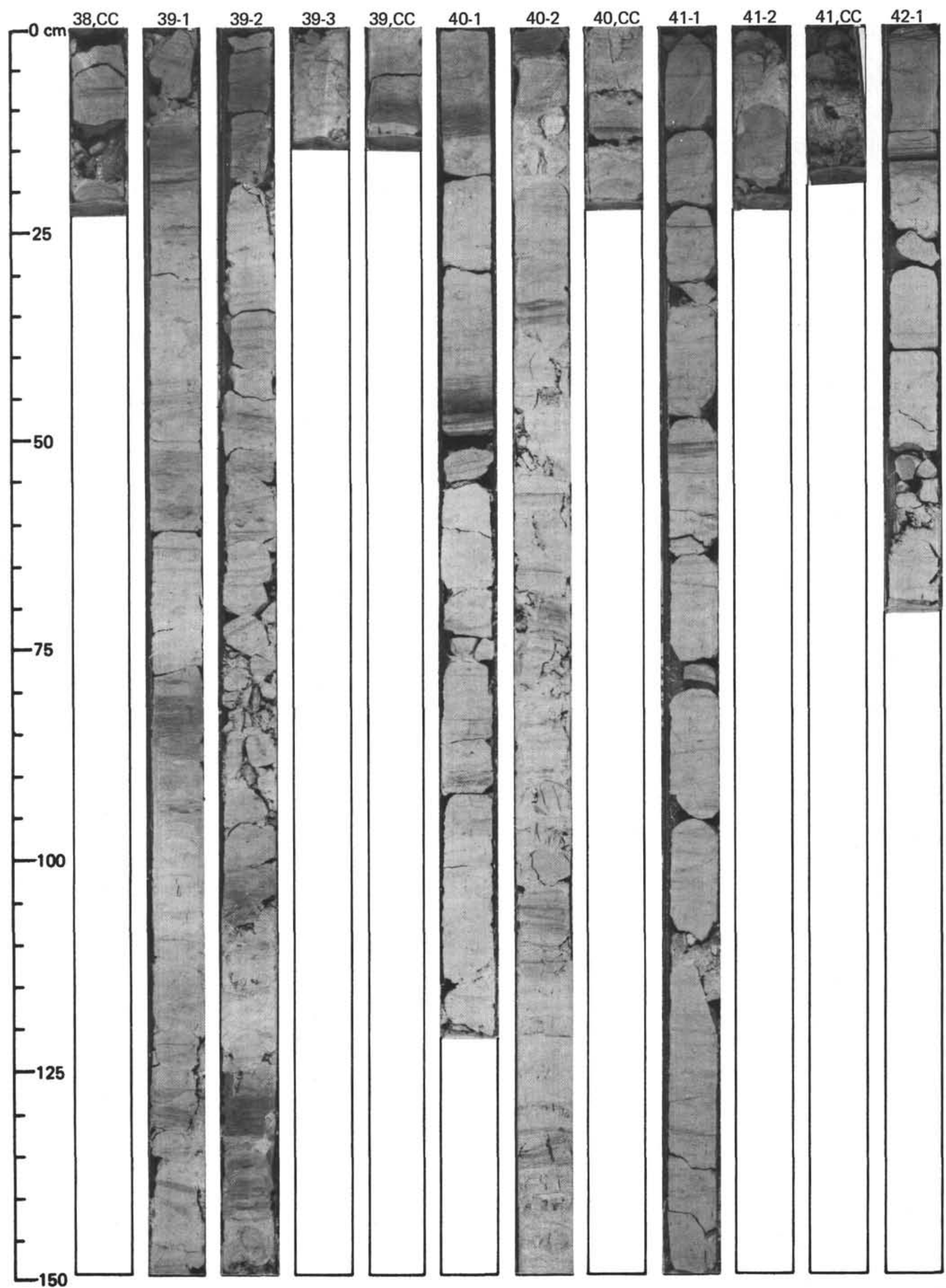




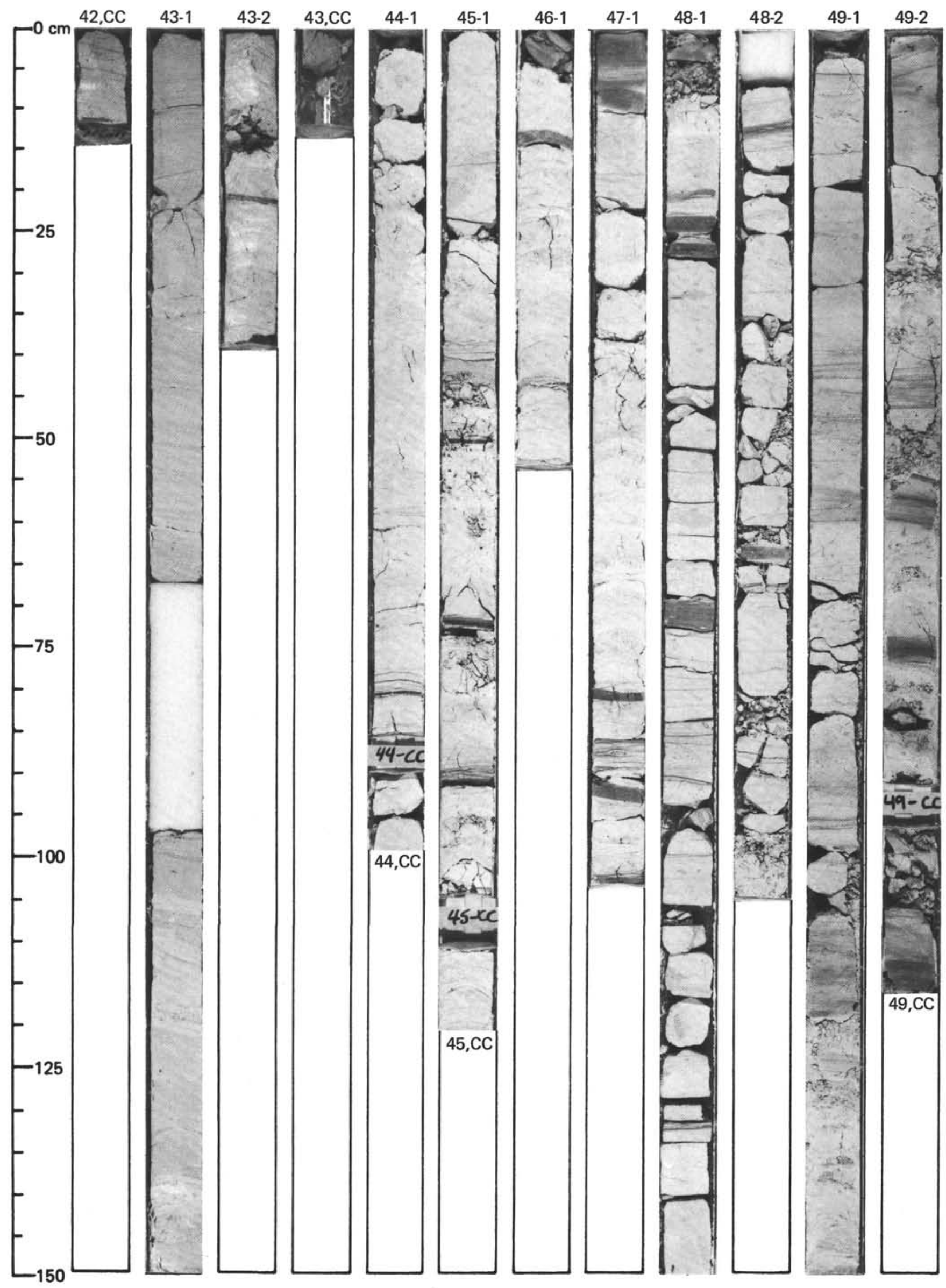


SITE 516 (HOLE 516F)

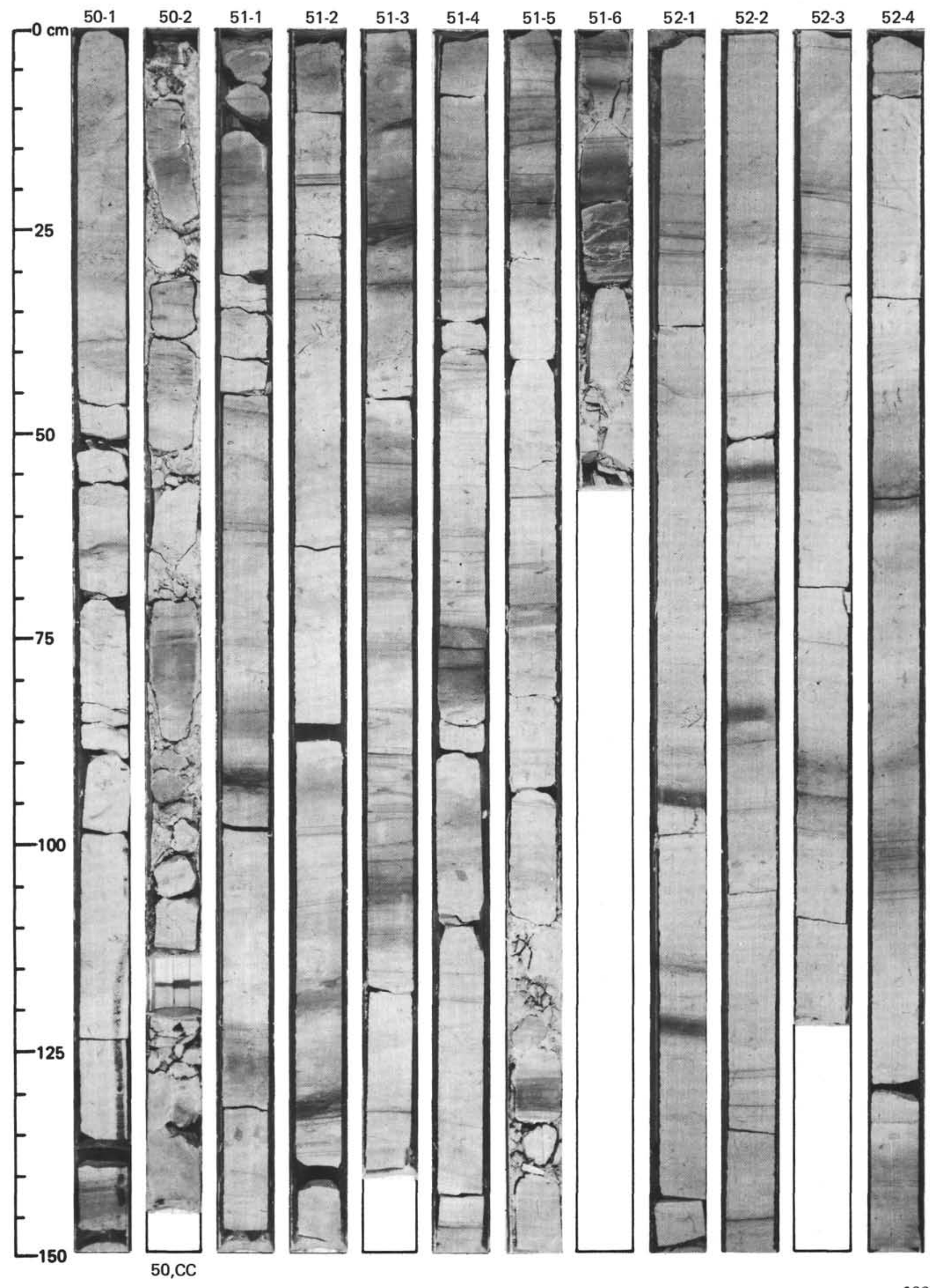




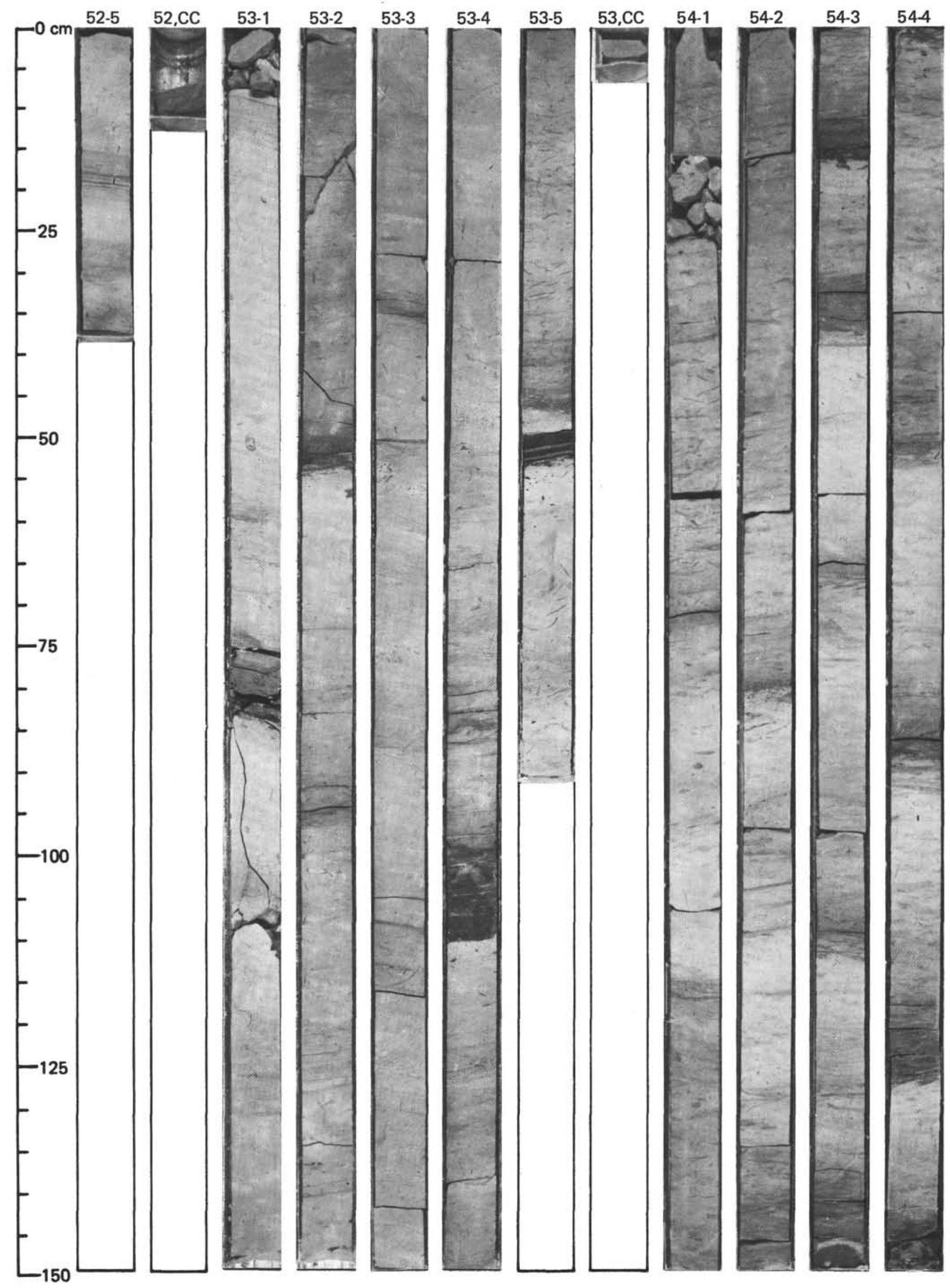




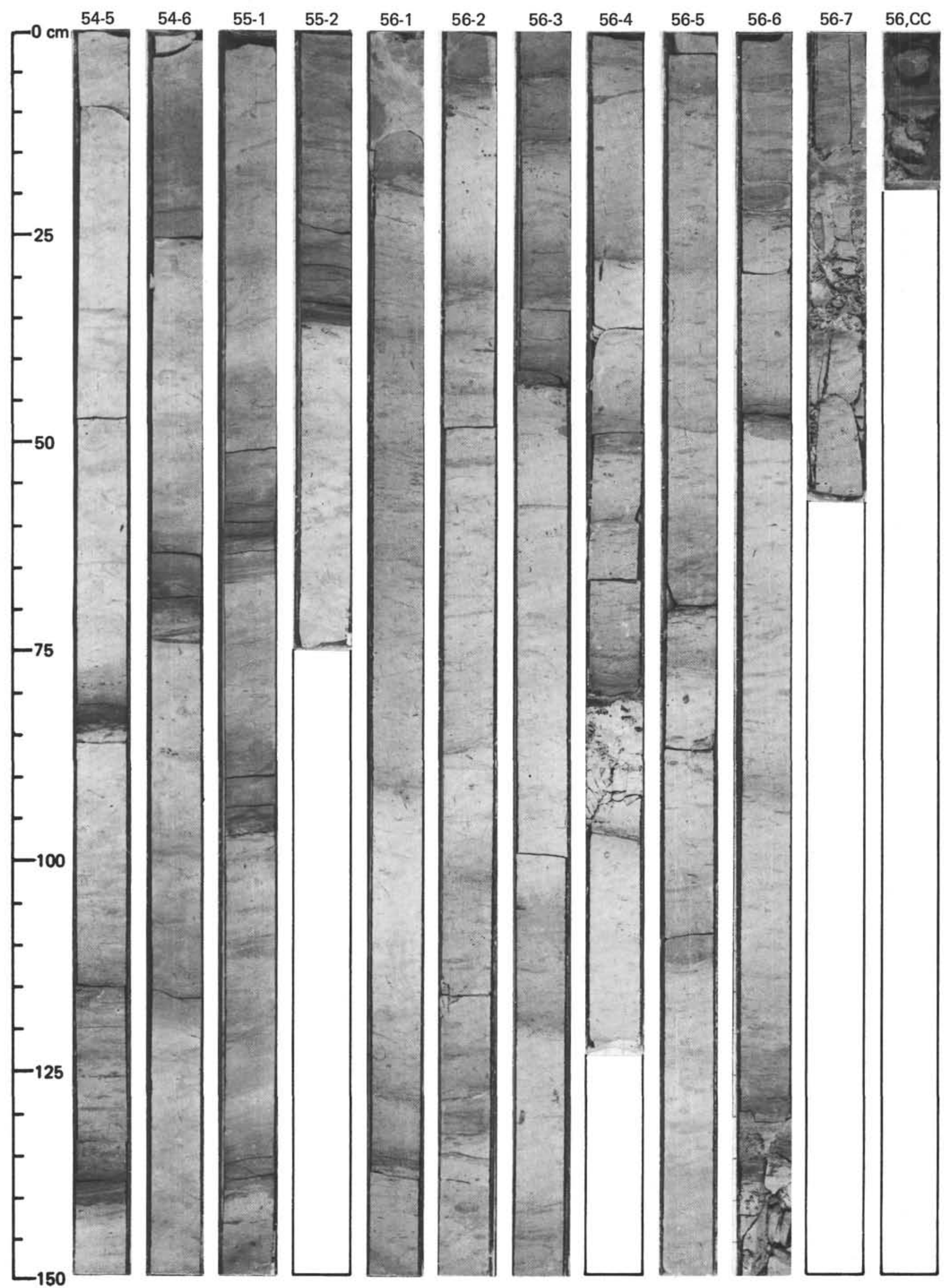


SITE 516 (HOLE 516F)

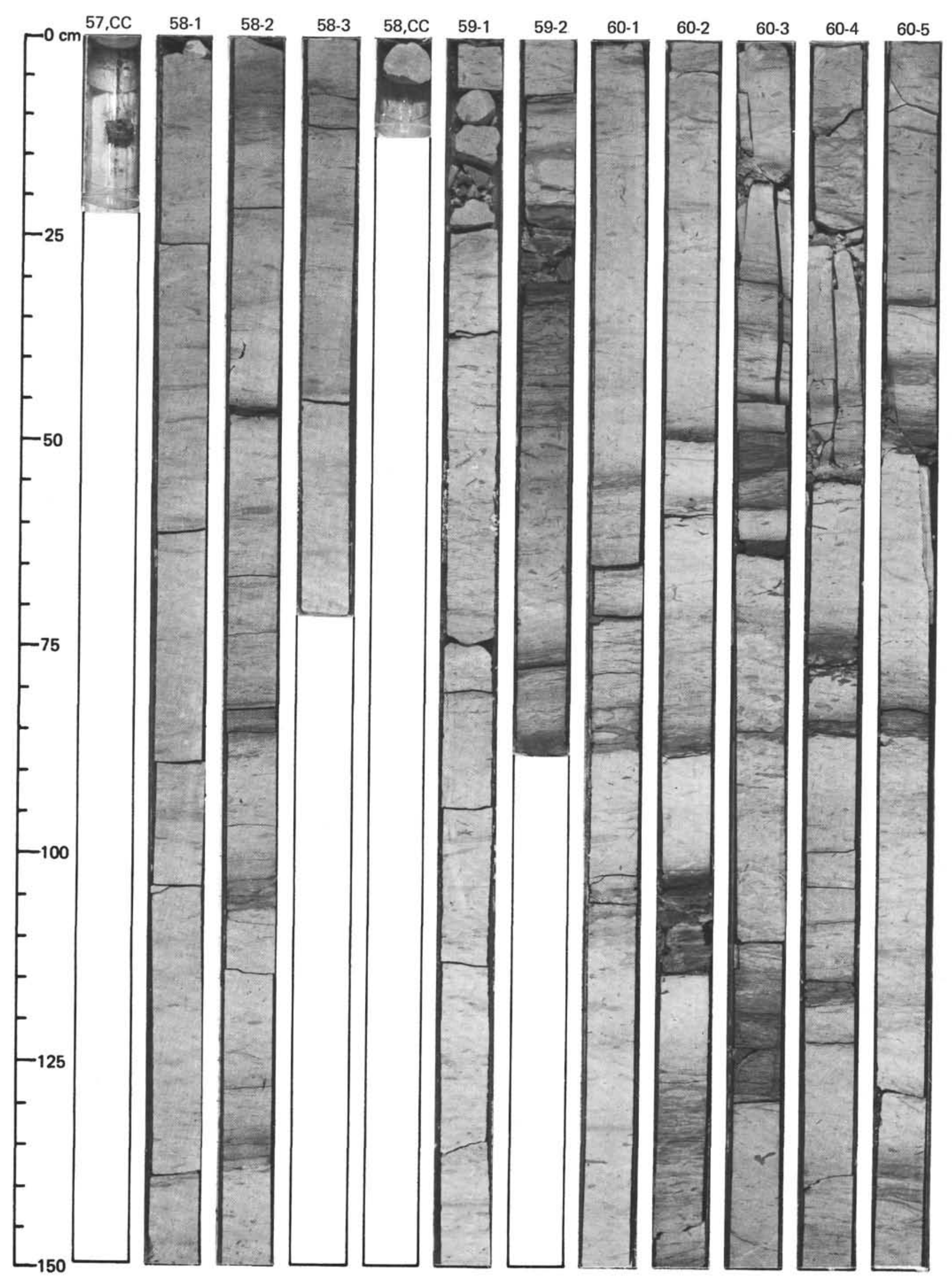




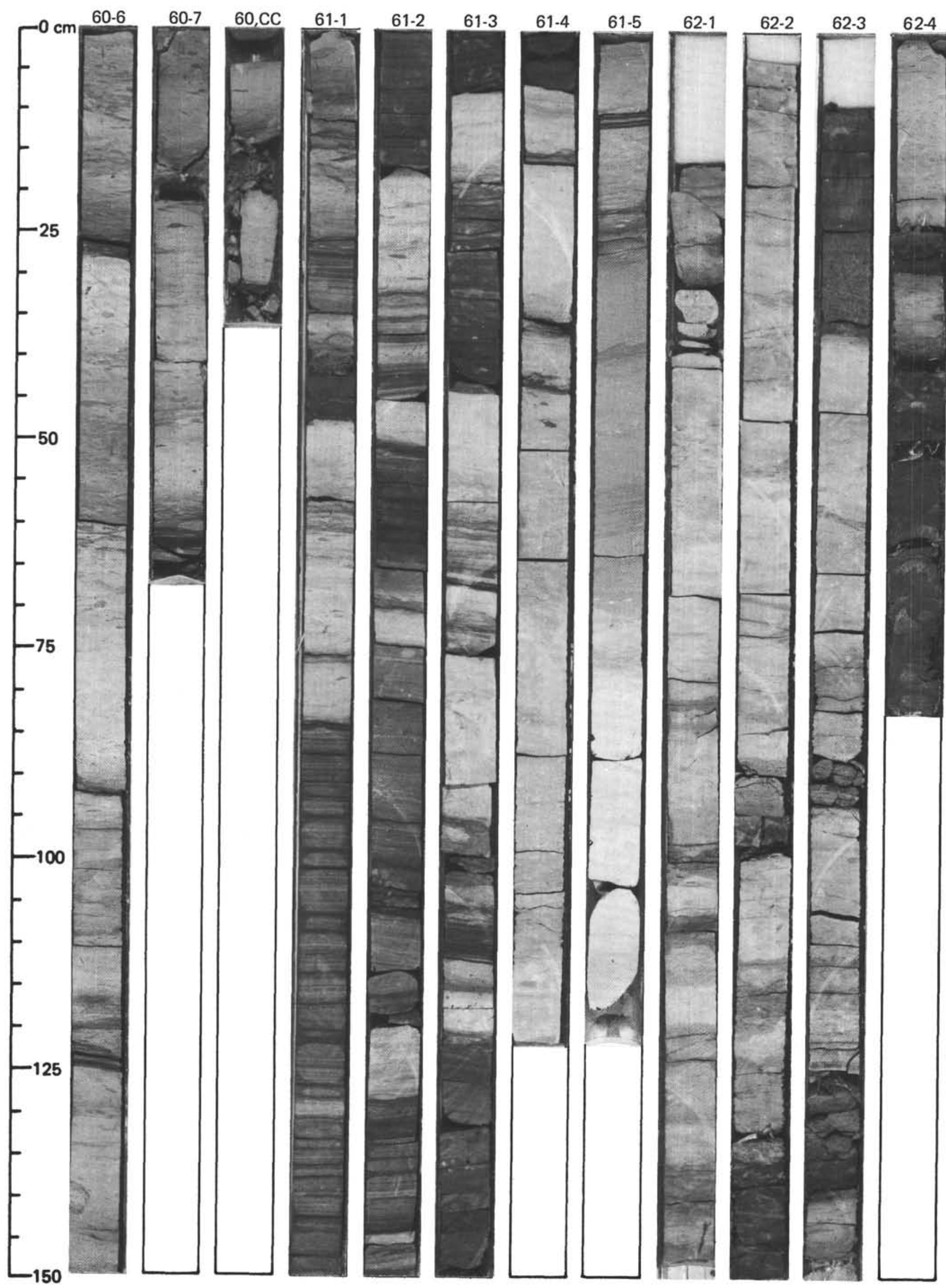




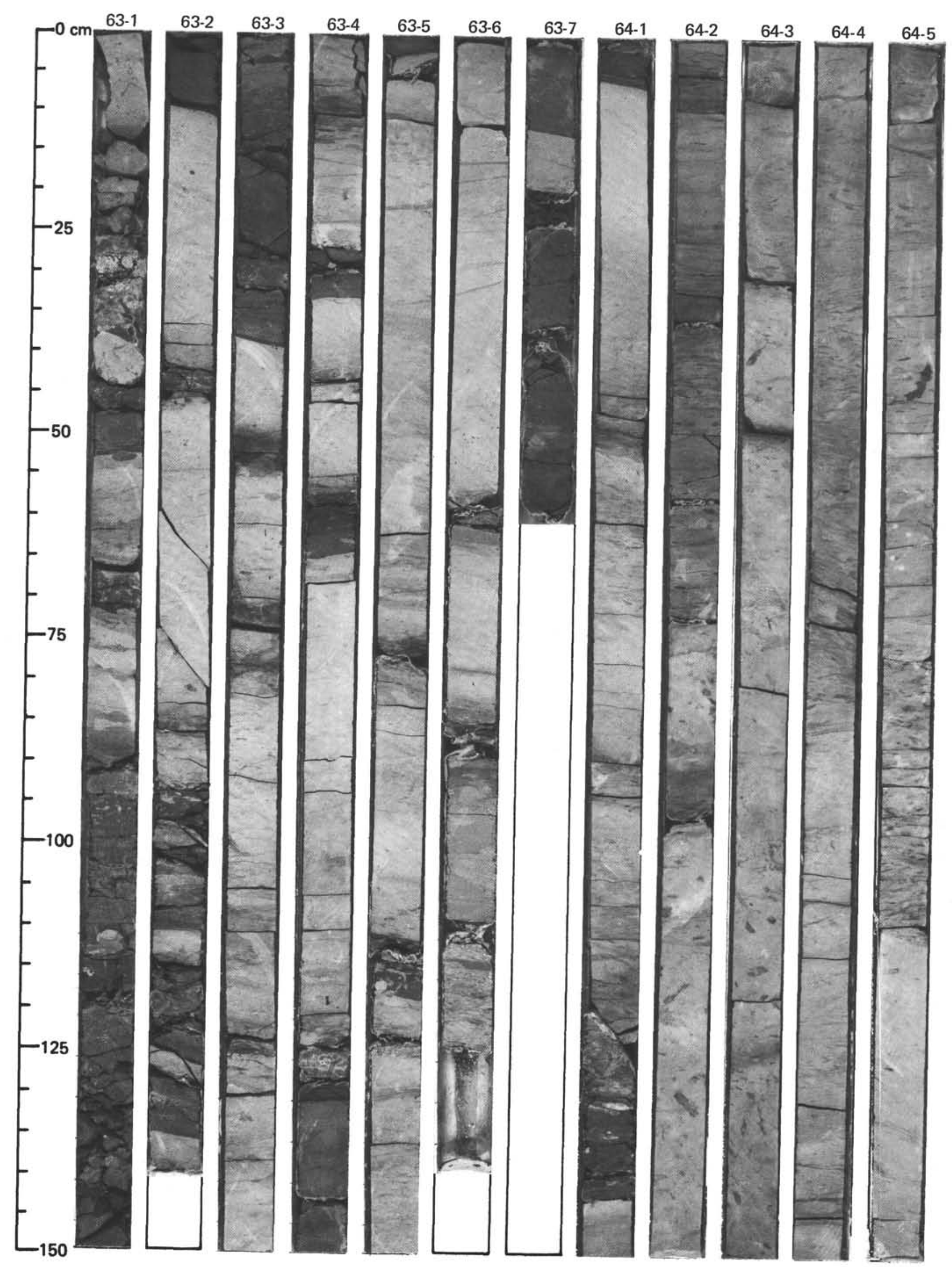


SITE 516 (HOLE 516F)

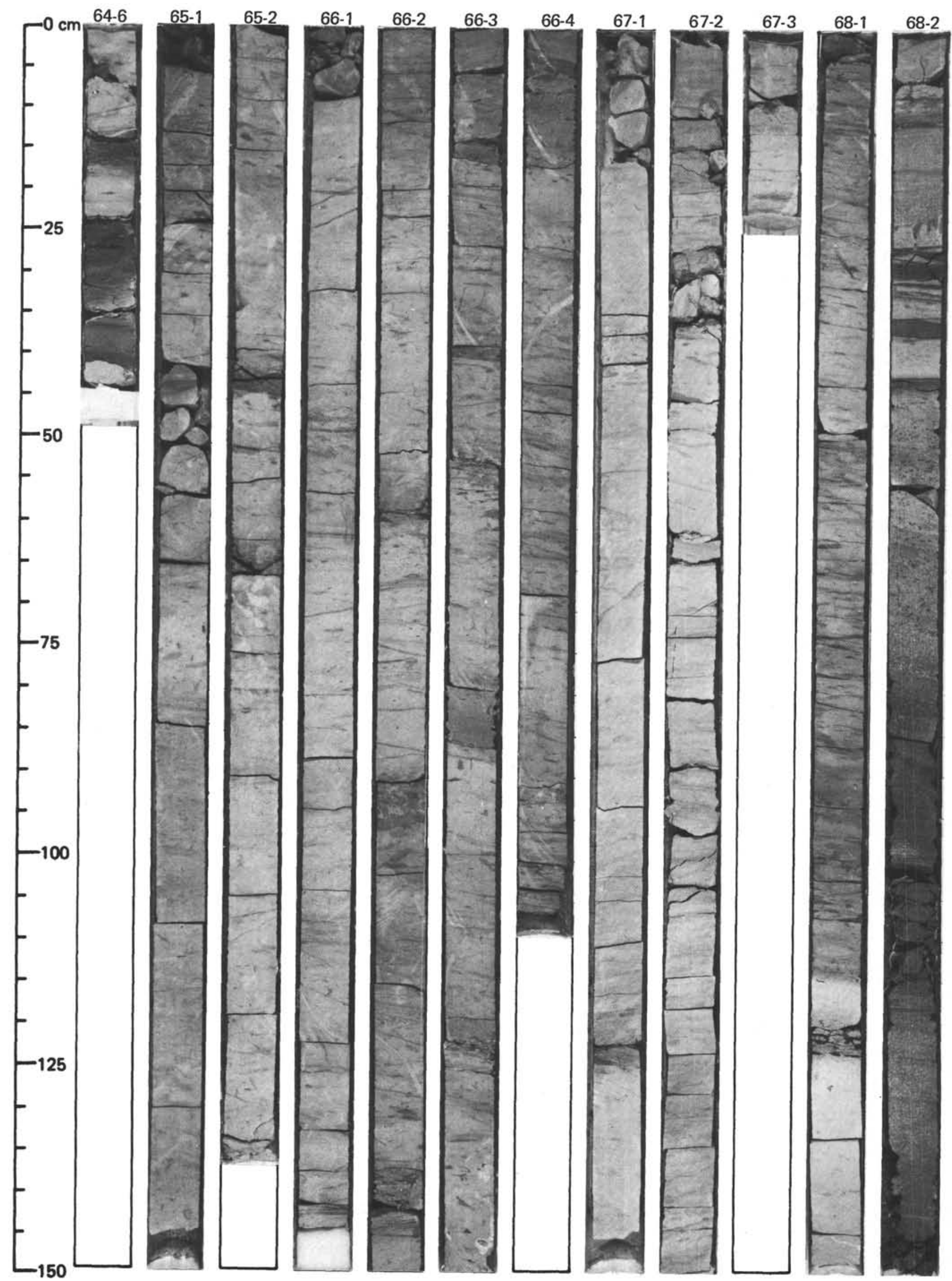




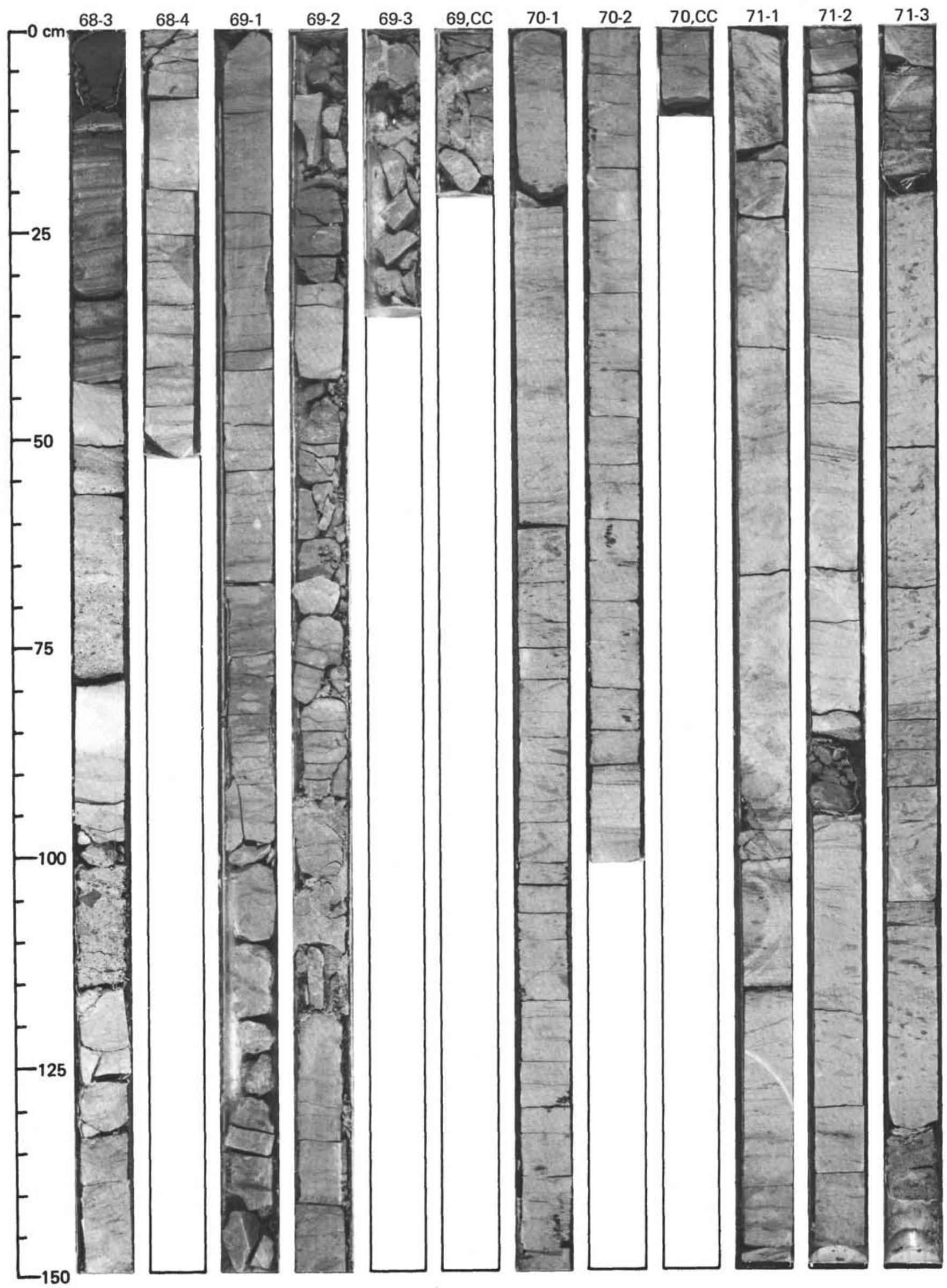


SITE 516 (HOLE 516F)

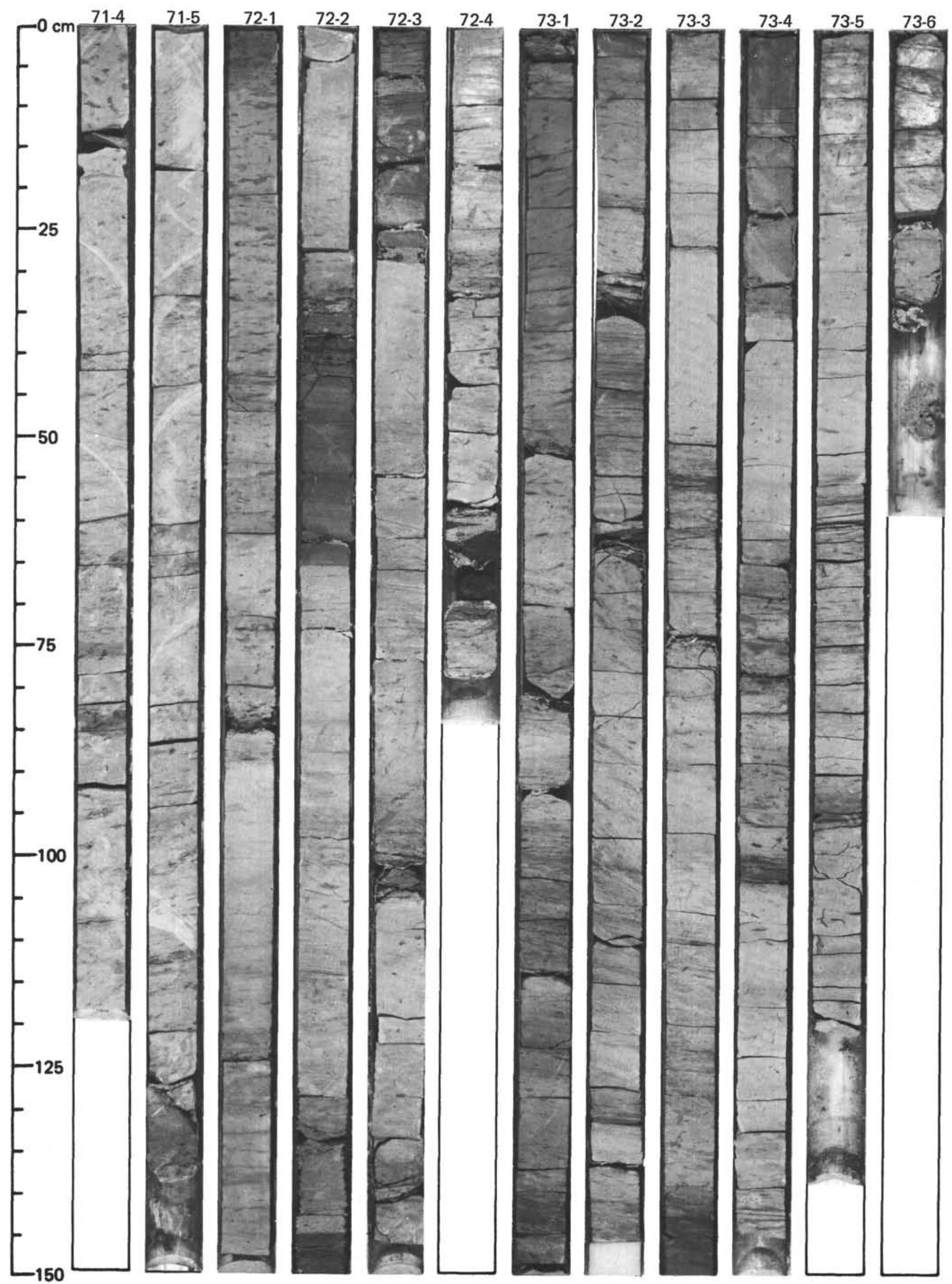




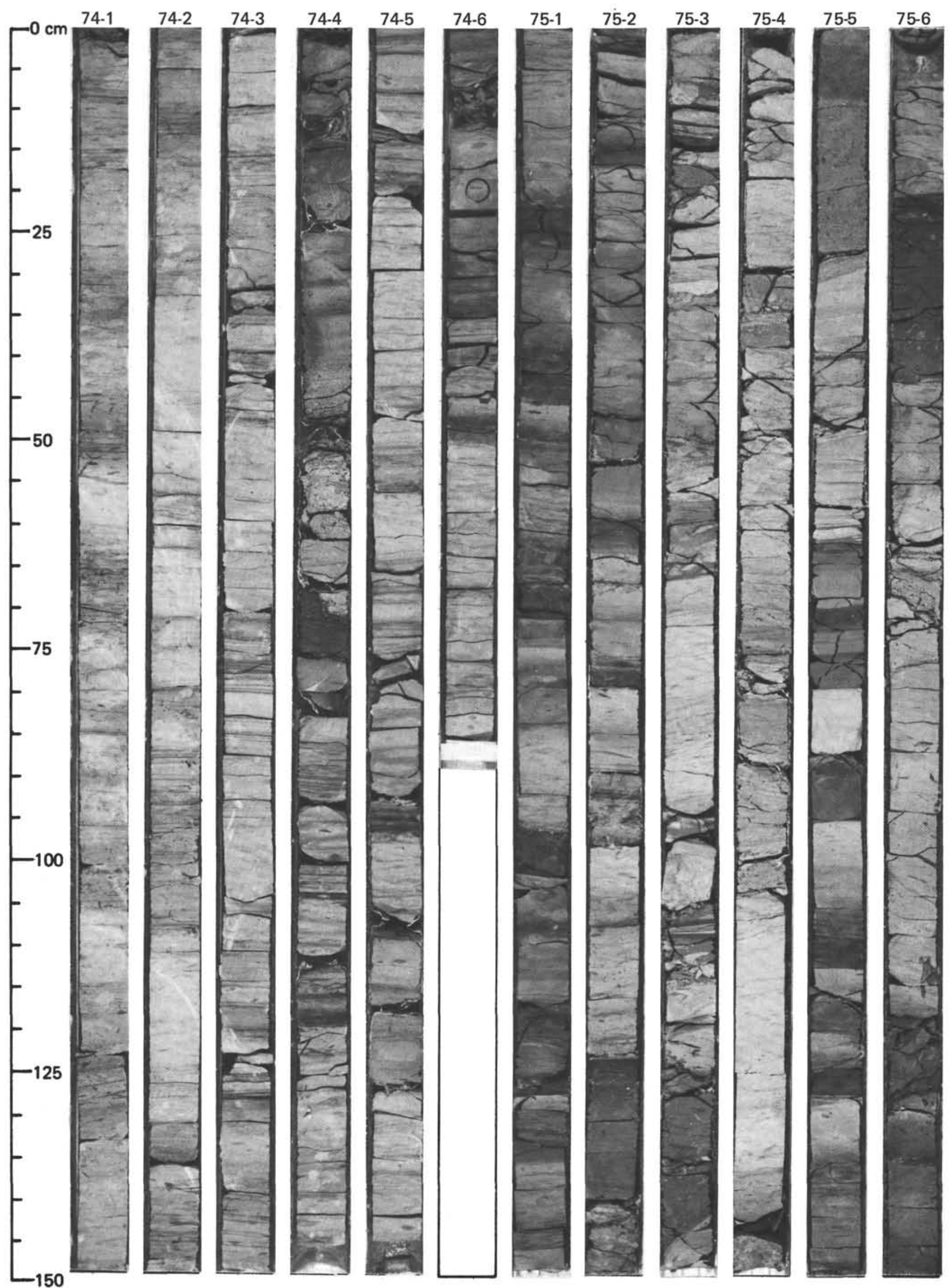




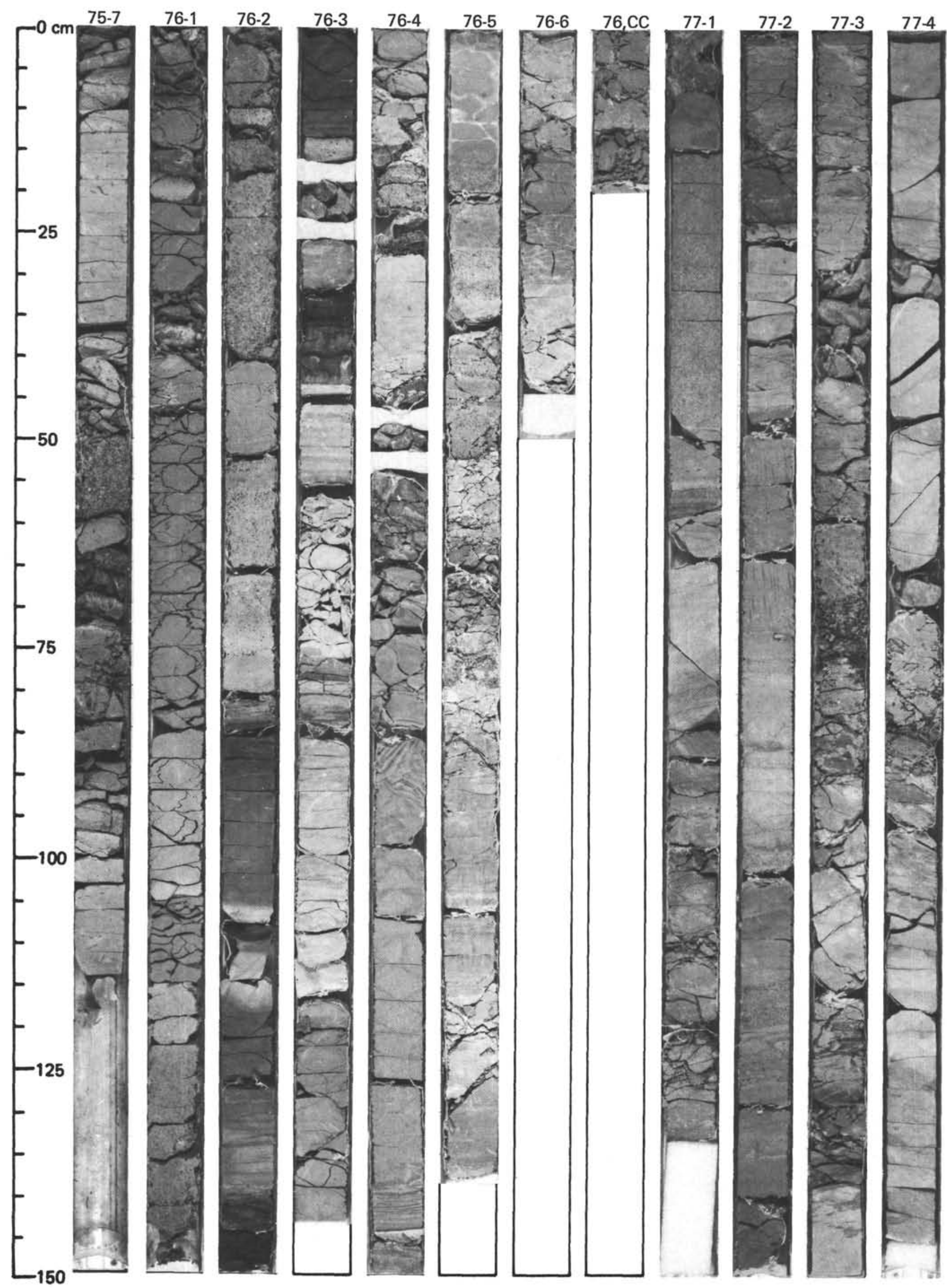


SITE 516 (HOLE 516F)

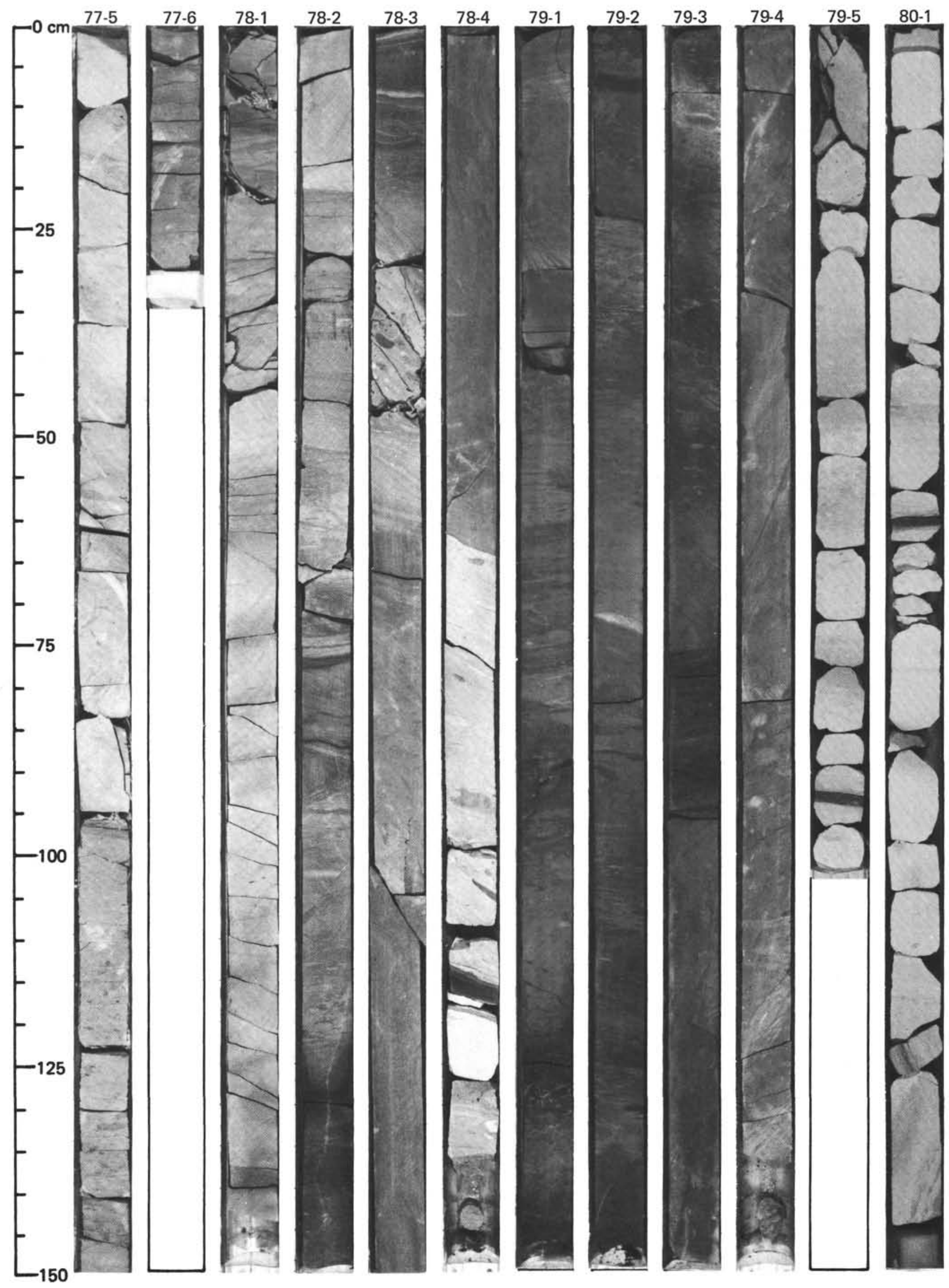




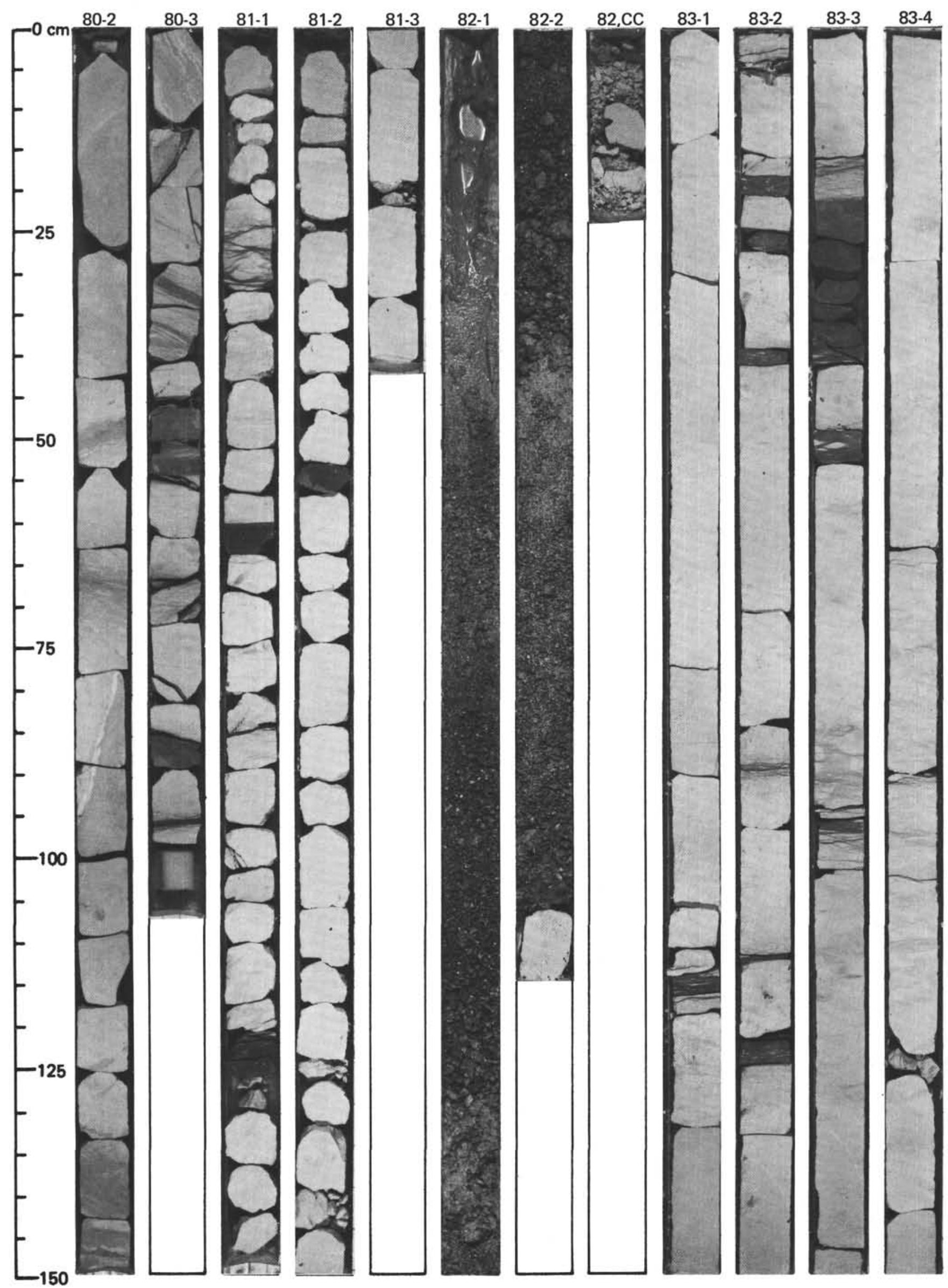




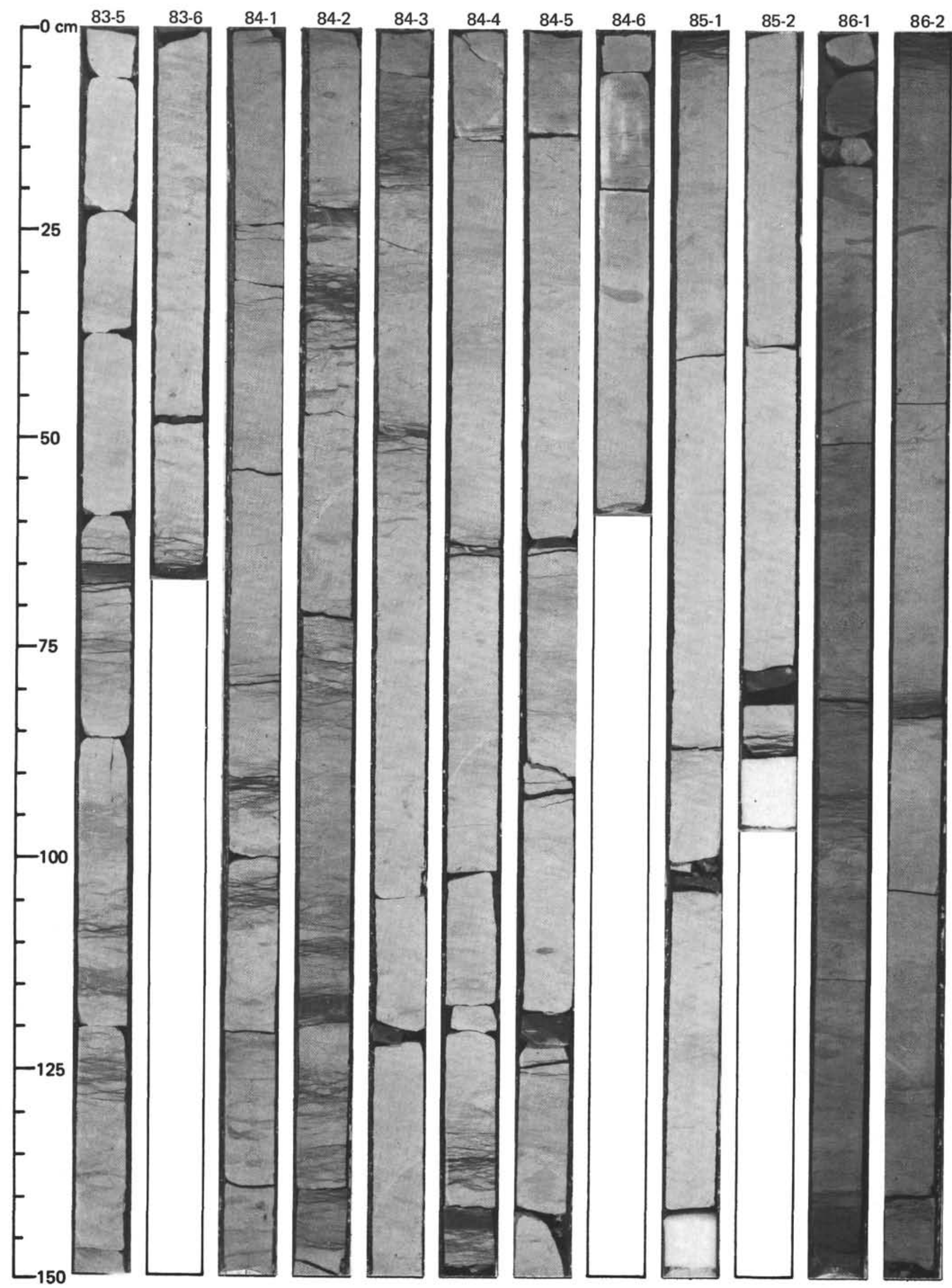


SITE 516 (HOLE 516F)

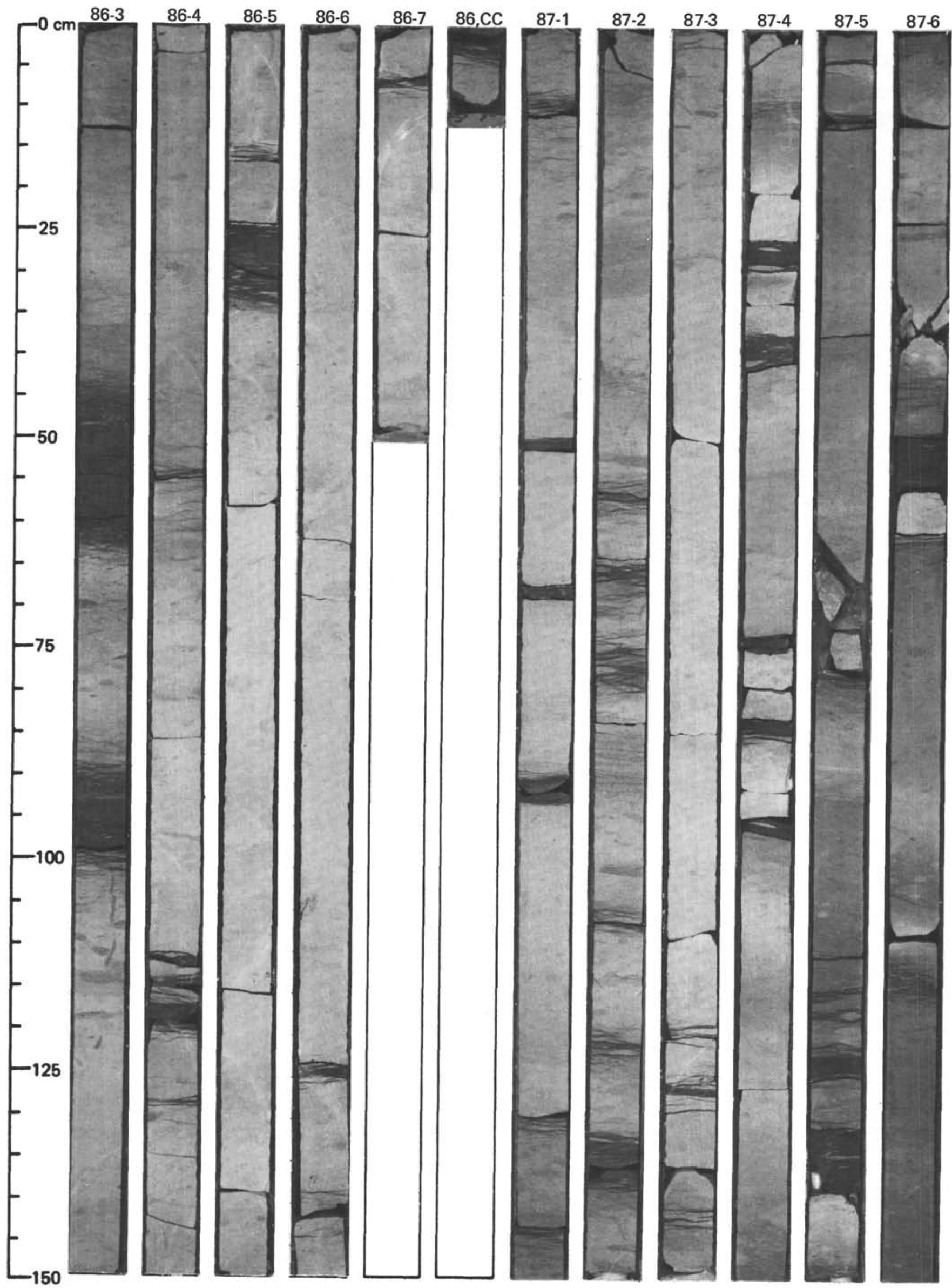




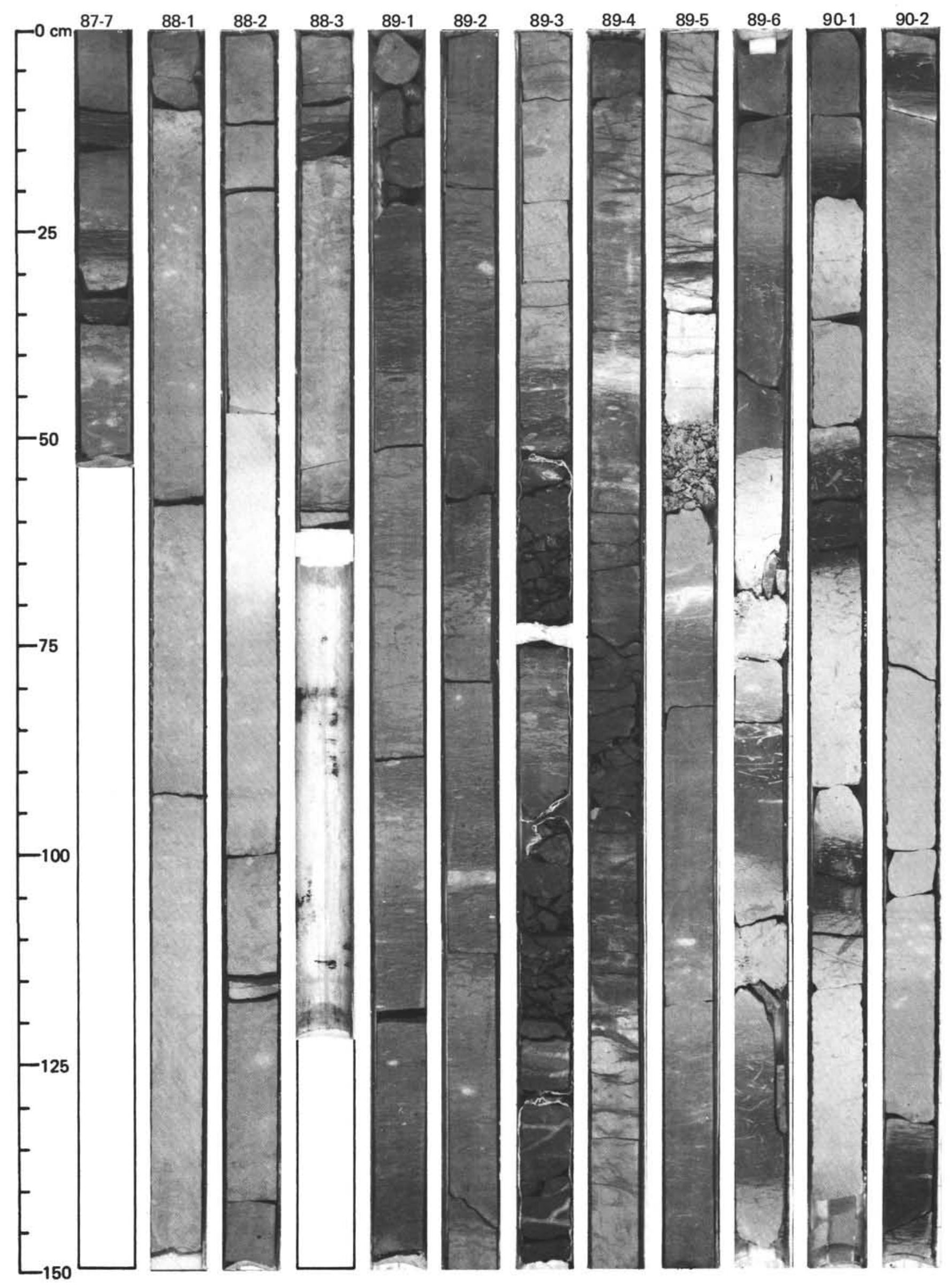


SITE 516 (HOLE 516F)

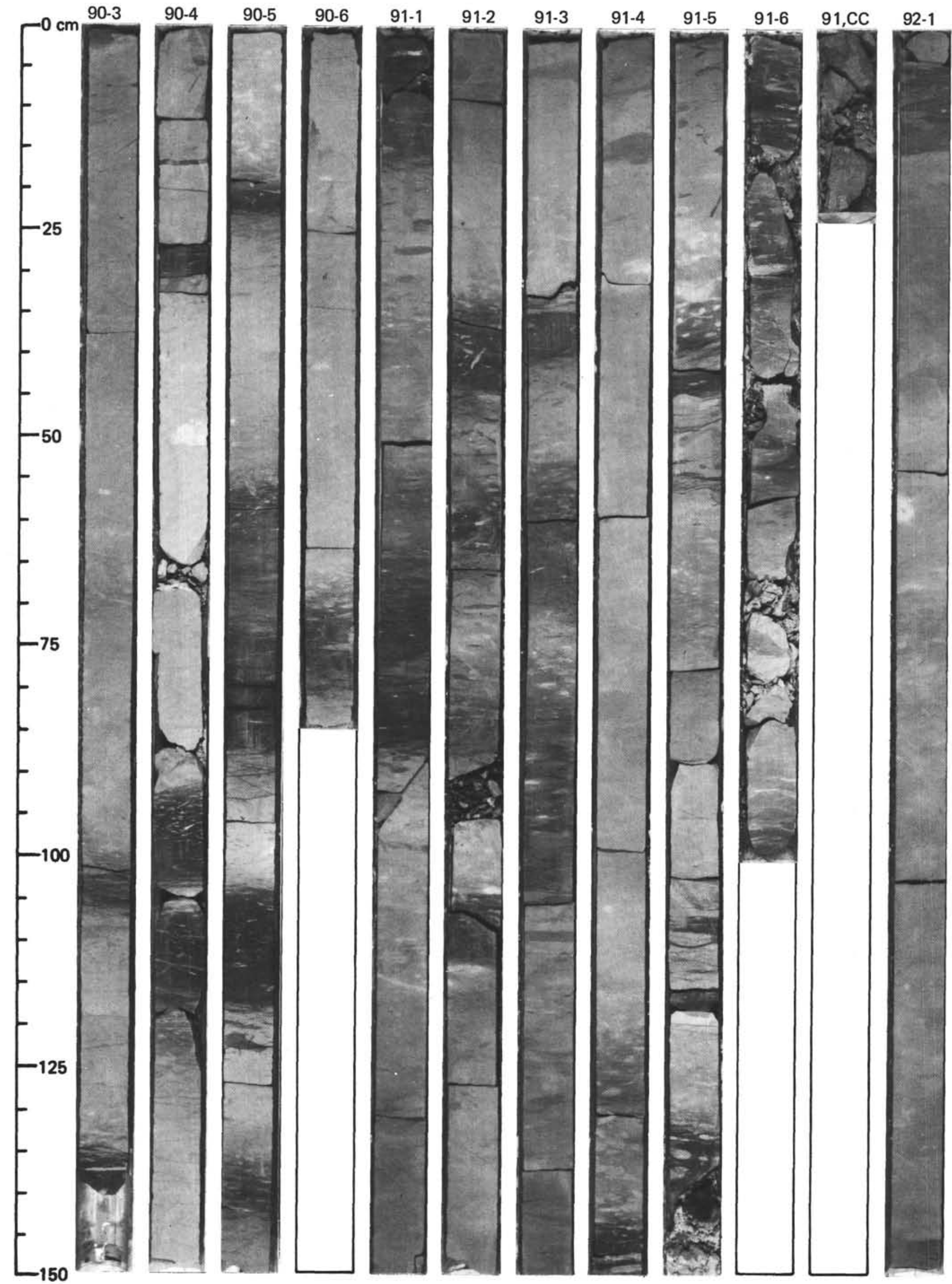




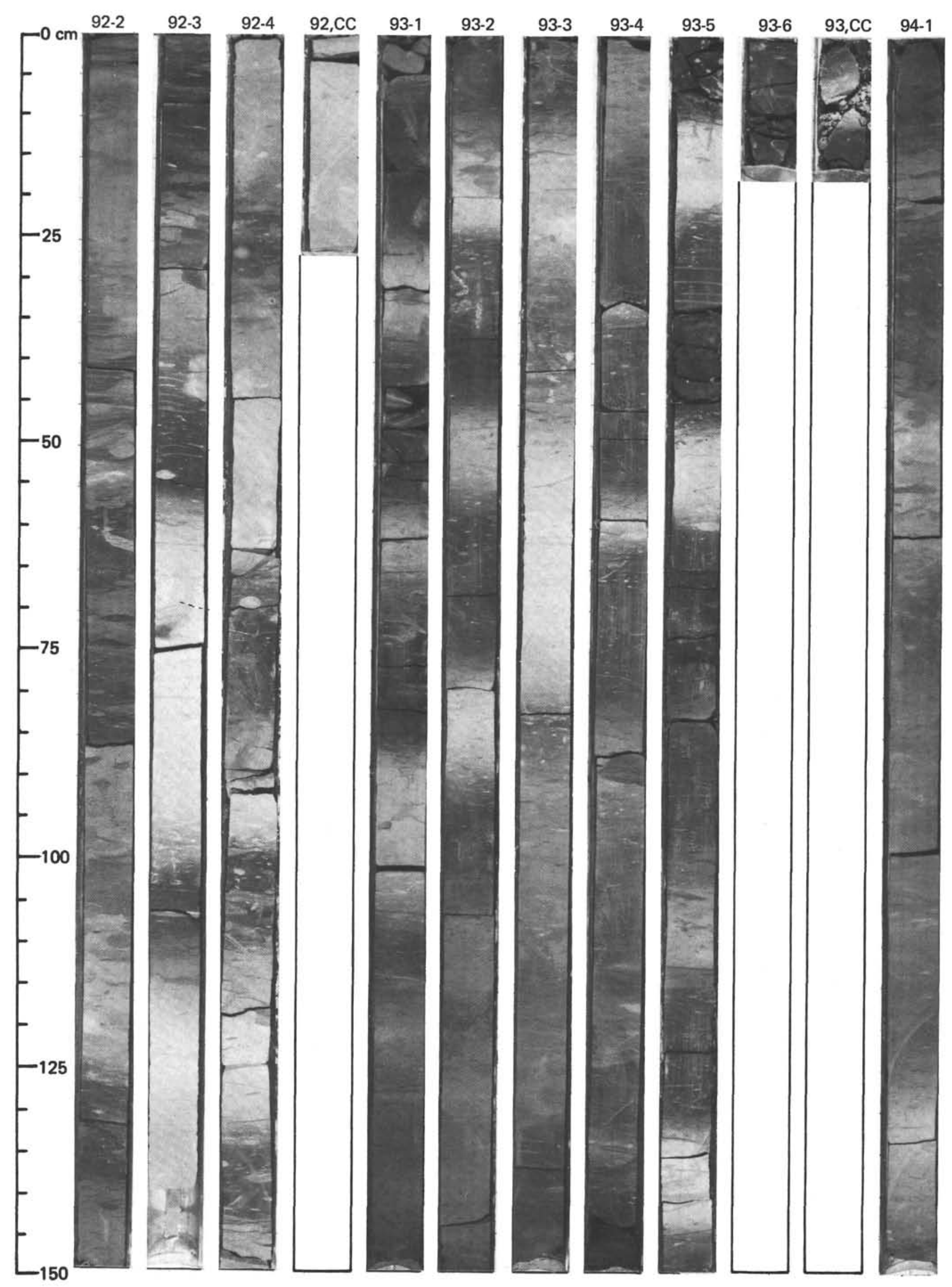




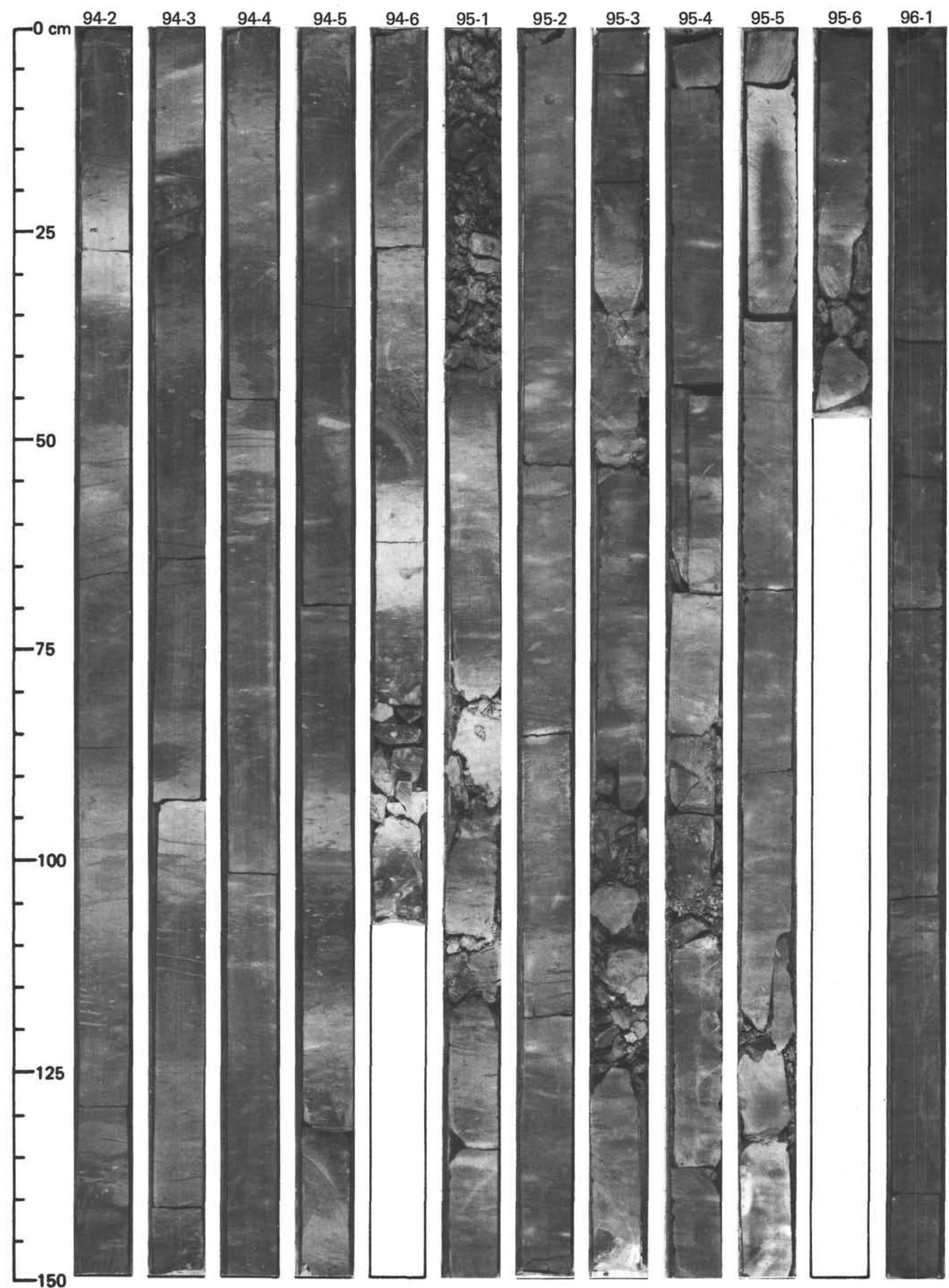




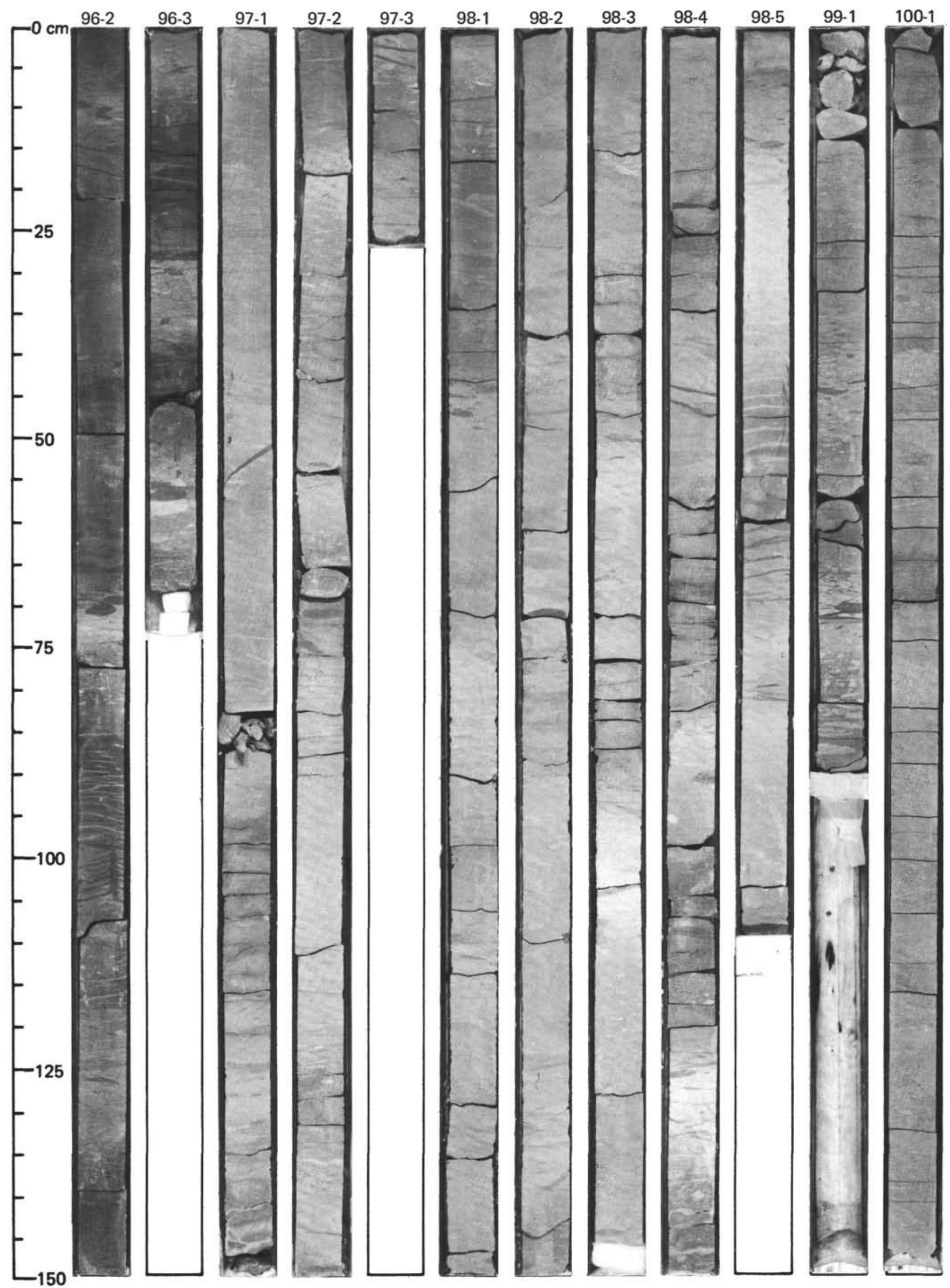




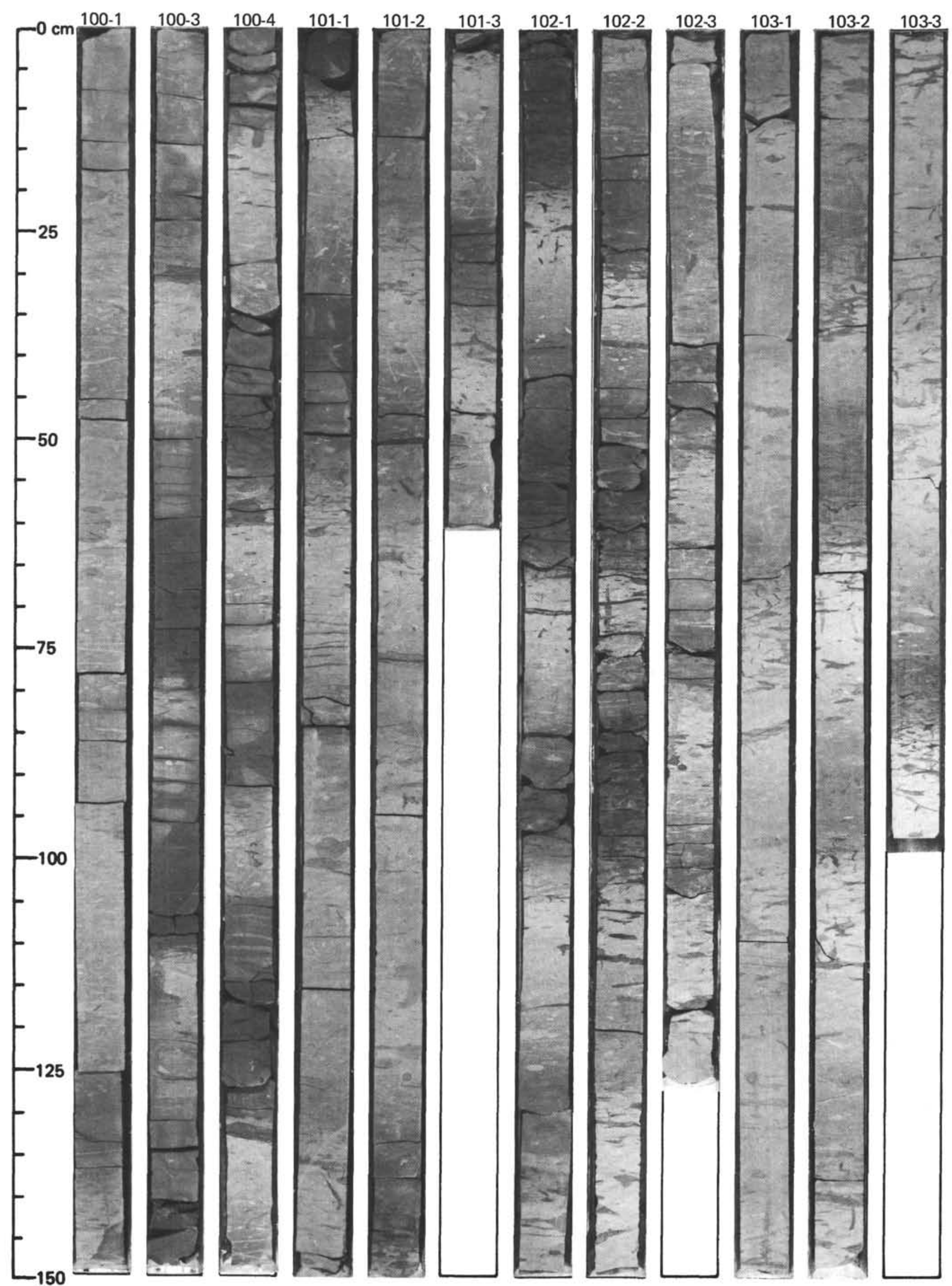




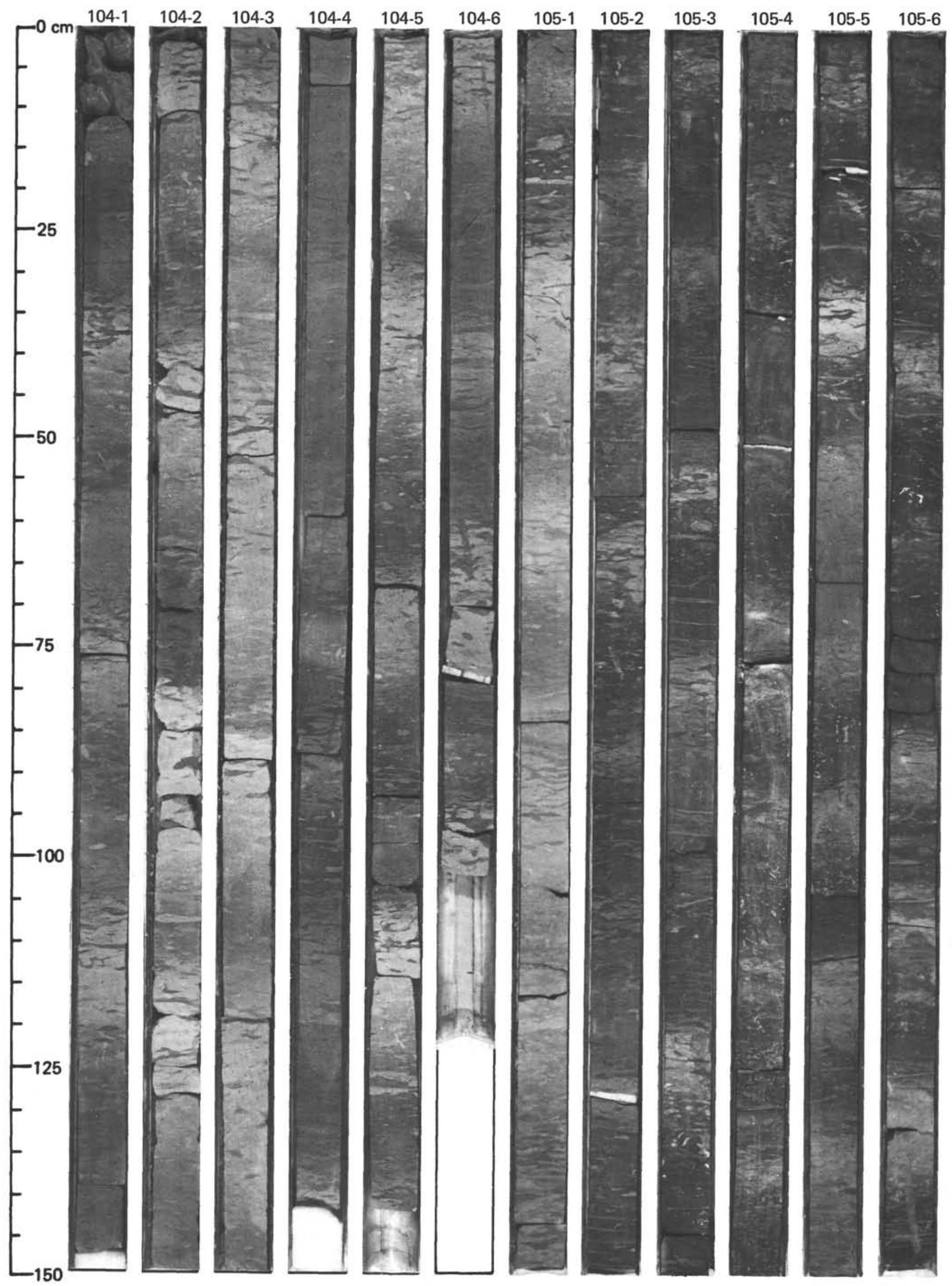




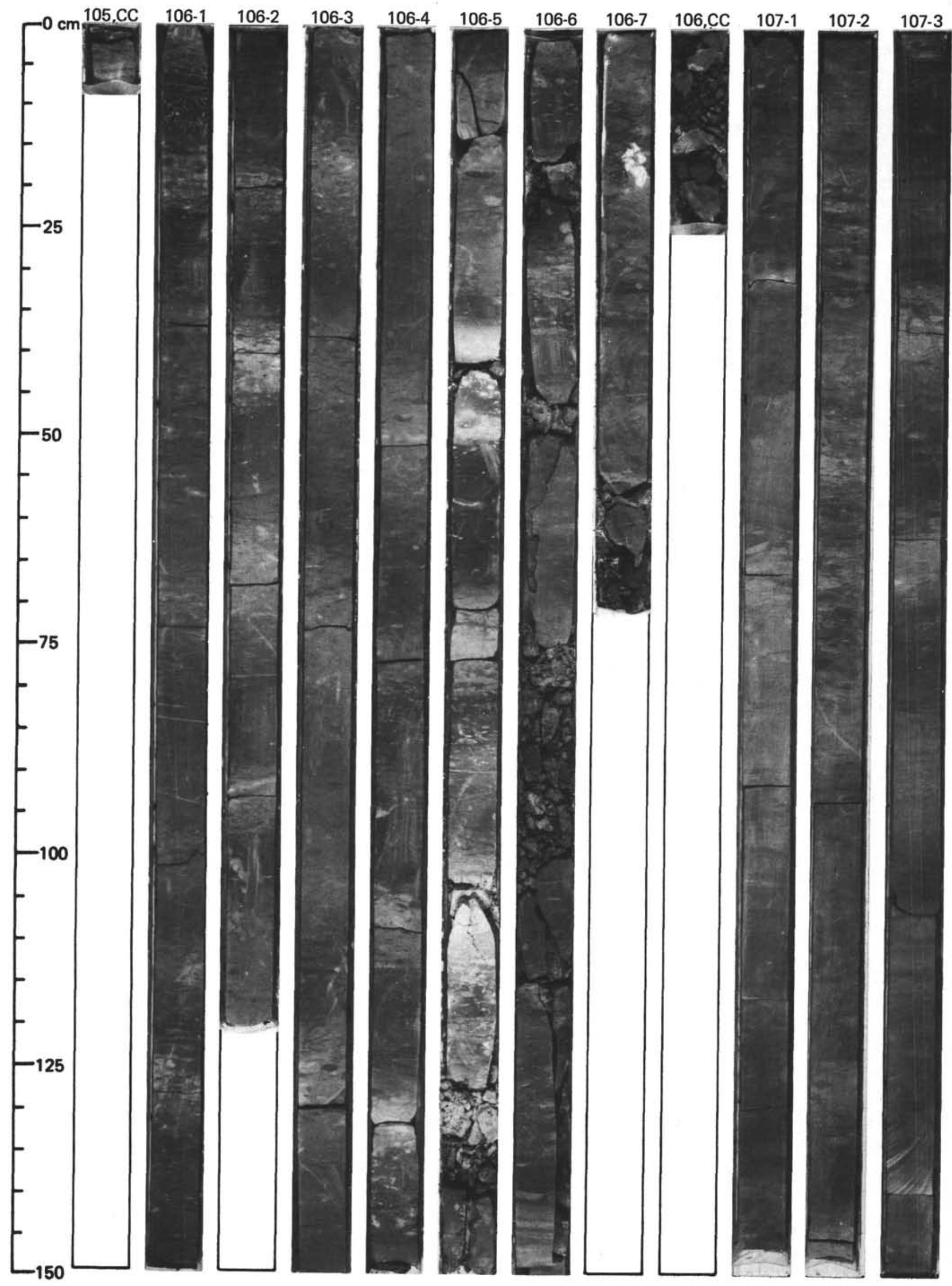




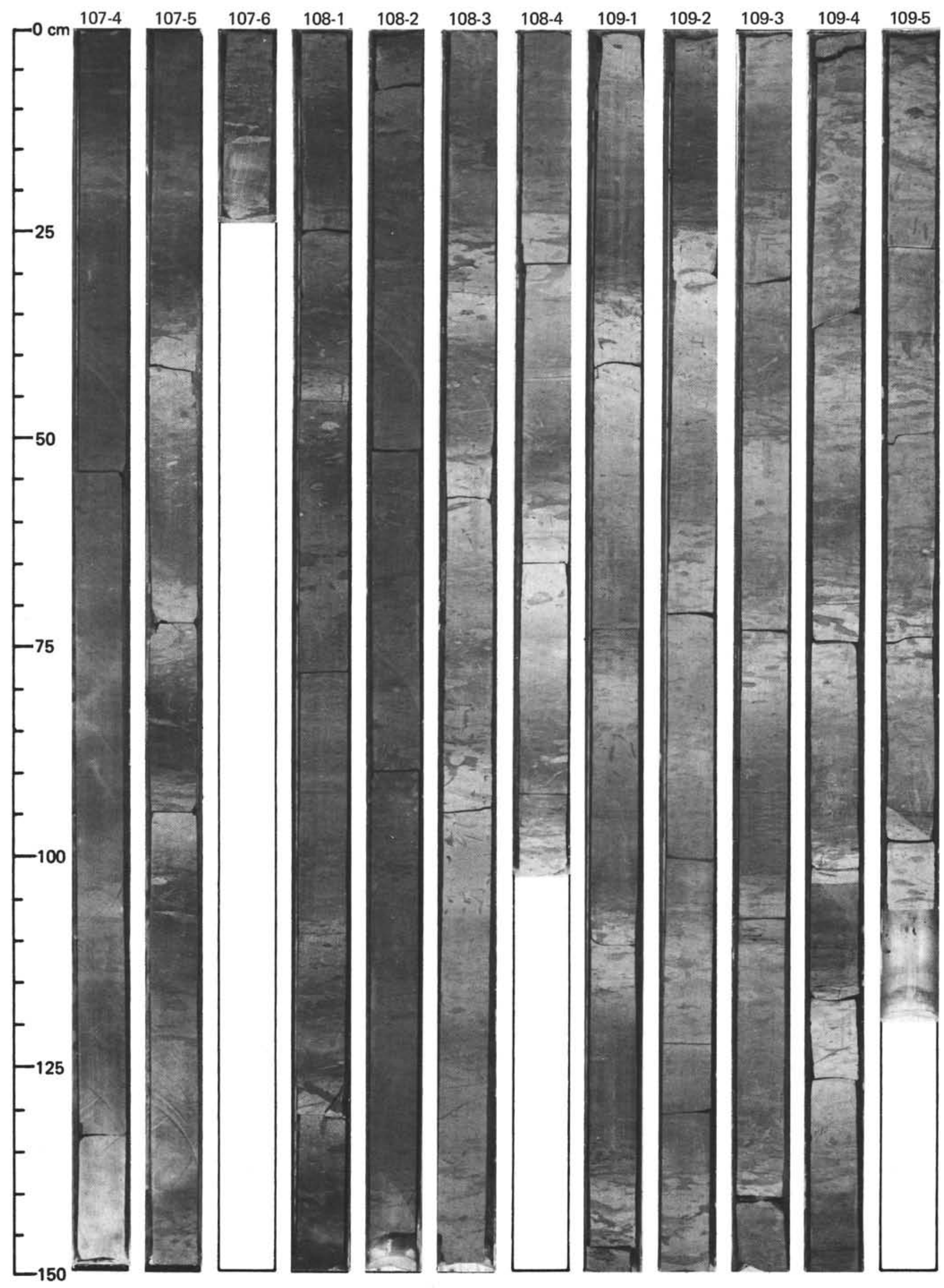


SITE 516 (HOLE 516F)

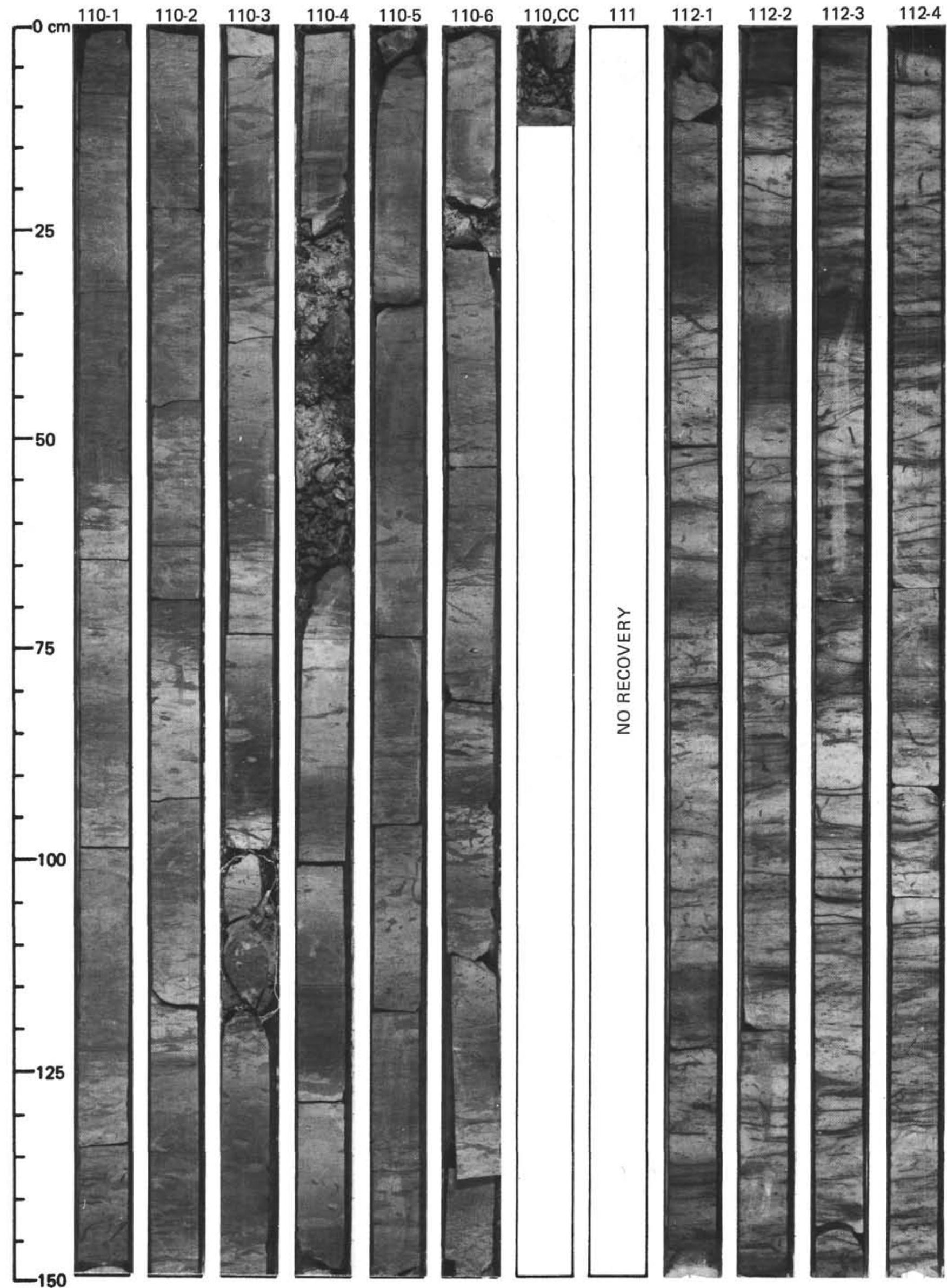




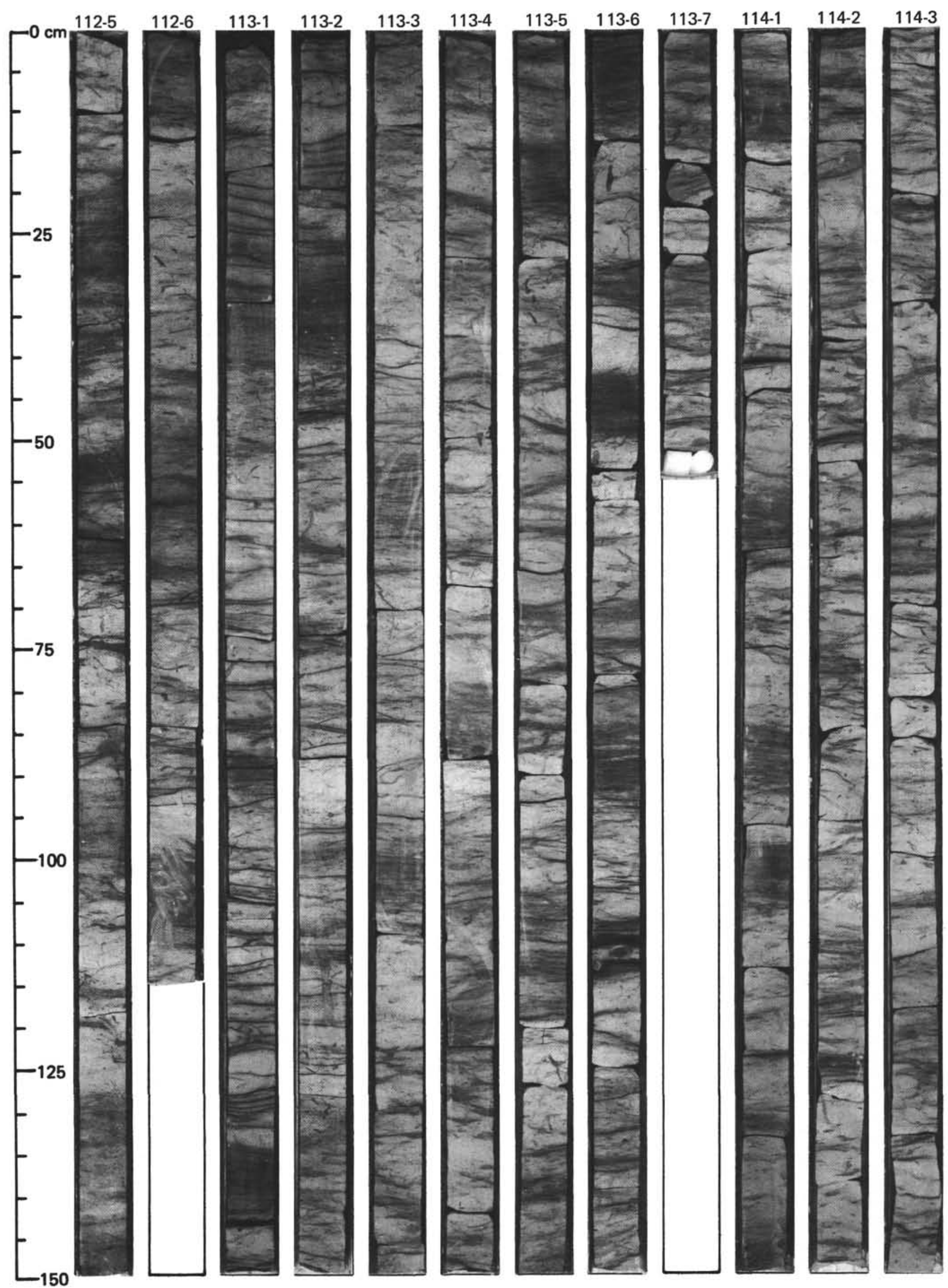


SITE 516 (HOLE 516F)

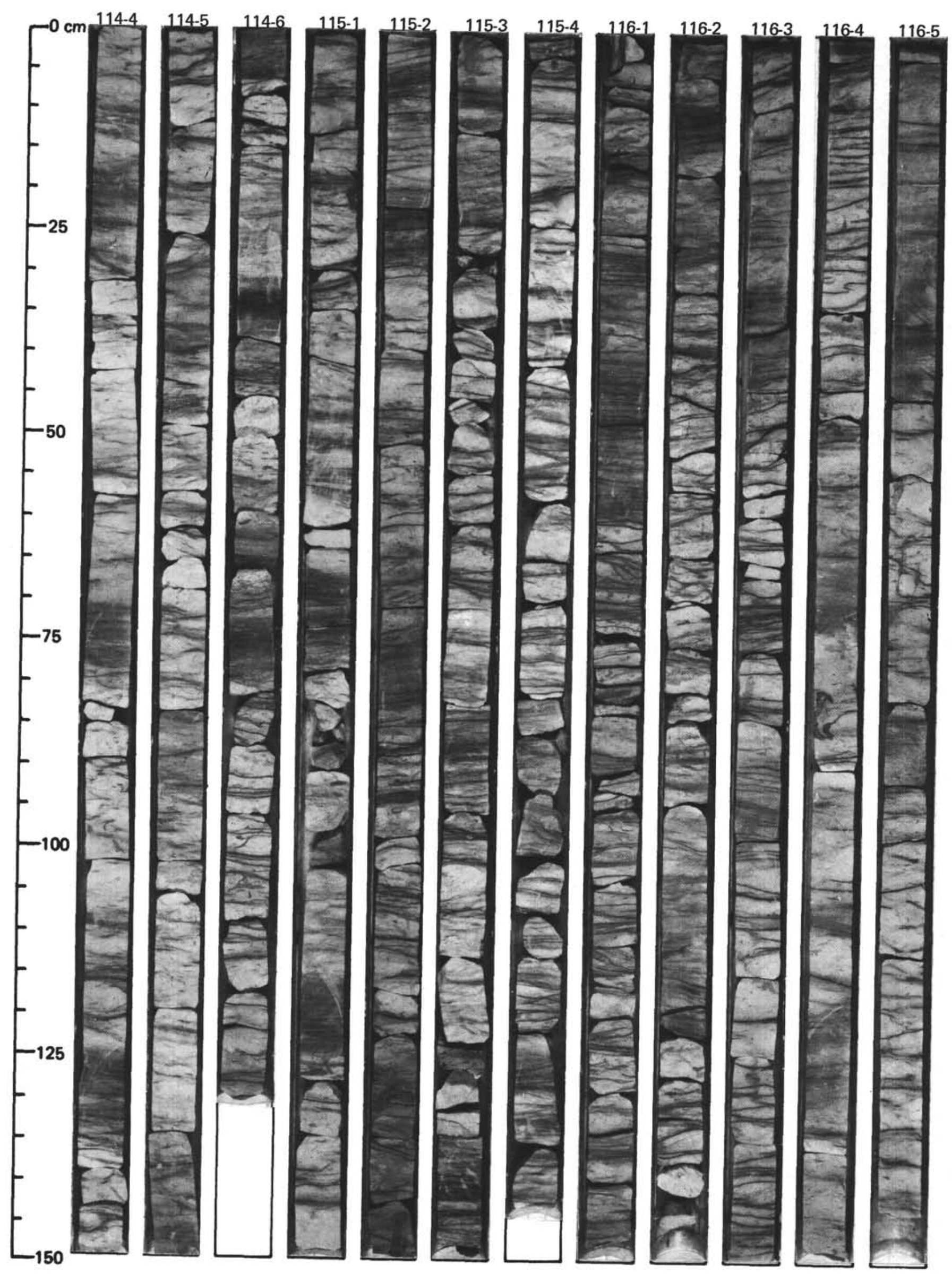




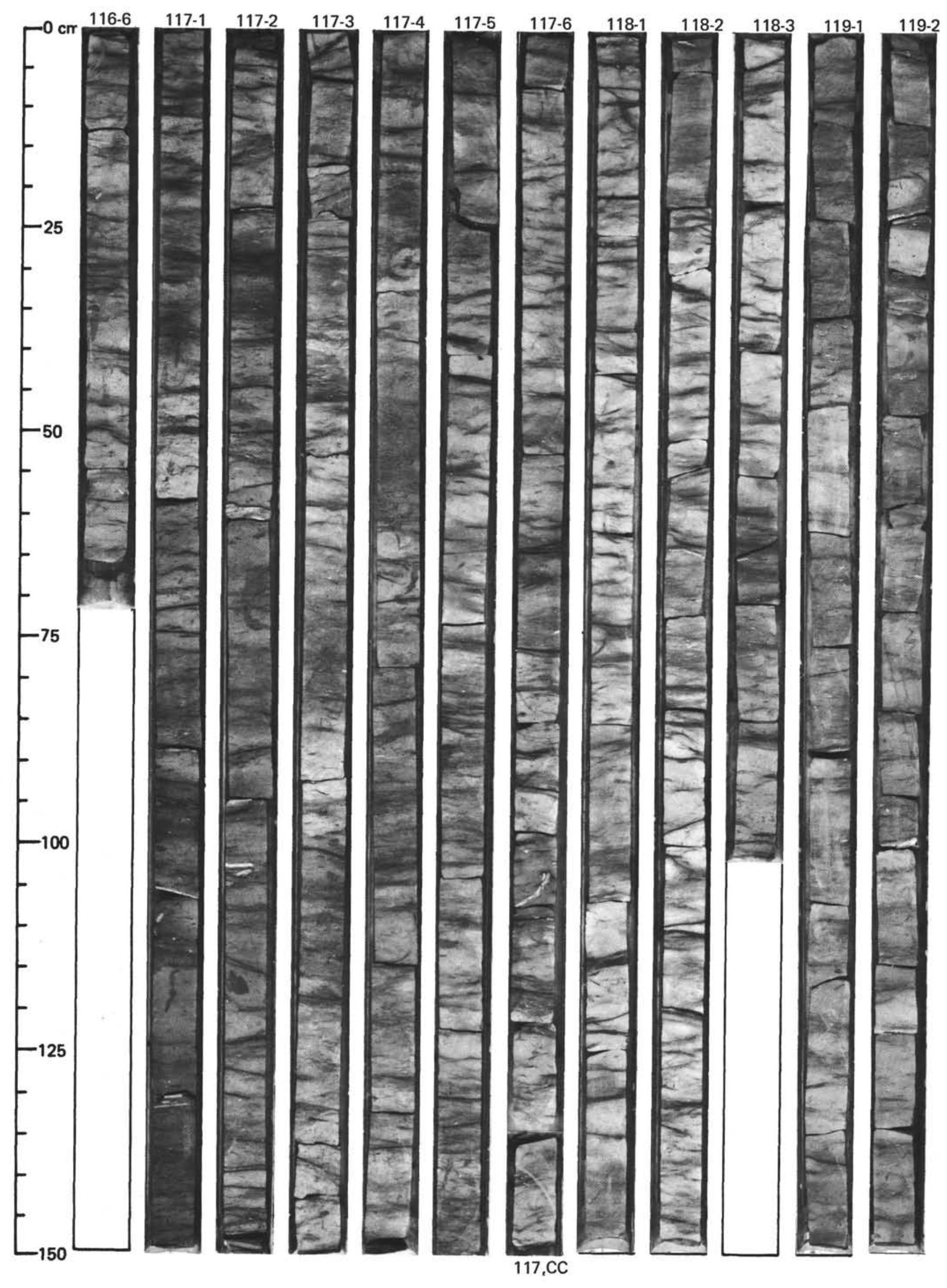


SITE 516 (HOLE 516F)

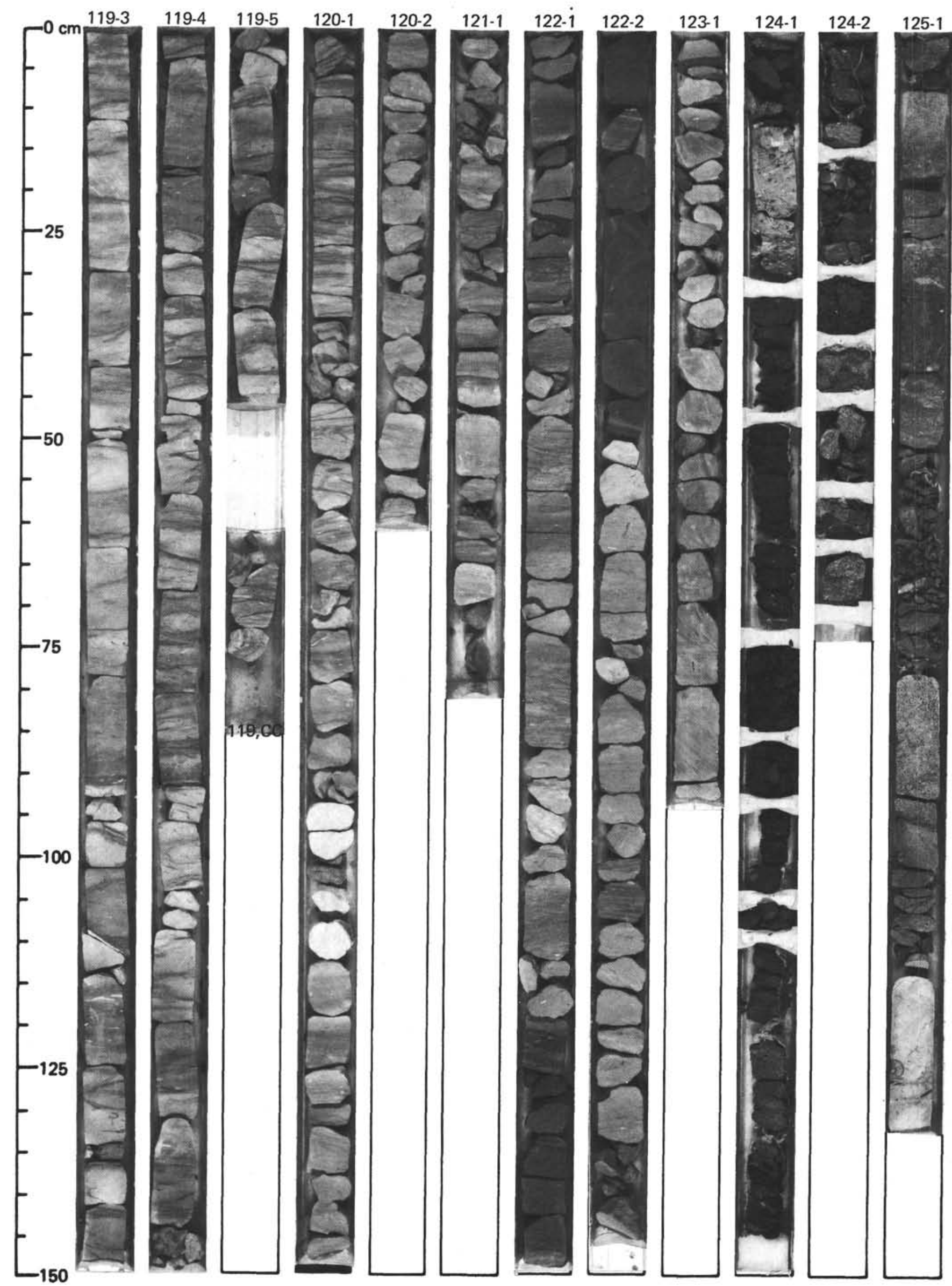




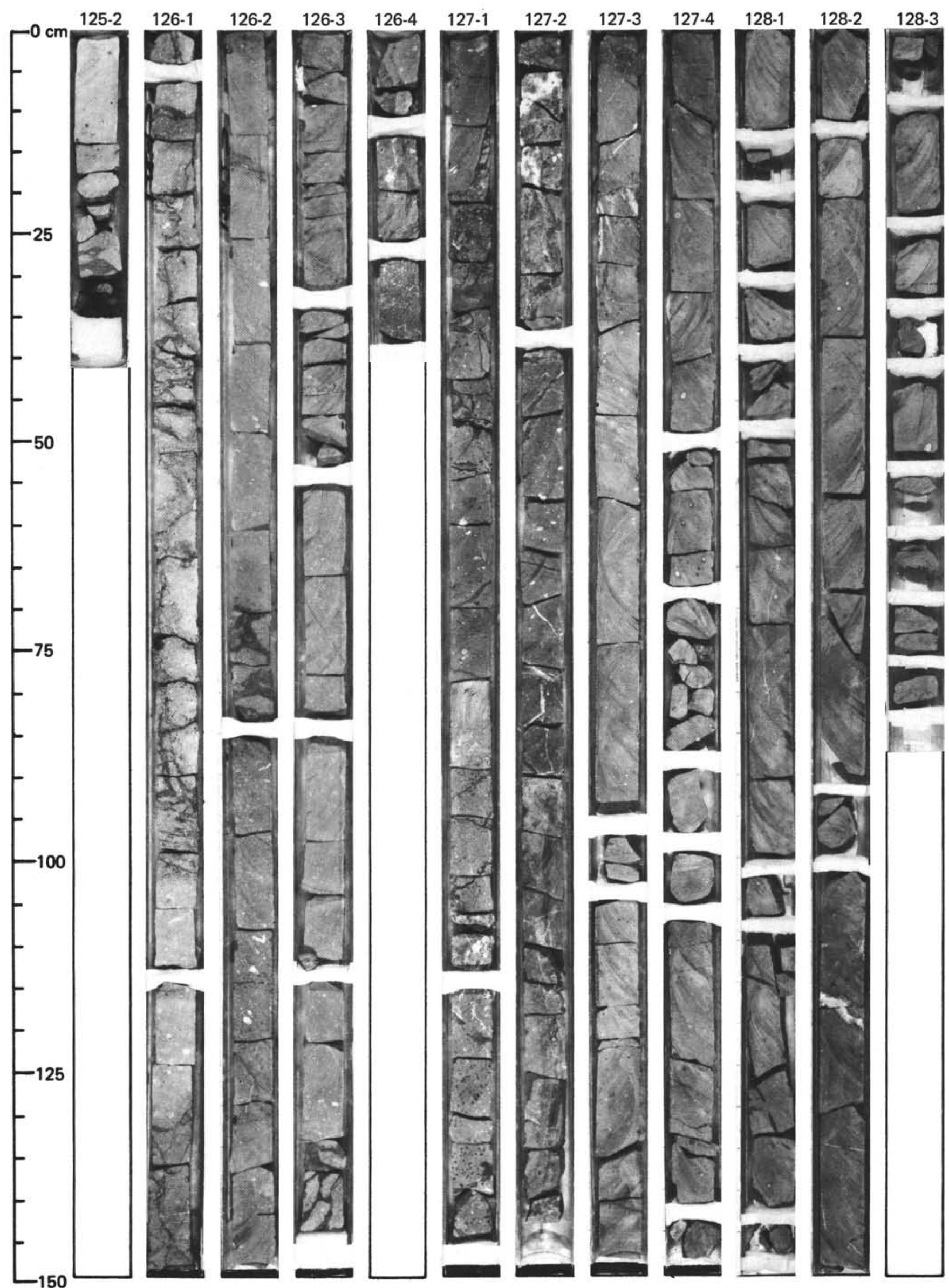

